La evolución de los valores sociales en Galicia 
La evolución de los valores sociales en Galicia

Coordinador

José Luis Veira Veira

Coautores

Pablo Castellanos García José Antonio López Rey Santiago Míguez González

Celia Muñoz Goy

José Atilano Pena López

José Manuel Sánchez Santos 


\section{LA EVOLUCIÓN DE LOS VALORES SOCIALES EN GALICIA}

Cualquier forma de reproducción, distribución, comunicación pública o transformación de esta obra solo puede ser realizada con la autorización de sus titulares, salvo excepción prevista por la ley. Diríjase a CEDRO (Centro Español de Derechos Reprográficos, www.cedro.org) si necesita fotocopiar o escanear algún fragmento de esta obra.

No está permitida la reproducción total o parcial de este libro, ni su tratamiento informático, ni la transmisión de ninguna forma o por cualquier medio, ya sea electrónico, mecánico, por fotocopia, por registro u otros métodos, sin el permiso previo y por escrito de los titulares del Copyright.

QR code es una marca registrada por Denso Wave, inc.

DERECHOS RESERVADOS 2010, respecto a la primera edición en español, por

(C) Netbiblo, S. L.

\section{netbriblo}

www.netbiblo.com

NETBIBLO, S. L.

C/. Rafael Alberti, 6 bajo izq.

Sta. Cristina 15172 Oleiros (La Coruña) - Spain

Tlf: +34981915500 • Fax: +34981915511

www.netbiblo.com

editorial@netbiblo.com

Miembro del Foro Europeo de Editores

ISBN: 978-84-9745-574-9

Directora Editorial: Cristina Seco López

Editora: Sheila Martínez Varela

Producción Editorial: Gesbiblo, S. L.

Impreso en España - Printed in Spain 


\section{CAPÍTULO 1}

\section{MODERNIZACIÓN Y CAMBIO CULTURAL EN GALICIA}

José Luis Veira Veira

1.1. Modernización y desarrollo humano

1.2. Los valores de la autoexpresión en Galicia en una perspectiva comparada

1.2.1. Los valores posmaterialistas ....................................................... 4

1.2.2. El proceso de individualización.......................................................... 11

1.2.3. El cambio de rol femenino......................................................... 17

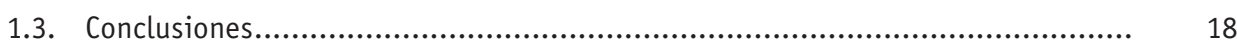

1.4. Referencias bibliográficas.................................................................. 19

\section{CAPÍTULO 2}

\section{VALORES: PROBLEMAS PÚBLICOS Y DILEMAS MORALES}

José Luis Veira Veira

2.1. Introducción

2.2. Lo más importante en la vida................................................................... 24

2.3. Integración y exclusión sociales: el caso de las minorías................................ $\quad 30$

2.4. Problemas públicos y dilemas morales ....................................................... 32

2.4.1. El dinero y las conductas deshonestas ............................................. 33

2.4.2. Problemas públicos derivados del uso del propio cuerpo ........................ 35

2.5. Galicia en una perspectiva comparada:

la permisividad como fenómeno diferencial ................................................ 40

2.6. Conclusiones................................................................................... 42

2.7. Referencias bibliográficas...................................................................... 43

\section{CAPÍTULO 3}

\section{RELIGIÓN Y ESPIRITUALIDADES DE VIDA}

José Luis Veira Veira

Celia Muñoz Goy

3.1. Introducción.

3.2. Situación social de la religión en Galicia ..................................................... 47

3.3. El proceso de secularización ................................................................... 52

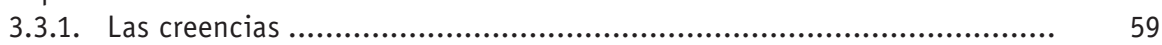

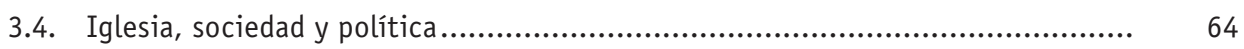

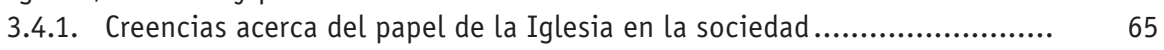

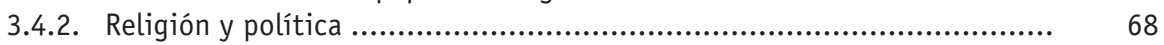

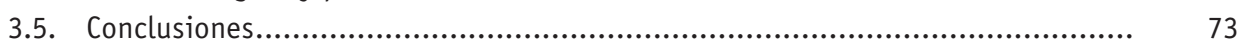

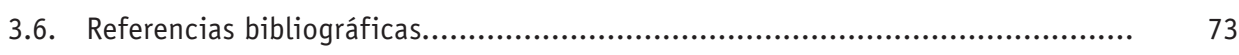




\section{CAPÍTULO 4}

\section{TRANSFORMACIONES RECIENTES DE LA FAMILIA EN GALICIA}

José Antonio López Rey

4.1. Introducción......................................................................... 75

4.2. Evolución de la natalidad y la fecundidad en Galicia ................................... 77

4.3. Matrimonio y divorcio en Galicia .......................................................... 80

4.4. Nuevos tipos familiares .............................................................. 89

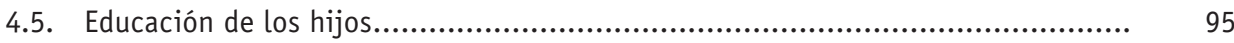

4.6. Conclusiones......................................................................... 100

4.7. Referencias bibliográficas........................................................... 102

\section{CAPITULO 5}

\section{IDENTIDAD NACIONAL, CONCIENCIA ÉTNICA Y MODERNIZACIÓN}

Santiago Míguez González

5.1. Introducción.

5.2. Las bases de la identidad: localismo, ruralidad y dispersión poblacional............ 105

5.3. El fenómeno de la emigración .......................................................... 106

5.4. El idioma ................................................................................. 107

5.5. La conciencia de la diferencia y el orgullo de ser gallego.............................. 113

5.6. La identidad localista en la EMV ......................................................... 114

5.7. Identidades múltiples, cambiantes y no excluyentes.................................... 116

5.8. La identidad nacional .............................................................. 119

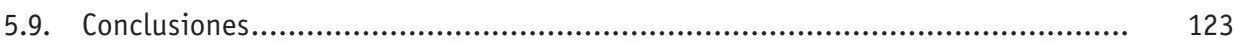

5.10. Referencias bibliográficas......................................................... 124

\section{CAPÍTULO 6}

\section{VALORES POLÍTICOS Y PARTICIPACIÓN EN GALICIA.} FACTORES DE CAMBIO Y CONTINUIDAD

Santiago Míguez González

6.1. Introducción

6.2. Los valores políticos y la dimensión izquierda-derecha............................... 128

6.2.1. Autoubicación política y amplitud de las respuestas .......................... 130

6.2.2. La distribución en la escala izquierda-derecha................................... 131

6.2.3. Autoposicionamiento político y variables sociodemográficas................. 132

6.2.4. La dimensión izquierda-derecha y la competición electoral ................... 134

6.2.5. El significado de las posiciones de izquierda y derecha....................... 137

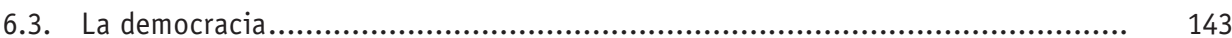

6.3.1. Apoyos y críticas a la democracia ............................................. 143

6.3.2. Incongruencias en las respuestas y posibles explicaciones.................. 145

6.4. La importancia y el interés por la política .............................................. 147

6.5. La participación política ................................................................... 152

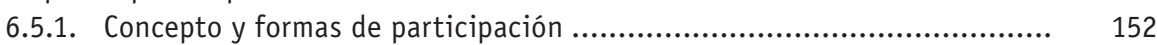

6.5.2. La participación electoral....................................................... 153

6.5.3. Otras formas de participación: manifestaciones, peticiones y boicots......................................................... 165

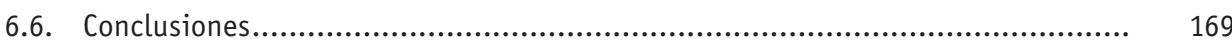

6.7. Referencias bibliográficas......................................................... 170 


\section{CAPÍTULO 7}

\section{GALICIA EN LA SOCIEDAD DE LA INFORMACIÓN}

José Antonio López Rey

7.1. Introducción............................................................................ 173

7.2. Sociedad e información .................................................................. 175

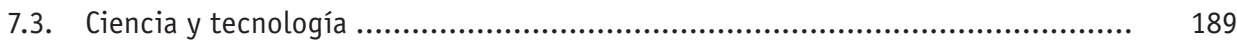

7.4. El medio ambiente ....................................................................... 200

7.5. La estructura del asociacionismo en Galicia........................................... 210

7.6. Conclusiones.......................................................................... 216

7.7. Referencias bibliográficas.......................................................... 217

\section{CAPÍTULO 8}

\section{LA CULTURA DEL TRABAJO EN GALICIA}

Celia Muñoz Goy

8.1. Introducción.

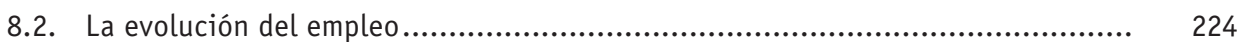

8.3. La centralidad del trabajo................................................................ 227

8.4. La ética del trabajo ..................................................................... 236

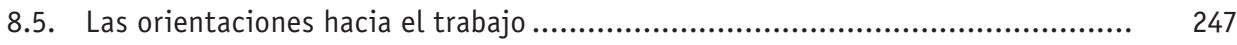

8.6. La individualización en el ámbito laboral .............................................. 255

8.7. Conclusiones........................................................................... 261

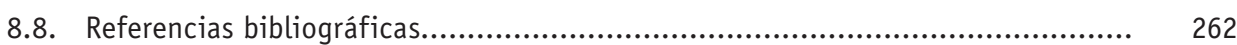

\section{CAPÍTULO 9}

\section{LA EVOLUCIÓN DEL CAPITAL SOCIAL EN GALICIA}

José Atilano Pena López

Pablo Castellanos García

9.1. Introducción

9.2. El capital social como una forma de capital comunitario................................ 266

9.2.1. La medición del capital social: confianza y redes sociales................... 269

9.2.2. Factores determinantes del capital social...................................... 272

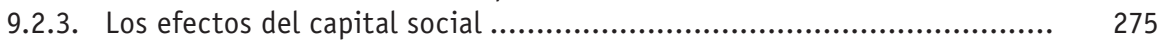

9.3. El capital social en Galicia: una aproximación empírica ................................. 279

9.3.1. La evolución de la confianza generalizada y la particular..................... 279

9.3.2. Confianza en las instituciones............................................... 285

9.4. La evolución del asociacionismo.......................................................... 288

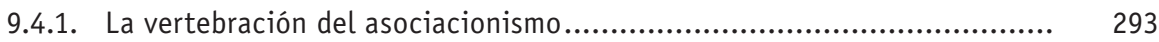

9.4.2. El asociacionismo y el declive del capital social............................. 294

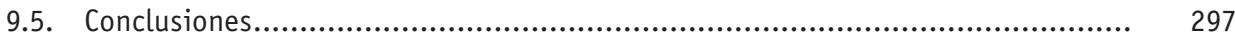

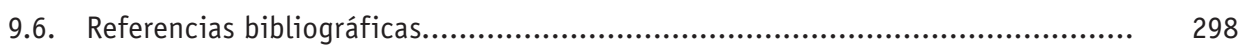

\section{CAPÍTULO 10}

FELICIDAD, BIENESTAR SUBJETIVO Y SATISFACCIÓN EN LA SOCIEDAD GALLEGA

José Atilano Pena López

José Manuel Sánchez Santos

10.1. Introducción

10.2. Felicidad: concepto y medición ........................................................ 303

10.3. La naturaleza paradójica de la relación entre felicidad e ingresos.................... 306

10.4. Una perspectiva holística: retornando a Aristóteles .................................... 310 
10.5. Una aproximación empírica a la función de felicidad de los gallegos

10.6. Trayectoria de la felicidad y sus determinantes en Galicia .............................. 319

10.6.1. Percepción de la felicidad .................................................................. 319

10.6.2. Renta, desarrollo y felicidad ............................................................ 322

10.6.3. Los "otros" determinantes de la felicidad............................................ 329

10.7. Conclusiones........................................................................................ 337

10.8. Referencias bibliográficas.................................................................. 339

\section{CAPÍTULO 11}

VALORES, ACTITUDES SOCIALES, SISTEMA ECONÓMICO

Y PAPEL DEL ESTADO EN LA ECONOMÍA

José Manuel Sánchez Santos

Pablo Castellanos Garcia

11.1. Introducción

11.2. La economía de libre mercado en Galicia: análisis de preferencias.................... 345

11.2.1. Los pilares básicos de la economía de mercado: propiedad privada y competencia.................................................... $\quad 345$

11.2.2. Valores morales, creencias y actitudes hacia el mercado ........................ 360

11.3. Legitimidad del mercado y papel del Gobierno en la economía ......................... 365

11.3.1. Demanda de redistribución: factores económicos y conductuales ............. 365

11.3.2. Responsabilidad individual versus responsabilidad del gobierno: ¿un problema de confianza? ............................................................. 376

11.4. Prioridades de política económica en la sociedad gallega ............................... 379

11.4.1. Del aumento de la producción a la mejora del bienestar ........................ 379

11.4.2. Crecimiento económico versus medio ambiente ................................... 383

11.5. Conclusiones.................................................................................. 384

11.6. Referencias bibliográficas..................................................................... 387

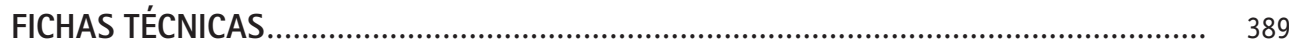

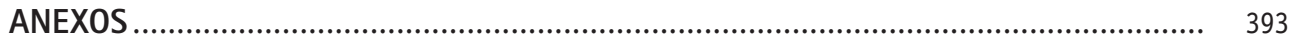


"If men define situations as real, they are real in their consequences"

William I. Thomas*

\section{INTRODUCCIÓN}

P ocos teoremas hay en el campo de las ciencias sociales que hayan tenido una aceptación tan unánime como el expresado por el sociólogo William I. Thomas. Su formulación es tan sencilla y comprensible que apenas puede ser cuestionada. Sin embargo, entraña una gran complejidad y encierra todo un programa metodológico para la investigación de la conducta humana, muy especialmente en el ámbito del estudio de las creencias y los valores. La afirmación de que la conducta humana depende del modo en el que una persona o grupo defina la situación en la que se encuentra, alude directamente a la importancia de sus creencias y valores en la construcción del significado de dicha situación.

El presente estudio sobre la evolución de los valores sociales en Galicia responde en líneas generales a un criterio metodológico acorde con el teorema citado. Aunque en esta investigación han participado estudiosos procedentes de distintas áreas de las ciencias sociales, y con diferentes sensibilidades, puede decirse que los hallazgos derivados de sus análisis son asumibles por la perspectiva teórica sugerida en el teorema, cuya seña de identidad es justamente el entendimiento de la realidad social partiendo de los "estados mentales" (creencias, valores, actitudes y preferencias) del sujeto y de los resultados agregados de dichos estados ${ }^{1}$.

Sin embargo el título del libro podría generar alguna confusión si se interpreta el término "evolución" desde una perspectiva funcionalista, incompatible con los fundamentos teóricos que inspiran el famoso teorema. Para aclarar esto baste con decir que aquí se utiliza el concepto de evolución como sinónimo de cambio social, eliminando con ello toda pretensión de explicación funcional supraindividual. Por evolución se entiende aquí un proceso de selección racional de los valores y creencias en consonancia con las nuevas situaciones sociales creadas: la Sociología consiste en el estudio sistemático y riguroso de las relaciones sociales que establecen los individuos entre sí como también de los grupos, instituciones y estructuras que de esas relaciones se derivan. Ello

* William I. Thomas (1928): The child in America: Behavior Problems and Programs. N.Y.: Knopf. PP: 571-572. Traducción de la sentencia: "Si las personas definen las situaciones como reales, éstas son reales en sus consecuencias".

De forma más genérica podría decirse que este enfoque concuerda con cualquiera de las distintas variantes del llamado individualismo metodológico. 
significa que los cambios sociales deben explicarse partiendo de la naturaleza y significado de las relaciones sociales prevalecientes en cada época. En el caso de Galicia por ejemplo, se observa una evolución de las creencias acerca de los valores más importantes que deben inculcarse a los hijos: de la obediencia y la fe religiosa se ha pasado a la responsabilidad y la tolerancia. Esta evolución es interpretada como una respuesta adaptativa de la sociedad a las nuevas situaciones familiares y sociales. El hecho de que las creencias y los valores sean considerados como respuestas adaptativas no menoscaba la racionalidad de las mismas, pues entre los humanos, lo más frecuente es que la adaptación a la situación se produzca mediante un proceso cognitivo, el cual tiene su expresión en las "buenas razones" que las personas tienen para actuar en un sentido $\mathrm{u}$ otro $^{2}$.

En consecuencia el estudio de las creencias y los valores de una sociedad se convierte en un aspecto nuclear de cualquier programa científico que aspire a comprender a fondo los cambios sociales, su sentido y su significado. El análisis de los valores sitúa al estudioso en una buena posición para diagnosticar las fortalezas y debilidades de la sociedad gallega en un mundo globalizado y plagado de turbulencias.

El análisis sistemático y secuencial (evolutivo) de los valores y creencias en la sociedad gallega puede arrojar luz sobre sus capacidades culturales a la vez que previene de posicionamientos retóricos anclados en el prejuicio o el estereotipo. El lector podrá constatar a lo largo del libro que la sociedad gallega mantiene valores y creencias muy similares a los de su entorno cultural, tanto si se refiere a España como a Europa u Occidente. Pero esta semejanza no oculta determinadas diferencias sustantivas y de ritmo en la evolución del cambio social. La sociedad gallega, como cualquier otra, no es uniforme ni se puede encasillar en conceptos extraídos de la literatura o la historia. Es cierto que la historia compartida contribuye a configurar los valores y creencias de una sociedad, pero también es cierto que las creencias y los valores cambian de significado a medida que las personas ven incrementada su autonomía personal y se "desvinculan" de las tradiciones y las estructuras de la modernidad. El proceso de individualización, esto es, el proceso en virtud del cual las personas se sienten emancipadas de las estructuras tradicionales (clase, estatus, partido, Iglesia, etc.) y configuran su propia escala de valores, está muy avanzado en la Galicia del siglo XXI; probablemente en mayor grado de lo que podría sospecharse a la luz de las cifras de encuesta. En este sentido puede afirmarse que una nueva sociedad emerge, coexistiendo todavía con la que está en proceso de descomposición. Sería un error considerar que esta división responde a la vieja dicotomía de las "dos Galicias", la tradicional y la progresista, pues probablemente ambas forman parte ya de la vieja modernidad. La posmodernidad

\footnotetext{
Véase a este respecto Raymond Boudon (1995): Le juste et le vrai. Ed. Fayard, Francia.
} 
se caracteriza por el abandono de las metanarrativas ideológicas en el ámbito científico-académico. La secularización, la individualización y el hedonismo conducen a planteamientos menos dogmáticos y más inmediatos. La sociedad de consumo y de la información ha situado a las masas en primer plano, porque de alguna manera son ellas las que consumen y a las que va dirigida la información. Todo ello conlleva un desplazamiento de los centros de poder que hace irreconocible la vieja pirámide que representaba todo el poder en la cúspide y nada en la base. La autoridad se encuentra en entredicho y cuestionada siempre, sea cual sea el ámbito en el que se manifieste, y debe responder a criterios de eficiencia y democracia.

Desde mediados de los años 90 un grupo de profesores de la Universidade da Coruña (hoy constituidos como grupo OSIM: www.osimudc.es) ha venido desarrollando una línea de investigación sobre la evolución y desarrollo de los valores sociales en Galicia, en una perspectiva comparada con España y Europa. La presente obra es el resultado de estos estudios y, en concreto, de tres proyectos de investigación financiados por la Xunta de Galicia y el Ministerio de Educación y Ciencia ${ }^{3}$.

El propósito de estos proyectos era configurar una base de datos lo suficientemente amplia en el tiempo que permitiera analizar la evolución de los valores sociales en Galicia. Al mismo tiempo era necesario adoptar una perspectiva comparada con nuestro entorno cultural más próximo, España y los países de la Unión Europea, con el fin de poder situar el sistema de valores de Galicia en un mundo globalizado. Para la consecución de estos objetivos se utilizó el cuestionario de la Encuesta Mundial de Valores, cuya aplicación a la realidad gallega permite la comparación con otros países.

En el presente libro se recogen los hallazgos obtenidos de los datos de tres oleadas de encuestas realizadas en Galicia los años 1995, 2001 y 2008. El resultado final es la descripción y representación de una Galicia que, alejada de los estereotipos y tópicos de siempre, no escapa al impacto de la globalización, cuyos efectos se hacen sentir en aspectos clave de su sistema de valores como son la moral, la religión, la política, la economía y la familia. Todos estos aspectos son analizados por sus autores respectivos a la luz de las tendencias que revelan los datos.

Estimamos que el presente libro, por su temática y metodología, puede resultar de gran interés para los estudiosos de las ciencias sociales por dos motivos: (a) porque en él encontrarán por primera vez datos referidos a los valores de la población gallega y su evolución temporal y (b) porque la exposición de estos datos

En 1993 se publicó un libro sobre las valores de la juventud gallega (A mocidade galega editado por la Xunta de Galicia). Los tres Proyectos de investigación son por orden cronológico: Desarrollo económico y cambio cultural en Galicia I y Desarrollo económico y cambio cultural en Galicia Il, financiados ambos por la Xunta de Galicia y Tendencias sociales en Galicia: un análisis comparado de los valores sociales, morales, políticos y económicos financiado por el MEC (SEJ2005-06585). 
es realizada teniendo en cuenta el rigor interpretativo a la luz de las corrientes teóricas más relevantes en ciencias sociales. Pero el libro también ofrece utilidad para las personas del público en general que están interesadas en la evolución de la realidad gallega. En sus páginas probablemente encontrarán confirmación o desafío a algunas de sus creencias sobre esta realidad. Puede decirse también que su lectura brinda un material de gran provecho para los estudiantes universitarios de la rama de las ciencias sociales y jurídicas. 


\section{MODERNIZACIÓN Y CAMBIO CULTURAL EN GALICIA}

José Luis Veira Veira

\subsection{MODERNIZACIÓN Y DESARROLLO HUMANO}

Para comprender el cambio cultural de cualquier sociedad del mundo occidental desarrollado es preciso partir del concepto de modernización. Desde la Ilustración y la Revolución Industrial y a lo largo de los siglos XIX y XX, las sociedades industrializadas experimentaron cambios profundos en los ámbitos de la economía, la tecnología, el sistema de creencias y los estilos de vida. En el plano del conocimiento, estos cambios suscitaron además la aparición de las dos teorías sociales más importantes e influyentes sobre la interpretación correcta de dichas transformaciones: las teorías de Marx y de Weber. La primera atribuía a las transformaciones económicas y tecnológicas el cambio cultural e institucional, y la segunda refinaba esta apreciación advirtiendo la importancia de los valores en el proceso de racionalización y de institucionalización de un nuevo sistema político y de dominación. Aunque ambas teorías tuvieron sus defensores y detractores, puede considerarse que una y otra estaban en lo cierto en lo fundamental, esto es, que existe un estrecho vínculo entre los valores sociales y el desarrollo socioeconómico.

Sin embargo, en la segunda mitad del siglo XX la teoría de la modernización parecía incapaz de dar cuenta de las nuevas transformaciones promovidas por la expansión de las nuevas tecnologías de la información y la globalización socioeconómica. La aparición de nuevas formas de entender el arte, la arquitectura y el cine propiciaron la difusión de corrientes teóricas en el campo del pensamiento filosófico y de las ciencias sociales, y que resumidamente se pueden aglutinar en torno al concepto de postmodernismo ${ }^{1}$. El advenimiento de la sociedad del conocimiento, la informática y en general la globalización provocaron un cierto

En los campos de la filosofía y las ciencias sociales Francia ofreció el grupo más nutrido de pensadores que pueden ser considerados como la vanguardia del postmodernismo: Foucault, Lyotard, Deleuze, Baudrillard, F. Jameson y Derrida entre otros. Todos ellos de inspiración marxista pero al mismo tiempo con intención de romper con la interpretación ortodoxa. 
decaimiento de la teoría de la modernización, juzgada insuficiente para explicar la nueva realidad emergente. Las corrientes postmodernistas intentaron suplir esta carencia recurriendo a nuevas reformulaciones e interpretaciones de la vida social, centrando su atención no tanto en los elementos comunes y universales como en lo particular y diverso. El postmodernismo se convierte así en un intento de interpretar la nueva realidad social actual, compleja, cambiante, flexible y contradictoria, pero que no acaba de suscitar un mínimo de consenso en torno a la atribución de un significado a la nueva situación. En realidad el postmodernismo suscitó interesantes y decisivas aportaciones en las artes, la arquitectura y el cine, configurando nuevos estilos de vida. En el terreno de las ciencias sociales sin embargo, su influencia, aunque importante, se limitó a ciertos aspectos parciales de la realidad social buscando la petit récit. En general el postmodernismo tuvo que lidiar con los nuevos tiempos en los que la ciencia ya no ofrecía seguridades como antaño y la consiguiente pérdida de fe en el progreso tecnológico (Lyotard, 1984) convirtiendo en problemáticas todas las fuentes del conocimiento.

Para el postmodernismo, una nueva cultura, un nuevo sistema de creencias y nuevos estilos de vida han emergido en la segunda mitad del siglo XX. Su empeño consiste en identificar los aspectos de esta nueva cultura. En la práctica ello supuso definir el postmodernismo en contraste con la modernidad. Así se pusieron en entredicho conceptos tales como "progreso" o "universalidad de creencias y valores" y se dirigió la atención a aquellos aspectos de la realidad social que marcaban diferencias particulares frente al universalismo; se buscó también lo local en lo global y, en general, se adoptó una postura contraria a toda pretensión metanarrativa como la de Marx o cualquier otra teoría con pretensiones de universalidad. Todo esto implicó además una crítica a la "visión occidental" del mundo, e introdujo un relativismo moral no exento de nihilismo en muchos casos.

Sin embargo el postmodernismo, a pesar de sus aciertos en la descripción y explicación de la vida social en las sociedades del hiperconsumo, del individualismo y el hedonismo (Lipovetsky, 1994) no logró todavía un consenso acerca del significado de todos estos cambios experimentados en las sociedades capitalistas avanzadas. En consecuencia aparecen dos posicionamientos respecto a lo que las teorías postmodernistas representan en la actualidad: (a) la posición de los defensores que ven el postmodernismo como el advenimiento de una nueva era que rompe con todo lo anterior y nos sitúa en una nueva condición social y existencial, requiriendo interpretaciones y análisis innovadores que arrinconen toda pretensión metanarrativa; (b) la posición de los detractores o críticos, que considera el postmodernismo bien como una de las manifestaciones culturales propias del modo de producción del capitalismo tardío ${ }^{2}$ con sus secuelas de

\footnotetext{
El primer sociólogo que empleó la expresión de "capitalismo tardío" fue el alemán Sombart, queriendo expresar con ella la paulatina pérdida de valores "empresariales", tales como la competitividad y el gusto por el riesgo. Por su parte F. Jameson utilizó este mismo término pero para referirse al capitalismo actual, por cuya razón se le atribuye, erróneamente, la paternidad del concepto.
}

\section{LA EVOLUCIÓN DE LOS VALORES SOCIALES EN GALICIA}


flexibilización, fragmentación de mercados, individualismo e hiperconsumo (Jameson, 1984) o bien como una ideología propia del capitalismo global (Harvey, 1989), e incluso como una nueva modernidad, emancipada de la falsa conciencia (Bauman, 1992).

En el año 2005 Ronald Inglehart y Christian Welzel presentan una proposición revisada de la teoría de la modernización aportando evidencias empíricas a partir de una base de datos impresionante que contiene información acerca de 81 sociedades, que representan el 85\% de la población mundial, desde 1981 hasta 2002 (Inglehart, R. y Welzel, Ch.; 2005; 2006). Esta teoría revisada de la modernización interpreta el cambio social contemporáneo "como un proceso de desarrollo humano que está produciendo cada vez más sociedades que dan más importancia a la libertad humana y a la autoexpresión. Un robusto cuerpo de datos transnacionales demuestra que: (a) la modernización socioeconómica, (b) el giro cultural hacia un mayor énfasis en los valores de la autoexpresión y (c) la democratización son componentes de un proceso singular y fundamental: el desarrollo humano. El principal tema de este proceso es la ampliación de la elección humana. La modernización socioeconómica reduce las constricciones externas a la elección humana a través del aumento de los recursos naturales, sociales y cognitivos de las personas. Esto conduce a un mayor énfasis de las masas en los valores de la autoexpresión, algo que, a su vez, genera un aumento de la demanda del público de libertades civiles y políticas, igualdad de género y un gobierno responsable, contribuyendo a instaurar y mantener instituciones más adecuadas para maximizar la elección humana: la democracia" (Inglehart y Welzel, 2006: 2-3).

Esta nueva interpretación de la modernidad basada en evidencias empíricas contiene al menos tres puntos clave: (a) ya no se hace referencia al concepto de progreso - lo cual marca una diferencia con la teoría clásica de la modernización-que es sustituido por el de desarrollo humano; (b) se pone el énfasis en la importancia de los nuevos valores como generadores de renovación institucional de las aspiraciones democráticas de las masas y (c) no se menciona para nada el concepto de postmodernidad — no aparece este término en ningún lugar de la obra- lo cual da a entender que no es preciso recurrir a esta noción para abordar el análisis de la nueva realidad social.

Los dos primeros puntos clave son el objeto de exploración en la Encuesta Mundial de Valores (EMV) aplicada en Galicia. De este modo se pudo comprobar y medir la intensidad y el alcance del proceso de modernización en Galicia en una perspectiva comparada con países de su entorno cultural. El hecho de que Galicia no haya pasado un proceso de industrialización comparable al de Inglaterra o Francia, tiene un interés añadido para testar la importancia de los valores como fuerza autónoma en las transformaciones democráticas que protagonizaron su historia reciente. Asimismo, la circunstancia de que la nueva teoría revisada de la modernización ponga el énfasis en el "desarrollo humano" y no solo en el "progreso 
económico" posibilita el análisis comparado entre sociedades de distintos niveles de desarrollo. La definición de la modernización como un proceso de desarrollo humano favorece una interpretación más completa de los cambios acaecidos en sociedades que, como la gallega, no pasaron por una fase de industrialización intensiva.

\subsection{LOS VALORES DE LA AUTOEXPRESIÓN EN GALICIA EN UNA PERSPECTIVA COMPARADA}

Siguiendo esta teoría revisada de la modernidad, y de acuerdo a los datos proporcionados por los sondeos internacionales, los nuevos valores concomitantes con la fase postindustrial de los países occidentales son los denominados valores de la auto-expresión: "estos valores dan creciente importancia a las libertades políticas y civiles de la democracia, que ofrece más libertad a las personas para perseguir la libertad de expresión y la autorrealización. Los nuevos valores de la auto-expresión transforman la modernización en un proceso de desarrollo humano al fomentar una sociedad que está cada vez más centrada en las personas. He aquí un reflejo de una transformación humanista de la modernidad" (Inglehart y Welzel, 2006: 3).

Estos valores, que podrían ser considerados como valores de la postmodernidad, se identifican en la Encuesta Mundial de Valores con las siguientes dimensiones: (a) El cambio de valores materialistas a posmaterialistas; (b) El proceso de individualización, medido en términos de un mayor sentimiento de control sobre la propia vida, un aumento de la autonomía individual y mayores aspiraciones de libertad y (c) El cambio de rol atribuido a la mujer.

\subsubsection{Los valores posmaterialistas}

El paulatino incremento de los valores posmaterialistas en Europa y Estados Unidos a partir del final de la II Guerra Mundial fue considerado como una "revolución silenciosa" (Inglehart, 1977). La denominación de "silenciosa" proviene del hecho de que es un cambio de mentalidad y de creencias que afecta a todas las clases y grupos sociales sin mediar ruido de sables. Y se considera una revolución porque a largo plazo significa una ruptura con las instituciones sociales tradicionales. La base empírica en la que se fundamenta la existencia de una revolución silenciosa la provee una larga serie de encuestas llevadas a cabo en todo el mundo - en más de 40 países - desde 1977 hasta nuestros días (Inglehart, 1977; 1991; 1994; 1998). Para ello, Inglehart ideó una escala de valores sociales y políticos que permitiera cuantificar el cambio operado en los distintos países en los que se aplicó la encuesta. Esta escala tiene su fundamento teórico en la Teoría de la Jerarquía de las Necesidades de Maslow ${ }^{3}$ (1954), la cual establece que la conducta humana está estrechamente ligada a la satisfacción de las necesidades ya sean de orden

La tesis del posmaterialismo de Inglehart se basa explícitamente en la teoría de la jerarquía de las necesidades de Maslow, según la cual las necesidades de orden superior como la autorrealización, el reconocimiento, la autoestima, la afiliación o la comunicación (vinculadas a valores no materiales) no aparecen como motivadoras de la conducta hasta que están relativamente satisfechas las necesidades de orden inferior como la supervivencia y la seguridad (vinculadas a valores materiales de existencia). 
fisiológico, como la comida, la vivienda y la seguridad, o de orden espiritual, como las necesidades de relación, comunicación o autorrealización. A las primeras, según Inglehart, se les puede llamar necesidades materiales y se corresponderían con valores materialistas, mientras que a las segundas corresponderían los valores posmaterialistas. La teoría subraya que una persona o un grupo tenderán a acrecentar su orientación posmaterialista a medida que son satisfechas sus necesidades materiales. Según esto, una sociedad económicamente desarrollada, debería mostrar una mayor difusión de los valores posmaterialistas entre su población, que una sociedad no desarrollada o en vías de serlo.

Ahora bien, si el porcentaje de población con valores posmaterialistas aumenta a medida que crece el producto interior bruto, ¿qué sucederá si decrece el producto interior debido a una crisis económica por ejemplo? ¿Disminuirá también el porcentaje de posmaterialistas? En caso afirmativo habrá que suponer que el cambio de valores no se produce de forma sostenida en el tiempo sino que dependerá de la coyuntura económica. Inglehart, sin embargo, mantiene que el cambio de valores se mantendrá a pesar de las crisis económicas, debido a que los individuos que crecieron en períodos de abundancia económica y estabilidad política — como es el caso de las generaciones nacidas después de la II Gran Guerra en Europa y Estados Unidos- y que fueron aleccionadas en valores posmaterialistas tenderán a mantener en su edad adulta esos mismos valores. Dicho de otro modo: para Inglehart el cambio de valores es generacional y por lo tanto, se puede hablar de un cambio de valores sin vuelta atrás, de tal modo que el diferencial entre posmaterialistas y materialistas siempre crecerá a favor de los primeros aunque puedan darse períodos en los que, debido a crisis económicas o políticas, esta diferencia puede verse mermada. Dos hipótesis avalan, según Inglehart, el cambio de valores en las sociedades industriales avanzadas: la hipótesis de la escasez y la hipótesis de la socialización.

Según la hipótesis de la escasez, los individuos cuya infancia y adolescencia transcurre en un ambiente de escasez económica y/o inestabilidad política valorarán más aquellos aspectos de la vida que confieren seguridad y estabilidad (valores materialistas), mientras que las personas criadas en un ambiente de prosperidad económica y estabilidad política pondrán más énfasis en los valores posmaterialistas como la calidad de vida, la autorrealización o la participación política (también denominados por Inglehart "valores de autoexpresión"). En principio, esta hipótesis parece sugerir que, tal como había afirmado Marx mucho antes, las condiciones materiales de existencia determinan los valores sociales; pero esta ley de correspondencia entre circunstancias económicas e ideología (valores en este caso) se matiza, debilitándola, con el enunciado de la hipótesis de la socialización. Pues, según esta hipótesis, las personas tienden a mantener en sus vidas adultas los valores que les fueron inculcados en su juventud, de manera que el cambio de valores se producirá finalmente, con independencia de los avatares económicos. 
Aunque estas hipótesis se mueven en un nivel individual (micro), Inglehart transfiere sus conclusiones a un nivel macro implicando una teoría del cambio social: el cambio social operado en las sociedades industriales avanzadas viene inducido por un cambio de valores, cuyo origen hay que encontrarlo en un largo período de bienestar económico y estabilidad política como el experimentado por las generaciones nacidas después de la II Guerra Mundial.

Para evaluar el grado y el alcance de este cambio de valores, Inglehart elaboró un índice de 12 items para medir el nivel de posmaterialismo en cada sociedad, según se muestra en el siguiente cuadro:

Tabla 1.1. Ítems de la dimensión materialismo/posmaterialismo.

\begin{tabular}{|c|c|}
\hline Ítems materialistas & Ítems posmaterialistas \\
\hline $\begin{array}{l}\text { Mantener un alto nivel de } \\
\text { crecimiento económico }\end{array}$ & $\begin{array}{c}\text { Lograr que la gente pueda participar más en cómo } \\
\text { se hacen las cosas en su comunidad y lugar } \\
\text { de trabajo }\end{array}$ \\
\hline $\begin{array}{l}\text { Asegurar que este país tenga unas fuerzas } \\
\text { armadas importantes }\end{array}$ & $\begin{array}{c}\text { Intentar que nuestras ciudades y nuestro campo } \\
\text { sean más bonitos }\end{array}$ \\
\hline Mantener el orden en el país & $\begin{array}{l}\text { Dar a la gente mayor participación en las } \\
\text { decisiones importantes del gobierno }\end{array}$ \\
\hline Luchar contra la subida de precios & Proteger la libertad de expresión \\
\hline Una economía estable & $\begin{array}{c}\text { Avanzar hacia una sociedad menos impersonal y } \\
\text { más humana }\end{array}$ \\
\hline La lucha contra la delincuencia & $\begin{array}{c}\text { Avanzar hacia una sociedad donde las ideas sean } \\
\text { más importantes que el dinero }\end{array}$ \\
\hline
\end{tabular}

Fuente: Elaboración propia a partir de Inglehart, 1997.

Cada uno de estos items expresa un objetivo nacional que ha de ser elegido por el entrevistado en un orden de preferencias, de manera que un materialista puro sería aquel que elige en primer lugar todos los objetivos de la columna de la izquierda y un posmaterialista puro sería el que elige los de la columna de la derecha. Naturalmente caben posiciones intermedias en una escala de 0-5, indicando el grado de posmaterialismo en cada caso.

La evolución de los valores posmaterialistas en Galicia, España y Europa

Los datos revelan similitudes y diferencias entre Galicia y España (Tabla 1.2 y gráficos 1.1 y 1.2). Tanto en Galicia como en España sobrevino un descenso de los valores posmaterialistas a lo largo de los tres años consultados. Este descenso de los valores posmaterialistas tiene como contrapartida lógica un incremento de los valores materialistas que, en el caso de Galicia, es aún mayor que en el de España. Esta "vuelta al materialismo" no se ajusta a lo esperado por la teoría

\section{6}


que predice un incremento constante del posmaterialismo en el tiempo. En cualquier caso, este giro al materialismo puede ser atribuido sencillamente a los efectos de la crisis económica que ya se empezaron a sentir a finales de 2006 y a lo largo de $2007^{4}$. Si bien la teoría predice los efectos coyunturales de las crisis económicas en la evolución de los valores posmaterialistas, resulta difícil atribuir en exclusiva a este hecho el descenso observado en Galicia y España en el período de 13 años que abarcaron las tres consultas. La cuestión probablemente es más compleja.

Tabla 1.2. Evolución del posmaterialismo en Galicia y en España.

\begin{tabular}{cccc} 
& Galicia 1995 & Galicia 2001 & Galicia 2008 \\
\hline Materialista & 6,2 & 7 & 13,1 \\
\hline 1 & 19,7 & 13,4 & 24,1 \\
\hline 2 & 24,5 & 27,2 & 28,8 \\
\hline 3 & 25,9 & 31,5 & 23,0 \\
\hline 4 & 15,5 & 14,5 & 8,0 \\
\hline Posmaterialista & 8,3 & 6,3 & 3,0 \\
\hline & España 1995 & España 2000 & España 2007 \\
\hline Materialista & 5,7 & 7,5 & 17,6 \\
\hline 1 & 16,1 & 17,8 & 28,3 \\
\hline 2 & 22,9 & 24,9 & 24,2 \\
\hline 3 & 28,7 & 29,3 & $\mathbf{1 4 , 1}$ \\
\hline 4 & 12,6 & 15,7 & 2,9
\end{tabular}

Fuente: EMV-ASEP España y EMV-Galicia. Elaboración propia.

En primer lugar, es preciso contemplar los datos de Galicia y España en una perspectiva comparada con otros países europeos y, en segundo lugar analizar algunos de los determinantes sociales del posmaterialismo con el fin de predecir si el giro hacia el materialismo es coyuntural debido a la crisis económica o por el contrario, cabe esperar una progresiva recuperación del posmaterialismo debido a los efectos generacionales.

\footnotetext{
$4 \quad$ En mayo de 2007 estalla en Galicia una huelga salvaje de 15 días de duración de los trabajadores del naval en Vigo y los mariscadores ferrolanos que boicotearon la planta de Reganosa a lo largo de todo el año, culminando con una manifestación multitudinaria en septiembre.
} 

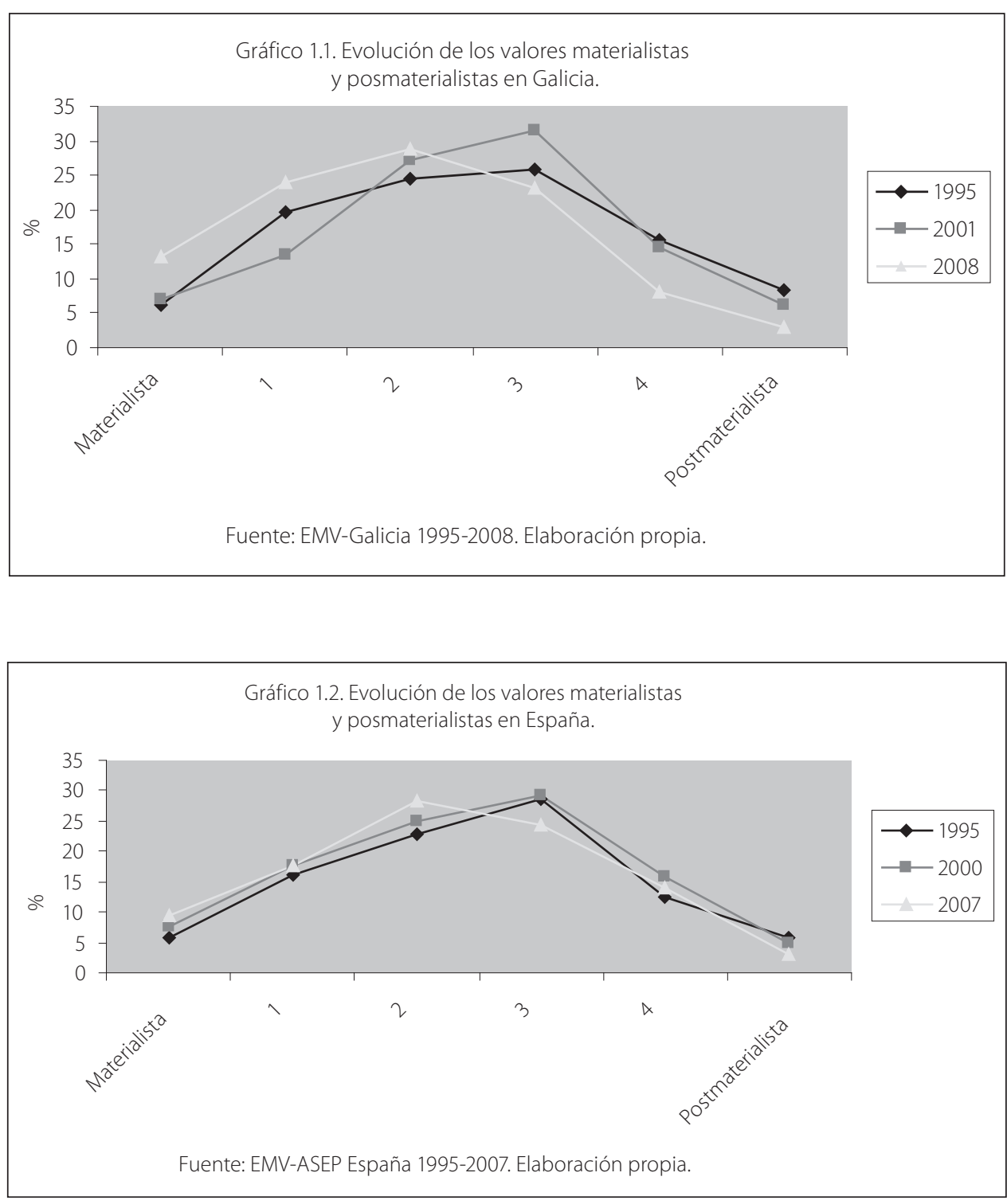

En el Gráfico 1.3 se muestra información acerca de los porcentajes de posmaterialistas para distintos países europeos incluyendo España y Galicia. En esta comparación internacional podemos observar que se cumple lo esperado: los países más ricos arrojan mayores índices de posmaterialismo, con excepción del caso finlandés, cuyos porcentajes corresponden a 2005. Galicia y España ocupan lugares modestos en la escala. Según esto resulta fácil comprender que la difusión de los valores posmaterialistas en Galicia sea precaria y fácilmente influenciable por la crisis económica. Lo mismo puede decirse de España. 


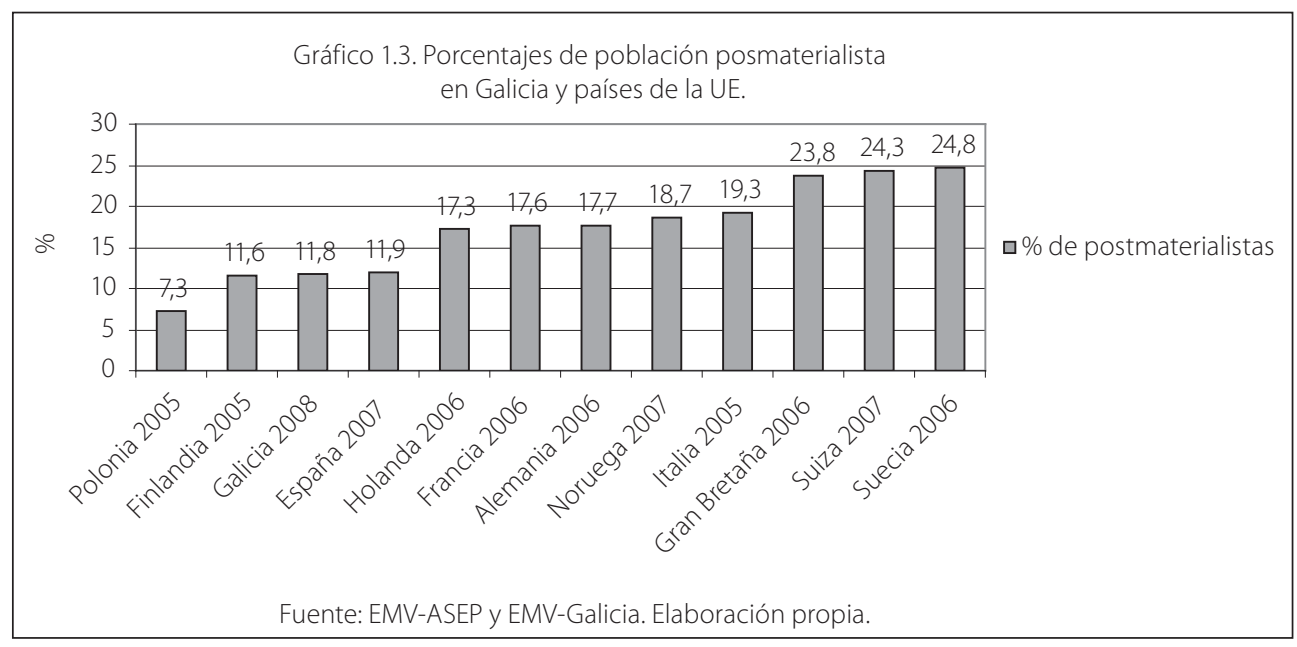

Una nueva perspectiva sobre el "giro hacia el materialismo" observado en estos años puede obtenerse si se utiliza una escala de tres categorías en las que se pueda matizar algo más el grado de compromiso con los valores materialistas o posmaterialistas. Para ello se ha utilizado una escala de 4 items: (1) Mantener el orden en la nación (valor materialista); (2) Aumentar la participación de los ciudadanos en las decisiones importantes de gobierno (valor posmaterialista); (3) combatir la subida de precios (valor materialista) y (4) Proteger la libertad de expresión (valor posmaterialista). Estos cuatro indicadores de la escala dan lugar a cuatro posicionamientos que se ordenan de la siguiente manera ${ }^{5}$ :

- Materialistas: aquellas personas que eligieron en primer y segundo lugar dos indicadores materialistas.

- Posmaterialistas: aquellas personas que eligieron en primer y segundo lugar dos indicadores posmaterialistas.

- Mixtos con orientación materialista: aquellas personas que eligieron en primer lugar un indicador materialista y en segundo lugar otro posmaterialista.

- Mixtos con orientación posmaterialista: aquellas personas que eligieron en primer lugar un indicador posmaterialista y en segundo lugar un indicador materialista.

En los gráficos 1.4 y 1.5 puede verse la distribución de la población según esta nueva escala en Galicia y en España para los años consultados. En ambos gráficos la distribución es similar, aunque existe una mayor incidencia del posmaterialismo en Galicia que en España si exceptuamos el último año de consulta (2008 para Galicia y 2007 para España). Un hecho relevante es que, en todos los sondeos efectuados, las categorías mixtas son las que arrojan porcentajes más altos. Ello indica que la mayor parte de la población trata de conciliar ambos tipos de valores

5 Esta escala fue utilizada por primera vez en 1993 por la profesora Celia Muñoz Goy en el Informe sobre la Juventud Gallega (Veira, Muñoz y Míguez, 1993). Por su parte Welzel utilizó recientemente la misma escala con fines parecidos (Welzel, 2007). 
y su orientación varía según la coyuntura económica. Si se suman los mixtos de orientación posmaterialista a los posmaterialistas puros y los mixtos de orientación materialista a los materialistas puros puede verse que las cifras entre Galicia y España se aproximan más, hasta el punto de casi coincidir en los dos últimos años: 30,8\% de posmaterialistas y mixtos en Galicia y 31,8\% en España.
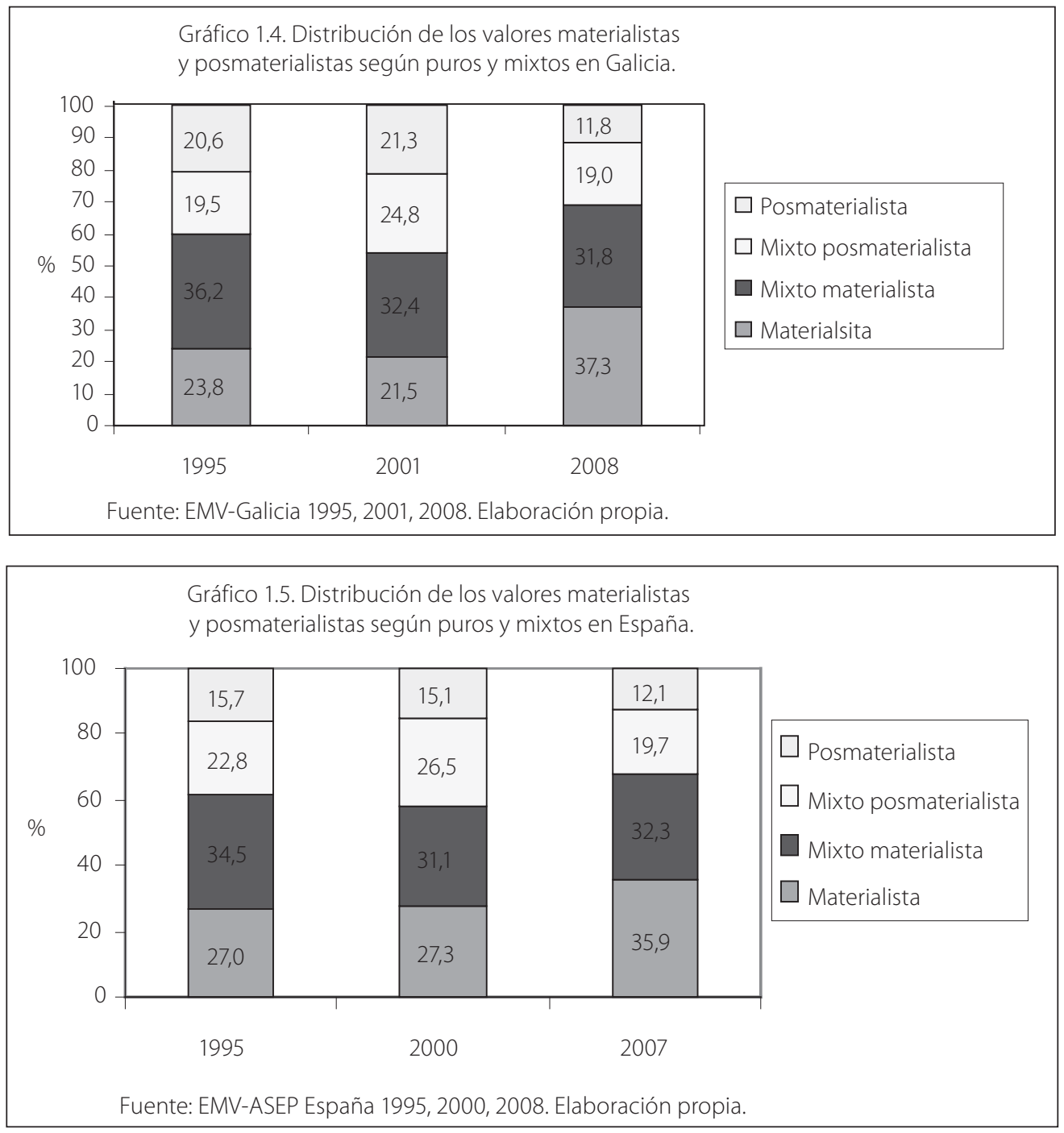

Pero, en cualquier caso, es evidente que la "franja posmaterialista" (la formada por la suma de los posmaterialistas puros y los mixtos de orientación posmaterialista) se ensancha en los años 2001 (Galicia) y 2000 (España) con respecto a la primera consulta (año 1995) acorde con lo esperado por la teoría, pero luego se contrae en los años 2007 (España) y 2008 (Galicia) interrumpiendo esta tendencia. Todo induce a pensar que la crisis económica está detrás de este giro hacia el materialismo. 


\subsubsection{El proceso de individualización}

Aunque la idea de una sociedad en creciente individualización ya fue un tema tratado por la sociología clásica (Tocqueville, Durkheim y Simmel entre otros) ha sido reavivado recientemente por el sociólogo alemán Ulrich Beck en su "tesis de la individualización" (Beck, 1992). Para este autor la modernización se da en dos fases, la simple y la reflexiva; la primera de ellas, que se inicia con la Revolución Industrial y el consiguiente desarrollo económico, se caracteriza por un proceso de "desincrustación" (disembedding) del individuo respecto a estructuras sociales tradicionales: en esta fase del proceso de individualización el individuo se libera de ataduras del pasado de modo que adquiere más autonomía en el ámbito de sus creencias y valores. La Iglesia o la Tradición ya no son tomadas como guías preferentes de la conducta y las estructuras jerárquicas tradicionales son postergadas. Pero este proceso de individualización correspondiente a la primera modernización tiene dos importantes limitaciones: por un lado, no afecta a todos por igual, y por otro se acompaña de un nuevo proceso de "re-incrustación" (reembedding) del individuo a nuevas estructuras emergentes. Así por ejemplo, las mujeres no se benefician del proceso de emancipación general en los mismos términos que los varones, siendo confinadas a la estructura familiar y privadas del acceso al mercado laboral. Además, surgen nuevas estructuras de identidad como las clases sociales.

Será en la fase reflexiva de la modernización cuando se intensifica el proceso de individualización de modo que el individuo llega a ser la unidad central de la vida social (Beck, 2002). En esta fase se produce una nueva "desincrustación" (disembedding) del individuo respecto a las estructuras propias de la modernización clásica. El caso más evidente es el de la emancipación de la mujer y la desaparición del rol femenino vinculado exclusivamente a la vida familiar. Por su parte, las clases sociales también pierden fuerza estructurante. Como consecuencia de todo ello, nos encontramos con una sociedad fuertemente individualizada, donde las personas se emancipan de los vínculos tradicionales, aumentando sus opciones de elección. En esta nueva fase de la modernización los individuos adquieren mayor autonomía en la toma de decisiones relativas a su vida social cotidiana y a sus proyectos vitales ${ }^{6}$.

Los datos facilitados por la EMV permite medir la intensidad del proceso de individualización en la sociedad a través de tres variables: el sentimiento de control y dominio sobre la propia vida, el índice de autonomía individual y las aspiraciones de libertad.

Es preciso señalar que Beck no comparte la idea de que la individualización representa una mayor autonomía real del individuo, pues a su juicio el proceso de individualización mismo es una imposición de las nuevas estructuras emergentes. En este punto no existe unanimidad en la comunidad de sociólogos. Para una posición contraria a la de Beck puede consultarse a R. Boudon (Boudon, 2002: 13-16). 
Libertad de elección y control sobre la propia vida

La capacidad de elegir y de tomar decisiones sobre la propia vida es un componente básico de la individualización, que se caracteriza precisamente por el incremento de las opciones para escoger entre diversas alternativas, sin tener que seguir prescripciones externas dictadas por la tradición o la autoridad de las instituciones sociales. Puede decirse que una sociedad estará tanto más individualizada cuanto mayor sea el porcentaje de población que se siente libre para tomar decisiones que afectan a su vida. Los datos obtenidos para España y Galicia muestran que existe un proceso claro de individualización en este ámbito de la libertad para controlar la propia vida. En los gráficos 1.6 y 1.7 puede apreciarse que tanto en Galicia como en España ha habido un incremento significativo del sentimiento de libertad para controlar la propia vida. En una escala de 1 a 10, donde 1 significa ninguna libertad y control, y 10 mucha libertad y control, las medias para Galicia fueron de 6,6 en 1995, 6,9 en 2001 y 7,3 en el 2008, es decir, han subido constantemente hasta situarse en un nivel superior a la media europea. La misma tendencia se puede observar para España aunque con puntuaciones ligeramente más bajas que las de Galicia (Tabla 1.3).
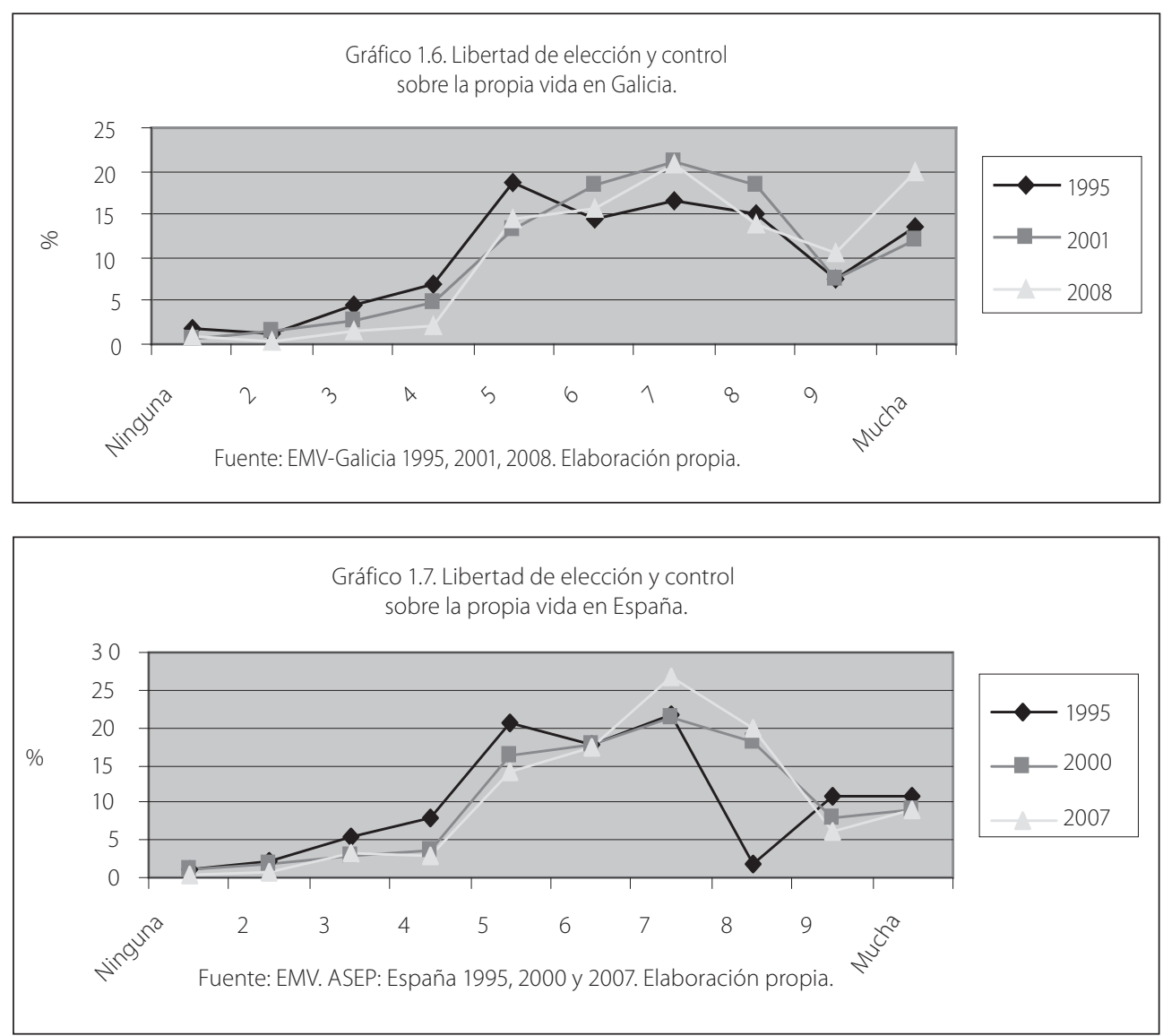
Tabla 1.3. Puntuaciones medias por países del grado de libertad y control sobre la propia vida.

\begin{tabular}{ll}
\hline Suecia 2006 & 7,8 \\
\hline Noruega 2007 & 7,7 \\
\hline Suiza 2007 & 7,6 \\
\hline Finlandia 2005 & 7,5 \\
\hline Gran Bretaña 2006 & 7,3 \\
\hline Galicia 2008 & 7,3 \\
\hline España 2007 & 6,9 \\
\hline Alemania 2006 & 6,8 \\
\hline Francia 2006 & 6,7 \\
\hline Países Bajos 2006 & 6,7 \\
\hline Polonia 2005 & 6,6 \\
\hline Italia 2005 & 6,3 \\
\hline Promedio & 7,1 \\
\hline
\end{tabular}

Fuente: ASEP-EMV y EMV-Galicia. Elaboración propia.

En este caso, a diferencia de lo que pasaba con la evolución del posmaterialismo, los datos referidos a Galicia responden a la predicción teórica de que el proceso de individualización es un fenómeno inevitable y en constante aumento (Beck, 2002). Esta supuesta emancipación de los individuos respecto a las estructuras sociales tradicionales es un fenómeno típico de la posmodernidad o, si se quiere, de la modernidad reflexiva. E independientemente de la valoración que se haga del fenómeno, se puede presumir que nos hallamos ante un fenómeno global de "desincrustación" (disembedding) de las estructuras sociales clásicas, como son las clases sociales o determinados roles sociales relacionados con la autoridad o el género. Que este proceso se esté dando en Galicia desmiente en gran parte la imagen, excesivamente difundida, de una Galicia anclada en el pasado e impregnada de creencias y valores propios de una sociedad rural tradicional. La población gallega muestra indicios fuertes de individualización en consonancia con su entorno cultural, España y Europa.

Índice de autonomía individual

El índice de autonomía individual utilizado en la Encuesta Mundial de Valores puede considerarse como otra medida del grado de individualización. Este índice se forma partiendo de la pregunta acerca de la importancia que se le concede a determinadas cualidades que deben ser inculcadas a los niños en el hogar. Estas cualidades son por un lado la "independencia" y la "determinación", que 
se suponen valores individualistas que refuerzan la autonomía personal, y por otro "la fe religiosa" y la "obediencia", a las que se atribuye un efecto reductor de la autonomía individual ${ }^{7}$. En un entorno europeo puede observarse que Galicia y España se sitúan, junto con Polonia, en los últimos puestos de acuerdo con el porcentaje de gente que ha puntuado positivo en la escala, es decir que ha puntuado por encima de 0 (Gráfico 1.8). Este resultado atenúa en parte la impresión de una fuerte individualización detectada en la dimensión sobre el control sobre la propia vida, analizado anteriormente. En este caso parece que la individualización no es tan intensa como cabría esperar. Cualquier hipótesis explicativa es conjetural y de difícil demostración. Pero debe señalarse la coincidencia siguiente: los países católicos suman porcentajes menores de autonomía individual que los países mayoritariamente no católicos, exceptuando el caso de Gran Bretaña.

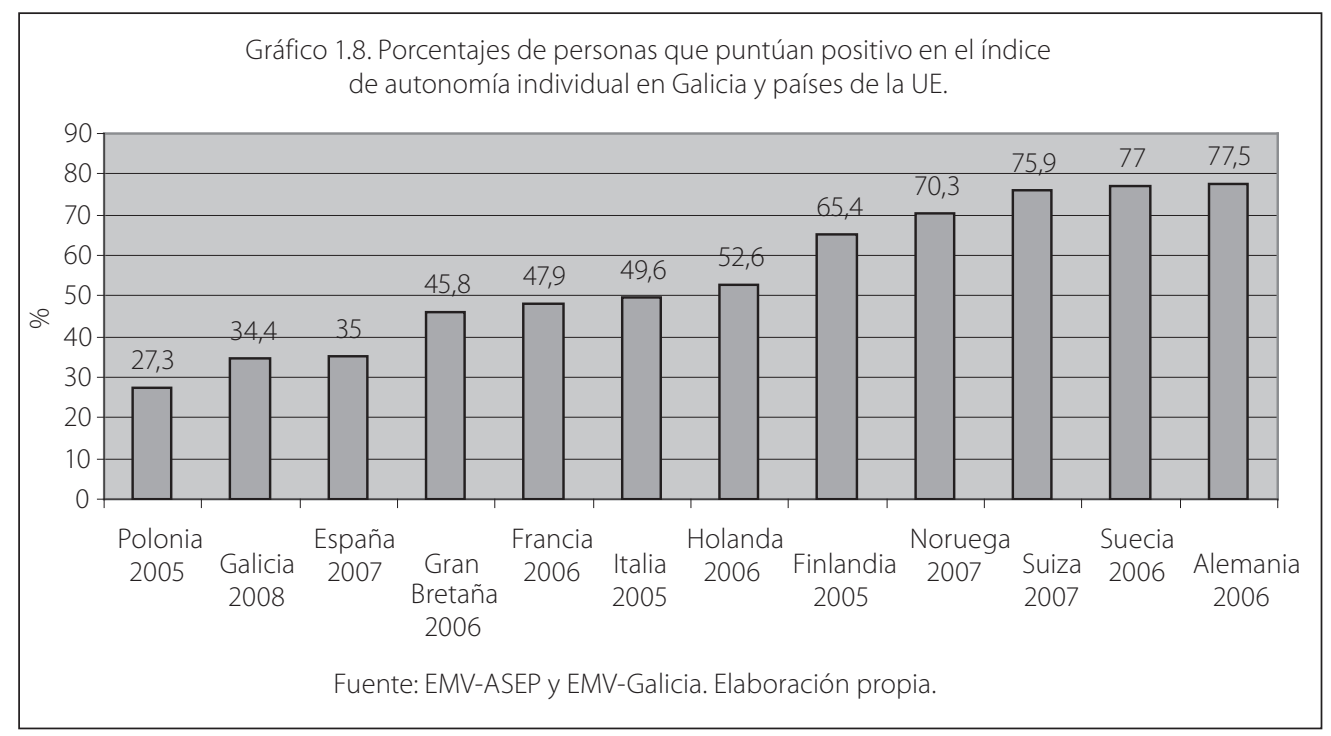

Sin embargo, la tesis de la individualización puede seguir manteniéndose si se tiene en cuenta la evolución del índice de autonomía individual por año de consulta y según cohortes de nacimiento. En Galicia ocurre que en las tres consultas la tendencia es la misma: el índice de autonomía individual crece con las cohortes más recientes, es decir, las más jóvenes (gráficos 1.9 y 1.10). Ello indica que, a pesar de no alcanzar porcentajes similares a los de otros países más individualizados, Galicia se orienta en esta dirección.

\footnotetext{
El índice es elaborado de la siguiente manera: (independencia + determinación) - (fe religiosa + obediencia). Como resultado se obtiene una escala positiva de 0 a 2 y una negativa de 0 a -2 . Los valores negativos indican menor grado de autonomía individual.
} 

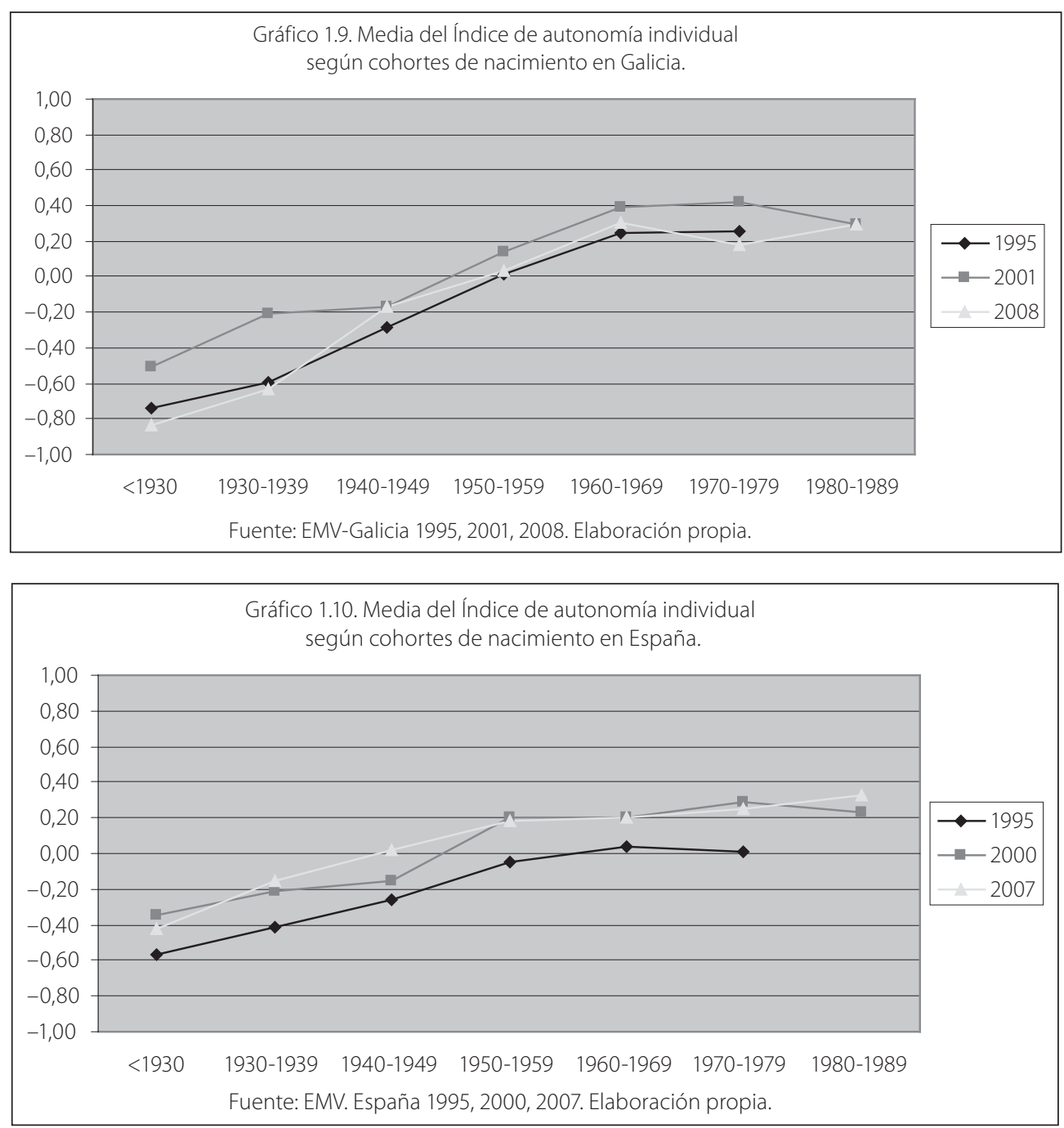

La modernidad individual y las aspiraciones de libertad

En 1978 Alex Inkeles publicó un estudio sobre las diferencias nacionales en la modernidad individual (Inkeles, 1978). La noción de "modernidad individual" quería reflejar las orientaciones psicológicas de los individuos en un contexto de modernidad, entendiendo por ésta no solo la democratización de la política sino también otros aspectos como la industrialización, la burocratización, la racionalización, la secularización, la urbanización y la expansión de la educación. El objetivo era encontrar orientaciones psicológicas universales entre las poblaciones de las sociedades modernas. La hipótesis de Inkeles era que la modernización provoca cambios fundamentales en las orientaciones de la gente. 
Esta hipótesis ha sido probada de forma más extensiva por Inglehart aplicando su teoría del cambio general de valores posmaterialistas. En definitiva, Inglehart pretende mostrar también que la modernización favorece la emergencia de nuevas orientaciones de valor, que él rubrica como posmaterialistas. Ahora bien, existen ciertas dificultades para corroborar que la modernización correlaciona con los valores posmaterialistas, pues, como se ha visto, la gran mayoría de la población se adhiere al materialismo — sobre todo en períodos de crisis - o cuando menos adopta posturas mixtas. Da la impresión de que el posmaterialismo puede ser flor de primavera, que a la menor dificultad circunstancial desaparece.

Christian Welzel aborda esta dificultad matizando que la teoría puede mantenerse si se definen las necesidades de autorrealización de la posición más alta en la escala de Maslow en términos "hedonísticos", es decir, en términos de estilos de vida lujosa, que requiere grandes cantidades de dinero para hacer efectivos los valores posmaterialistas (Welzel, 2007) Aparece así una paradoja: los valores materialistas siempre estarán presentes y nunca serán sustituidos por los valores posmaterialistas, por la sencilla razón de que éstos no pueden realizarse sin aquéllos. Para eludir en parte esta dificultad, Welzel prefiere centrarse en dos de los ítems que componen la batería del índice materialismo-posmaterialismo y que son además los que se han mantenido sin interrupción en todos los cuestionarios de las distintas consultas; estos ítems son "la libertad de expresión" y "dar mayor participación a la gente en la toma de decisiones de sus gobiernos". Estas orientaciones reflejan, según Welzel, actitudes y valores liberales, muy en consonancia con la modernidad individual ${ }^{8}$.

Puede llamarse orientación moderada o fuerte hacia valores libertarios la de aquellos porcentajes de población que puntuaron 2 ó 3 en la escala de "aspiración de libertad". Si se cruzan los resultados así obtenidos con las cohortes de nacimiento se verá que el índice de aspiraciones de libertad crece en relación inversa a la edad; es decir las generaciones más jóvenes muestran una mayor aspiración de libertad que las generaciones mayores (gráficos 1.11 y 1.12) También puede observarse cómo las consultas del 2007 y 2008 para España y Galicia respectivamente arrojan menores porcentajes de población con aspiraciones libertarias moderadas o fuertes. Este hecho regresivo es concomitante con el descenso del posmaterialismo ya observado en el período de crisis e inseguridad económica. La circunstancia de que afecte a todas las generaciones es prueba de que hay un efecto período claro, si bien no desaparecen la diferencias entre las cohortes.

\footnotetext{
El índice de Aspiraciones de Libertad se forma a partir de la escala de materialismo-posmaterialismo donde 2 ítems pertenecen a la categoría materialista (mantener el orden en la nación y luchar contra la subida de precios) y otros 2 a la posmaterialista (proteger la libertad de expresión y dar mayor participación a la gente en las decisiones de gobierno). Las personas que no mencionan ni en primer ni en segundo lugar ninguno de los dos ítems liberales son puntuados con 0; los que atribuyen segunda prioridad a alguno de ellos alcanzan un 1; los que atribuyen primera prioridad a uno de ellos puntúan 2 y puntúan 3 aquellos que mencionan los dos ítems "liberales" como primera y segunda prioridad.
} 

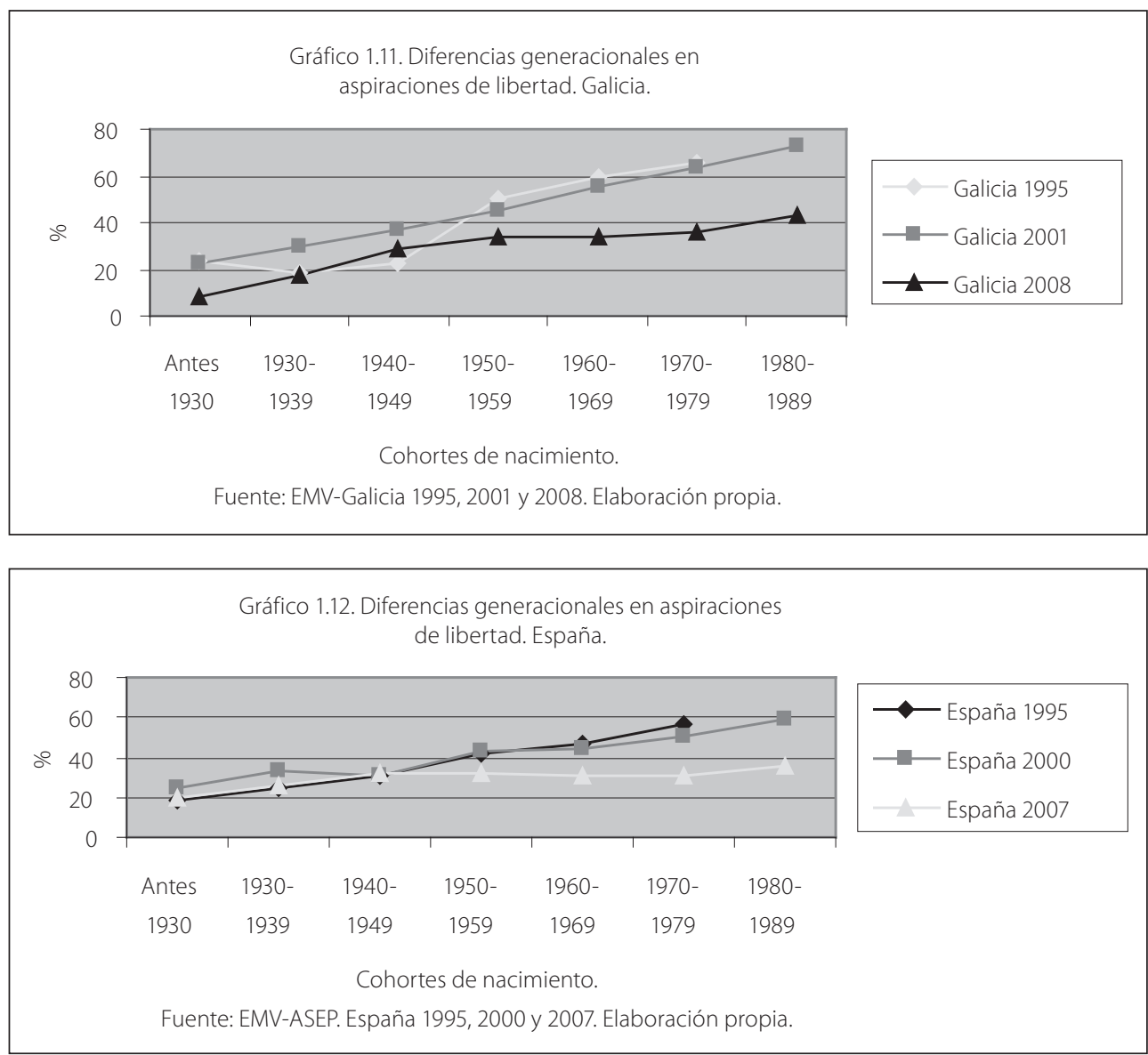

\subsubsection{El cambio de rol femenino}

Uno de los fenómenos más reconocidos por todos los estudios realizados en el ámbito de la sociología del género ha sido la transformación del papel de la mujer en las sociedades industriales y de servicios. Se han señalado múltiples causas para la explicación de este cambio: desde la creciente incorporación de la mujer al mercado laboral hasta la aparición de fármacos que permiten el control de la natalidad, pasando por el incremento del nivel de estudios de las mujeres y la lucha por una mayor autonomía e igualdad de derechos con el varón, por citar solo algunos de los más importantes.

En el contexto de la tesis de la individualización, el proceso de transformación del rol tradicional femenino, que confinaba a las mujeres a las tareas del hogar y a la crianza de los hijos, es visto como un movimiento significativo de "desincrustación" (disembedding) por el cual las mujeres se emancipan de su estatus sexual cuasi-adscrito y les permite obtener mayor autonomía en la planificación de sus biografías. 
En la EMV se utiliza la pregunta "¿Cree Vd. que una mujer necesita tener hijos para realizarse o, por el contrario, cree que ello no es necesario?" con el fin de medir el grado de acuerdo con el rol de la procreación y cuidado de la prole atribuido a la mujer. Bien mirado, resulta de difícil interpretación la respuesta a esta pregunta, sobre todo si consideramos que el hecho de tener hijos puede haber llegado a ser ya un valor de autoexpresión. Hoy en día la procreación no es algo impuesto por el destino o la tradición social sino algo escogido como forma de vida y fuente de autorrealización. De hecho puede llegar a ser uno de los valores de autoexpresión más posmodernos. En cualquier caso, convendrá de momento ceñirse aquí a la interpretación más al uso, que consiste en considerar la autorrealización femenina a través de la procreación como una orientación tradicional del estatus y rol de la mujer.

En Galicia y en España los porcentajes de población que consideran que la mujer no necesita tener hijos para sentirse realizada son algo superiores a los que creen que sea necesario (Tabla 1.4).

Tabla 1.4. Población que cree que una mujer no necesita tener hijos para sentirse realizada (\%).

\begin{tabular}{lcc} 
& 1995 & $\mathbf{2 0 0 0 / 2 0 0 1}$ \\
\hline España & 55,3 & 52,2 \\
\hline Galicia & 57,2 & 54,1 \\
\hline
\end{tabular}

Fuente: EMV-ASEP y EMVG. Elaboración propia.

Los datos parecen corroborar la tesis de la "desincrustación" de la mujer del rol tradicional de la maternidad como fuente exclusiva de realización. Debe notarse sin embargo un ligero descenso de los porcentajes que podría iniciar una tendencia en sentido contrario. Desafortunadamente, esta pregunta no fue incluida en el cuestionario del 2008. Pero no sería sorprendente que en el futuro esta tendencia se invirtiera por las razones, apuntadas anteriormente, relacionadas con los valores de la autoexpresión: la maternidad ya no será un rol adscrito sino elegido y, por tanto, fuente de autorrealización.

\subsection{CONCLUSIONES}

De los datos y reflexiones expuestos se deduce que en Galicia se ha dado un cambio cultural acorde con las tesis de la modernización. Este cambio cultural sigue las pautas del proceso de individualización en un doble sentido: declive de las estructuras tradicionales como determinantes del comportamiento e incremento de la autonomía individual en lo que se refiere a un mayor control sobre la propia vida. No obstante, este cambio no se ha dado en la misma medida en lo que se refiere a una mayor adscripción a los valores 
posmaterialistas. Es altamente probable que la crisis económica esté detrás de esta vuelta a los valores materialistas.

En una perspectiva comparada, Galicia, junto con España, acusa el impacto del cambio cultural, en la forma aquí considerada, de forma menos intensa que en la mayoría de los países europeos consultados. Sin embargo, puede predecirse que las transformaciones motivadas por el proceso de individualización seguirán desarrollándose en los próximos años. Como bien señaló Baumann, nos guste o no "la individualización ha llegado para quedarse" (Baumann, 2003: 26).

\subsection{REFERENCIAS BIBLIOGRÁFICAS}

Bauman, Z. (2003): "Individualmente, pero juntos", en Beck, U. y Beck, E. (2003): La individualización, Ed. Paidós Ibérica, Barcelona.

Beck, U. (2001): La sociedad del Riesgo. Hacia una nueva modernidad, Ed. Paidós, Barcelona.

Beck, U. y Beck, E. (2003): La individualización, Ed. Paidós Ibérica, Barcelona.

Boudon, R. (2002): Déclin de la morale? Déclin des valeurs?, Presses Universitaires de France, París.

Diez Nicolás, J. (2003): “Two Contradictory Hipótesis on Globalization: Societal Convergente or Civilization Differentiation and Clash", en Inglehart, R. (2003): Human Values and Social Change: Findings from de Values Survey. Inglehart, Ed. Brill, Leiden.

Inglehart, R. (1977): The Silent Revolution: Changing Values and Political Styles, Princeton, Princeton University Press.

Inglehart, R. (1991): El cambio cultural en las sociedades industriales avanzadas, Madrid, CIS.

Inglehart, R. (1994): "Modernización y post-modernización: la cambiante relación entre el desarrollo económico, cambio cultural y político", en Díez Nicolás, J. y Inglehart, R. (Eds.): Tendencias mundiales de cambio en los valores sociales y políticos, Madrid, Fundesco: 63-107.

Inglehart, R. (1998): Modernización y postmodernización: el cambio cultural, económico y político en 43 sociedades avanzadas, Madrid, CIS.

Inkeles, A. (1978): "National Differences in Individual Modernity", en Comparative Studies in Sociology, 1: 47-72.

Lipovetsky, G. (1994): El crepúsculo del deber. La ética indolora de los nuevos tiempos democráticos, Anagrama, Barcelona.

Maslow, A. (1954): Motivation and Personality, Nueva York, Haper and Row.

Veira, J. L., Muñoz, C. y míguez, S. (1993): A Mocidade Galega, Xunta de Galicia, Consellería de Cultura e Xuventude.

Welzel, C. (2007): "Individual Modernity", en Dalton, R. J. y Klingemann, H. D. (2007): The Oxford Handbook of Political Behaviour, Ed. Robert E. Gooding, Oxford. 


\section{VALORES: PROBLEMAS PÚBLICOS Y DILEMAS MORALES}

José Luis Veira Veira

\subsection{INTRODUCCIÓN}

Las creencias son ideas o teorías acerca de cómo funciona el mundo, las cosas y las personas. Se puede creer que el origen del mundo es una creación de Dios o por el contrario, creer que es producto de un "big-bang"; también se puede creer que los seres humanos son buenos por naturaleza o por el contrario, que son malos de nacimiento; asimismo se puede creer que las personas son juguetes del destino y que todo lo que les ocurre es producto de un guión ya escrito (fatalismo) o por el contrario, se puede creer que la suerte de la gente no está echada sino que dependerá de su esfuerzo y de sus actos; en fin, se puede creer que todo iría mejor si se siguen los consejos y tradiciones de los mayores o por el contrario, que se mejoraría el futuro si se adoptaran actitudes innovadoras o incluso transgresoras.

Las creencias tienen un impacto importante en el comportamiento y los valores de la gente; así, si uno está convencido de que los seres humanos son malos por naturaleza o son proclives a realizar el mal en cuanto la ocasión se lo permita, es muy probable que uno admita la necesidad y aún la conveniencia de dotarse de instituciones como la pena de muerte o la cadena perpetua y sea partidario del endurecimiento de las penas, el reforzamiento policial, la disciplina escolar o el control estricto sobre el trabajo en la fábrica. En el caso opuesto de que uno crea en la bondad natural de las personas, sus preferencias se orientarán más hacia la eliminación de la pena de muerte y la suavización de las penas en beneficio de una política de reinserción laboral para los delincuentes, un mayor énfasis en la educación basada en la responsabilidad y confianza individuales y una mayor autonomía en el puesto de trabajo.

Pero, ¿ide donde proceden estas creencias? Y más importante aún, ¿cuál es la razón de su variedad entre los grupos sociales? Las creencias tienen su origen en diversas fuentes como pueden ser la autoridad (por ejemplo las creencias derivadas de textos sagrados como la Biblia o el Corán), el proceso de socialización (la transmisión de valores en la escuela y en la familia), la experiencia (la escuela de 
la vida) o el descubrimiento científico. Siguiendo a Boudon pueden distinguirse dos grandes grupos de creencias: las creencias prescriptivas o normativas y las creencias descriptivas o científicas. Las primeras son creencias referidas a ideas sobre lo que es justo o injusto, bueno o malo, legítimo o ilegítimo y cualquier otra que incluya un criterio de valor moral. Las segundas, las creencias descriptivas, son las derivadas de juicios lógicos o empíricos propios del método científico: "2+2=4" o "la tierra es redonda". Lo más interesante es que las creencias normativas se originan y se mantienen siguiendo pautas similares a las teorías científicas, es decir, una creencia cambia o es sustituida por otra cuando aparecen nuevas evidencias o razones que apoyan una nueva creencia (Boudon, 1995). Si las personas mantienen un determinado tipo de creencias, tanto normativas como científicas, es porque tienen fuertes razones y argumentos para hacerlo, a la vez que no existen en su horizonte cognitivo otras razones alternativas que puedan cuestionar aquellas creencias. Si uno cree, por ejemplo, que la tierra es redonda, es porque tiene argumentos y razones que avalan esta idea y porque además no existe ninguna argumentación en contra que sea plausible (nótese que durante siglos la humanidad creyó que la tierra era plana, por las mismas razones que ahora cree que es redonda). De este modo las creencias, tanto normativas como descriptivas, están fundamentadas en las razones aducidas de forma consciente o inconsciente por los individuos y refrendadas por la aprobación o desaprobación social. Hay que añadir que para el mantenimiento y transmisión de una creencia, en la mayor parte de los casos, no es suficiente con tener buenas razones, es necesario además tener la convicción de que otros comparten y aprueban la misma creencia. Esta es la naturaleza social de los valores y las creencias. Y por ello, debe esperarse que haya siempre variación en la jerarquía de valores en las distintas sociedades, del mismo modo que sucede con las creencias.

Hay una estrecha conexión entre creencias y valores. Un valor representa el grado de importancia y utilidad que se le da a algo en orden a satisfacer una necesidad humana. Las creencias contribuyen a la certeza o verosimilitud de que ese algo es valioso. Un cambio de creencia puede hacer perder utilidad a un objeto o idea, sin que por ello se vea afectada su importancia. Según esto puede suceder que un valor tradicional (la familia, por ejemplo) pierda parte de su utilidad y atractivo, aun manteniendo su importancia, debido a que el compromiso que conlleva la realización de ese valor requiere sacrificios que pueden entrar en colisión con el proceso general de individualización de intereses ${ }^{1}$.

Los valores son respuestas adaptativas y, como tales, tienden a ajustarse a los requerimientos del entorno físico y social (Díez Nicolás, 2004). Desde una perspectiva evolucionista, los valores son el resultado de una selección cuyo

La individualización es un proceso en virtud del cual se produce una "desincrustación" (disembedding) de los individuos respecto a los moldes institucionales clásicos que le vinculaban a la religión, la política o la clase social, de modo tal que experimenta un incremento de su autonomía para decidir sobre todos los aspectos de su vida. 
criterio fundamental es la ventaja competitiva o de adaptación que supone para la supervivencia del grupo humano. En las sociedades desarrolladas las personas se han ido acostumbrando a vivir en entornos abiertos en los que nadie quiere perderse oportunidades, haciendo que el compromiso con los valores sea más dificultoso. Valores como la familia y el trabajo siguen siendo valores muy importantes pero de difícil conciliación con un entorno social fuertemente individualizado. En la sociedad "líquida" descrita por Bauman cada uno debe nadar a su aire y como pueda, y ello lleva a la gente a evitar compromisos fuertes en un mar de incertidumbres (Bauman, 2003).

Esta diferencia entre la importancia y las ventajas de utilidad de los valores explica el hecho contradictorio de que por un lado sigue habiendo una gran valoración de la familia, a la vez que por otro se incrementan los divorcios, disminuye drásticamente el número de hijos por pareja y se retrasa la edad de matrimonio. De tal forma que la llamada "crisis de valores" no consiste en una "pérdida" de valores sino en una inadecuación entre aspiraciones e instituciones. Probablemente todo el mundo "ansía" una familia pero no todo el mundo "quiere" una familia (Baumann en una entrevista en ABC, 28 Mayo 2010).

En este sentido, la crisis de valores de la sociedad actual debería ser interpretada no tanto como una pérdida de valores cuanto por el hecho de que las restricciones institucionales entran en conflicto con el proceso de individualización de intereses, provocando el abandono y la desmotivación institucionales. Dos ejemplos típicos pueden verse en los casos de la familia y el trabajo. La emancipación de la mujer — que es uno de los aspectos más dominantes del proceso de individualización de intereses - se ha encontrado con fuertes restricciones institucionales provenientes tanto de la familia tradicional como de las condiciones de contratación laboral. Esto explica que persista la importancia dada a la familia o el trabajo, al mismo tiempo que se observa una crisis familiar y una relativa pérdida de centralidad del trabajo. Este desajuste provocado por las restricciones institucionales del pasado es una de las causas de la creencia en la llamada crisis de valores. Pero el proceso de individualización de intereses no actúa en contra de estas restricciones directamente sino que orienta a los sujetos hacia tipos de adaptación desviados como el retraimiento, que se traduce en desmotivación institucional y evitación de compromisos, y que algunos han interpretado como el crepúsculo del sentido del deber (Lipovesky, 1994).

De los datos que se exponen a continuación puede inferirse el sistema de creencias y valores en Galicia en lo que se refiere a tres aspectos importantes: lo que es más importante en la vida; los problemas públicos derivados de la exclusión social de las minorías y algunos de los dilemas morales más aireados en los medios de comunicación de masas. Estos tres aspectos no agotan, por supuesto, el cuadro completo de un sistema de valores, pero sí representan algunas de las preocupaciones básicas de la sociedad actual. 


\subsection{LO MÁS IMPORTANTE EN LA VIDA}

En la Tabla 2.1 puede verse la evolución en Galicia de la importancia dada a seis aspectos de la vida como son la familia, el trabajo, la amistad, el tiempo libre, la política y la religión. Lo primero que hay que destacar es que esta evolución presenta una jerarquía latente entre los seis valores, observable tanto en Galicia como en España (gráficos 2.1 y 2.2) y que parece contradecir en parte la creencia generalizada en una crisis de valores. Esta jerarquía implícita emerge cuando se observa en la consulta del 2008 que la familia, el trabajo y la amistad son aspectos de la vida valorados como muy o bastante importantes por más del $90 \%$ de la población gallega. A continuación se sitúa el tiempo libre como el aspecto más valorado, alcanzando un 89,4\%. Los aspectos menos valorados son la religión y la política: solo el $41,1 \%$ y el $27 \%$ respectivamente los valoran mucho o bastante en la consulta de 2008

La evolución de esta jerarquía latente muestra también que solo la familia, la amistad y el tiempo libre son valores "en alza", llamando concretamente la atención la particularidad de que el ocio no solo alcanza casi la misma puntuación que el trabajo, sino que además éste, el valor del trabajo, presenta un retroceso que va de un 95\% en 1995 a un 90,5\% en 2008 (ver a este respecto el Capítulo 8 sobre la pérdida de centralidad del trabajo) mientras que la valoración del tiempo libre va de un $86,2 \%$ a un $89,4 \%$ en los mismos años.

En el otro extremo de la escala jerárquica se hallan la religión y la política que son los aspectos menos valorados aunque con una diferencia notable entre ellos a favor de la religión. No obstante, la política, al contrario que la religión, presenta un cierto ascenso en el 2008 respecto a las consultas anteriores. En el caso de la política todo parece indicar que sus fluctuaciones coinciden con los ciclos económicos: en años de bonanza disminuye el interés mientras que en época de crisis se incrementa la preocupación por la política.

A pesar de esta fuerte adscripción a los valores tradicionales, es admisible la sospecha de que existe un cierto retraimiento de las personas respecto a estos mismos valores. El hecho de que se siga atribuyendo mucha importancia a la familia y el trabajo, por ejemplo, no significa necesariamente que haya aumentado el grado de compromiso con estos valores. Los datos más bien sugieren lo contrario; en la Tabla 2.2 donde se muestran las distintas correlaciones entre los valores analizados y los grupos de edad, se observa que la familia, la religión, el tiempo libre y en menor medida el trabajo son aspectos cuya valoración varía según los grupos de edad. Así por ejemplo la familia y la religión suelen estar más valoradas cuanto mayor es la edad mientras que con el tiempo libre es a la inversa: a menor edad mayor valoración del ocio ${ }^{2}$.

La interpretación de las correlaciones debe hacerse teniendo en cuenta que las escala de "importancia" y de "edad" no van en la misma dirección; la edad va de menos a más y la importancia de más a menos. 
Tabla 2.1. Importancia de los diversos aspectos de la vida. Galicia.

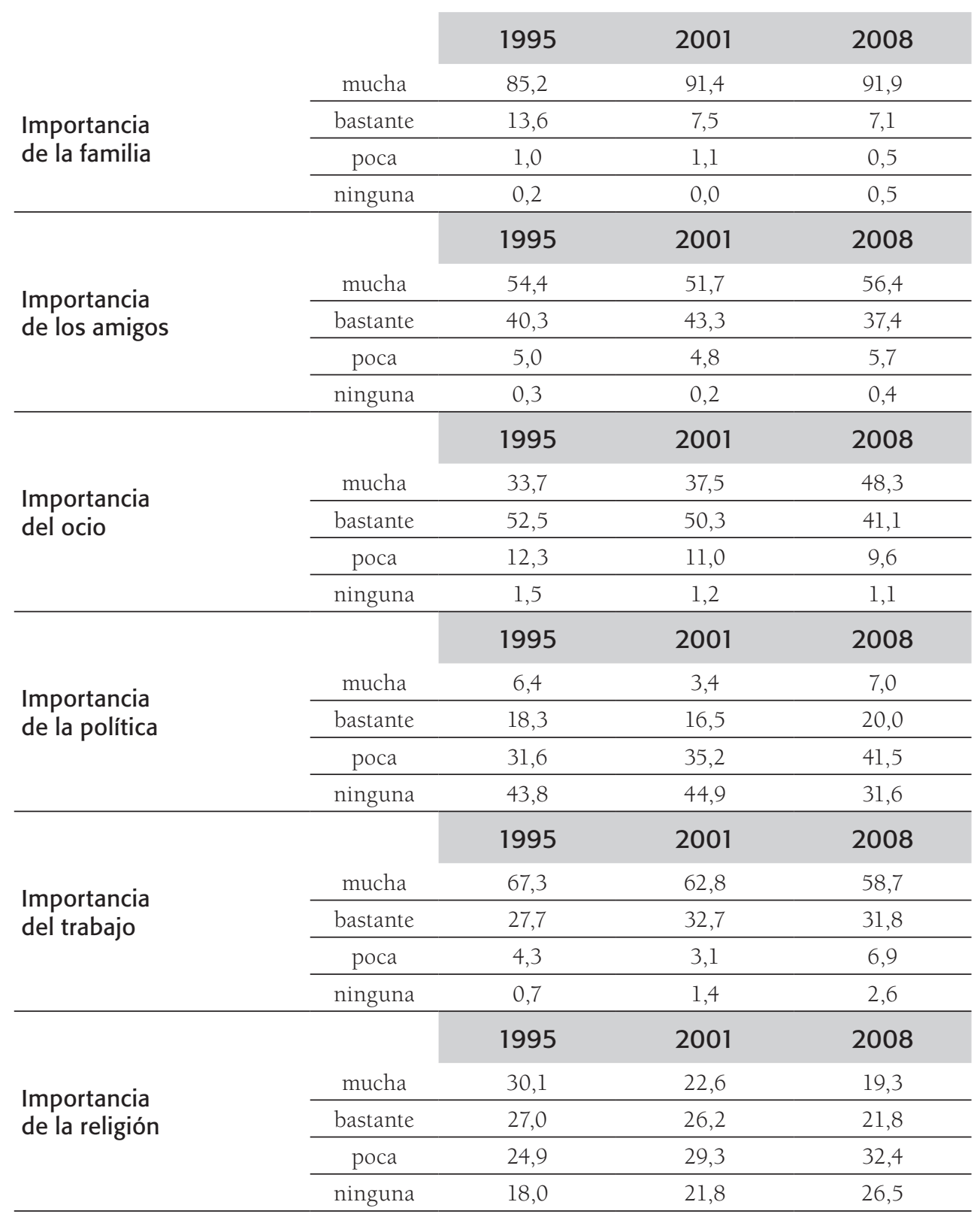

Fuente: EMV-Galicia, 1995, 2001 y 2008. Elaboración propia. 

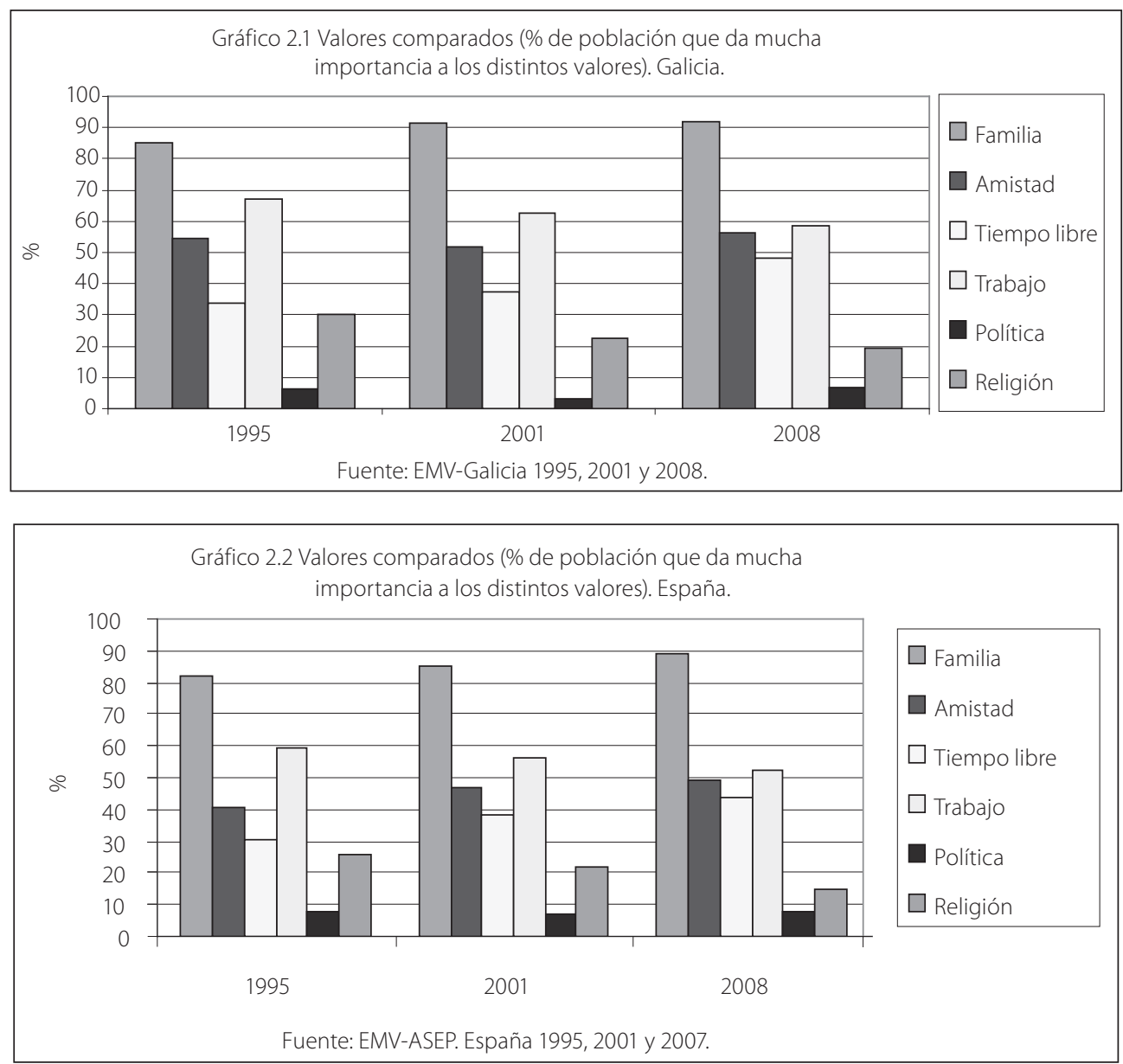

La persistencia de estas diferencias de valoración entre los grupos de edad en las tres consultas realizadas indica un efecto de la edad o ciclo de vida sobre los valores. Ello supondría admitir que no existe algo parecido a un cambio de valores en el conjunto de la sociedad gallega, pues los jóvenes tenderían a asumir los valores de los mayores según van cumpliendo años. Pero un análisis más atento de los datos refleja un cambio generacional en el tiempo, como se muestra en los gráficos 2.3, 2.4 y 2.5 donde las mismas cohortes de nacimiento se comportan de manera similar en las tres consultas realizadas. Es decir, cada cohorte de nacimiento arroja porcentajes similares de valoración en los distintos años de consulta, lo cual indica que el cambio en dicha valoración no es solo por efecto de ciclo de vida (efecto edad) sino también efecto generacional y, en consecuencia, puede predecirse un cambio de valores en el tiempo. Ahora bien, este cambio generacional no se da con la misma claridad en los tres aspectos analizados, la familia, el tiempo libre y la religión. 
Tabla 2.2. Correlaciones entre grupos de edad e importancia de los valores. Galicia.

\begin{tabular}{lcccc}
\hline \multirow{2}{*}{ Importancia familia } & Coeficiente de correlación & $-0,106$ & $-0,062$ & $-0,128$ \\
\hline \multirow{2}{*}{ Importancia amigos } & Sig. (bilateral) & 0,000 & 0,011 & 0,000 \\
\cline { 2 - 5 } Importancia tiempo libre & Coeficiente de correlación & $-0,010$ & 0,014 & $-0,048$ \\
\cline { 2 - 5 } & Coeficiente de correlación & 0,084 & 0,094 & 0,130 \\
\hline \multirow{2}{*}{ Importancia política } & Sig. (bilateral) & 0,000 & 0,000 & 0,000 \\
\hline & Coeficiente de correlación & 0,010 & 0,085 & 0,202 \\
\hline \multirow{2}{*}{ Importancia trabajo } & Sig. (bilateral) & 0,624 & 0,000 & 0,000 \\
\hline & Coeficiente de correlación & $-0,006$ & $-0,086$ & 0,032 \\
\hline Importancia religión & Sig. (bilateral) & 0,763 & 0,000 & 0,205 \\
\hline & Coeficiente de correlación & $-0,365$ & $-0,434$ & $-0,375$ \\
\hline & Sig. (bilateral) & 0,000 & 0,000 & 0,000 \\
\hline
\end{tabular}

Fuente: EMV-Galicia 1995, 2001 y 2008. Elaboración propia.

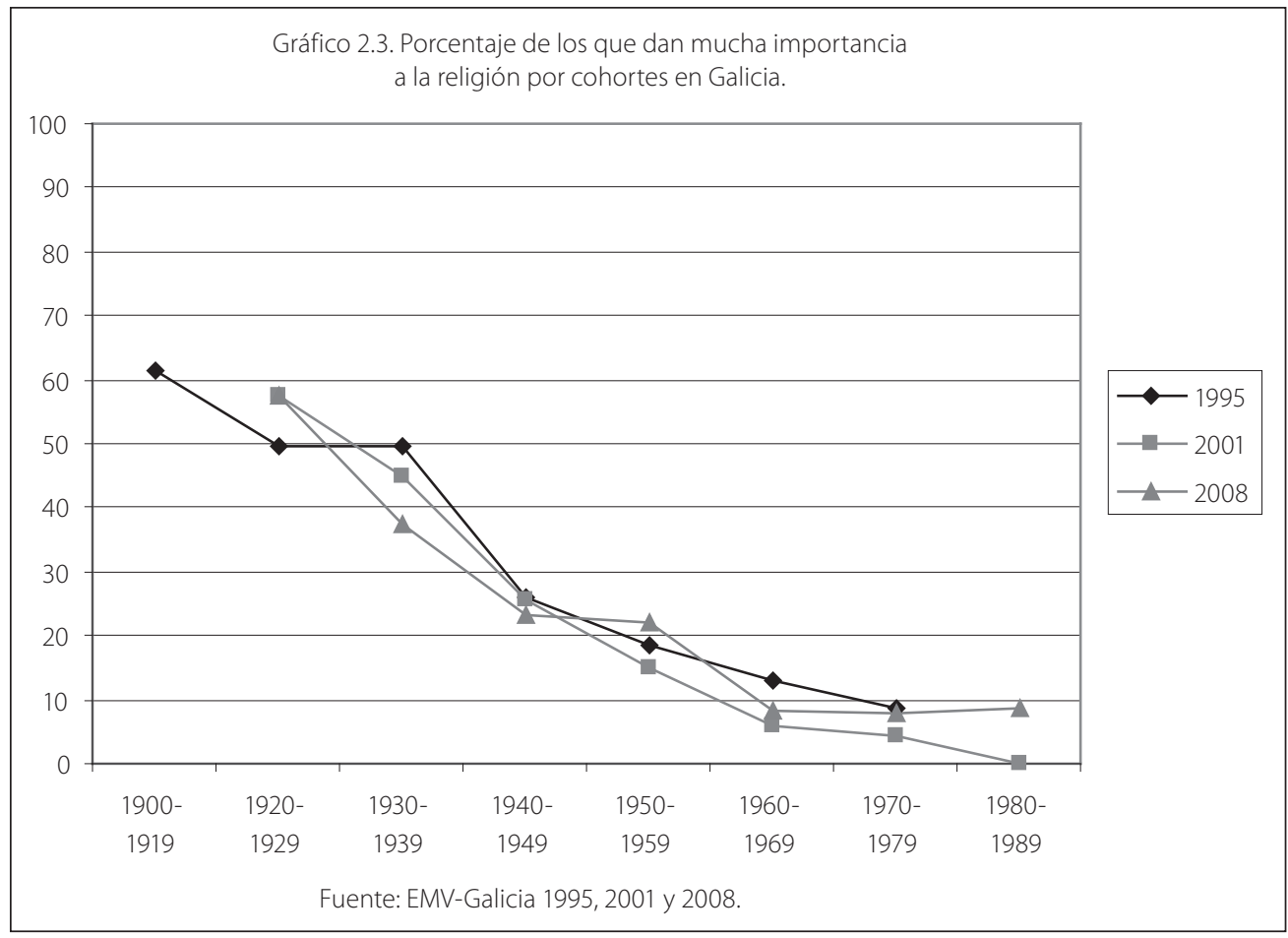



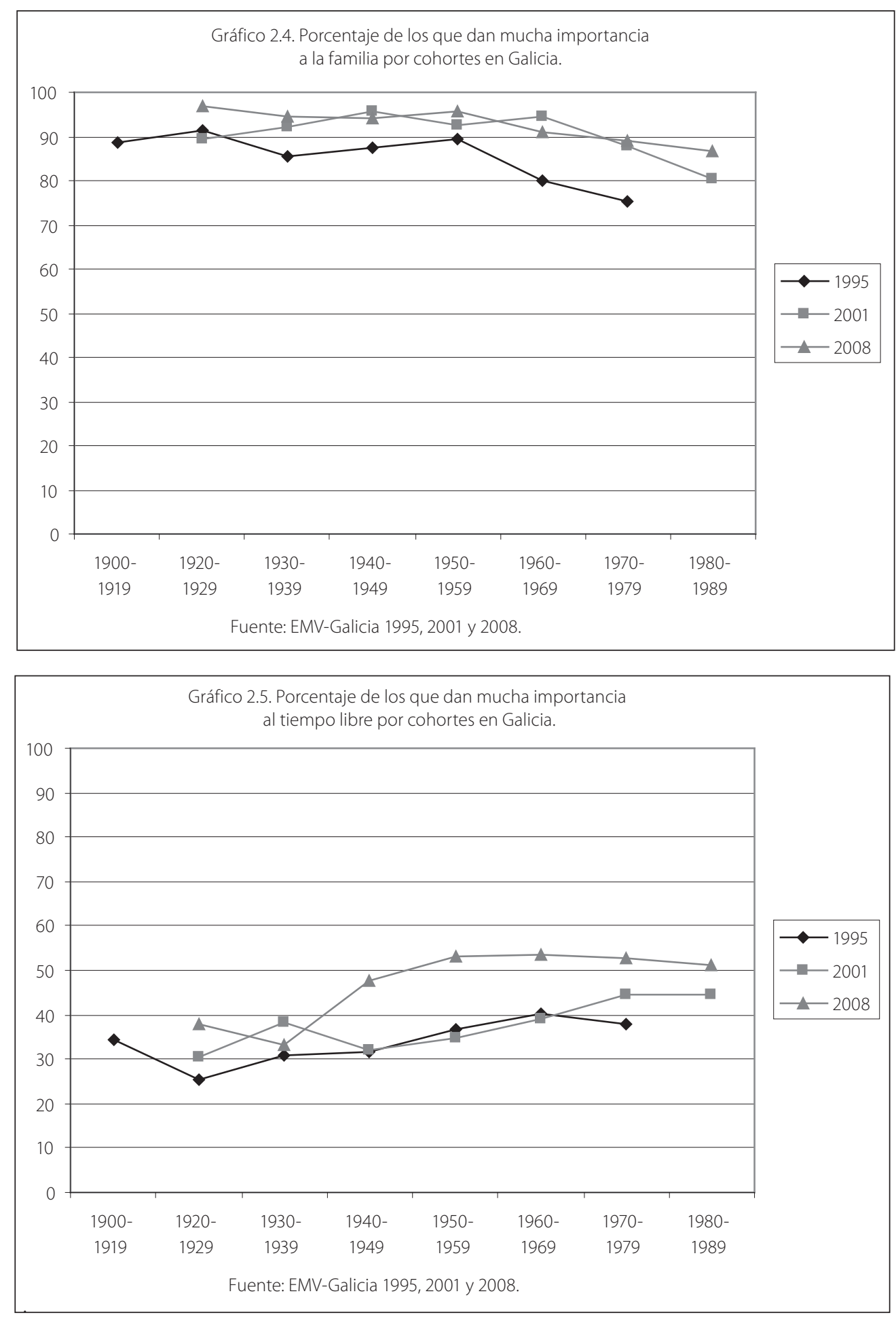
El cambio real de valores se observa de forma más clara en la valoración de la religión (Gráfico 2.3); si se repara en que cada cohorte se comporta de forma similar en las tres consultas realizadas, se verá que las cohortes de nacimiento posteriores al año 1929 hasta el año 1979 presentan porcentajes muy similares de valoración de la religión a pesar de pertenecer a grupos de edad diferentes en el momento de la entrevista, indicando con ello un cambio generacional en el tiempo, representado por un retroceso en la valoración de la religión.

En cuanto a la familia resulta difícil deslindar el efecto edad del efecto generacional, por el hecho de que la valoración de este aspecto de la vida es muy alta y uniforme en todos los grupos de edad. Sin embargo, no se debe descartar esta posibilidad porque las tres líneas del gráfico correspondientes a las tres consultas siguen una curva muy similar (Gráfico 2.4).

Finalmente, los datos referidos a la valoración del tiempo libre no permiten aventurar con la misma certeza un cambio generacional. Aunque los datos de las consultas de los años 1995 y 2001 parecen confirmar un efecto generacional, dadas las similitudes de porcentajes entre las distintas cohortes de edad, esta evidencia desaparece con los datos de 2008, donde todas las cohortes posteriores a 1939 experimentan un incremento fuerte en la valoración del tiempo libre (Gráfico 2.5). En este caso, cabría pensar que junto al efecto de la edad hay también un efecto período, además de generacional.

Brevemente, puede concluirse que la familia, el tiempo libre y la amistad son valores que están en alza, mientras que el trabajo y la religión sufren un retroceso (mucho más acusado en este último caso) y la política, que es el aspecto menos valorado, experimenta un ligero ascenso, aunque poco significativo dado el escaso valor que se le atribuye. Por otra parte, puede afirmarse que son la religión y la familia los aspectos más afectados por un cambio generacional. De existir una crisis de valores sería en el ámbito de la religión y la familia fundamentalmente. Pero, como se señalaba más arriba, la "pérdida" de valores es una creencia que, aunque muy extendida y aireada por los medios de comunicación, debe ser contemplada como tal. Es decir, es preciso preguntarse por su certeza y/o su utilidad. En cuanto a la certeza de la creencia en una crisis familiar ya se ha visto que es muy relativa, dada la práctica unanimidad que hay en torno a la valoración de la familia, y en cuanto a la religión es probable que más que una pérdida de valores religiosos haya un cambio en el significado mismo del concepto de religión, que pasa a ser más un asunto privado que público.

Si se aplica el criterio de la utilidad a la creencia en una pérdida de valores, las razones de su implantación y aceptación social son más evidentes. En primer lugar, la creencia generalizada de que vivimos en una sociedad que está perdiendo sus valores favorece los intereses ideológicos de cualquier signo: tanto la derecha como la izquierda pueden utilizar para sus intereses el discurso de la pérdida de valores; aquélla para hacer un llamamiento al rearme moral y ésta para anunciar el advenimiento de nuevos valores de progreso. 
Pero a la luz de los datos expuestos solo puede asegurarse que hay una crisis de valores en los aspectos señalados y en el sentido de que las instituciones actuales sobre las que se basan la familia y la religión presentan fuertes restricciones institucionales a la autonomía individual y al proceso más general de individualización de intereses. La creencia extendida en una pérdida de valores proviene por tanto de dos fuentes: de los intereses ideológicos y del hecho real de que existe un paulatino descenso del grado de compromiso institucional (retraimiento y desmotivación).

\subsection{INTEGRACIÓN Y EXCLUSIÓN SOCIALES: EL CASO DE LAS MINORÍAS}

El etnocentrismo es la tendencia emocional que hace de la cultura propia el criterio exclusivo para interpretar los comportamientos de otros grupos, razas o sociedades. El etnocentrismo mantiene viva la creencia de que las costumbres, los valores, las tradiciones y la gente propias de una cultura o nación son mejores que las de otras razas, etnias o naciones. La distancia social entre los grupos, que se manifiesta en distintos grados de rechazo, es una consecuencia de las creencias etnocéntricas. Esta distancia social puede quedar reducida a la mera incomprensión, sin más consecuencias, pero también puede originar xenofobia y hasta racismo. Uno de los mayores problemas públicos en las sociedades actuales, muy plurales en su composición cultural y etnográfica, es la precaria integración social de las minorías culturales y étnicas. Para ello es primordial conocer el grado de rechazo que hay respecto a ciertas minorías que se distinguen por su etnia, religión, cultura o sencillamente estilos de vida.

La distancia social mide el grado de rechazo aplicado a un grupo o a un estilo de vida determinado. En la Tabla 2.3 se muestran los datos referidos al rechazo que suscitan distintos grupos o conductas en Galicia a través de las tres consultas realizadas. La pregunta efectuada a los entrevistados era sobre a qué tipo de personas no le gustaría tener como vecinos.

Lo que más destaca en estos datos es comprobar que hay tres conjuntos cuyo rechazo social va en claro aumento desde 1995 hasta 2008, que son los drogadictos, los que beben mucho y los gitanos. Estos colectivos son también los que sufren un mayor rechazo en los tres años consultados. Otros conjuntos como los afectados por el SIDA, los homosexuales y los de otras razas, experimentan también un cierto rechazo pero en menor medida y con tendencia claramente decreciente. Respecto a los trabajadores inmigrantes el grado de rechazo es muy bajo y apenas varía a lo largo del tiempo. En el 2008 se preguntó también sobre los miembros de otras religiones, los que hablan otro idioma y las parejas no casadas, para los que no se dispone de datos en las dos consultas anteriores. En cualquier caso, ninguno de estos conjuntos arroja porcentajes muy altos.

La imputación de responsabilidad, la ausencia de autocontrol y el riesgo son los tres criterios por los que se ordena la escala de rechazo de los distintos colectivos. 
Son justamente las conductas que ofrecen más riesgo, que implican una falta de autocontrol (como en el caso del bebedor) y que derivan de un estatus adquirido y no adscrito, del cual es responsable el sujeto, las que más rechazo reciben. El caso de los gitanos no puede ser una excepción al criterio de estatus adquirido - el gitano no es responsable de serlo, como tampoco lo es el payo- porque el rechazo que manifiestan los entrevistados está orientado más bien a determinados estilos de vida de este colectivo y no al hecho de que sean gitanos. Lo que produce rechazo no es la pertenencia a la etnia gitana, sino la asociación que se hace entre determinados estilos de vida gitana y delincuencia o automarginación.

Tabla 2.3. Porcentaje de población que no le gustaría tener como vecinos a los siguientes grupos en Galicia.

\begin{tabular}{llll} 
& 1995 & 2001 & 2008 \\
\hline Drogadictos & 58,5 & 54,9 & 67 \\
\hline Beben mucho & 50,1 & 46,4 & 54,5 \\
\hline Gitanos & & 37,2 & 46,8 \\
\hline Afectados por el SIDA & 27,1 & 23,5 & 20,5 \\
\hline Homosexuales & 28,8 & 20,6 & 14 \\
\hline De otra raza & 11,8 & 10,3 & 9,8 \\
\hline Inmigrantes* & 8 & 9,9 & 9,2 \\
\hline Otra religión & & & 8,6 \\
\hline Hablan otro idioma & & & 6,5 \\
\hline Parejas no casadas & & 4,3 \\
\hline
\end{tabular}

* En el 2001 y 2005 "trabajadores extranjeros".

Fuente: EMV-Galicia 1995, 2001 y 2008. Elaboración propia.

En una perspectiva comparada con España, Galicia ofrece en general un mayor grado de rechazo hacia todos los grupos. Sin embargo, tanto España como Galicia están por debajo del nivel medio de rechazo si se comparan con el resto del mundo (Tabla 2.4), exceptuando el caso de los gitanos, en cuyo caso la explicación podría estar en el hecho de que en la mayoría de los países consultados este grupo étnico apenas tiene presencia.

En una sociedad globalizada los problemas de integración social de las minorías son importantes por su trascendencia pública y porque pueden afectar a la convivencia. En este sentido puede afirmarse que la opinión pública gallega evoluciona favorablemente hacia la tolerancia y la aceptación de la diversidad, 
centrando su rechazo en las conductas más que en las categorías étnicas o religiosas. El rechazo se dirige no a los colectivos en cuanto tales - gitanos, inmigrantes, miembros de otra religión, etc. - sino al hecho de que desafían e incluso amenazan estilos de vida propios. En consecuencia puede afirmarse que la utilización pública de la conflictividad interétnica o religiosa tiene más bien raíces políticas que sociales o morales. La conflictividad ideológica potencial de las diferencias no es una cuestión que, a la luz de los datos expuestos, provenga de las actitudes de la población, sino que apunta a intereses más altos.

Tabla 2.4. Porcentajes de población que no les gustaría tener por vecinos a los siguientes grupos, en España y en el mundo.

\begin{tabular}{lcc} 
& España (2007) & Mundo* \\
\hline Drogadictos & 64,3 & 71,5 \\
\hline Beben mucho & 38,3 & 59,0 \\
\hline Gitanos & 35,9 & 3,7 \\
\hline Afectados por el SIDA & 16,2 & 34,9 \\
\hline Homosexuales & 7,4 & 42,5 \\
\hline De otra raza & 6,8 & 15,5 \\
\hline Trabajadores inmigrantes & 6,5 & 19,8 \\
\hline Otra religión & 5,7 & 15,6 \\
\hline Hablan otro idioma & 3,2 & 12,0 \\
\hline Parejas no casadas & 3,5 & 19,4 \\
\hline
\end{tabular}

* Incluye todos los países que participaron en la WVS en la oleada de 2005-2008.

Fuente: EMV-ASEP. España y Mundo. Elaboración propia.

\subsection{PROBLEMAS PÚBLICOS Y DILEMAS MORALES}

La crisis de valores no significa necesariamente que haya habido una involución de los sentimientos morales en las sociedades avanzadas. Más bien parece suceder lo contrario pues la crisis de valores tiene su contrapunto en un incremento de la sensibilidad moral colectiva. A pesar de las atrocidades y de la violencia que transmiten los medios de comunicación de masas, lo cierto es que nunca hubo tantas protestas y manifestaciones públicas a favor de la paz y en contra de todo tipo de violencia. Los gobiernos se ven obligados a recalificar las acciones bélicas contra otros Estados como guerras "preventivas" para no indignar a la opinión pública; las 
condenas contra la violencia de género son cada vez más frecuentes e intensas; la indignación popular contra la corrupción política también se incrementa y, en fin, las movilizaciones contra el terrorismo y la corrupción económica también son ya habituales. Si se considera que en todas las épocas hubo guerras, violencia indiscriminada y corrupción, es justo señalar esta movilización de la opinión pública como una característica de la época actual.

Incluso en el plano personal hay constancia de este desarrollo de la sensibilidad moral. Un ejemplo notable es la aplicación de la pena de muerte. Incluso en aquellos estados en los que todavía se aplica la máxima pena, ésta se hace en un ambiente recogido y discreto y no a la luz pública como antaño, con la asistencia incluso de un público ansioso de ver el espectáculo de la ejecución. A este respecto es muy ilustrativa la imagen que transmite la escritora del siglo XVII Madame de Sévigné, en la carta que escribe a su hija, donde le confiesa el disfrute y la excitación que le producía la asistencia a la ejecución pública en la guillotina de un asesino ${ }^{3}$. Difícilmente se puede imaginar una aprobación social de estos sentimientos en la actualidad.

Los datos que se exponen a continuación revelan que el sentido moral de la población no solo no se ha debilitado sino que en muchos casos se manifiesta con rotundidad estadística. Para una mejor comprensión y explicación se han diferenciado dos ámbitos de enjuiciamiento moral del comportamiento social: las conductas deshonestas referidas al dinero y los problemas públicos derivados del uso del propio cuerpo.

\subsubsection{El dinero y las conductas deshonestas}

Reclamar beneficios sin derecho a ellos, evitar pagar un billete en el transporte público, engañar en el pago de impuestos y aceptar un soborno son conductas que suscitan una amplia reprobación social en Galicia. La deshonestidad en materia económica está muy mal vista y casi nunca justificada. Tal y como se muestra en el Gráfico 2.6, en los tres años consultados, todas estas conductas no son nunca o casi nunca justificadas para la mayoría de la población: en una escala de 1 a 10 donde 1 significa que nunca justificaría una conducta y 10 siempre justificaría, ninguna sobrepasa el 2,5 de media. Entre todas ellas destaca el soborno que es reprobado con mayor contundencia no sobrepasando el 1,5 de media. Difícilmente puede encontrarse otro ejemplo de consenso moral, si exceptuamos el universal rechazo al homicidio. En el ámbito de la moral económica es manifiesto un amplio acuerdo en la condena sin paliativos de cualquier conducta deshonesta, por muy leve que sea la transgresión de la norma. En España ocurre lo mismo, aunque en este caso se observa una ligerísima tendencia a incrementar la justificación (Gráfico 2.7).

Citado por Raymond Boudon (Boudon, 2001: 77). 
El consenso acerca de la moral económica descansa con toda probabilidad en la creencia comúnmente aceptada de que nunca es justo ni legítimo beneficiarse a costa de los demás y en el precepto más universal de todas las religiones basado en la ley de la reciprocidad: no hagas a los demás lo que no quieras que te hagan a ti. No existen argumentos para mantener una posición contraria al respecto. El daño que se causa a los demás es la línea roja que no debe ser sobrepasada ni siquiera en nombre de una sociedad individualizada. Traspasar esta línea roja supone una amenaza a la convivencia y un peligro para el grupo. Por este motivo hay escasa variación en el grado de rechazo que producen las conductas deshonestas referidas al dinero Pero esto no ocurre en otros ámbitos de la moral como puede verse a continuación.

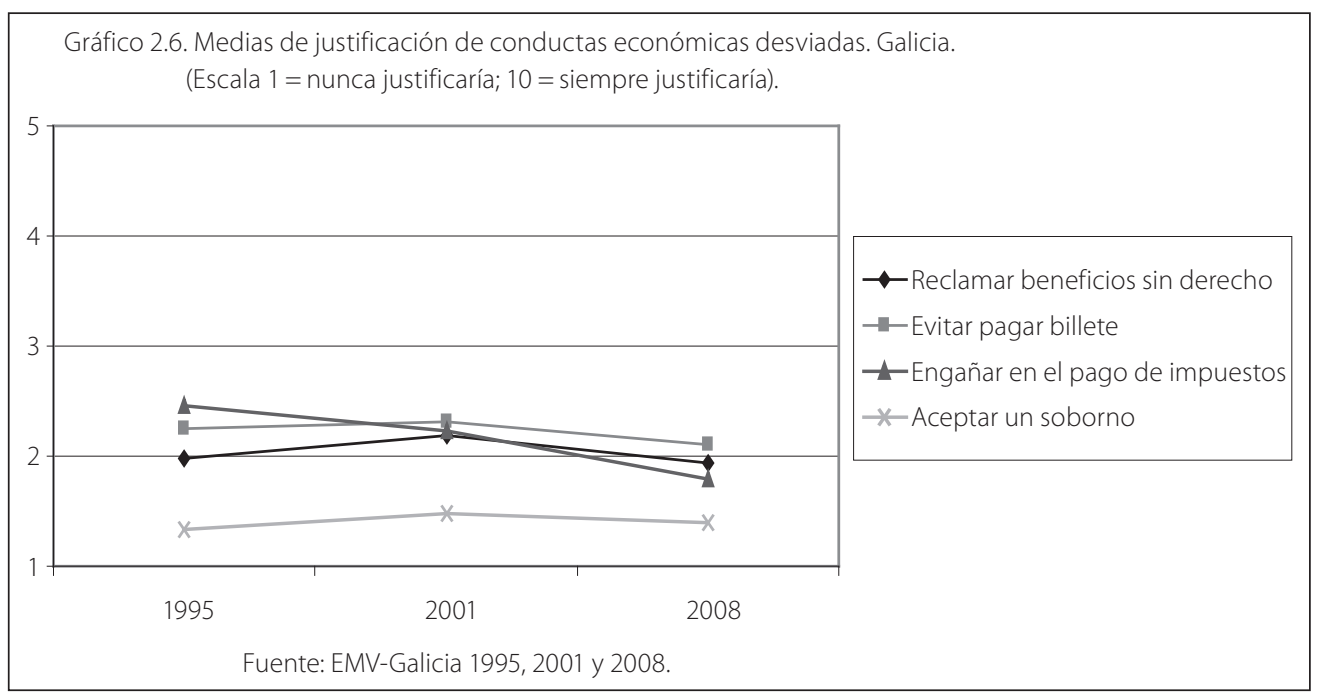

Gráfico 2.7. Medias de justificación de conductas económicas desviadas. España.

(Escala 1 = nunca justificaría; 10 = siempre justificaría)

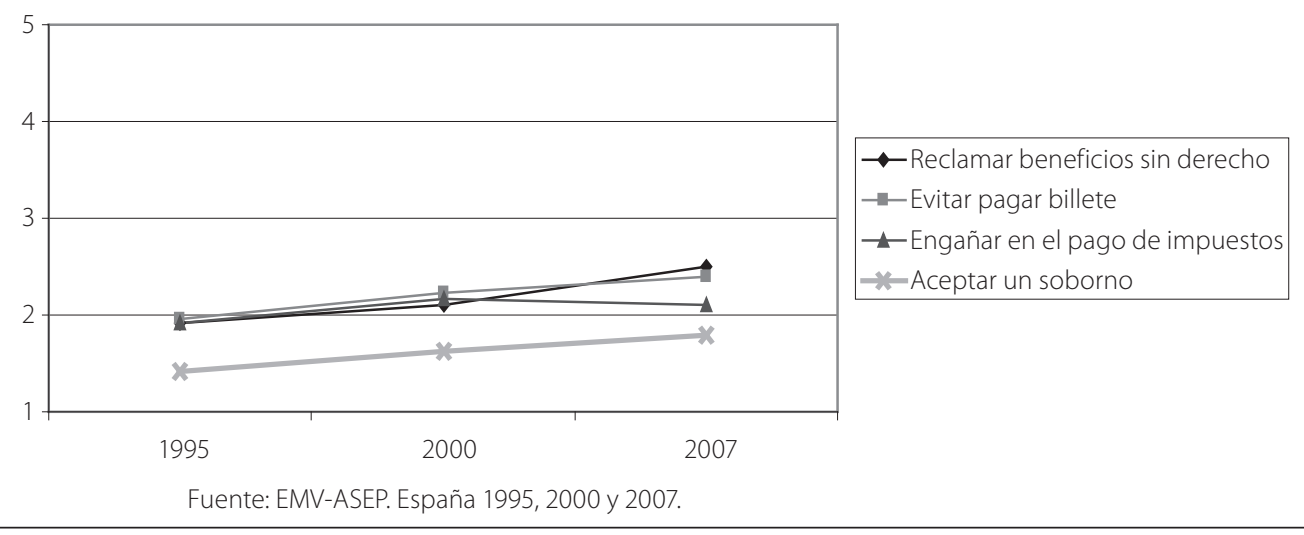




\subsubsection{Problemas públicos derivados del uso del propio cuerpo}

La justificación de conductas derivadas del uso del propio cuerpo, tales como la homosexualidad, la prostitución, el aborto, el suicidio o la eutanasia no suscitan el mismo grado de consenso que las conductas referidas al dinero. En este caso hay más variación en la intensidad de la justificación o injustificación y se está lejos del consenso moral. La creencia en el derecho al libre uso del propio cuerpo es concordante con el proceso de individualización. La creencia en un derecho a disponer del propio cuerpo según plazca y de acuerdo a los propios intereses, ha arraigado con cierta fuerza en muchas personas, pero con intensidad variable según este pretendido "derecho" ponga o no en peligro la libertad o los derechos ajenos.

Los gráficos 2.8 a 2.12 muestran los distintos niveles de justificación para cada una de las conductas analizadas, y en todos los casos pueden observarse dos tendencias: un incremento paulatino de la permisividad social ante estas conductas _ aunque con diferencias notables entre ellas - en el período de 1995 a 2008 y también entre las cohortes de nacimiento más recientes. Todo ello hace suponer un cambio en la jerarquía de valores que no se da en el caso de la deshonestidad económica.

En una escala de 1 a 10 se ha medido en sentido ascendente el grado de justificación de estas conductas, de modo que 1 significa que "nunca está justificada" la conducta en cuestión y 10 que "siempre está justificada". Puede convenirse que a partir del punto 5 para arriba comienzan las actitudes permisivas. Es interesante comprobar que en todos los casos, salvo en los casos del suicidio y algo menos en el de la prostitución, el punto 5 comienza a ser sobrepasado por las dos cohortes inmediatamente posteriores a la Guerra Civil y que configuraron las generaciones de la "contracultura" y la "protesta" (los nacidos entre 1940 y 1959 compartieron y algunos protagonizaron por su juventud la experiencia vital de los años 60 y 70, períodos caracterizados por las revueltas contraculturales y la protesta contra la dictadura).

La creencia en la libertad como fundamento del orden social fue el legado que recibieron las cohortes más recientes, nacidas entre 1970 y 1989. Estas últimas generaciones compartieron padres más permisivos y una sociedad de consumo que amplió las posibilidades de elección personal en todos los ámbitos de la vida, no solo del consumo. Sus padres tuvieron que elegir un modelo educativo más permisivo por dos razones fundamentales: bien porque creían en los valores de la libertad y la tolerancia, que la dictadura les había negado, bien porque intuían que las actitudes autoritarias ya no resultaban eficaces para conservar el orden familiar sino que era necesario negociar con los hijos círculos cada vez más amplios de permisividad y libertad. Los datos parecen corroborar estas hipótesis si 
se tiene en cuenta que, salvo en el caso del suicidio, estas nuevas generaciones ya nunca bajan del 5 en su escala de justificaciones. Sin embargo, es preciso señalar lo que podría significar un punto de inflexión a partir de la cohorte de 1970-79, desde la que se interrumpe la tendencia ascendente de la permisividad.

La justificación de la homosexualidad ha sufrido una evolución en el sentido ascendente de modo que en el 2008 hay más personas dispuestas a justificar de algún modo esta orientación sexual que en 1995 y 2001. También las cohortes más jóvenes resultan ser mucho más tolerantes con la homosexualidad que las generaciones nacidas antes de 1960. No obstante, aunque las cohortes más recientes — las nacidas entre 1970 y 1989 — siguen esta tendencia de ser más permisivas que las anteriores, han experimentado un ligero descenso en los años 2001 y 2008. La interpretación de este pequeño giro de las últimas cohortes no es fácil, y solo posteriores consultas podrán confirmar si es realmente una tendencia a la baja en la permisividad o simplemente un efecto período.

La prostitución es una conducta mucho menos justificada pero también sigue la pauta de un incremento de la permisividad con el paso de los años y con las generaciones más jóvenes. Pero en este caso la justificación no sobrepasa el 6 en una escala de 0 a 10 e inicia un descenso en las últimas generaciones tanto en el 2001 como en el 2008. Esta menor justificación de la prostitución quizás sea debido a la creencia de que esta conducta es fruto de una elección y por tanto quien la adopta incurre en responsabilidad individual.

La justificación del aborto también experimenta un incremento en el grado de permisividad de manera que en las últimas generaciones la media se mueve entre 6 y 7 para los años 1995, 2001 y 2008. En el caso del aborto se puede ver claramente que las posiciones generacionales son casi idénticas en los tres años consultados, lo que indica la existencia de un cambio generacional. Sin embargo, al igual que en los dos casos anteriores, se observa un ligero descenso en las generaciones más jóvenes en los años 2001 y 2008.

En cuanto a la eutanasia y el suicidio la población sabe discernir claramente entre ambas conductas porque concede mayor justificación a la primera que a la segunda. La justificación de la eutanasia se encuentra entre el 6 y el 7 de la escala entre las cohortes posteriores a 1939, mientras que el suicidio no alcanza el 5 ni siquiera entre los más jóvenes. Si no fuera así es que juzgaría ambas conductas por el mismo rasero. Seguramente los entrevistados encuentran buenas razones para justificar mucho más la eutanasia que el suicidio. La más importante de estas razones es quizás que la eutanasia se percibe como una decisión que requiere un proceso de negociación a tres bandas (enfermo, médico y familia) mientras que la decisión del suicida no cuenta en absoluto 
con nadie y se sitúa al margen de la sociedad, dejando en muchas ocasiones un sentimiento de culpa difuso en el grupo ${ }^{4}$.

Para resumir, puede afirmarse que en el ámbito de la moral referida al propio cuerpo existe una tendencia hacia una mayor permisividad, que se confirma sobre todo a partir de la cohorte de 1940-49 cuya media en la escala se sitúa ya en muchos casos por encima del 5; esta tendencia cobra impulso además por las políticas de igualdad desarrolladas en los últimos años, además de la legalización de los matrimonios homosexuales, la nueva legislación sobre el aborto y la aireación en los medios de comunicación de los temas de la eutanasia y la prostitución suscitando debates sobre su posible regularización. La evolución futura de esta tendencia puede que presente un punto de inflexión a juzgar por los datos de 2008 referidos a las generaciones más jóvenes que interrumpen la propensión a más permisividad.

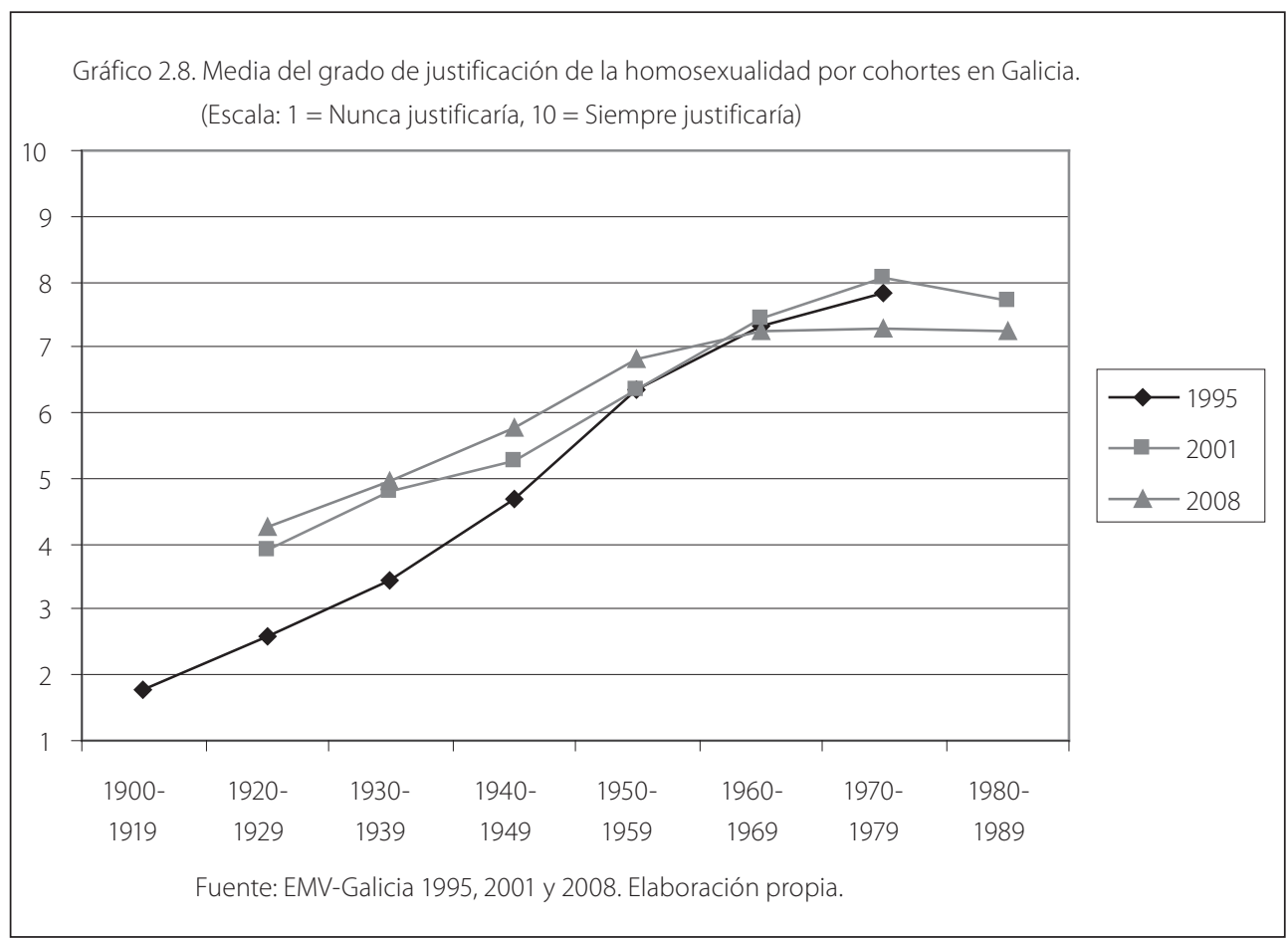

4 A pesar de todo ello hay también tendencia a una mayor permisividad del suicidio, debido quizás al convencimiento cada vez más común de que esta conducta obedece a una enfermedad y no a una decisión responsable. Si esta creencia es confirmada por la medicina cabe esperar un incremento de permisividad ante el comportamiento del suicida. La consideración del suicida como enfermo le exime de parte de la responsabilidad de su conducta. 

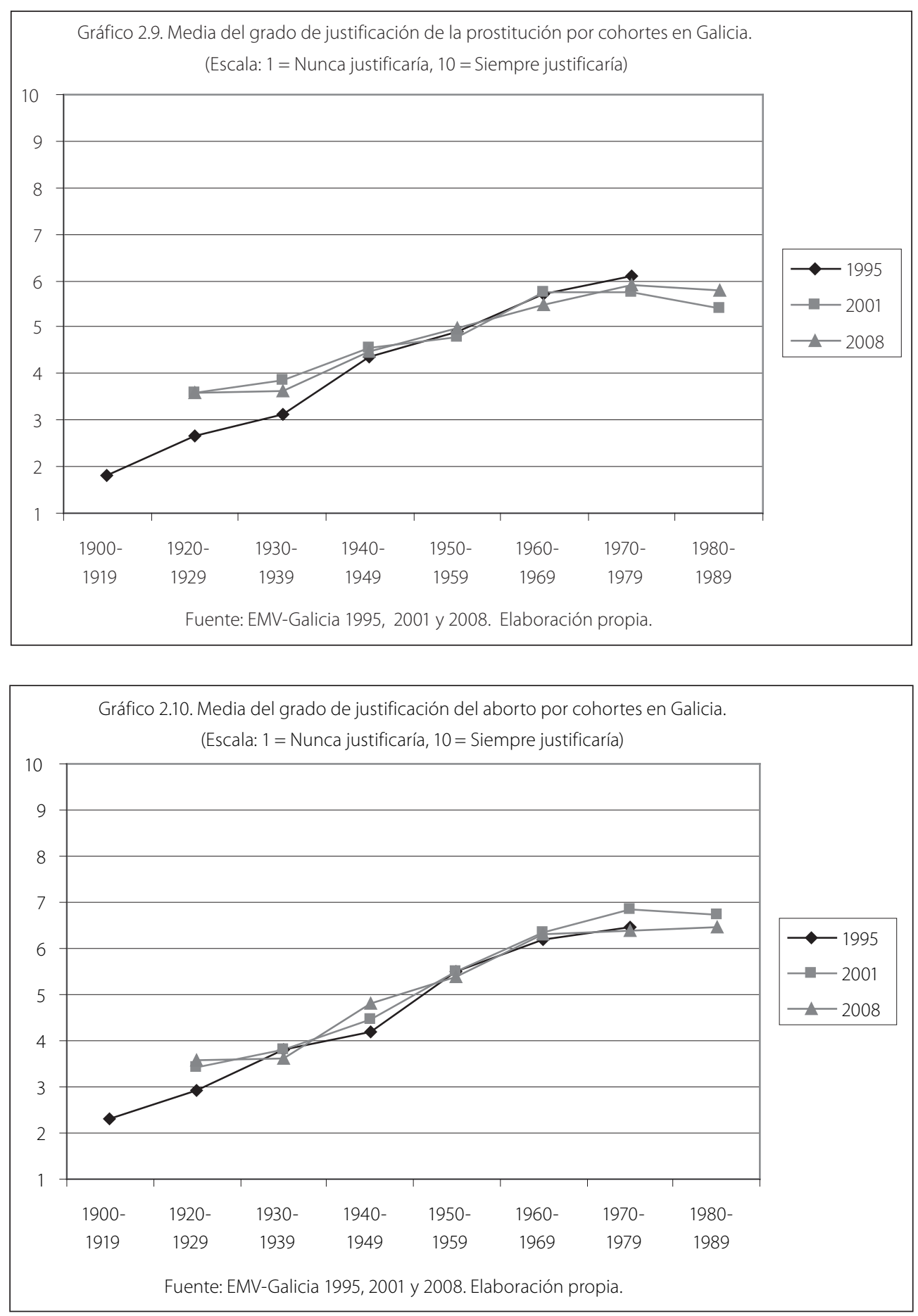

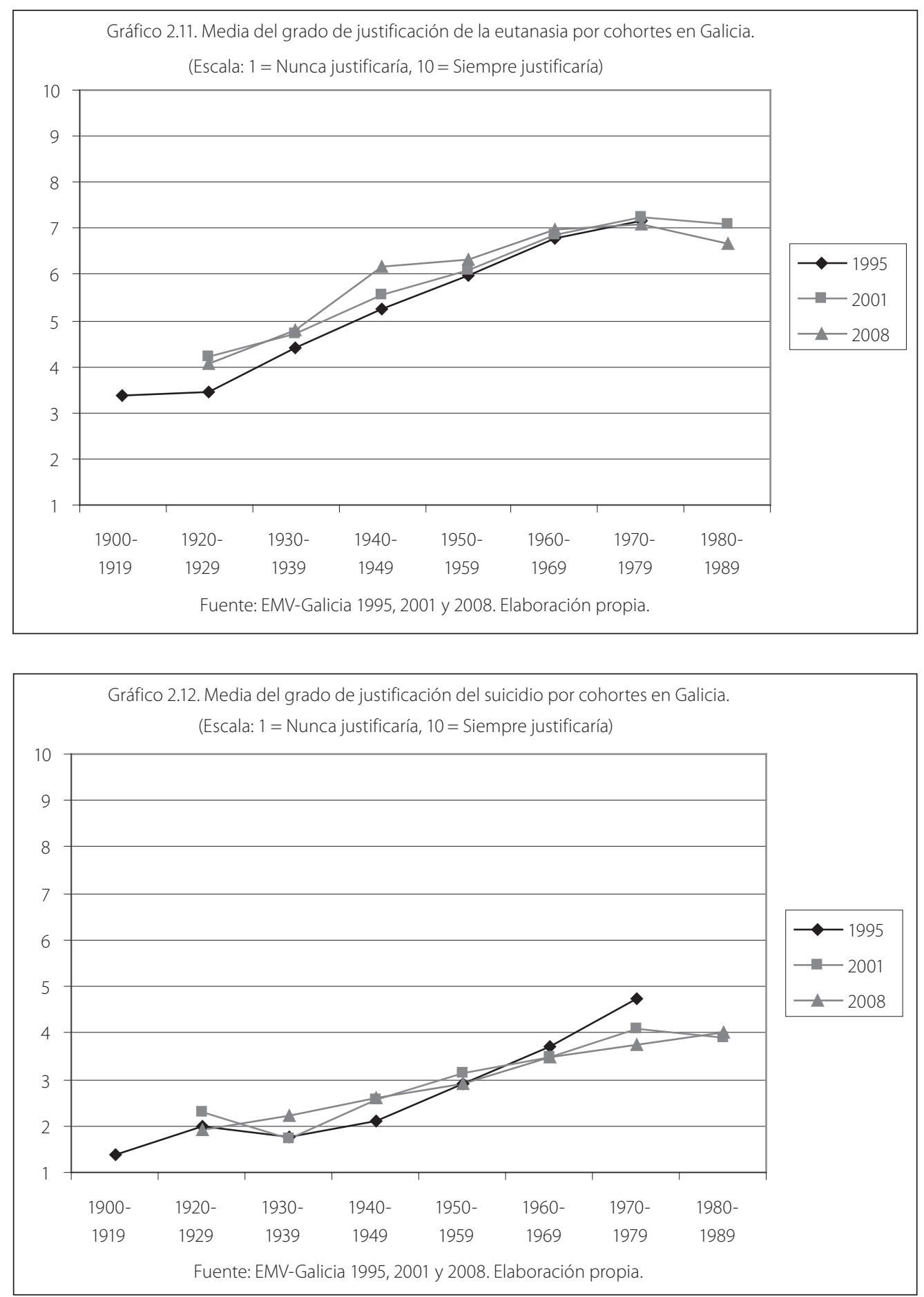


\subsection{GALICIA EN UNA PERSPECTIVA COMPARADA: LA PERMISIVIDAD COMO FENÓMENO DIFERENCIAL}

Hasta ahora hemos visto que una sociedad permisiva se abre paso en Galicia en todos los ámbitos, aunque mucho más en el caso de aquellos aspectos que afectan al uso del propio cuerpo que en los referidos a asuntos económicos. También hemos comprobado que esta evolución hacia una sociedad cada vez más permisiva se corresponde con un cambio generacional.

Para profundizar en esta tendencia hacia una sociedad más permisiva nada mejor que efectuar una amplia comparación entre distintos universos sociales. En los gráficos 2.13 y 2.14 se muestran los datos acerca del grado de justificación de las conductas relacionadas con el dinero y de las relacionadas con el uso del propio cuerpo. A efectos comparativos se han escogido cuatro ámbitos: Galicia, España, Europa y el Mundo. Para simplificar, el análisis se ha limitado a las siguientes fuentes de datos: para Galicia y España las encuestas de 2008 y 2007 respectivamente; para la Unión Europea se han escogido los 11 países incluidos en la Encuesta Mundial de Valores y que eran miembros de la Unión en el momento de realización de la encuesta ${ }^{5}$ y para el Mundo se han utilizado todos los países que participaron en las diferentes oleadas de la encuesta desde 2005 a 2008 (en total 57 países con una muestra total de 82.992 entrevistas).

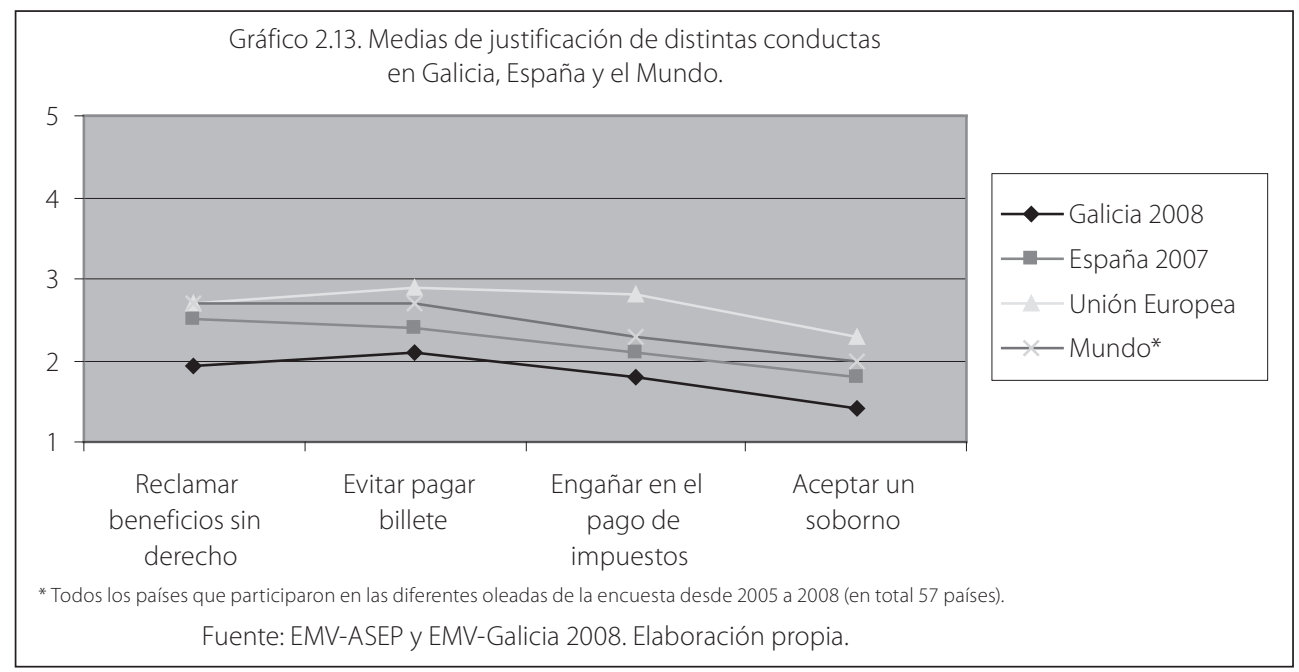

Tanto en el grado de justificación de las conductas relacionadas con el dinero como con las referidas al uso del propio cuerpo, Galicia aparece claramente diferenciada tanto de las medias europeas como españolas y mundiales. A la hora de justificar conductas desviadas, en lo que concierne al dinero, los gallegos entienden que reclamar beneficios sin derecho al Estado, engañar en el pago de

Estos países son: Alemania, Chipre, Eslovenia, España, Finlandia, Francia, Italia, Países Bajos, Polonia, Reino Unido y Suecia. 
impuestos o aceptar un soborno, son conductas siempre o casi siempre injustificables y no alcanzan una media de 2 puntos en la escala; la puntuación más alta corresponde a "evitar pagar un billete" con un 2,1. Ciertamente estas conductas también son muy poco justificables en España, la Unión Europea y el Mundo en general, pero en casi todos los casos califican por encima del 2, a excepción del soborno en España $(1,8)$. Conviene señalar también que tanto España como Galicia, puntúan por debajo de las medias europea y mundial, lo que las convierte en países con una moral muy estricta en todo aquello que atañe a cuestiones de comportamiento desviado en asuntos donde media el dinero. La permisividad social en este ámbito es muy baja: los fraudes económicos nunca o casi nunca son justificados; enriquecerse o beneficiarse a costa de los demás es uno de los comportamientos peor vistos por los gallegos.

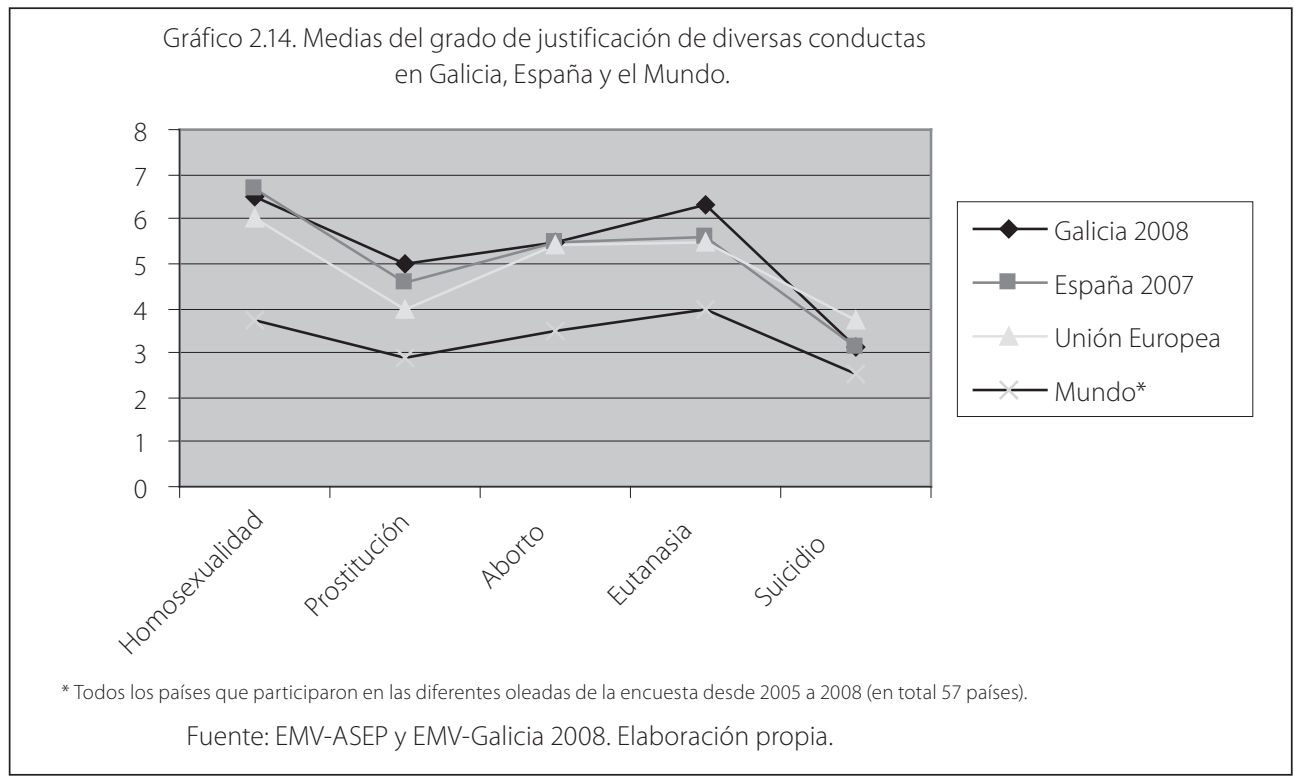

En cuanto a la media del grado de justificación de conductas relacionadas con el uso del propio cuerpo ocurre todo lo contrario: Galicia aparece como la sociedad más permisiva comparada con la media de las sociedades española, europea y mundial. La permisividad de la sociedad gallega es particularmente alta en los casos de la homosexualidad y la eutanasia, siguiendo en esto pautas similares a las otras medias de las muestras española, europea y mundial. Solamente en el caso de la homosexualidad Galicia es superada por España en permisividad en tan solo dos décimas (6,7 frente a 6,5), pero en el resto de las conductas sometidas a justificación, Galicia es más permisiva, especialmente en el caso de la eutanasia. No resulta fácil encontrar una explicación a este hecho diferencial de Galicia en la moral referida al uso del propio cuerpo. Todo lo que se pueda decir son conjeturas con mayor o menor grado de credibilidad. 
No obstante pueden aventurarse algunas suposiciones plausibles basadas en distintas fuentes y según los casos. Así, por ejemplo, es sabido que en los últimos lustros temas como la homosexualidad, la eutanasia y el aborto han sido objeto de legislaciones permisivas en España y otros países europeos, lo cual sin duda impulsó esta corriente de permisividad. En cuanto a la prostitución, la aireación pública en los medios de comunicación de masas hace que sea percibida como una consecuencia de explotación económica de las mafias, más que como una conducta de la que el sujeto es responsable.

Pero aún admitiendo estas razones, subsiste el interrogante de porqué en Galicia hay una mayor tendencia que en España a justificar este tipo de comportamientos. La observación y el conocimiento directo de la sociedad gallega pueden dar, sin embargo, alguna pista. Por ejemplo, es sabido que durante el franquismo e incluso antes de la dictadura, Galicia siempre destacó por otorgar reconocimiento a los entonces llamados "hijos ilegítimos". Era frecuente encontrar en los testamentos la asignación de una parte de la herencia a estos hijos nacidos fuera del matrimonio. Este reconocimiento social de los hijos ilegítimos no era usual en otras partes de España, lo cual muestra una mayor tolerancia y permisividad sobre conductas que, en aquellos tiempos, eran rechazadas o poco justificables. Este ejemplo puede ilustrar un rasgo cultural propio de la sociedad gallega, proclive al reconocimiento de los derechos del individuo por encima de prejuicios sociales o religiosos.

\subsection{CONCLUSIONES}

El sistema de valores de Galicia, en los aspectos aquí analizados, se mueve entre el cambio y la tradición, de manera que se mantiene la importancia de la familia, el trabajo y la amistad, a la vez que se observan tendencias de cambio acerca del valor atribuido a la religión o la política y se incrementa el valor del ocio. El diagnóstico es el de una sociedad orientada a la individualización de intereses, pero que reconoce la importancia de instituciones clásicas, más en un terreno ideal que en el de los compromisos concretos. En consecuencia, la llamada crisis de valores, debería ser interpretada como un retraimiento del compromiso con las instituciones tradicionales — tales como la religión, la familia o la política— más que como un declive de los valores morales o éticos que comportan dichas instituciones. La causa de este retraimiento o desmotivación hay que buscarla en las restricciones institucionales que entran en contradicción con la individualización de intereses: la gente sigue valorando mucho la familia o el trabajo pero su grado de compromiso decae en cuanto perciben algún tipo de amenaza para su autonomía personal (individualización).

En Galicia la familia, la amistad y el tiempo libre son los aspectos más valorados y además con tendencia al alza. El trabajo también es uno de los aspectos de la vida más valorados, pero con propensión al descenso y por lo tanto, a una cierta pérdida de centralidad. La religión y la política ocupan el penúltimo y 
último puesto respectivamente en la escala de valoración de los gallegos. Esta pérdida de interés por la religión y la política es concomitante con el ciclo vital y la generación; los más jóvenes conceden a la religión y la política mucha menos importancia que los de más edad. Pero a este efecto de la edad hay que añadir un efecto de cohorte, lo cual significa que hay un cambio generacional de valores, y no simplemente de opinión según la edad.

La media del grado de rechazo hacia determinadas minorías o conductas es en Galicia menor que en Europa pero mayor que en España. Los grupos más rechazados son aquellos a los que se les atribuye responsabilidad por su conducta: drogadictos, bebedores y gitanos. En este sentido hay que suponer que el rechazo a los gitanos no proviene de su pertenencia a una etnia sino del hecho de que se les asocia con determinadas conductas o estilos de vida no deseables.

La tendencia observada es que en todos los casos, excepto en el de la homosexualidad, el rechazo ha ido en aumento en los tres años consultados. En el caso de la homosexualidad el descenso es significativo y atribuible quizás a la entrada en vigor de leyes que han favorecido la ampliación de derechos de este colectivo.

El hecho diferencial más llamativo del sistema de valores en Galicia se refiere al alto grado de permisividad en lo que concierne al uso del propio cuerpo. La población gallega es muy estricta a la hora de juzgar conductas económicas desviadas - como son engañar a hacienda, no pagar un billete de bus, o practicar un soborno- pero más permisiva que la media europea y española a la hora de justificar conductas como la eutanasia, la homosexualidad, el aborto o la prostitución. Solamente en el caso del suicidio la sociedad gallega es poco permisiva y se acerca a las medias de su entorno cultural, tanto español como europeo.

La permisividad de la sociedad gallega es, desde este punto de vista, un hecho diferencial que rompe más de un tópico acerca de la cultura de los gallegos, aunque también es bien conocida la tesis del arraigado escepticismo galaico muy acorde con el relativismo cultural. Si la prudencia y el relativismo han sido señalados por la literatura y la tradición verbal como rasgos culturales de Galicia, ha de concluirse que la permisividad es su consecuencia.

\subsection{REFERENCIAS BIBLIOGRÁFICAS}

Bauman, Z. (2003): Modernidad líquida. FCE, México.

Boudon, R. (2001): The Originf Values. Sociology and Philosophy of Beliefs, Transaction Publishers,New Brunswick, USA.

Boudon, R. (1995): Le juste et le vrai. Ėtudes sur l'objetivité des valeurs et de la connaissance, Fayard, París.

Díez Nicolás, J. (2004): El dilema de la supervivencia: los españoles ante el medio ambiente. Madrid, Obra Social, Caja Madrid.

Lipovetsky, G. (1994): El crepúsculo del deber. La ética indolora de los nuevos tiempos democráticos, Anagrama, Barcelona. 


\section{RELIGIÓN Y ESPIRITUALIDADES DE VIDA}

José Luis Veira Veira

Celia Muñoz Goy

\subsection{INTRODUCCIÓN}

Aunque pueda parecer paradójico, el estudio de la religión resulta ser, en muchos aspectos, la mejor forma de entender la naturaleza de las sociedades avanzadas. El carácter paradójico se debe a la creencia muy extendida de que la religión es un fenómeno del pasado y que no se corresponde con una sociedad caracterizada por sus logros científicos y tecnológicos. A esta creencia contribuyó decisivamente la Ilustración, con su idea de que en la era de la Razón y la Ciencia la religión no tendría cabida. Esta es también la postura que adoptan algunas teorías de la secularización.

Una mirada retrospectiva indica que todos los clásicos de la Sociología, desde Durkheim a Max Weber, han tenido que recurrir a la explicación del fenómeno religioso como algo inherente a la sociedad. Y hoy en día los estudios sobre la religión no solo proliferan sino que están resultando de gran ayuda para comprender la sociedad actual globalizada. Desde las teorías que anuncian el choque inevitable de civilizaciones hasta las que apuntan a un entendimiento universal de las distintas confesiones religiosas o a la configuración de unos valores mínimos que faciliten la cohesión social en un mundo globalizado, es evidente que el fenómeno religioso sigue presente en la actualidad y no de forma marginal precisamente.

Para Luckmann la religiosidad no es, como vaticinaban los filósofos y moralistas de la Ilustración, una manifestación propia de las sociedades arcaicas o tradicionales, sino que forma parte incuestionable de la vida social contemporánea: "la religión no es una fase pasajera en la evolución de la humanidad sino, más bien, un aspecto universal de la vida humana, un componente de la conditio humana" (Luckmann, 2008a: 15). La defensa de la religiosidad como un componente universal de la vida social obliga a repensar los datos empíricos de la secularización, a reinterpretarlos desde otros supuestos teóricos y a no anunciar precipitadamente la muerte de Dios o la desaparición de toda forma de pensamiento trascendente. 
Partiendo de este reconocimiento de la persistencia de la religiosidad en las sociedades actuales, en sus múltiples formas, la perspectiva sociológica requiere abordar dos aspectos importantes al respecto: el primero es conocer el origen y naturaleza de eso que se denomina "religiosidad" y el segundo es explicar la variación social existente entre individuos y sociedades y su conexión con las religiones organizadas. A estas dos preocupaciones metodológicas habría que añadir la del papel que juega la religión en lo que concierne a la cohesión social de nuestras sociedades en un mundo global.

El tratamiento adecuado de estos requerimientos no es el objetivo de este capítulo, donde solo se pretende dar cuenta del estado actual de la religión y la religiosidad en Galicia desde una perspectiva comparada. Pero es importante aclarar el significado de términos como religiosidad o la función religiosa en las sociedades actuales.

Suele admitirse que la religiosidad o los sentimientos religiosos tienen su origen en experiencias subjetivas de trascendencia. Estas experiencias provienen de distintos niveles como pueden ser la vida cotidiana, o de acontecimientos extraordinarios relacionados con la vida y la muerte, meditación, sueños, dolores extremos, etc. Las experiencias subjetivas de trascendencia "llegan a objetivarse socialmente, en lo que se puede definir como representaciones colectivas religiosas y formulan la cosmovisión en términos inteligibles como un modelo de conducta de la vida individual y colectiva. Este modelo define la manera en la que la realidad cotidiana se relaciona con las realidades trascendentales. Identifica los elementos de estas realidades, ofrece nombres e iconos para las mismas y define su tratamiento adecuado. Las metáforas, los símbolos y los rituales contribuyen a edificar un puente entre estos dos ámbitos diferentes de la realidad" (Luckman, 2008a: 17).

Puede decirse que la religión forma parte importante, incluso muchas veces nuclear, de la cosmovisión colectiva de una sociedad. Pero en la actualidad se han efectuado transformaciones sociales profundas que han alterado esta centralidad de la religión como fuente de cosmovisiones colectivas. Este nuevo contexto requiere tener en cuenta dos factores fundamentales: la globalización y la multiculturalidad. La globalización trajo consigo el pluralismo religioso y como consecuencia de ello la quiebra del monopolio religioso. Las cosmovisiones circulan hoy libremente y forman parte del paisaje religioso de cualquier sociedad avanzada. Este pluralismo de las creencias fomenta el relativismo religioso y socava toda pretensión de supremacía por parte de cualquier religión institucionalizada. Por su parte, la multiculturalidad, estimulada por las importantes corrientes migratorias, plantea de nuevo el problema del papel de las religiones en la consecución de la necesaria cohesión social.

Es en este nuevo contexto de globalización y multiculturalidad donde se deben situar las interpretaciones de los datos obtenidos sobre los valores, creencias, actitudes y comportamientos religiosos. Así, por ejemplo, aunque los datos sobre la disminución de la frecuencia de asistencia a ritos religiosos refuerzan la tesis 
de la secularización, no se debe deducir de ello un desvanecimiento inevitable de la religiosidad. Más bien todo lo contrario: si se desvía el foco de atención de la frecuencia de la asistencia a ritos religiosos, para centrarla en las nuevas formas de espiritualidad y de experiencias subjetivas trascendentes, podría concluirse que "la predicción, hecha desde el pensamiento ilustrado y sus modernas ramificaciones en teoría sociológica de la secularización, de que la religión es un fenómeno histórico pasajero, ha demostrado ser profundamente errónea" (Luckmann, 2008a: 25).

En este punto es necesario indagar acerca de esta nueva forma de religiosidad que trae el nuevo contexto de la globalización y la multiculturalidad. En este sentido puede decirse que el rasgo dominante de las nuevas formas de religiosidad es la profundización en la individualización de la espiritualidad: se ha pasado de un pluralismo religioso, basado en la libertad de elección por parte del sujeto, a una situación de mercado donde la oferta religiosa no solo es más variada sino que además permite la combinación de creencias a la carta. La individualización de la religiosidad no solo permite al sujeto escoger entre las distintas ofertas, sino que incluso puede hacerse su propia composición partiendo de lo que hay en el mercado. La nueva relación entre una forma mercantil de la religión y la individualización sugiere un cambio fundamental en las relaciones entre individuo y religiones organizadas. Este giro hacia el modelo de "oferta" religiosa viene a completar el proceso iniciado por el pluralismo religioso y la libertad de elección (Beck, 2009: 158).

Podría decirse, no obstante, que la globalización y la multiculturalidad no afectan a las grandes religiones universales, puesto que éstas han sido siempre globales y se han podido concretar históricamente en culturas diversas. Sin embargo, aunque la Iglesia Católica (como otras iglesias universales) haya sido desde sus orígenes un global player, lo cierto es que para ser considerado católico hay que "ser de una determinada opinión, estar bautizado y ser cristiano" (Beck, 2009: 60). La relación actual del individuo con la oferta religiosa no presenta estas restricciones organizativas o institucionales. Las iglesias han de competir en un mercado religioso donde los individuos juegan un papel de consumidor de bienes y servicios religiosos y, por lo tanto, las formas de espiritualidad pueden variar enormemente y carecer en muchos casos de una organización estable. En esta situación surge una nueva forma religiosa que se dio en llamar "la religión invisible" (Luckmann, 1973). Esta nueva forma viene caracterizada por la emergencia de las llamadas "espiritualidades de vida" que surgen de la búsqueda de la trascendencia en las actividades y experiencias subjetivas de la vida cotidiana, como la meditación, la salud corporal, los sueños, el misticismo, el deporte, etc.

\subsection{SITUACIÓN SOCIAL DE LA RELIGIÓN EN GALICIA}

Conseguir datos oficiales sobre afiliación religiosa no es fácil debido a que nadie está obligado a declarar su religión de pertenencia. De todos modos se dispone de dos fuentes: las de la propia Iglesia Católica y las derivadas de encuestas. La 
primera de ellas proporciona únicamente datos referidos a la religión católica y las segundas, aunque suelen indagar sobre otras religiones distintas a la católica, solo ofrecen datos aproximados. En cualquier caso, y dado que la religión católica es mayoritaria en Galicia, conviene hacer una referencia a algunos datos obtenidos de la Oficina de Estadística y Sociología de la Iglesia (OESI).

Según los datos de la Iglesia Católica (OESI, 1995) en 1993 había en España un $94,3 \%$ de población católica respecto al total de población (un total de 37.303.768 católicos de una población total de 39.553.265 personas residentes).

De acuerdo con la misma fuente, en Galicia (provincia eclesiástica de Santiago de Compostela que comprende las diócesis de Santiago de Compostela, Lugo, Ourense, Mondoñedo-Ferrol y Tui-Vigo) el porcentaje de población católica respecto al total de población asciende al 98,77\% (un total de 2.653.459 católicos de una población total de 2.686 .471 personas residentes).

Se supone que en estas estadísticas se cuentan como "católicos" a todas las personas bautizadas, independientemente de si actualmente se consideran católicas o si son practicantes o no. En consecuencia se puede esperar que los datos de encuesta ofrezcan alguna variación respecto a los oficiales facilitados por la propia Iglesia Católica. En las encuestas suele preguntarse por el sentimiento de pertenencia a una religión, pero no si está o no bautizado.

El Centro de Investigaciones sobre la Realidad Social (CIRES) — según recoge OESI (1995: 165-166) - estima que la media anual de las respuestas que dicen pertenecer a la Iglesia Católica fue, en el año 1990, el 88,13\% de la población española, en el año 1991 el 89,43\%, en el año 1992 el 91,33\%, en el año 1993 el 91,51\%, en el año 1994 hasta noviembre el 91,17\%. Los que dicen pertenecer a "otra religión distinta de la Católica" obtienen estas medias: en el año 1990 el 1,23\%, en el año 1991 el 1,09\%, en el año 1992 el 0,99\%, en el año 1993 el 1,34\%, en el año 1994 el 1,34\%. La media de los que dicen "no pertenecer a ninguna religión" fue en el año 1990 el 9,73\%, en el año 1991 el 8,63\%, en el año 1992 el 7,39\%, en el año 1993 el 7,1\% y en el año 1994 el 7,47\%.

Estos datos son elocuentes acerca del grado de implantación de la religión católica en España, independientemente de si se considera solo a los bautizados o a los creyentes. Por otra parte, la presencia social de la Iglesia Católica en España no tiene parangón si se tiene en cuenta el número de iglesias/parroquias existentes. Según los datos de la Iglesia Católica (Conferencia Episcopal Española, 2007) en 2005 había en España un total de 23.060 parroquias, que para una población total de 44.108 .530 personas representa una media de 1.913 personas por parroquia. En Galicia, según los mismos datos, el número de parroquias era en 2005 de 3641, que para una población total de 2.724 .302 personas representa una media de 748 personas por parroquia.

Así pues, tanto en Galicia como en España, la religión católica parte de una posición claramente dominante en el mercado religioso. Sin embargo, un análisis más detenido de los datos de encuesta revela que ha comenzado un cierto declive 
en el sentimiento de pertenencia a la religión católica. Según los datos del CIS (2007), durante el año 2007 la media de personas que se declararon católicas fue del $79 \%^{1}$, cifra sensiblemente menor que las de los porcentajes calculados sobre las personas bautizadas. Además este porcentaje parece seguir una pauta descendente: en el último barómetro del CIS de 2010 el porcentaje de los que se declaran católicos bajó al 75\%. No obstante se trata de cifras aún muy por encima de la media europea, pero tratándose de España no deja de ser significativo.

Esta tendencia a la disminución en el número de personas que se sienten pertenecientes a la religión católica también se observa en las tres últimas oleadas de la Encuesta Mundial de Valores en Galicia y en España. En el Gráfico 3.1 se puede observar como en España el porcentaje ha ido disminuyendo en los tres años de consulta, pasando de 83,9\% en 1995 a 80,8\% en 2007; la misma tendencia se observa en Galicia, aunque con un repunte en el 2001, pasando de 87,5\% en 1995 al 83,8\% en 2008 (Gráfico 3.2).
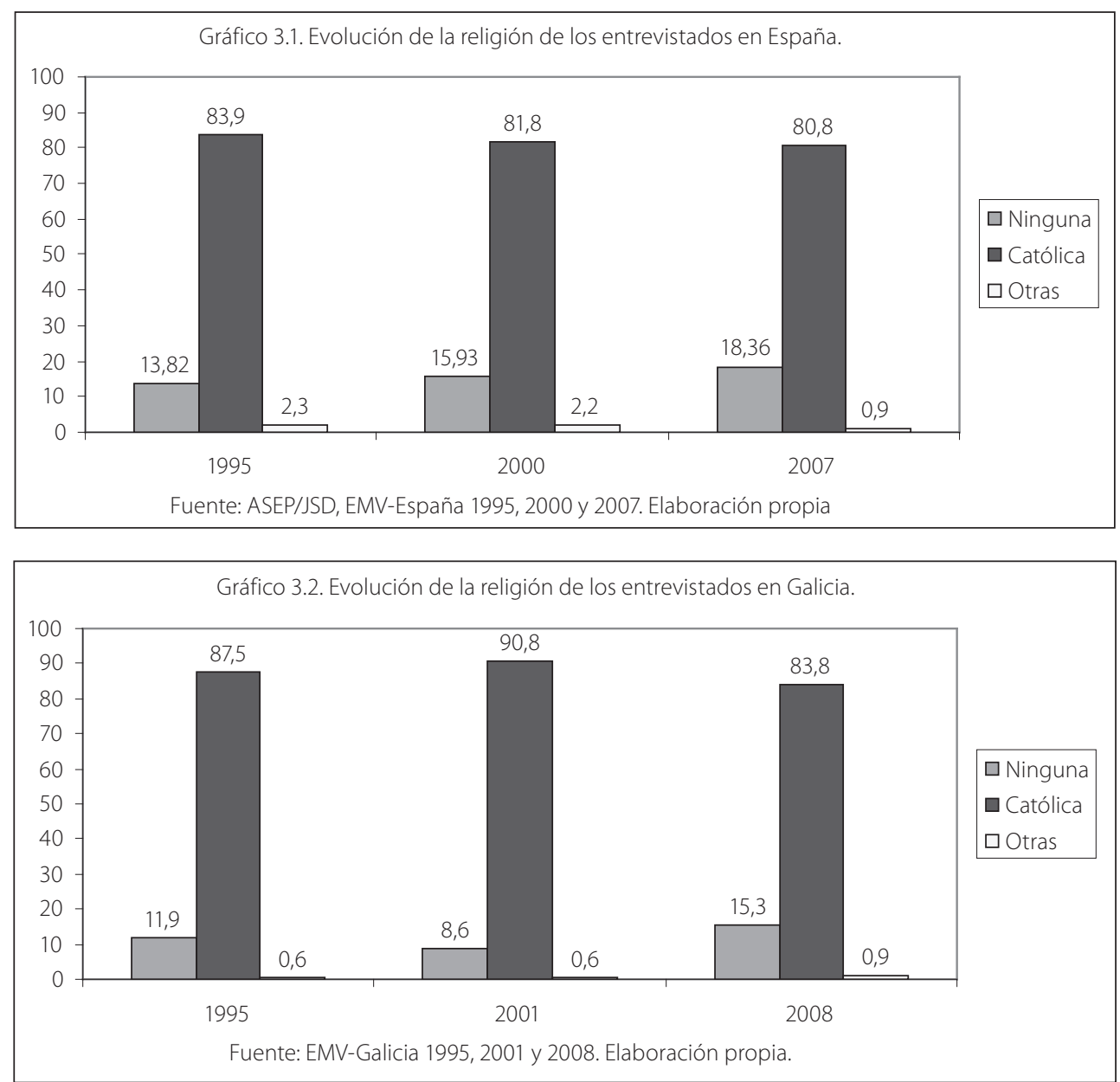

El porcentaje medio se ha calculado teniendo en cuenta los 11 Barómetros del CIS en 2007. 
El compromiso económico con la Iglesia también es un dato revelador para evaluar un posible declive de la religión católica en España y Galicia. La cantidad de asignaciones tributarias a la Iglesia Católica en las declaraciones de impuestos es un buen ejemplo de este compromiso económico. En la Tabla 3.1 se muestran los porcentajes de declaraciones de la renta destinadas a la Iglesia Católica, en exclusiva o compartida con otros fines sociales, durante cinco años. Los datos indican un descenso de las declaraciones con destino exclusivo a la Iglesia Católica tanto en Galicia como en España.

Tabla 3.1. Porcentaje de declaraciones destinadas a la Iglesia o a la Iglesia y fines sociales

\begin{tabular}{ccccc} 
España & \multicolumn{2}{c}{ Galicia } \\
\hline & $\begin{array}{c}\text { \% declaraciones } \\
\text { destinadas a la } \\
\text { Iglesia Católica } \\
\text { en exclusiva }\end{array}$ & $\begin{array}{c}\text { \% declaraciones } \\
\text { destinadas a la } \\
\text { Iglesia Católica y } \\
\text { otros fines sociales }\end{array}$ & $\begin{array}{c}\text { \% declaraciones } \\
\text { destinadas a la } \\
\text { Iglesia Católica } \\
\text { en exclusiva }\end{array}$ & $\begin{array}{c}\text { \% declaraciones } \\
\text { destinadas a la } \\
\text { Iglesia Católica y } \\
\text { otros fines sociales }\end{array}$ \\
\hline 2001 & 27,45 & 11,67 & 24,93 & 9,95 \\
\hline 2002 & 22,01 & 11,27 & 20,04 & 8,95 \\
\hline 2003 & 22,46 & 11,86 & 20,03 & 9,87 \\
\hline 2004 & 21,85 & 11,61 & 19,29 & 10,14 \\
\hline
\end{tabular}

Fuente: Conferencia Episcopal Española (2007). Elaboración propia.

En cuanto a las asignaciones compartidas con otros fines sociales también bajan pero en menor medida. Si algo se puede deducir de estos datos es que un porcentaje elevado de católicos decide no hacer aportaciones económicas a su Iglesia. Si la fuerza e implantación de una institución se mide por el número de seguidores comprometidos, habría que decir que la Iglesia Católica goza de una excelente implantación social, pero con un importante porcentaje de seguidores que podrían calificarse como free riders, es decir, personas con afiliación católica declarada pero poco proclives a comprometerse con la organización a la que dicen pertenecer.

La lectura de estos datos plantea una cuestión sobre la que es necesario reflexionar: averiguar las razones por las que disminuye el porcentaje de población que se declara perteneciente a la religión católica. Volviendo a los gráficos 3.1 y 3.2 , se observa que por un lado se incrementa el porcentaje de personas que no se identifica con ninguna religión, tanto en Galicia como en España, y que por otro disminuye la afiliación a otras religiones en España, si bien hay un ligero aumento en Galicia. 
En este sentido se confirma la tesis de que en España, la transición política a la democracia supuso la aparición de un nuevo paisaje religioso: "las migraciones y conversiones han cambiado el mapa religioso de España. Además de los miles que sin más dejan la Iglesia — los que en otros tiempos hubieran sido estigmatizados con el epíteto de "apóstatas"- , hay que tener en cuenta a los que cambian de Iglesia o de religión, unos 20.000 al año, con destino a la Iglesia Evangélica, unos 12.000 a la cohorte de Testigos de Jehová, 1.800 en el 2006, y en números menores al Budismo, Mormones, Islam e incluso Judaísmo, pese al nulo proselitismo de estos últimos. El resultado último es que en la actualidad más de tres millones de personas, el 7\% de la población española, pertenecen a confesiones distintas a la católica, que congrega en torno al 80\% de la población." (González Anleo, 2008: 63-64).

Según esto, todo parece indicar que en el descenso del porcentaje de católicos, además de los que se decidieron a ingresar en las filas de los ateos, agnósticos o incrédulos, también algo tuvo que ver el impacto de la nueva oferta religiosa propiciada por la libertad de culto. La inmigración también puede señalarse como un elemento importante de este nuevo paisaje religioso, aunque en este caso quizás tenga escaso reflejo en las encuestas a domicilio, por tratarse de un colectivo reducido y de momento con escasa accesibilidad para la selección muestral.

En cualquier caso, la tendencia más llamativa en este nuevo escenario religioso es la persistente fuga de católicos hacia las filas de la incredulidad, el ateísmo o el agnosticismo. Se habla incluso de un exilio religioso de los postcatólicos (González Anleo, 2008) cuyos nuevos hogares religiosos serían las religiones alternativas como la Iglesia Evangélica (a la que pertenecen muchos inmigrantes sudamericanos) o espiritualidades de vida definidas por Luckmann como "religión invisible" (Luckmann: 1973, 2008b). Probablemente sean éstas últimas las que ejerzan un mayor atractivo sobre los postcatólicos debido a dos razones fundamentales: por un lado estas espiritualidades de vida — que tratan de conectar los diversos niveles de la vida con lo trascendente, como el culto al cuerpo, la meditación, el misticismo, y un buen número de ideologías sobre la naturaleza como el ecologismo o el movimiento New Age - son concordantes con el proceso de individualización y un mercado con mayor oferta religiosa, y por otro lado el proceso de adaptación al pluralismo religioso hizo pensar a estos postcatólicos que si la religión católica ya no es la única verdadera, no suscita interés explorar otras y prefieren la opción de una religiosidad/espiritualidad a la carta.

Resumiendo, puede decirse que en el nuevo paisaje de la religión en Galicia y España predomina la Iglesia Católica en un régimen de cuasi-monopolio, en el que no obstante se observan datos que apuntan a un paulatino impacto de la 
oferta de otras religiones y a un incremento de los porcentajes de ateos, agnósticos o simplemente incrédulos. Detrás de estas tendencias se encuentran sin duda los procesos de individualización y de secularización.

\subsection{EL PROCESO DE SECULARIZACIÓN}

Ya se ha mostrado anteriormente (Capítulo 2; Tabla 2.1) una caída de los porcentajes de población que consideran a la religión como un aspecto de mucha o bastante importancia en sus vidas; de un 57,1\% en el año 1995 descendió al $41,1 \%$ en 2008. Este dato por sí solo indica una tendencia bastante firme hacia la secularización de la sociedad gallega. Pero este indicador solo muestra el grado de importancia que se le asigna a la religión y que es claramente inferior que el otorgado a otros aspectos como la familia y el trabajo o la amistad. A continuación se exponen dos tendencias que expresan de forma más precisa la fuerte propensión hacia la secularización, tanto en Galicia como en España. Estas dos tendencias son la disminución de la religiosidad y la asistencia a ritos religiosos.

Realmente resulta espectacular comprobar la caída de la religiosidad en España y Galicia. Las cifras muestran un avanzado estado de secularización en un país considerado tradicionalmente católico. La disminución de la religiosidad ha sido medida preguntando a los entrevistados si se consideraban personas religiosas, no religiosas o ateas. En el Gráfico 3.3 puede observarse que en Galicia la caída de los porcentajes de personas religiosas es bastante drástica, pasando de un $75,8 \%$ en 1995 a un 63,3\% en 2008. En España esta caída es todavía mayor: de un $69,2 \%$ a un 45,6\% (Gráfico 3.4). Estos datos representan un cambio asombroso, dada la imagen estereotipada que se tiene de España como un país con fuertes creencias religiosas. El cambio viene además reforzado por el incremento de los ateos y no religiosos, que en el caso de España ya superan a los religiosos en la consulta de 2007.

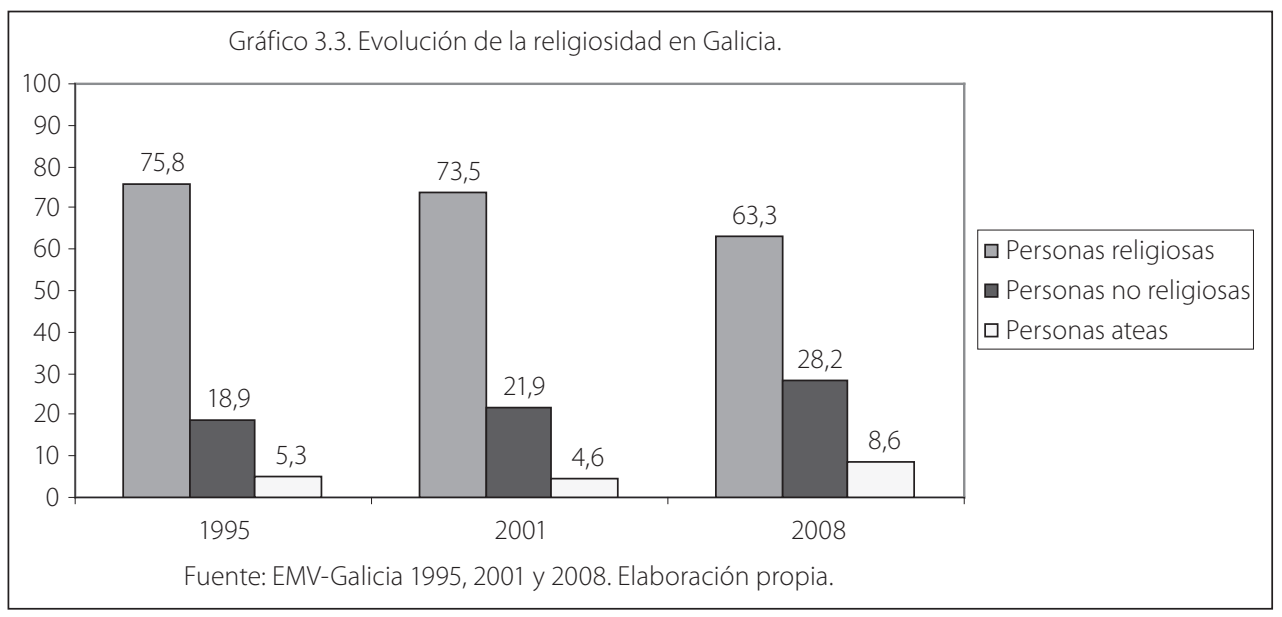




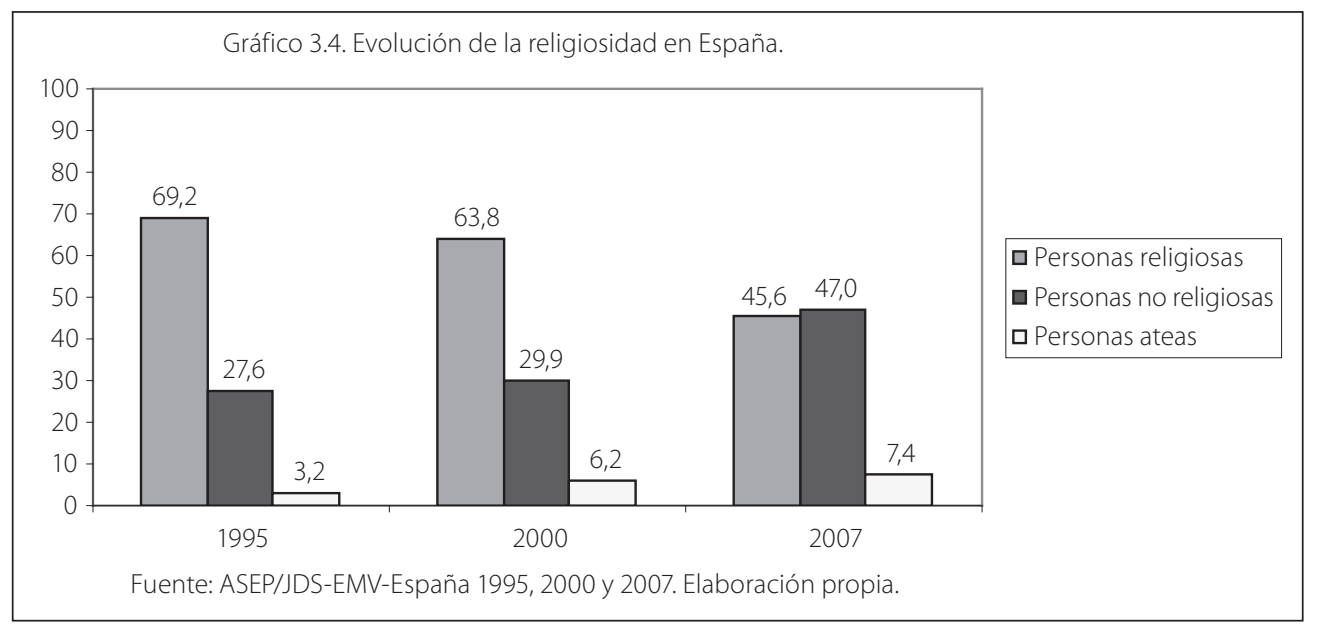

Tabla 3.2. Religiosidad en los países de la Unión Europea.

\begin{tabular}{|c|c|c|c|c|}
\hline & $\begin{array}{c}\text { Una persona } \\
\text { religiosa }\end{array}$ & $\begin{array}{c}\text { Una persona } \\
\text { no religiosa }\end{array}$ & $\begin{array}{c}\text { Un ateo } \\
\text { convencido }\end{array}$ & $\mathrm{N}$ \\
\hline Alemania & $42,9 \%$ & $38,0 \%$ & $19,2 \%$ & 1958 \\
\hline Chipre & $61,6 \%$ & $36,3 \%$ & $2,1 \%$ & 1049 \\
\hline Eslovenia & $72,6 \%$ & $17,6 \%$ & $9,8 \%$ & 915 \\
\hline España & $45,6 \%$ & $47,0 \%$ & $7,4 \%$ & 1166 \\
\hline Finlandia & $60,1 \%$ & $36,8 \%$ & $3,1 \%$ & 986 \\
\hline Francia & $46,9 \%$ & $36,0 \%$ & $17,1 \%$ & 990 \\
\hline Italia & $88,0 \%$ & $9,3 \%$ & $2,7 \%$ & 977 \\
\hline $\begin{array}{l}\text { Países } \\
\text { Bajos }\end{array}$ & $56,9 \%$ & $35,6 \%$ & $7,5 \%$ & 936 \\
\hline Polonia & $94,6 \%$ & $4,0 \%$ & $1,4 \%$ & 972 \\
\hline $\begin{array}{l}\text { Reino } \\
\text { Unido }\end{array}$ & $48,7 \%$ & $40,9 \%$ & $10,4 \%$ & 1009 \\
\hline Suecia & $33,4 \%$ & $49,3 \%$ & $17,2 \%$ & 981 \\
\hline $\begin{array}{l}\text { Media } \\
\text { países UE }\end{array}$ & $57,5 \%$ & $32,8 \%$ & $9,7 \%$ & 11939 \\
\hline $\begin{array}{l}\text { Media } \\
\text { mundial }\end{array}$ & $70,0 \%$ & $25,0 \%$ & $5,0 \%$ & 80078 \\
\hline
\end{tabular}

Fuente: ASEP/JDS, Estudio Mundial de Valores Oleada 5 (2005-2008). Elaboración propia. 
Si se contempla este fenómeno de la caída de la religiosidad desde una perspectiva comparada ${ }^{2}$, el cambio social operado resulta todavía más evidente. En la Tabla 3.2 los datos muestran que España está por debajo de la media europea en cuanto a religiosidad. Solamente Alemania y Suecia tienen porcentajes más bajos que España. Galicia, en cambio, con el 63,3\% está por encima de media europea (57,5\%) pero lejos de otros países católicos como Italia y Polonia.

En Galicia esta religiosidad va asociada a variables como la edad, el nivel de estudios y el posicionamiento político, de tal manera que se dan porcentajes más altos de religiosidad entre las personas de mayor edad, menor nivel de estudios y entre los que se posicionan políticamente a la derecha. En la Tabla 3.3 se muestran las correlaciones entre la religiosidad y estas variables. Aunque las correlaciones bajan un poco en el año 2008 (especialmente la correlación con el nivel de estudios), debe destacarse la persistencia de la correlación en el tiempo.

Tabla 3.3. Correlaciones de Spearman entre la religiosidad y distintas variables sociodemográficas en Galicia.

\begin{tabular}{lccc} 
& 1995 & 2001 & $\mathbf{2 0 0 8}$ \\
\hline Edad & $0,374^{* *}$ & $0,371^{* *}$ & $0,368^{* *}$ \\
\hline Nivel de estudios & $-0,343^{* *}$ & $-0,352^{* *}$ & $-0,223^{* *}$ \\
\hline Posicionamiento político & $0,308^{* *}$ & $0,342^{* *}$ & $0,305^{* *}$ \\
\hline
\end{tabular}

** La correlación es significativa al nivel 0,01 (bilateral).

Fuente: EMV-Galicia 1995, 2001 y 2008. Elaboración propia.

La frecuencia con que se asiste a la Iglesia también es un indicador del grado de compromiso con la religión. En Galicia la asistencia a la Iglesia ha venido disminuyendo desde 1995 (Gráfico 3.5) como también en España (Gráfico 3.6). En concreto, la asistencia semanal -la que supone un mayor grado de compromiso con la fe- ha caído en Galicia de un 37,6\% a un 22,7\% y en España ha pasado de un $25,5 \%$ a un $15,8 \%$. Las cifras sugieren un elevado índice de secularización en ambas sociedades, que corrobora los datos anteriores sobre el descenso de la religiosidad. Estos datos completan el cuadro de un paisaje religioso en franca decadencia en cuanto al compromiso con la fe. En un país de tradición católica como España, que el 58,5\% de la población no asista nunca o casi nunca a la

\footnotetext{
Para contar con una perspectiva comparada se han utilizado los datos de todos los países de la Unión Europea (UE) en los que se realizó la Encuesta Mundial de Valores en la última oleada (2005-2008), así como una media de todos los países del mundo. En algunas de las tablas posteriores no aparecen exactamente los mismos países, puesto que en las adaptaciones nacionales del cuestionario no siempre se incluyeron todas las preguntas.
} 
iglesia es un síntoma claro de quiebra de esa tradición. No obstante, al comparar esta situación con el resto de la UE se observa que Galicia está por encima de la media en asistencia a la iglesia, mientras que España se sitúa algo más de un punto por debajo en la asistencia semanal y casi cuatro puntos en la mensual (Tabla 3.4).
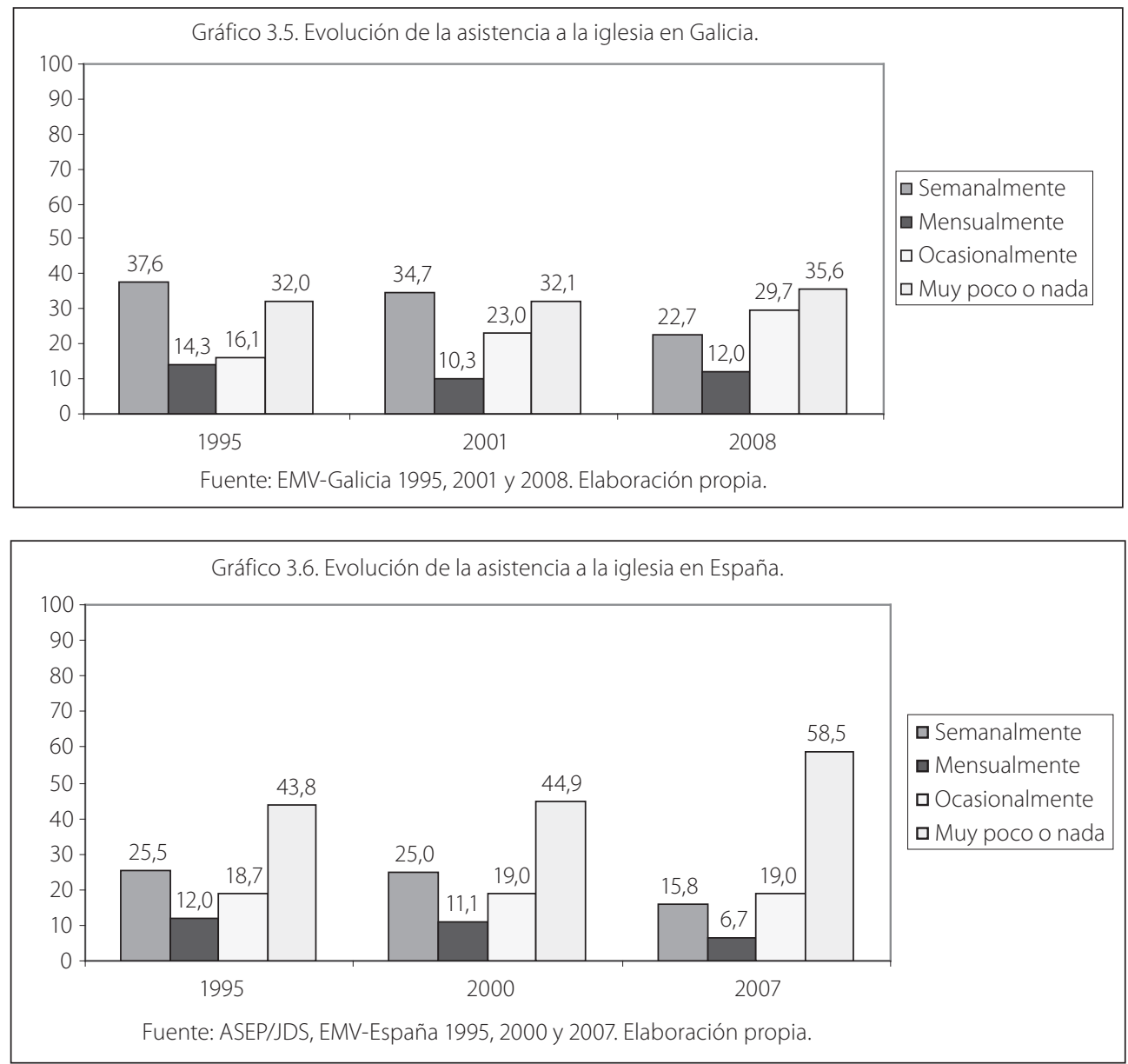

La edad, el nivel de estudios y el posicionamiento político son las variables que tienen mayor asociación con la frecuencia de asistencia a la iglesia. Los jóvenes asisten menos a la iglesia que los mayores, como también los de niveles más altos de estudios y los que se posicionan políticamente a la izquierda. De nuevo aquí se da un ligero descenso de las correlaciones en el año 2008, especialmente en el caso del nivel de estudios (Tabla 3.5). Pero la persistencia de las correlaciones es suficiente para que se pueda afirmar una fuerte asociación entre estas variables y la asistencia a ritos religiosos. 
Tabla 3.4. Frecuencia de asistencia a la iglesia, en los países de la Unión Europea.

\begin{tabular}{lccccc} 
& & & & & Muy poco \\
& Semanalmente & Mensualmente & Ocasionalmente & o nada & N \\
\hline Alemania & $8,1 \%$ & $10,8 \%$ & $24,1 \%$ & $57,1 \%$ & 2012 \\
\hline Chipre & $18,9 \%$ & $15,0 \%$ & $45,5 \%$ & $20,7 \%$ & 1049 \\
\hline Eslovenia & $18,6 \%$ & $10,0 \%$ & $35,0 \%$ & $36,3 \%$ & 1010 \\
\hline España & $15,8 \%$ & $6,7 \%$ & $19,1 \%$ & $58,5 \%$ & 1179 \\
\hline Finlandia & $6,7 \%$ & $7,8 \%$ & $40,2 \%$ & $45,5 \%$ & 1010 \\
\hline Francia & $7,2 \%$ & $3,8 \%$ & $21,6 \%$ & $67,3 \%$ & 997 \\
\hline Italia & $31,5 \%$ & $22,7 \%$ & $29,1 \%$ & $16,7 \%$ & 1000 \\
\hline $\begin{array}{l}\text { Países } \\
\text { Bajos }\end{array}$ & $11,7 \%$ & $7,4 \%$ & $20,0 \%$ & $61,0 \%$ & 989 \\
\hline $\begin{array}{l}\text { Polonia } \\
\text { Reino }\end{array}$ & $57,7 \%$ & $17,7 \%$ & $17,3 \%$ & $7,2 \%$ & 993 \\
\hline Unido & $17,3 \%$ & $6,2 \%$ & $19,9 \%$ & $56,7 \%$ & 1034 \\
\hline $\begin{array}{l}\text { Suecia } \\
\text { Media }\end{array}$ & $3,2 \%$ & $4,7 \%$ & $26,2 \%$ & $66,0 \%$ & 1002 \\
\hline $\begin{array}{l}\text { Países UE } \\
\text { Media }\end{array}$ & $17,0 \%$ & $10,3 \%$ & $26,8 \%$ & $45,9 \%$ & 12275 \\
\hline mundial & $35,3 \%$ & $10,9 \%$ & $21,1 \%$ & $32,6 \%$ & 77143 \\
\hline
\end{tabular}

Fuente: ASEP/JDS. Estudio Mundial de Valores Oleada 5 (2005-2008). Elaboración propia.

Tabla 3.5. Correlaciones de Spearman entre asistencia a la iglesia y distintas variables sociodemográficas en Galicia.

\begin{tabular}{lccc} 
& 1995 & 2001 & 2008 \\
\hline Edad & $0,460^{* *}$ & $0,503^{* *}$ & $0,437^{* *}$ \\
\hline Nivel de estudios & $-0,350^{* *}$ & $-0,374^{* *}$ & $-0,281^{* *}$ \\
\hline Posicionamiento político & $0,284^{* *}$ & $0,331^{* *}$ & $0,347^{* *}$ \\
\hline
\end{tabular}

** La correlación es significativa al nivel 0,01 bilateral.

Fuente: EMV-Galicia 1995, 2001 y 2008. Elaboración propia.

Las dos tendencias señaladas, las disminuciones en los porcentajes de religiosidad y de asistencia a la iglesia, son los indicadores más claros del proceso de secularización en España y en Galicia. Como se ha mostrado, estas tendencias se 
mantienen a través de las tres consultas realizadas, con mayor intensidad en el caso de España que en el de Galicia. Pero en ambos casos se sitúan en torno a la media de la UE. La novedad reside en la velocidad del proceso, pues en España, y también en Galicia, la fuerte caída de la religiosidad y la asistencia a la iglesia se da en un período relativamente corto de nuestra historia reciente.

Es de esperar que este proceso de secularización afecte a otros aspectos muy relacionados con la religiosidad, como es la búsqueda de sentido y significado a la vida. Una de las funciones primordiales de la religión ha sido la de suministrar a sus fieles claves y significados que den sentido a sus vidas. Pensar en el significado de la vida siempre tuvo un sentido religioso, de trascendencia. Es difícil imaginar una sociedad en la que sus miembros no se planteen nunca el sentido de la vida. Sin embargo, ocurre. También en este aspecto se ha observado una reducción de la frecuencia con que la gente piensa en el sentido y significado de sus vidas. Los gráficos 3.7 y 3.8 muestran que el porcentaje de los que piensan con frecuencia en el sentido y significado de la vida disminuye drásticamente desde 1995, tanto en Galicia como en España. En España, concretamente, se alcanza una cifra que está muy por debajo de la media europea (Tabla 3.6). Sin embargo, es posible que, para realizar una interpretación correcta y más matizada del fenómeno, este porcentaje deba sumarse al de los que afirman que piensan algunas veces en el significado de sus vidas. Ello se debe a que pensar con cierta frecuencia en el significado de la propia vida probablemente sea un lujo al alcance de pocos. Pensar en el sentido de la vida solo es posible cuando uno se para y reflexiona, o cuando una circunstancia extraordinaria incita a la trascendencia. En tal caso, sumando los porcentajes de los que piensan con frecuencia y algunas veces en el sentido de la vida el paisaje que se contempla difiere mucho del anterior: los porcentajes para Galicia suben por encima del 70\%, excepto en 2008 que se sitúa en el 67,6\%; en España las cifras son algo menores pero similares. Ello quiere decir que a pesar del proceso de secularización las personas siguen buscando respuestas y conexiones con lo trascendente, dondequiera que puedan encontrarlas. Sin embargo, también es preciso añadir que al considerar de forma agregada los porcentajes de los que piensan con frecuencia o algunas veces en el significado de la vida se sigue manteniendo la tendencia descendente y además se obtienen valores inferiores a la media europea.

La edad, el nivel de estudios y el posicionamiento político son variables asociadas a la frecuencia con la que se piensa en el significado de la vida (Tabla 3.7). Pero en este caso, a diferencia de las correlaciones vistas con anterioridad, la intensidad de las relaciones es más débil e incluso cambia de dirección en algunos años. La reflexión que sugieren estos datos es que pensar sobre el significado de la vida ha perdido probablemente gran parte de su carga religiosa tradicional y aparece como una conducta más vinculada a la privatización de la trascendencia y a las espiritualidades de vida. De ahí su débil correlación con el posicionamiento político. 

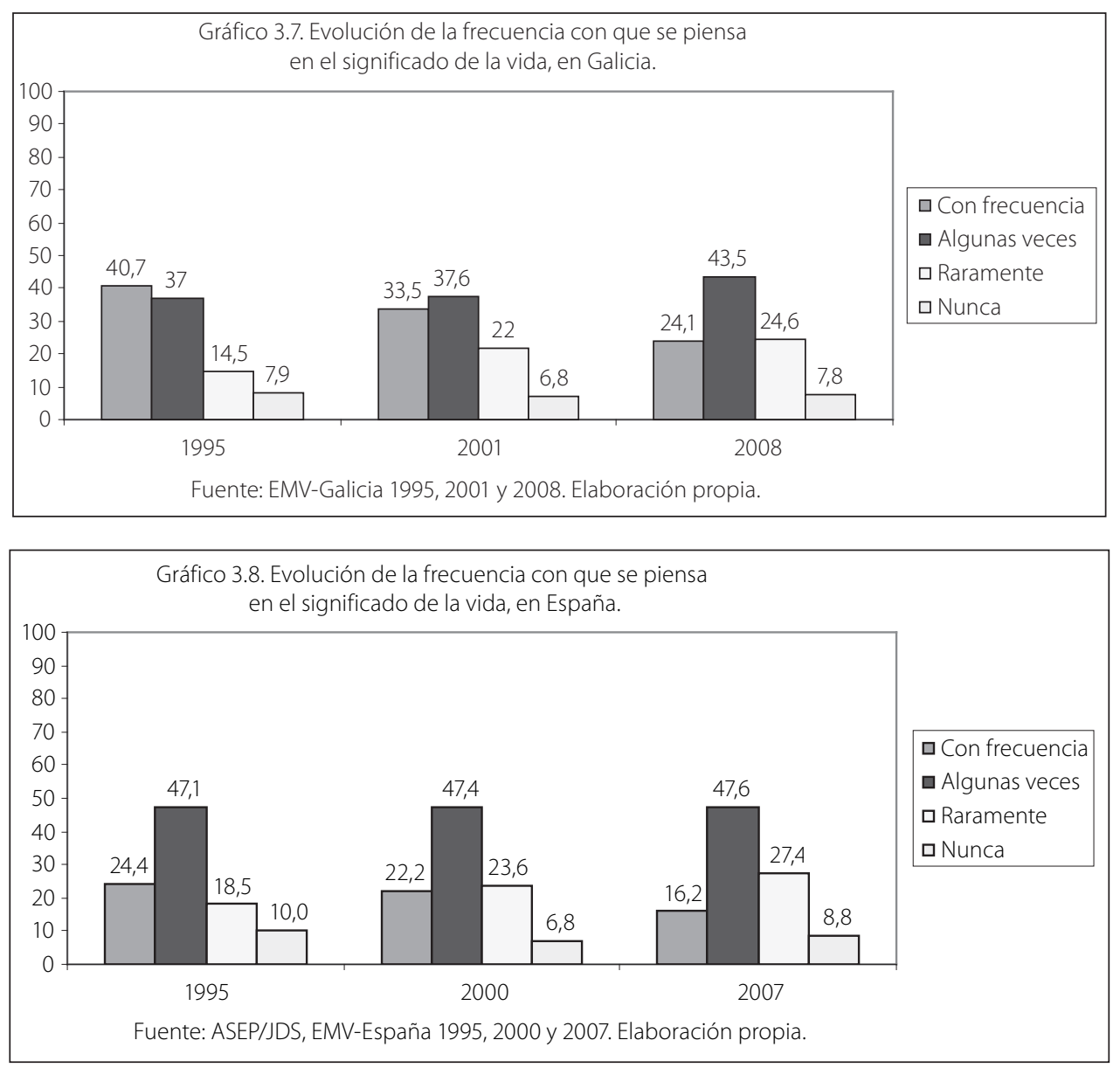

Tabla 3.6. Frecuencia con la que se piensa sobre el significado y el objeto de la vida, en los países de la Unión Europea.

\begin{tabular}{lccccc} 
& & Algunas & & \\
& Con frecuencia & veces & Raramente & Nunca & N \\
\hline Alemania & $28,7 \%$ & $41,1 \%$ & $22,7 \%$ & $7,4 \%$ & 2039 \\
\hline Chipre & $44,4 \%$ & $37,2 \%$ & $12,9 \%$ & $5,5 \%$ & 1046 \\
\hline Eslovenia & $31,1 \%$ & $45,0 \%$ & $14,9 \%$ & $8,9 \%$ & 1019 \\
\hline España & $16,2 \%$ & $47,6 \%$ & $27,4 \%$ & $8,8 \%$ & 1191 \\
\hline Finlandia & $40,6 \%$ & $38,0 \%$ & $18,4 \%$ & $2,9 \%$ & 1013 \\
\hline Francia & $44,3 \%$ & $34,9 \%$ & $14,9 \%$ & $5,9 \%$ & 995 \\
\hline Italia & $46,9 \%$ & $41,4 \%$ & $8,8 \%$ & $2,9 \%$ & 1009 \\
\hline
\end{tabular}




\begin{tabular}{|c|c|c|c|c|c|}
\hline & Con frecuencia & $\begin{array}{c}\text { Algunas } \\
\text { veces }\end{array}$ & Raramente & Nunca & $\mathrm{N}$ \\
\hline $\begin{array}{l}\text { Países } \\
\text { Bajos }\end{array}$ & $33,4 \%$ & $46,5 \%$ & $16,1 \%$ & $4,0 \%$ & 1042 \\
\hline Polonia & $33,0 \%$ & $39,2 \%$ & $19,6 \%$ & $8,1 \%$ & 994 \\
\hline $\begin{array}{l}\text { Reino } \\
\text { Unido }\end{array}$ & $38,1 \%$ & $36,6 \%$ & $17,5 \%$ & $7,8 \%$ & 1032 \\
\hline Suecia & $31,2 \%$ & $38,5 \%$ & $24,1 \%$ & $6,2 \%$ & 1001 \\
\hline $\begin{array}{l}\text { Media } \\
\text { países UE }\end{array}$ & $34,5 \%$ & $40,7 \%$ & $18,5 \%$ & $6,4 \%$ & 12382 \\
\hline $\begin{array}{l}\text { Media } \\
\text { mundial }\end{array}$ & $46,2 \%$ & $35,3 \%$ & $13,8 \%$ & $4,7 \%$ & 81126 \\
\hline
\end{tabular}

Fuente: ASEP/JDS, Estudio Mundial de Valores Oleada 5 (2005-2008). Elaboración propia.

Tabla 3.7. Correlaciones de Spearman entre la frecuencia con que se piensa en el significado de la vida y distintas variables sociodemográficas en Galicia.

\begin{tabular}{lccc} 
& 1995 & 2001 & 2008 \\
\hline Edad & $-0,057$ & $0,122^{* *}$ & $0,053^{*}$ \\
\hline Nivel de estudios & $0,123^{* *}$ & $-0,066^{*}$ & $-0,059^{*}$ \\
\hline Posicionamiento político & $-0,018$ & $0,114^{* *}$ & $0,050^{*}$ \\
\hline
\end{tabular}

* La correlación es significativa al nivel 0,05 bilateral.

** La correlación es significativa al nivel 0,01 bilateral.

Fuente: EMV-Galicia 1995, 2001 y 2008. Elaboración propia.

\subsubsection{Las creencias}

Ser una persona religiosa implica creer en fuerzas o principios sobrenaturales. Determinados valores son creencias que explican y dan sentido a la vida; a este tipo de creencias pertenecen los valores religiosos. A partir de ahí se pueden desarrollar creencias más concretas dependiendo de cada religión en particular. En el ámbito religioso europeo, las creencias en Dios, en el infierno, en la vida después de la muerte, en el alma, en el demonio, en el cielo y en el pecado son parte del credo religioso predominante. Pero estas creencias tienen un grado de implantación diverso entre la población.

Las creencias que alcanzan un mayor nivel de difusión social son las ideas de un Dios y un alma individual. El 88,9\% en 1995 y el 89\% en 2001 creen que Dios existe; y más del $70 \%$ en ambos años cree que hay un alma individual. Pocas creencias son tan ampliamente compartidas. A considerable distancia se sitúan las creencias en la vida después de la muerte, el pecado y el cielo. Las ideas 
del infierno y el demonio son las menos compartidas (Veira, 2007: 96-99). Estas diferencias en las creencias pueden explicarse a partir de la teoría según la cual una idea o creencia tendrá más posibilidad de durar en el tiempo y mantenerse si conlleva un mensaje de felicidad, esperanza o dignidad humanas. Por esta razón se cree más en el cielo que en el infierno, más en el alma — que hace inmortal a la persona- que en el diablo, etc. (Boudon, 2002: 39-41).

La amplia difusión de la creencia en Dios no se corresponde exactamente con la importancia que Dios tiene en la vida de las personas. En la Tabla 3.8 se exponen las medias de esta importancia en los países de la UE y se advierte que casi todas —salvo Chipre, Polonia e Italia — están muy por debajo de la media mundial $(7,8)$. Europa es quizás una de las regiones del mundo donde se percibe con más claridad el proceso de secularización. Hay países que, como Suecia, Alemania, Francia y Países Bajos tienen una media por debajo del 5. España, aún considerándose un país católico, su media se sitúa en un 5,3 y la de Galicia en 6,2 en 2008. A estas bajas puntuaciones hay que añadir una clara tendencia descendente de las medias, algo más pronunciada en España que en Galicia (gráficos 3.9 y 3.10).

Tabla 3.8. Media de la importancia de Dios en la vida de los entrevistados, en los países de la Unión Europea (Escala: $1=$ Nada importante $10=$ Muy importante).

\begin{tabular}{|c|c|c|}
\hline & Media & $\mathrm{N}$ \\
\hline Alemania & 4,5 & 2007 \\
\hline Chipre & 8,7 & 1049 \\
\hline Eslovenia & 5,4 & 989 \\
\hline España & 5,3 & 1180 \\
\hline Finlandia & 6,0 & 998 \\
\hline Francia & 4,7 & 994 \\
\hline Italia & 7,8 & 994 \\
\hline Países Bajos & 4,5 & 1020 \\
\hline Polonia & 8,7 & 981 \\
\hline Reino Unido & 5,6 & 1025 \\
\hline Suecia & 3,9 & 994 \\
\hline Media países UE & 5,8 & 12231 \\
\hline Media mundial & 7,8 & 81017 \\
\hline
\end{tabular}

Fuente: ASEP/JDS, Estudio Mundial de Valores Oleada 5 (2005-2008). Elaboración propia. 

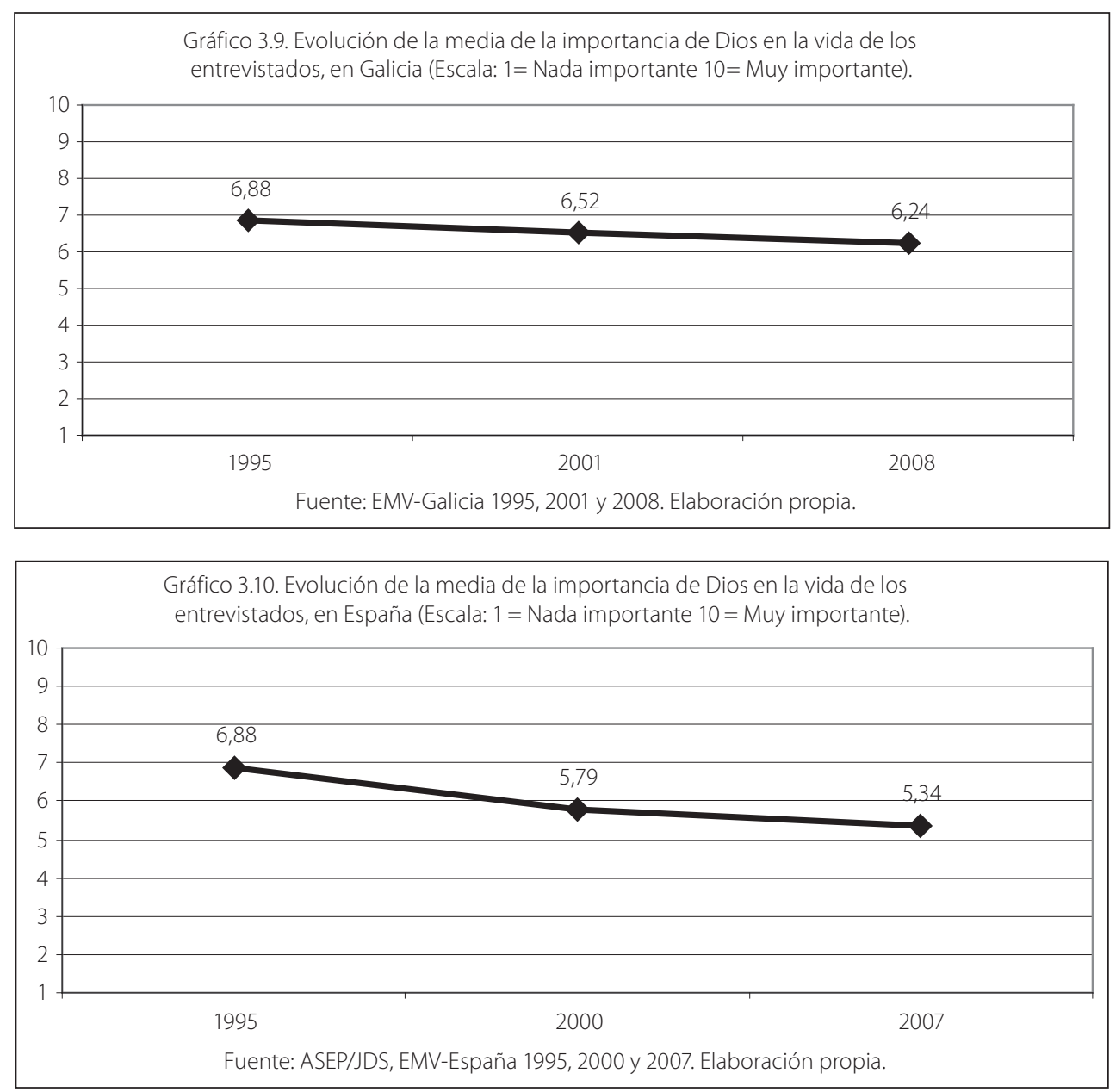

Nuevamente en este caso se aprecian importantes correlaciones entre las variables edad, nivel de estudios y posicionamiento político (Tabla 3.9) en el sentido de que la importancia de Dios aumenta con la edad, con el posicionamiento político hacia la derecha y cuanto más bajo es el nivel de estudios. La intensidad de las correlaciones disminuye con la edad y el nivel de estudios en 2008, mientras que la que concierne al posicionamiento político es más estable. Todo indica que las creencias políticas y religiosas tienen un alto grado de concomitancia.

Todas las religiones dan mucha importancia a actividades tales como el rezo, la meditación o cualquier otro tipo de recogimiento espiritual que induzca al pensamiento trascendente o a la conexión con Dios. También aquí la media europea está muy por debajo de la media mundial y España, en concreto, ocupa el puesto más bajo de la UE en consonancia con el proceso de secularización (Tabla 3.10). En el caso de Galicia el porcentaje de los que rezan o meditan alguna vez está 11 puntos por encima de la media española, pero por debajo de 
la europea (gráficos 3.11 y 3.12). En este aspecto, tanto España como Galicia se desmarcan fuertemente de los otros dos países considerados de tradición católica como son Italia y Polonia. Esta peculiaridad de los casos español y gallego es uno de los rasgos culturales más diferentes que destacan en el ámbito de los valores. Si además se tiene en cuenta que la tendencia en los dos años consultados es decreciente cabe pensar que existen fuertes razones para que esto ocurra. Algunas de ellas podrían encontrarse en la historia reciente de nuestro país: la secularización vertiginosa que comenzó en España a finales de la dictadura, acrecentándose después con la democracia, dio paso a un nuevo paisaje religioso donde muchos antiguos creyentes, advirtiendo que ya no hay una religión verdadera, optan por engrosar las filas de la incredulidad o del "pasotismo endurecido y sombrío" (Richard, 2008: 11) antes que explorar nuevas ofertas religiosas.

Tabla 3.9. Correlaciones de Spearman entre la importancia de Dios en la vida de los entrevistados y distintas variables sociodemográficas en Galicia.

\begin{tabular}{lccc} 
& 1995 & $\mathbf{2 0 0 1}$ & $\mathbf{2 0 0 8}$ \\
\hline Edad & $0,405^{* *}$ & $0,430^{* *}$ & $0,365^{* *}$ \\
\hline Nivel de estudios & $-0,314^{* *}$ & $-0,352^{* *}$ & $-0,221^{* *}$ \\
\hline Posicionamiento político & $0,347^{* *}$ & $0,356^{* *}$ & $0,346^{* *}$ \\
\hline
\end{tabular}

** La correlación es significativa al nivel 0,01 bilateral.

Fuente: EMV-Galicia 1995, 2001 y 2008. Elaboración propia.

Tabla 3.10. Porcentajes de respuesta a la pregunta sobre si "idedica parte de su tiempo al rezo, la meditación, la contemplación, o algo similar?", en los países de la Unión Europea.

\begin{tabular}{llll} 
& Sí & No & N \\
\hline Alemania & $47,0 \%$ & $53,0 \%$ & 1994 \\
\hline Chipre & $74,8 \%$ & $25,2 \%$ & 1047 \\
\hline Eslovenia & $49,3 \%$ & $50,7 \%$ & 1002 \\
\hline España & $33,6 \%$ & $66,4 \%$ & 1179 \\
\hline Finlandia & $70,1 \%$ & $29,9 \%$ & 993 \\
\hline Italia & $77,7 \%$ & $22,3 \%$ & 979 \\
\hline Polonia & $87,0 \%$ & $13,0 \%$ & 963 \\
\hline Suecia & $46,7 \%$ & $53,3 \%$ & 992 \\
\hline Media países UE & $58,7 \%$ & $41,3 \%$ & 9149 \\
\hline Media mundial & $76,9 \%$ & $23,1 \%$ & 68536 \\
\hline
\end{tabular}

Fuente: ASEP/JDS, Estudio Mundial de Valores Oleada 5 (2005-2008). Elaboración propia. 

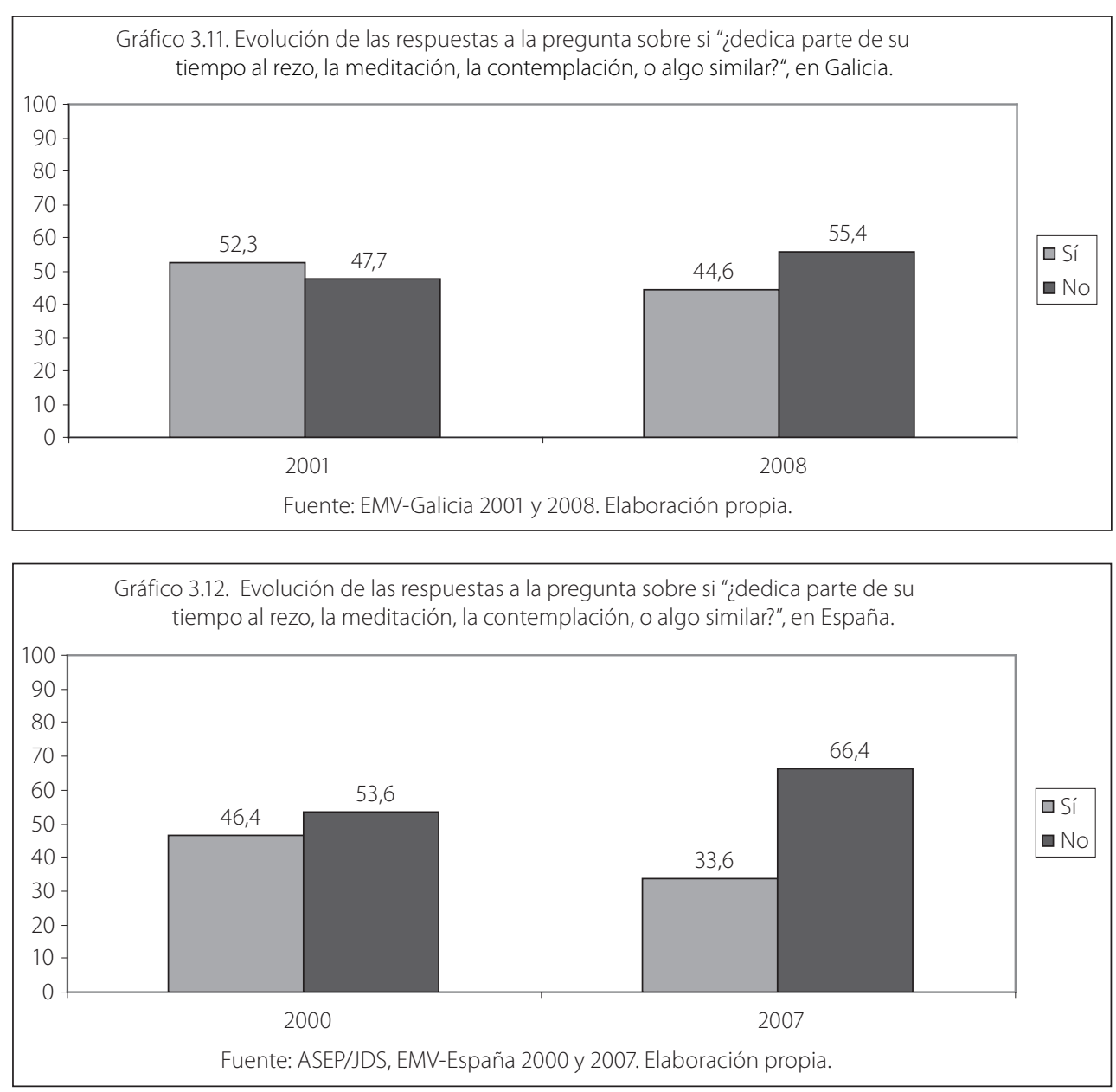

Una vez disipadas las culturas de la "vergüenza" y la "culpa", propias del franquismo, sobreviene la sociedad de la decepción, fruto del hedonismo consumista. La religión ya no puede ofrecer consuelo y fortaleza y la sociedad se orienta hacia otras formas de religión no institucionalizada que calme la ansiedad y la incertidumbre de lo trascendente: "Para combatir la decepción, las sociedades tradicionales tenían el consuelo religioso; las sociedades hipermodernas utilizan de cortafuegos la incitación incesante a consumir, a gozar, a cambiar. Tras las 'técnicas' reguladas colectivamente por el mundo de la religión, han llegado las 'medicaciones' diversificadas y desreguladas del universo individualista en régimen de autoservicio" (Lipovetsky, 2008: 23-24).

A esta situación de desencanto se llega en las sociedades europeas de un modo evolutivo y gradual, fruto de un proceso de secularización prolongado, pero en España el paréntesis obligado de la dictadura interrumpió este proceso reapareciendo al final con enorme vigor, lo que dio lugar a una oscilación pendular muy acusada, explicando en parte su singularidad en el mapa religioso europeo. 


\subsection{IGLESIA, SOCIEDAD Y POLÍTICA}

Ya se ha comentado el proceso de secularización llevado a cabo en Galicia a través de los cambios operados en las creencias y la conducta religiosas. El hecho más destacado por su singularidad es que esta secularización ha alcanzado cotas con frecuencia superiores a la media europea, aunque algo por debajo de la media española. Tanto en lo que concierne a religiosidad como a asistencia a ritos religiosos o a la importancia de Dios en la vida de las personas y la práctica del rezo, Galicia y España han evolucionado hacia un desencanto y pasotismo religioso sin parangón en Europa, salvo el caso de Suecia. Se ha apuntado también que las causas de esta decepción religiosa se encuentran en la historia reciente de nuestra sociedad, cuyos ciudadanos se toparon, a la salida de la dictadura, con un pluralismo religioso no esperado que sacudió y relativizó sus conciencias de forma súbita. En estas circunstancias, el poscatolicismo español se deslizó por la pendiente del relativismo moral más acorde con el proceso de individualización de intereses. Por otra parte, durante el presente período de gobierno socialista se han vuelto a plantear viejos conflictos religioso-políticos, tanto en el ámbito de las relaciones Iglesia-Estado como en la esfera de la moral y la forma de entender los derechos humanos (ley del matrimonio entre personas del mismo sexo, ley del aborto, debates sobre la eutanasia, etc.). La Iglesia se ha sentido hostigada por estos planteamientos por lo que, en general, el clima entre ambas instituciones es cada vez más tenso. Esta tirantez entre Gobierno e Iglesia está teniendo gran eco mediático y sin duda está influyendo en las actitudes de la población hacia la Iglesia.

Pero también se ha señalado que, a pesar de todo, una gran mayoría sigue considerándose católica y cree en Dios aunque su importancia en la vida cotidiana haya descendido. Este dato, discordante con el proceso de secularización, debe ser contemplado a la luz de la información sobre lo que opina la gente acerca del papel de la Iglesia en la sociedad. Puede que muchas personas sigan considerándose católicas — por el hecho de estar bautizadas - pero se distancian de la Iglesia porque juzgan críticamente su papel en la sociedad actual. La Iglesia desempeña un papel público y como tal ha de conectar no solo con sus fieles sino con la sociedad en general. No puede ser ajena a los problemas morales, espirituales y sociales de toda índole que afectan a los ciudadanos. La forma y eficiencia en el desempeño de esta función pública es decisiva para no entrar en un proceso de desequilibrio organizativo marcado por la pérdida de vocaciones y de fieles. En un mercado de múltiples ofertas religiosas no caben las posiciones cómodas derivadas de un monopolio religioso heredado. Si la Iglesia Católica aspira a conservar su liderazgo moral y espiritual del pasado ha de ser eficiente en su papel y capaz de volver a ser referente para la solución de los múltiples problemas que aquejan a la sociedad. 


\subsubsection{Creencias acerca del papel de la Iglesia en la sociedad}

En el Gráfico 3.13 se muestra la evolución de los porcentajes de población gallega que cree que la Iglesia da respuesta adecuada a los problemas morales, espirituales, familiares y sociales. Estos porcentajes no logran superar el 30\%, salvo en el caso de los problemas espirituales que alcanza el 46,8 en 2001 y desciende al 42,2 en 2008. Teniendo en cuenta que en torno al 94\% de la población está bautizada, estos porcentajes son muy bajos y ha de concluirse que la gran mayoría de los católicos bautizados no cree que la Iglesia esté dando respuestas adecuadas a los problemas sociales y personales. Este juicio crítico a la Iglesia se endurece especialmente entre las generaciones más jóvenes.

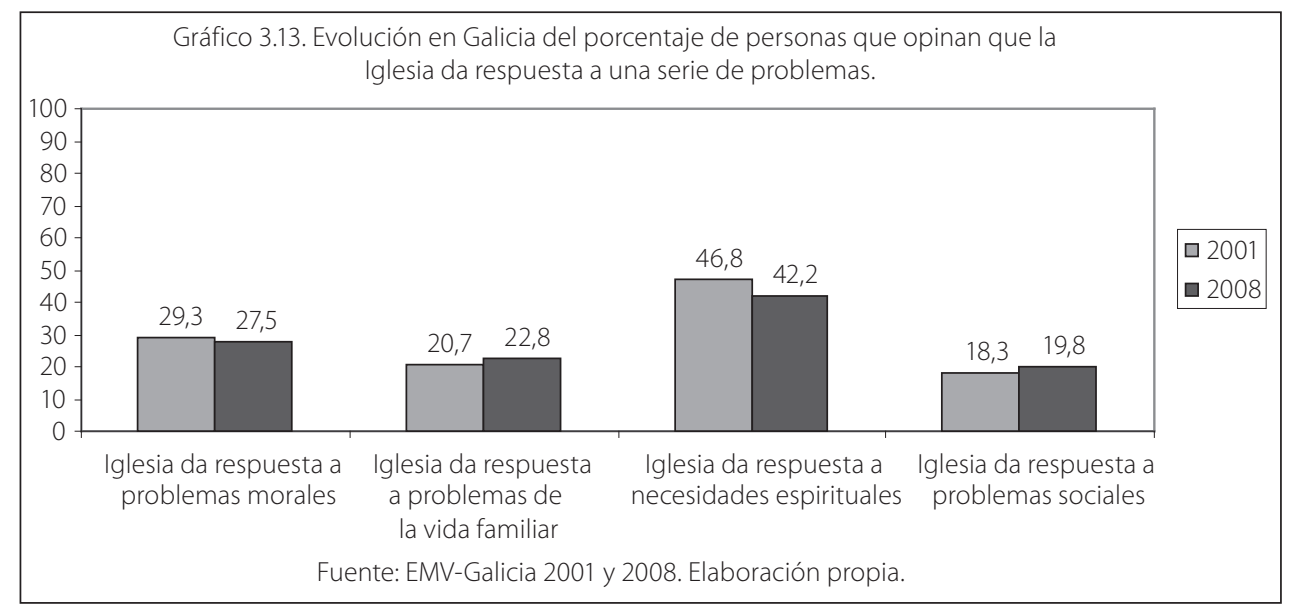

En los gráficos 3.14 a 3.17 se puede ver la distribución, por cohortes de nacimiento en Galicia, de los porcentajes de personas que creen que la Iglesia da respuesta a los problemas morales, familiares, espirituales y sociales. En todos los casos se observa que los porcentajes disminuyen entre las generaciones más jóvenes. También es de destacar el dato siguiente: el punto de inflexión se produce siempre, salvo en el caso de los problemas espirituales, en la cohorte de nacidos en el período 1940-49. A partir de esta generación los porcentajes caen por debajo del 30\% y ya no vuelven a recuperarse. A pesar de que esta generación, hay que recordarlo, fue educada en el nacional-catolicismo español del franquismo, posteriormente experimentó los movimientos contraculturales de los años 60 y tal vez por ello mantiene la tendencia decreciente de las cohortes anteriores. Este simple hecho debiera hacer reflexionar a todos aquellos que creen en el poder omnímodo del adoctrinamiento en el pensamiento único, ya se haga por vía autoritaria o democrática. La "revolución silenciosa", iniciada en torno a los años 60 en España, sentó las bases para el desarrollo de la sociedad hipermoderna del consumo y el hedonismo, que con el tiempo desembocaría en la actual sociedad de la "decepción" tan bien caracterizada por Lipovetsky (2008). 

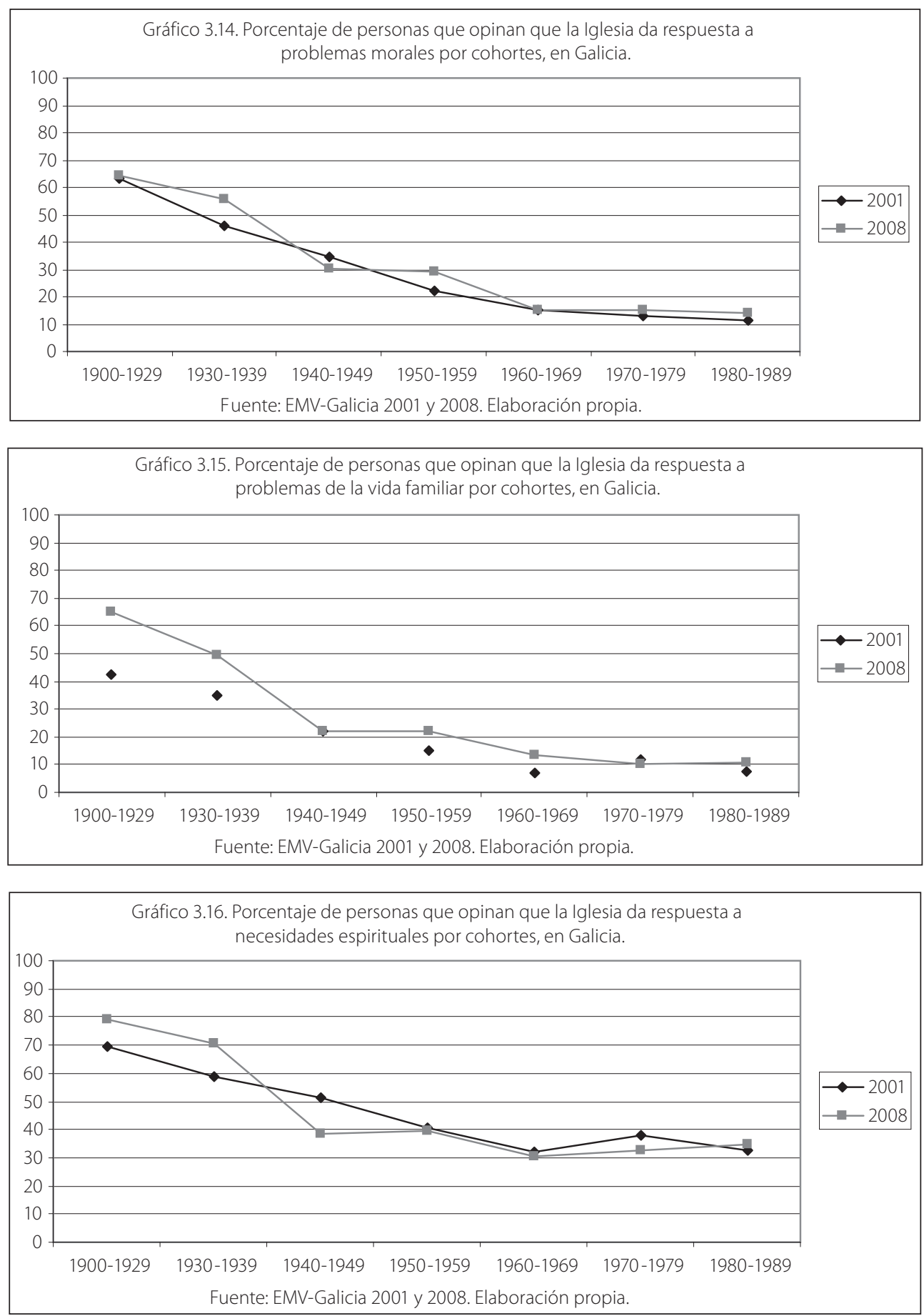


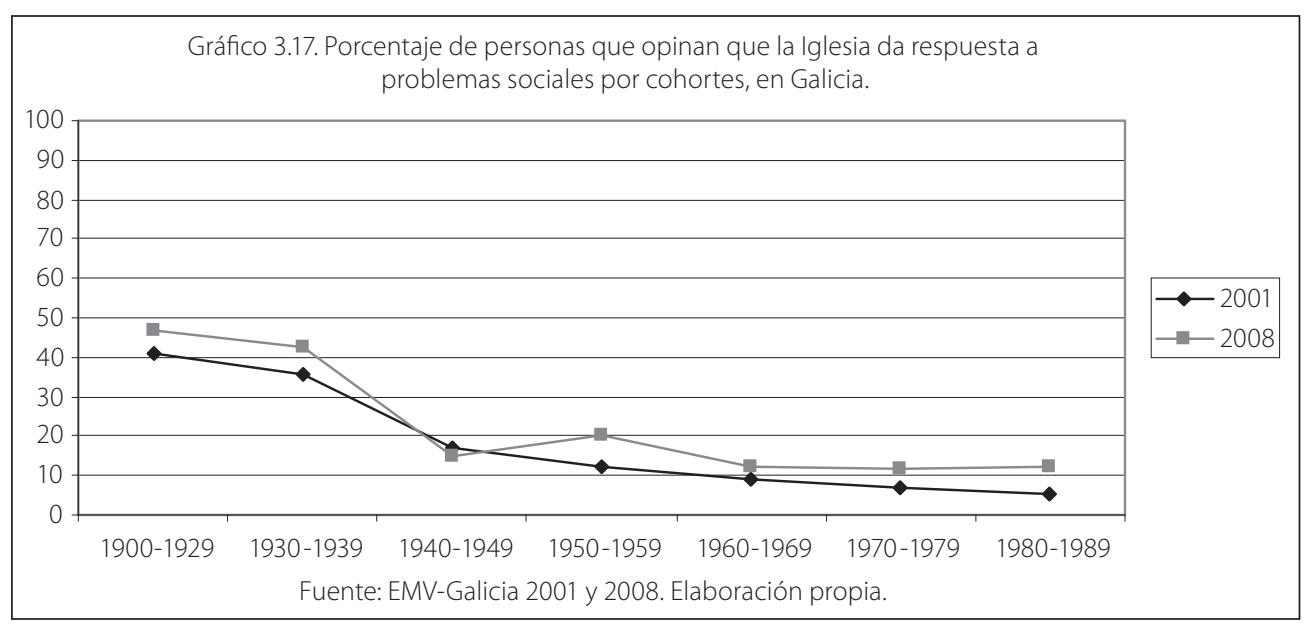

La comparación con los datos europeos da una imagen todavía más clara del tsunami que arrasó en gran parte la esperanza depositada en la Iglesia por muchos poscatólicos gallegos. Comparando el Gráfico 3.13 y la Tabla 3.11 puede verse que la utilidad que los gallegos perciben en el papel social de la Iglesia no solo es la más baja de la UE sino también que la media española. Los bajos porcentajes de personas que opinan que la Iglesia da soluciones a los problemas morales, sociales, espirituales y familiares se deben fundamentalmente a las cohortes de edad más jóvenes. El diagnóstico final es que la Iglesia está teniendo dificultades para conectar con las generaciones más jóvenes, que son también las más individualizadas. En consecuencia, todos los datos corroboran la tendencia hacia una privatización del fenómeno religioso (preludio del advenimiento de las religiones invisibles) en Galicia. Esta privatización de lo religioso conlleva un distanciamiento de la Iglesia organizada.

En este punto resulta casi inevitable hacer una comparación entre la política y la religión en sus dimensiones organizativas, porque ambas son las esferas más afectadas por el proceso de individualización: si se ha visto un distanciamiento creciente de la población respecto a la Iglesia y sus ritos, también hay un alejamiento respecto a los partidos políticos y a los políticos en particular -recientemente el CIS (Barómetros de opinión de febrero a junio de 2010) ofreció el dato de que los españoles sitúan a los políticos como el tercer problema del país, por encima del terrorismo-. Estas tendencias no indican un rechazo a la espiritualidad ni tampoco a la democracia; más bien denuncian la forma de resolver los problemas morales y espirituales por parte de la Iglesia y la forma de hacer política por parte de los políticos profesionales. Las dimensiones religiosa y política son comparables en el sentido siguiente: ambas experimentan tendencias de distanciamiento y pérdida de interés (pasotismo) por parte de la población —especialmente de las generaciones más jóvenesdebido al mal funcionamiento de las organizaciones orientadas a resolver los 
problemas espirituales, morales, sociales y políticos. La crítica hay que situarla, pues, en el plano organizativo. Son los aspectos organizativos de la Iglesia y de los partidos políticos los que suscitan desconfianza y distanciamiento: las personas perciben una contradicción importante entre lo que se predica y lo que se hace. Los casos de corrupción económica (la política como negocio y no como servicio público), la ausencia de democracia dentro de los propios partidos políticos que se autodefinen como demócratas ${ }^{3}$, la degradación moral que suponen los casos de pederastia en el seno de la Iglesia, el blindaje de los políticos en cuanto a privilegios, prebendas y sinecuras, la postergación de la mujer en las jerarquías eclesiásticas, etc., son ejemplos de situaciones y hechos que requieren transformaciones profundas si se aspira a la legitimidad institucional. En caso contrario la brecha entre ciudadanía y política o religión organizadas será cada vez más profunda.

Tabla 3.11. Porcentajes de personas que opinan que la Iglesia da respuestas a una serie de problemas, en los países de la Unión Europea.

\begin{tabular}{lcccc} 
Alemania & $\begin{array}{c}\text { Problemas } \\
\text { morales }\end{array}$ & $\begin{array}{c}\text { Problemas de } \\
\text { la vida familiar }\end{array}$ & $\begin{array}{c}\text { Necesidades } \\
\text { espirituales }\end{array}$ & $\begin{array}{c}\text { Problemas } \\
\text { sociales }\end{array}$ \\
\hline Chipre & $42,6 \%$ & $34,5 \%$ & $48,0 \%$ & $29,6 \%$ \\
\hline Eslovenia & $43,7 \%$ & $41,5 \%$ & $50,6 \%$ & $38,4 \%$ \\
\hline España & $43,2 \%$ & $43,9 \%$ & $68,5 \%$ & $29,2 \%$ \\
\hline Finlandia & $35,2 \%$ & $27,8 \%$ & $45,8 \%$ & $24,4 \%$ \\
\hline Italia & $47,6 \%$ & $50,3 \%$ & $76,1 \%$ & $38,5 \%$ \\
\hline Polonia & $64,2 \%$ & $52,0 \%$ & $82,5 \%$ & $49,5 \%$ \\
\hline Suecia & $66,7 \%$ & $66,1 \%$ & $83,9 \%$ & $46,8 \%$ \\
\hline Media países UE & $29,9 \%$ & $21,6 \%$ & $63,2 \%$ & $19,0 \%$ \\
\hline Media mundial & $46,0 \%$ & $41,2 \%$ & $62,5 \%$ & $33,7 \%$ \\
\hline
\end{tabular}

Fuente: ASEP/JDS, Estudio Mundial de Valores Oleada 5 (2005-2008). Elaboración propia.

\subsubsection{Religión y política}

Las creencias laicistas acerca de la bondad de la independencia del estado respecto a toda organización o confesión religiosa están muy arraigadas en las sociedades europeas y también en Galicia. En los gráficos 3.18 a 3.21 se

Todos los partidos políticos tienden a ser oligárquicos confirmando la "ley de hierro de la oligarquía" formulada
por Robert Michels (1969). 
muestran datos de opinión sobre el papel que deben o no jugar las creencias religiosas y los líderes de organizaciones religiosas en la política. En general, puede decirse que existe cierto consenso en el rechazo a la idea de que la religión deba influir en la política de un gobierno. Este rechazo puede observarse a través de cuatro preguntas acerca de si los políticos que no creen en Dios no son adecuados para ocupar puestos políticos, si los líderes religiosos no deben influir en el voto político, si sería mejor para España que los puestos políticos fueran ocupados por personas con fuertes convicciones religiosas y, finalmente, si los líderes religiosos no deberían influir en la toma de decisiones de los gobiernos.

Una gran parte de la población gallega (el 72,7\% en 2001 y el 77,2\% en 2008) rechaza en alguna medida la idea de que los políticos que no creen en Dios no deben ocupar puestos políticos (Gráfico 3.18). También es preciso notar que entre ambos años se da un incremento de los que están de acuerdo, que sería destacable si no fuera porque el porcentaje sobre el total de la población es muy bajo.
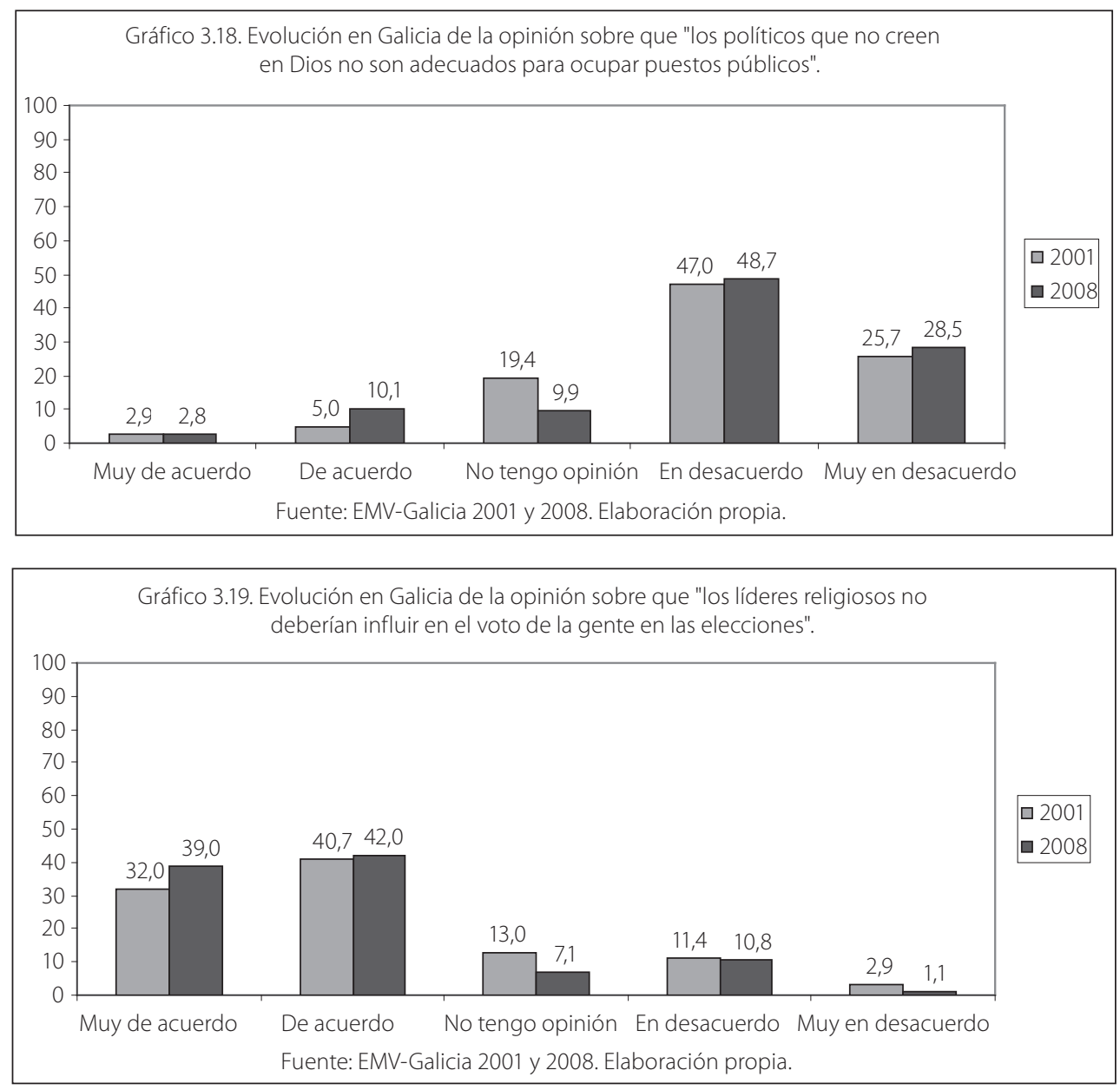

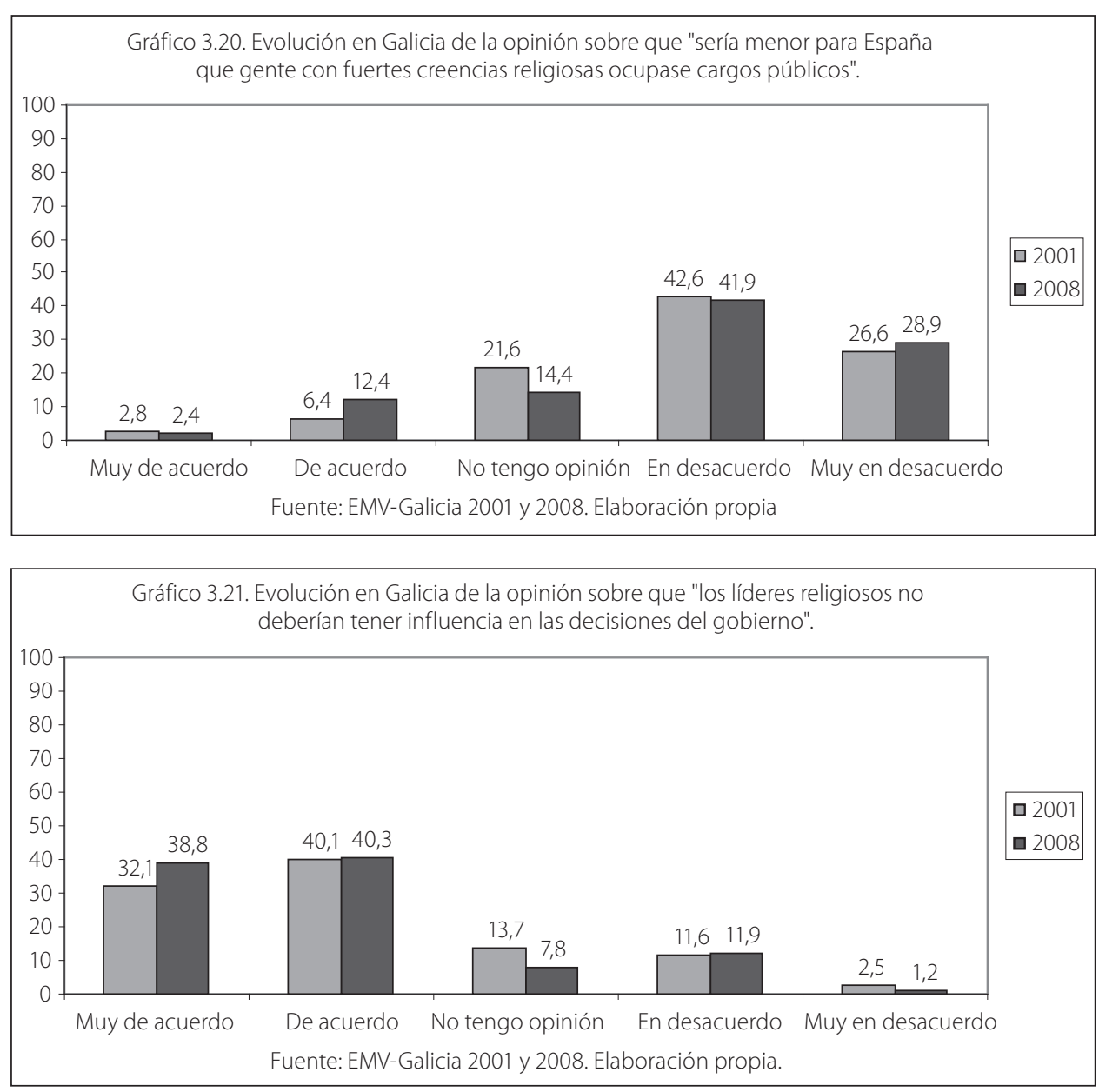

En cuanto a las ideas de si los líderes de organizaciones religiosas deben influir en el voto de los electores o en las decisiones de gobierno (gráficos 3.19 y 3.21) son rechazadas por más del 70\% de los gallegos en 2001 y alrededor del $80 \%$ en 2008. Tampoco está bien considerada la idea de que sería mejor para España que los gobernantes tengan fuertes convicciones religiosas (Gráfico 3.20), pues en torno al $70 \%$ de la población entrevistada así lo confirma en los dos años consultados. En consecuencia puede apreciarse una tendencia clara: las posiciones laicistas (en sus diversas matizaciones) están muy extendidas entre la población gallega, confirmando la creencia generalizada en la bondad y conveniencia de una separación clara entre Iglesia y Estado.

La difusión de las creencias laicistas en Galicia está en consonancia con su entorno cultural. En las tablas 3.12 a 3.15 puede comprobarse esta concordancia cultural que, sin entrar en detalles y diferencias de porcentajes entre países, sitúa a Galicia en la línea de los países occidentales de su entorno. 
Tabla 3.12. Opinión sobre si "los políticos que no creen en Dios no son adecuados para ocupar cargos públicos", en los países de la Unión Europea.

\begin{tabular}{lcccccc} 
& $\begin{array}{c}\text { Muy de } \\
\text { acuerdo }\end{array}$ & Acuerdo & $\begin{array}{c}\text { No tiene } \\
\text { opinión }\end{array}$ & \multicolumn{3}{c}{$\begin{array}{c}\text { Muy en } \\
\text { Desacuerdo }\end{array}$} \\
\hline Alemania & $2,5 \%$ & $8,6 \%$ & $19,8 \%$ & $23,5 \%$ & $45,6 \%$ & 1940 \\
\hline Chipre & $15,2 \%$ & $22,3 \%$ & $27,1 \%$ & $24,6 \%$ & $10,8 \%$ & 1046 \\
\hline Eslovenia & $4,1 \%$ & $6,4 \%$ & $16,0 \%$ & $38,2 \%$ & $35,2 \%$ & 979 \\
\hline España & $2,2 \%$ & $9,1 \%$ & $14,4 \%$ & $41,1 \%$ & $33,3 \%$ & 1146 \\
\hline Finlandia & $4,0 \%$ & $5,4 \%$ & $20,1 \%$ & $43,9 \%$ & $26,6 \%$ & 997 \\
\hline Italia & $2,8 \%$ & $9,7 \%$ & $28,9 \%$ & $43,0 \%$ & $15,6 \%$ & 967 \\
\hline Polonia & $7,2 \%$ & $10,6 \%$ & $18,9 \%$ & $43,3 \%$ & $19,9 \%$ & 937 \\
\hline Suecia & $0,7 \%$ & $3,0 \%$ & $9,7 \%$ & $36,8 \%$ & $49,9 \%$ & 994 \\
\hline $\begin{array}{l}\text { Media } \\
\text { países UE }\end{array}$ & $4,6 \%$ & $9,4 \%$ & $19,3 \%$ & $35,4 \%$ & $31,3 \%$ & 9006 \\
\hline $\begin{array}{l}\text { Media } \\
\text { mundial }\end{array}$ & $21,2 \%$ & $20,4 \%$ & $19,2 \%$ & $24,9 \%$ & $14,2 \%$ & 63835 \\
\hline
\end{tabular}

Fuente: ASEP/JDS, Estudio Mundial de Valores Oleada 5 (2005-2008). Elaboración propia.

Tabla 3.13. Opinión sobre si "los líderes religiosos no deberían tener influencia en el voto de la gente", en los países de la Unión Europea.

\begin{tabular}{lcccccc} 
& $\begin{array}{l}\text { Muy de } \\
\text { acuerdo }\end{array}$ & Acuerdo & $\begin{array}{c}\text { No tiene } \\
\text { opinión }\end{array}$ & Desacuerdo & $\begin{array}{c}\text { Muy en } \\
\text { desacuerdo }\end{array}$ & $\mathrm{N}$ \\
\hline Alemania & $43,8 \%$ & $29,0 \%$ & $16,3 \%$ & $7,4 \%$ & $3,5 \%$ & 1944 \\
\hline Chipre & $37,2 \%$ & $41,0 \%$ & $14,8 \%$ & $4,6 \%$ & $2,3 \%$ & 1046 \\
\hline Eslovenia & $38,6 \%$ & $34,9 \%$ & $11,4 \%$ & $9,5 \%$ & $5,5 \%$ & 976 \\
\hline España & $37,8 \%$ & $36,5 \%$ & $13,8 \%$ & $8,4 \%$ & $3,4 \%$ & 1143 \\
\hline Finlandia & $34,7 \%$ & $34,9 \%$ & $16,4 \%$ & $11,2 \%$ & $2,9 \%$ & 1004 \\
\hline Italia & $24,4 \%$ & $46,9 \%$ & $17,2 \%$ & $9,0 \%$ & $2,6 \%$ & 971 \\
\hline Polonia & $52,7 \%$ & $30,0 \%$ & $6,8 \%$ & $6,5 \%$ & $4,0 \%$ & 961 \\
\hline Suecia & $48,4 \%$ & $32,3 \%$ & $6,4 \%$ & $8,0 \%$ & $4,9 \%$ & 998 \\
\hline $\begin{array}{l}\text { Media } \\
\text { países UE }\end{array}$ & $40,1 \%$ & $35,0 \%$ & $13,3 \%$ & $8,0 \%$ & $3,6 \%$ & 9043 \\
\hline $\begin{array}{l}\text { Media } \\
\text { mundial }\end{array}$ & $29,9 \%$ & $37,4 \%$ & $17,1 \%$ & $12,5 \%$ & $3,2 \%$ & 63572 \\
\hline
\end{tabular}

Fuente: ASEP/JDS, Estudio Mundial de Valores Oleada 5 (2005-2008). Elaboración propia. 
Tabla 3.14. Opinión sobre si "sería mejor si gente con fuertes creencias religiosas ocupase los cargos públicos", en los países de la Unión Europea.

\begin{tabular}{lcccccc} 
& $\begin{array}{c}\text { Muy de } \\
\text { acuerdo }\end{array}$ & Acuerdo & $\begin{array}{c}\text { No tiene } \\
\text { opinión }\end{array}$ & \multicolumn{3}{c}{ Desacuerdo } \\
\hline Alemania & $4,6 \%$ & $15,7 \%$ & $28,7 \%$ & $21,8 \%$ & $29,1 \%$ & 1915 \\
\hline Chipre & $5,4 \%$ & $13,6 \%$ & $35,4 \%$ & $28,8 \%$ & $16,8 \%$ & 1046 \\
\hline Eslovenia & $3,1 \%$ & $6,6 \%$ & $16,0 \%$ & $38,6 \%$ & $35,7 \%$ & 974 \\
\hline España & $2,4 \%$ & $10,4 \%$ & $20,0 \%$ & $37,8 \%$ & $29,4 \%$ & 1123 \\
\hline Finlandia & $2,3 \%$ & $9,4 \%$ & $21,3 \%$ & $43,0 \%$ & $24,0 \%$ & 1004 \\
\hline Italia & $3,6 \%$ & $14,2 \%$ & $36,1 \%$ & $35,5 \%$ & $10,5 \%$ & 971 \\
\hline Polonia & $9,9 \%$ & $19,9 \%$ & $28,7 \%$ & $29,0 \%$ & $12,4 \%$ & 922 \\
\hline Suecia & $0,8 \%$ & $4,6 \%$ & $13,6 \%$ & $37,6 \%$ & $43,4 \%$ & 987 \\
\hline $\begin{array}{l}\text { Media } \\
\text { países UE }\end{array}$ & $4,0 \%$ & $12,1 \%$ & $25,3 \%$ & $32,8 \%$ & $25,7 \%$ & 8942 \\
\hline $\begin{array}{l}\text { Media } \\
\text { mundial }\end{array}$ & $16,9 \%$ & $26,5 \%$ & $23,4 \%$ & $22,3 \%$ & $11,0 \%$ & 63173 \\
\hline
\end{tabular}

Fuente: ASEP/JDS, Estudio Mundial de Valores Oleada 5 (2005).

Tabla 3.15. Opinión sobre si "los líderes religiosos no deberían tener influencia en las decisiones del gobierno", en los países de la Unión Europea.

\begin{tabular}{lcccccc} 
& $\begin{array}{c}\text { Muy de } \\
\text { acuerdo }\end{array}$ & Acuerdo & $\begin{array}{c}\text { No tiene } \\
\text { opinión }\end{array}$ & Desacuerdo & $\begin{array}{c}\text { Muy en } \\
\text { desacuerdo }\end{array}$ & $\mathrm{N}$ \\
\hline Alemania & $42,8 \%$ & $24,5 \%$ & $18,5 \%$ & $10,1 \%$ & $4,1 \%$ & 1954 \\
\hline Chipre & $36,5 \%$ & $37,6 \%$ & $17,6 \%$ & $4,8 \%$ & $3,4 \%$ & 1046 \\
\hline Eslovenia & $36,4 \%$ & $33,5 \%$ & $13,1 \%$ & $11,2 \%$ & $5,8 \%$ & 977 \\
\hline España & $37,4 \%$ & $35,0 \%$ & $15,2 \%$ & $9,1 \%$ & $3,4 \%$ & 1135 \\
\hline Finlandia & $33,2 \%$ & $31,3 \%$ & $20,5 \%$ & $12,2 \%$ & $2,7 \%$ & 1007 \\
\hline Italia & $23,9 \%$ & $45,7 \%$ & $18,9 \%$ & $10,1 \%$ & $1,4 \%$ & 970 \\
\hline Polonia & $44,8 \%$ & $33,4 \%$ & $10,3 \%$ & $8,5 \%$ & $3,0 \%$ & 946 \\
\hline Suecia & $42,5 \%$ & $32,9 \%$ & $11,5 \%$ & $8,9 \%$ & $4,3 \%$ & 989 \\
\hline $\begin{array}{l}\text { Media } \\
\text { países UE }\end{array}$ & $37,8 \%$ & $33,2 \%$ & $16,0 \%$ & $9,4 \%$ & $3,6 \%$ & 9024 \\
\hline $\begin{array}{l}\text { Media } \\
\text { mundial }\end{array}$ & $27,5 \%$ & $34,9 \%$ & $19,0 \%$ & $14,6 \%$ & $4,0 \%$ & 60939 \\
\hline
\end{tabular}

Fuente: ASEP/JDS, Estudio Mundial de Valores Oleada 5 (2005-2008). Elaboración propia.

72 LA EVOLUCIÓN DE LOS VALORES SOCIALES EN GALICIA 


\subsection{CONCLUSIONES}

Cuando se mide la frecuencia con la que las personas acuden a ritos religiosos, rezan o participan de creencias laicistas, debe concluirse que en Galicia se ha dado en los últimos años un importante proceso de secularización. Este proceso de secularización es más evidente en las generaciones más jóvenes. Probablemente, y a la luz de las interpretaciones teóricas más recientes en el campo de la Sociología de la religión, este proceso de secularización va acompañado de una nueva búsqueda de espiritualidades de vida en un mercado religioso cada vez más dinámico. La religiosidad se privatiza y se vincula con el proceso más general de individualización de intereses.

Sin embargo, y a pesar de este avanzado estado de secularización, sigue siendo muy alto el porcentaje de gallegos que se considera católico, lo cual indica que los desencantados de la religión han preferido irse al agnosticismo, a las espiritualidades de vida o simplemente convertirse en free riders de la Iglesia organizada, sin intentar explorar otras opciones religiosas. Esta situación se traduce en un enjuiciamiento crítico de la Iglesia tanto en lo que se refiere a su contribución a resolver problemas morales, familiares, espirituales o sociales como al papel que deben jugar las creencias religiosas y sus líderes en la política. En ambos casos la población gallega se posiciona claramente a favor de una separación entre religión y política a la vez que manifiesta una opinión más bien negativa acerca de la capacidad de la Iglesia para dar solución a los problemas morales y espirituales de la sociedad.

\subsection{REFERENCIAS BIBLIOGRÁFICAS}

Beck, U. (2009): El Dios personal. La individualización de la religión y el "espiritu" del cosmopolitismo. Paidós, Madrid.

Boudon, R. (2002): Déclin de la morale? Déclin des valeurs? PUF, París.

CIS (2007): Barómetros de opinión 2007 (Estudios no 2672, 2677, 2681, 2700, $2705,2724,2728,2732,2735,2742$ y 2746). Centro de Investigaciones Sociológicas, Madrid.

CIS (2010): Barómetros de opinión 2010 Febrero, Marzo, Abril, Mayo y Junio (Estudios $n^{\circ} 2830,2831,2834,2836$ y 2838). Centro de Investigaciones Sociológicas, Madrid.

Conferencia Episcopal Española. Secretaría General (2007): La Iglesia Católica en España. Estadísticas. Edición 2007. Madrid, Edice.

González Anleo, J. (2008): "El postcatólico español y el pluralismo religioso" en Bericat Alastuey, E. (Coord.): El fenómeno religioso. Presencia de la religión y la religiosidad en las sociedades avanzadas. Centro de estudios andaluces, Sevilla: 57-76.

Lipovetsky, G. (2008): La sociedad de la decepción. Barcelona, Anagrama. 
Luckmann, T. (1973): La religión invisible. El problema de la religión en la sociedad moderna. Ediciones Sígueme, Salamanca.

Luckmann, T. (2008a): "Reflexiones sobre Religión y Moralidad" en Bericat Alastuey, E. (Coord.): El fenómeno religioso. Presencia de la religión y la religiosidad en las sociedades avanzadas. Centro de estudios andaluces, Sevilla: 15-25.

Luckmann, T. (2008b): Conocimiento y sociedad. Ensayos sobre acción, religión y comunicación. (Parte III: Religión). Ed. Trotta, Madrid: 129-151.

Michels, R. (1969): Los partidos politicos. Un estudio sociológico de las tendencias oligárquicas de la democracia moderna, Vol. I. Amorrortu, Buenos Aires.

OESI (Oficina de Estadística y Sociología de la Iglesia) (1995): Estadísticas de la Iglesia Católica en España, 1995. Edice, Madrid.

Richard, B. (2008): "Prefacio" en Lipovetsky, G.: La sociedad de la decepción. Anagrama, Barcelona: 9-14.

Veira Veira, J. L. (2007): "Valores religiosos" en Veira Veira, J. L. (Dir.): Las actitudes y los valores sociales en Galicia. Centro de Investigaciones Sociológicas, Madrid: 87-105. 


\section{TRANSFORMACIONES RECIENTES DE LA FAMILIA EN GALICIA}

José Antonio López Rey

\subsection{INTRODUCCIÓN}

La familia es una institución social clave. Es el principal, aunque no el único, agente socializador, es decir, el encargado de realizar la transmisión cultural básica a los nuevos miembros de la sociedad de manera que los niños, mediante el aprendizaje de los símbolos y del lenguaje, así como de valores, creencias y normas, adquieren las habilidades necesarias para ser en el futuro miembros plenos de dicha sociedad. Por esta razón, se dice que la principal función de la familia se refiere al ámbito reproductivo, porque contribuye de manera especial a reproducir la sociedad y, por eso mismo también, es un elemento que, en la medida que cumple con la función de transmitir información cultural de generación en generación, contribuye a su estabilidad.

Pero esto no significa que la familia no esté, a su vez, sujeta a cambios. Por el contrario, y como cualquier institución, es también fruto de los individuos que la conforman, que la llevan a la práctica y refleja los cambios que ocurren en el seno de la sociedad. Así por ejemplo, se suele afirmar que en las sociedades modernas el tipo de familia habitual es el de familia nuclear, es decir, el compuesto por los padres e hijos, frente al modelo de familia extensa característico de las sociedades tradicionales y formado por otros parientes (abuelos o tíos) (Del Campo y Rodríguez Brioso, 2002).

Según Salustiano del Campo, la transición de la familia extensa a la nuclear se produjo en España antes de los años 50 del siglo XX, década a partir de la cual se sucederían cambios importantes como la reducción del tamaño medio de la familia o la reducción de la natalidad, especialmente en los años 60 y, ya en los 80 , la extensión de otro tipo de estructuras familiares diferentes de la nuclear (como la monoparental) así como el aumento del número de hijos fuera del matrimonio (Del Campo y Rodríguez Brioso, 2002: 103). En cualquier caso, lo más relevante en las últimas décadas en lo relativo a la familia es el cambio de estatus que ha tenido la mujer. La incorporación de la mujer al mercado de trabajo, así como la derogación de leyes que relegaban a la mujer a un papel secundario, evidenciaron la creciente 
igualdad entre los dos sexos en el ámbito público. Esta igualdad creciente se ha ido extendiendo también a los espacios doméstico y privado (Gutiérrez Sastre, 2002), lo que ha supuesto cambios importantes en la familia con respecto a épocas pasadas en materia de, por ejemplo, planificación familiar.

Poco a poco la familia española ha ido evolucionando de manera parecida a la de Europa Occidental: ha aumentado el número de hogares y se ha reducido el tamaño medio de los mismos. No obstante, se mantienen como elementos característicos del sistema familiar español un mayor peso de los hogares nucleares (padre, madre e hijos) y de la convivencia de varias generaciones (abuelos) y una menor importancia relativa de los hogares monoparentales, de la cohabitación y de jóvenes adultos que viven solos (Valero, 1995: 91).

En cualquier caso, la familia ha asistido a unos cambios profundos en poco tiempo. Un ejemplo de lo radical de estos cambios se puede ver en los distintos modelos acerca de lo que es y de lo que debe ser la familia según las diferentes generaciones que la pueden conformar (la de los abuelos, la de los padres y la de los jóvenes y los niños). Las relaciones (de confianza, de respeto, de autoridad, etc.) entre los hijos y los padres son diferentes de las que éstos mantuvieron en su día con los abuelos y mucho más de las que éstos mantuvieron a su vez con sus padres. Estos cambios, en definitiva, son reflejo de los que han acontecido en la sociedad occidental, tanto en lo material como en lo cultural.

Galicia no es una excepción. Los rasgos esenciales del cambio en el caso gallego han sido tratados por Veira (2007a: 60-86), quien los explica a partir del cambio cultural. En las últimas décadas se habría venido produciendo un proceso de individualización (Inglehart, 1998; Ester Halman y De Moor, 1994), que se puede definir sucintamente como que los individuos de una sociedad tienden a desarrollar su propia escala de valores, prescindiendo en parte de los valores institucionalizados por la tradición (Veira, 2007b: 3). Esto significa que es el propio individuo quien toma las decisiones en aquello que concierne a su vida y en función de sus propios valores, preferencias, intereses y costes de realización (y no otro tipo de instancias como la tradición, la costumbre, instituciones religiosas, etc.). Por esta razón la individualización se puede entender también como una mayor inclinación a poner el énfasis en los valores de la felicidad y la autorrealización personales. El proceso de individualización puede, en cualquier caso, explicar los cambios ocurridos en materia de estructura familiar, tipos de unión de la pareja, nacimientos, etc.

En este capítulo se profundiza en la descripción de la realidad gallega, tanto en lo que se refiere a los comportamientos (cómo ha evolucionado la natalidad, el matrimonio y el divorcio) como a la valoración que los gallegos hacen del matrimonio, del divorcio, de algunas de las nuevas formas de familia y de los valores en los que se piensa que es necesario criar a los hijos. Se compara la evolución del caso gallego a partir de la explotación de tres encuestas (realizadas en los años 1995, 2001 y 2008) con el español (encuestas realizadas en 1995, 2000 y 2007) 
y, siempre que sea posible, con países de nuestro entorno cultural cercano. La mayoría de los países seleccionados para realizar la comparación son, por diversos motivos, referencia en el entorno europeo: Alemania, Francia, Italia, Reino Unido, Holanda y Suiza; a los que se suman Polonia, por su tradición cultural católica, así como Finlandia, Noruega y Suecia como representantes de la Europa nórdica. Por otro lado, se han tenido en cuenta países relevantes de la OCDE, como EE. UU. y Japón, y también los considerados emergentes (China, Brasil, Rusia e India).

El objetivo último de este capítulo es poder explicar la importancia que se atribuye a la familia y los comportamientos y opiniones expresados por la población. Hay que resaltar que en Galicia existe casi unanimidad a la hora de valorar la familia. Esta institución es muy importante en la vida para el 91,9\% de los gallegos y bastante importante para el 7,1\%, matices que, sumados, arrojan la cifra del 99\%. Sin embargo, existen comportamientos demográficos que matizan dicha importancia y consideraciones acerca de la vida familiar (el matrimonio, el divorcio, lo que se debe enseñar a los hijos, etc.) que merecen ser explicados.

\subsection{EVOLUCIÓN DE LA NATALIDAD Y LA FECUNDIDAD EN GALICIA}

Existen diversos indicadores para medir los nacimientos ocurridos en una sociedad. La tasa bruta de natalidad, por ejemplo, pone en relación el número de nacimientos con la población total, mientras que la tasa de fecundidad, de carácter más específico, relaciona los nacimientos solamente con las mujeres en edad fértil (definidas como aquellas con edades comprendidas entre los 15 y los 49 años); otro indicador, de gran poder ilustrativo, es el número medio de hijos por mujer en edad fértil, puesto que cuando es igual o superior a 2,1 se considera asegurado el reemplazo generacional. Pues bien, si se comparan los indicadores de natalidad y de fecundidad de las últimas tres décadas se comprobará que han bajado drásticamente.

La tasa bruta de natalidad, que se elabora teniendo en cuenta el conjunto de la población, es un indicador poco preciso pero permite comparar lo que ocurre en Galicia y en España con otros países de nuestro entorno. Como muestra el Gráfico 4.1, en 1976 nacían en Galicia 16,3 niños por cada 1.000 habitantes, casi dos más que la media europea. En líneas generales el descenso en la natalidad ocurre a partir de ese año, pero en el caso de Galicia es mucho más pronunciado. De hecho, Galicia ofreció los valores más bajos de Europa en 2007.

La tasa general de fecundidad, en Galicia, era en 1976 de 69 nacimientos por cada 1.000 mujeres en edad fértil y a partir de ese año desciende hasta alcanzar un mínimo de 27,8 en 1996 (2,48 veces menos), momento a partir del cual sube ligeramente hasta los 35,1 de 2008. España ofrece una evolución similar a la de Galicia, aunque con valores superiores, ya que en España se pasó de un valor de 79,5 en 1976 a un mínimo de 35,5 en 1998 (2,24 veces menor) repuntando a partir de entonces hasta el 45,2 de 2008. 

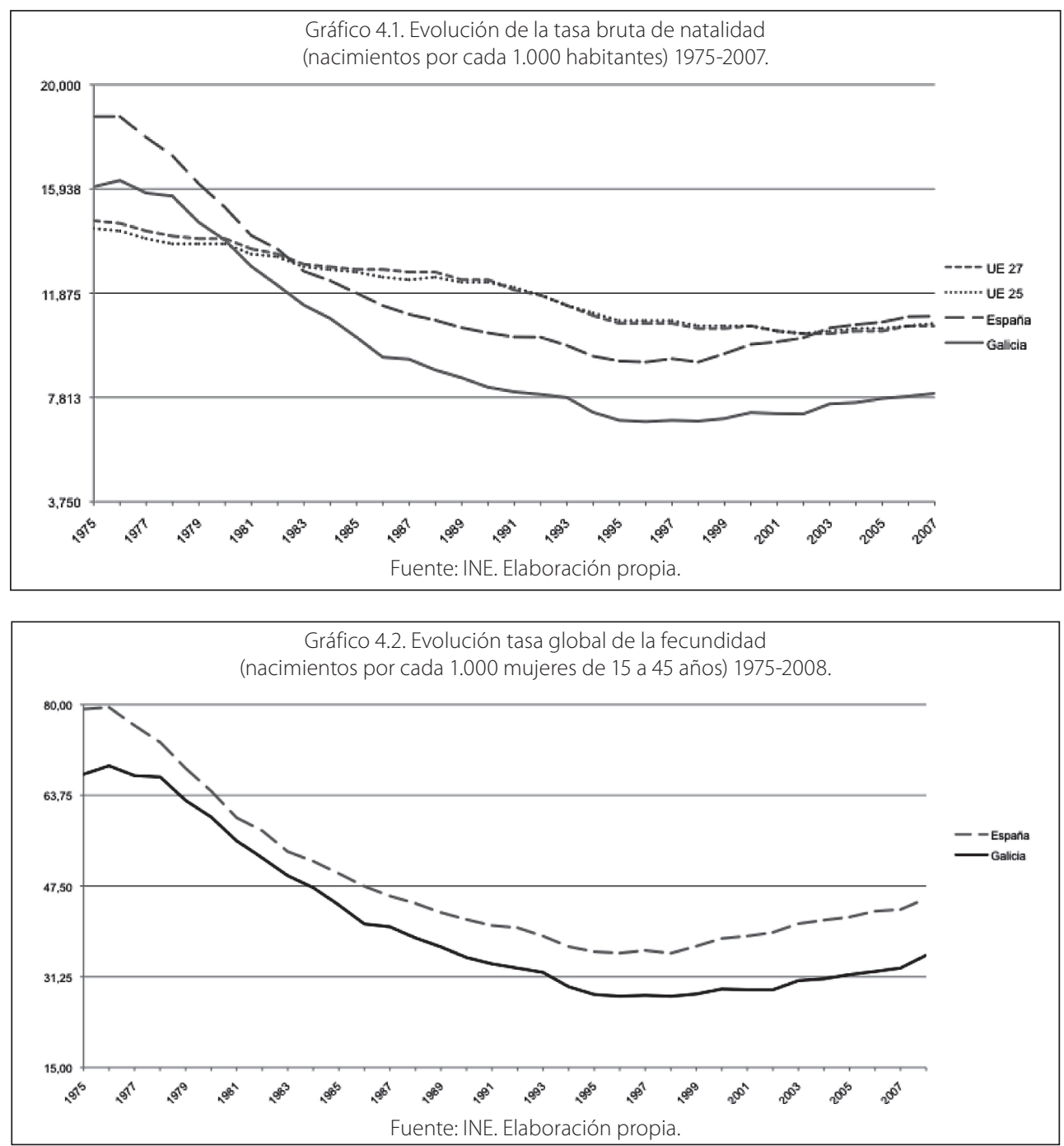

El tercer indicador contemplado corrobora lo afirmado anteriormente. El número medio de hijos por mujer en Galicia en 1976 fue de 2,4 (2,7 en España), mientras que en 2008 era de 1,1 (1,5 en España), habiéndose alcanzado los valores mínimos en 1998 (0,9 para Galicia y 1,2 para España). Si se observa el Gráfico 4.3 se podrá comprobar cómo entre 1995 y 2004 los valores para Galicia eran inferiores a la unidad.

Si se atiende a lo que ocurría en Europa ${ }^{1}$, España ocupaba el segundo lugar en el ranking de hijos por mujer en 1975, por detrás de Irlanda, y Galicia se asemejaba a países como la República Checa $(2,4)$ o Hungría $(2,4)$. En

Datos tomados del INE. Solo se tienen en cuenta los países para los que existe información para los años citados. 
2007, sin embargo, Islandia e Irlanda siguen encabezando el elenco (2,1 y 2 respectivamente), mientras que España desciende al decimonoveno puesto $(1,4)$ y Galicia descendería al último $(1,1)$.

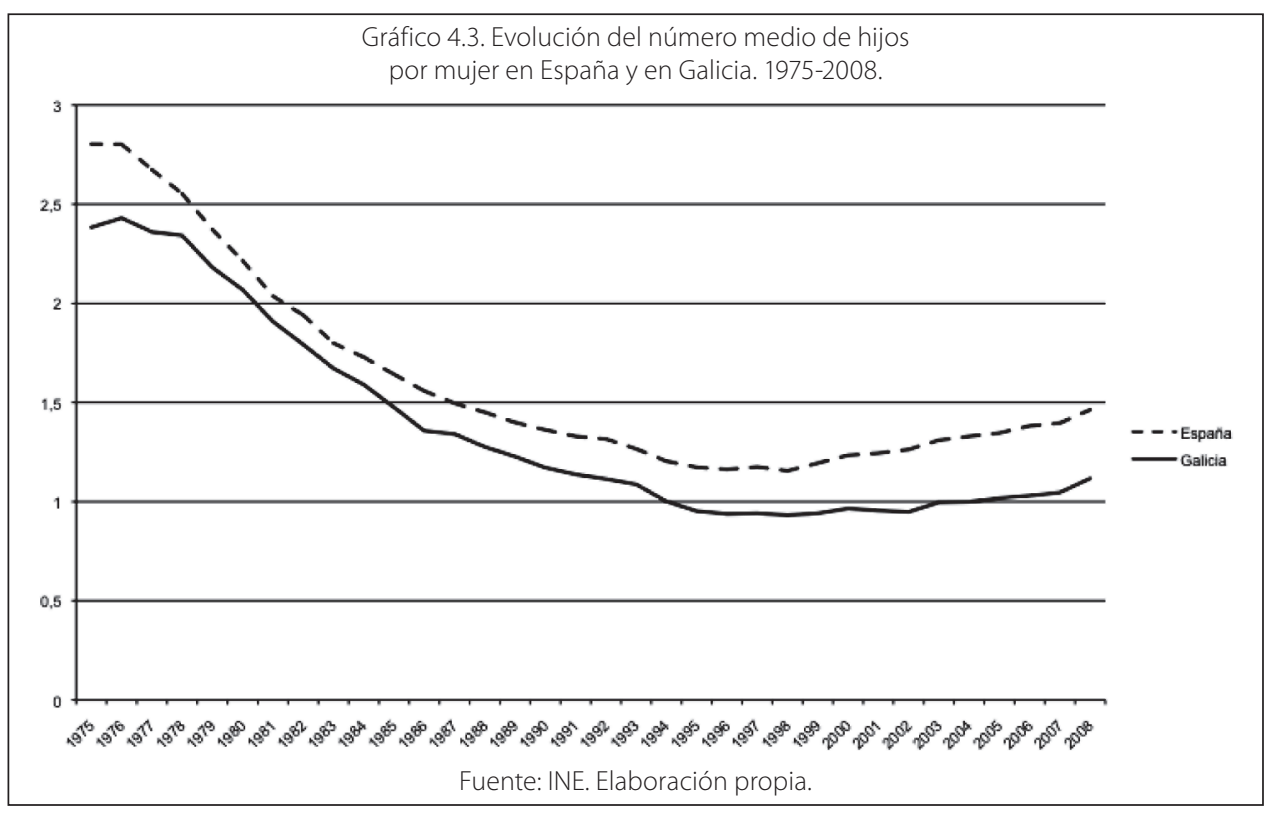

Pero no solo hay menos nacimientos sino que también las madres son cada vez mayores. Con la excepción del período comprendido entre 1975 y 1981, en el que se redujo mínimamente, la edad media con la que las mujeres llegan a la maternidad ha pasado en Galicia de 28,1 años en 1975 a 31,6 en 2008 (28,8 y 30,8 en España).

Según Eurostat ${ }^{2}$ en 1975 España, Portugal y Galicia ofrecían las edades medias más elevadas en las que las mujeres llegaban a la maternidad (28,7, 28,3 y 28,1 años respectivamente). En 2006 Galicia lideraría un hipotético ranking europeo con una media de 31,4 años. Más interesante resulta comprobar cómo han variado las posiciones de ese ranking atendiendo a las comunidades autónomas españolas: en 1975 Galicia era la tercera comunidad donde más jóvenes eran las madres por término medio, por detrás de Baleares (28) y Asturias $(27,6)$; en 2008, sin embargo, es la segunda comunidad donde mayores son las mujeres que llegan a la maternidad $(31,6)$, por detrás del País Vasco $(32,2)$.

Del comportamiento demográfico de la sociedad gallega que hemos descrito se deduce que actualmente Galicia es uno de los lugares de Europa donde menos niños nacen, pero esto no ha sido siempre así. Por el contrario, hasta finales de los años 70 Galicia ofrecía unos valores superiores a los de la media 
de la Europa de los 25. Es a partir de 1979 cuando se inicia un descenso, que se empieza a corregir 20 años después gracias a la llegada de inmigrantes (IGE, 2008). Algunos autores interpretan esta realidad como una condición previa a la modernidad y no como una consecuencia de ella (Pérez Díaz y MacInnes, 2008). Desde esta perspectiva, solo hasta épocas recientes la sociedad no ha alcanzado la eficiencia reproductiva, que se puede caracterizar en que, al aumentar la esperanza de vida media, lo hace también la proporción de quienes pueden contribuir a la reproducción generacional en edades altas y se reduce la intensidad individual con que se asumía la función procreadora (Pérez Díaz y MacInnes, 2008: 103).

\subsection{MATRIMONIO Y DIVORCIO EN GALICIA}

Galicia no se ha caracterizado por ser una comunidad que destacase por una elevada tasa de nupcialidad. Ya desde 1975 se observa este fenómeno pues se celebraron 6,9 matrimonios por cada 1.000 habitantes, por 9,3 en Madrid o 8,4 en las Islas Baleares, siendo la media española de 7,6 (la misma que la de la Europa de los 25). Tres décadas después, la tasa ha bajado hasta el 4,1\%o en 2007, un descenso ligeramente mayor que el de la media española $(4,5 \%$ ) o europea $(4,8 \%)$. Otras comunidades autónomas como las Islas Canarias, las Baleares o Madrid, por ejemplo, redujeron a la mitad su tasa de nupcialidad.

Este descenso, no muy importante en un margen de tiempo tan amplio, oculta no obstante un cambio cultural de mayor importancia. En efecto, el descenso en la nupcialidad que se observa en el Gráfico 4.4 ocurre a pesar de que la generación del "baby boom" se ha hecho adulta y, por término medio, ya se ha casado ${ }^{3}$, lo que debería no haber reducido sino incrementado la nupcialidad. Es decir, si por simple inercia demográfica las cohortes del "baby boom" deberían haberse hecho notar cuando les llegó el momento de casarse, la tasa de nupcialidad por el contrario, es más o menos constante en su curva descendente.

En la encuesta mundial de valores llevada a cabo en Galicia (EMV-Galicia) y en España (ASEP/JDS, Estudio Mundial de Valores, España) se indagó acerca de la opinión que tenía la población sobre si el matrimonio está pasado de moda, lo que puede aportar luz a un comportamiento demográfico que, de suyo, denota un cambio paulatino en la consideración de dicha institución. El Gráfico 4.5 muestra cómo en España el porcentaje de quienes lo consideran desfasado prácticamente se dobló en apenas doce años, pasando del 16,7\% al 32,9\%. En Galicia esta institución ya era anticuada para más de un 20\% de la población en 1995, aumentando quienes así piensan en casi un $11 \%$.

Según el INE, en 1975 la edad media de acceso al matrimonio era de 27 años para los varones y de 23,8 para las mujeres en Galicia (27,4 y 24,6 en España respectivamente); en 2008 la edad fue de 34,1 y 31,3 respectivamente (34,5 y 31,5 en España respectivamente). 

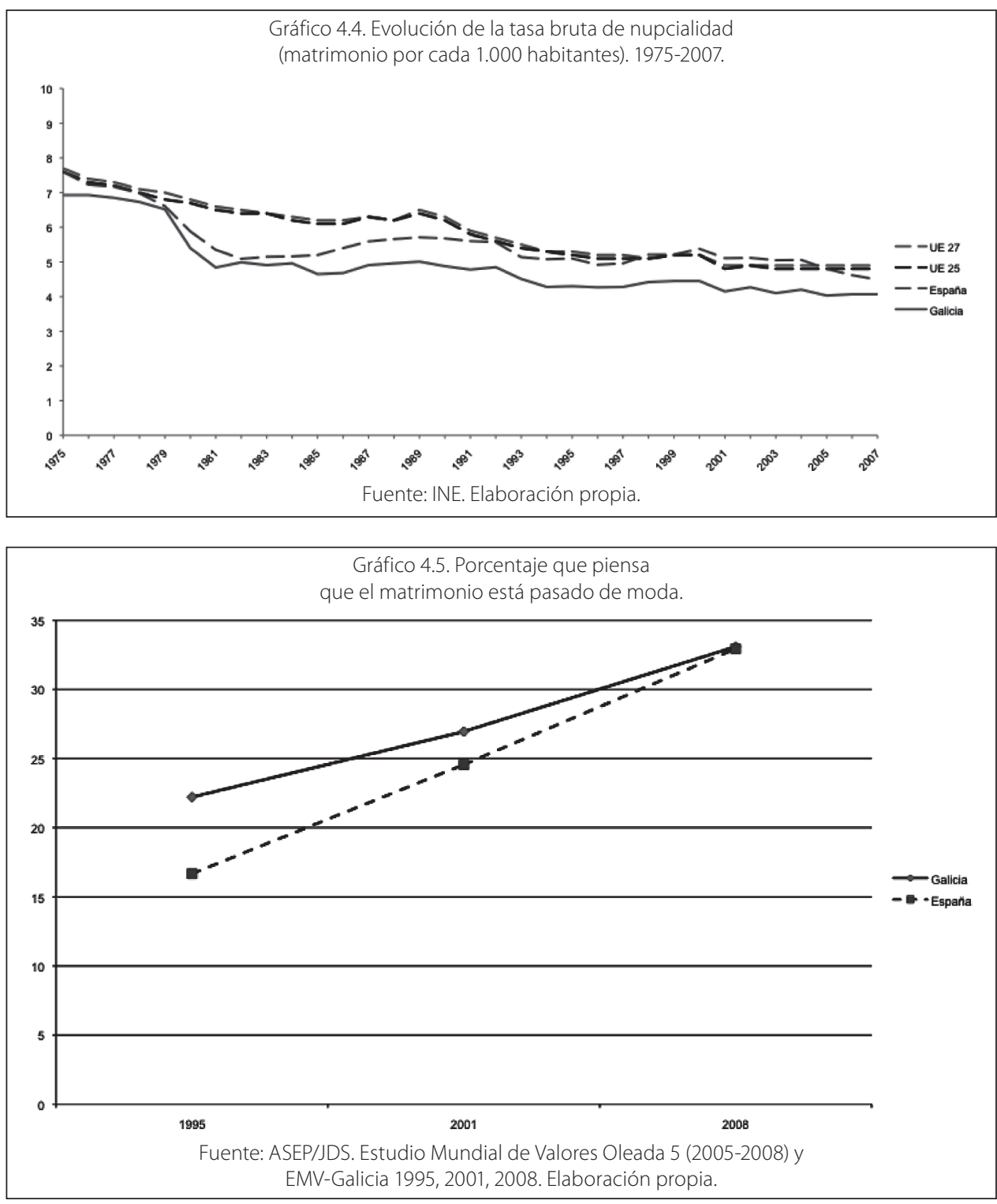

Si se compara Galicia en el plano internacional, se observa que la gallega (y la española) son sociedades donde la valoración de la institución matrimonial, aunque elevada, no lo es tanto como en otros países. En el Gráfico 4.6 se puede ver cómo en Japón menos de un 6\% considera la formalización del vínculo de pareja como algo pasado de moda, porcentaje que es del 8,9\% en Polonia y de alrededor de un 12\% en China y en los Estados Unidos.

No se debe perder de vista lo esencial, esto es, que el matrimonio sigue siendo una opción válida para algo más de dos tercios de la población. No obstante, si se tiene en cuenta que hasta fechas recientes era el único mecanismo socialmente 
establecido para el acceso al sexo contrario (y las consecuencias de ello derivadas como tener hijos, su cuidado y crianza, etc.) y hasta para el abandono de la mujer de la casa paterna, debemos profundizar en los factores sociodemográficos que influyen en que esté aumentando la opinión de que esta institución está pasada de moda.

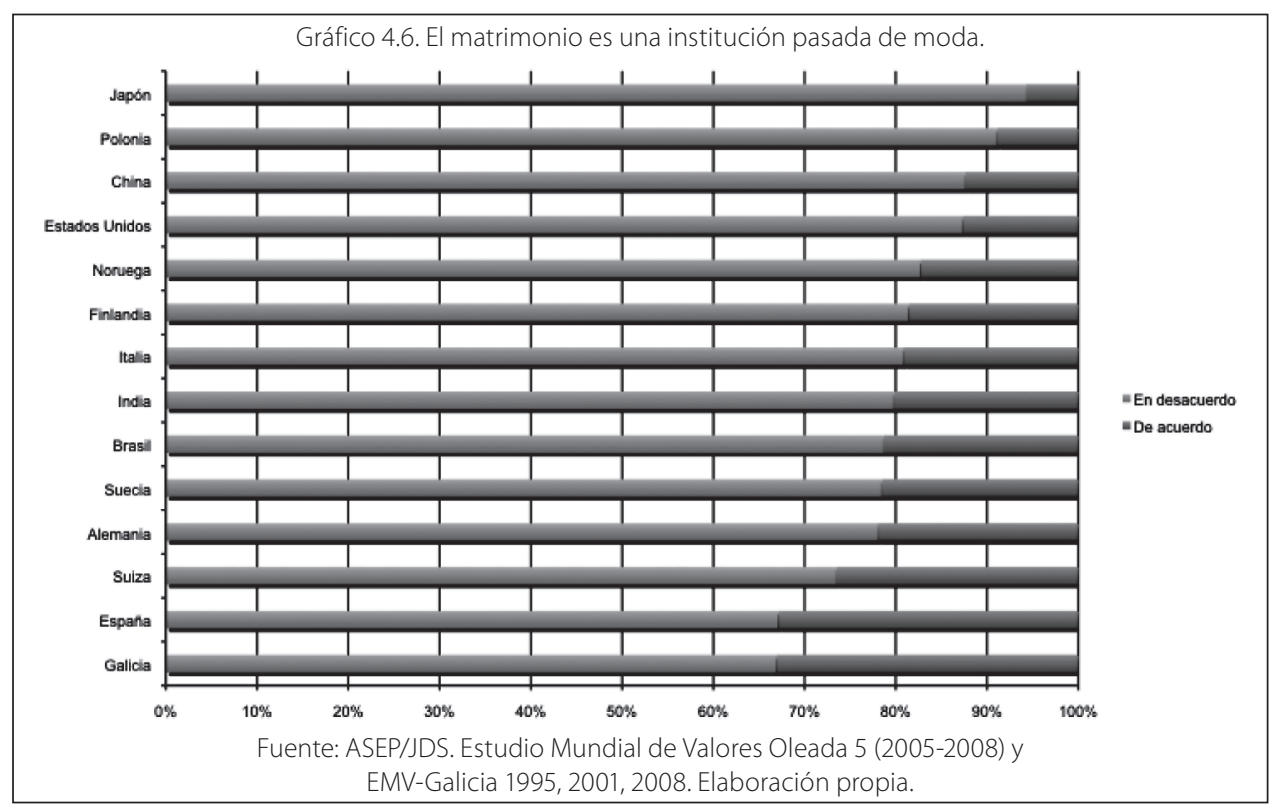

Si se atiende a lo que opinan sobre el matrimonio varones y mujeres, parece confirmarse el tópico de que los hombres son más reacios a formalizar las relaciones de pareja, puesto que un $37,2 \%$ de los mismos entiende que el matrimonio está anticuado por un $29 \%$ de las mujeres.

El nivel de estudios también parece influir, ya que el matrimonio goza de menor aceptación cuanto más alto es el nivel de estudios alcanzado (salvo en la categoría del nivel más alto, en la que la consideración del matrimonio repunta). Por otra parte, existe una relación positiva entre la creencia en que el matrimonio está desfasado y la asunción de valores posmaterialistas; así, el porcentaje de quienes lo consideran pasado de moda es de un 25,8\% entre los que tienen valores materialistas puros, de un 34,4\% entre los que manifiestan valores materialistas mixtos, de un 39,2\% entre los que tienen valores posmaterialistas mixtos y de un $44,1 \%$ si se trata de quienes asumen valores posmaterialistas puros.

Pero las variables que muestran mayores diferencias en la consideración del matrimonio son la edad y el hecho de ser padres. En efecto, el 47,7\% de quienes no tienen hijos ven la institución como algo pasado de moda, porcentaje que desciende al $27,4 \%$ si se tiene un hijo y al $24,9 \%$ si son dos o más. Se 
podría pensar que es la edad la que subyace a esta relación, pero no es así. Por ejemplo, si consideramos solo el grupo de edad de entre 35 y 44 años el $48,8 \%$ de los que no son padres considera el matrimonio desfasado, un $17,2 \%$ más que los tienen un hijo y un 18,9\% más que los que tienen dos o más hijos. Cabría argüir que, en realidad, los hijos se tienen mayoritariamente dentro del matrimonio, lo cual es cierto, pero también lo es que el 29,9\% de los casados sin hijos cree que el matrimonio está pasado de moda, mientras que cuando se tienen hijos el porcentaje desciende al 24,2\%; lo mismo ocurre entre los que viven en pareja, los que no creen en la vigencia del matrimonio son el 60,4\% si no tienen hijos, pero el $47 \%$ si los tienen. La maternidad (y la paternidad), pues, ayudan a explicar la consideración del matrimonio como algo no pasado de moda para una parte importante de la población. La tarea de la crianza de los niños se convierte en un proyecto común para la pareja y los vínculos establecidos entre sus miembros se revalorizan ${ }^{4}$.

En lo que se refiere a la edad, entre las personas mayores de 65 años quienes entienden en 2008 el matrimonio como algo desfasado son solo el 17,1\% (Tabla 4.1); este porcentaje supera el $31 \%$ en el grupo de edad de entre 55-64 años, desciende al 27,3\% en el grupo de 45-54 años, sube al 36,1\% en el de entre 35-44 años, aumenta significativamente al 48,5\% en el de 25-34 años y es del 52,5\% entre los que tienen entre 18 y 24 años. Esta variación puede explicarse en el sentido de que son los más jóvenes los que menos desean los vínculos formales y estables que conlleva una institución como la del matrimonio. Y esta es una postura bastante sensata si tenemos en cuenta que en España y en Galicia las condiciones de acceso y permanencia en el mercado de trabajo obligan a una fuerte dependencia de la familia de origen, que suele actuar como colchón ante las contingencias de la situación laboral. En este sentido, el propio mercado de la vivienda en España es un factor que incide negativamente en la formación familiar temprana (y hasta en la conformación de parejas de hecho jóvenes), puesto que está excesivamente orientado a la tenencia en propiedad y dificulta los alquileres (Jurado Guerrero, 2003: 113). Las obligaciones adquiridas por el matrimonio se pueden percibir entonces como más difíciles de afrontar.

Pero si los jóvenes no creen en el matrimonio no se debe exclusivamente a razones de índole económica vinculadas al ciclo vital. El hecho es que cada vez son más los jóvenes que no creen en el matrimonio. Desde 2001 la opinión de que es algo pasado de moda aumentó en un 12,1\% entre el grupo de edad de 18 a 24 años y en un 18,3\% en el grupo de entre 25 y 34 años.

Hay que señalar que la edad puede ser un factor explicativo en este caso. 
Tabla 4.1. Cree que el matrimonio está pasado de moda (en porcentaje).

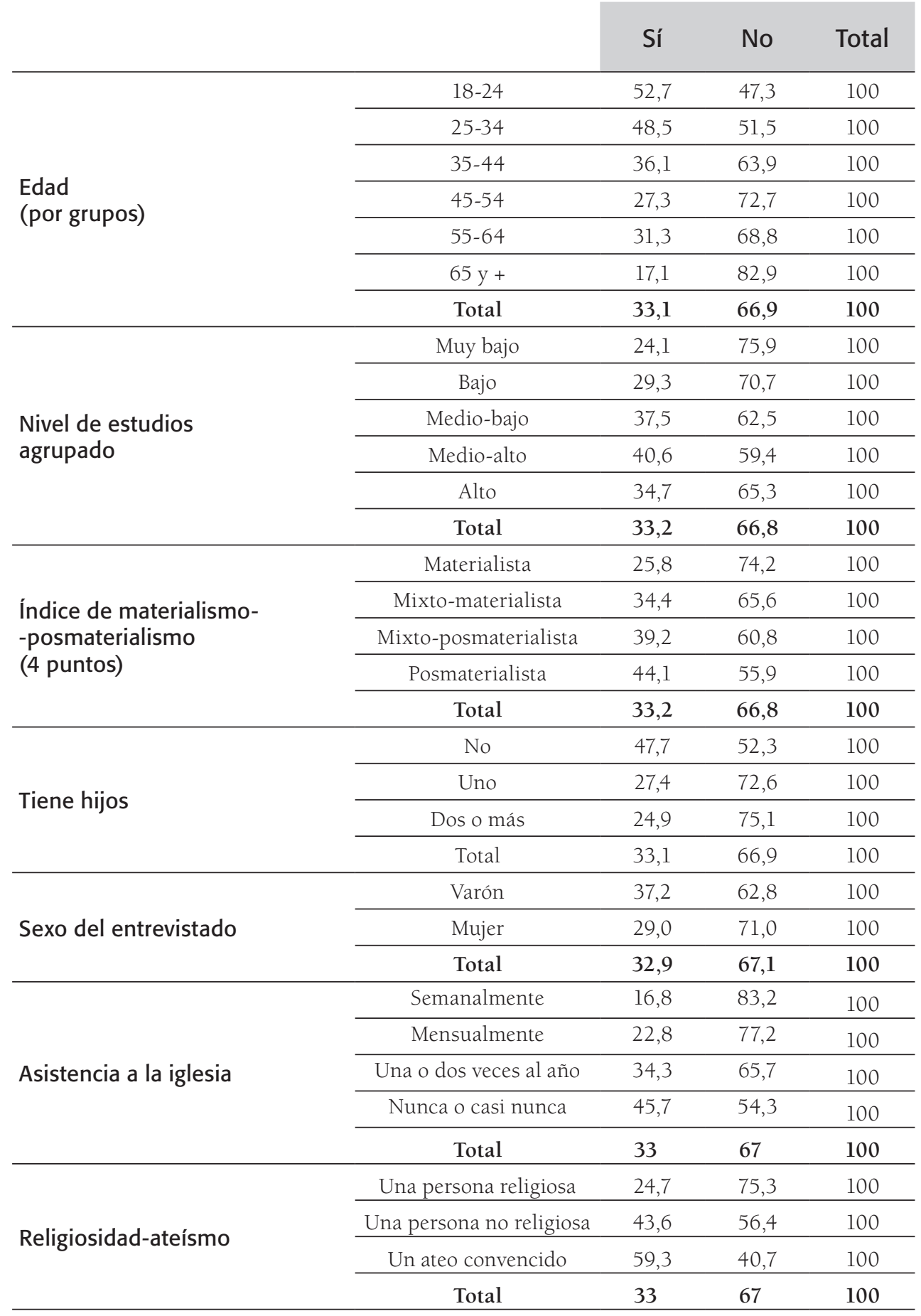

Fuente: EMV-Galicia 2008. Elaboración propia. 
No obstante, en el Gráfico 4.7 se observa cómo la opinión acerca del matrimonio está fuertemente condicionada por el efecto generación. La hipótesis de la socialización supone que en las primeras etapas de la vida, los acontecimientos históricos (políticos, culturales, sociales, económicos, etc.) vividos durante la etapa de socialización primaria y que son compartidos por los coetáneos, influyen en la concepción que estos tendrán sobre la realidad en su vida adulta (Inglehart, 1998: 60-63). En este caso podemos comprobar que las puntuaciones son bastante similares para cada generación en las tres encuestas ${ }^{5}$. Esto confirma que la visión del matrimonio tiene un fuerte componente generacional: es la cohorte nacida en los años 50 la que manifiesta un cambio creciente en la concepción del matrimonio como algo desfasado. Es precisamente en esa década cuando se empezaron a superar las fases más duras de la postguerra, cuando con el Plan de Estabilización se superó la autarquía y comenzó el crecimiento económico y cuando el régimen franquista se abrió al exterior y muy especialmente al turismo (Míguez, 1990). Esta tendencia creciente se mantiene en las cohortes nacidas en la década de los 60 y también en la de los 70, y se dispara en la nacida en los años 80 , la primera de la democracia, lo que sugiere que el matrimonio vaya a ser una opción cada vez menos escogida en el futuro y que la evolución de la tasa de nupcialidad comentada anteriormente continuará su curva descendente, incluso de manera más acusada.

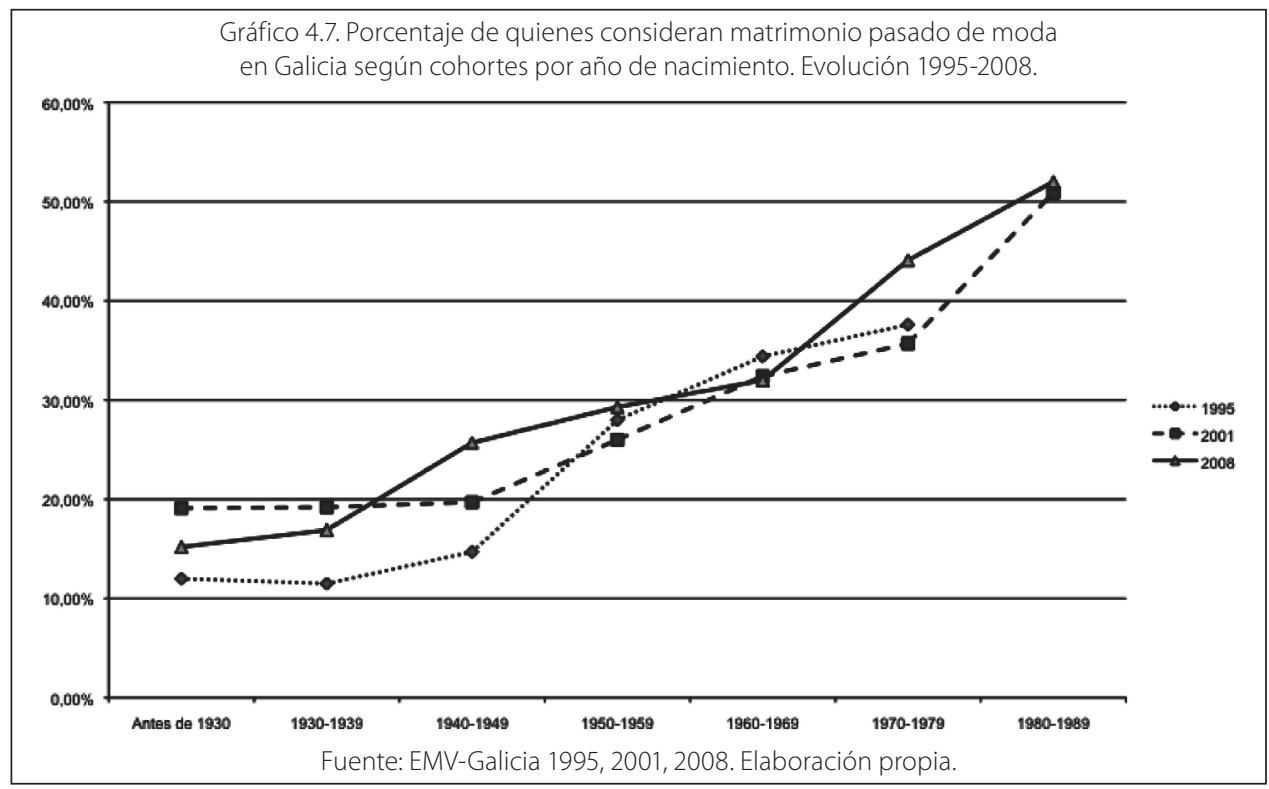

La media de las distancias porcentuales para cada cohorte de edad no es superior al $6 \%$. Donde más distancia existe es en la generación nacida entre 1940 y 1949, pero tampoco ofrece diferencias de tendencia con respecto a las generaciones anterior o posterior a ella. Por otro lado, las diferencias entre las tres encuestas en lo que se refiere a las puntuaciones de las generaciones nacidas en los años 50, 60 y 80 son mínimas (no superan el 3,3\%). 
Empleando una metáfora médica que resuma lo comentado hasta ahora, se podría decir que el matrimonio por el momento goza de una relativa buena salud, pero que su situación dista de ser estable. En efecto, sigue siendo una institución válida para dos de cada tres gallegos, pero menos para las generaciones más jóvenes y su descrédito aumenta a medida que nuevas generaciones se incorporan a la vida adulta. Pero hay que dudar además de la fortaleza de los vínculos que, supuestamente, establece entre los miembros de la pareja.

En el Gráfico 4.8 se muestra la evolución de la relación entre las tasas de matrimonios y de rupturas matrimoniales (incluyendo divorcios, separaciones y anulaciones) ocurridas entre 1998 y 2006 y se puede comprobar que en solo nueve años se ha pasado en Galicia de celebrarse 4,5 matrimonios por cada 1.000 habitantes a 4,1, mientras que la tasa de separaciones ascendió de 2 a 3,1 (en España los matrimonios se redujeron del 5,2\%o al 4,6\%o, mientras que la tasa de rupturas pasó del 2,3\%o al 3,3\%o).

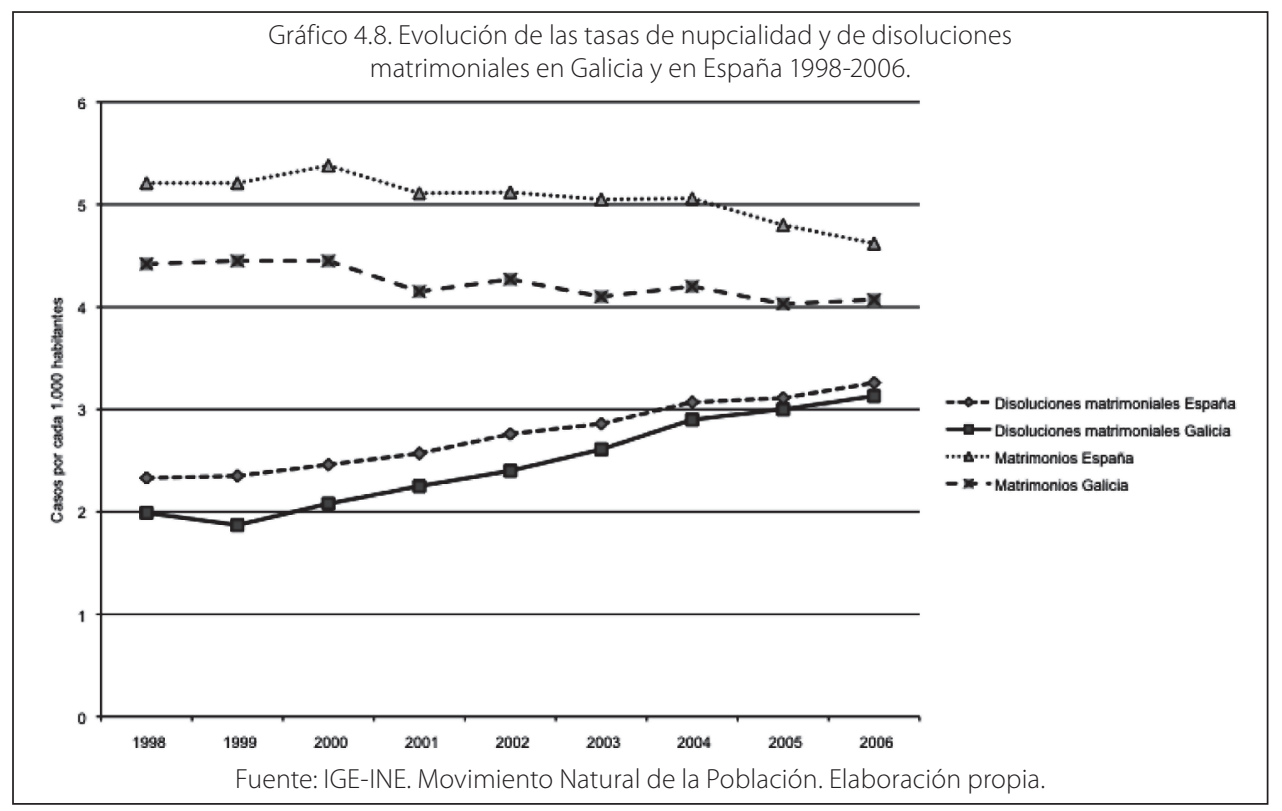

El matrimonio ya no es, ni mucho menos, una unión "para siempre". Sigue manteniendo el significado de hacer pública y social la unión entre dos personas, pero el compromiso que comporta ha perdido la fuerza que lo caracterizó antaño, puesto que hasta no hace mucho tiempo (menos de treinta años), el divorcio era ilegal. El matrimonio, pues, ha cambiado de significado; ya no se percibe como una institución superior al individuo en el plano moral, por la cual hay que sacrificar, llegado el caso, el bienestar o interés individual. Por el contrario, el matrimonio se vive como un contrato que hace explícita la unión entre dos personas, que 
comporta beneficios sociales y económicos para la pareja, pero que puede ser (y es) disuelto si se entiende como insatisfactorio por uno de los miembros de la pareja.

Es la secularización de las relaciones sociales lo que subyace a este cambio en la concepción del matrimonio (Tabla 4.1). El 75,3\% de quienes creen en Dios entiende que el matrimonio sigue siendo una institución vigente hoy en día; este porcentaje se reduce al 56,4\% entre los no creyentes y al 40,7\% entre los que se definen a sí mismos como ateos. Por otro lado, conforme disminuye la frecuencia de asistencia a misa, aumenta la proporción de quienes ven el matrimonio como algo desfasado. Esto mismo ocurre, como veremos más adelante, con relación a la consideración del tipo ideal familiar, y también con la justificación del divorcio.

Como se puede observar en la Tabla 4.2, existen algunas variables que están relacionadas con la mayor o menor justificación del divorcio. Así, la gente que se considera religiosa lo justifica menos que los que no se consideran religiosos y éstos aun menos que quienes se declaran ateos (valores medios de 6,7, 8 y 8,7 respectivamente en una escala de 10 puntos). Los católicos también lo justifican en menor medida que los que no se consideran adeptos de ninguna religión (7,1 y 8,4 respectivamente) y, en este sentido, la participación frecuente en las ceremonias religiosas es una variable que tiene una relación creciente con la justificación del divorcio: a mayor frecuencia de asistencia a la iglesia, menor justificación del divorcio, lo que da cuenta de la influencia que las iglesias organizadas tienen a la hora de conformar opinión. Por otro lado, y manteniéndonos todavía en el plano cultural, también el tipo de valores asumidos son una variable relevante, ya que a medida que se avanza hacia posturas posmaterialistas, mayor es la justificación del divorcio.

Es evidente que el estado civil está relacionado con la justificación del divorcio. Los divorciados y separados justifican más la formalización de la ruptura de la pareja $(8,8$ y 8 respectivamente) que quienes todavía se mantienen en el matrimonio $(6,9)$ o quienes lo vieron truncado por fallecimiento de uno de los cónyuges $(6,1)$. Sin embargo, resulta interesante comprobar cómo entre quienes viven en pareja la justificación es mayor que entre los solteros ( 8,3 y 7,8 respectivamente), mayor incluso que entre los separados, lo que da la idea de que la disolución de la pareja es una posibilidad muy real para quienes conviven juntos, posiblemente hasta el punto de decidir que no compensa dar el paso hacia el matrimonio.

En el Gráfico 4.9 se ponen en relación las puntuaciones medias de las distintas cohortes de las encuestas de 1995, 2001 y 2008. En él se puede comprobar que la justificación del divorcio está relacionada positivamente con el año de nacimiento. Las puntuaciones de cada cohorte son muy similares en las distintas consultas, lo que confirma que la creciente justificación del divorcio obedece a un cambio cultural constatable en que cada nueva generación aporta cada vez más individuos que entienden la ruptura de la pareja como algo normal y justificable. En definitiva, se trata de legitimar que el individuo pueda decidir sobre su vida en detrimento de 
otras instituciones sociales que, hasta fechas recientes, tenían un mayor poder a la hora de definir lo que se podía o no hacer.

Tabla 4.2. Justificación del divorcio según distintas variables. Valores medios de una escala de 10 puntos donde $1=$ nunca justificaría el divorcio y $10=$ lo justificaría siempre.

\begin{tabular}{|c|c|c|}
\hline \multirow{6}{*}{ Estado civil } & Casado/a & 6,9 \\
\hline & Viviendo en pareja & 8,3 \\
\hline & Divorciado/a & 8,8 \\
\hline & Separado/a & 8 \\
\hline & Viudo/a & 6,1 \\
\hline & Soltero/a & 7,8 \\
\hline \multirow{4}{*}{$\begin{array}{l}\text { Índice de materialismo-posmaterialismo } \\
\text { (4 puntos) }\end{array}$} & Materialista & 6,6 \\
\hline & Mixto-materialista & 7,4 \\
\hline & Mixto-posmaterialista & 7,7 \\
\hline & Posmaterialista & 8,4 \\
\hline \multirow{3}{*}{ Es una persona } & Religiosa & 6,7 \\
\hline & No religiosa & 8 \\
\hline & Ateo convencido & 8,7 \\
\hline \multirow{2}{*}{ Religión } & Ninguna & 8,4 \\
\hline & Católica Romana & 7,1 \\
\hline \multirow{5}{*}{ Nivel de estudios } & Muy bajo & 6 \\
\hline & Bajo & 7 \\
\hline & Medio-bajo & 7,8 \\
\hline & Medio-alto & 7,9 \\
\hline & Alto & 7,8 \\
\hline \multirow{4}{*}{ Tamaño de municipio } & Menos de 10.001 hab. & 6,5 \\
\hline & 10.001-50.000 hab. & 7,3 \\
\hline & 50.001-200.000 hab. & 7,4 \\
\hline & Más de 200.000 hab. & 8,5 \\
\hline \multirow{7}{*}{ Frecuencia de asistencia a la iglesia } & Más de 1 vez a la semana & 5 \\
\hline & Una vez a la semana & 5,7 \\
\hline & Una vez al mes & 6,6 \\
\hline & Solo en festividades & 7,5 \\
\hline & Una vez al año & 8,1 \\
\hline & Con menos frecuencia & 7,6 \\
\hline & Nunca & 8,5 \\
\hline
\end{tabular}

Fuente: EMV-Galicia 2008. Elaboración propia. 


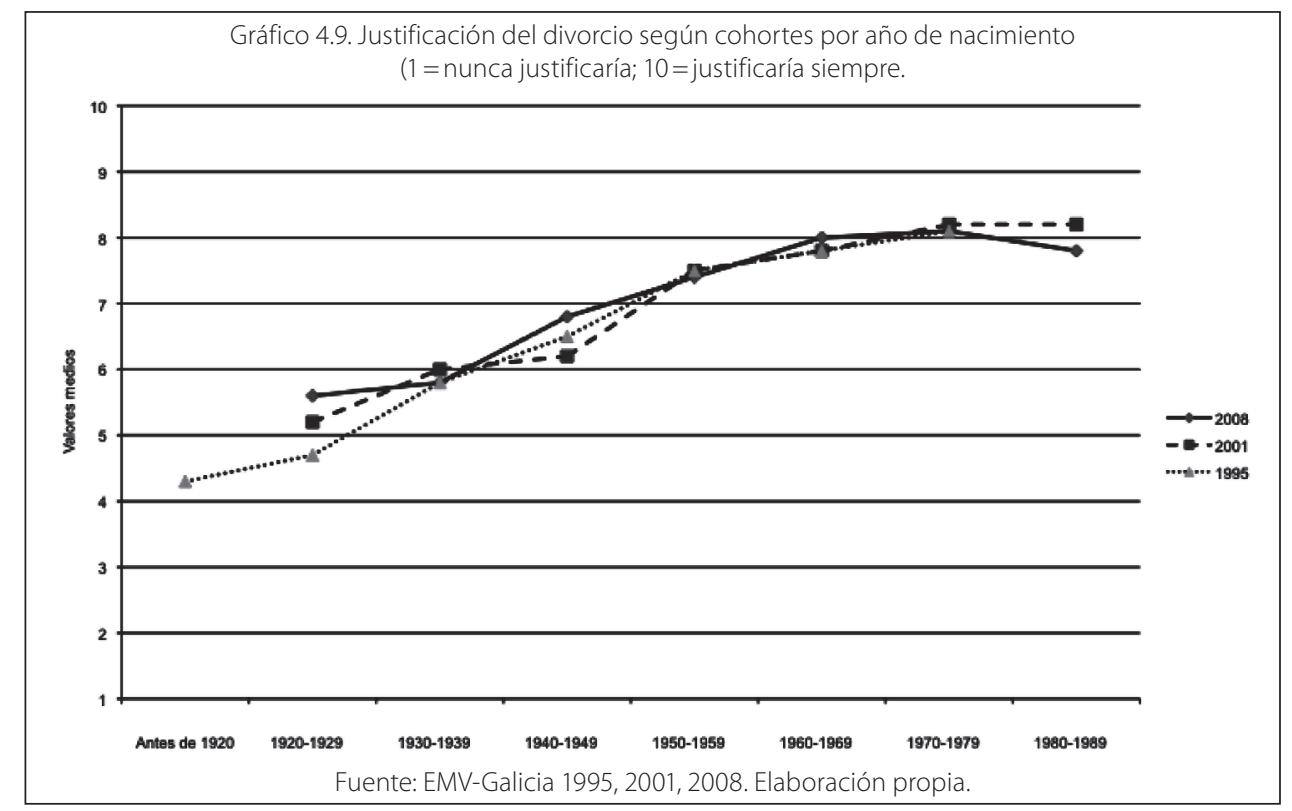

\subsection{NUEVOS TIPOS FAMILIARES}

Uno de los cambios más importantes de las últimas décadas se da en la concepción de lo que debe ser una familia. La familia nuclear, formada por la madre, el padre y la descendencia, sigue siendo el modelo ideal para la mayor parte de la gente, no solo en España y Galicia, sino en el mundo. En efecto, y como se muestra en el Gráfico 4.10, de los países consultados tan solo en Suecia hay una mayoría que estaría en desacuerdo con la frase propuesta. En el resto de los países referenciados prima el acuerdo, que es variable según las sociedades. Así, son una mayoría pero no muy amplia en Finlandia, Estados Unidos, Noruega y Galicia, pues oscilan entre el 51\% y el 60\%; mayor en España y Suiza (entre el $61 \%$ y el $70 \%$ ), aun mayor en el caso de Brasil, Alemania, Japón, e India (entre el $81 \%$ y el $90 \%$ ) y casi unánime en Italia, Polonia y China $(93,1 \%$, $95,1 \%$ y $96,8 \%$ respectivamente).

En Galicia y en España, como hemos visto, es una mayoría la que piensa que los niños deben contar con las dos figuras, la paterna y la materna, en la unidad familiar. Pero la tendencia es a que cada vez menos gente opine así, como se puede ver en el Gráfico 4.11.

Entre los factores que influyen en que se tenga una opinión u otra se encuentran los de tipo sociodemográfico y de tipo cultural y, entre estos últimos, muy especialmente, los religiosos. En efecto, la mayor parte de quienes se declaran ateos está en desacuerdo con la idea de que los niños necesiten un padre y una madre (55,9\%), mientras que entre los que se consideran no religiosos el porcentaje desciende al 42,3\% y al 23,9\% entre quienes se declaran religiosos. La participación en los 
ritos religiosos es otra variable relacionada claramente, puesto que el acuerdo con que los niños necesiten de las dos figuras paternas aumenta conforme lo hace la frecuencia de asistencia a misa. La relación es inversa, por el contrario, con la asunción de valores posmaterialistas ya que, aunque la mayoría está de acuerdo con la frase comentada, el grado de acuerdo disminuye según aumenta el tipo de valores interiorizado (cuanto más posmaterialistas, menor acuerdo).
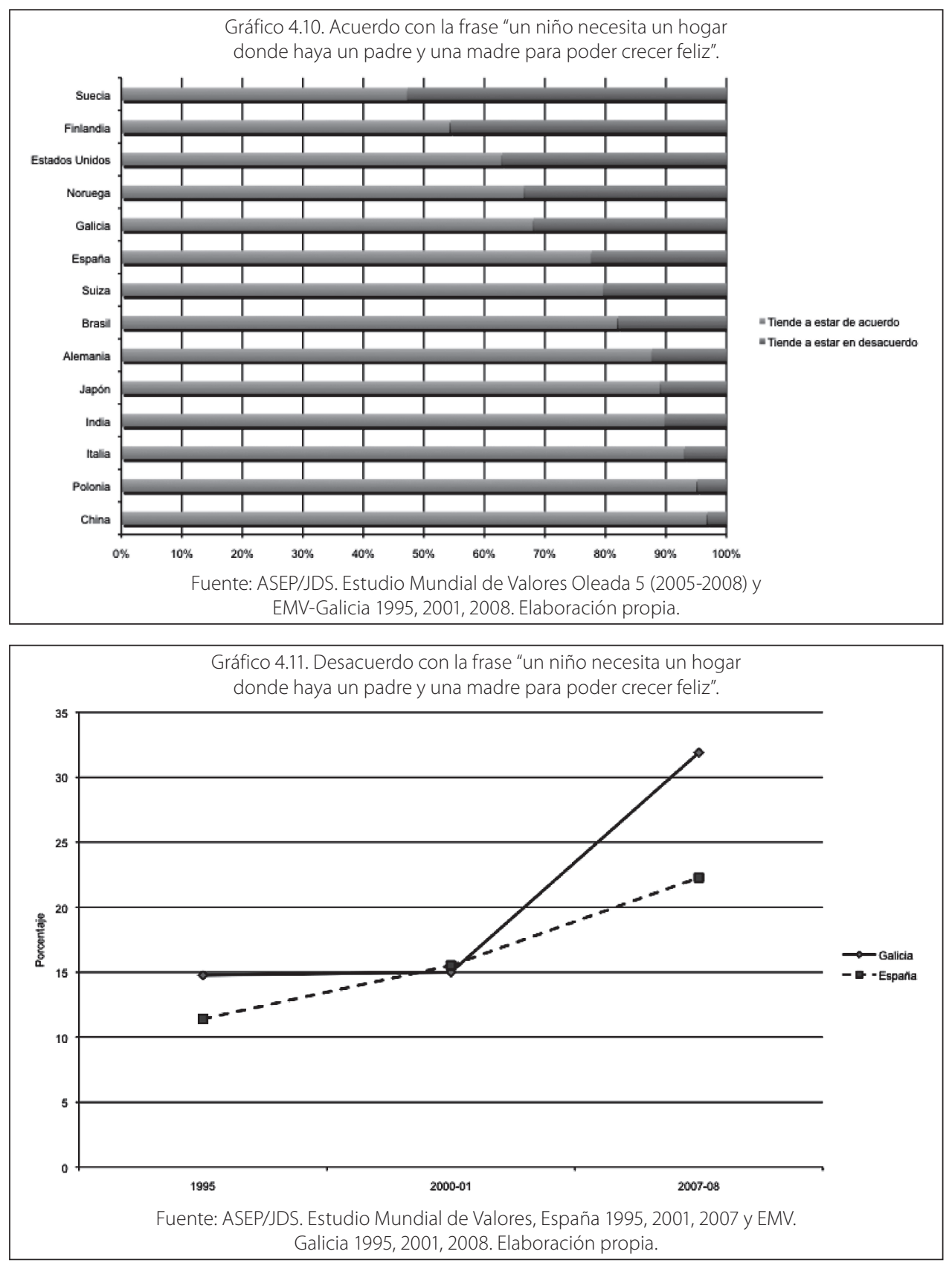
El nivel de estudios alcanzado influye también. El grado de acuerdo con que se necesitan padre y madre en la unidad familiar es muy alto entre quienes tienen un nivel de estudios muy bajo y bajo (entre el $80 \%$ y el $82 \%$ ), y menor entre quienes lo tienen medio bajo, medio alto y alto (entre el $57 \%$ y el $58,5 \%$ ).

Por otro lado, es la cohorte de nacimiento la variable sociodemográfica que muestra más poder explicativo. Las cohortes más antiguas están más de acuerdo que las más recientes. Finalmente, entre los varones se da un mayor acuerdo que entre las mujeres (71,6\% frente al 65,1\%).

El estado civil también influye en la percepción de lo que es deseable para un niño. Quienes muestran un mayor grado de acuerdo con que los niños necesiten de un padre y una madre son los viudos $(85,9 \%)$ seguidos de los separados $(74,3 \%)$ y los casados $(72,6 \%)$. Es curiosa esta relación porque indica un posible efecto de coyuntura vital: las personas separadas muestran un grado de acuerdo semejante (incluso superior) al de quienes están casadas y tienen una clara preferencia por el modelo de familia nuclear; en el caso de las personas viudas habría que interpretar su grado de acuerdo (el más elevado) como una combinación de la opinión característica de los casados junto con el efecto de la generación. Un grado de acuerdo sensiblemente menor es el que muestran las personas que están solteras $(57,4 \%)$ y las que viven en pareja $(58,2 \%)$, aunque en estos casos el grado de desacuerdo supera ya el $40 \%$. Finalmente, aquellas personas que han oficializado la ruptura matrimonial, y como cabría esperar, son quienes menos de acuerdo están con la frase anterior y, de hecho, los únicos que mayoritariamente manifiestan desacuerdo con ella.

Pero una cosa es la preferencia por un tipo de estructura familiar en abstracto y otra bien distinta la aprobación concreta de un modelo familiar diferente al que nos gustaría pero que, no obstante, es el propio de muchas personas de nuestro entorno. Así, si bien se desea mayoritariamente en Galicia que los niños cuenten con un padre y una madre, también se aprueba de forma mayoritaria que las mujeres puedan desempeñar su maternidad sin necesidad de estar casadas.

En este sentido, uno de los indicadores demográficos que mejor muestran el cambio social acaecido en los últimos años en Galicia y en España es el que se refiere al porcentaje de nacidos de madre soltera. La maternidad fuera de la familia era considerada no hace mucho tiempo motivo de deshonra familiar y causa suficiente para estigmatizar a la mujer. En un breve lapso de tiempo, sin embargo, esto se ha normalizado convirtiéndose en una forma más de estructura familiar.

En 1975 el porcentaje de nacidos de madres solteras era del 2 en España y del 3,4 en Galicia, que se situaba a la cabeza de las regiones españolas en este concepto. En 2008 estos valores se multiplicaron por 16,3 y por 9,6 respectivamente alcanzando porcentajes del 33,2\% de nacidos de madres solteras en España y del 32,3\% en Galicia ${ }^{6}$ (Gráfico 4.12).

6 En la Comunidad Canaria, por ejemplo, en 2008 fueron más los nacidos de madres solteras que quienes nacieron en familias constituidas formalmente $(55,8 \%)$; junto con las Islas Baleares $(40,8 \%)$ y Cataluña $(37,9 \%)$ son las comunidades autónomas que elevan la media española. 
Tabla 4.3. Acuerdo con la frase "un niño necesita padre y madre" (en porcentaje).

\begin{tabular}{|c|c|c|c|c|}
\hline & \\
\hline & & $\begin{array}{c}\text { De } \\
\text { acuerdo }\end{array}$ & $\begin{array}{c}\text { En } \\
\text { desacuerdo }\end{array}$ & Total \\
\hline \multirow{2}{*}{ Sexo del entrevistado } & Varón & 71,6 & 28,4 & 100 \\
\hline & Mujer & 65,1 & 34,9 & 100 \\
\hline \multirow{5}{*}{$\begin{array}{l}\text { Nivel de estudios } \\
\text { agrupado }\end{array}$} & Muy bajo & 80,1 & 19,9 & 100 \\
\hline & Bajo & 81,6 & 18,4 & 100 \\
\hline & Medio-bajo & 58,1 & 41,9 & 100 \\
\hline & Medio-alto & 57 & 43 & 100 \\
\hline & Alto & 57,2 & 42,8 & 100 \\
\hline \multirow{4}{*}{$\begin{array}{l}\text { Índice de materialismo- } \\
\text {-posmaterialismo } \\
\text { (4 puntos) }\end{array}$} & Materialista & 78,3 & 21,7 & 100 \\
\hline & Mixto-materialista & 66,4 & 33,6 & 100 \\
\hline & Mixto-posmaterialista & 63,2 & 36,8 & 100 \\
\hline & Posmaterialista & 51,1 & 48,9 & 100 \\
\hline \multirow{7}{*}{$\begin{array}{l}\text { Cohortes por año } \\
\text { de nacimiento }\end{array}$} & Antes de 1930 & 87,9 & 12,1 & 100 \\
\hline & 1930-1939 & 84,9 & 15,1 & 100 \\
\hline & 1940-1949 & 81,6 & 18,4 & 100 \\
\hline & $1950-1959$ & 75,2 & 24,8 & 100 \\
\hline & 1960-1969 & 59,2 & 40,8 & 100 \\
\hline & $1970-1979$ & 54,9 & 45,1 & 100 \\
\hline & 1980-1989 & 52,8 & 47,2 & 100 \\
\hline \multirow{6}{*}{ Estado civil } & Casado/a & 72,6 & 27,4 & 100 \\
\hline & Viviendo en pareja & 58,2 & 41,8 & 100 \\
\hline & Divorciado/a & 49 & 51 & 100 \\
\hline & Separado/a & 74,3 & 25,7 & 100 \\
\hline & Viudo/a & 85,9 & 14,1 & 100 \\
\hline & Soltero/a & 57,4 & 42,6 & 100 \\
\hline \multirow{2}{*}{ Religión } & Ninguna & 49 & 51 & 100 \\
\hline & Católica & 71,8 & 28,2 & 100 \\
\hline \multirow{4}{*}{ Asistencia a la iglesia } & Semanalmente & 86,9 & 13,1 & 100 \\
\hline & Mensualmente & 77,1 & 22,9 & 100 \\
\hline & Una o dos veces al año & 64,9 & 35,1 & 100 \\
\hline & Nunca o casi nunca & 56,0 & 44,0 & 100 \\
\hline \multirow{3}{*}{ Religiosidad } & Una persona religiosa & 76,1 & 23,9 & 100 \\
\hline & Una persona no religiosa & 57,7 & 42,3 & 100 \\
\hline & Un ateo convencido & 44,1 & 55,9 & 100 \\
\hline
\end{tabular}

Fuente: EMV-Galicia 1995, 2001 y 2008. Elaboración propia. 
En estos años el porcentaje de nacimientos ocurridos fuera de la institución del matrimonio en Galicia es algo inferior que en España. No obstante, en la comunidad gallega se da una mayor (aunque ligera) aprobación a este tipo de familia (Gráfico 4.13). En 1995 un 76,5\% de los gallegos aprobaba este modelo familiar (74,8\% en España), mientras que en 2008 el porcentaje subió al 80,2\% (79,7\% en el caso de España). En Galicia y en España es, por otro lado, donde mayor aprobación existe con respecto a la maternidad en soltería, muy por delante de países como Francia (62,3\%), Países Bajos (58,7\%), Estados Unidos (52,2\%), Suecia $(49,1 \%)$ o Reino Unido (33,5\%). En China e India el rechazo manifiesto es abrumadoramente superior a la aprobación (85,1\% y 76,9\% respectivamente), siendo más también en Japón, Suiza, Italia, Reino Unido y Alemania los que desaprueban que los que aprueban.
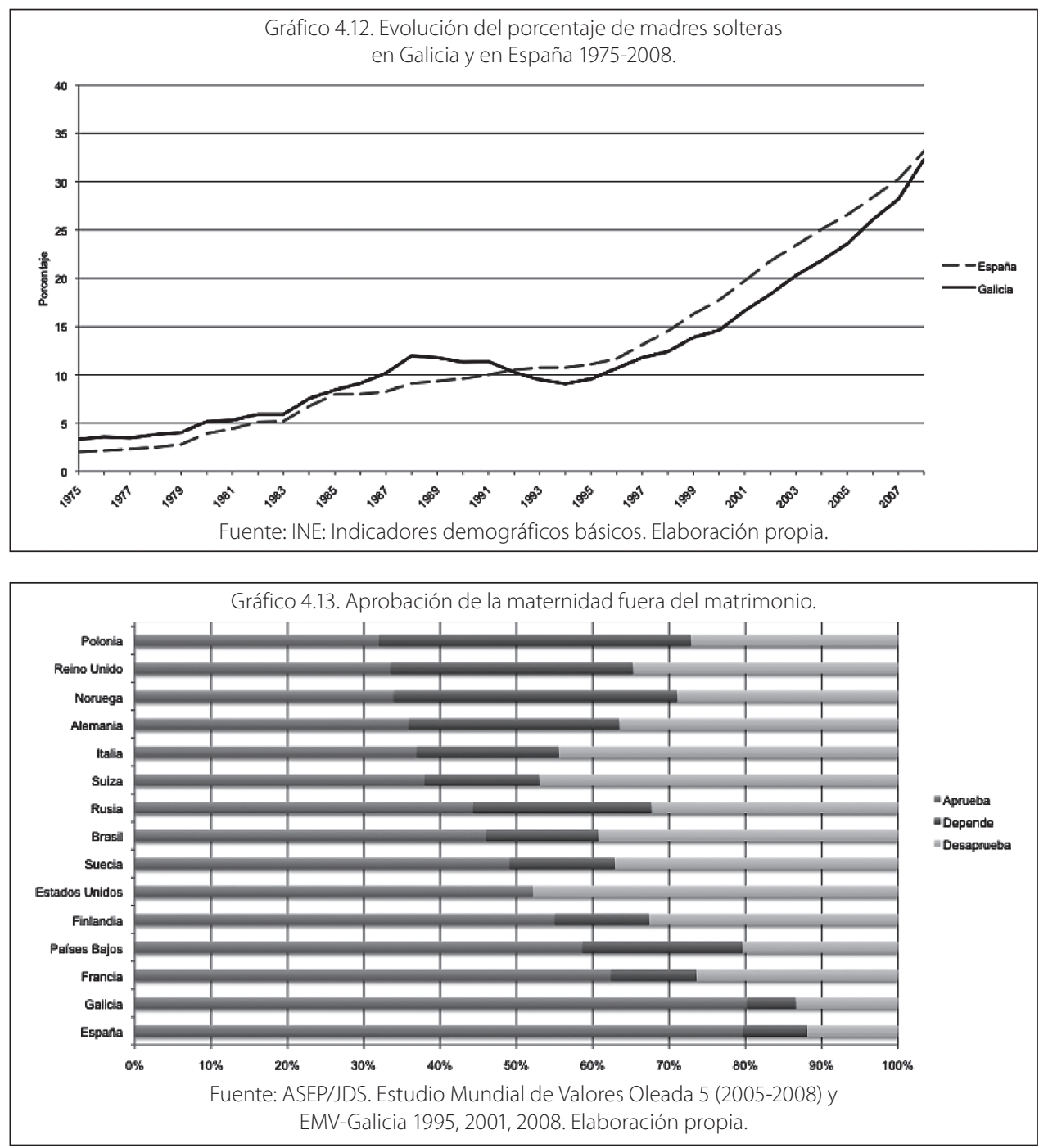
Tabla 4.4. Variables que influyen en la aprobación/desaprobación de las madres solteras (en porcentaje).

Aprobaría Desaprobaría Depende Total

\begin{tabular}{|c|c|c|c|c|c|}
\hline \multirow{8}{*}{$\begin{array}{l}\text { Generaciones } \\
\text { (por año } \\
\text { de nacimiento) }\end{array}$} & Antes de 1930 & 40,8 & 38,8 & 20,4 & 100 \\
\hline & 1930-1939 & 66,2 & 24,7 & 9,1 & 100 \\
\hline & 1940-1949 & 74,8 & 18,3 & 6,9 & 100 \\
\hline & 1950-1959 & 81,9 & 10,3 & 7,8 & 100 \\
\hline & 1960-1969 & 88,2 & 8,1 & 3,7 & 100 \\
\hline & 1970-1979 & 87,7 & 9 & 3,2 & 100 \\
\hline & 1980-1989 & 92,4 & 4 & 3,6 & 100 \\
\hline & Total & 80,1 & 13,5 & 6,4 & 100 \\
\hline \multirow{6}{*}{$\begin{array}{l}\text { Nivel de } \\
\text { estudios } \\
\text { agrupado }\end{array}$} & Muy bajo & 67,4 & 24,7 & 7,9 & 100 \\
\hline & Bajo & 77,9 & 12,6 & 9,5 & 100 \\
\hline & Medio-bajo & 85,8 & 11,3 & 3 & 100 \\
\hline & Medio-alto & 87,7 & 8,7 & 3,6 & 100 \\
\hline & Alto & 81,6 & 9,8 & 8,6 & 100 \\
\hline & Total & 80,2 & 13,4 & 6,3 & 100 \\
\hline \multirow{5}{*}{$\begin{array}{l}\text { Índice } \\
\text { de materialismo- } \\
\text {-posmaterialismo } \\
\text { (4 puntos) }\end{array}$} & Materialista & 66,3 & 22,1 & 11,6 & 100 \\
\hline & Mixto-materialista & 87,1 & 9,5 & 3,4 & 100 \\
\hline & Mixto-posmaterialista & 88,7 & 9,3 & 2 & 100 \\
\hline & Posmaterialista & 92,5 & 3,8 & 3,8 & 100 \\
\hline & Total & 80,3 & 13,5 & 6,2 & 100 \\
\hline \multirow{3}{*}{$\begin{array}{l}\text { Sexo } \\
\text { del entrevistado }\end{array}$} & Varón & 76,3 & 17 & 6,7 & 100 \\
\hline & Mujer & 83,7 & 10,2 & 6 & 100 \\
\hline & Total & 80,2 & 13,5 & 6,3 & 100 \\
\hline
\end{tabular}

Fuente: EMV-Galicia 2008. Elaboración propia.

La aprobación de este tipo de familia varía en función del grupo o colectivo concreto de que se trate (Tabla 4.4). La aprueban más las mujeres $(83,7 \%)$ que los varones (76,3\%), las cohortes más recientes (92,4\% de quienes nacieron en los años 80 , por el 40,8\% de quienes nacieron antes de 1930) y cuenta con más aprobación por quienes asumen valores posmaterialistas (el 92,5\% de los posmaterialistas puros, por el $66,3 \%$ de quienes manifiestan valores materialistas puros). Existe una mayor desaprobación explícita de la maternidad en soltería por las cohortes de mayor edad (38,8\%), de menor nivel de estudios $(24,7 \%)$ y de valores materialistas $(22,1 \%)$ (Tabla 4.4). 


\subsection{EDUCACIÓN DE LOS HIJOS}

Una de las principales funciones de la familia es la de transmitir a los niños los valores que, conformando así su personalidad, les permitirán en el futuro valerse por sí mismos y ser miembros plenos de la sociedad. No obstante, el proceso de socialización nunca se realiza de manera completa porque los mismos valores transmitidos pueden ser inconsistentes o incluso incompatibles entre sí. Ahora bien, conocer el énfasis que se haga en unos u otros valores es interesante por la información que proporciona acerca de lo que es considerado importante por una sociedad. Si además se dispone de la evolución de su preferencia a lo largo del tiempo, obtendremos una idea aproximada del cambio cultural. En este sentido, y si bien no ha transcurrido el tiempo suficiente como para extraer conclusiones definitivas de los datos que se ofrecen, la variación de las preferencias escogidas en 1995 y en 2008 sí tiene interés para percibir la dirección del cambio.

Tabla 4.5. Considera importante inculcar a los niños (en porcentaje).

\begin{tabular}{lcccccc} 
& \multicolumn{3}{c}{ Galicia } & \multicolumn{3}{c}{ España } \\
& 2008 & 1995 & $\begin{array}{c}\text { \% de } \\
\text { cambio }\end{array}$ & $\mathbf{2 0 0 7}$ & $\mathbf{1 9 9 5}$ & $\begin{array}{c}\% \text { de } \\
\text { cambio }\end{array}$ \\
\hline Independencia & 42,6 & 31,2 & 36,5 & 31,4 & 24,8 & 26,7 \\
\hline Esfuerzo en el trabajo & 61,7 & 60,8 & 1,6 & 62,6 & 64,4 & $-2,7$ \\
\hline Responsabilidad & 82,3 & 75,5 & 9,1 & 69,7 & 69,8 & $-0,2$ \\
\hline Imaginación & 25,0 & 26,1 & $-4,2$ & 20,4 & 21,7 & $-6,2$ \\
\hline Tolerancia & 84,9 & 75,3 & 12,8 & 71,7 & 75,6 & $-5,2$ \\
\hline Sobriedad & 23,1 & 22,2 & 4,3 & 18,9 & 19,0 & $-0,6$ \\
\hline Determinación & 27,3 & 18,0 & 52,0 & 29,6 & 21,2 & 39,5 \\
\hline Fe religiosa & 17,3 & 24,9 & $-30,4$ & 11,2 & 21,8 & $-48,3$ \\
\hline Abnegación & 42,4 & 13,5 & 214,1 & 33,5 & 14,3 & 135,0 \\
\hline Obediencia & 54,9 & 46,9 & 17,1 & 36,9 & 43,8 & $-15,7$ \\
\hline & $\begin{array}{r}\text { Fuente: ASEP/JDS, EMV-España 1995 y 2007 } \\
\text { y EMV-Galicia 1995 y 2008. Elaboración propia. }\end{array}$ & &
\end{tabular}

En la Tabla 4.5 se relacionan las respuestas de dos oleadas de encuestas realizadas en Galicia (en 1995 y 2008) y en España (en 1995 y 2007) mediante una tasa o porcentaje de variación entre ambos períodos ${ }^{7}$. Lo primero que se advierte es la gran semejanza entre ambas sociedades en cuanto a la jerarquización de lo que es importante inculcar a los niños, así como una relativa estabilidad

Este porcentaje de variación se ha calculado mediante la fórmula $\left(\left(X^{\prime}-X\right) / X\right) \cdot 100$ 
de estas preferencias a lo largo del tiempo. La tolerancia, la responsabilidad, el esfuerzo en el trabajo y la obediencia son seleccionados siempre por delante en las cuatro encuestas. La independencia es el quinto rasgo seleccionado en orden de preferencia (sexto en el caso de España en 2007); y la solidaridad pasó de ocupar la última posición de la lista al sexto puesto en Galicia y quinto en España ${ }^{8}$. El resto de atributos (la determinación, la imaginación, la sobriedad y la fe religiosa) son destacados por menos de un 30\% de los encuestados y no ofrecen grandes diferencias entre los casos gallego y español, así como a lo largo del tiempo. Quizás sea reseñable que la fe religiosa pierde fuerza con el tiempo (más en España que en Galicia) y que la gana la determinación.

Estos datos confirman la tendencia apuntada para Galicia por Veira (Veira, 2007a: 76-77) unas relaciones familiares dominadas por el intercambio y la negociación en mayor medida que por el modelo de dirección única de padres a hijos. De hecho, la tolerancia y la responsabilidad son las cualidades más resaltadas (superando el 80\% y aumentando el porcentaje de respuesta con respecto a 1995). Este modelo combina valores individualistas (tolerancia y responsabilidad) con tradicionales (esfuerzo en el trabajo) y en él pierden importancia algunos valores materialistas: cualidades como la fe religiosa y el espíritu de ahorro o sobriedad, propias de sociedades regidas por la escasez.

Son muchos los factores que pueden explicar, en mayor o menor medida, las preferencias en Galicia por unos valores u otros en 2008 (Tabla 4.6). El sexo, por ejemplo, influye en el sentido de que los varones enfatizaron las cualidades de la determinación y la imaginación (10,5\% y 6,4\% más que las mujeres respectivamente), mientras que las mujeres destacaron más las creencias religiosas y la solidaridad y el altruismo (en porcentajes superiores al de los varones del 10,5\% y $6,3 \%$ respectivamente).

No daremos porcentajes concretos para no hacer demasiado farragosa la lectura, pero sí queremos señalar que la edad es otro factor explicativo importante (cuanto más jóvenes son las personas más valoran la independencia y la imaginación, mientras que las personas mayores señalan la responsabilidad y la fe religiosa), el tamaño del municipio (cuanto mayor es, más se mencionan la imaginación y la tolerancia y cuanto más pequeño la obediencia), el nivel de estudios (a mayor nivel de estudios mayor es el porcentaje de respuesta en valores como independencia, esfuerzo en el trabajo, determinación y solidaridad, y menor en obediencia, sobriedad y fe religiosa) y los valores posmaterialistas (cuanto más posmaterialistas son los valores, más se prefieren la imaginación y la determinación y menos la obediencia y las creencias religiosas). Habida cuenta de que la pregunta versaba sobre lo que se considera adecuado inculcarle a los hijos, pareció relevante tener en cuenta si efectivamente se tienen hijos o no, independientemente de la edad, resultó ser esta una variable explicativa en los casos de la independencia, imaginación y solidaridad (más valorada por quienes

Muy probablemente este aumento se deba al cambio en la formulación de la pregunta, que pasó de ser la abnegación en 1995 a la solidaridad y el altruismo en 2008, con el importante matiz que dicho cambio comporta. 
no tienen hijos), así como el esfuerzo en el trabajo, sobriedad y ahorro, obediencia y las creencias religiosas (más valoradas por quienes tienen hijos).

Tabla 4.6. Variables explicativas de los valores considerados importantes para inculcar a los hijos en Galicia en 2008 y sentido de la relación.

\begin{tabular}{lcccccc} 
& Sexo & $\begin{array}{c}\text { Tiene } \\
\text { hijos }\end{array}$ & Edad & $\begin{array}{c}\text { Tamaño de } \\
\text { municipio }\end{array}$ & Estudios & $\begin{array}{c}\text { Valores } \\
\text { posmaterialistas }\end{array}$ \\
\hline Independencia & Varón + & Negativa & Negativa & - & Positiva & - \\
\hline $\begin{array}{l}\text { Esfuerzo } \\
\text { en el trabajo }\end{array}$ & - & Positiva & - & - & Positiva & - \\
\hline Responsabilidad & - & - & Positiva & - & - & - \\
\hline Imaginación & - & Negativa & Negativa & Positiva & - & Positiva \\
\hline Tolerancia & - & - & - & Positiva & - & - \\
\hline Sobriedad & - & Positiva & - & - & Negativa & - \\
\hline Determinación & Varón + & - & - & - & Positiva & Positiva \\
\hline Fe religiosa & Mujer + & Positiva & Positiva & - & Negativa & Negativa \\
\hline $\begin{array}{l}\text { Solidaridad/ } \\
\text { altruismo }\end{array}$ & Mujer + & Negativa & - & - & Positiva & - \\
\hline \begin{tabular}{l} 
Obediencia \\
\hline
\end{tabular} & - & Positiva & - & Negativa & Negativa & Negativa \\
\hline
\end{tabular}

Fuente: EMV-Galicia 2008. Elaboración propia.

Resulta interesante comparar lo que se contestó en Galicia con las respuestas dadas en otras sociedades. En la Tabla 4.7 aparecen los datos referidos a Galicia y España junto con los de los Estados Unidos, Japón y diversos países europeos, así como las llamadas economías emergentes (China, Brasil e India). En ella se puede observar cómo Galicia destaca por señalar la obediencia (por detrás de Brasil e India) y el altruismo (por detrás de Francia, Reino Unido, Japón e Italia) en mayor medida que otras sociedades. En lo que se refiere a las creencias religiosas ocupa una posición media, ya que se encuentra a distancia de Brasil, los Estados Unidos, Polonia, India e Italia (que superan el 33\% de respuestas para esta cualidad) pero destaca de entre la mayor parte de las sociedades europeas, junto con el Reino Unido, con valores superiores al 15\%.

Posición intermedia también es la que ocupa en lo relativo a una cualidad como el sentido de la responsabilidad (aunque con un porcentaje del 82,3\%, que la sitúa más cerca de un país como Japón que de España). En otros valores como son la independencia (42,6\%), la determinación y perseverancia (27,3\%) o la imaginación (25\%) Galicia obtiene, sin embargo, puntuaciones que se parecen a las más bajas de entre las sociedades analizadas. 
Para sintetizar parte de esta información y, de paso, ubicar a Galicia en el contexto internacional, puede resultar útil emplear el índice de autonomía (Inglehart y Welzel, 2005). Éste se construye a partir de las variables fe religiosa, obediencia, determinación o perseverancia e independencia. Sus valores oscilan entre -2 , que representa conceder mucha importancia a los valores tradicionales de obediencia y creencias religiosas, y +2 , que equivale a seleccionar valores vinculados a la autonomía personal como la independencia y la determinación.

En el Gráfico 4.14 se muestran los resultados de dicho índice en los países analizados y Galicia. Destaca, en primer lugar, que las sociedades que consideran más importante socializar a sus nuevas generaciones en valores tendentes a conformar individuos con autonomía personal son los países nórdicos junto con Japón, Alemania, Suiza y China; en todos ellos los porcentajes de las categorías +1 y +2 agrupadas superan el $60 \%$. Por el contrario, entre las sociedades que enfatizan inculcar la obediencia y las creencias religiosas destaca Brasil (el único en el que las categorías -1 y -2 agrupadas superan el 50\%), Polonia (donde superan el 40\%) y Galicia (con un porcentaje superior al 36\%).

Finalmente, queremos comentar dos aspectos que ejemplifican la situación de Galicia en la actualidad y que pueden llegar a ser relevantes de cara al futuro. El trabajo duro y la sobriedad y ahorro son característicos de sociedades de la escasez pero, de hecho, estos valores se encontraban también en la base de la revolución industrial, como afirma Weber en La ética protestante y el espíritu del capitalismo. No debe extrañar entonces que los países que prefieren en mayor medida inculcar a sus hijos dichos valores sean China (90,2\% el trabajo duro y $69,1 \%$ la sobriedad), Rusia ( $88,9 \%$ y $52,7 \%$ ) o la India ( $81,7 \%$ y $55,7 \%$ ), todos ellos economías emergentes en rápida transición a un modelo económico capitalista.

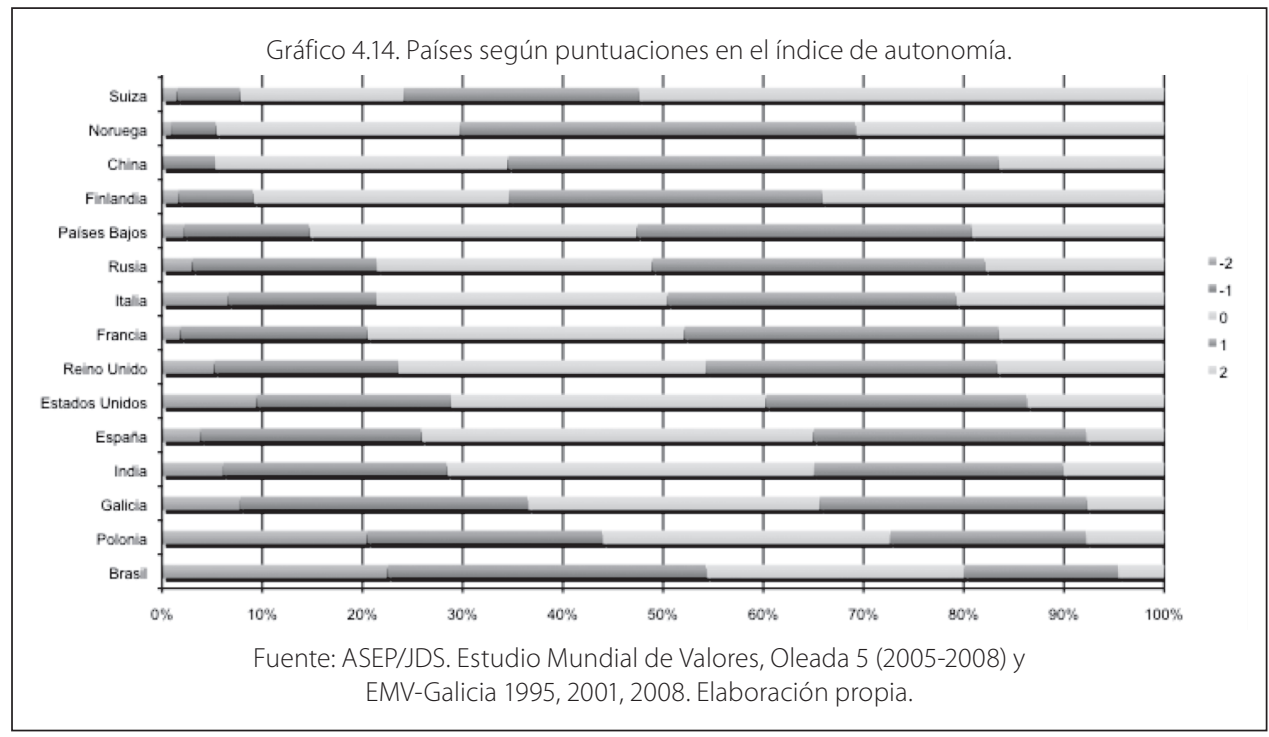




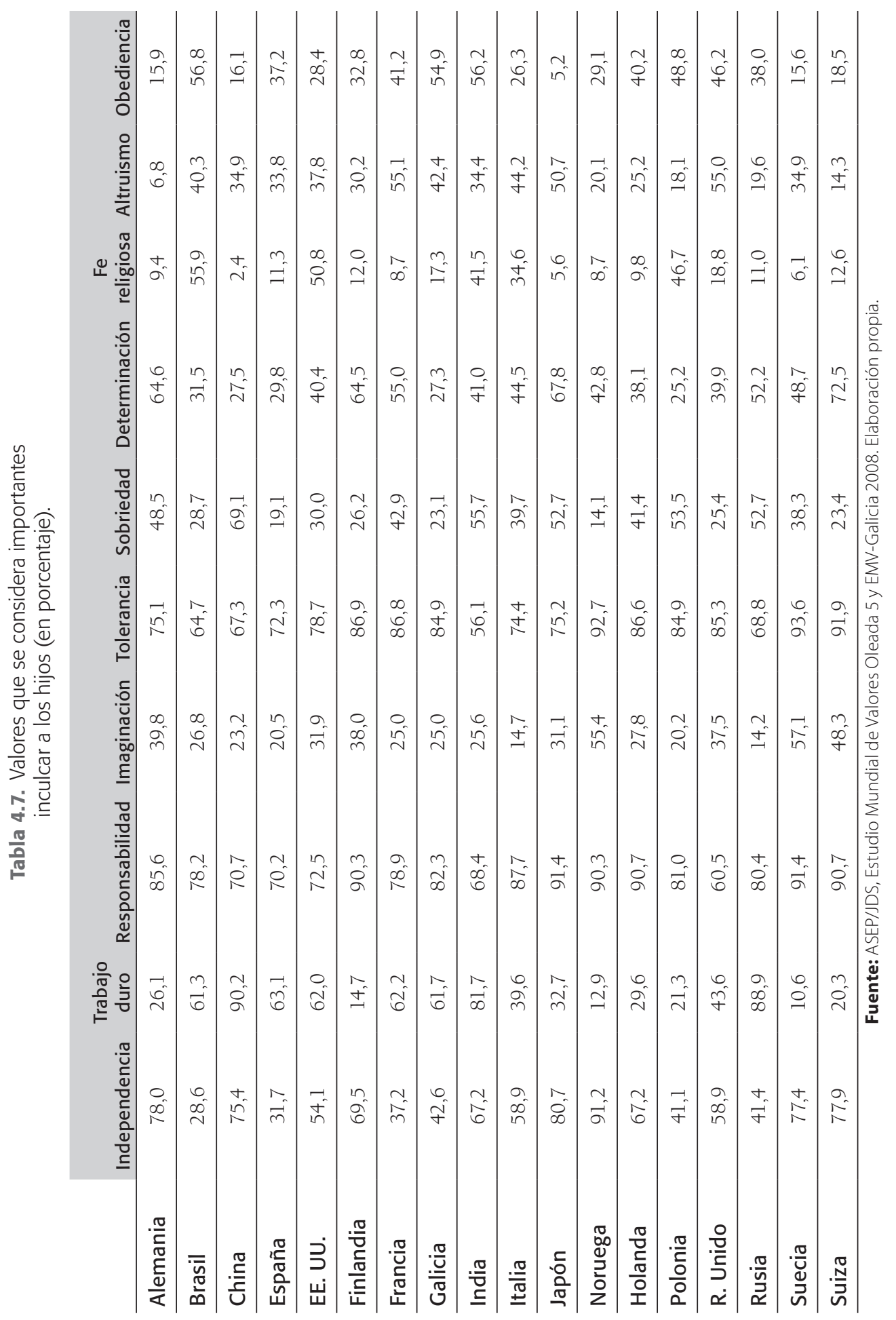

TRANSFORMACIONES RECIENTES DE LA FAMILIA... 
Como simple comparación, Noruega, que encabezó el listado de países ordenados según el índice de desarrollo humano en 2007, ofrece porcentajes del $12,9 \%$ para la cualidad del trabajo duro, del $14,1 \%$ para la sobriedad y ahorro y del 92,7\% para la tolerancia y respeto, lo que da idea de que en aquellas sociedades que se han modernizado se prefieren valores denominados de autoexpresión. En Galicia, la tolerancia es también una cualidad importante, puesto que el 84,9\% de los encuestados así lo expresaron; el trabajo duro, por otro lado, es un valor a inculcar a los hijos para un $61,7 \%$ de la población (entre un $20 \%$ y un $30 \%$ menos que en China, Rusia e India y valor ligeramente inferior al de Estados Unidos, Francia o España, pero cinco veces más que el caso noruego o sueco). Sin embargo, Galicia es, junto con España y tras Noruega, una de las sociedades donde menos importancia se da a la sobriedad y el ahorro (23,1\%). En Galicia, pues, a los hijos se les inculca que hay que trabajar (pero no tanto como en China, que es un país en expansión), pero no ahorrar (aspecto en el que nos parecemos a los noruegos, que efectivamente son un país rico). Que todavía se insista en el trabajo pero no tanto en la sobriedad es un indicador de que los gallegos se hallan en pleno proceso de adaptación cultural a unas condiciones materiales que ya no son de escasez.

\subsection{CONCLUSIONES}

A tenor de los datos expuestos en este capítulo, la familia es una institución muy valorada, lo que contradice la opinión, más o menos generalizada, de que está en crisis (Veira, 2007a: 60). En efecto, es una institución considerada muy importante para el 91,9\% de los gallegos (si sumamos también a quienes la consideran bastante importante el porcentaje es del 99\%). Y, sin embargo, se ha constatado el descenso de la natalidad (especialmente acusado en el caso gallego), el descenso en el número de matrimonios así como el descenso en la consideración de que esta institución está pasada de moda (sobre todo entre los jóvenes) y el aumento de las rupturas matrimoniales.

La aparente contradicción entre las tendencias demográficas y la opinión expresada sobre las diversas cuestiones familiares aquí comentadas, por un lado, y la importancia concedida a la familia, por otro, no es tal. Lo que ocurre es que formar una familia no es ya una obligación sino más bien una opción, que a veces puede convertirse en un lujo (Veira, 2007a: 61). Además, y en lo que respecta a la familia de origen, las relaciones paterno filiales caracterizadas por la autoridad han dado paso a otras en las que prima el intercambio y la negociación.

En la base de estos cambios está el tránsito de unos valores en los que dominaban la obediencia, el sacrificio, la autoridad y la disciplina a otro marco cultural donde priman valores orientados a la felicidad y a la realización personal, la libertad y el logro individual, así como a las relaciones igualitarias.

El problema es que cuando una parte importante de la población ha asumido estos valores encuentra, no obstante, dificultades para alcanzar los objetivos que 
de ellos se derivan (que se han convertido en lo deseable para la gente). Estas dificultades radican especialmente en la necesidad de alcanzar ciertos niveles de seguridad, en materia de vivienda o trabajo por ejemplo, como paso previo al de la realización personal, que es el espacio donde se sitúa ahora la familia (y no en el de la obligación moral).

La familia, pues, es muy importante para la gente porque es apreciada, pero sobre todo como un valor terminal, esto es, como una meta a alcanzar. De ahí que se entienda como ideal o deseable que los niños nazcan en familias que cuentan con un padre y una madre. Dicho esto, los valores instrumentales se han reforzado en los últimos tiempos, de manera que las preferencias se imponen a lo ideal o deseable; especialmente en coyunturas en las que lo deseable debe ser pospuesto para su consecución debido a los condicionantes materiales. Esta es la razón que explica que cada vez son más los hijos nacidos fuera del matrimonio.

En lo que se refiere a la socialización de los niños, en Galicia se combina un modelo propio de las sociedades materialistas (que hace hincapié en aspectos como el esfuerzo en el trabajo) con otro caracterizado por valores posmaterialistas (como la tolerancia). Posiblemente el rápido cambio acaecido en materia de incorporación a la sociedad de consumo explique también el poco énfasis que se pone en valores como el ahorro o la sobriedad.

Por otro lado, no cabe duda de que Galicia se halla inmersa en un proceso de individualización, que puede haber ocasionado la cada vez menor consideración del contrato matrimonial. Creemos además que este proceso actúa incidiendo especialmente en pautas características de la sociedad gallega. Si dicho proceso consiste, entre otras cosas, en que el individuo (y no el grupo, la costumbre o la autoridad), sea el centro de la toma de decisiones sobre aquello que concierne a la propia vida, la primera consecuencia en el plano valorativo es el aumento de la importancia del respeto y la tolerancia como simple mecanismo para que la individualización pueda ocurrir sin conflictos. En este sentido, Galicia es una de las sociedades donde se destaca la tolerancia como un valor deseable para inculcárselo a los hijos; además es donde, siempre según la opinión expresada, se practica en mayor grado, si la medimos por ejemplo en la aprobación de que las mujeres puedan ser madres solteras.

Finalmente, podemos concluir que la familia nuclear resiste bastante bien el embate del tiempo. Es una forma de alcanzar la felicidad y el desarrollo personal; para su consecución, pues, sirven tanto instituciones clásicas como el vínculo matrimonial, pero también otras vías menos formales. En cualquier caso, es deseada como meta; y todo aquello que la entorpezca o dificulte perderá legitimidad y, por el contrario, lo que la haga posible crecerá en apoyo. Así se entiende que aumente la aprobación del divorcio (como necesario para que, una vez se ha demostrado rota una relación, se pueda intentar alcanzar la felicidad con otra) y baje la del vínculo matrimonial (en el mismo sentido que antes, si se percibe como algo rígido dificulta un posible cambio en caso de fracasar la relación). 


\subsection{REFERENCIAS BIBLIOGRÁFICAS}

Del Campo, Salustiano y Rodríguez-Brioso, Ma del Mar (2002): "La gran transformación de la familia española durante la segunda mitad del siglo XX" en Reis 100: 103-165.

Ester, P., Halman, L. y De Moor, R. (1994): The individualiziong society, Tilburg, Tilburg University Press.

Gutiérrez Sastre, Marta (2002): "Triangular público, doméstico y privado, o ¿cómo negociar en pareja?" en Reis 99: 61-85.

IGE (2008): Panorama demográfico de Galicia. Año 2006. [Consultado en www.ige.eu/estatico/pdfs/s3/.../panorama_demografico_galicia_2006.pdf el 12/06/2010].

Inglehart, Ronald (1991): El cambio cultural en las sociedades industriales avanzadas. Madrid, CIS.

Inglehart, Ronald (1998): Modernización y postmodernización: El cambio cultural, económico y político en 43 sociedades, Madrid, CIS.

Inglehart, Ronald y Welzel, Christian (2005): Modernization, cultural change, and democracy: the human development sequence. Nueva York, Cambridge University Press.

Innerarity Grau, Daniel (2006): "La nueva urbanidad" en Claves de razón práctica 159: 68-76.

Jurado Guerrero, Teresa (2003): "La vivienda como determinante de la formación familiar en España desde una perspectiva comparada", Reis 103: 113-157.

Míguez González, Santiago (1990): La preparación de la transición a la democracia en España, Zaragoza, Prensas Universitarias.

Pérez Díaz, Julio y MaCinnes, John (2008): "La tercera revolución de la modernidad; la revolución reproductiva" en Reis 122: 89-118.

Simmel, Georg (2005): "La metrópilis y la vida mental" en Bifurcaciones. Revista de estudios culturales urbanos 4. [Consultado en www.bifurcaciones.cl/004/ reserva.htm el 29/06/2010].

Valero, Ángeles (1995): "El sistema familiar español. Recorrido a través del último cuarto de siglo" en Reis 70: 91-105.

Veira Veira, José Luis (2007a): "Valores familiares" en José Luis Veira (Dir.) Las actitudes y los valores sociales en Galicia, Madrid, CIS: 60-86.

Veira Veira, José Luis (2007b): "La sociedad individualizada" en José Luis Veira (Dir.) Las actitudes y los valores sociales en Galicia, Madrid, CIS: 1-29. 


\section{IDENTIDAD NACIONAL, CONCIENCIA ÉTNICA Y MODERNIZACIÓN}

Santiago Míguez González

\subsection{INTRODUCCIÓN}

La identificación con un determinado ámbito territorial es una forma de ser, de tener raíces, de ser alguien. Permite ubicarnos socialmente y, al mismo tiempo, ser ubicados por los demás. La identificación con un grupo territorial actúa como un esquema sobre uno mismo y puede tener consecuencias en los procesos cognitivos y evaluativos que realiza el individuo (Tajfel, 1978: 26-61; Parekh, 2005: 237). El sentimiento de identidad territorial puede llegar a constituir para algunas personas la base fundamental de su identidad, aunque para otras puede ser algo secundario y de poca importancia. Según su intensidad, puede intervenir también en la selección de los estímulos y en el procesamiento de la información procedente del ambiente social así como en la adopción de posiciones ante temas o problemas (issue positions). Además, al facilitar la comunicación y el intercambio entre los miembros del grupo, los sentimientos identitarios son importantes para la estructuración del orden social como un conjunto de grupos e instituciones (Merelman, 1986: 278; Conover, 1984: 760-765).

Casi todo el mundo acepta que lo que permite hablar de pueblos o grupos étnicos exige la concurrencia de dos elementos, uno de carácter objetivo, representado por la existencia de algunos rasgos etno-culturales propios y otro de carácter subjetivo, consistente en el lazo afectivo hacia el grupo y/o la tierra en la que se nació o se vive. Los sentimientos de identidad territorial pueden tener así un fundamento étnico-cultural — por ejemplo, un patrimonio histórico o un idioma propio-que sirven para fijar la textura emocional del grupo y para marcar los límites frente a otros grupos (Fought, 2006). Como es sabido, en el debate ideológico del nacionalismo algunas corrientes basándose en una suerte de determinismo geográfico, tradición o raza, han llegado a afirmar que la nación es un hecho independiente de la voluntad de los pueblos, lo que significa olvidar que los elementos étnicoculturales no constituyen en sí mismos la identidad, pues aunque se consideren elementos sustanciales, solo lo son en tanto sirven para recrear el discurso afirmativo 
de esa identidad ${ }^{1}$. Por otra parte, en las sociedades plurales, las características etnoculturales pueden ser algo demasiado vago para especificarlas y llegar a un acuerdo respecto a ellas, raramente son compartidas por todos y casi siempre pertenecen al ámbito de la vida privada. Además pueden convertirse fácilmente en un instrumento apto para suprimir estilos de vida y formas de conducta considerados poco convenientes (Parekh, 2005: 343).

Según la teoría clásica, el proceso de construcción de la identidad puede incluir dos momentos sucesivos: el primero se corresponde con la formación de la identidad de grupo (group identification) y, el segundo, con la llamada conciencia de grupo (group consciousness), la cual aplicado al tema que nos ocupa se traduce en la identidad nacional. La conciencia de grupo o identidad nacional, supone la existencia previa del sentimiento de identificación, pero incluye la politización de las aspiraciones del grupo y, en este sentido, exige la creación de un discurso interpretativo de la realidad y un programa de actuación (Miller, 1995; Gilbert 1998). El elemento distintivo consiste en la presencia de la dimensión política², de manera que al sentimiento de formar parte de un ente colectivo-territorial, la identidad nacional añade la convicción de que este ente es un sujeto colectivo de derechos políticos, lo que implica el reconocimiento del autogobierno, la soberanía compartida y/o la autodeterminación (Harty y Murphy, 2008: 31).

Las bases de la identidad como fenómeno social y político pueden estar relacionadas en mayor o menor medida con factores étnicos pero en su activación intervienen factores contextuales, de manera que una vez elaborada, ésta puede permanecer en estado de latencia para activarse en determinadas circunstancias, cuando los individuos la perciben como útil para sus intereses particulares. Por tanto, en función del contexto o si se prefiere en función de la estructura de oportunidades, la identidad actúa como una precondición para la acción política (Rogowski, 1974: 71) ${ }^{3}$. Como veremos, en el caso de la identidad territorial gallega este hecho se manifiesta con la experiencia de la emigración.

Hoy asistimos tanto a una competencia entre muchos referentes identitarios así como a una profunda negociación sobre el contenido y el significado de las identidades que nos ofrece un mercado, que en las sociedades occidentales

En este mismo sentido, Fernández de Rota argumenta que "no hay criterios justificativos de estos tipos de identidad colectiva que tengan una validez universal. Ni las costumbres, ni el color de la piel ni la religión ni el territorio ni siquiera el lenguaje. (...) A nivel lingüístico, una identidad nacional tan poderosa hoy día como la suiza, puede saltar por encima de la pluralidad, mientras que en cambio pueden crearse barreras nacionales fragmentando una homogeneidad lingüística, en el no menos potente caso de las nacionalidades hispanoamericanas" (Fernández de Rota, 1991: 205-206). En un sentido similar: Máiz Suárez (1997) y Gondar Portasany (2005).

2 Los componentes de la conciencia de grupo son: (a) la identificación de grupo; (b) la aceptación y preferencia por los miembros del grupo (polar affect); (c) la expresión de actitudes de defensa del grupo, ya sea de satisfacción o discriminación respecto a la situación en que se encuentra comparativamente el grupo (polar power); (d) la atribución de responsabilidad de la situación al "sistema" o a determinados grupos o individuos) (individual vs. system blame). Miller, A. H. et al. (1981).

3 Por otra parte, un exceso de identificación grupal puede generar despersonalización, exacerbación etnocéntrica y fanatismo político. Es sabido que quien llega a asimilar in toto su propia identidad personal con la de un determinado grupo, puede acabar anulando muchas otras opciones de interacción social. 
avanzadas tiene un carácter abierto. En este sentido, las identidades, como estructuras cognitivas y afectivas, no deberían entenderse ni como inmutables ni como incompatibles entre sí.

Este capítulo está dedicado a analizar los principales referentes de la identidad territorial y nacional de los gallegos a lo largo del período 1984-2009. Como podrá comprobarse a lo largo de sus páginas se recogen observaciones procedentes de varias ciencias sociales (Psicología Social, Antropología y Sociología) además de la Ciencia Política, con el fin de proporcionar la visión multidisciplinar que impone la complejidad de este tema.

\subsection{LAS BASES DE LA IDENTIDAD: LOCALISMO, RURALIDAD Y DISPERSIÓN POBLACIONAL}

Uno de los rasgos tradicionalmente más señalados de la identidad de los gallegos es el de la presencia de lealtades hacia entidades territoriales muy reducidas y cerradas como la parroquia o la aldea, de tal manera que las señas identitarias de la gran mayoría de los gallegos tradicionalmente no superaban los límites de la comarca a la que pertenecían. El sentimiento de identificación con referentes de naturaleza supra-local, como la región o el estado, solo se hacía efectivo y se manifestaba cuando se salía fuera y se mantenían relaciones con otros pueblos. Esto tenía lugar básicamente por dos motivos, el primero, cuando se iba al ejército y, el segundo, cuando se emigraba por razones económicas.

Este localismo estaba estrechamente relacionado con la geografía humana de la región y ello al menos por tres motivos: (a) el predominio del mundo rural, (b) la extremada dispersión de la población, y (c) la ausencia de una gran ciudad que, como capital de la región, actuase como elemento vertebrador de la misma.

Hasta los años ochenta del siglo XX, el dominio del mundo rural en Galicia era absoluto desde casi todos los puntos de vista. La población ocupada en el sector primario superaba a la del secundario y terciario. En este aspecto Galicia no era muy diferente a otros territorios, pero los patrones específicos de este rasgo sí eran bien distintos. Así, frente a otras regiones del sur de Europa (España incluida) y especialmente frente a las regiones mediterráneas, los principales contrastes eran los siguientes: (a) pequeña explotación y pequeña propiedad frente al sistema latifundista; (b) trabajo familiar frente al asalariado; (c) dominio del policultivo y la ganadería, frente al monocultivo especializado; (d) emigración como solución a un incremento demográfico sin empleo "próximo" en lugar del crecimiento urbano.

Por otra parte, muchas de las transformaciones del mundo rural europeo no se generalizaron en Galicia hasta muy tardíamente, por lo que otra de las señas de identidad de Galicia deriva precisamente del retraso modernizador. Sin embargo, hay que destacar que ya desde finales del siglo XIX, frente a la inacción estatal y a la explotación por parte de una clase de rentistas herederos de la hidalguía forista, el campesinado gallego supo hacerse con el control de la propiedad de 
la tierra y más tarde, a través de la innovación técnica, poner en marcha un proceso de mercantilización de la economía que finalmente ha dado lugar a una creciente capacidad de comercialización de productos de alta calidad. En todo caso, a pesar de las transformaciones más recientes de este sector de la economía gallega, el largo predominio histórico de la ruralidad tradicional (resumida en "vaca, hórreo, cruceiro y gaita") seguirá siendo por mucho tiempo un símbolo del país (Villares, 1982 y 2001; Fernández Prieto et al., 1996).

La geografía humana de Galicia se caracteriza todavía por una fuerte dispersión poblacional lo que unido al hecho de no disponer de una adecuada red de comunicaciones, hacía de esta región un mundo de pequeños lugares (Máiz, 1996: 38). De hecho, a pesar del proceso de despoblamiento de la gran mayoría de las comarcas rurales, según datos del Instituto Gallego de Estadística, en los 315 ayuntamientos de la región todavía existen algo más de treinta mil entidades singulares de población, de las que el 89,4\% (26.929) cuenta con menos de cien habitantes ${ }^{4}$. No obstante, no debemos dejar de señalar que actualmente y tras varias décadas de intensas transformaciones, lo más significativo ha sido el paso a una situación en la que, a grandes rasgos, cabe distinguir entre una Galicia interior, esencialmente rural y muy poco habitada, y una Galicia costera, mucho más urbanizada y muy densamente poblada. Así, la Galicia interior, tras haber sufrido un proceso de despoblamiento generalizado, que en muchos partidos judiciales ha sido una verdadera catástrofe demográfica ${ }^{5}$, comprende el $70 \%$ del territorio pero solo aporta un $28 \%$ de la población. Por el contrario, la llamada Galicia costera que, en consecuencia, representa un 30\% del territorio y concentra al $72 \%$ de la población restante (casi dos millones de personas), conforma una de las zonas más densamente pobladas de Europa (De Juana y Vázquez, 2005: $421-243)^{6}$.

\subsection{EL FENÓMENO DE LA EMIGRACIÓN}

Como señalamos, las razones que explican la construcción y el desarrollo de la identidad están relacionadas con factores contextuales. En el caso de la identidad territorial gallega, un ejemplo de este hecho fue la experiencia de la emigración.

4 Vid. Galicia en cifras 2008, IGE, 2009, pág.23. Se entiende por entidad singular de población, cualquier área habitada del término municipal —o excepcionalmente deshabitada_, claramente diferenciada por el hecho de que sus edificaciones pueden ser perfectamente identificadas sobre el terreno y conocida por una denominación específica.

5 Como los de Becerreá, A Fonsagrada, Quiroga, Trives, Bande, Celanova, Allariz, Rivadavia, O Bolo, Chantada, Monforte, Sarria y Xinzo. Conviene recordar que hasta mediados del siglo XIX Galicia era una de las regiones españolas más densamente pobladas. Así, por ejemplo, en 1860 mientras la densidad media en España era de 31,05 habitantes por kilómetro cuadrado, en Galicia llegaba hasta los 60,9.

6 En realidad con las excepciones de los enclaves urbanos de Lugo y Ourense, por el peso de su capitalidad provincial, y de la comarca de A Coruña, por su dinamismo económico, el crecimiento poblacional de Galicia se circunscribe a la imaginaria línea costera que partiendo de Santiago-Negreira llega hasta la desembocadura del río Miño, en La Guardia. "Dicho de otra manera, la gran dorsal montañosa que se alarga desde Bandeira hasta Arbo-As Neves dividiría la zona de más crecimiento y vitalidad de Galicia de aquella otra que va perdiendo población paulatinamente o se mantiene con esfuerzo, como Ferrol o Viveiro". (De Juana, J. y Alejandro Vázquez, 2005: 421). 
Conviene recordar que el fenómeno migratorio en Galicia entre 1826 (primer año del que se tienen datos fiables) y 1975, desequilibró las pautas demográficas tradicionales de tal manera que el conjunto de las migraciones extraterritoriales habrían producido una pérdida neta de algo más de 1,3 millones de habitantes, lo que unido a la cifra que representarían sus descendientes, suponen casi cinco millones de personas.

La emigración forjó una sociedad demográficamente feminizada y prematuramente envejecida y, a su vez, activó cambios psicológicos y afectó a las costumbres sociales. Esto dio lugar a la creación de todo un imaginario social cargado de desesperanza sobre las condiciones económico-sociales, las soledades personales y las separaciones, así como de referentes sobre el éxito de indianos y otros retornados (De Juana y Vázquez, 2005: 437-438). Ligando su futuro a la expatriación y al verse fuera de su entorno, los emigrantes activaron unas señas de identidad territorial superadoras del localismo — que manifestaban cuando estaban en Galicia- al constatar que compartían unos rasgos comunes y sobre todo un mismo idioma. En este sentido, el proceso migratorio fue clave para la configuración de la identidad del pueblo gallego. Así, lejos de las limitaciones que en Galicia imponía la presencia de unas fuerzas sociales arcaizantes (como una Iglesia muy castellanizada), un sistema político caciquil y largos períodos de falta de libertades, los emigrantes gallegos elaboraron un discurso en el que a la defensa del progreso social y económico de su región unieron reivindicaciones abiertamente nacionalistas. Ello explica que la propia Academia Galega se constituyese con fondos de la comunidad gallega en Cuba en 1905, o que el himno de Galicia, cuya letra corresponde a un poema de Eduardo Pondal, de su obra Queixumes dos Pinos (1886), se estrenase el 20 de diciembre de 1907 en el Gran Teatro de La Habana. No obstante, la identidad que se acabaría desarrollando en la emigración lo haría con unos caracteres muy simbólicos y con matices universalistas, al representar a Galicia como un referente básicamente cultural y afectivo, por encima de la nacionalidad (que mantendrán como españoles y que compartirán en muchos casos como mexicanos, argentinos, etc. $)^{7}$.

\subsection{EL IDIOMA}

Las relaciones entre lengua e identidad han recibido atención desde muchas perspectivas. Desde la teoría de la identidad se afirma que el uso de un idioma propio adquirido a lo largo del proceso de socialización, es un factor fundamental para la consolidación de la identidad. Por ello, los hechos diferenciales lingüísticos aun suscitan una acentuada emotividad tanto desde la postura reivindicativa

En desarrollo del artículo 7 del Estatuto de Galicia, el reconocimiento oficial de la importancia de las comunidades gallegas en el exterior y de su aportación al progreso socioeconómico e identitario de Galicia se materializó con la ley 4/1983 de 15 de junio del Parlamento de Galicia, que lleva el título "de reconocimiento de la galleguidad". A su vez, en desarrollo de esta ley se han dictado otras normas, como la ley de Turismo de Galicia, que en su artículo 9 prevé la firma de acuerdos con las comunidades gallegas en el exterior por considerarlas "un vehículo preferente de promoción turística fuera de nuestras fronteras" (Ley 14/2008 de 3, de diciembre de turismo de Galicia. BOE no 64 de 16/03/2009; Diario Oficial de Galicia nº 246 de 19/12/2008). 
de respeto a las diferencias y afirmación identitaria así como desde la postura negadora de ese respeto (Vilas Nogueira, 1975: 66; Ninyoles, 1972).

En Galicia, al contrario que en el País Vasco o Cataluña, el idioma y la etnicidad en general han tenido funciones contradictorias. A partir de los siglos XVII y XVIII, el idioma gallego, tan ensalzado por Alfonso X y convertido en lengua culta durante más de doscientos años, primero en la corte de León y luego en la de Toledo, pasó a ser un marcador social negativo a causa de la fuerte castellanización que habían experimentado la Iglesia y las clases superiores. A pesar de su uso masivo por la población campesina y la defensa que en algunas ocasiones hicieron de ella algunos ilustrados, como Feijoo y Sarmiento, las actitudes negativas se generalizaron y el gallego dejó de considerarse oficialmente un idioma, para ser calificado como una variedad dialectal sin prestigio del castellano.

Hasta bien entrado el siglo XIX no se producirá un resurgimiento del gallego como idioma culto y una abierta defensa de su normalización que, como idioma del pueblo, le alejase del estado de fluidez dialectal expuesto a toda clase de contestaciones $^{8}$. En el siglo XX el nacionalismo gallego surge expresamente determinado por la afirmación de la diferenciación idiomática. Así su primera manifestación asociativa fue la constitución de la Irmandade dos amigos da fala, que tuvo lugar en A Coruña el 18 de junio de 1916 y a la que siguió la constitución de entidades idénticas en otras ciudades y villas. Su órgano de expresión, A Nosa Terra, sería más tarde el portavoz del Partido Galeguista. La primera asamblea nacionalista fue promovida por estas organizaciones en Lugo en 1918. Cuando se proclamó la II República, la obtención de un estatuto jurídico que respetase los idiomas regionales fue una de las razones más invocadas del deseo de autonomía y el Estatuto de Autonomía de Galicia, aprobado en junio de 1936, dio al gallego el rango de idioma cooficial con el castellano (Vilas Nogueira, 1975: 83).

Con la dictadura franquista, se volvió a la castellanización y a la represión del gallego, aunque en este punto no se llegó al nivel de Cataluña o el País Vasco. Lo cierto es que mientras se impedía o se ridiculizaba la publicación de obras en gallego, ésta siguió siendo la lengua hablada por la mayoría, dando lugar a una situación de diglosia (más que de bilingüismo) ya que el uso de uno u otro idioma (gallego o castellano) no venía dado por la libre elección (lo que sería bilingüismo) sino impuesto por normas sociales y/o el contexto. En suma, una escisión

8 Mucho antes de que publicasen sus principales obras los grandes escritores gallegos como Rosalía de Castro, Curros Enríquez o Eduardo Pondal, comenzaron a circular a comienzos del siglo XIX, al calor del proceso de alfabetización de las masas populares, infinidad de manuscritos en gallego y memorias personales de gente humilde. "Estos textos, la mayoría humorísticos y chocarreros, les parecían a los primeros exegetas del galleguismo poco serios al no estar impresos ni bien escritos, pero a nosotros nos revelan hasta qué punto los gallegos tenían su idioma, literalmente en la punta de la lengua. Esta literatura popular, que prosiguió a lo largo del siglo $X X$, a menudo en forma de carteles de ciego, coplillas y chistes, fue la que consumieron los hablantes rurales del gallego". (Murado, 2008: 183). 
o superposición lingüística entre una lengua culta, con prestigio y asociada al poder y otra inculta, propia de las clases más menesterosas.

Tras la instauración del sistema democrático y la aprobación de la Constitución de 1978 y del Estatuto de Autonomía de Galicia en 1981, la preocupación por la salud del idioma gallego ha pasado a ser también una competencia de la administración. Así, el Estatuto de Autonomía, establece que la lengua propia de Galicia es el gallego. En síntesis, éste afirma, por una parte, que el gallego y el castellano son idiomas oficiales que todos tienen el derecho de conocer y usar. Por otra parte, se declara que los poderes públicos potenciarán el uso del gallego en todos los órdenes de la vida pública, cultural e informativa y dispondrán de los medios para facilitar su conocimiento. Hoy, como resultado del proceso de normalización, el gallego está en todos los ámbitos de la vida pública e institucional, hasta el punto de que el día en que Galicia se celebra a sí misma no es tanto el día de Galicia (el 25 de julio) como el día das Letras Galegas (el 17 de mayo), que conmemora la publicación en 1863 del primer poemario de Rosalía de Castro en gallego, (Cantares Gallegos) en la Habana, una obra que se considera el punto de partida del "Rexurdimento" o renacimiento cultural de Galicia.

Para conocer la evolución reciente de las competencias lingüísticas en gallego disponemos de la información que proporciona el Instituto Gallego de Estadística. Tomando como referencia datos de 1991 y 2003, cabe señalar, en primer lugar, que la inmensa mayoría de los gallegos afirman entender y saber hablar el gallego (mucho o bastante). En cuanto a lo primero (entender), los porcentajes rondan el 96\% y, en cuanto a lo segundo (saber hablar), lo hacen en torno al 88-90\%. En segundo lugar, por lo que se refiere a las competencias lingüísticas relativas a saber leer y escribir en gallego, éstas son inferiores y especialmente en lo relativo a escribir en gallego. No obstante, la evolución entre 1991 y 2003 ha sido muy positiva en ambos casos. De esta forma, mientras en 1991 quienes afirmaban saber leer en gallego (mucho o bastante) representaban a algo menos de la mitad de la población (49,3), en 2003 este porcentaje se incrementó en casi cuarenta puntos porcentuales, llegando hasta el 85,7\%. Y aunque en menor grado, lo mismo ocurre con la competencia relativa a saber escribir en gallego, que pasó del 34,8 en 1991 al 52,8 de $2003^{9}$ (Gráfico 5.1).

En cuanto al uso cotidiano del idioma, las tres series de la EMV-Galicia incluyeron una pregunta sobre el idioma que habla en casa con tres opciones categóricas (gallego, español y otra). Los resultados muestran que entre 1995 y 2008, y para el total de la muestra entrevistada, el uso doméstico del gallego habría descendido en siete puntos porcentuales frente al español (del 52,3 en 1995 al 45,2 en 2008) (Gráfico 5.2).

Instituto Galego de Estadística, Censo de Población y viviendas, 1991; Encuesta sobre las condiciones de vida de las familias, 2003. 

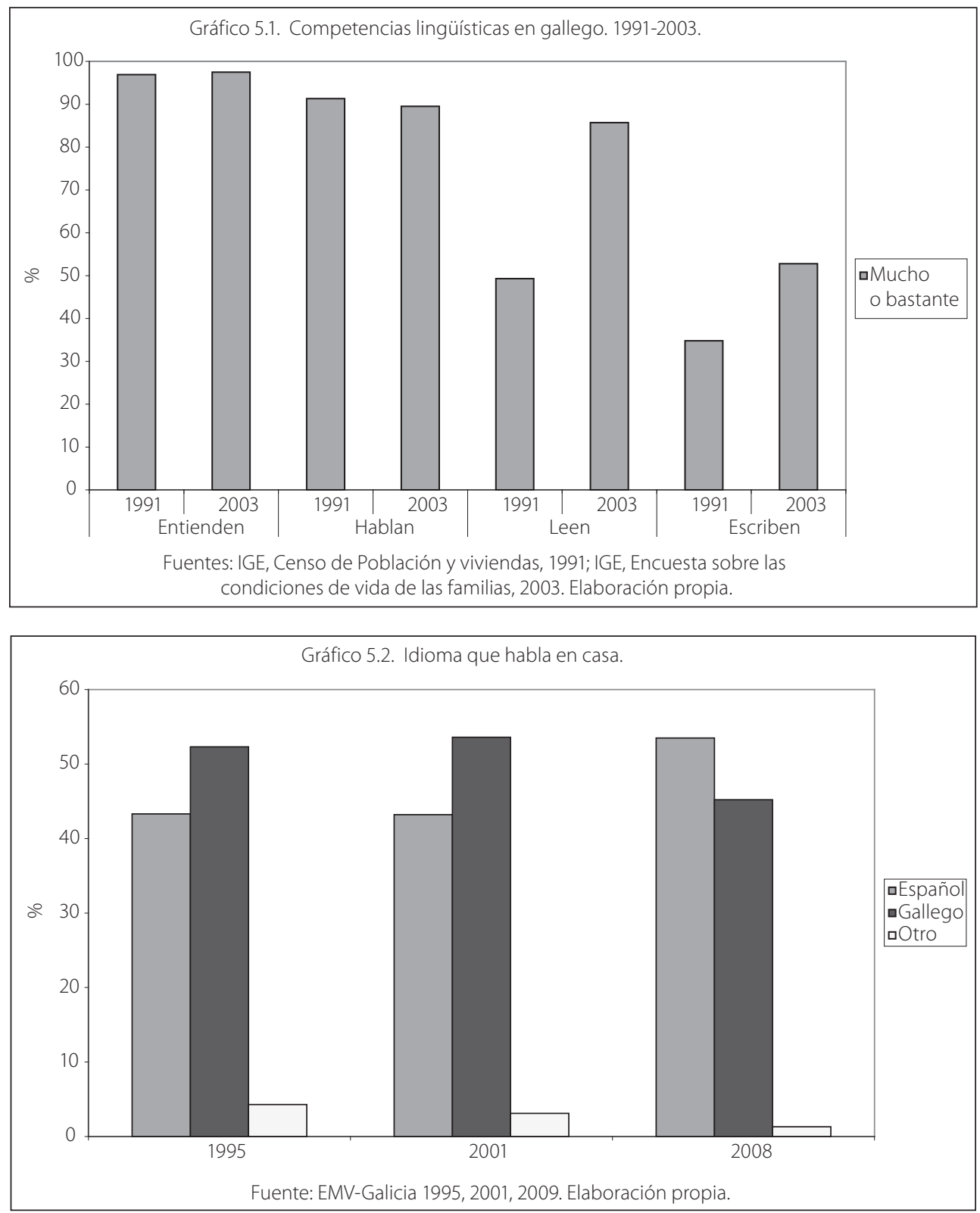

Por otra parte, el análisis sociodemográfico muestra que las variables relativas a la edad y al tipo de hábitat tienen un alto grado de asociación con la relativa al idioma que se habla habitualmente. Así, en la serie de 2008 se puede apreciar que el gallego es la lengua habitual solo entre los nacidos antes de 1950, llegando al 65\% entre los nacidos antes de 1930. Entre las generaciones más jóvenes, el idioma que habla en casa es mayoritariamente el castellano. Esto es así sobre todo para las generaciones nacidas en las décadas de los 
sesenta y setenta (37,7 y 33,1 gallego) porque para los nacidos después de 1980 - cuando el gallego se acababa de convertir en lengua oficial y su enseñanza se convertía por primera vez en obligatoria - el porcentaje de gallego-hablantes se incrementa notablemente (41,7) (Gráfico 5.3).

El análisis de la relación entre el uso cotidiano del gallego y la variable hábitat, se puede resumir señalando que el gallego es mayoritario solamente en los municipios inferiores a los diez mil habitantes. Comparte un porcentaje similar con el castellano en los de diez mil a cincuenta mil habitantes, pero cae hasta un tímido $25 \%$ en los que cuentan con más de 50.000 habitantes, y apenas representa el 20\% en los de más de 200.000 (Gráfico 5.4).

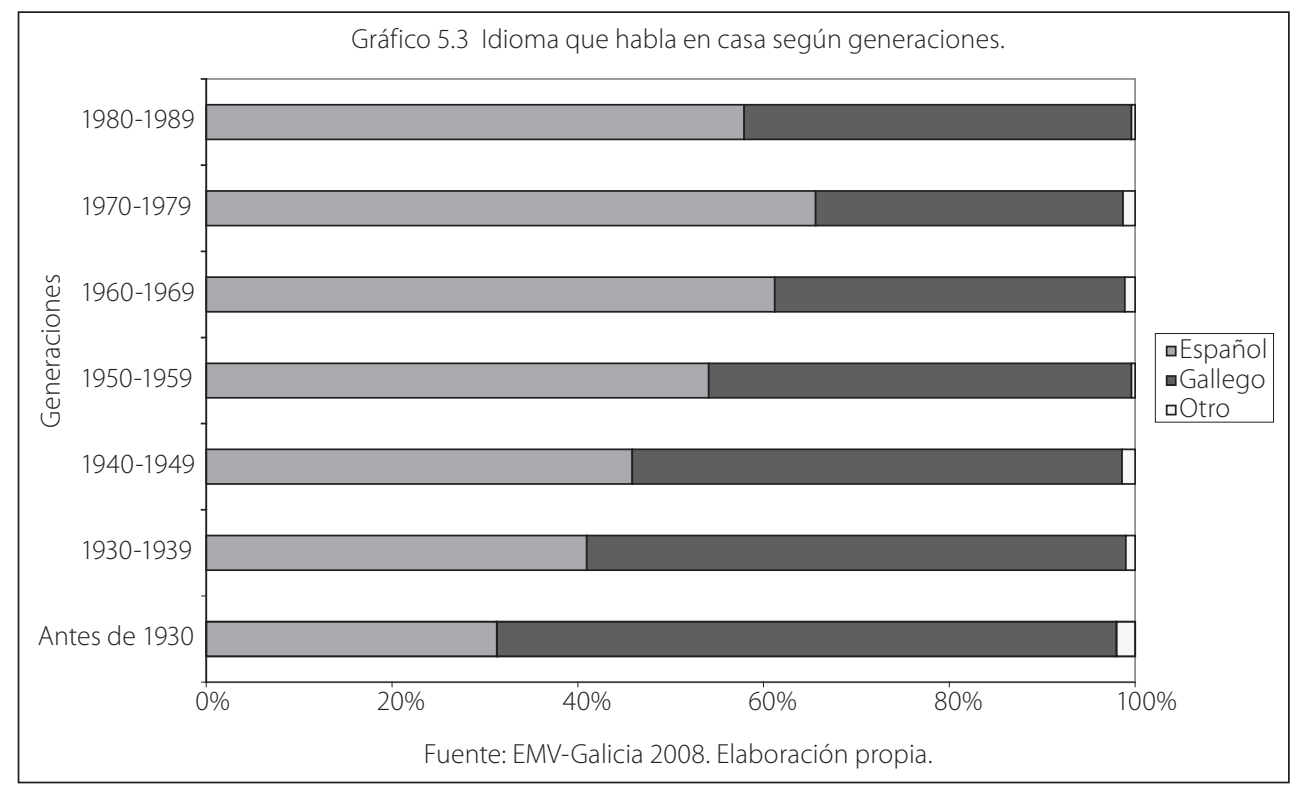

Para completar esta descripción de la situación, los datos que proporciona el Consello da Cultura Galega, relativos al idioma que se habla con más frecuencia, muestran que las zonas en las que se habla menos gallego son las comarcas de las ciudades atlánticas de Vigo, A Coruña y Ferrol, donde el castellano es la lengua principal. En todas las demás, el gallego es la lengua predominante. En éstas la situación se resume, a su vez, en tres grupos de comarcas: (a) las comarcas urbanas de Pontevedra, Santiago, Lugo y Ourense, en las que el uso del gallego es ligeramente superior al castellano; (b) las comarcas de A Coruña Oriental, las del sur de Lugo y todas las de la provincia de Ourense, exceptuando la capital, en las que su uso es muy elevado; (c) por último, el uso del gallego se acerca al monolingüismo en las áreas que comprenden el interior de la provincia de Pontevedra, el norte de Lugo y la costa no urbana de la provincia de A Coruña ${ }^{10}$.

10 Un resumen de esta problemática puede consultarse en la página web del Consello da Cultura Galega (www. consellodacultura.org). 


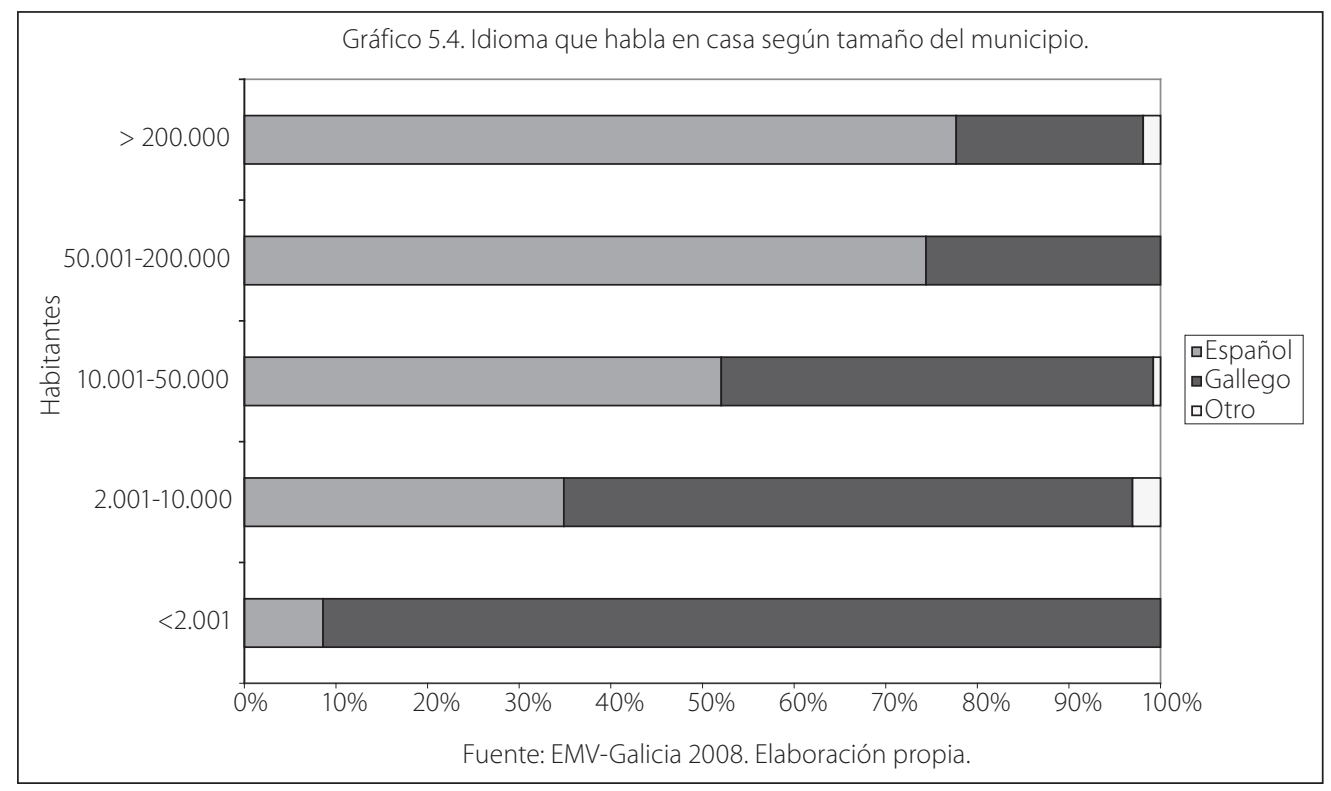

Es indudable la importancia que ha tenido la oficialización y posterior normalización de la lengua gallega para su desarrollo y sobre todo para evitar el retroceso que venía sufriendo desde los años sesenta como lengua hablada. La situación actual muestra, en todo caso, factores ambivalentes. De una parte, hemos visto que las competencias lingüísticas, especialmente las de leer y escribir en gallego, se incrementaron notablemente a partir de los años noventa pero, en sentido opuesto, cada vez se habla menos gallego que castellano.

En todo caso, cabe preguntarse si siguen existiendo prejuicios o actitudes negativas hacia el gallego o, lo que es casi lo mismo, hacia los gallegohablantes. Sobre las actitudes sociolingüísticas se han realizado estudios de carácter cualitativo en los que todavía a comienzos del siglo XXI se constata la persistencia de algunos prejuicios que tradicionalmente habían asociado a los gallego-parlantes con una procedencia rural, la incultura y/o el atraso socioeconómico. También el uso del gallego en el ámbito laboral se asociaba con profesiones de bajo prestigio. Por otro lado, el gallego normativo se consideraba propio de las esferas elitistas de la docencia y la administración, y era calificado de artificial, de aprendido, de libro, o exclusivo de la politica. Finalmente, también se ha constatado que han surgido nuevos prejuicios que asocian el uso del gallego con la adscripción a opciones políticas nacionalistas $=$ conflictivas $^{11}$.

Para determinar la relación de asociación entre el sentimiento identitario y el uso habitual del idioma gallego y tomando como referencia los datos de la

11 Véase por ejemplo, Suárez Fernández, I. et al. (2002): "Aproximación cualitativa ás actitudes lingüísticas dos mozos galegos. Resultados dunha investigación baseada en grupos de discusión", Seminario de Sociolingüística de la RAG, Actas del II Simposio Internacional de bilingüismo. 
EMV-Galicia, se cruzaron las variables relativas al idioma que habla en casa y al sentimiento de identidad nacional, (que incluye las opciones solo gallego, más gallego que español, tan gallego como español, más español que gallego y solo español). El resultado del análisis de correlación entre ambas variables muestra un valor relativamente importante, con un coeficiente de contingencia de 0,235 y un alto nivel de significación estadística $(0,00)$. En el Gráfico 5.5, puede observarse, que los porcentajes de gallego-hablantes se reducen progresivamente conforme disminuye la identificación gallega en beneficio de la española. Así, por una parte, entre los que se sienten solo gallegos o más gallegos que españoles, el idioma habitual es mayoritariamente el gallego, con porcentajes del 86,8 y 67,1 respectivamente. Por otra parte, entre los que mantienen una identidad dual como tan gallegos como españoles, los porcentajes se reparten por mitades entre los hablantes en castellano y en gallego $(49,8$ y 50,2). Finalmente, entre los más españoles que gallegos y los solo españoles el uso del castellano es mayoritario, sin que existan diferencias entre ambos tipos de identidad $(60,5$ y 60,9$)$.

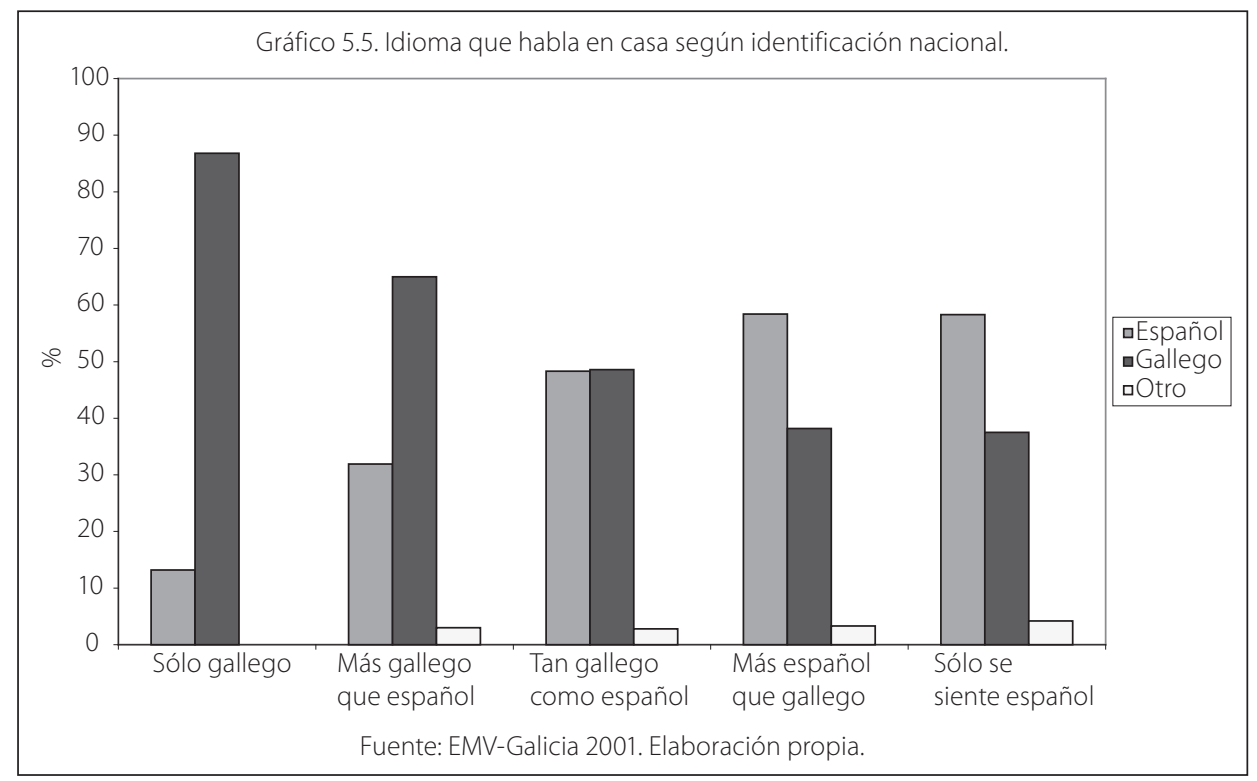

\subsection{LA CONCIENCIA DE LA DIFERENCIA Y EL ORGULLO DE SER GALLEGO}

En una encuesta realizada en 1976 en España en la que se planteaba a los entrevistados "si estando usted en el extranjero le preguntaran de dónde es iqué diría?", los resultados mostraron que el 53\% de la submuestra gallega optaba por la opción "de Galicia", superando en ello a todas las demás, incluidas las del País Vasco (47\%) y Cataluña (23\%) ${ }^{12}$. Desde entonces, todos los estudios

\footnotetext{
12 Fuente: Jiménez Blanco et al., 1977: 47, citado en Montero J. R. y Mariano Torcal, 1990: 41.
} 
de opinión que como el anterior han incluido indicadores de la identidad territorial, han venido mostrando, por una parte, que los gallegos muestran una inequívoca y mayoritaria identidad territorial y, por otra parte, una afirmación de esa misma identidad a través de la manifestación del orgullo de ser gallegos. En este sentido, los datos de las tres series de la EMV-Galicia muestran que existe una práctica unanimidad cuando se trata esta cuestión, de manera que los porcentajes correspondientes a quienes se sienten muy orgullosos oscilan entre el 75,8 de 1995 y el 80,5 de 2008, los cuales sumados a los correspondientes a quienes se consideran bastante orgullosos, hacen que las cifras ronden el 95-98\% (Gráfico 5.6).

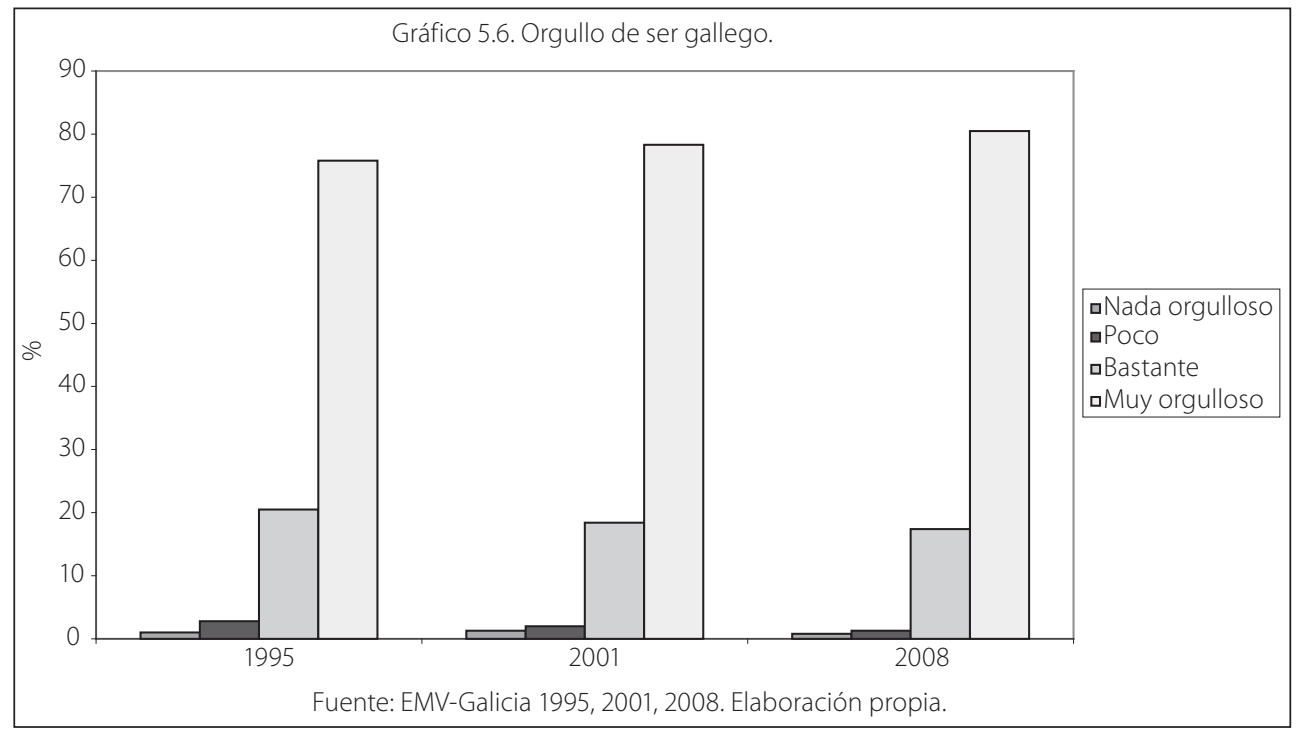

\subsection{LA IDENTIDAD LOCALISTA EN LA EMV}

En las series de la EMV-Galicia también se puede observar la fuerte presencia de la identidad localista, tal como anunciamos al comienzo de este capítulo. Concretamente en las de 1995 y 2001 la pregunta que se formuló a este respecto pedía a los entrevistados que señalaran por orden de preferencia los dos grupos geográficos a los que consideraban que pertenecían, pudiendo elegir entre las siguientes opciones: (1) la comunidad local, (2) Galicia (3) España, (4) la Unión Europea, y (5) el mundo. Es importante destacar que en estas dos series las opciones se presentaban como excluyentes, mientras que en la última (2008), aunque la pregunta tenía una formulación similar, las opciones eran no-excluyentes con el fin de que los entrevistados manifestaran su grado de acuerdo con cada una de las diferentes opciones identitarias.

Pues bien, por una parte, como primera opción, la localidad en la que vive fue también la más señalada en 1995 (43\%) y en 2001 se incrementó, llegando 
hasta el 57\% del total. Como segunda opción, los porcentajes correspondientes a Galicia pasaron del 28\% al 19,5 entre 1995 y 2001, y los de España lo hicieron del 19,0 al 14,8. (Gráfico 5.7). Por otra parte, en cuanto a la segunda opción identitaria, la mayoría de los entrevistados señaló la correspondiente a Galicia (1995: 50,1; 2001: 57,4), seguida por la opción de España (1995: 25,5; 2001: 22,9). Los otros referentes (Europa y el mundo,) ya como primera o segunda opción, apenas reunieron porcentajes en torno al 3-7\% (Gráfico 5.8).
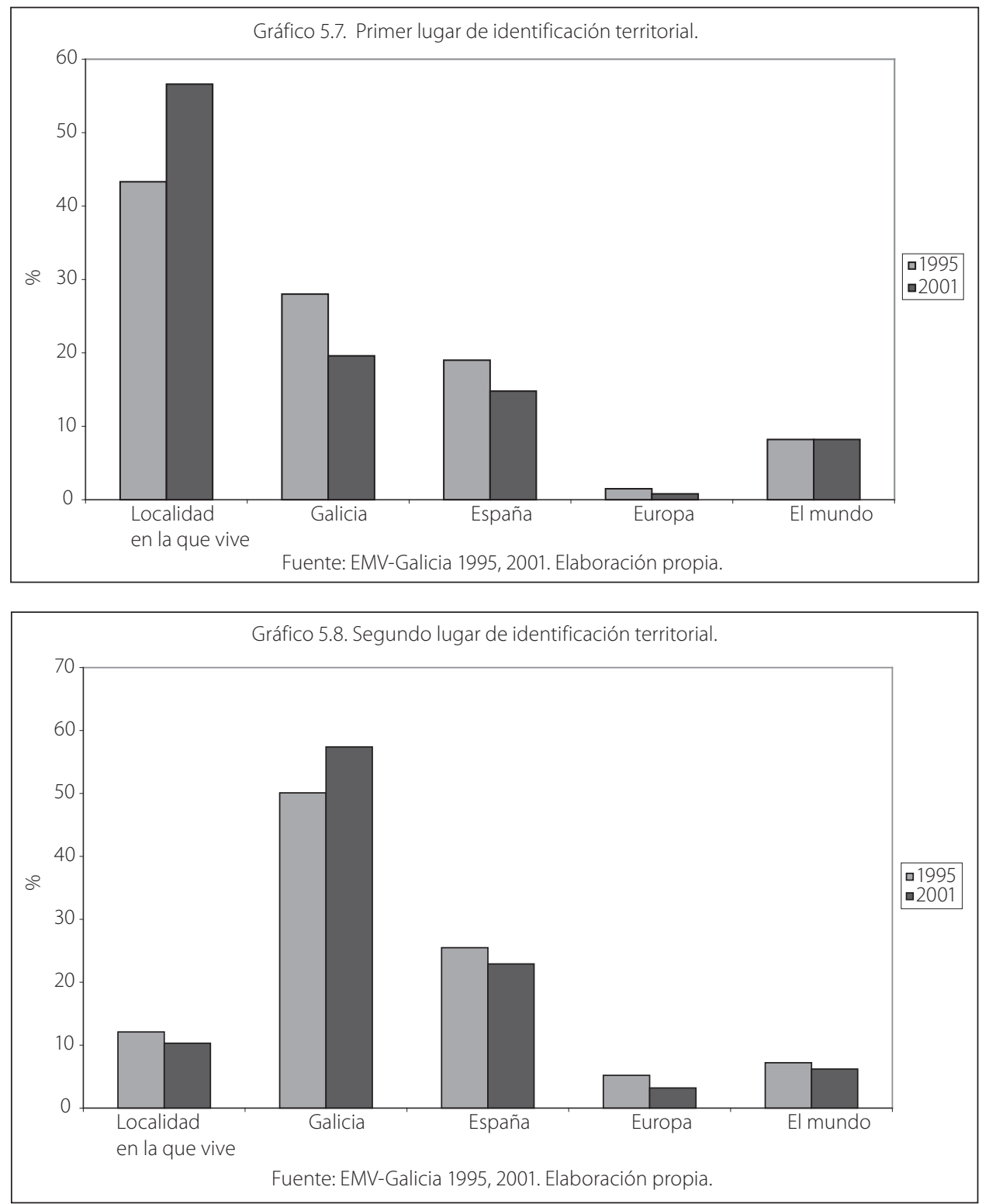
El análisis pormenorizado según factores sociodemográficos muestra que en esta cuestión las diferencias más destacables entre los entrevistados corresponden a la variable del tamaño del municipio, confirmando lo que se dijo anteriormente sobre la relación existente entre el tipo de hábitat y la naturaleza de la identidad territorial. Como puede observarse en el Gráfico 5.9, los porcentajes correspondientes a la localidad en la que se vive se incrementan notablemente entre los entrevistados que residen en los ayuntamientos menos poblados, llegando a superar el $80 \%$ en los que cuentan con menos de dos mil habitantes, mientras que los sentimientos de identificación con Galicia así como con España aumentan conforme lo hace el tamaño poblacional.

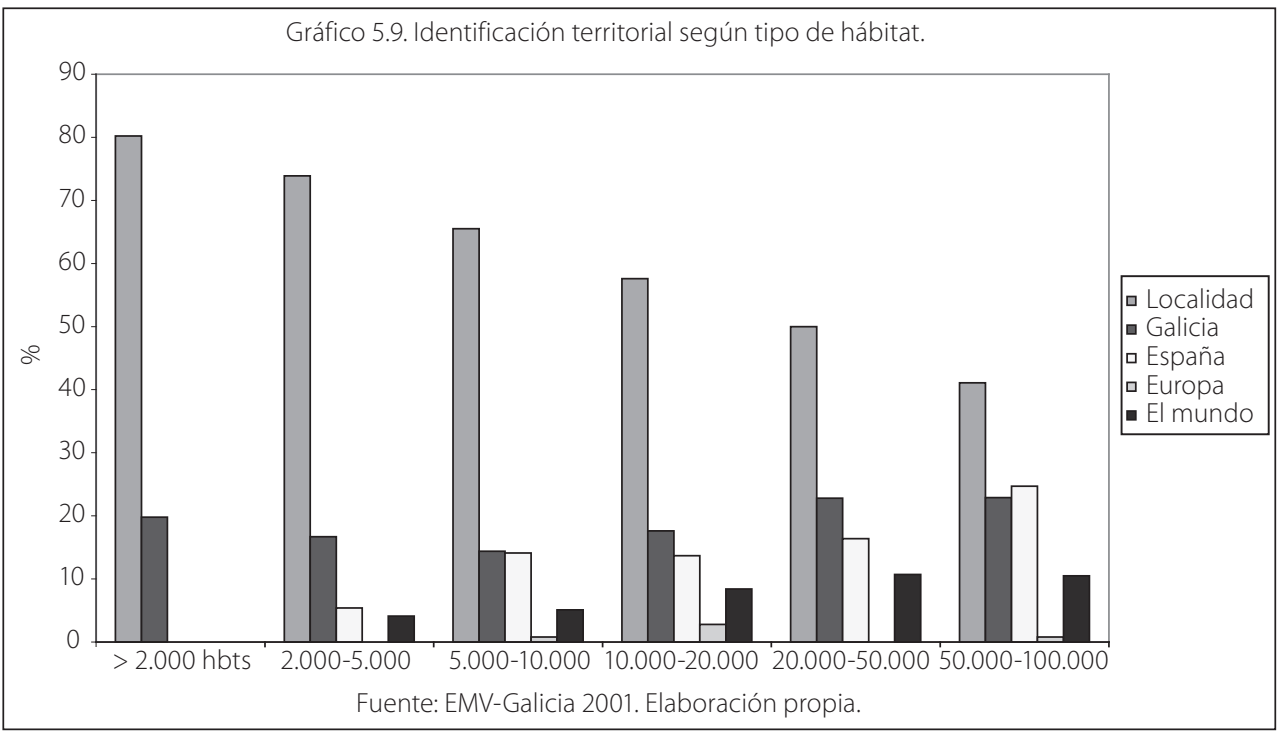

\subsection{IDENTIDADES MÚLTIPLES, CAMBIANTES Y NO EXCLUYENTES}

Como señalamos, en la última serie de la EMV-Galicia (2008) las diferentes opciones identitarias fueron presentadas como no excluyentes para tratar de determinar el grado de acuerdo con cada una de ellas. Los resultados muestran que existe una conciencia identitaria múltiple, una aceptación de los diferentes referentes hasta el punto de que para la mayoría de los gallegos no existe incompatibilidad entre sentirse miembro de la comunidad local, español o europeo o incluso ciudadano del mundo y, a la vez, individuo autónomo.

En cuanto a la comunidad local, prácticamente casi todos los entrevistados mostraron algún grado de acuerdo (Gráfico 5.10). El enunciado de esta opción podría no estar libre de algún equívoco ya que en el marco de esta pregunta, por comunidad local podría entenderse el ámbito estrictamente local (parroquia, pueblo o ciudad) o el ámbito regional supra-local (Galicia). En cualquier caso, el análisis comparado con varios países europeos permite observar que Galicia y España 
muestran los índices más elevados en este tipo de identidad (Gráfico 5.11) y aunque las muestras gallega y española presentan cifras similares, existe una clara diferencia entre ambas cuando observamos los resultados relativos a quienes se muestran muy de acuerdo con la opción localista (Galicia, 44,2; España, 38,7) (Tabla 5.1).

En cuanto a la identidad con el estado-nación (España), el porcentaje de entrevistados que muestra algún grado de acuerdo es también muy elevado $(92,6)$. En este caso, la proporción es algo menor que el de la muestra española $(96,1)$ y lo mismo hay que decir respecto a quienes manifiestan estar muy de acuerdo con la identidad española (44,2 en Galicia; 50,0 en España).

Por lo que se refiere a la opción de la Unión Europea, la gran mayoría de los gallegos manifiesta también algún grado de acuerdo $(90,2)$, superando, por una parte, en algo más de cinco puntos porcentuales a la muestra española $(85,2)$ $\mathrm{y}$, por otra parte, situándose a la cabeza de las demás submuestras nacionales incluidas en el Gráfico 5.11. En este punto hay que destacar que quienes afirman sentirse muy de acuerdo $(32,6)$ representan casi el doble de los correspondientes a España. Algo similar ocurre con los porcentajes de la opción más universalista (ciudadano del mundo), ya que el porcentaje de entrevistados que muestran algún grado de acuerdo es prácticamente igual al correspondiente a la identidad europea $(91,3)$. Esto supone, por una parte, nada menos que once puntos porcentuales por encima de la media española $(79,1)$ y, por otra parte, que Galicia supere también por este concepto a los demás países europeos incluidos en el Gráfico 5.11. En cuanto a la última opción, (individuo autónomo) Galicia muestra también una cifra muy alta $(85,1)$, seis puntos por encima de España $(79,1)$ y en relación con los otros países solo es superada por Suecia $(94,9)$.

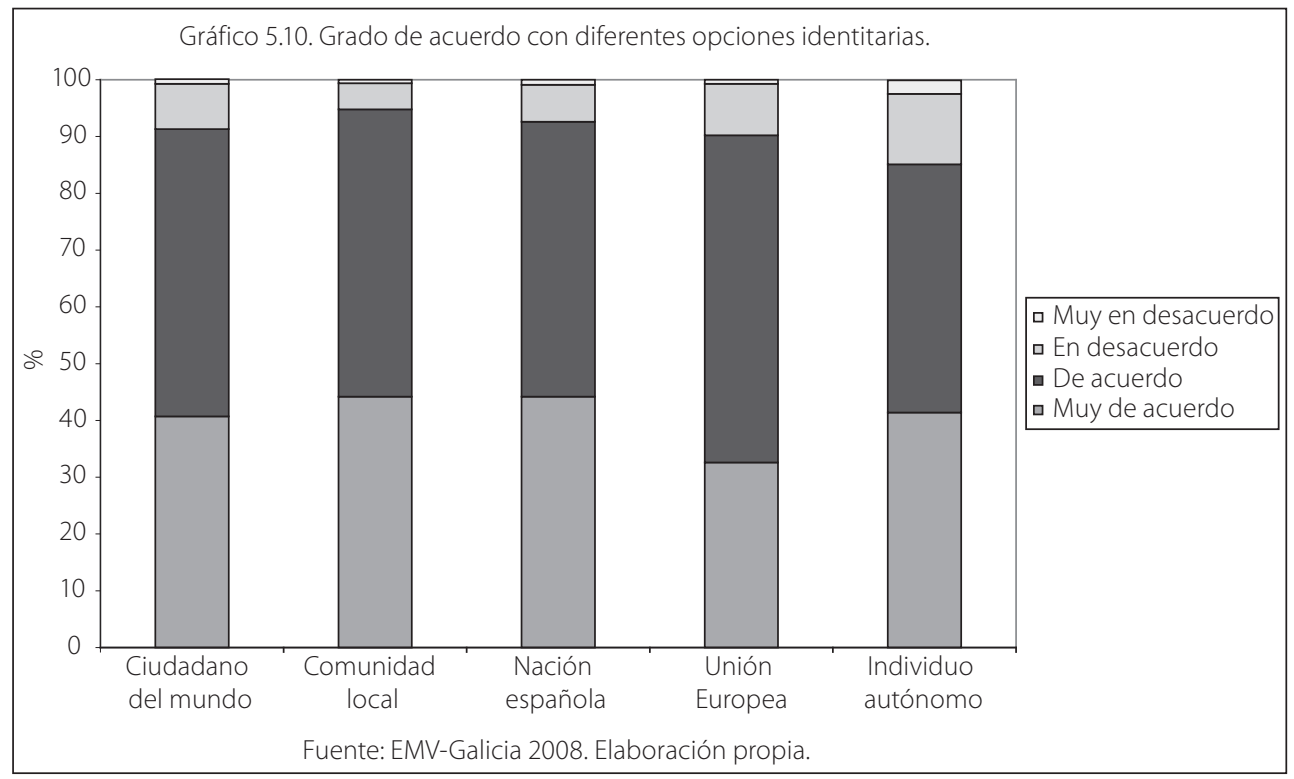

IDENTIDAD NACIONAL, CONCIENCIA ÉTNICA... 


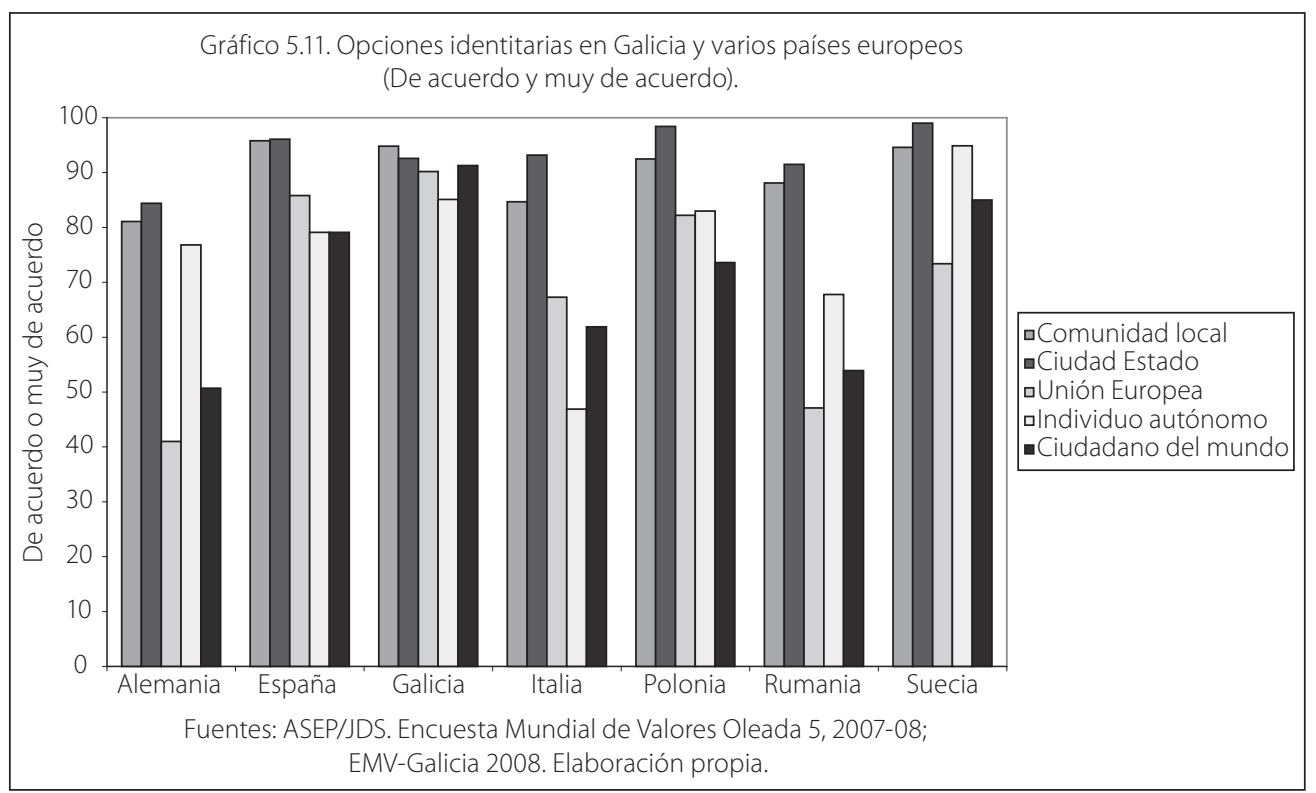

Tabla 5.1. Opciones identitarias en Galicia y varios países europeos (Muy de acuerdo).

\begin{tabular}{lccccc} 
& $\begin{array}{c}\text { Comunidad } \\
\text { local }\end{array}$ & $\begin{array}{c}\text { Nación } \\
\text { Estado }\end{array}$ & $\begin{array}{c}\text { Unión } \\
\text { Europea }\end{array}$ & $\begin{array}{c}\text { Ciudadano } \\
\text { del mundo }\end{array}$ & $\begin{array}{c}\text { Individuo } \\
\text { autónomo }\end{array}$ \\
\hline Alemania & 38,4 & 38,2 & 8,6 & 16,5 & 37,1 \\
\hline España & 38,7 & 50 & 18,3 & 23,6 & 21,6 \\
\hline Galicia & 44,2 & 44,2 & 32,6 & 40,7 & 41,4 \\
\hline Italia & 35,6 & 48,2 & 19,7 & 20,4 & 16,9 \\
\hline Polonia & 38,7 & 57,3 & 23,7 & 22,1 & 36 \\
\hline Rumania & 41,7 & 50,6 & 14,3 & 16,6 & 26,4 \\
\hline Suecia & 22,4 & 46,4 & 13,6 & 18,3 & 37,7 \\
\hline
\end{tabular}

Fuente: ASEP/JDS, Encuesta Mundial de Valores Oleada 5 (2005-08); EMV-Galicia 2008. Elaboración propia.

Por otra parte, para determinar el grado de compatibilidad entre las diferentes opciones identitarias se realizó un análisis de correlación en el que, como puede observarse en la Tabla 5.2, todos los coeficientes tienen signo positivo, es decir, no son excluyentes y son estadísticamente significativos. En suma, según los datos de la EMV, la gran mayoría de los gallegos son partidarios de una identidad múltiple y no excluyente en la que no parecen existir apenas contradicciones entre los diferentes referentes identitarios. 
Tabla 5.2. Correlaciones entre varias opciones identitarias (Rho de Spearman).

\begin{tabular}{lcccc} 
& $\begin{array}{c}\text { Comunidad } \\
\text { local }\end{array}$ & $\begin{array}{c}\text { Nación } \\
\text { española }\end{array}$ & $\begin{array}{c}\text { Unión } \\
\text { Europea }\end{array}$ & $\begin{array}{c}\text { Individuo } \\
\text { autónomo }\end{array}$ \\
\hline $\begin{array}{l}\text { Ciudadano } \\
\text { del mundo }\end{array}$ & 0,440 & 0,408 & 0,636 & 0,266 \\
\hline Comunidad local & 0,622 & 0,504 & 0,333 \\
\hline Nación española & & 0,638 & 0,282 \\
\hline Unión Europea & & & 0,351 \\
\hline
\end{tabular}

Todas las correlaciones son significativas al nivel 0,01 (bilateral).

Fuente: EMV-Galicia 2008. Elaboración propia.

\subsection{LA IDENTIDAD NACIONAL}

La aprobación de la Constitución de 1978 supuso un intento por resolver el contencioso histórico sobre la definición de España como estado-nación, de manera que el Estado de las Autonomías se convirtió en el marco con el que acomodar, por un lado, las reivindicaciones sobre la unidad cultural y política de España y, por otro lado, las demandas de las élites nacionalistas. Más concretamente, la Constitución de 1978 reconoció los rasgos específicos de algunas Comunidades Autónomas y remitió a los Estatutos de Autonomía la concreción de los elementos que históricamente han configurado la personalidad de los diferentes pueblos de España y que en épocas anteriores habían sido prohibidos y menospreciados por el Estado centralista (Aja, 1999: 160).

Galicia obtuvo su Estatuto de Autonomía el 6 de abril de 1981, quedando definida en su artículo primero cómo nacionalidad histórica, al nivel de Cataluña y País Vasco, asumiendo como tarea principal "la defensa de la identidad de Galicia" y de sus intereses así como la promoción de la solidaridad entre cuantos integran el pueblo gallego ${ }^{13}$. Lo cierto es que a pesar de disponer de una extendida conciencia de la diferencia étnica y de haber accedido a la condición de nacionalidad histórica, desde los primeros estudios de opinión se ha venido constatando que el grado de nacionalismo es de los más bajos de España (Vilas Nogueira, 1999; Llera Ramo, 2002). Para explicar este déficit nacionalista se han señalado razones de diversa naturaleza, siendo las más recurrentes las siguientes:

1. La inexistencia de instituciones efectivas de autogobierno durante el Antiguo Régimen, ya que la llamada Xunta do Reino de Galicia no puede considerarse

13 En desarrollo del artículo 6 del Estatuto se aprobó la ley de Símbolos de Galicia (Ley 5/1984 de 29 de mayo), que en su artículo $1^{\circ}$ proclama: "La bandera, el escudo y el himno de Galicia simbolizan su identidad como nacionalidad histórica". 
un auténtico órgano de representación y gobierno, dada la total sumisión a los intereses de la monarquía española (Beramendi, 2007: 43).

2. La debilidad del movimiento nacionalista/galleguista durante el siglo XIX, constituido por una pluralidad político-cultural de movimientos regionalistas y nacionalistas con muy vario alcance y significación, siempre tuvieron carácter marginal en el escenario político salvo durante II República (Máiz, 1996: 39).

3. Las ambivalencias de la etnicidad y concretamente la existencia de un estereotipo negativo de la etnicidad gallega, que se intensificó en el siglo XIX con la introducción y generalización de los mecanismos de nacionalización y socialización españolista del Estado liberal (enseñanza, servicio militar, prensa, funcionariado), lo que hizo que la etnicidad gallega funcionase a contrario, como un poderoso inhibidor de la implantación social de cualquier idea nacional gallega (Beramendi, 1996: 287).

Para conocer la evolución actual de la identidad nacional de los gallegos recurriremos a uno de los indicadores más utilizados en los estudios sobre esta problemática, consistente en la pregunta de qué se siente Vd., ante la que los entrevistados deben elegir entre alguna de las siguientes opciones: (1) solo gallego, (2) más gallego que español (3) tan gallego como español (4) más español que gallego y (5) solo español. Los datos que se recogen en el Gráfico 5.12 resumen la evolución entre 1984 y 2009 y en síntesis, pueden resumirse en las siguientes observaciones.

En primer lugar, desde la primera serie (1984) la opción mayoritaria es la de tan gallego como español, que además de ser la preferida por más de la mitad de los entrevistados, ha venido manteniendo una constante progresión hasta la actualidad, llegando en 2009 hasta el 65\%. En segundo lugar, la opción más gallego que español representa un porcentaje que a lo largo del período se mueve en torno al 20-28\% del total. En tercer lugar, la opción más español que gallego obtiene porcentajes mucho más reducidos ya que en ninguna de las series llega a superar el 10\% del total y en la de 2009 solo representa al 4\%. Por último, las dos opciones restantes de solo español o solo gallego son muy minoritarias ya que en ninguna de las series llegan a superar el 9\%. (Tabla 5.3 y Gráfico 5.12).

Como vemos, las opciones que representan una identidad dual recogen porcentajes que a lo largo del período 1984-2009, rondan en total el 80-90\% de las respuestas. Por una parte, esto confirma la tendencia observada desde los años noventa para el conjunto de España, en el sentido de que más de los dos tercios de entrevistados manifiestan una identidad como españoles y como miembros de su comunidad. Lo cual parece evidenciar que la legitimidad democrática permite sostener una identidad nacional como gallego y español sin grandes contradicciones (Moreno, 1997: 124-136). Por otra parte, el hecho de que las opciones de tan gallego como español y la de más gallego que español sean las más importantes, pone de manifiesto cuales son los límites reales del debate sobre la cuestión nacional en Galicia (Míguez González, 2007: 198-204). Finalmente, los bajos porcentajes 
que corresponden a las opciones solo español o más español que gallego (5,4 y 4,0 en 2009) vuelven a poner de manifiesto que Galicia es una de las comunidades menos españolistas, y ello a pesar de que la identidad nacional española ha experimentado una profunda mutación al hacerse más democrática, autonomista, europeísta y modernizadora, lo que para la gran mayoría se ha hecho más aceptable (Beramendi, 2002: 128-129).

Tabla 5.3. Identificación nacional Galicia 1986-2008 (\%).

\begin{tabular}{lccccc} 
& 1984 & 1986 & 1995 & 2001 & 2009 \\
\hline Solo gallego & 10 & 6,5 & 8,7 & 5,6 & 5 \\
\hline $\begin{array}{l}\text { Más gallego que } \\
\text { español }\end{array}$ & 22 & 27,5 & 22,8 & 28,1 & 20 \\
\hline $\begin{array}{l}\text { Tan gallego como } \\
\text { español }\end{array}$ & 52 & 53 & 54,7 & 56,4 & 65 \\
\hline $\begin{array}{l}\text { Más español que } \\
\text { gallego }\end{array}$ & 7 & 8 & 9,6 & 8 & 4 \\
\hline $\begin{array}{l}\text { Solo español } \\
\text { Total }\end{array}$ & 8 & 5 & 4,2 & 2 & 5,4 \\
\hline$(\mathrm{n}=)$ & 100 & 100 & 100 & 100 & 100 \\
\hline
\end{tabular}

Fuente: Banco de Datos del CIS para 1984, 1986 y 2009;

EMV-Galicia para 1995 y 2001. Elaboración propia.

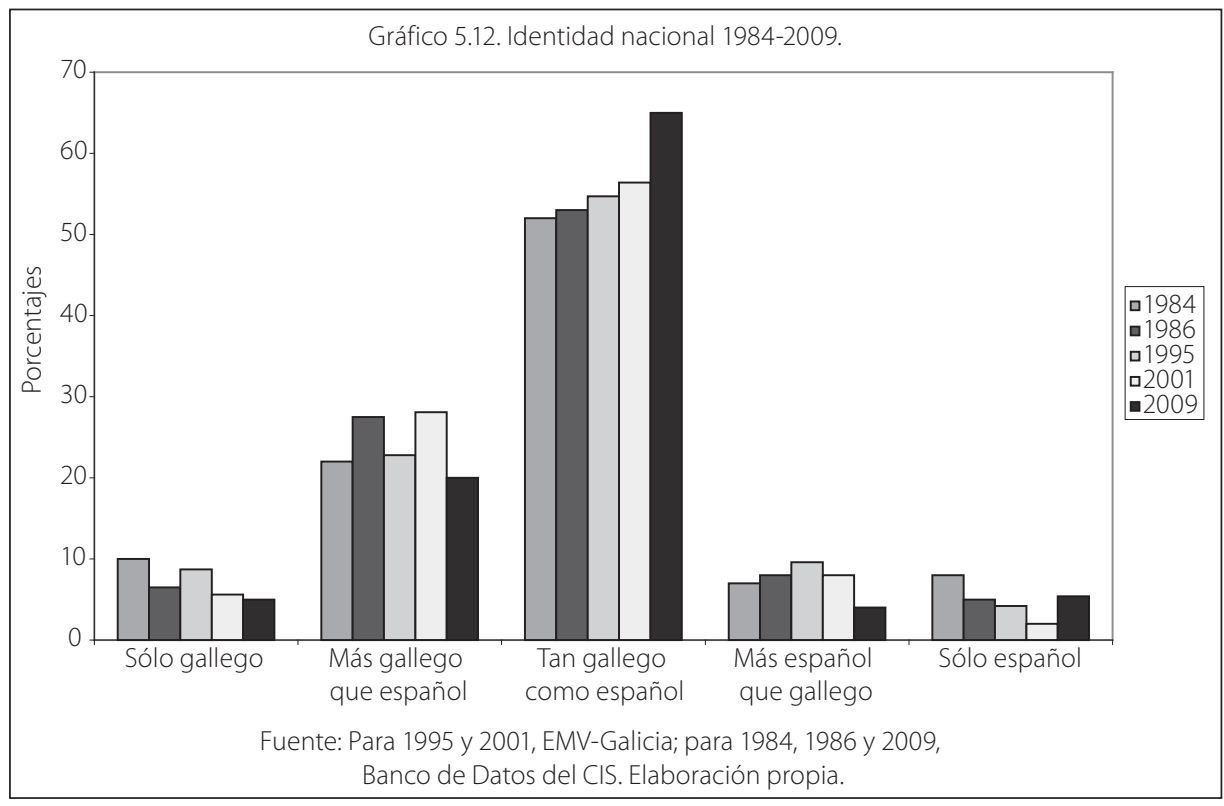

IDENTIDAD NACIONAL, CONCIENCIA ÉTNICA.. 
La evolución de las preferencias sobre la organización territorial del estado pueden observarse en el Gráfico 5.13, que muestra la importante transformación registrada entre 1988 y 2009. Concretamente, las opiniones favorables hacia el actual Estado de las Autonomías han conocido un incremento espectacular, en perjuicio de las partidarias de un estado centralista. Así, la opción de un Estado con comunidades autónomas como en la actualidad pasó de ser la preferida por algo menos de la tercera parte de los entrevistados en 1988 (32\%), a ser la opción mayoritaria con el apoyo del 62\% en 2009. Mientras tanto, los partidarios de un Estado sin autonomías, que en 1988 suponían un 23\% del total, en 2009 se han visto reducidos a un 10\%. En cuanto a la opción de un Estado con comunidades autónomas con mayor autonomía, ésta ha venido representando en torno al 16/19\% y, por último, la de un Estado que reconozca el derecho a la independencia de las CC. AA. puede considerarse muy marginal ya que no supera el $2 \%$.

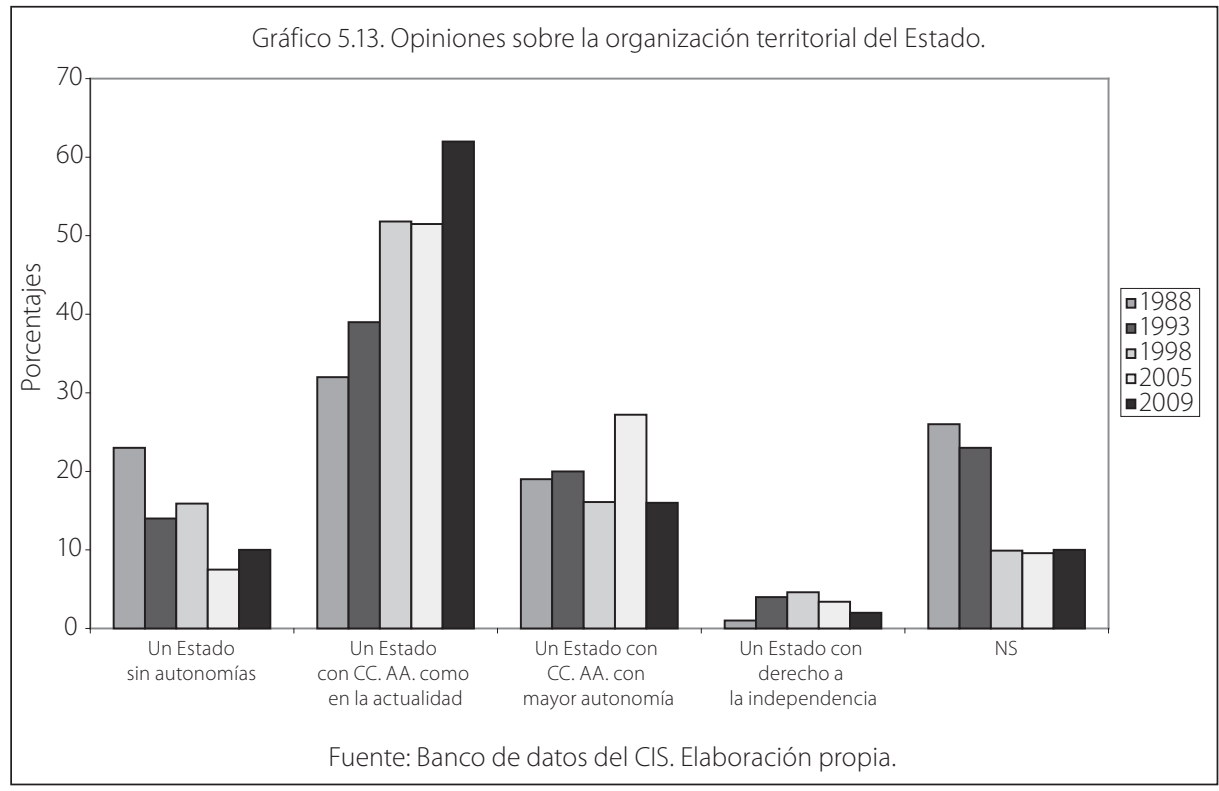

Para completar el análisis de esta problemática resulta de gran interés tratar de determinar cuáles son actualmente las preferencias sobre la organización territorial del Estado de los votantes de las tres opciones políticas más importantes del subsistema regional de partidos (Gráfico 5.14). En primer lugar, la gran mayoría de los votantes del PP y del PSOE se muestran partidarios de la opción de un Estado con CC. AA. como en la actualidad y, en ambos casos, con porcentajes muy similares, en torno al 67-68\%. Esta representa solo al 37,1\% de los votantes del BNG, ya que es superada en algo más de ocho puntos por la de un Estado con CC. AA. con mayor autonomía $(45,3)$ opción que entre los del PSOE es mucho más reducida $(17,9)$ y aun más entre los del PP $(8,1)$. En segundo lugar, la preferencia por la opción de un Estado sin autonomías solo tiene cierta importancia entre 
los votantes del PP $(13,8)$ ya que entre los del PSOE y del BNG representa una opción muy minoritaria (6,8 y 3,7 respectivamente). Finalmente, la de un Estado con derecho a la independencia para las CC. AA., que como se señaló para el total de los entrevistados no pasa de ser puramente marginal, también lo es para los votantes de los tres partidos aunque, como era lógico esperar, encuentra algunas mayores preferencias entre los votantes del BNG $(8,6)$.

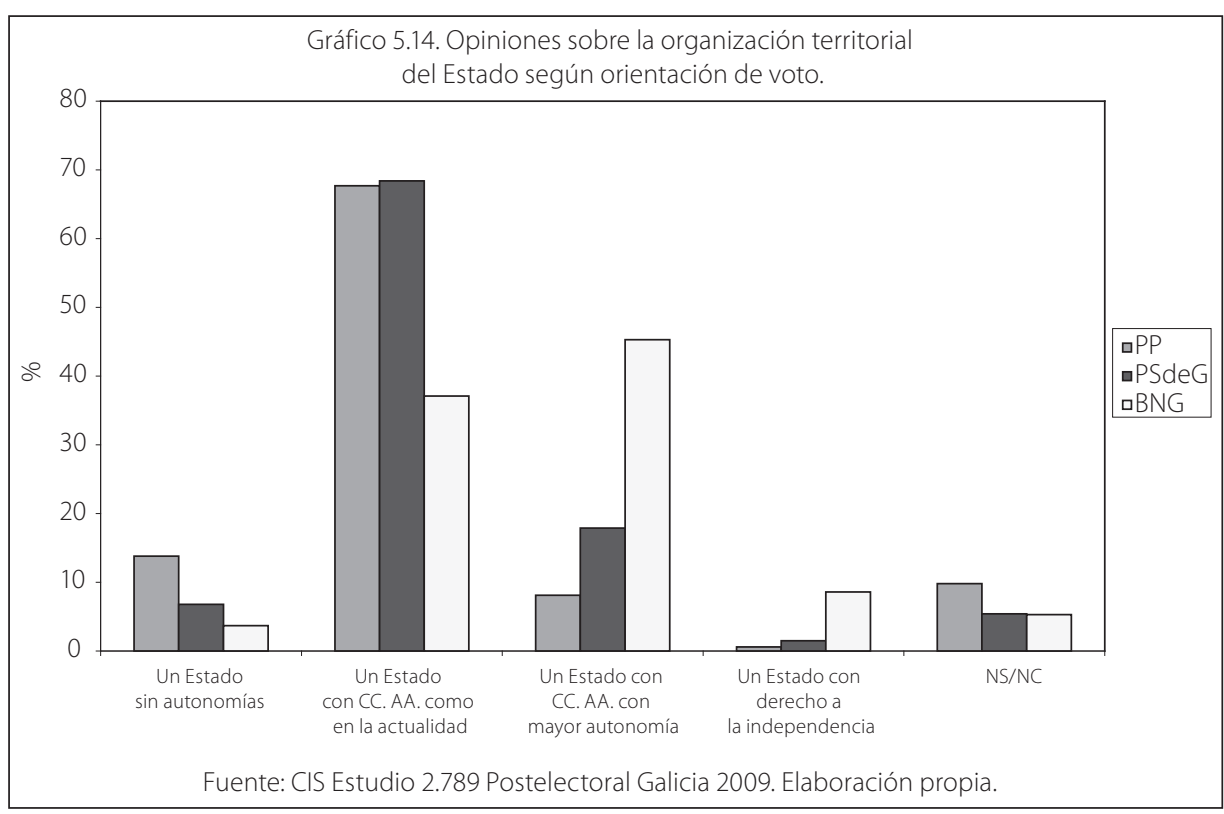

\subsection{CONCLUSIONES}

En este capítulo se han analizado los caracteres de la conciencia étnica de los gallegos así como los rasgos más sobresalientes de su identidad nacional. Concretamente, se han tratado de explicar los factores más importantes para la construcción de estos sentimientos identitarios. Estos han sido, esencialmente, la experiencia histórica de la emigración y el hecho de disponer de una lengua propia, ampliamente utilizada por la gran mayoría. En este sentido, se ha puesto de manifiesto que la progresión observada en las competencias lingüísticas, sobre todo las de leer y escribir en gallego, a partir de la aprobación del Estatuto de Autonomía y de las políticas de normalización lingüística, convive con un relativo retroceso en su uso cotidiano.

Por otra parte, en cuanto a los elementos que caracterizan estos sentimientos identitarios, debe señalarse, en primer lugar, que la presencia de un fuerte componente localista no parece incompatible con una extendida conciencia de la diferencia así como con el orgullo de ser gallego. En segundo lugar, hay que destacar la flexibilidad y/o compatibilidad de los sentimientos identitarios como gallegos, españoles, europeos, etc. 
Por lo que se refiere a la identidad nacional es importante recordar, en primer lugar, el constante progreso de las identidades duales y, más concretamente, las de tan gallego como español o más gallego que español, frente al carácter prácticamente marginal de las más españolistas (más español como gallego o solo español). En segundo lugar, el análisis de la evolución de los principales indicadores ha podido confirmar el constante incremento a lo largo del período estudiado, de los apoyos que recibe el actual Estado de las Autonomías frente a sus posibles alternativas y, finalmente, se ha puesto de manifiesto la relación de asociación entre los sentimientos identitarios y el uso del idioma gallego.

\subsection{REFERENCIAS BIBLIOGRÁFICAS}

Aja, E. (1999): El Estado Autonómico. Federalismo y hechos diferenciales, Madrid, Alianza.

Beramendi, J. (1996): "Conciencia étnica e conciencias nacionais en Galicia", en Gerardo Pereira Menaut (Coord.) Galicia fai dous mil anos. O feito diferencial. Historia (vol. II), Museo do Pobo Galego, Santiago: 277-300.

Beramendi, J. (2002): "Identidad, etnicidad y estado en España. Siglos XIX y XX". En Safran, W. y Máiz, R. (Coords.) Identidad y autogobierno en sociedades multiculturales, Ariel, Barcelona.

Beramendi, J. (2007): De provincia a nación. Historia do galeguismo político, Vigo, Ed. Xerais: 113-135.

CECS (1997): "15 años de experiencia autonómica: un balance" en Informe España 1996. Fundación Encuentro Madrid: 373-563.

Conover, P. J. (1984): "Influence of Group Identifications" en The Journal of Politics, vol. 46: 760-784.

De Juana, J. y Prada, J. (2005): "Historia e identidad en Galicia", en De Juana, J. y J. Prada (Coords.), Historia contemporánea de Galicia, Barcelona, Ariel: 17-30.

De Juana, J. y Vázquez, A. (2005): "Población y emigración en Galicia" en De Juana, J. y Prada, J. (Coords.), Historia contemporánea de Galicia, Barcelona, Ariel: 393-440.

Fernández de Rota y Monter, J. A. (1991): "Identidad y recreación histórica en Galicia", en Revista de Antropología Social no 0: 205-215. Editorial Universidad Complutense, Madrid.

Fernández de Rota y Monter, J. A. (2005): Nacionalismo, cultura y tradición. Anthropos, Barcelona.

Fernández Prieto, L., Balboa López, X. L. y Artiaga Rego, A. (1996): "O proceso de adaptación do mundo agrario ó capitalismo", en Gerardo Pereira Menaut (Coord.) Galicia fai dous mil anos. O feito diferencial. Historia (vol. II), Museo do Pobo Galego, Santiago: 201-218.

Fought, C. (2006): Language and Ethnicity, Cambridge University Press, Nueva York. Gilbert, P. (1998): The Philosophy of Nationalism, Westview Press, Boulder.

\section{LA EVOLUCIÓN DE LOS VALORES SOCIALES EN GALICIA}


Gondar Portasany, M. (2005): "Galicia/Europa. Una batalla por la identidad" en De Juana y J. Prada (Coords.), Historia contemporánea de Galicia, Barcelona, Ariel: 519-544.

Harty, S. y Murphy, M. M. (2008): Por una ciudadanía multinacional, 451 Editores, Madrid.

Instituto Galego de Estadística (2009): Galicia en cifras 2008, IGE.

Jiménez Blanco, J., García Ferrando, M., López Aranguren, E. y Beltrán, M. (1977): La conciencia regional en España, Centro de Investigaciones Sociológicas, Madrid.

Llera Ramo, F. (2002): "La opinión pública: la diversidad de una nación plural", en Subirats, J. y Gallego, R., Veinte años de autonomías en España. Leyes, políticas públicas, instituciones y opinión pública, Madrid, CIS: 321-376.

Máiz Suárez, R. (1996): "Nación de Breogán: oportunidades políticas y estrategias enmarcadoras en el movimiento nacionalista gallego (1886-1996)" Revista de Estudios Políticos, 92: 33-75.

Máiz Suarez, R. (1997): A idea de Nación, Vigo, Xerais.

Merelman, R. M. (1986): "Domination, Self-Justification, and Self-Doubt: Some Social-Psychological Considerations" The Journal of Politics, vol. 48: 276-300.

Míguez González, S. (2007): "La cultura política de los gallegos", en José Luis Veira (Dir.) Las actitudes y valores sociales en Galicia, Centro de Investigaciones Sociológicas, Madrid: 189-245.

Miller, A. H. et al. (1981): "Group Consciousness", en American Journal of Political Science, 25: 494-511.

Miller, R. (1995): On Nacionality, Oxford University Press, Oxford.

Montero, J. R. y Torcal, M. "Autonomías y comunidades autónomas en España: preferencias, dimensiones y orientaciones políticas", Revista de Estudios Políticos, 70: 33-91.

Moreno, L. (1997): La federalización de España. Poder político y territorio. Siglo XXI, Madrid.

Murado, M. A. (2008): Otra idea de Galicia, Debate, Barcelona.

Ninyoles, R. L. (1972): Idioma y poder social, Tecnos, Madrid.

Parekh, B. (2005): Repensando el multiculturalismo. Diversidad cultural y teoría politica. Istmo, Madrid.

Precedo Ledo, A. (1998): Geografía Humana de Galicia, Oikos-Tau, Barcelona.

Rogowski, R. (1974): Rational Legitimacy: A Theory of Political Support, Princeton, NJ, Princeton University Press.

Tajfel, H. (1978): "Intergroup Behavior: II Group Perspectives", en Henri Tajfel y Colin Fraser (Eds.) Introducing Social Psychology. Harmondsworth, Middlesex, Penguin.

Vilas Nogueira, X. (1975): O Estatuto Galego, Edicions do Rueiro, A Coruña. 
Vilas Nogueira, J. (1999): "Competitivos, jerárquicos e igualitaristas en Galicia: prosopografía”. Revista de Estudios Políticos, 103: 9-49.

Villares Paz, R. (1982): La propiedad de la tierra en Galicia. 1500-1936, Siglo XXI, Madrid.

Villares Paz, R. (2001): "Sobre a identidade histórica de Galicia" en VV. AA., Galicia: unha luz no Atlántico, Xerais, Vigo. 


\section{VALORES POLÍTICOS Y PARTICIPACIÓN EN GALICIA. FACTORES DE CAMBIO Y CONTINUIDAD}

Santiago Míguez González

\subsection{INTRODUCCIÓN}

Este capítulo está dedicado a analizar los valores, las actitudes y la participación política en Galicia. Siguiendo una ordenación clásica de las diferentes dimensiones de la cultura política, según el paradigma establecido por Almond y Verba en su obra pionera La Cultura Cívica ${ }^{1}$, en primer lugar, se analizarán lo que pueden considerarse las bases de la política, es decir, los principales valores y actitudes hacia el orden político-social. En este punto, el estudio se concreta en un análisis comparado con España y varios países europeos de la dimensión izquierda-derecha y de la que se tratará de determinar su evolución y significado a partir de los datos de las tres últimas series de la Encuesta Mundial de Valores.

A continuación, se examinan las actitudes hacia la democracia, prestando especial atención a las críticas hacia su funcionamiento. Tras ello seguirá el análisis de los niveles de implicación e interés por la política, incluyendo un intento de explicación de por qué los gallegos, como la mayoría de los españoles, muestran unas actitudes tan generalizadas de alejamiento y desinterés hacia los temas políticos.

Finalmente, la última parte tiene como objeto el estudio de la participación política y se subdivide en dos apartados. En el primero y más extenso se estudian los niveles, fluctuaciones y tendencias de la participación en los diferentes tipos de elecciones mientras que el segundo apartado está dedicado a analizar los niveles de participación política no-electoral, incluyendo tres formas de activismo político (manifestaciones, firma de peticiones y boicots a la compra de determinados productos). También en este punto se presenta un resumen de los principales factores que explican las razones de los diferentes niveles de implicación en este tipo de actividades.

Almond, G. y S. Verba (1963). 


\subsection{LOS VALORES POLÍTICOS Y LA DIMENSIÓN IZQUIERDA-DERECHA}

Los valores políticos son concepciones de lo moralmente deseable y pueden ser observados indirectamente en las evaluaciones y actividades de los individuos. Valores como los de justicia, legitimidad, legalidad, libertad, participación, etc., representan percepciones básicas de un orden político anhelado y permiten realizar juicios sobre si una situación política concreta o una determinada actuación de las autoridades es buena o mala, favorable o desfavorable.

Como elementos básicos de una determinada cultura política su relevancia empírica puede ser establecida descubriendo los conjuntos de actitudes que conforman las acciones y teniendo en cuenta que si los individuos no cuentan con ellos, o si están mal formados o son inconsistentes, sus acciones serán erráticas o anómicas (Thompson, M., R. Ellis y A. Wildavsky, 1992). En suma, los valores no son algo externo a la política sino que, por el contrario, constituyen su quintaesencia ya que son la base para la construcción y reconstrucción de la vida en sociedad (Wildasky, 1987: 5; Hahman, 2007: 307).

La dimensión izquierda-derecha es uno de los principales instrumentos para el estudio de los valores políticos. Para muchas personas de las sociedades de Europa occidental el autoposicionamiento en el eje izquierda/derecha constituye un instrumento muy útil para orientarse en la complejidad de la vida política ya que permite simplificar la realidad y adoptar posiciones ante muchos temas del debate público. Además, como dimensión espacial de la política, la escala izquierda-derecha muestra una gran capacidad expresiva ya que permite definir no solo las nociones de los extremos y el centro sino también otras intermedias, como las de centroderecha o centroizquierda. Por ello, la dimensión izquierda-derecha sirve para ordenar espacialmente a los partidos políticos así como para autosituarse respecto a ellos con una mayor o menor cercanía. (Vilas Nogueira, 1991). Para mucha gente la posición que ocupa el partido del gobierno o la coalición gobernante en la dimensión izquierda-derecha, determina sus expectativas sobre el crecimiento del gasto estatal, los esfuerzos por reducir el desempleo o la igualdad de las rentas. Por ello, la dimensión izquierda-derecha es un predictor de la orientación de voto, especialmente en elecciones de ámbito nacional.

Sus orígenes como dimensión política se remontan a la Revolución francesa y su significado comenzó denotando posiciones de clase. En efecto, cuando los Estados Generales dieron paso a la Asamblea Nacional (1791), la fracción de la nobleza que se implicó en el proceso se situó a la derecha de la presidencia y el Tercer Estado lo hizo a la izquierda. No obstante, muy pronto ambas posiciones adoptaron nuevos significados: la derecha se asoció con la defensa de la monarquía y con posiciones conservadoras mientras que la izquierda se identificó con el cambio revolucionario y la limitación del poder real. 
Desde mediados del siglo XIX la dimensión izquierda-derecha ha tenido como referentes el conflicto de clases (obreros vs. patronos) y el papel del Estado como elemento redistribuidor de la riqueza frente al libremercado. A partir de los años sesenta del XX incorporó nuevos aspectos. En ese contexto surgió una nueva izquierda que junto con la defensa de las políticas redistributivas que identificaban a la izquierda tradicional, comenzó a propugnar nuevas organizaciones menos jerarquizadas y reivindicaciones de mayor libertad y autonomía personal. Por su parte, la derecha también se transformó al asumir los logros del modelo socioeconómico de los Estados de Bienestar y al moldear sus posiciones como más centristas y abiertas a la negociación.

Desde los años ochenta, las diferencias entre la izquierda y la derecha se redujeron en temas socioeconómicos, como consecuencia, entre otras razones, del final de la Guerra Fría y de la ausencia de una alternativa global al libremercado (Sani y Sartori, 1983). Además, como resultado de la globalización y de la progresiva europeización de los asuntos económicos, cada vez son menores las posibilidades de una acción autónoma de los gobiernos, lo que ha supuesto que las diferencias entre la izquierda y la derecha en aspectos económicos y en el papel del Estado hayan seguido menguando, al tiempo que han ido surgiendo nuevos temas y organizaciones (ecologistas, feministas, etc.). En este sentido, las diferencias actuales entre la izquierda y la derecha en las sociedades occidentales son la consecuencia del desarrollo económico y la terciarización de la economía con la consecuente consolidación de unas clases medias con altos niveles educativos. Además, los intensos procesos de secularización que dieron lugar a la pérdida del papel hegemónico que disfrutaba la Iglesia en la inculcación de valores y actitudes sobre la gran mayoría de las poblaciones, se han visto acompañados de un incremento generalizado tanto de los niveles de información como de los procesos de educación formal o reglada.

Como resultado de estos procesos ha tenido lugar un debilitamiento de los cleavages tradicionales (clase social y religión) que en países como España constituían las principales fuentes de polarización política. En este marco de cambio cultural cobran relevancia nuevos valores relacionados con la independencia y la autorrealización personal, el respeto al entorno, la solidaridad internacional y los derechos de las minorías. El estudio de esta transformación condujo a la formulación de la dimensión materialismo-posmaterialismo, elaborada por Ronald Inglehart a comienzos de la década de los setenta del siglo XX, a partir de la observación del cambio de valores en las generaciones nacidas después de la II Guerra Mundial y socializadas en un entorno de estabilidad política y seguridad material sin precedentes en la historia de los países más avanzados económicamente (Inglehart, 1977). Como esta problemática se estudia en varios capítulos de este libro, para evitar repeticiones innecesarias, nos remitimos a ellos. 


\subsubsection{Autoubicación política y amplitud de las respuestas}

De acuerdo con los datos de la Encuesta Social Europea (ESS) una media de en torno al 88\% de los respondentes en más de veinte países logra autoubicarse en la escala izquierda-derecha aunque existen algunas variaciones. Los respondentes que encuentran mayores dificultades para autoubicarse pertenecen, por una parte, a algunos países del sur de Europa, como Portugal $(34,1)$ y, por otra parte, a países del Este, como Polonia $(20,1)$. En sentido opuesto, los porcentajes más reducidos de no-respuesta se registran en los países escandinavos ${ }^{2}$. Por su parte, las series de la Encuesta Mundial de Valores realizadas entre 2005 y 2008 coinciden en buena medida con los resultados de la ESS, de manera que los porcentajes más bajos de no-respuesta corresponden a países como Suecia $(2,8)$ y los más altos a Rumanía $(48,7)$ o Polonia $(28,2)$ e Italia $(26,7)(\text { Tabla } 6.1)^{3}$.

Tabla 6.1. Autoubicación política en Galicia y en varios países europeos. 2005-2008.

\begin{tabular}{lccccccc} 
& Alemania & Italia & Polonia & Rumanía & Suecia & España & Galicia \\
\hline Izquierda & 9,5 & 9,5 & 5,1 & 4,6 & 6,8 & 10,6 & 13,7 \\
\hline Centroizquierda & 24,9 & 22,3 & 6,7 & 5,2 & 27,1 & 32,8 & 29,0 \\
\hline Centro & 39,9 & 21,9 & 36,1 & 21,8 & 25,3 & 26,5 & 33,1 \\
\hline Centroderecha & 11,9 & 14,6 & 13,7 & 11,0 & 30,5 & 14,6 & 12,9 \\
\hline Derecha & 2,2 & 4,9 & 10,2 & 8,8 & 7,5 & 2,6 & 7,3 \\
\hline NS/NC & 11,6 & 26,7 & 28,2 & 48,7 & 2,8 & 12,9 & 3,1 \\
\hline Total & 100,0 & 100,0 & 100,0 & 100,0 & 100,0 & 100,0 & 100 \\
\hline Media & 4,7 & 5,0 & 5,8 & 5,9 & 5,5 & 4,6 & 4,8 \\
\hline
\end{tabular}

Fuente: ASEP-JDS Estudio Mundial de Valores Oleada 5 (2005-2008);

EMV-Galicia 2008. Elaboración propia.

En Galicia los porcentajes de no-respuesta son similares a los de España en las series de la EMV de 1995 y 2001, en las que rondan el 20\%, pero en la última (2007-8) se redujeron en ambos casos, especialmente en Galicia, situándose respectivamente en el 12,9 (España) y en el 3,1 (Galicia). La información recogida en la Tabla 6.2 permite observar que la mayor proporción de no-respuesta se encuentra

\footnotetext{
En estos países los porcentajes de respondentes que no logran autoubicarse eran los siguientes: Dinamarca, 6,5; Finlandia, 4,6; Suecia, 4,9 y Noruega, 2,2. (Mair, 2007: 209-210).

3 En la EMV la pregunta sobre la variable del autoposicionamiento izquierda-derecha se formulaba así: "en política la gente habla de la izquierda y de la derecha. En la siguiente escala, ¿dónde se autoposicionaría Vd., en términos generales, siendo 1 = izquierda y 10 = derecha?". En este capítulo la escala se presenta simplificada en cinco posiciones $(1,2=$ izquierda, 3,4 = centroizquierda, 5,6 = centro, 7,8 = centroderecha y 9,10 = derecha).
} 
entre las personas más alejadas de la estructura de oportunidad política por su bajo nivel de estudios y mayor edad (Míguez, 2007: 207).

\subsubsection{La distribución en la escala izquierda-derecha}

La distribución de los entrevistados en las diferentes posiciones de la escala izquierda-derecha se caracteriza, en primer lugar, por un progresivo predominio de la posición de centro. En 1987 esta posición representaba al 21\% de la población pero actualmente es la más poblada, al agrupar a algo más de un tercio del total. En segundo lugar, el centroizquierda fue hasta 1990 la posición que reunía un porcentaje más elevado, pero en las series de 1995 y 2001 descendió hasta el 18-22\%, para volver a incrementarse en 2008 hasta el 29\% del total. En España, esta distribución aparece invertida, ya que la posición dominante sigue siendo la de centroizquierda con un 32,8 frente al 26,5\% del centro. En tercer lugar, el centroderecha ha registrado pocas fluctuaciones, oscilando entre el 16-13\%. En la última serie (2008) el porcentaje correspondiente era algo inferior al de España (12,9 y 14,6, respectivamente). Por último, las posiciones más extremas registran unas proporciones ligeramente más elevadas en Galicia que en España. La derecha ha mantenido un porcentaje del $7 \%$ sin variaciones en las tres series de la EMV y, en España, este porcentaje es, como decimos, todavía más reducido $(2,6)$. La izquierda ha registrado algunas oscilaciones entre 1995 y 2008 y este último año llegó al 13,7\% (10,6 en España), superando por una pequeña diferencia el porcentaje correspondiente al centroderecha (gráficos 6.1 y 6.2).

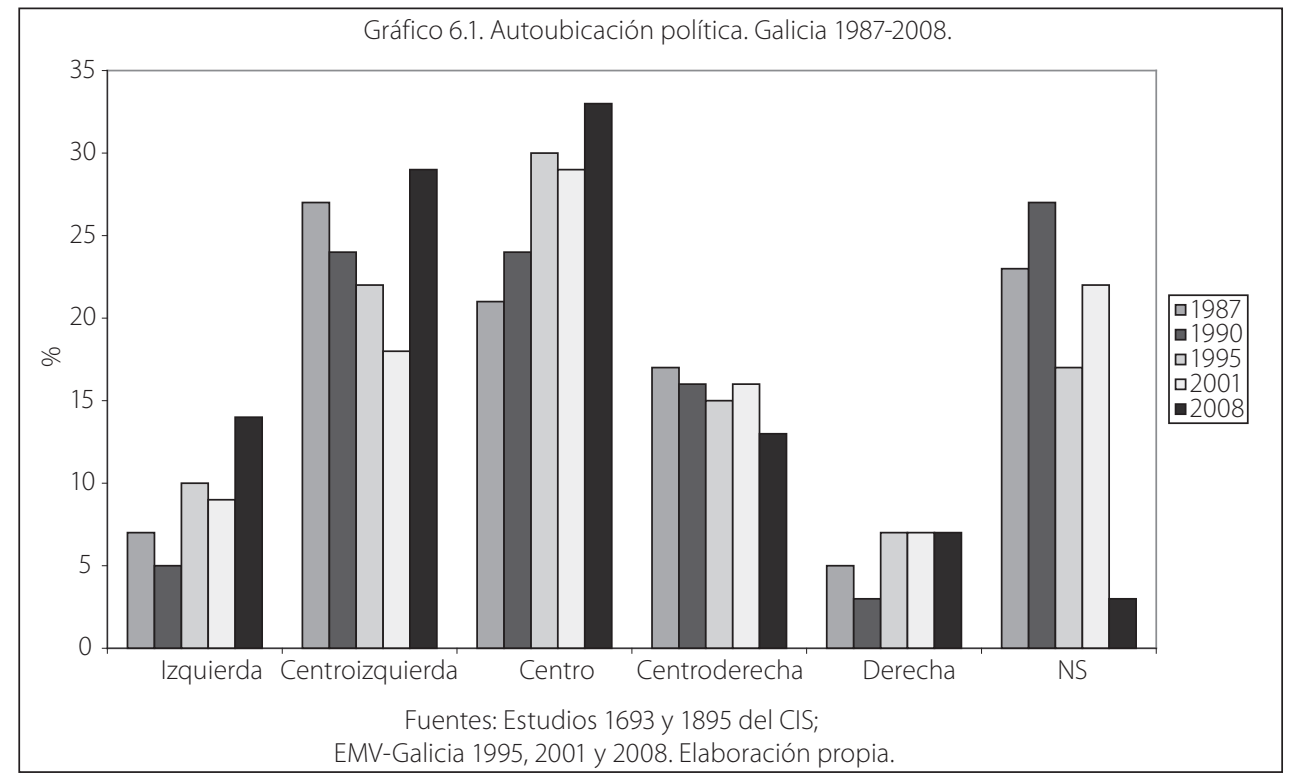

En resumen y teniendo en cuenta los valores medios de la escala de autoubicación política, España y Galicia con medias de 4,6 y 4,8 respectivamente, se sitúan en una posición moderada de centroizquierda, similar a la de Alemania $(4,7)$ y 
a cierta distancia de las posiciones más centradas del resto de países (Tabla 6.1 y gráficos 6.1 y 6.2).

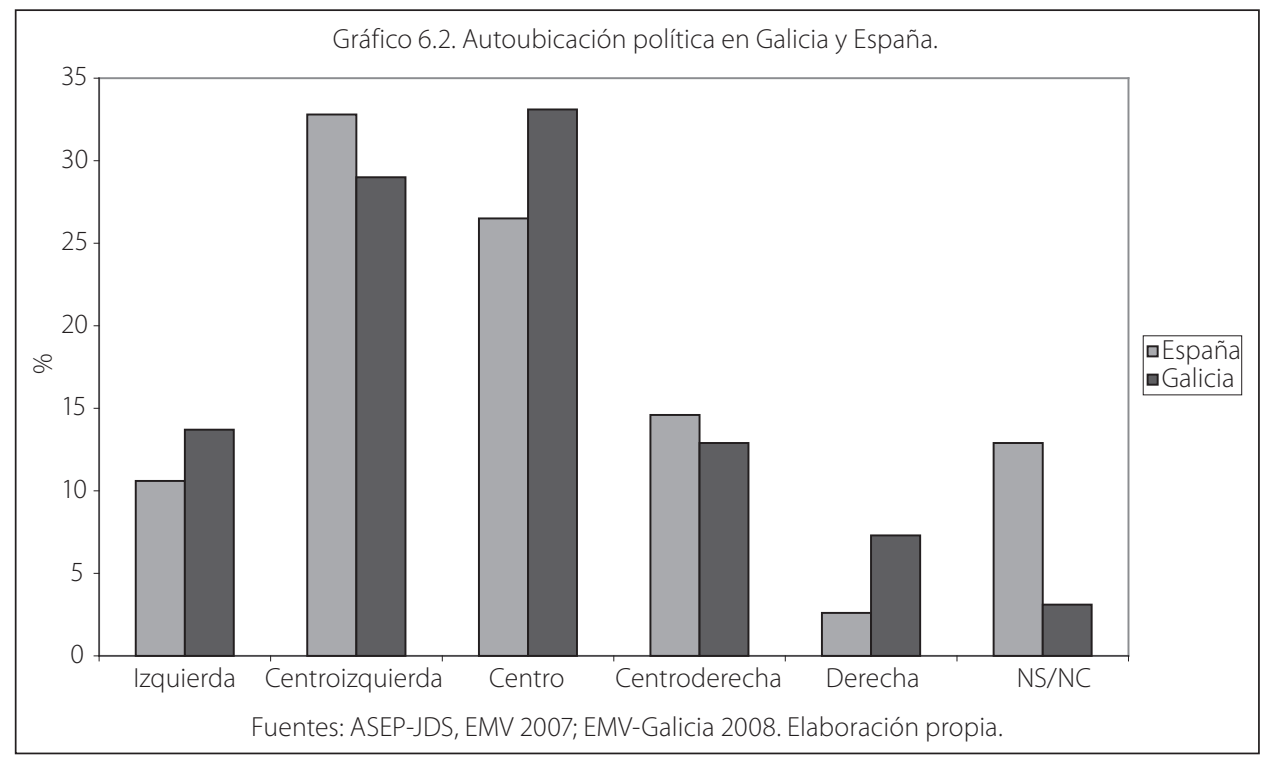

\subsubsection{Autoposicionamiento político y variables sociodemográficas}

La mayoría de las diferencias según los caracteres sociodemográficos de los entrevistados están claramente interrelacionadas, revelando un solapamiento de las variables de edad, nivel de estudios y ocupación. En síntesis, las principales observaciones son las siguientes. Por sexos, las mujeres aparecen en mayor proporción que los varones en la posición de centro (36,6 mujeres; 29,9 varones) mientras que éstos lo hacen en la de centroizquierda (33,5 varones; 25,0 mujeres). Por edades, los más jóvenes ocupan mucho más que el resto las posiciones de izquierda $(24,2)$ y centroizquierda $(36,4)$ mientras que los de mayor edad lo hacen en la derecha $(15,3)$. Según el nivel de estudios, los que cuentan con el nivel más alto se sitúan en la posición de izquierda $(19,8)$ por encima de la media, mientras que los del nivel más bajo lo hacen en la de derecha $(12,7)$. Según la ocupación principal, las mayores diferencias respecto a la media las aportan tanto los estudiantes, que ocupan en mayor proporción las posiciones de izquierda y centroizquierda $(25,6$ y 36,6), así como las amas de casa en la posición de centro $(43,3)$ y los jubilados y pensionistas en la derecha $(14,3)$. Por último, según el tamaño poblacional hay que destacar que los municipios de menos de diez mil habitantes cuentan con una mayor proporción de personas en las posiciones de centroderecha $(15,2)$ y derecha $(10,4)$, los de entre diez mil y cincuenta mil lo hacen en la de centro $(38,5) \mathrm{y}$, finalmente, en los de más de 200.000 habitantes se encuentra la mayor proporción de entrevistados de posiciones de izquierda $(19,6)$ y centroizquierda $(32,7)$ (Tabla 6.2). 


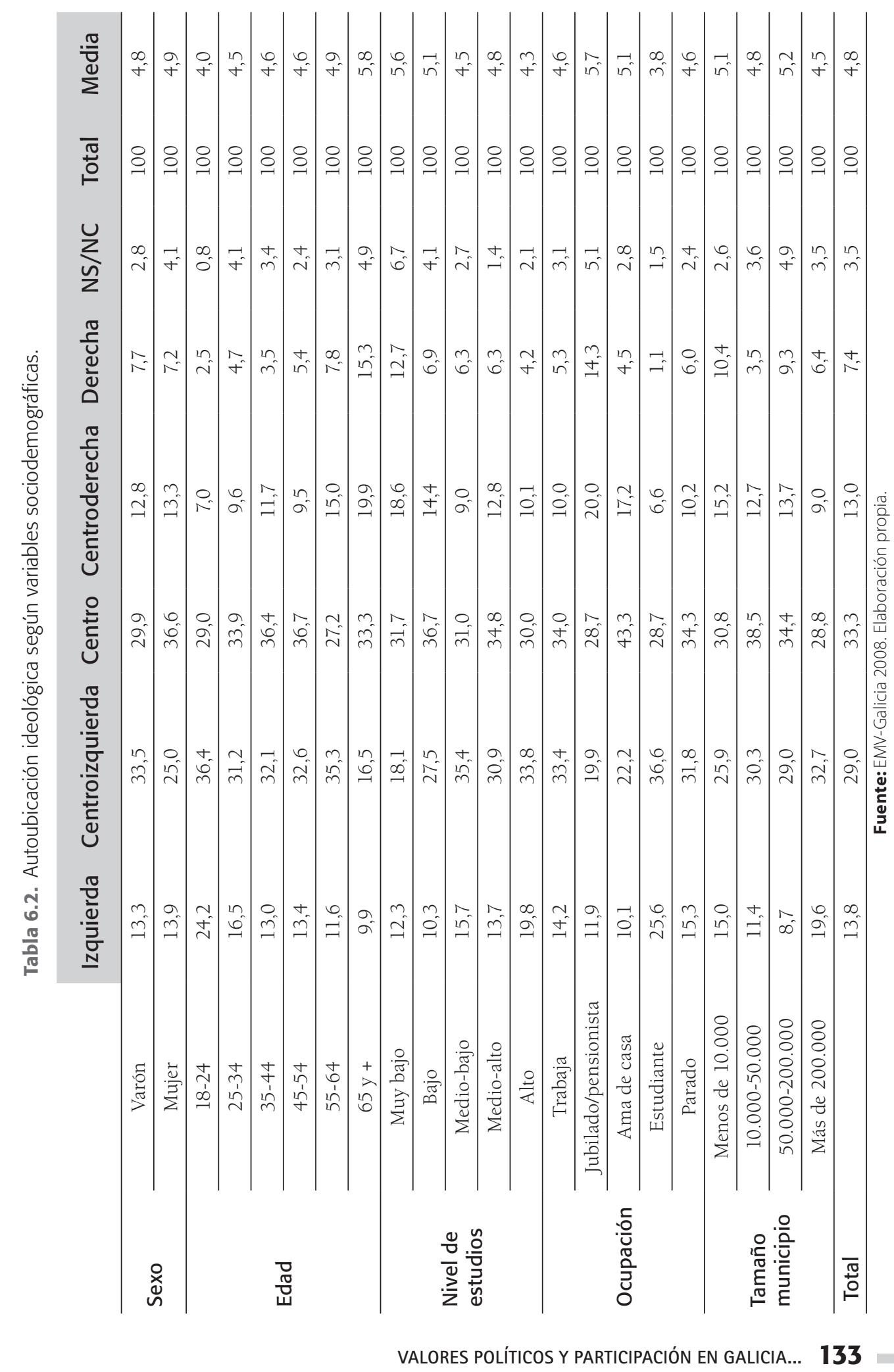




\subsubsection{La dimensión izquierda-derecha y la competición electoral}

Desde las primeras elecciones de la democracia las preferencias electorales de los gallegos se han dirigido mayoritariamente hacia partidos moderados de centro y centroderecha, cuyos principales representantes han sido la UCD hasta 1979 y AP/PP a partir de entonces. La crisis de la UCD dio lugar a la formación de varios partidos regionales de centro de tamaño reducido y de los que el más importante fue Coalición Galega, que logró cierto protagonismo durante los años centrales de la década de los ochenta, al recibir muchos votos procedentes de la extinta UCD en las provincias de Ourense y Lugo y constituirse en partido pívot para la formación de mayorías de gobierno al nivel autonómico y local. Tras su desaparición, la competición electoral ha tenido como principales protagonistas en los diferentes tipos de elecciones al PP, al PSdeG-PSOE y desde 1993, al BNG ${ }^{4}$.

La emergencia electoral del BNG ha tenido una especial relevancia ya que a diferencia de las demás nacionalidades históricas, el cleavage nacionalista comenzó teniendo en Galicia una menor trascendencia política ${ }^{5}$. Además ha permitido formar coaliciones de gobierno con el PSdeG-PSOE en muchos ayuntamientos y, tras la pérdida por el PP de la mayoría absoluta en 2005, pudo acceder por primera vez al gobierno de la comunidad en coalición con el PSdeG-PSOE. En cualquier caso, las mayorías absolutas que ha logrado el PP desde 1989 hasta 2005 y, de nuevo, en 2009, permiten definir al subsistema regional de partidos bajo el formato del sistema de partido predominante (gráficos 6.3, 6.4 y 6.5).

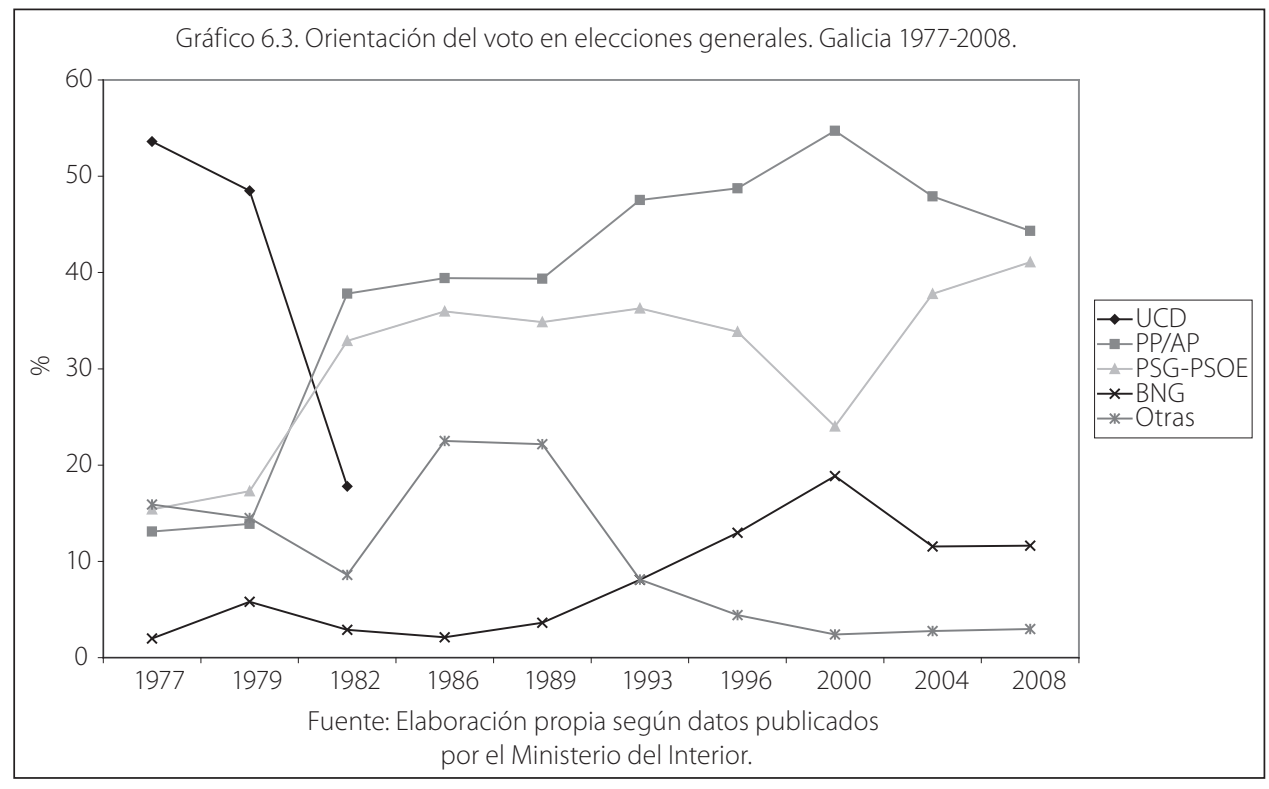

Para una historia de la vida política en Galicia desde 1977 hasta 2005 veáse De Juana López, J. y J. Prada (2005) Esta problemática se estudia en el Capítulo 5 de este libro. 

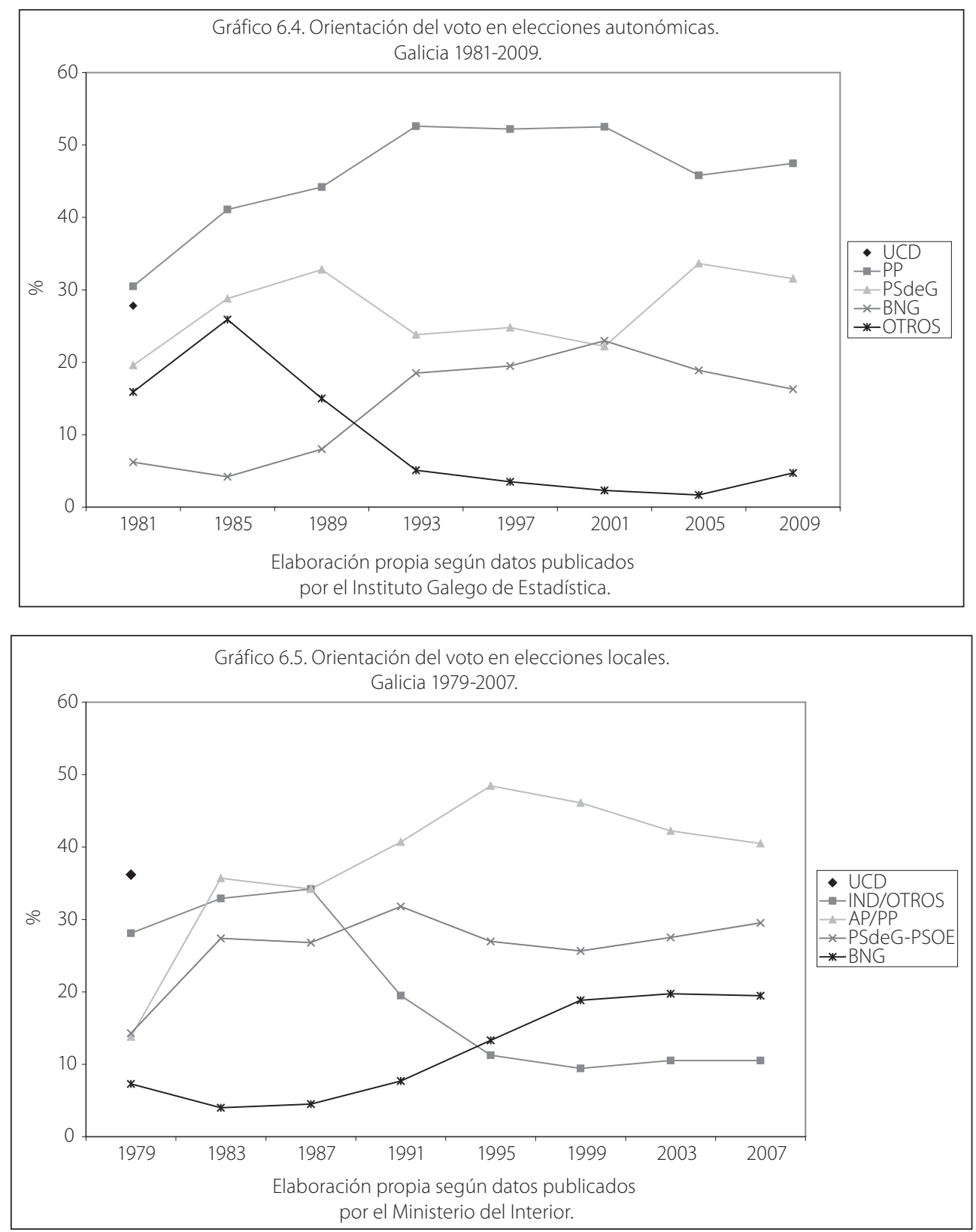

Según los datos de la última serie de la EMV-Galicia, la distribución actual de los votantes de los tres partidos en la escala izquierda-derecha se puede resumir como sigue. Por una parte, en la composición del voto del PP las posiciones de centro y centroderecha son las más importantes. La de centro es casi mayoritaria ya que representa al 45,9\% de sus votantes, mientras que la de centroderecha supone algo menos de la tercera parte del total $(32,0)$. El resto de su electorado 
procede esencialmente de la derecha $(19,9)$. Por otra parte, mientras el PP reúne a la gran mayoría de los votantes del centro y a la práctica totalidad de los de centroderecha y derecha, el PSdeG-PSOE y el BNG se disputan a los votantes de las posiciones del centroizquierda (57,3 PSdeG-PSOE; 44,7 BNG) y de la izquierda (22,2 PSdeG-PSOE; 38,1 BNG). No obstante, ambos reúnen un pequeño porcentaje del electorado de centro, aunque éste es poco importante en la composición total de su voto, de manera que los centristas suponen, respectivamente, el 17,7 y el 15,0\% (Gráfico 6.6).

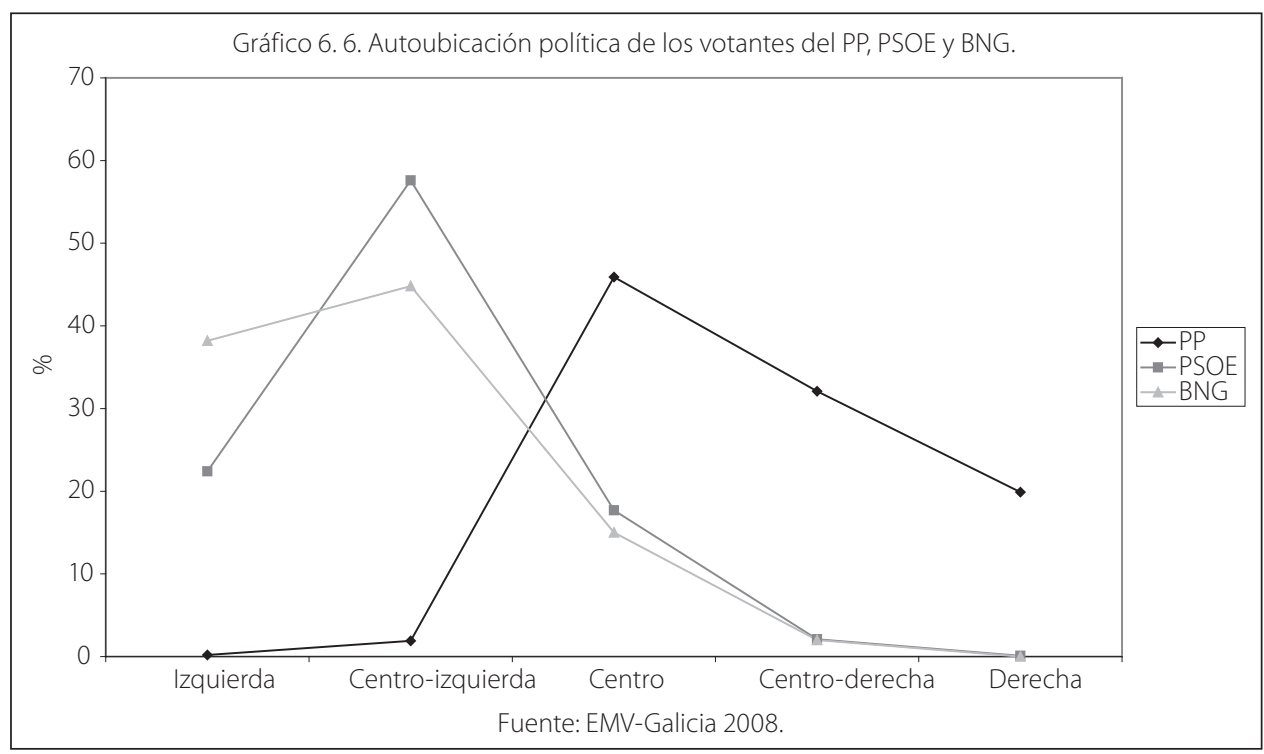

Un aspecto que no debe pasarse por alto en el análisis de esta problemática es el relativo a la distribución espacial de los partidos en la escala izquierda-derecha según la opinión de los votantes. Se trata de saber en qué posición de la escala sitúan los votantes a cada partido y cuál es la diferencia entre las posiciones de votantes y partidos. La respuesta a esta cuestión se resume en el Gráfico 6.7. En primer lugar, para el total de electores, el PP esta ubicado en el punto 7,8 de la escala. Mientras tanto, sus votantes se autoubican en una posición moderada de centroderecha $(6,5)$ pero al PP lo sitúan en una posición más extrema $(7,5)$. Por su parte, los votantes del PSdeG-PSOE y del BNG ubican al PP mucho más a la derecha (8,2 y 8,4 respectivamente). En segundo lugar, la ubicación del PSdeG-PSOE y el BNG, por una parte, para el total de electores, se corresponde en el primer caso, claramente con el centroizquierda $(4,1)$ y, en el caso del BNG su situación se aproxima más a la izquierda $(2,6)$. Por otra parte, los votantes del PSdeG-PSOE y el BNG se autoubican en el centroizquierda en unas posiciones no excesivamente alejadas entre si (PSdeG-PSOE 3,7; BNG 3,1) y, en ambos casos, ubican tanto al PSdeG-PSOE como al BNG en posiciones algo alejadas de las suyas propias. Al 
PSdeG-PSOE, lo sitúan un poco más a la derecha $(4,0$ y 4,4) y al BNG un poco más a la izquierda (2,8 en ambos casos). Finalmente, para los votantes del PP ambos partidos estarían respectivamente en los puntos 3,3 y 2,2 de la escala.

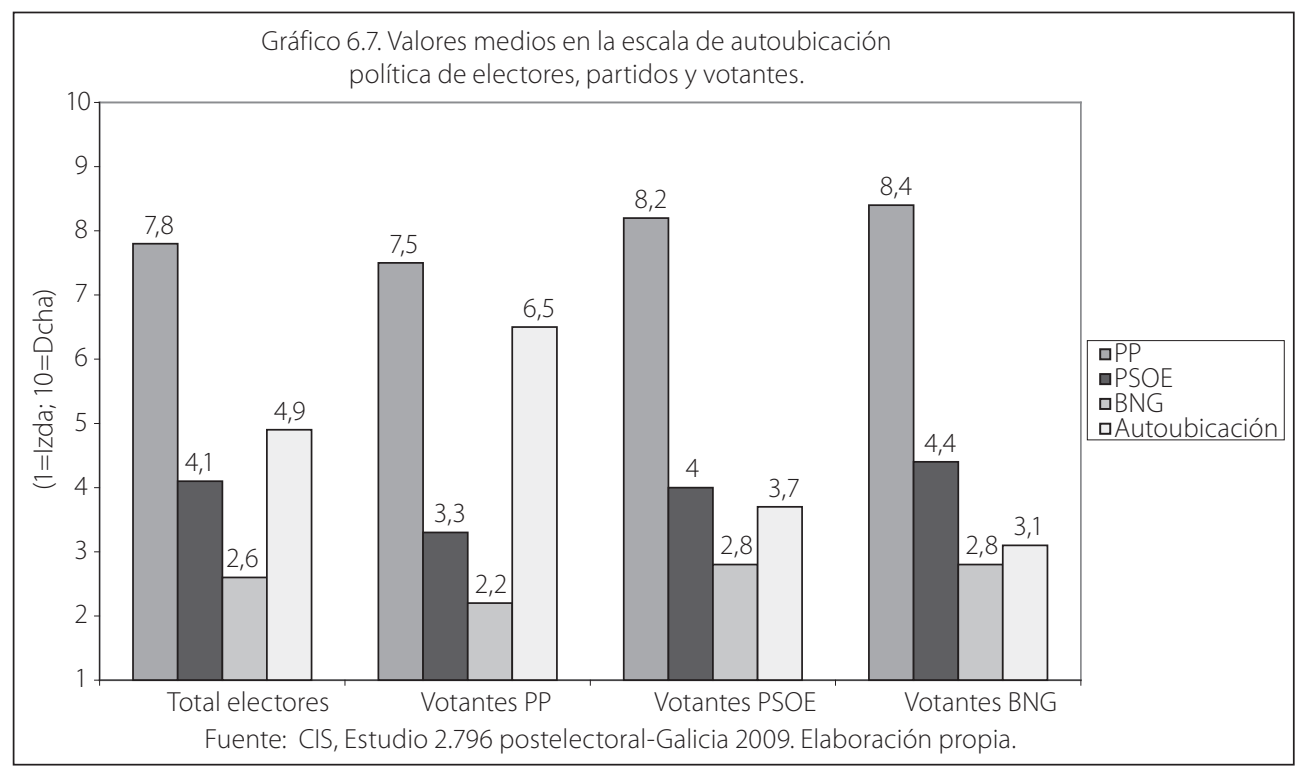

\subsubsection{El significado de las posiciones de izquierda y derecha}

Como se ha señalado, en España la dimensión izquierda-derecha ha tenido tradicionalmente como principales referentes los cleavages de clase y religión pero en la actualidad su importancia se habría visto reducida (Díez Medrano, 1994). Ahora trataremos de responder a la pregunta de en qué medida la transformación en las posiciones de la escala izquierda-derecha, a la que nos hemos referido al comienzo de esta parte, ha tenido lugar también entre los gallegos.

Para analizar esta problemática se llevaron a cabo pruebas estadísticas sobre muchas variables incluidas en los cuestionarios de la EMV y de las que aquí se presenta, por una parte, un resumen del análisis de correlación entre la variable relativa a la autoubicación izquierda-derecha y las variables clásicas de naturaleza socioeconómica, a las que se han añadido las relativas a la confianza en la Iglesia, la justificación del aborto y de la homosexualidad. Con el fin de comparar los resultados de Galicia con los de España y algunos países europeos, este análisis se realizó, en primer lugar sobre las series de la última oleada de la EMV (20052008) (Tabla 6.3). En segundo lugar, para tratar de determinar los cambios registrados en el significado de las posiciones a lo largo del período 1995-2008, se llevó a cabo el mismo análisis sobre las tres series de la EMV-Galicia (Tabla 6.4). Finalmente, se presenta un resumen de los valores medios de cada posición en la escala izquierda-derecha respecto a las variables incluidas en el análisis, lo cual 
permite entender mejor los componentes principales de cada posición en Galicia (Tabla 6.5 y Gráfico 6.3) ${ }^{6}$.

La comparación de los resultados de Galicia con los de España y otros países europeos permite afirmar que Galicia y España muestran unas pautas similares aunque con algunos matices diferenciadores. Así, los valores de correlación relativos a las variables socioeconómicas y la responsabilidad del Estado sitúan a ambas en una posición intermedia, similar a la de Alemania. En cuanto a las otras variables, es decir, la confianza en la Iglesia y la justificación de la homosexualidad y el aborto, su incidencia sobre la dimensión izquierda-derecha supera a los demás países, incluyendo a los de mayor tradición católica, como Italia y Polonia.

Las principales diferencias entre Galicia y España afectan a los valores de correlación relativos a la igualdad en los ingresos (0,128 España; 0,215 Galicia) y la responsabilidad del Estado (0,091 España; 0,181 Galicia) que, como puede observarse, son superiores en Galicia. Estas diferencias son menores en cuanto a la confianza en la Iglesia, en lo que España supera a Galicia (0,400 y 0,377 respectivamente) y, en sentido inverso, a la justificación de la homosexualidad (Galicia, 0,335; España 0,287) En las otras tres cuestiones la similitud es la norma ${ }^{7}$.

Por lo que se refiere a la evolución de los valores de correlación en Galicia entre 1995 y 2008 la Tabla 6.3 muestra, por una parte, un incremento en lo relativo a la igualdad de ingresos y la responsabilidad del Estado, si bien ese incremento es algo superior en lo primero (de 0,077 a 0,215 ) que en lo segundo (de 0,043 a 0,181). Las otras dos variables clásicas, relativas a la bondad de la competencia y a la naturaleza pública o privada de la propiedad de las empresas, mostraban en 1995 unos valores relativamente importantes (0,115 y 0,247 respectivamente) pero en 2008 menguaron notablemente (0,002 y 0,199, respectivamente). Finalmente, en cuanto a la confianza en la Iglesia y a la justificación de la homosexualidad y el aborto los valores de correlación superan a los de las variables clásicas y las dos últimas muestran una tendencia ascendente en las dos últimas series (Tabla 6.3).

Estas observaciones se complementan con la información que se resume en la Tabla 6.5 y en el Gráfico 6.3, en los que para cada posición de la dimensión izquierda-derecha, se pueden observar los valores medios respecto a las siete variables incluidas en el análisis.

6 Las preguntas correspondientes a las variables clásicas pedían a los entrevistados que manifestaran su grado de acuerdo en una escala de 1 a 10 con varias frases presentadas de forma bipolar y que concretamente se referían a: (1) la igualdad de ingresos frente al esfuerzo individual, (2) la propiedad pública o privada de las empresas, (3) la responsabilidad del individuo o del Estado para lograr un medio de vida, y (4) la naturaleza positiva o negativa de la competencia. Por otra parte, las relativas a (5) la justificación del aborto y (6) la homosexualidad también contaban con una escala de 1 a 10, pero la relativa a (7) la confianza en la Iglesia se formuló inicialmente sobre una escala de 1 a 4 aunque aquí se presenta proyectada en otra de 1 a 10 para poder establecer comparaciones.

7 Los valores del coeficiente de correlación van de -1 a +1. El signo del coeficiente indica la dirección de la relación y el valor absoluto del coeficiente de correlación indica la fuerza de la relación entre las variables. Los valores absolutos mayores indican que la relación es mayor. 


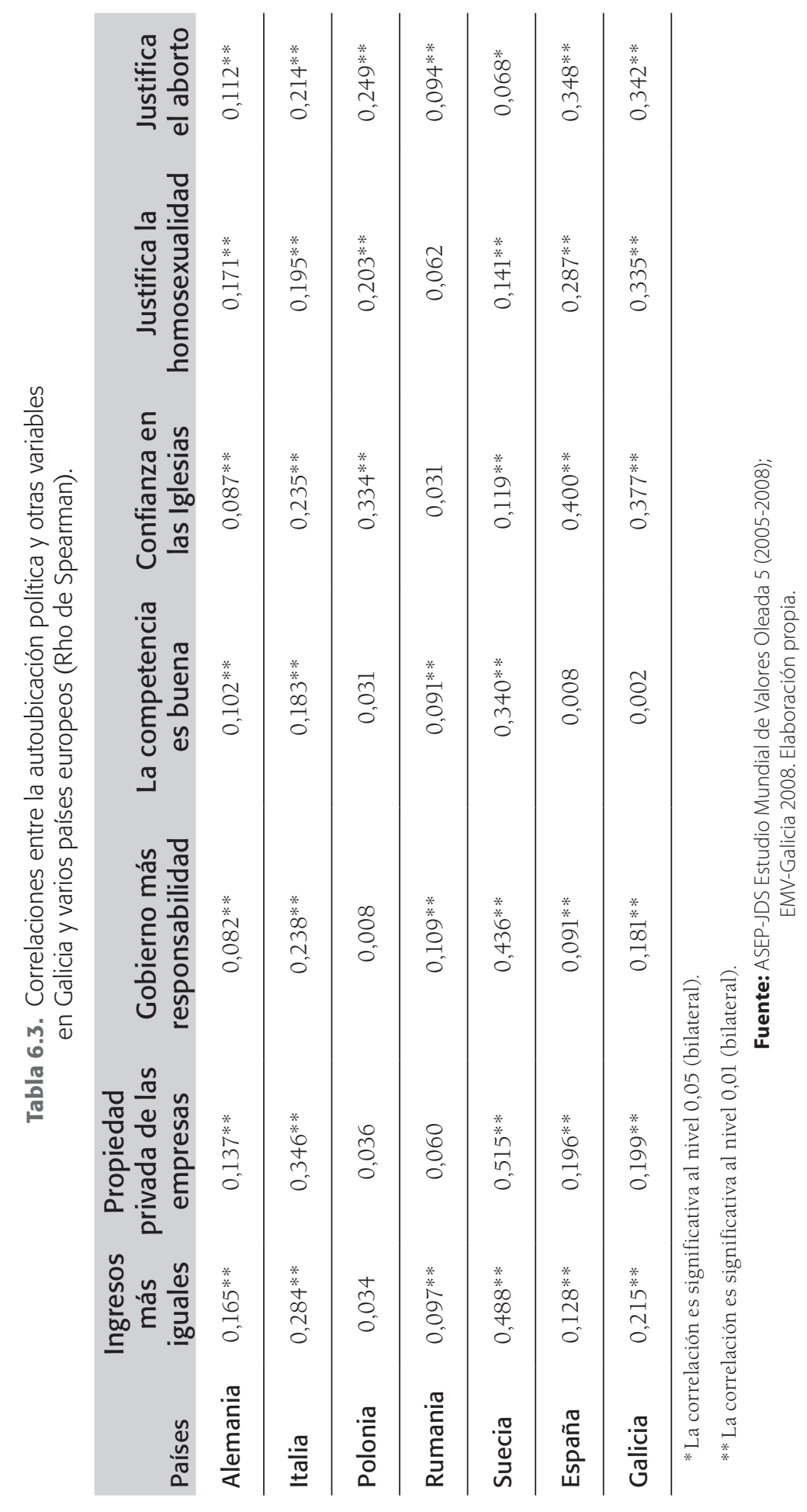

VALORES POLÍTICOS Y PARTICIPACIÓN EN GALICIA... 139 
Tabla 6.4. Evolución de los valores de correlación entre la autoubicación política y otras variables en Galicia (Rho de Spearman).

\begin{tabular}{|c|c|c|c|c|}
\hline & & \\
\hline & & 1995 & 2001 & 2008 \\
\hline \multirow{3}{*}{$\begin{array}{l}\text { Los ingresos deberían } \\
\text { ser más iguales }\end{array}$} & $\begin{array}{c}\text { Coeficiente } \\
\text { de correlación }\end{array}$ & $0,077^{*}$ & $0,150 * *$ & $0,215^{* *}$ \\
\hline & Sig. (bilateral) & 0,018 & 0,000 & 0,000 \\
\hline & Casos & 957 & 893 & 1557 \\
\hline \multirow{3}{*}{$\begin{array}{l}\text { Debería incrementarse } \\
\text { la propiedad privada } \\
\text { de las empresas }\end{array}$} & $\begin{array}{c}\text { Coeficiente } \\
\text { de correlación }\end{array}$ & $0,247 * *$ & $0,190 * *$ & $0,199 * *$ \\
\hline & Sig. (bilateral) & 0,000 & 0,000 & 0,000 \\
\hline & Casos & 885 & 829 & 1534 \\
\hline \multirow{3}{*}{$\begin{array}{l}\text { El Gobierno debería } \\
\text { asumir más } \\
\text { responsabilidad en } \\
\text { proporcionar un } \\
\text { medio de vida }\end{array}$} & $\begin{array}{c}\text { Coeficiente } \\
\text { de correlación }\end{array}$ & 0,043 & $0,116^{* *}$ & $0,181^{* *}$ \\
\hline & Sig. (bilateral) & 0,192 & 0,001 & 0,000 \\
\hline & Casos & 936 & 896 & 1553 \\
\hline \multirow{3}{*}{$\begin{array}{l}\text { La competencia } \\
\text { es buena }\end{array}$} & $\begin{array}{c}\text { Coeficiente } \\
\text { de correlación }\end{array}$ & $0,115^{* *}$ & 0,048 & 0,002 \\
\hline & Sig. (bilateral) & 0,000 & 0,155 & 0,937 \\
\hline & Casos & 938 & 881 & 1556 \\
\hline \multirow{3}{*}{$\begin{array}{l}\text { Confianza } \\
\text { en la Iglesia }\end{array}$} & $\begin{array}{c}\text { Coeficiente } \\
\text { de correlación }\end{array}$ & $0,388 * *$ & $0,350 * *$ & $0,377^{* *}$ \\
\hline & Sig. (bilateral) & 0,000 & 0,000 & 0,000 \\
\hline & Casos & 966 & 910 & 1555 \\
\hline \multirow{3}{*}{$\begin{array}{l}\text { Justifica } \\
\text { la homosexualidad }\end{array}$} & $\begin{array}{c}\text { Coeficiente } \\
\text { de correlación }\end{array}$ & $0,278^{* *}$ & $0,286^{* *}$ & $0,335^{* *}$ \\
\hline & Sig. (bilateral) & 0,000 & 0,000 & 0,000 \\
\hline & Casos & 929 & 845 & 1533 \\
\hline \multirow{3}{*}{$\begin{array}{l}\text { Justifica } \\
\text { el aborto }\end{array}$} & $\begin{array}{c}\text { Coeficiente } \\
\text { de correlación }\end{array}$ & $0,327 * *$ & $0,324 * *$ & $0,342 * *$ \\
\hline & Sig. (bilateral) & 0,000 & 0,000 & 0,000 \\
\hline & Casos & 951 & 865 & 1549 \\
\hline
\end{tabular}

\footnotetext{
* La correlación es significativa al nivel 0,05 (bilateral).

** La correlación es significativa al nivel 0,01 (bilateral).
}

Fuente: EMV-Galicia 2008. Elaboración propia. 


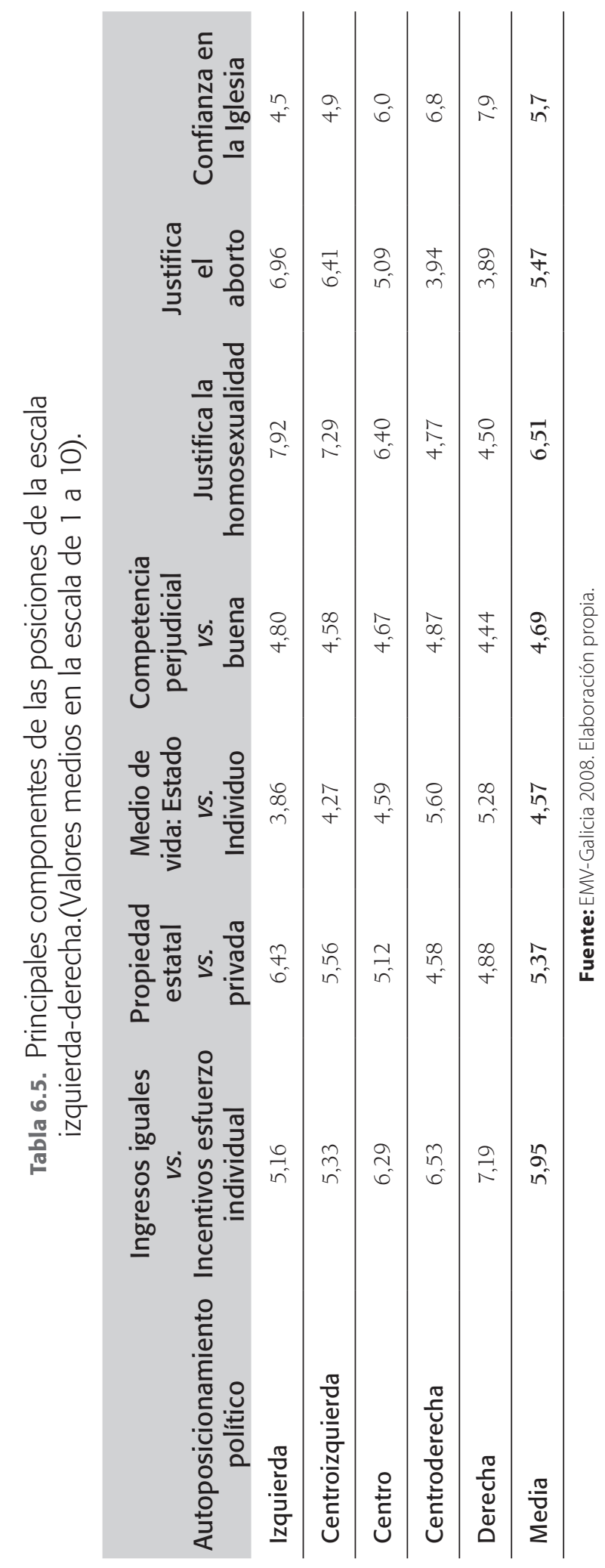

VALORES POLÍTICOS Y PARTICIPACIÓN EN GALICIA... 


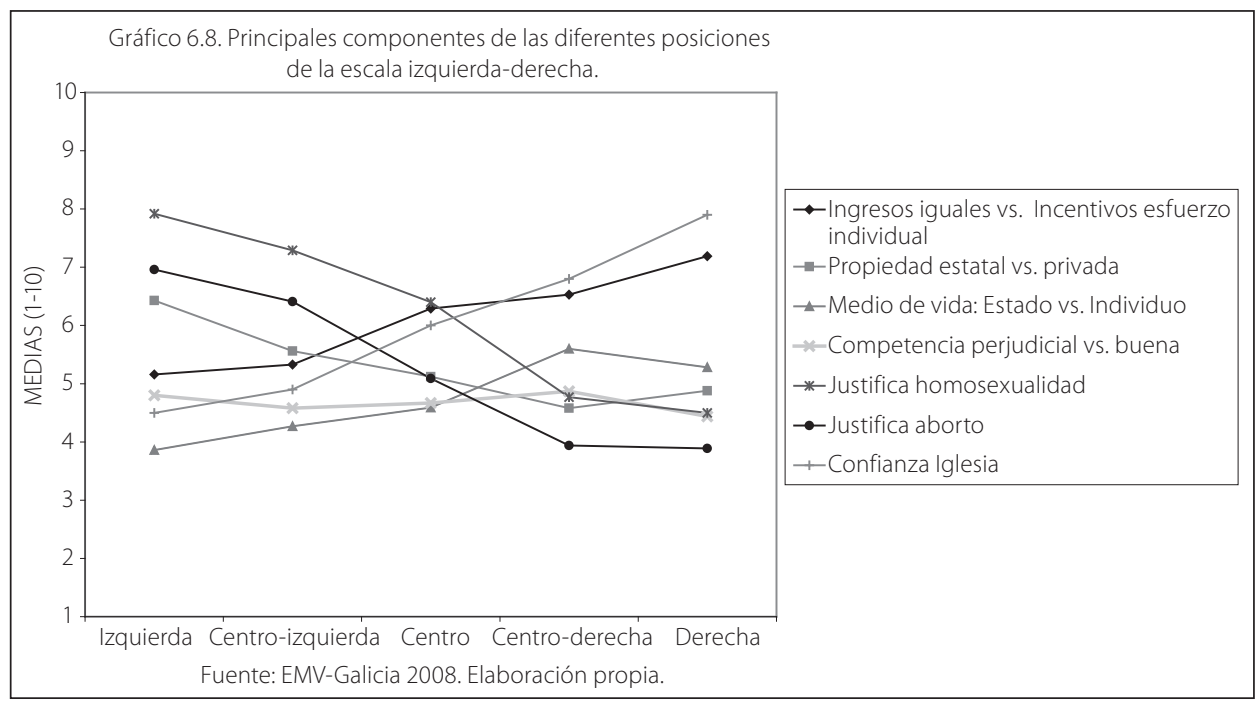

Como resumen de las anteriores observaciones puede afirmarse que la dimensión izquierda-derecha tiene en Galicia un papel relevante como elemento estructurador de valores y actitudes. Su evolución muestra, por una parte, que aunque haya menguado la incidencia de algunos temas clásicos, como el papel de la competencia o la propiedad de las grandes empresas, en cambio otros aspectos, como los relativos a la igualdad de los ingresos y el papel del Estado han incrementado su importancia. Este hecho puede explicarse por el inferior nivel de riqueza y la mayor precariedad laboral que puede haber en Galicia, aunque también puede estar relacionado con la actual crisis económica.

Por otra parte, el cleavage religioso y el debate sobre el papel de la Iglesia siguen manteniendo una relativa importancia aunque sin la trascendencia que tuvo en el pasado. Al mismo tiempo, han cobrado especial relevancia otros temas relativos a la independencia y la libertad personal, como son los de la justificación del aborto y de la homosexualidad. En todo caso, a la vista de la no excesiva polarización que puede observarse tanto al nivel agregado, en la distribución de la población a lo largo de la escala izquierda-derecha, como cuando se analizan de forma más singularizada los aspectos de la dimensión izquierda-derecha, Galicia se caracteriza por una relativa moderación política, una alta dosis de tolerancia y un consenso en lo fundamental.

Finalmente, la distribución de la población gallega en el eje izquierda-derecha confirma el carácter moderado de las posiciones políticas de la mayoría, pero también demuestra la falacia del extendido tópico consistente en considerar a los gallegos como conservadores (Sangrador, 1996). En efecto, si el conservadurismo se corresponde a las posiciones de derecha y centroderecha, el porcentaje de personas a las que se les podría aplicar esa etiqueta ideológica no supera el 20\% del total. 


\subsection{LA DEMOCRACIA}

Desde los primeros estudios que se publicaron al inicio de la transición, la democracia ha sido progresivamente considerada por los españoles como la mejor forma de gobierno. Este hecho sorprendió a muchos analistas, sobre todo teniendo en cuenta la prolongada experiencia de autoritarismo que supuso el franquismo y el hecho de que otros países que habían vivido experiencias similares no alcanzasen los niveles de aceptación de la democracia que se registraban en España. Las explicaciones del alto nivel de legitimidad con que comenzó contando la democracia se buscaron en la atracción que para los españoles suscitaba el desarrollo económico y las condiciones de vida que disfrutaban los países más avanzados de nuestro entorno. En este sentido, para la gran mayoría de los entrevistados la democracia sería el sistema de gobierno del mundo civilizado y, en particular, de nuestro contexto geocultural, de modo que resultaba muy difícil imaginar una alternativa mejor. En suma, el mimetismo respecto al exterior era el recurso con que suplir la ausencia de una secular tradición democrática (Vilas Nogueira, 1999: 24).

\subsubsection{Apoyos y críticas a la democracia}

Para la inmensa mayoría de los gallegos la democracia es actualmente la mejor forma de gobierno, de tal manera que los porcentajes de aceptación (como bueno o muy bueno para este país) superan desde 1995 el 90\% (94,8 en 2008). No obstante, esto tiene lugar al mismo tiempo que una amplia proporción de personas manifiesta una cierta insatisfacción tanto con su rendimiento y eficacia como con el funcionamiento de algunas de sus instituciones y, en general, con los partidos y la clase política.

Para analizar esta problemática la EMV incluyó una pregunta en la que se pedía a los entrevistados que valorasen la democracia y otras formas de gobierno, presentadas como alternativas para este país. Estas eran: (1) el gobierno de un líder fuerte, (2) el gobierno por expertos y (3) el gobierno militar ${ }^{8}$.

La evolución de estos indicadores puede resumirse, destacando, por una parte, que tras la importante reducción que tuvo lugar en 2001 en los porcentajes de quienes valoraban positivamente el gobierno por expertos y el de un líder fuerte, en la última serie (2007/08) se produjo un repunte de ambas variables. Por otra parte, la alternativa del gobierno militar tiene un carácter minoritario y tanto en 2001 como en 2008, apenas fue valorada positivamente por un cinco por cien de los entrevistados (Tabla 6.6 y Gráfico 6.9).

\footnotetext{
La formulación de la pregunta era la siguiente: "Ahora voy a describirle diversos tipos de sistemas políticos y a preguntarle qué piensa Vd. de cada uno de ellos como forma de gobernar este país. Para cada uno de ellos, ¿diría Vd. que es un modo muy bueno, bastante bueno, bastante malo o muy malo de gobernar este país?: 1. Tener un líder fuerte que no tuviera que preocuparse por el Parlamento ni por las elecciones. 2. Expertos, no un Gobierno, que tome las decisiones de acuerdo con lo que ellos piensen que es lo mejor para este país, 3. Tener un gobierno militar, 4. Tener un sistema democrático".
} 


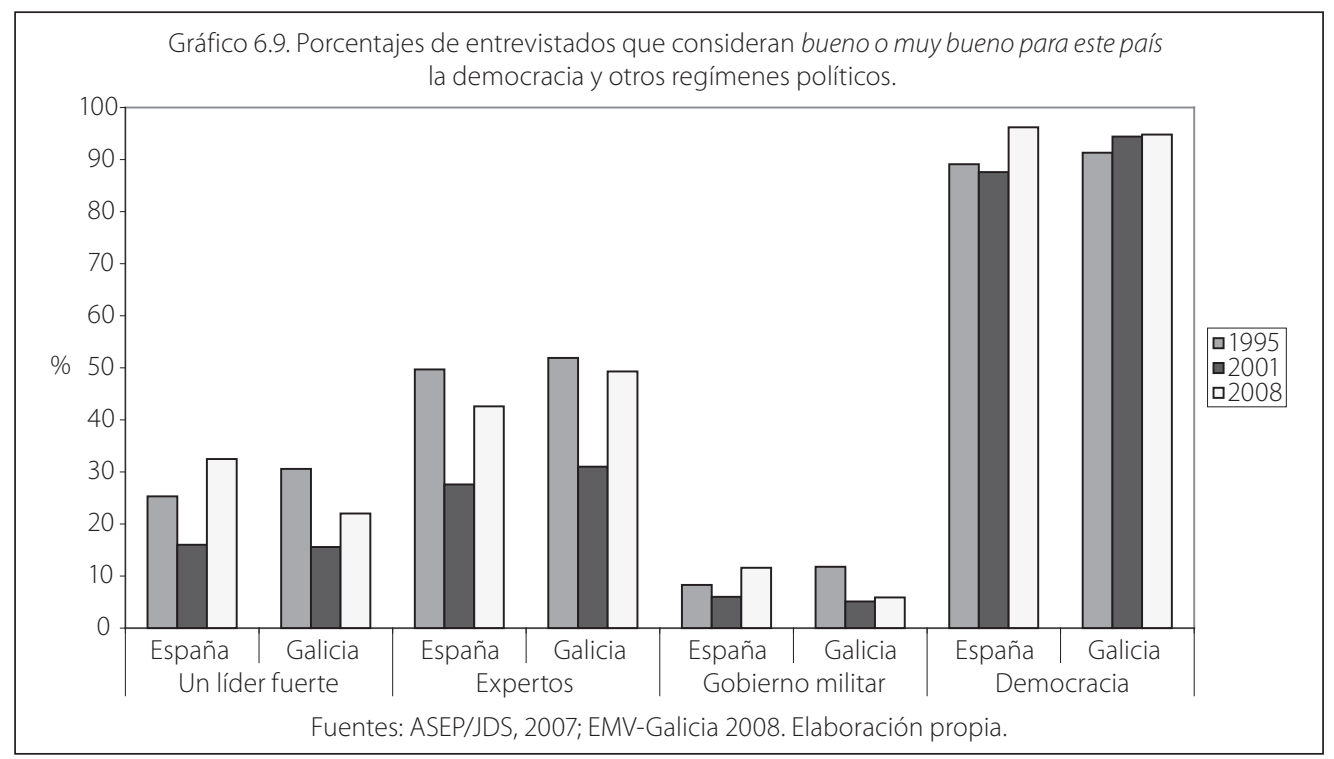

Tabla 6.6. Evolución de la valoración de la democracia y de otras formas de gobierno consideradas como buenas o muy buenas para este país.

\begin{tabular}{|c|c|c|c|c|}
\hline & & \\
\hline & & 1995 & 2001 & $2007 / 08$ \\
\hline \multirow{2}{*}{ Un líder fuerte } & España & 25,3 & 16,0 & 32,5 \\
\hline & Galicia & 30,6 & 15,6 & 22,0 \\
\hline \multirow{2}{*}{ Expertos } & España & 49,7 & 27,6 & 42,6 \\
\hline & Galicia & 51,9 & 31,0 & 49,3 \\
\hline \multirow{2}{*}{ Gobierno militar } & España & 8,3 & 6,0 & 11,6 \\
\hline & Galicia & 11,8 & 5,1 & 5,9 \\
\hline \multirow{2}{*}{ Democracia } & España & 89,1 & 87,6 & 96,2 \\
\hline & Galicia & 91,3 & 94,4 & 94,8 \\
\hline
\end{tabular}

Fuente: ASEP/JDS, 2007; EMV-Galicia 2008. Elaboración propia.

La comparación con las cifras de España muestra, por una parte, que el gobierno de un líder fuerte y el gobierno militar comenzaron siendo algo superiores en Galicia pero en la última serie (2007/08) esta relación se invirtió y los porcentajes de España superaron los de Galicia en ambos conceptos. En el caso del líder fuerte la diferencia que comenzó siendo de cinco puntos se duplicó (32,5 España; 22,0 Galicia). En cuanto al gobierno militar esa diferencia es ahora de cinco puntos (11,6 España; 5,9 Galicia). Por otra parte, los apoyos con que cuenta en Galicia la opción

144 LA EVOLUCIÓN DE LOS VALORES SOCIALES EN GALICIA 
del gobierno por expertos superan a los de España y de la pequeña diferencia que había entre ambas en 1995 y 2001, se ha pasado a otra que llega en 2008 a los seis puntos porcentuales (42,6 España; 49,3 Galicia) (Tabla 6.6 y Gráfico 6.9).

Para completar la información sobre esta problemática, el Gráfico 6.10 permite observar los datos relativos a la última serie de la EMV para Galicia y varios países europeos. Por una parte, la aceptación del gobierno por expertos es muy elevada en todos ellos y, salvo en Suecia $(36,2)$ e Italia $(48,8)$, todos superan el porcentaje gallego. Por otra parte, en cuanto al gobierno por un líder fuerte la situación se invierte, y tanto Galicia como España presentan porcentajes algo superiores al resto, con la notable excepción de Rumanía $(78,2)$. Finalmente, respecto al gobierno militar, Galicia muestra un porcentaje similar al de Alemania $(3,2)$, Italia $(6,5)$ y Suecia $(4,7)$, e inferior como ya se ha señalado, al de España $(11,9)$. Los países excomunistas incluidos en el Gráfico 6.10 superan el 20\%.

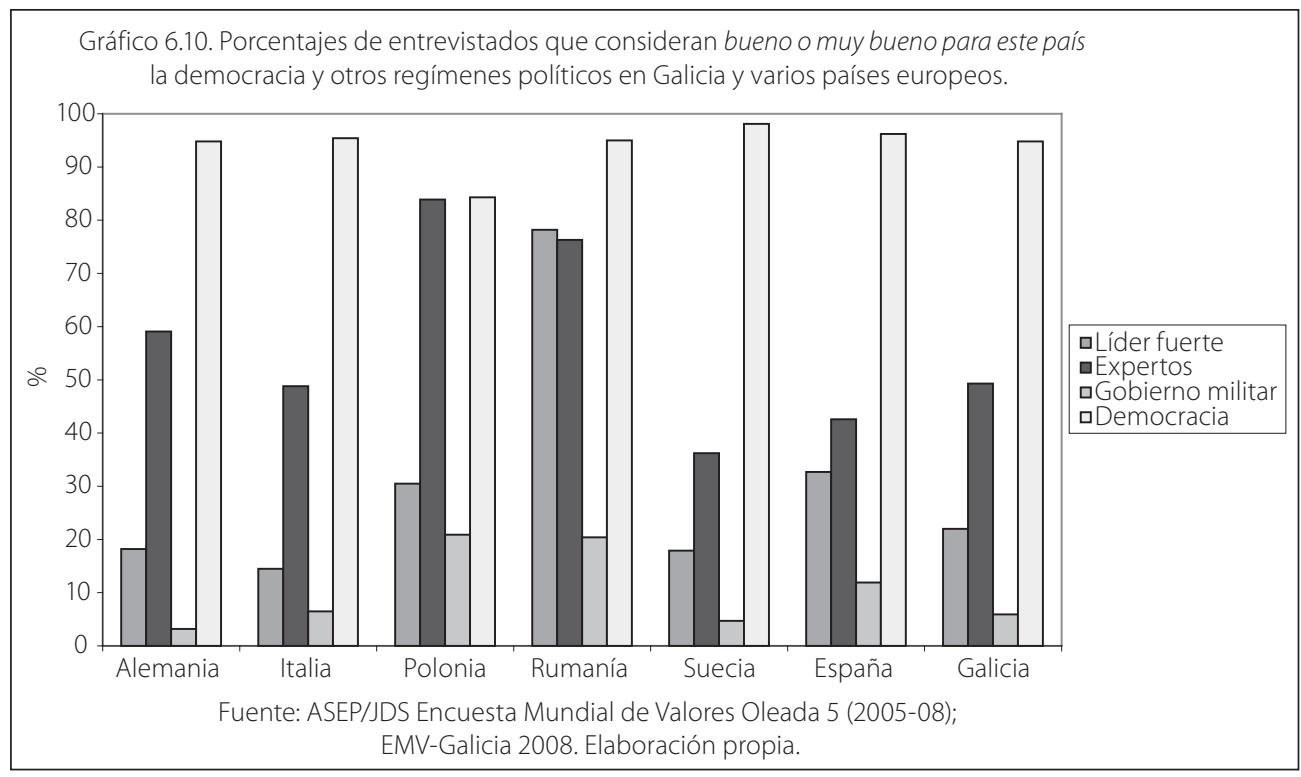

\subsubsection{Incongruencias en las respuestas y posibles explicaciones}

Si tenemos en cuenta tanto la importante legitimidad con que cuenta la democracia así como las altas puntuaciones que obtienen las alternativas del líder fuerte y, sobre todo, el gobierno por expertos, parece inevitable concluir que en este punto existe una clara incongruencia en las respuestas de los entrevistados. Por ejemplo, en Galicia, entre los que consideraban como bueno o muy bueno el gobierno de un líder fuerte, nada menos que el 91,7 opinaba lo mismo del gobierno democrático; para el gobierno de expertos este porcentaje era del 95,5; e incluso para el gobierno militar del 77,7 .

Para aclarar esta situación, se realizó un análisis de correlación entre las cuatro formas de gobierno con los datos de las tres series de la EMV y como era de esperar 
todas las correlaciones (salvo en 2008 la del gobierno por expertos) tienen signo negativo, es decir, la valoración de la democracia está en relación inversa a la de sus alternativas con la única excepción del gobierno por expertos en la serie de 2008. El valor de las correlaciones permite afirmar, en este sentido, que la incompatibilidad del gobierno militar con la democracia es muy fuerte, sobre todo en las series de $1995(-0,302)$ y $2008(-0,311)$. En cuanto a las otras alternativas a la democracia, aunque las correlaciones sean también estadísticamente significativas, el valor de correlación (y con ello la incompatibilidad) se reduce notablemente en relación con la alternativa del líder fuerte $(-0,242$ en 2008) y prácticamente desaparece en relación con el gobierno por expertos (0,052 en 2008) (Tabla 6.7).

Tabla 6.7. Correlaciones entre la democracia y otras formas de gobierno. Galicia 1995-2001 (Rho de Spearman).

\begin{tabular}{ccccc} 
& & Líder fuerte & Expertos & Gobierno militar \\
\hline \multirow{3}{*}{ Democracia } & 1995 & $-0,221^{* *}$ & $-0,005$ & $-0,302^{* *}$ \\
\cline { 2 - 5 } & 2001 & $-0,183^{* *}$ & $-0,028$ & $-0,068^{*}$ \\
\cline { 2 - 5 } & 2008 & $-0,242^{* *}$ & $0,052^{*}$ & $-0,311^{* *}$ \\
\hline
\end{tabular}

* La correlación es significativa al nivel 0,05 (bilateral).

** La correlación es significativa al nivel 0,01.

Fuente: EMV-Galicia 1995, 2001, 2008.

Dejando a un lado la alternativa del gobierno militar, que como decimos, representa una clara negación de la democracia, los apoyos que recibe tanto el gobierno de un líder fuerte como el gobierno por expertos obedecen a factores de diferente naturaleza. Por una parte, más que de alternativas en el sentido duro del término, parecen representar una crítica sobre algunos aspectos del funcionamiento de la democracia realmente existente, así como una necesidad de rectificación, en el sentido, de un liderazgo más relevante así como de una clase política mejor preparada.

Teniendo en cuenta los valores de correlación y la evolución de los apoyos que reciben, la alternativa del líder fuerte parece estar mucho más asociada con factores coyunturales. Estos podrían estar representados por las situaciones de debilidad del gobierno al no contar con mayorías absolutas en el Parlamento. De hecho, mientras los mayores apoyos a la alternativa del líder fuerte se registraron en las series de 1995 y 2008, coincidiendo con gobiernos sin mayoría absoluta (el último de Felipe González y el segundo de Rodríguez Zapatero), los menores apoyos tuvieron lugar en la serie de 2001, en este caso correspondiéndose con el segundo gobierno de Aznar, que sí contaba con esa mayoría.

Finalmente, la mayor estabilidad que presentan los apoyos a la alternativa del gobierno por expertos parece evidenciar la presencia de factores más de fondo, 
de naturaleza más estructural, por su mayor alcance en el tiempo, relacionados, en nuestra opinión, con la escasa confianza en los partidos políticos y la clase política en general que caracteriza la cultura política de los gallegos y de los españoles, desde la instauración de la democracia.

\subsection{LA IMPORTANCIA Y EL INTERÉS POR LA POLÍTICA}

En los cuestionarios de Encuesta Mundial de Valores la pregunta sobre la importancia de la politica se plantea de forma genérica junto con otros aspectos de la vida como la familia, los amigos, el tiempo libre, el trabajo y la religión, remitiendo de esta forma a una dimensión afectiva, para conocer el lugar que ocupa entre las preocupaciones vitales de los ciudadanos. Por su parte la relativa al interés por la política supone pasar a una dimensión actitudinal y, por lo tanto, más próxima a la acción política.

Los resultados de las series de la EMV-Galicia muestran que entre 1995 y 2008, la proporción de entrevistados para los que la política tiene bastante o mucha importancia apenas superaba el $25 \%$ del total. Esta cifra es similar a la de España y dista bastante de las correspondientes a muchos países europeos (Gráfico 6.11). Por su parte, la pregunta relativa al interés por la política muestra una realidad similar, de manera que quienes declaran tener mucho o bastante apenas representan a algo más de un tercio del total de entrevistados tanto en Galicia como en España.

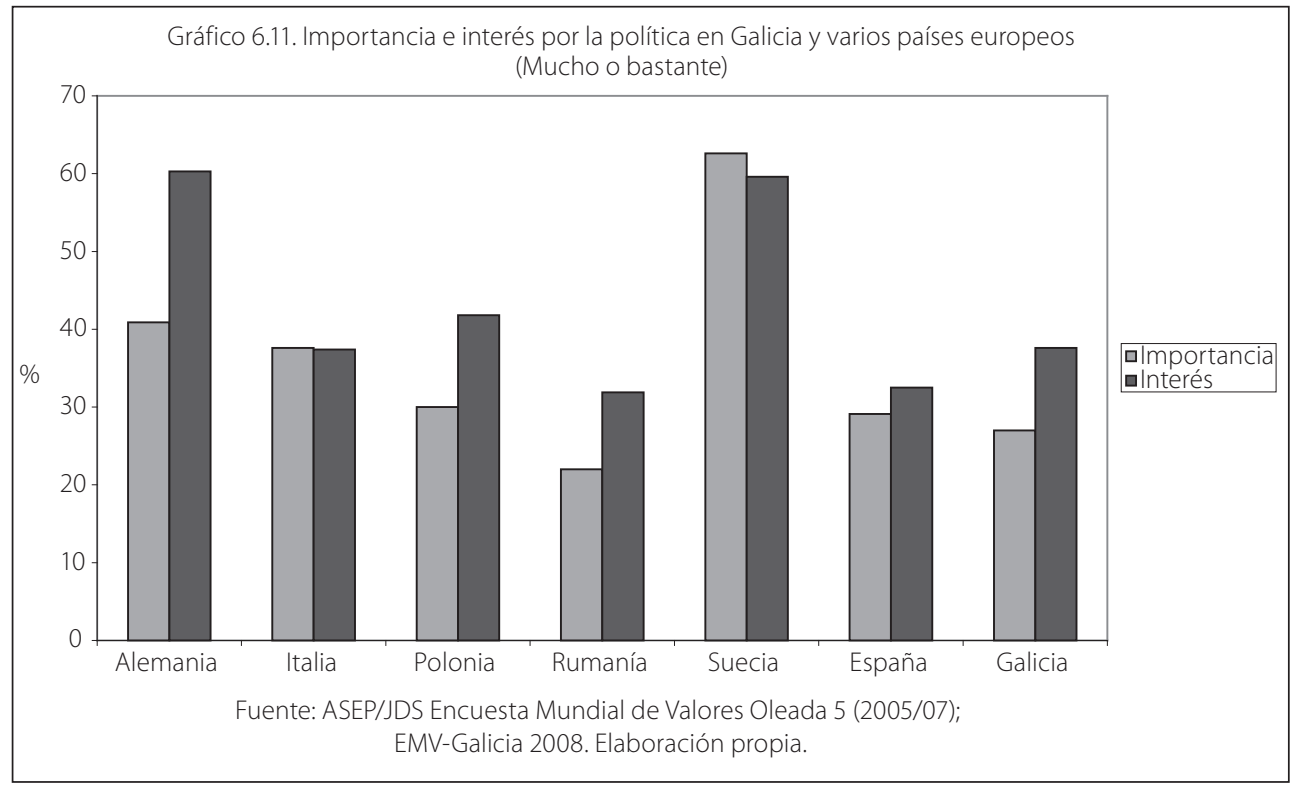

Cuando se trata de explicar por qué la política obtiene tan malos resultados es inevitable comenzar señalando que no estamos ante un clima de opinión, sino que se trata de una actitud fuertemente arraigada y cuya persistencia se puede observar desde el inicio de la democracia. Las pequeñas oscilaciones que se han 
podido registrar en este indicador están siempre relacionadas con el contexto político. Así, el interés fue creciente hasta 1978 coincidiendo con la aprobación de la Constitución, alcanzándose entonces la cota máxima de todo el período con un 38\% del total. Los índices fueron relativamente elevados también en 1981 (35\%) y en 1982 (33\%) por la trascendencia que se atribuyó tanto al intento del golpe de Estado como a la crisis de la UCD y las expectativas que generó la formación del primer gobierno socialista de la democracia recién instaurada. Sin embargo, a partir de 1982 el interés volvió a descender y la situación apenas ha variado desde entonces y ni la perspectiva de cambios de gobierno ni las noticias sobre escándalos políticos han conseguido incrementar el interés por la política (Míguez, 2001; Vallespín, 2008: 483-487).

Existe un amplio acuerdo en considerar que buena parte de las razones del alejamiento de la política hay que buscarlas en la complejidad de los procesos de decisión política, cuya comprensión requiere estar en disposición de un mínimo bagaje de elementos cognitivos, de manera que la política solo deja de ser inaccesible cuando el individuo logra comprenderla, lo que presupone estar en posesión de un adecuado nivel de estudios (Van Deth, 1995: 60-64; Morán y Benedicto, 1995: 44).

El análisis de las series de la EMV-Galicia confirma en parte lo anterior, ya que los porcentajes de quienes consideran bastante o muy importante la política o afirman tener mucho o bastante interés, se incrementan notablemente entre los miembros del grupo con mayor nivel de instrucción (43,7 y 57,2\% respectivamente). Estos porcentajes se reducen en veintiocho y diecinueve puntos respectivamente entre los entrevistados que cuentan con los niveles de estudios más bajos (Tabla 6.8). Por lo demás, la relevancia del nivel educativo eclipsa las tradicionales diferencias según sexo, ya que éstas pierden su fuerza explicativa cuando se analizan introduciendo como variable de control la relativa al nivel de estudios (Gráfico 6.12).

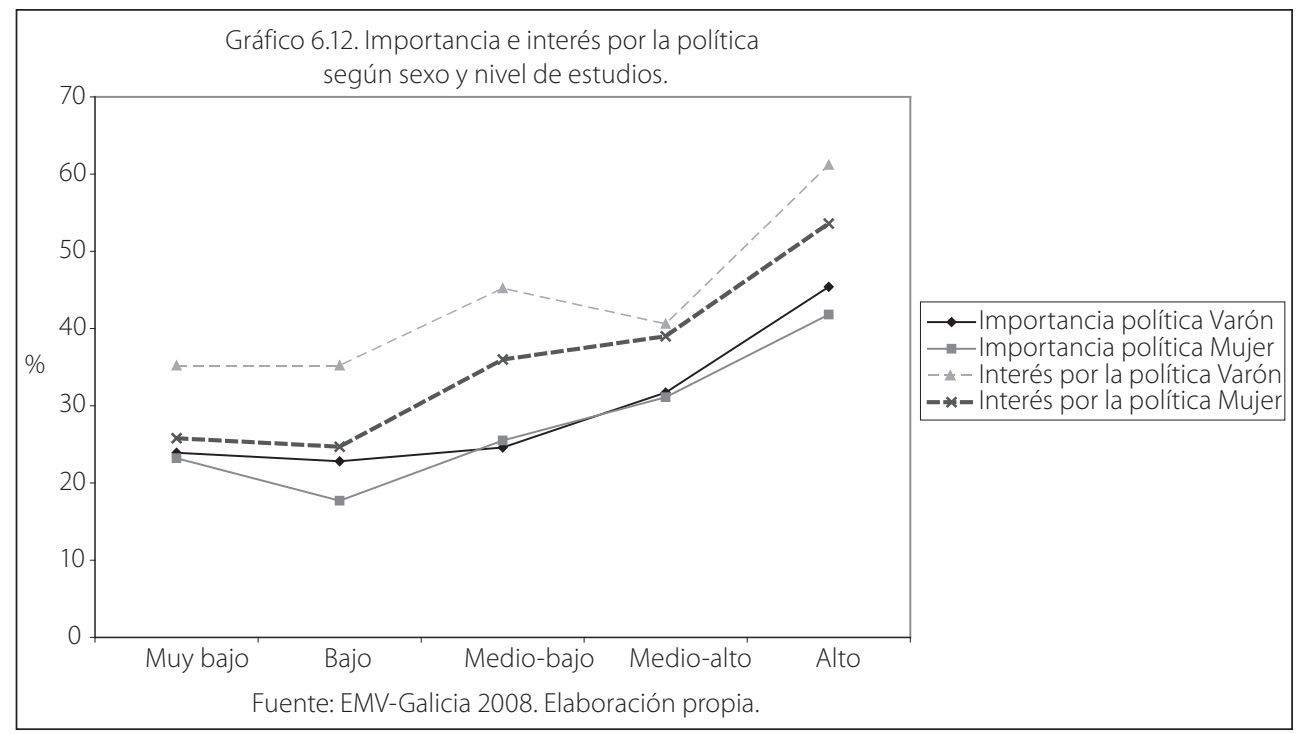


Tabla 6.8. Importancia e interés por la política según variables sociodemográficas y autoubicación política (Mucho o bastante).

\begin{tabular}{|c|c|c|c|}
\hline & & \\
\hline & & Interés & Importancia \\
\hline \multirow{2}{*}{ Sexo } & Varón & 41,8 & 27,6 \\
\hline & Mujer & 33,5 & 25,9 \\
\hline \multirow{6}{*}{ Edad } & $18-24$ & 39,5 & 26,5 \\
\hline & $25-34$ & 35,8 & 28,1 \\
\hline & $35-44$ & 42,1 & 25,6 \\
\hline & $45-54$ & 42,6 & 25,2 \\
\hline & $55-64$ & 41,5 & 31,8 \\
\hline & $65 y+$ & 29,5 & 25,6 \\
\hline \multirow{5}{*}{ Nivel de estudios } & Muy bajo & 29,5 & 23,5 \\
\hline & Bajo & 29,8 & 20,2 \\
\hline & Medio-bajo & 41,0 & 25,2 \\
\hline & Medio-alto & 40,1 & 32,1 \\
\hline & Alto & 57,2 & 43,7 \\
\hline \multirow{5}{*}{ Ocupación } & Trabaja & 41,2 & 27,0 \\
\hline & Jubilado/pensionista & 33,2 & 28,1 \\
\hline & Ama de casa & 28,0 & 21,0 \\
\hline & Estudiante & 40,8 & 33,6 \\
\hline & Parado & 36,4 & 26,5 \\
\hline \multirow{4}{*}{$\begin{array}{l}\text { Tamaño } \\
\text { del municipio }\end{array}$} & Menos de 10.001 hab. & 35,1 & 26,1 \\
\hline & 10.001-50.000 hab. & 37,7 & 23,8 \\
\hline & 50.001-200.000 hab. & 44,3 & 32,7 \\
\hline & Más de 200.000 hab. & 36,1 & 28,5 \\
\hline \multirow{5}{*}{$\begin{array}{l}\text { Autoposicionamiento } \\
\text { ideológico }\end{array}$} & Izquierda & 56,5 & 46,7 \\
\hline & Centroizquierda & 44,1 & 25,6 \\
\hline & Centro & 26,2 & 18,0 \\
\hline & Centroderecha & 36,6 & 31,6 \\
\hline & Derecha & 45,7 & 37,4 \\
\hline \multirow{4}{*}{$\begin{array}{l}\text { Intención } \\
\text { de voto }\end{array}$} & $\mathrm{PP}$ & 34,7 & 27,8 \\
\hline & PSOE & 44,0 & 27,7 \\
\hline & BNG & 54,9 & 38,9 \\
\hline & Abstención & 3,9 & 3,2 \\
\hline Total & & 37,6 & 27,0 \\
\hline
\end{tabular}

Fuente: EMV-Galicia 2008. Elaboración propia. 
Como acabamos de observar, aunque no hay duda sobre la relevancia de la variable nivel de estudios, esta condición no parece suficiente a la hora de explicar el grado de importancia e interés por la política, por lo que sería necesario analizar con mayor profundidad los factores que participan en la construcción de los significados de la política. Parece obvio que el estudio de esta cuestión desbordaría los límites de este capítulo, no obstante cabe apuntar algunas consideraciones.

En este sentido, se suelen señalar como principales factores de ese proceso de construcción de lo que significa la política para la mayoría de los ciudadanos: (1) las tradiciones sociales y políticas, y los procesos de socialización; (2) la acción de las élites en cuanto productoras e intérpretes de realidades y significados; (3) las pautas de interacción que mantienen individuos, grupos e instituciones en su calidad de actores políticos (Benedicto, 1997: 228-229; Míguez, 2007: 227).

En cuanto a la importancia de las tradiciones y los procesos de socialización se suele mencionar la herencia del régimen franquista, por el hecho de que las generaciones de mayor edad y que han tenido menos oportunidades educativas habrían sido socializadas en valores y actitudes de despolitización y apatía. Esta hipótesis fue planteada con preocupación en los últimos años de la dictadura como uno de los posibles handicaps de la nueva democracia española, si bien pronto se demostró su invalidez ante el éxito del proceso de resocialización de las generaciones de mayor edad (Justel, 1992).

También se ha insistido en la fuerte presencia entre los españoles de actitudes particularistas, lo que junto con la actual crisis generalizada de lo público, se manifestaría en el tan señalado proceso de privatización o individualización de los valores, en el que la política se reduciría a una mera gestión de asuntos privados (Vallespín, 2008: 486). En Galicia este proceso de individualización se ve reforzado por la presencia de unos sentimientos identitarios fuertemente localistas y ello tanto entre los propios ciudadanos como entre los partidos y las élites políticas, lo que acaba reduciendo el ámbito de la política no solo a un asunto privado sino a algo meramente local o, como mucho, comarcal o provincial ${ }^{9}$. En este sentido, el Gráfico 6.13 permite observar como el desinterés por la política está mucho más extendido entre quienes afirman sentirse más de la localidad en la que viven que entre quienes mantienen identidades supralocales.

En segundo lugar, en cuanto a los caracteres de la praxis de las élites políticas, éstos se pueden resumir por: (1) la opacidad y secretismo con las que rodean sus negociaciones para alcanzar pactos y compromisos, (2) la monopolización de la acción política por las cúpulas dirigentes de los partidos y (3) por la

Vid. Capítulo 5 de esta obra. 
tendencia a la privatización del discurso político, hasta convertirlo en una especie de reserva solamente accesible para iniciados. Así, en una reciente encuesta del CIS en Galicia, casi la mitad de los entrevistados se mostró bastante o muy de acuerdo con la frase que afirma que "generalmente, la política es tan complicada que la gente como yo no puede entender lo que pasa" (Gráfico 6.14).
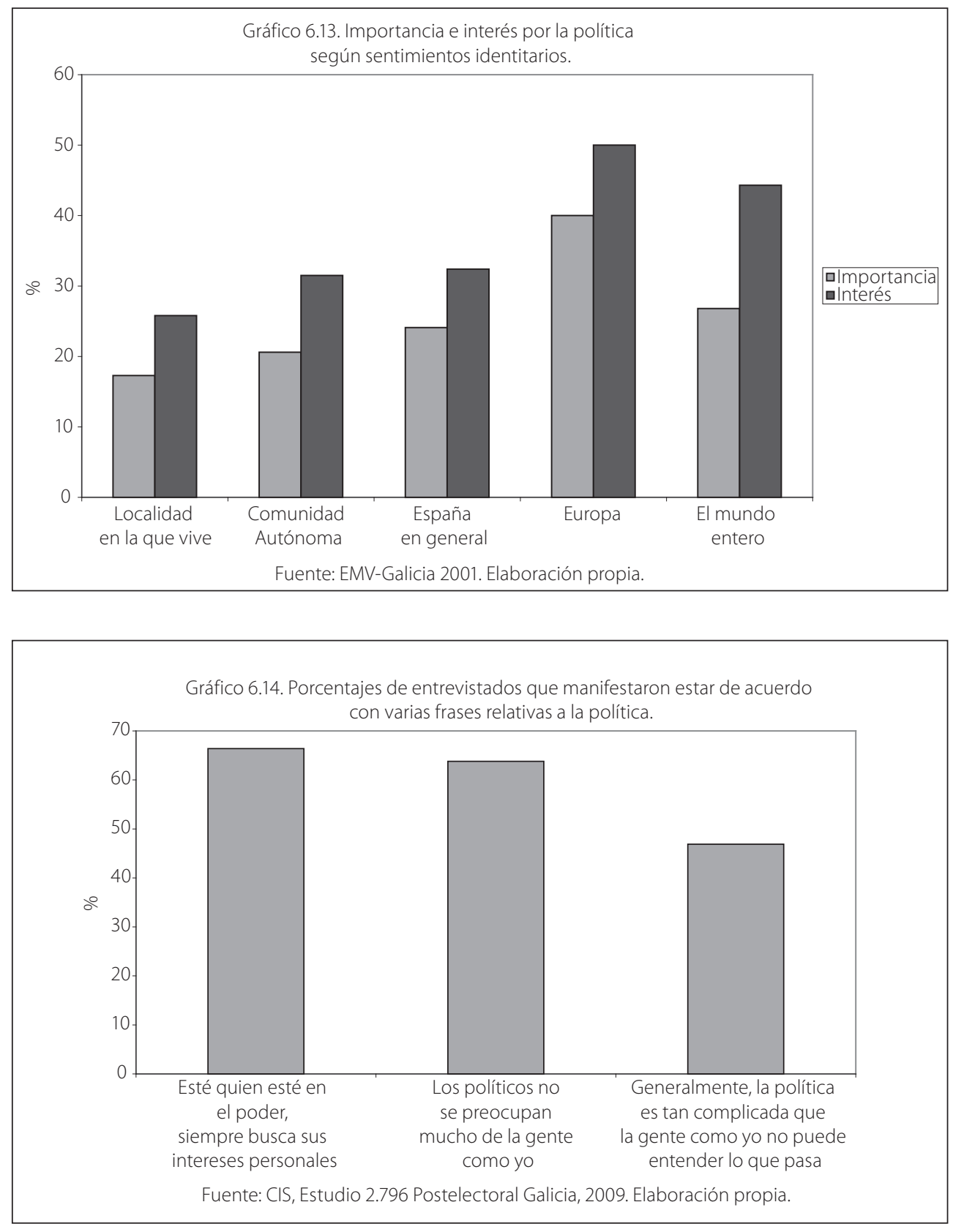
Finalmente, por lo que respecta a las pautas de interacción entre individuos, grupos e instituciones políticas, los estudios de opinión permiten comprobar la fuerte presencia de sentimientos de ineficacia política personal y de alienación política. Por ejemplo, en el mismo estudio del CIS en torno al 65\% de los entrevistados manifestó estar de acuerdo con frases en las que se afirmaba que "los políticos no se preocupan mucho de la gente como yo" o "esté quien esté en el poder, siempre busca sus intereses personales" (Gráfico 6.14).

\subsection{LA PARTICIPACIÓN POLÍTICA}

\subsubsection{Concepto y formas de participación}

La teoría de la democracia parte de la premisa de que sin competencia entre las élites y sin participación ciudadana no hay democracia. Así, tanto desde una perspectiva normativa como desde un planteamiento minimalista de la democracia, es necesario que exista un cierto interés o curiosidad por la política así como un nivel de participación suficiente para trasladar las demandas y quejas de los ciudadanos. Además, la participación ciudadana obliga a los gobiernos y a los políticos a ser más responsables al sentirse controlados (Torcal, Montero y Teorell, 2006: 47; Bonet,Martín y Montero, 2006: 118).

En general, hasta la mitad del siglo XX hablar de participación política en los países con democracias consolidadas consistía básicamente en hablar de elecciones, campañas electorales y lobbying, es decir, un tipo de actividades protegidas y dirigidas por el propio sistema. Otras formas de participación podían ser aceptadas, pero generalmente eran contempladas como excepcionales o no-convencionales. Por este motivo, la mayoría de las definiciones de la participación política consideraban que ésta podía entenderse como el conjunto de acciones llevadas a cabo por los ciudadanos con el fin de elegir a los principales miembros de la élite política o de influir en sus decisiones (Milbrath, 1965; Verba y Nie, 1972).

En el debate actual sobre la democracia se señalan algunas limitaciones en este tipo de definiciones por el hecho de que su objetivo o destino (target) hacia el que se dirige es exclusivamente la élite política. En este sentido, parece necesario ampliar el ámbito de la definición para incluir actividades dirigidas hacia corporaciones o instituciones no-gubernamentales, pero cuyas consecuencias tienen un claro sentido político (Font, J. y M. Méndez, 2008: 521). Piénsese, por ejemplo, en la ocupación del edificio de una empresa altamente contaminante por parte de un grupo ecologista o en una campaña de boicots por parte de un grupo feminista a la compra de productos cuya publicidad se basa en mensajes sexistas. Y es que en la sociedad industrial avanzada el llamado proceso de movilización cognitiva, que trae consigo mayores niveles de educación e información, produce tipos más activos y exigentes de participación de masas. Es decir, la participación electoral 
sigue siendo deseable como ejemplo de obligación cívica, pero ya no es un indicador fiable de participación ciudadana y cada vez están más extendidas formas de participación dirigidas a influir en decisiones políticas específicas, aunque no siempre estén orientadas hacia las instituciones políticas. Se trata de un nuevo activismo político que se caracteriza por (1) desafiar a las élites, (2) buscar objetivos concretos, (3) basarse en grupos ad-hoc y, finalmente, (4) por requerir unos mayores niveles de cualificación política (Inglehart, 1998: 223).

\subsubsection{La participación electoral}

\section{Las elecciones en Galicia: de la apatía a la participación}

Desde las primeras elecciones generales de 1977 hasta las europeas de 2009, los gallegos han sido llamados a las urnas en treinta y seis ocasiones. En este período tuvieron lugar diez elecciones generales, ocho autonómicas y ocho locales, seis europeas y cuatro referéndums. Solo hubo siete años, de los treinta y dos del período, sin ninguna consulta electoral ${ }^{10}$.

Galicia cuenta con unas cifras medias de participación inferiores a las nacionales en todo tipo de elecciones. Esto es debido fundamentalmente a los altos niveles de abstención que se registraron hasta bien entrada la década de los ochenta, cuando el diferencial de abstención respecto a la media nacional superaba los diez puntos porcentuales. En elecciones generales lo hizo así hasta 1986, en las elecciones locales hasta 1983, en las autonómicas hasta 1985, y en las europeas hasta 1989. A partir de entonces, el progresivo incremento de la participación ha hecho que la situación se modificase muy notablemente (Míguez, 1998) ${ }^{11}$.

Actualmente la diferencia con la media nacional ronda los 3-4 puntos porcentuales en elecciones generales. En elecciones locales las diferencias desaparecieron a partir de 1991. En las autonómicas, respecto a las CC. AA. con un régimen autonómico similar (Cataluña, País Vasco y Andalucía), Galicia dejó de ser la más abstencionista a partir de las terceras elecciones (1989), siendo desde entonces superada en varias ocasiones por Cataluña y el País Vasco.

Estos fueron 1984, 1988, 1990, 1992, 1998, 2002 y 2006.

11 Las altas cifras de abstención en las primeras convocatorias electorales deben una parte de su explicación a la Ilamada abstención técnica, motivada por la existencia de unos censos electorales deficientes, plagados de dobles inscripciones e incluso de personas ya fallecidas, debidas en muchos casos a la picaresca de los ayuntamientos de inflar sus padrones (a partir de los cuales se confeccionan los censos), para optar a mayores asignaciones presupuestarias. Esta era una práctica relativamente frecuente en regiones con menos recursos como Galicia, que cuenta con un alto porcentaje de población emigrada y/o ausente, temporal o permanentemente. La situación se agravó en las elecciones de 1979, por las deficiencias que generó la urgente inclusión de los mayores de 18 años. A comienzos de los años ochenta se calculaba que la abstención técnica aportaba al total de abstención un 10\% al nivel nacional, pero en Galicia era superior. Así, con motivo del referéndum autonómico (1980), en el que la abstención superó el 72\%, el Ministerio del Interior reconoció que en muchos ayuntamientos los censos estaban inflados en casi un 40\%. La depuración llevada a cabo en 1981 afectó a un millón de inscripciones al nivel nacional, pero su efecto sobre el descenso de la abstención solo se dejaría notar tras las elecciones generales de 1982. A partir de entonces y hasta 1991, las estimaciones sobre la abstención técnica rondaban el 2-5\% del total. Tras la depuración de 1991 las dobles inscripciones apenas superan, según la Oficina del Censo Electoral, el 1\% del total de censados y, en todo caso, debe tenerse en cuenta que a pesar de la revisión anual de los padrones municipales, las dobles inscripciones siguen un procedimiento lento para su rectificación como consecuencia de las cautelas establecidas para garantizar el derecho al sufragio. Fuente: INE. 
Finalmente, en las elecciones europeas los niveles de abstención son similares a los nacionales. En suma, a lo largo de este período, el descenso de la abstención en Galicia ha sido de tal magnitud que, como señaló Manuel Justel, representó el principal factor de la tendencia nacional hacia una mayor homogeneidad en los niveles interregionales de participación (Justel, 1995: 89 y 374).
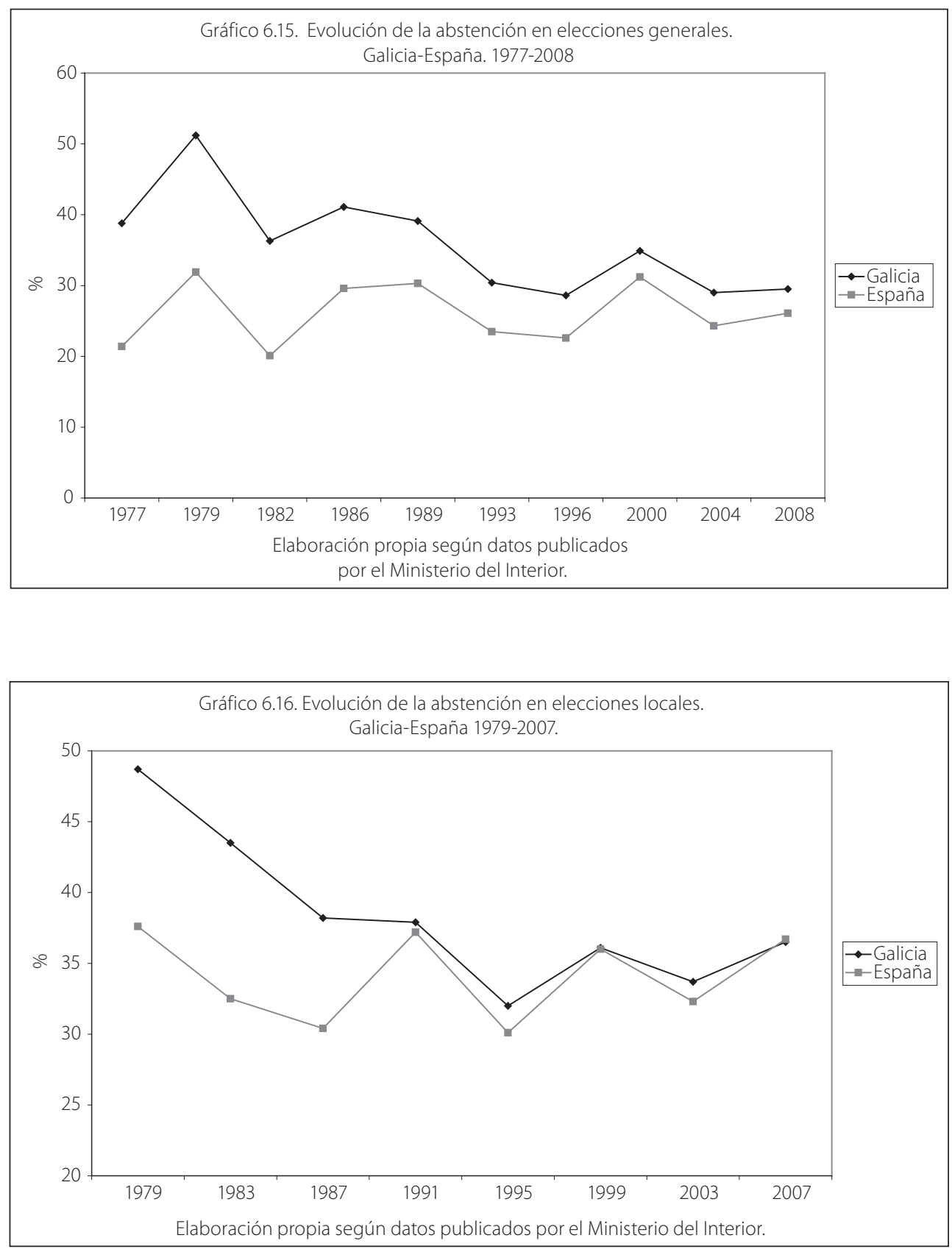

154 LA EVOLUCIÓN DE LOS VALORES SOCIALES EN GALICIA 

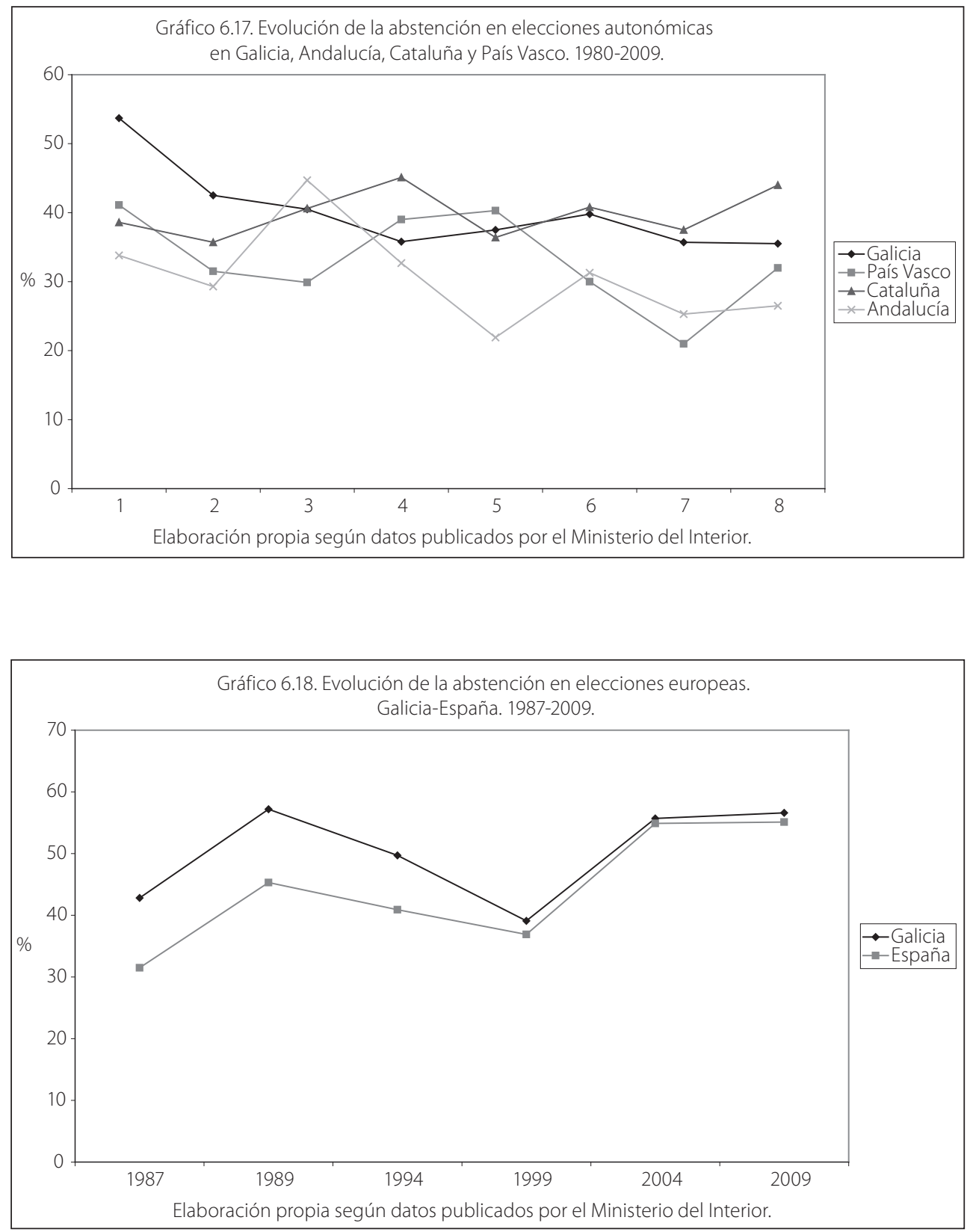
La participación según el tipo de elección

Las variaciones en los niveles de participación en los diferentes tipos de elecciones responden fundamentalmente a la importancia atribuida por electores y partidos a cada tipo de elección. En este punto, Galicia ha seguido una pauta similar a la media nacional. Así, los porcentajes más bajos de abstención corresponden a las elecciones generales, cuya cifra media para el período 1977-2008 es del 35,8. A éstas le siguen, en orden creciente de abstención, las elecciones locales $(38,3)$ y, a continuación, las autonómicas $(40,1)$. Finalmente, las menos participativas han sido las elecciones europeas, cuya cifra media de abstención en Galicia es del 50,2. En la Tabla 6.9 también se incluye información relativa a los referéndums. En este caso la cifra media de abstención es la más elevada (61\%), lo que está motivado sobre todo por la muy baja participación en el referéndum autonómico de 1980, en el que la abstención llegó al 72,7\% (tablas 6.9 a 6.13).

Tabla 6.9. Niveles medios de abstención en elecciones y referéndums 1977-2009.

\begin{tabular}{lccccc} 
& Generales & Autonómicas & Locales & Europeas & Referéndums \\
\hline Galicia & 35,8 & 40,1 & 38,3 & 50,2 & $61,0 / 57,2^{* *}$ \\
\hline España & 26,1 & $35,9^{*}$ & 34,1 & 44,3 & 43,8 \\
\hline $\begin{array}{l}\text { Diferencia } \\
\text { Galicia/España }\end{array}$ & 9,7 & 4,2 & 4,2 & 5,9 & $13,4^{* * *}$ \\
\hline
\end{tabular}

* Incluye las CC. AA. con el mismo régimen autonómico, es decir Andalucía, Cataluña, Galicia y País Vasco.

** El primer porcentaje incluye el referéndum de autonomía.

*** Para este cálculo se tienen en cuenta solo los referéndums nacionales.

Fuente: Elaboración propia a partir de los datos del Ministerio del Interior.

Tabla 6.10. Evolución de los niveles de abstención en elecciones generales. 1977-2008.

$\begin{array}{llllllllll}1977 & 1979 & 1982 & 1986 & 1989 & 1993 & 1996 & 2000 & 2004 & 2008\end{array}$ Media

\begin{tabular}{lccccccccccc}
\hline Galicia & 38,8 & 51,2 & 36,3 & 41,1 & 39,1 & 30,4 & 28,6 & 34,9 & 29 & 29,5 & 35,8 \\
\hline España & 21,4 & 31,9 & 20,1 & 29,6 & 30,3 & 23,5 & 22,6 & 31,2 & 24,3 & 26,1 & 26,1 \\
\hline $\begin{array}{l}\text { Diferencia } \\
\text { Galicia/España }\end{array}$ & 17,4 & 19,3 & 16,3 & 11,5 & 8,8 & 6,9 & 6,0 & 3,7 & 4,7 & 3,4 & 9,7 \\
\hline
\end{tabular}

Fuente: Elaboración propia a partir de los datos del Ministerio del Interior. 
Tabla 6.11. Evolución de los niveles de abstención en elecciones locales. 1979-2007.

$\begin{array}{lllllllll}1979 & 1983 & 1987 & 1991 & 1995 & 1999 & 2003 & 2007 & \text { Media }\end{array}$

\begin{tabular}{lccccccccc}
\hline Galicia & 48,7 & 43,5 & 38,2 & 37,9 & 32 & 36,1 & 33,7 & 36,5 & 38,3 \\
\hline España & 37,6 & 32,5 & 30,4 & 37,2 & 30,1 & 36 & 32,3 & 36,7 & 34,1 \\
\hline $\begin{array}{l}\text { Diferencia } \\
\text { Galicia/España }\end{array}$ & 11,1 & 11,0 & 7,8 & 0,7 & 1,9 & 0,1 & 1,4 & $-0,2$ & 4,2 \\
\hline
\end{tabular}

Fuente: Elaboración propia a partir de los datos del Ministerio del Interior.

Tabla 6.12. Evolución de los niveles de abstención en elecciones autonómicas en Galicia, País Vasco, Cataluña y Andalucía. 1981-2009.

\begin{tabular}{|c|c|c|c|c|c|c|c|c|c|}
\hline & 1 & 2 & 3 & 4 & 5 & 6 & 7 & 8 & Media \\
\hline Galicia & 53,7 & 42,5 & 40,5 & 35,8 & 37,5 & 39,8 & 35,7 & 35,5 & 40,1 \\
\hline País Vasco & 41,1 & 31,5 & 29,9 & 39,0 & 40,3 & 30,0 & 21,0 & 32,0 & 33,1 \\
\hline Cataluña & 38,6 & 35,7 & 40,6 & 45,1 & 36,4 & 40,8 & 37,5 & 44,0 & 39,8 \\
\hline Andalucía & 33,8 & 29,3 & 44,7 & 32,7 & 21,9 & 31,3 & 25,3 & 26,5 & 30,6 \\
\hline
\end{tabular}

Fuente: Elaboración propia a partir de los datos del Ministerio del Interior.

Tabla 6.13. Evolución de los niveles de abstención en elecciones europeas. 1987-2009.

\begin{tabular}{lccccccc} 
& 1987 & 1989 & 1994 & 1999 & 2004 & 2009 & Media \\
\hline Galicia & 42,8 & 57,2 & 49,7 & 39,1 & 55,7 & 56,6 & 50,2 \\
\hline España & 31,4 & 45,2 & 40,8 & 36,9 & 54,8 & 55,1 & 44,3 \\
\hline $\begin{array}{l}\text { Diferencia } \\
\text { Galicia/España }\end{array}$ & 11,4 & 12,0 & 8,9 & 2,2 & 0,5 & 1,5 & 5,9 \\
\hline
\end{tabular}

Elaboración propia a partir de los datos del Ministerio del Interior.

Diferencias interprovinciales

Galicia comenzó siendo la región con los mayores contrastes internos en sus tasas de participación electoral. En este sentido, las provincias más urbanizadas y desarrolladas económicamente (Pontevedra y A Coruña) empezaron siendo más participativas que las más rurales y menos desarrolladas (Lugo y Ourense) (Tabla 6.14). Esta situación parecía mostrar una relación de asociación entre los niveles de participación y los caracteres socioeconómicos pero se ha modificado 
a lo largo del período. Concretamente, las diferencias interprovinciales se han reducido notablemente, dando lugar tanto a unos niveles de abstención más homogéneos, y la ordenación de las provincias según sus niveles de abstención es muy diferente de la inicial. En este sentido, aunque las provincias de A Coruña y Pontevedra han seguido una evolución relativamente similar, las de Lugo y Ourense registran ahora las mayores diferencias, lo que revela la presencia de factores adicionales a los meramente socioeconómicos.

Tabla 6.14. Niveles medios de abstención en elecciones y referéndums por provincias (1977-2009).

\section{Generales Autonómicas Locales Europeas Referéndums}

\begin{tabular}{llllll}
\hline Galicia & 35,8 & 40,1 & 38,3 & 50,2 & 61,0 \\
\hline A Coruña & 35,2 & 40,6 & 39,4 & 51,1 & 57,3 \\
\hline Lugo & 35,9 & 38,1 & 33,5 & 48,2 & 66,8 \\
\hline Ourense & 40,3 & 42,1 & 40,9 & 50,5 & 67,6 \\
\hline Pontevedra & 33,6 & 39,2 & 37,3 & 49,5 & 57,2 \\
\hline $\begin{array}{l}\text { Máxima } \\
\text { diferencia } \\
\text { interprovincial }\end{array}$ & 6,7 & 4 & 7,4 & 2,9 & 10,4 \\
\hline
\end{tabular}

Fuente: Elaboración propia a partir de los datos del Ministerio del Interior.

Concretamente, la provincia de Lugo comenzó registrando unos niveles de abstención algo superiores a la media regional en generales y autonómicas, pero actualmente es la menos abstencionista en los cuatro tipos de elecciones. Esta condición la ostenta respecto a las elecciones generales desde 1996 y en las europeas desde 1999, pero en autonómicas se remonta a 1989 y en elecciones locales ha sido siempre la más participativa (salvo en 1987 por muy poca diferencia). Por su parte, Ourense aunque sigue siendo la más abstencionista en elecciones generales, desde las del año 2000 ha visto reducida la diferencia con la provincia más participativa a poco más de tres puntos porcentuales. En los otros tres tipos de elecciones también comenzó siendo la más abstencionista, pero esa condición la perdió a partir de 1993 (tablas 6.15 a 6.18). 


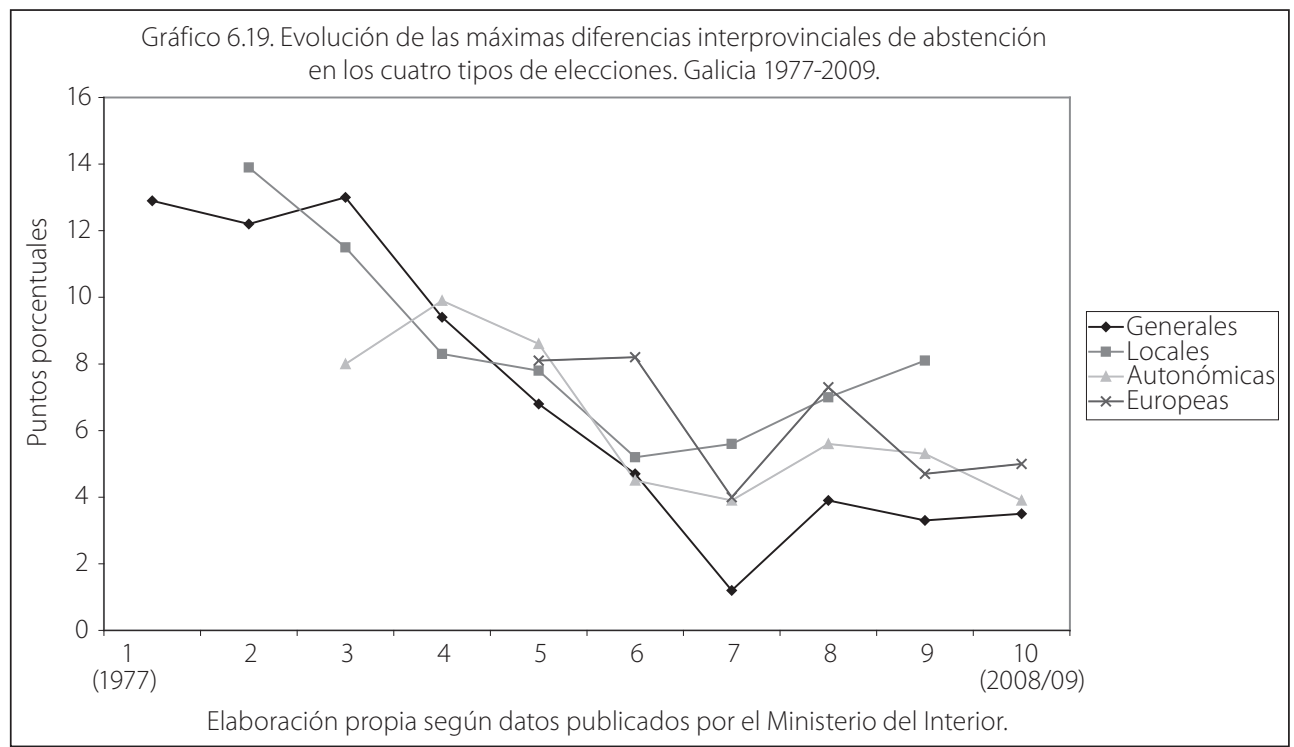

Tabla 6.15. Evolución de los niveles de abstención en elecciones generales por provincias.

1977197919821986198919931996200020042008 Media

\begin{tabular}{lccccccccccc}
\hline Galicia & 38,8 & 51,2 & 36,3 & 41,1 & 39,1 & 30,4 & 28,6 & 34,9 & 29 & 29,5 & 35,8 \\
\hline A Coruña & 36,6 & 46,6 & 35,0 & 40,3 & 39,2 & 30,2 & 29,1 & 36,1 & 29,4 & 30,0 & 35,2 \\
\hline Lugo & 43,3 & 49,3 & 39,2 & 43,2 & 38,8 & 30,1 & 27,9 & 32,2 & 27,6 & 27,9 & 35,9 \\
\hline Ourense & 47,3 & 57,8 & 44,9 & 49,3 & 43,7 & 33,7 & 29,1 & 34,8 & 31,9 & 31,4 & 40,3 \\
\hline Pontevedra & 34,4 & 45,6 & 31,9 & 39,9 & 36,9 & 29,0 & 27,9 & 34,6 & 27,8 & 28,7 & 33,6 \\
\hline $\begin{array}{l}\text { Máxima } \\
\text { diferencia } \\
\text { interprovincial }\end{array}$ & 12,7 & 12,2 & 13,0 & 9,4 & 6,8 & 4,7 & 1,2 & 3,9 & 3,3 & 3,5 & \\
\hline
\end{tabular}

Fuente: Elaboración propia a partir de los datos del Ministerio del Interior. 
Tabla 6.16. Evolución de los niveles de abstención en elecciones locales por provincias.

\begin{tabular}{lccccccccc} 
& 1979 & 1983 & 1987 & 1991 & 1995 & 1999 & 2003 & 2007 & Media \\
\hline Galicia & 48,7 & 43,5 & 38,2 & 37,9 & 32,0 & 36,1 & 33,7 & 36,5 & 38,3 \\
\hline A Coruña & 49,1 & 42,1 & 39,9 & 38,9 & 34,2 & 37,6 & 35,1 & 38,8 & 39,4 \\
\hline Lugo & 42,5 & 37,6 & 35,5 & 32,5 & 29,0 & 32,0 & 28,6 & 30,7 & 33,5 \\
\hline Ourense & 56,4 & 49,1 & 43 & 40,3 & 32,2 & 34,8 & 35,6 & 35,9 & 40,9 \\
\hline $\begin{array}{l}\text { Pontevedra } \\
47,2\end{array}$ & 40,3 & 34,7 & 38,0 & 32,8 & 36,4 & 33,4 & 36,1 & 37,3 \\
\hline $\begin{array}{l}\text { Máxima } \\
\text { diferencia } \\
\text { interprovincial }\end{array}$ & 13,9 & 11,5 & 8,3 & 7,8 & 5,2 & 5,6 & 7,0 & 8,1 & \\
\hline
\end{tabular}

Fuente: Elaboración propia a partir de los datos del Ministerio del Interior.

Tabla 6.17. Evolución de los niveles de abstención en elecciones autonómicas por provincias.

\begin{tabular}{lccccccccc} 
& 1981 & 1985 & 1989 & 1993 & 1997 & 2001 & 2005 & 2009 & Media \\
\hline Galicia & 53,7 & 42,5 & 40,5 & 35,8 & 37,5 & 39,8 & 35,7 & 35,5 & 40,1 \\
\hline A Coruña & 52,6 & 40,9 & 40,7 & 37,6 & 38,9 & 40,9 & 36,7 & 37,0 & 40,6 \\
\hline Lugo & 57,4 & 43,0 & 36,8 & 33,1 & 35,0 & 35,3 & 31,4 & 33,1 & 38,1 \\
\hline Ourense & 58,5 & 49,7 & 45,4 & 36,4 & 36,3 & 39,4 & 35,5 & 35,8 & 42,1 \\
\hline Pontevedra & 50,5 & 40,8 & 39,3 & 34,4 & 37,2 & 40,4 & 36,4 & 34,6 & 39,2 \\
\hline $\begin{array}{l}\text { Máxima } \\
\text { diferencia } \\
\text { interprovincial }\end{array}$ & 8,0 & 8,9 & 8,6 & 4,5 & 3,9 & 5,6 & 5,3 & 3,9 & \\
\hline
\end{tabular}

Fuente: Elaboración propia a partir de los datos del Ministerio del Interior. 
Tabla 6.18. Evolución de los niveles de abstención en elecciones europeas (1987-2009).

\begin{tabular}{lccccccc} 
& 1987 & 1989 & 1994 & 1999 & 2004 & 2009 & Media \\
\hline Galicia & 42,8 & 57,2 & 49,7 & 39,1 & 55,7 & 56,6 & 50,2 \\
\hline A Coruña & 42,1 & 56,5 & 51,2 & 41,6 & 56,9 & 58,6 & 51,1 \\
\hline Lugo & 41,3 & 60,3 & 47,7 & 34,3 & 52,2 & 53,6 & 48,2 \\
\hline Ourense & 49,3 & 62,3 & 47,2 & 36,7 & 53,8 & 53,6 & 50,5 \\
\hline Pontevedra & 41,2 & 54,0 & 49,8 & 39,1 & 56,2 & 56,6 & 49,5 \\
\hline $\begin{array}{l}\text { Máxima } \\
\text { diferencia } \\
\text { interprovincial }\end{array}$ & 8,1 & 8,2 & 4,0 & 7,3 & 4,7 & 5,0 & 2,9 \\
\hline
\end{tabular}

Fuente: Elaboración propia a partir de los datos del Ministerio del Interior.

Participación electoral y variables sociodemográficas

El estudio de esta problemática plantea algunos problemas derivados del hecho de que en los estudios de opinión los porcentajes de entrevistados que declaran su comportamiento abstencionista son muy reducidos, lo que da lugar a que las submuestras de abstencionistas sean demasiado cortas para poder llevar a cabo análisis estadísticamente representativos de los diferentes grupos de entrevistados según edad, nivel de estudios, etc. No es difícil entender que para muchos entrevistados ocultar su condición de abstencionistas es moralmente menos costoso que reconocer que han incumplido con la obligación cívica de votar. En este sentido, para el estudio de los factores de la abstención parecen más indicadas otras técnicas de naturaleza cualitativa como las entrevistas en profundidad y los grupos de discusión ${ }^{12}$.

Teniendo en cuenta estas limitaciones, la Tabla 6.19 recoge los indicadores de la intención de voto en elecciones generales de las dos primeras series de la EMV-Galicia y el de recuerdo de voto de la serie de 2008. La evolución entre 1995 y 2008 se resume en los siguientes extremos. En primer lugar, según sexos, apenas se registran cambios en la composición de la abstención. En segundo lugar, según edades, ha tenido lugar un incremento entre los grupos intermedios (de entre 25 a 54 años), de tal manera que, sumados los porcentajes correspondientes en 1995 éstos aportaban el 38,3\% del total de la abstención,

12 Para entender este problema de forma más clara valga este ejemplo: en las autonómicas de 1993 la abstención real fue del 38,9\%, pero en el sondeo postelectoral del CIS de ese año (estudio 2.070) solo se declaró un 18\% de abstención, lo que supone una submuestra de abstencionistas de algo más de 350 casos, que es a todas luces insuficiente si se quiere hacer un análisis por grupos de edad o nivel de estudios. Sobre esta problemática, Justel, M. (1995) pp. 382 y ss. 
pero en 2008 llegaban hasta el 49,8. En tercer lugar, según nivel de estudios los datos muestran una reducción de la abstención en los niveles más bajos. En cuarto lugar, según la ocupación principal, ha tenido lugar un considerable aumento de la abstención entre los grupos profesionalmente activos (trabaja en la Tabla 6.19). Así, en 1995 el porcentaje que aportaba este colectivo al total de abstención era del 36,5\%, pero en 2008 se incrementó hasta el 51,3. Mientras tanto, la aportación de los estudiantes y las amas de casa se redujo en cuatro y catorce puntos respectivamente. Finalmente, según el tamaño del municipio de residencia lo más relevante ha sido, por una parte, el descenso de la abstención en los municipios de menos de diez mil habitantes y, en sentido opuesto, el incremento de la misma en los de mayor tamaño poblacional (más de 200.000) (Tabla 6.19).

Todas estas observaciones, junto con las relativas a la evolución de las diferencias provinciales del apartado anterior, confirman que Galicia comparte las tendencias observadas para España y otros países de nuestro entorno. En resumen, la abstención electoral ha pasado de ser un fenómeno fundamentalmente rural para concentrarse en los mayores núcleos urbanos y, al mismo tiempo, cada vez aparece menos asociada a los sectores de población dependiente (mayores, jóvenes y amas de casa) así como a los de menor nivel de estudios.

\section{Competitividad electoral y fluctuaciones en la participación}

Las fluctuaciones en los niveles de participación se pueden explicar por la debilidad de las identidades ideológicas y por la inexistencia de vínculos fuertes con los partidos, frente a una mayor influencia de factores coyunturales y especialmente por el grado de competitividad de cada elección ${ }^{13} \mathrm{o}$, si se prefiere, por la mayor o menor incertidumbre respecto al resultado y la posibilidad de una alternancia en el gobierno. En este sentido, España registra el nivel más elevado de fluctuación de los países de nuestro entorno europeo en las tasas de participación en elecciones generales (Font, J. y M. Méndez, 2008: 523; Montero, 1984).

En Galicia, las variaciones en los niveles de participación han seguido una pauta similar a la del resto de España y ello tanto en elecciones generales, como en las locales y europeas (Tabla 6.20). En las elecciones generales, dejando a un lado las inaugurales de 1977 y las de 1982, que tuvieron lugar tras un intento de golpe de estado y la crisis de la UCD, tanto en España como en Galicia las elecciones más participativas coinciden con aquellas que registran las menores diferencias en los resultados de los dos partidos más votados (1993, 1996, 2004 y 2008) (Gráfico 6.20).

13 Se entiende por competitividad la diferencia en porcentaje de votos (competitividad electoral) o de escaños (competitividad parlamentaria) entre los dos partidos más votados.

\section{LA EVOLUCIÓN DE LOS VALORES SOCIALES EN GALICIA}


Tabla 6.19. Composición de la abstención según variables sociodemográficas.

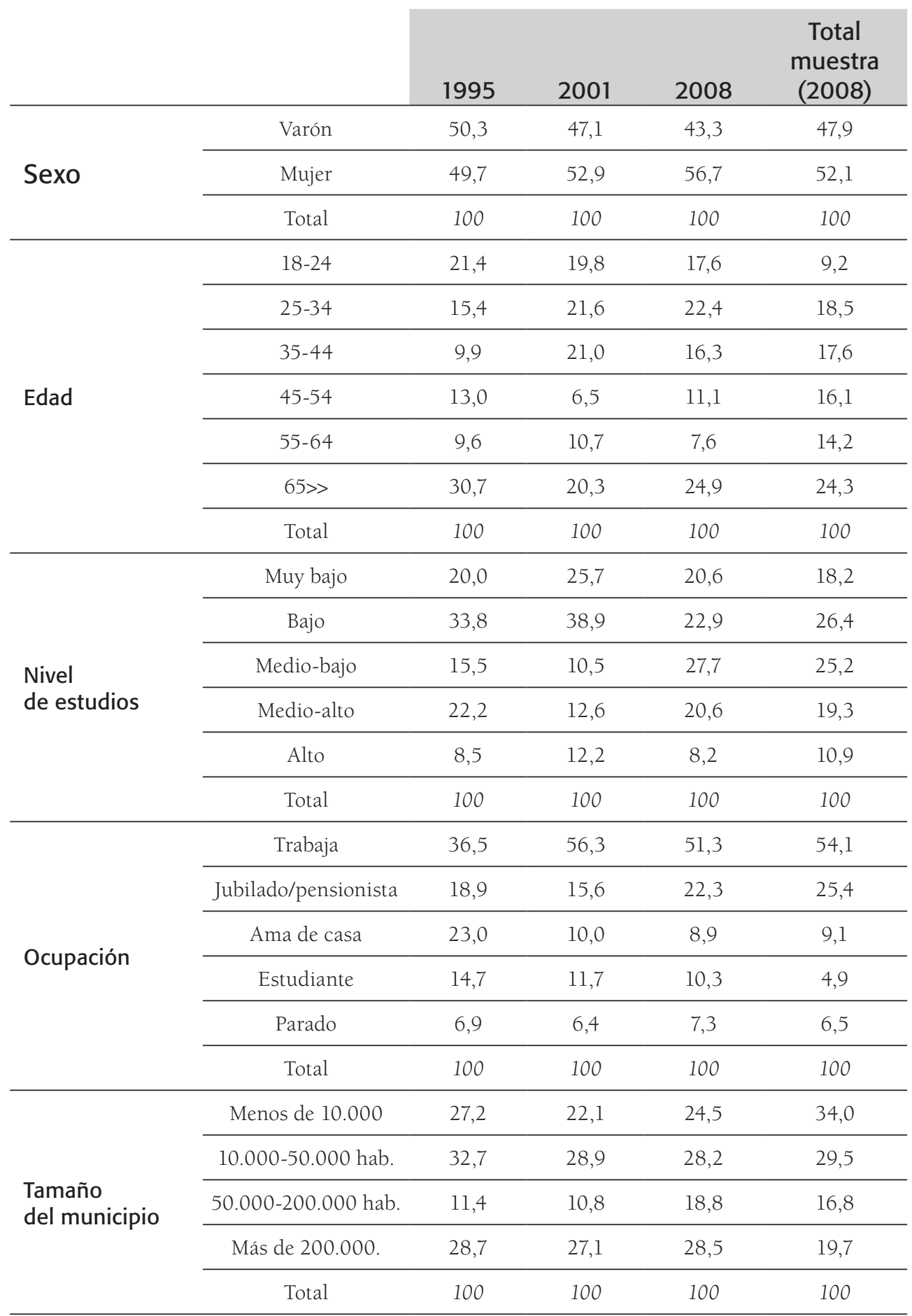

Fuente: EMV-Galicia 1995, 2001, 2008. Elaboración propia. 
Tabla 6.20. Fluctuación media en los cuatro tipos de elecciones (1977-2009).

\begin{tabular}{ccccc} 
& Generales & Autonómicas & Locales & Europeas \\
\hline Galicia & 6,4 & 3,7 & 3,7 & 10,0 \\
\hline España & 7,6 & $\begin{array}{c}\text { Andalucía: } 8,4 \\
\text { Cataluña: } 5,0 \\
\text { País Vasco: } 6,9\end{array}$ & 5,0 & 8,0 \\
\hline
\end{tabular}

Fuente: Elaboración propia a partir de datos del Ministerio del Interior.

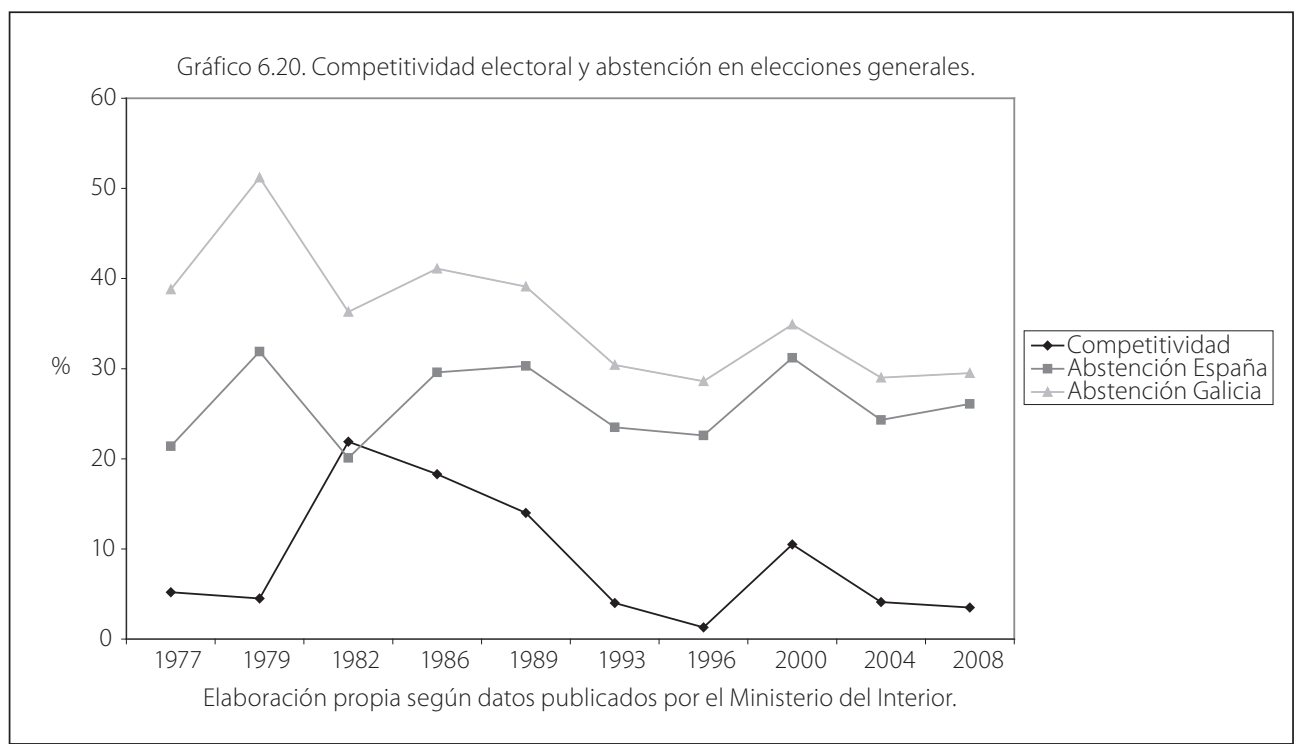

En cuanto a las elecciones locales, el nivel medio de fluctuación es algo inferior al de España (3,7 y 5,0 respectivamente) y el hecho de que sigan una pauta similar debe explicarse por el significado supramunicipal que ha ido adoptando este tipo de comicios, cada vez más influenciados por la coyuntura política nacional. En este sentido, cabe recordar que las elecciones municipales se caracterizan: (1) por su celebración simultánea a nivel estatal, (2) por el predominio de los partidos de ámbito estatal, en perjuicio de los partidos localistas y las listas de independientes, y (3) por el tratamiento de los resultados electorales por parte de los medios de comunicación y los propios partidos, que plantean este tipo de comicios como un referéndum sobre la gestión del gobierno central.

En las elecciones autonómicas el nivel medio de fluctuación es de 3,7 puntos, algo inferior al de las CC. AA. que celebran sus comicios en fechas diferentes a las de régimen común. En este caso, las fluctuaciones en los niveles de 
participación también están relacionadas con la incertidumbre de los resultados y el grado de competitividad. No obstante, hay que tener en cuenta que dada la naturaleza del subsistema gallego de partidos que, como ya se ha señalado, puede definirse como de partido predominante ${ }^{14}$, la posibilidad de alternancia en el gobierno está determinada por la pérdida de la mayoría absoluta pero, sobre todo, por la necesaria formación de una coalición de gobierno entre el segundo y el tercer partido (PSdeG-PSOE y BNG), ya que por separado ambos partidos distan mucho de obtener la mayoría absoluta. Por este motivo, en el Gráfico 6.21 se ha incluido junto con el índice de competitividad, la diferencia entre los porcentajes de votos del PP y los de la coalición PsdeG-PSOE y BNG.

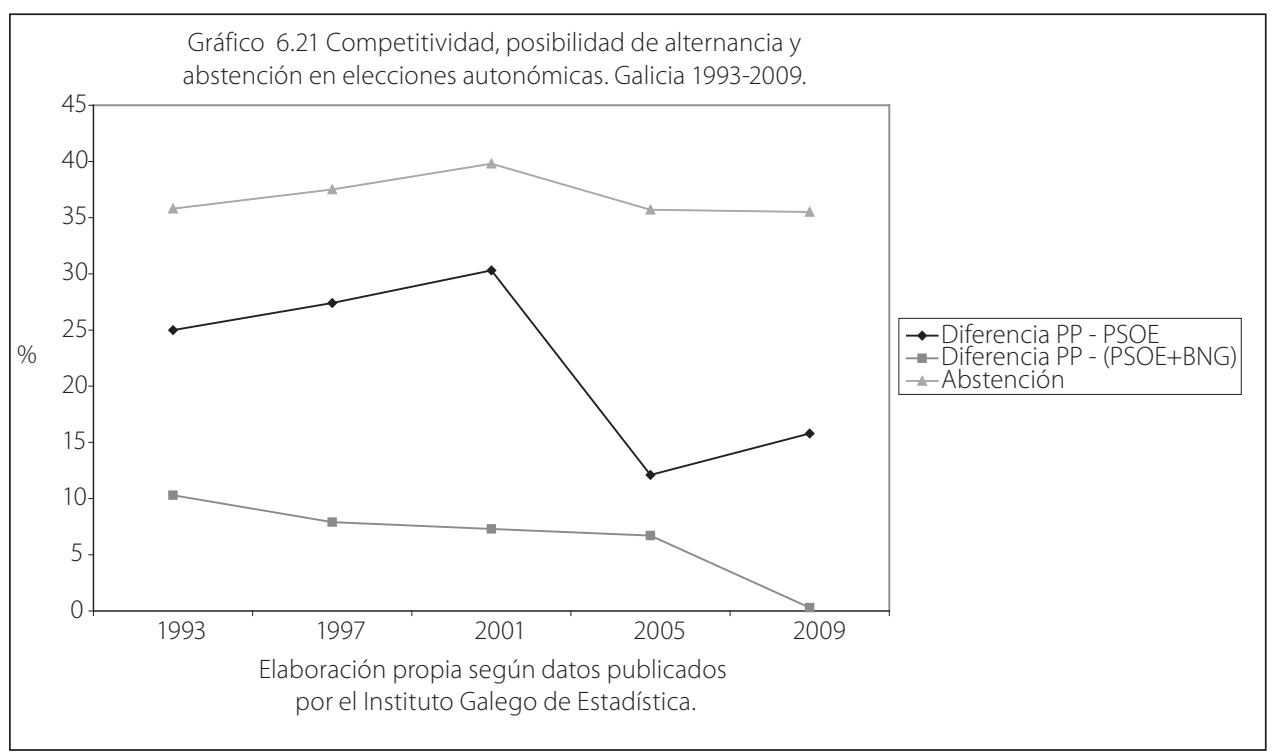

\subsubsection{Otras formas de participación: manifestaciones, peticiones y boicots}

De las tres formas de participación no-electoral incluidas en las series de la EMV, las más importantes tanto en Galicia como en España por los porcentajes de participantes que registra cada una de ellas, son las manifestaciones y la firma de peticiones, mientras que la llamada participación de consumo (boicots a la compra de determinados productos) es mucho más reducida. En general, otros países europeos mantienen una ordenación similar, aunque Galicia muestra niveles de participación inferiores en los tres tipos de participación, especialmente en la firma de peticiones y la participación en boicots (Gráfico 6.22).

14 Vid. supra el Apartado 6.1.4. La dimensión izquierda-derecha y la competición electoral. 

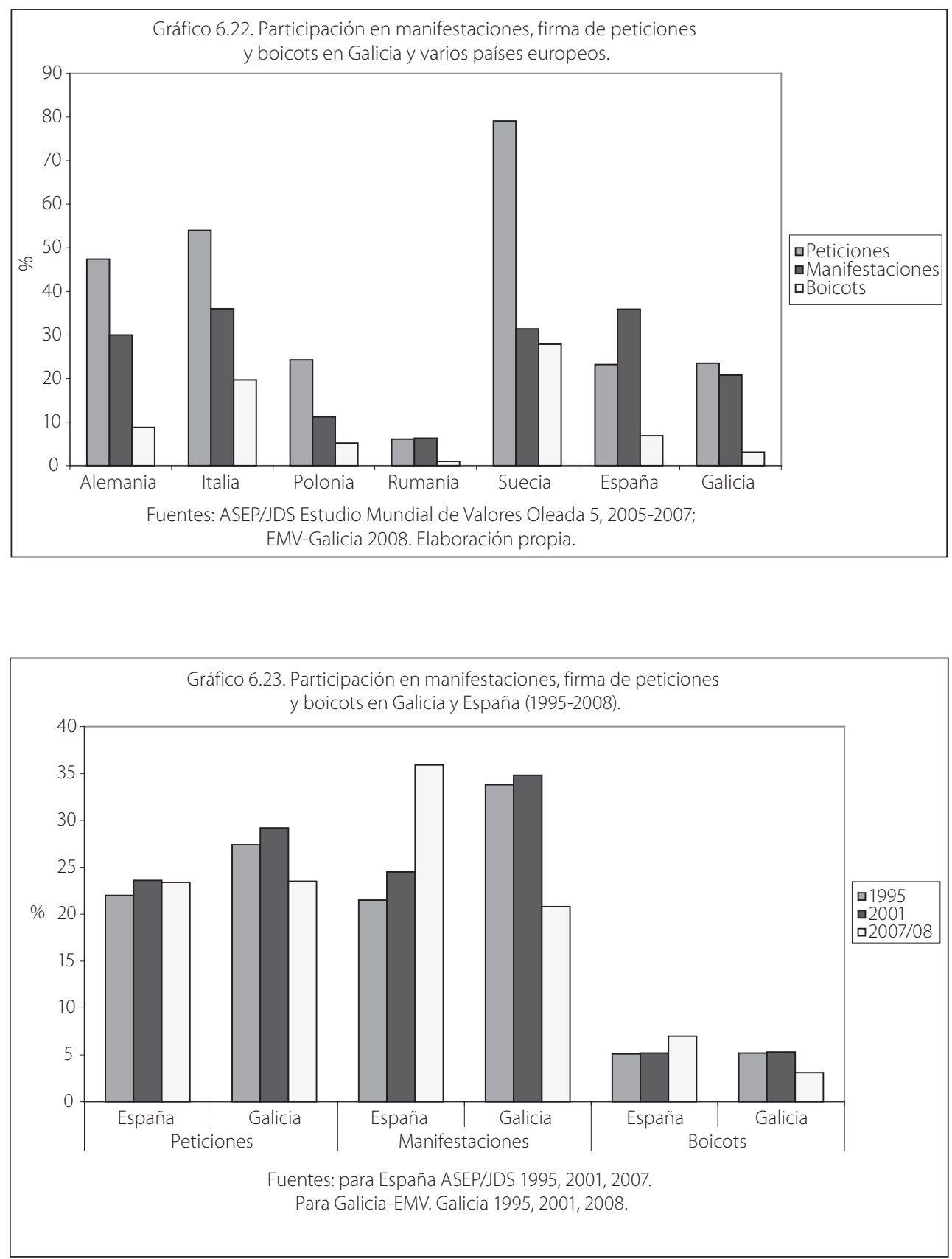
La evolución seguida entre 1995 y 2008 ha supuesto una reducción en los porcentajes de los tres tipos de participación. Así, quienes afirmaban haber participado en manifestaciones en las series de 1995 y 2001 representaban una tercera parte del total, pero en la de 2008 ese porcentaje cayó hasta el 20,8\%. En cuanto a la firma de peticiones y a la participación en boicots la reducción fue algo inferior. En el primer caso pasó del 27,4 al 23,5\% y en el segundo del 5,2 al 3,1 (Gráfico 6.23).

Con el fin de determinar cuáles son los principales factores que explican el mayor o menor grado de participación en estos tres tipos de activismo político, se realizó un análisis de correlación (Eta) con las variables sociodemográficas así como con las relativas al interés por la política, la autoubicación política y la escala de posmaterialismo (tablas 6.21 y 6.22).

Los resultados muestran que las relaciones de asociación más importantes son las que tienen lugar, por una parte, con la edad, el nivel de estudios y el nivel de ingresos, y, por otra parte, con el interés por la política. También es destacable la relación entre la participación en manifestaciones y el autoposicionamiento político (izquierda-derecha), así como con la escala de posmaterialismo, pero en ambos casos esta relación es menos importante en las otras formas de participación.

En síntesis, teniendo en cuenta que el nivel de estudios y el de ingresos constituyen aspectos de la posición social, resulta evidente la relación que existe entre ésta y el activismo no-convencional, lo que confirma que las desigualdades sociales tienden a traducirse de manera bastante directa en desigualdades de acceso a los mecanismos de participación. Por otra parte, la asociación entre estos tipos de activismo y el interés por la política confirma que la presencia de interés por los temas políticos actúa a la manera de prerrequisito fundamental de la participación política.

En suma, podemos concluir que para Galicia el grado de activismo se sustenta, como en el resto de España, sobre dos fenómenos bastante arraigados en la cultura política. Como han señalado Morán y Benedicto, por una parte, se trataría de la escasa fuerza del conjunto de actitudes y valores políticos que conforman el sustrato de implicación subjetiva de los ciudadanos en el mundo político y, por otra parte, "de la intensidad con que las desigualdades de la estructura social se trasponen al ámbito político, cuya consecuencia más visible es la tendencia hacia el alejamiento, cuando no exclusión, de la actividad política de los grupos sociales que cuentan con menos recursos" (Morán, M. L. y J. Benedicto, 1995: 83). 
Tabla 6.21. Participación en peticiones, manifestaciones y boicots según variables sociodemográficas y políticas.

\section{Peticiones Manifestaciones Boicots}

\begin{tabular}{|c|c|c|c|c|}
\hline \multirow{2}{*}{ Sexo } & Varón & 23,7 & 20,3 & 3,3 \\
\hline & Mujer & 23,0 & 20,9 & 2,9 \\
\hline \multirow{6}{*}{ Edad } & $18-24$ & 19,3 & 26,6 & 3,1 \\
\hline & $25-34$ & 29,2 & 26,2 & 5,1 \\
\hline & $35-44$ & 32,2 & 25,7 & 5,4 \\
\hline & $45-54$ & 30,7 & 25,2 & 2,2 \\
\hline & $55-64$ & 20,7 & 19,6 & 2,4 \\
\hline & $65 y+$ & 11,3 & 8,6 &, 7 \\
\hline \multirow{5}{*}{ Nivel de estudios } & Muy bajo & 9,9 & 7,9 &, 3 \\
\hline & Bajo & 15,3 & 16,1 & 1,2 \\
\hline & Medio-bajo & 29,7 & 22,9 & 3,0 \\
\hline & Medio-alto & 26,6 & 22,5 & 3,9 \\
\hline & Alto & 46,3 & 46,1 & 11,0 \\
\hline \multirow{5}{*}{ Ocupación } & Trabaja & 29,2 & 25,6 & 4,4 \\
\hline & Jubilado/pensionista & 13,8 & 11,6 & 1,0 \\
\hline & Ama de casa & 16,9 & 10,7 & 6 \\
\hline & Estudiante & 23,6 & 34,4 & 4,1 \\
\hline & Parado & 23,1 & 21,0 & 2,0 \\
\hline \multirow{4}{*}{$\begin{array}{l}\text { Tamaño } \\
\text { municipio }\end{array}$} & Menos de 10.001 hab. & 16,1 & 16,4 & 1,8 \\
\hline & 10.001-50.000 hab. & 27,9 & 17,8 & 3,4 \\
\hline & 50.001-200.000 hab. & 32,7 & 30,8 & 5,9 \\
\hline & Más de 200.000 hab. & 21,7 & 24,1 & 2,4 \\
\hline \multirow{3}{*}{ Ingresos } & $0-1.299$ & 17,7 & 14,4 & 1,8 \\
\hline & $1.300-2.000$ & 21,2 & 20,0 & 2,6 \\
\hline & $2.000>>$ & 37,1 & 30,5 & 5,5 \\
\hline \multirow{6}{*}{$\begin{array}{l}\text { Autoubicación } \\
\text { política }\end{array}$} & Izquierda & 37,8 & 42,0 & 7,9 \\
\hline & Centroizquierda & 27,1 & 26,5 & 3,2 \\
\hline & Centro & 18,7 & 14,0 & 1,7 \\
\hline & Centroderecha & 19,7 & 13,0 & 2,6 \\
\hline & Derecha & 20,4 & 10,7 & 1,6 \\
\hline & NS & 3,3 & 3,6 &, 0 \\
\hline
\end{tabular}


Peticiones Manifestaciones Boicots

\begin{tabular}{lcccc}
\hline \multirow{2}{*}{$\begin{array}{l}\text { Índice de } \\
\text { posmaterialismo }\end{array}$} & Materialista & 14,8 & 8,8 & 1,3 \\
\cline { 2 - 5 } & Mixto-Materialista & 25,1 & 17,8 & 1,9 \\
\cline { 2 - 5 } & Mixto-Posmaterialista & 30,6 & 32,4 & 4,5 \\
\cline { 2 - 5 } & Posmaterialista & 36,0 & 46,4 & 9,6 \\
\hline \multirow{3}{*}{$\begin{array}{l}\text { Interés por } \\
\text { la política }\end{array}$} & Mucho & 47,5 & 39,7 & 9,0 \\
\cline { 2 - 5 } & Bastante & 32,2 & 30,9 & 4,5 \\
\cline { 2 - 5 } & Poco & 19,0 & 16,9 & 1,5 \\
\hline Total & Nada & 13,2 & 10,7 & 1,3 \\
\hline
\end{tabular}

Fuente: EMV-Galicia 2008. Elaboración propia.

Tabla 6.22. Relaciones de asociación entre el activismo político no-convencional y variables sociodemográficas y políticas (Eta).

\begin{tabular}{lccc} 
& Peticiones & Manifestaciones & Boicots \\
\hline Edad & 0,297 & 0,266 & 0,208 \\
\hline Nivel de estudios & 0,260 & 0,255 & 0,176 \\
\hline Nivel de ingresos & 0,231 & 0,202 & 0,127 \\
\hline Tamaño municipio & 0,149 & 0,131 & 0,084 \\
\hline Interés por la política & 0,269 & 0,254 & 0,143 \\
\hline Escala de posmaterialismo & 0,178 & 0,313 & 0,151 \\
\hline Autoubicación política & 0,191 & 0,276 & 0,134 \\
\hline
\end{tabular}

Fuente: EMV-Galicia 2008. Elaboración propia.

\subsection{CONCLUSIONES}

A lo largo de este capítulo hemos podido analizar las principales dimensiones de la cultura política de los gallegos y el grado de implicación en las diferentes formas de participación, tratando de determinar las razones que explican la dinámica de cada una de ellas. En este sentido, las principales observaciones pueden resumirse como sigue. En primer lugar, se ha podido determinar la importancia de la dimensión izquierda-derecha como eje estructurador de valores y actitudes políticas. En su reciente evolución no se observa una polarización excesiva aunque algunos aspectos relativos a igualdad de los ingresos y el papel del Estado siguen mostrando una especial importancia y lo mismo hay que decir 
del cleavage religioso. Junto a ello, lo más destacable es la progresiva importancia de nuevos temas relativos a la independencia y la libertad personales. Finalmente, el análisis ha servido para demostrar que lejos de los tópicos, los gallegos del siglo XXI no se caracterizan precisamente por su conservadurismo.

En segundo lugar, el estudio de las actitudes hacia la democracia y sus posibles alternativas ha confirmado los amplios apoyos con que cuenta el régimen democrático pero también ha mostrado la presencia generalizada de actitudes críticas, que si bien en algunos aspectos pueden ser atribuidas a factores coyunturales, en otros casos se deben atribuir a la presencia de factores de fondo y prolongados en el tiempo, como son las actitudes de desconfianza hacia la clase política y los partidos.

Finalmente, en lo relativo a la participación política, la mayor parte de las observaciones confirman que Galicia comparte tendencias muy similares a las observadas para España y otros países de nuestro entorno. Concretamente, en cuanto a la abstención electoral, ésta ha dejado de estar asociada al mundo rural para concentrarse en los mayores núcleos urbanos y, al mismo tiempo, cada vez aparece menos asociada a los sectores de población dependiente (mayores, jóvenes y amas de casa). Por otra parte, las variaciones en los niveles de participación demuestran que existe una tónica muy similar a la del resto de España, de manera que aquellas se explican por la incertidumbre de los resultados y el grado de competitividad. En cuanto a la participación no-electoral, se ha podido observar, de un lado, que con algunas variaciones los niveles de participación son algo inferiores a los de España y aun más respecto a otros países de nuestro entorno y, por otro lado, que el interés por la política actúa como un prerrequisito del grado de activismo y está muy relacionado con el nivel de estudios y la posición económica.

\subsection{REFERENCIAS BIBLIOGRÁFICAS}

Almond, G. y S. Verba (1963): The Civic Culture, Princeton, Princeton University Press. (Edición española: La cultura cívica. Estudio sobre la participación democrática en cinco naciones, Madrid. Euroamérica, 1970).

Benedicto, J. (1997): "Las bases culturales de la ciudadanía democrática en España", en Del Castillo, P. e Ismael Crespo, Cultura politica. Enfoques teóricos y análisis empíricos. Valencia, Tirant Lo Blanch: 223-258.

Bonet, E.; I. Martín y J. R. Montero (2006): "Las actitudes políticas de los españoles" en Montero, J. R., J. Font y M. Torcal (Eds.) Ciudadanos, asociaciones y participación en España. Madrid, Centro de Investigaciones Sociológicas: 105-132.

De Juana López, J. y J. Prada (2005): "La transición política y la Galicia postautonómica" en De Juana López, J. y J. Prada (Coords.) Historia contemporánea de Galicia. Barcelona, Ariel: 353-390. 
Díez Medrano, J. (1994): "El significado de los conceptos de izquierda y de derecha: una perspectiva comparada" en Díez Nicolás, J. y R. Inglehart (Eds.) Tendencias mundiales de cambio en los valores sociales y politicos, Madrid, Fundesco: 423-437.

Font, J. y M. Méndez (2008): "La participación política en España" en Jiménez de Parga, M. y F. Vallespín (Eds.) La Política, Vol.II de Del Campo S. y J. F. Tezanos (Dirs.) España Siglo XXI, Madrid, Ed. Bibliotecanueva: 519-549.

Halman, L. (2007): "Political Values" en Dalton, R. J. y H. D. Klingemann (Eds.) The Oxford Handbook of Political Behavior. Nueva York: Oxford University Press: 305-322.

Inglehart, R. (1977): The Silent Revolution. Princeton: Princeton University Press.

Inglehart, R. (1998): Modernización y posmodernización. El cambio cultural, económico y politico en 43 sociedades, Madrid, Centro de Investigaciones Sociológicas.

Justel, M. (1992): "Edad y cultura política". Revista Española de Investigaciones Sociológicas: 57-96.

Justel, M. (1995): La abstención electoral en España, 1977-1993. Madrid, Centro de Investigaciones Sociológicas.

Mair, P. (2007): "Left-Right Orientations" en Dalton, R. J. y H. D. Klingemann (Eds.) The Oxford Handbook of Political Behavior, Nueva York, Oxford University Press: 206-222.

Míguez, S. (1998): "De la apatía a la participación: la evolución de la abstención en las elecciones autonómicas de Galicia (1981-1997)", Sociológica. Revista de pensamiento social, 3: 39-68.

Míguez, S. (2001): "La Cultura Política" en Alcántara, M. y A. Martínez, Política y gobierno en España. (2a ed.) Valencia, Tirant lo Blanch: 449-469.

Míguez, S. (2007): "La cultura política de los gallegos", en Veira, J. L. (Dir.) Las actitudes y los valores sociales en Galicia, Madrid, Centro de Investigaciones Sociológicas: 189-243.

Milbrath, L. (1965): Political Participation, Chicago, Rand McNally.

Montero, J. R. (1984): "Niveles, fluctuaciones y tendencias del abstencionismo electoral", Revista Española de Investigaciones Sociológicas 28: 223-242.

Morán, M. ${ }^{a}$ L. y J. Benedicto (1995): La cultura politica de los españoles, Madrid, Centro de Investigaciones Sociológicas.

Sangrador, J. L. (1996): "Identidades, actitudes y estereotipos en la España de las Autonomías", Opiniones y Actitudes no 10, Centro de Investigaciones Sociológicas.

Sani, G. y Sartori, G. (1983): "Polarization, Fragmentation and Competition in Western Democracies", en Daalder, H. y P. Mair (Eds.) Western European Party Systems. Londres, Sage: 307-340.

Thompson, M., R. Ellis y A. Wildavsky (1992): "Political Cultures", en Hawkesworth, M. y M. Kogan, Encyclopedia of Government and Politics, Londres-Nueva York, Routledge: 508-509. 
Torcal, M., J. R. Montero y J. Teorell (2006): "La participación política en España: modos y niveles en perspectiva comparada”, en Montero, J. R, J. Font y M. Torcal (Eds.) Ciudadanos, asociaciones y participación en España. CIS, Madrid: 47-75.

Vallespín, F. (2008): "La política en España: agentes y comportamientos políticos" en Jiménez de Parga, M. y F. Vallespín (Eds.) La Política, Vol. II de Del Campo S. y José Felix Tezanos (Dirs.) España Siglo XXI, Madrid, Ed. Bibliotecanueva: 519-549.

Van Deth, J. W. (1995): "A Macro Setting for Micro Politics" en Van Deth, J. W. y E. Scarbrough (Eds.) The Impact of Values, Oxford University Press, 1995: 48-75.

Verba, S. y Nie, N. (1972): Participation in America: Political Democracy and Social Equality. Nueva York, Harper \& Co.

Vilas Nogueira, J. (1991): "Las metáforas espaciales en el análisis de los sistemas de partidos” en Revista del Centro de Estudios Constitucionales 10: 139-157.

Vilas Nogueira, J. (1999): "Competitivos, jerárquicos e igualitaristas en Galicia: prosopografía". Revista de Estudios Políticos, 103: 9-49.

Wildasky, A. (1987): "Choosing preferences by constructing institutions; a cultural theory of preference formation", American Political Science Review, 81: 3-22. 


\section{GALICIA EN LA SOCIEDAD DE LA INFORMACIÓN}

José Antonio López Rey

\subsection{INTRODUCCIÓN}

Normalmente se entiende por sociedad de la información un modelo de organización social que se empieza a percibir en el último tercio del siglo XX y en el cual el sector servicios desplaza a la industria como medio principal de generación de riqueza. Como es algo emergente y complejo no existe un consenso en la manera de definirlo ${ }^{1}$. En cualquier caso, casi todos los autores coinciden en que, en esta nueva sociedad, los empleos basados en la gestión de la información superan a los que requieren algún tipo de esfuerzo físico. Por esa razón, las tecnologías que permiten el manejo de grandes cantidades de información, las llamadas nuevas tecnologías de la información y comunicación (NTIC), son la base tecnológica que configura esta nueva sociedad. Las NTIC, además, han conectado a personas, grupos e instituciones entre sí (desde los mercados financieros hasta los gobiernos) de manera inimaginable hace apenas unas décadas. Nos situamos, pues, ante una serie de cambios de gran calado que darán lugar a un nuevo modelo societal. Este modelo, todavía en ciernes, implicará progresivamente transformaciones significativas con respecto a cuestiones tales como la economía y la política, pero también la cultura y las relaciones sociales. Dicho de otro modo, podemos hallarnos ante cambios sociales, económicos, políticos y culturales tan importantes como los que supuso la Revolución Industrial.

A finales del siglo XVIII, cuando se empezaron a percibir indicios del cambio de modelo económico que conduciría finalmente a la moderna sociedad industrial,

Los diferentes términos que tratan de explicar este nuevo modelo social responden a los intereses de los diversos autores por enfatizar algunos de sus aspectos. Así, por ejemplo, Castells señala la diferencia entre sociedad de la información y sociedad informacional; en el primer caso se destaca el papel que la información tiene en la sociedad actual (pero no difiere esencialmente de la función que ha tenido históricamente), mientras que en el segundo se llama la atención sobre un nuevo modelo de organización social transformado por la producción, gestión y distribución de la información realizadas a través de las nuevas tecnologías (Castells, 2001: 51). Baigorri, por su parte, prefiere el término de sociedad telemática porque la exclusividad histórica de la nueva sociedad radica en la posibilidad de superación de las barreras espacio-temporales (Baigorri et al., 2005: 2; tomado de Chaves, 2004: 1 y 14). 
Galicia no se encontraba en una mala situación para afrontarlo debido, entre otras razones, a que la industria se hallaba bastante repartida por todo el territorio y entre la población en general, ya que una de cada tres familias obtenía ingresos de este sector (Carmona y Nadal, 2005: $5^{2}$ ) y a que el acceso a los mercados internacionales se podía realizar con facilidad a través de las rutas marítimas (Murado, 2008: 137). Fue, sin embargo, en la implantación del modelo industrial cuando Galicia perdió el tren de la modernización debido a un escaso interés por la innovación tecnológica (Alonso Álvarez, 2005: 38) y a cambios en la coyuntura, a los que no fueron ajenas en muchos casos las decisiones en materia de política internacional (Murado, 2008) y arancelaria (Alonso Álvarez, 2005: 43). A medida que dicha modernización se iba desarrollando, se fueron agravando las carencias y déficits estructurales y sociales que lastrarían a Galicia hasta bien entrado el siglo XX.

A principios del siglo XXI nos encontramos en una situación semejante a la de hace 250 años: la implantación de una nueva tecnología básica conllevará cambios estructurales importantes, de los cuales están surgiendo ya nuevos escenarios, que pueden ser de oportunidad. Pero si bien en el pasado se perdió el tren de la modernización porque las estructuras políticas y sociales dificultaron la adaptación a los nuevos tiempos, los gallegos de hoy no se encuentran tan limitados como los de entonces para operar en el mercado global. Así, las vicisitudes que deban afrontar las empresas gallegas en el mercado actual dependerán más de cómo sepan gestionar sus activos que de la política de alianzas del Gobierno de España (que en los siglos XVIII y XIX se demostró nefasta para el desarrollo industrial de Galicia; Murado, 2008: 140 y 142).

En este capítulo se muestra el estado en el que se encuentra Galicia en relación a diferentes aspectos, bastante diferentes entre sí, pero importantes de cara al nuevo tipo de sociedad que se avecina. Asistimos al proceso denominado modernización reflexiva, por el que la sociedad que se inició con la Revolución Industrial se autotransforma generando otra nueva modernidad de principios, estructuras y significados todavía desconocidos (Beck, 1999). En este contexto, el uso que se hace de la información debe ser tenido en cuenta y, por eso, se comienza por un análisis del consumo de información que se realiza en Galicia; interesa tanto el realizado a través de las nuevas tecnologías como el que se produce a través de los soportes tradicionales, pues este proporciona una idea del interés existente por adquirir información por parte de la población. El desarrollo de la ciencia y sus aplicaciones tecnológicas está en el origen de las profundas transformaciones que ocurren tanto en las sociedades como en el entorno físico, lo que ha conllevado una mayor toma de conciencia sobre los problemas, y no solo las ventajas, que plantea. En este sentido, resulta conveniente conocer las opiniones y actitudes existentes ante la ciencia y la tecnología y, posteriormente,

Carmona y Nadal se refieren a la industria antes de la fábrica, esto es, al sector industrial previo a la Revolución Industrial.

\section{LA EVOLUCIÓN DE LOS VALORES SOCIALES EN GALICIA}


atender a la importancia que se concede al medio ambiente. Finalmente, en el actual proceso de cambio social tiene una especial importancia el proceso de individualización que supone que los individuos, al desintegrarse las certezas de la sociedad industrial, sienten la necesidad de encontrar y buscar otras nuevas (Beck, Giddens y Lash, 2001: 29), lo que adquiere una significación mayor si tenemos en cuenta que los logros de la modernidad introdujeron cada vez más espacios en los que era necesario ejercer el libre albedrío. Los individuos tratan de hallar la felicidad y esa búsqueda es una tarea personal que se emprende de múltiples maneras, a menudo con otros que se encuentran en la misma situación y con intereses coincidentes, lo que ensancha las redes sociales. Por eso en la última parte del capítulo se ofrece una panorámica general del asociacionismo existente en Galicia; el trabajo conjunto con los demás es, además de un importante elemento conformador de capital social, un buen indicador de lo que le interesa a la sociedad. Los datos comentados proceden en su mayor parte de la Encuesta Mundial de Valores realizada en Galicia (EMVG) en 2008, 2001 y 1995 y en España (ASEP/JDS) en 2007, 2000 y 1995; se comparará la situación gallega y española en la actualidad y, siempre que sea posible, en lo relativo al cambio ocurrido en los últimos años.

\subsection{SOCIEDAD E INFORMACIÓN}

En un tipo de sociedad donde la información sustituye a los productos industriales, y donde el principal activo son las personas y, más concretamente, sus ideas, resulta muy interesante conocer cómo es el consumo de información, ya sea a través de medios tradicionales, ya sea a través de las NTIC, por parte de la gente. En este caso, y a diferencia de otros indicadores en los que la sociedad gallega suele puntuar por debajo de la media española, el porcentaje de individuos que en Galicia afirmaron haber hecho uso de los diferentes medios de comunicación, supera al de la población española en su conjunto en todos los medios de comunicación por los que se preguntó. En algunos de ellos, como los informativos de radio y televisión, las diferencias no son muy relevantes (solo un 2,1\%); en otros, sin embargo, sí lo son e indican que, por término medio, la gente en Galicia se informa más que en España.

Estos datos cuestionan la imagen de Galicia que se puede forjar cualquier persona que esté acostumbrada a verla situada en los últimos puestos de los rankings en los que suelen aparecer relacionadas las comunidades autónomas. En Galicia el porcentaje de quienes afirmaron haber utilizado un periódico la semana anterior es de un 80,3\%, un 17,3\% más que la media española, y el de quienes leyeron una revista o un libro es del $47,4 \%$ y del 37\% respectivamente (un $15,4 \%$ y un $11,8 \%$ más que en España). En lo que se refiere a los medios audiovisuales de comunicación de masas, los espectadores de los informativos de radio o televisión fueron un 92,8\% y quienes se informaron a través de algún 
programa de análisis en profundidad a través de estos mismos medios un 54,1\%; los valores para el conjunto de España son, respectivamente, del 90,7\% y del $40,7 \%$. No obstante, son más llamativos los datos referidos a que quienes se informaron en Galicia a través de Internet fueron un 44,6\% (un 17\% más que en España) y a que quienes lo hicieron a través de una conversación mantenida con amigos o colegas fueron un 89,8\% (un 38,6\% por encima del valor para España). La sociedad gallega, pues, declara hacer un mayor uso que la española en cuanto a algunos medios de comunicación.

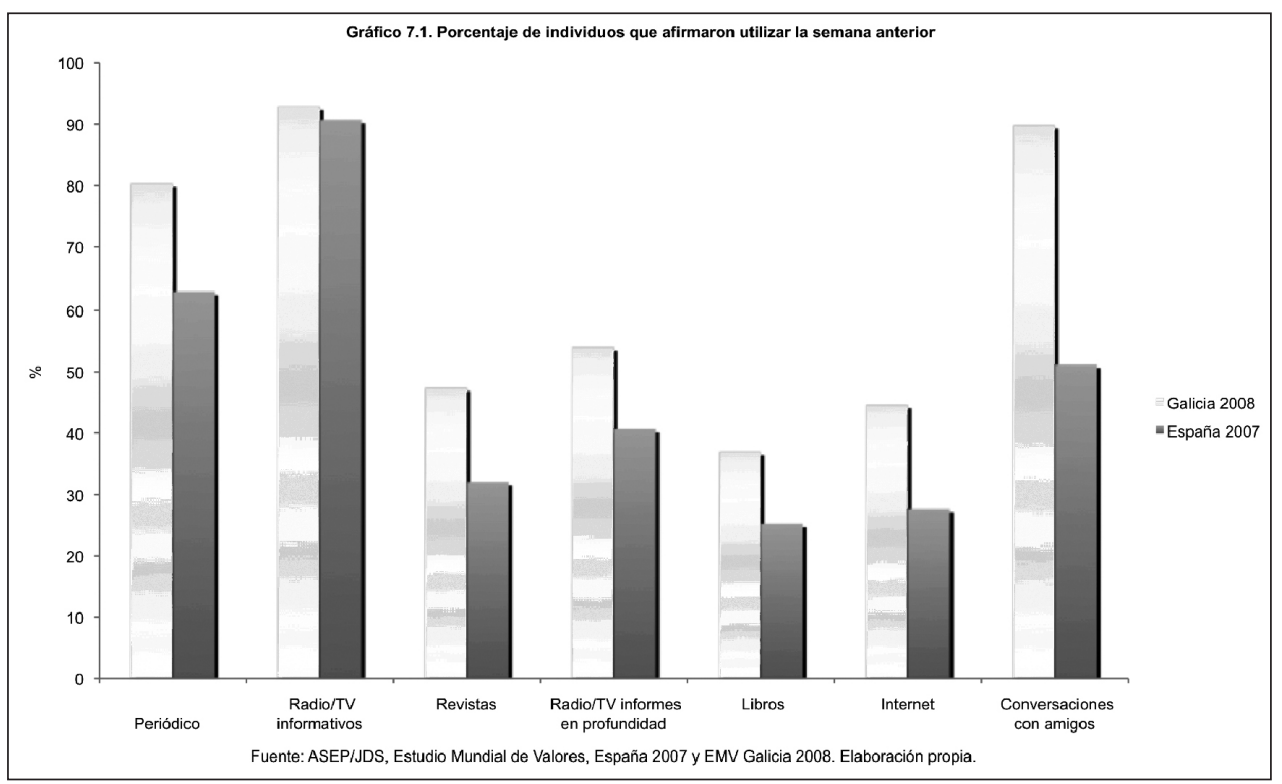

Sin embargo, en lo que se refiere al cine, Galicia se encuentra por debajo de la media española, tanto en materia de salas de exhibición (una media de casi 7 por cada 100.000 habitantes, por 9,6 que había en España), como en los espectadores por sala (27.510 en Galicia, 5.736 menos que en España) o los espectadores por habitante (1,9 en Galicia por 3,1 en España) ${ }^{3}$. En otro tipo de medios, como la radio o la televisión, el consumo es muy similar y las diferencias no suelen exceder del 3\%. Y sin embargo, si atendemos a los medios de letra impresa, Galicia puntúa por encima de la media en diversos indicadores.

Galicia es una de las comunidades donde la industria editorial es más acti$\mathrm{va}^{4}$. Si consideramos la década comprendida entre 1999 y 2008, Galicia fue la

\footnotetext{
3 Los datos son valores medios calculados para el período 2000-2007 según información publicada en el IGE (www.ige.eu/web/mostrar_actividade_estatistica.jsp?idioma=gl\&codigo=0206003001). Fuente: IGE (Enquisa de condicións de vida das familias. Ocio e hábitos culturais 2006); INE: Ministerio de Cultura, Instituto de Cinematografía y de las Artes Audiovisuales, Estadística de Cinematografía: Producción, Exhibición, Distribución y Fomento.

$4 \quad$ INE Datos de la Estadística de Bibliotecas referidos a los títulos por comunidades autónomas en las que fueron editados y período (www.ine.es/jaxi/menu.do?type=pcaxis\&path=/t12/p401/a2008\&file=pcaxis).
} 
séptima comunidad en la que se publicaron más títulos, representando una media del 3,4\% de la actividad editorial total en España, a mucha distancia de Madrid y Cataluña (con el 32,8\% y el 29,9\% respectivamente de producción editorial media para toda la década), pero no tanto de Andalucía $(7,6 \%)$ y de la Comunidad Valenciana (5,8\%), y cerca de Castilla y León (4,2\%) y País Vasco (3,8\%). En 2008, por ejemplo, y con 3.747 libros, fue la quinta comunidad en cuanto a títulos publicados, lo que supuso el 4,3\% de la producción editorial española. Y si ponemos en relación el número de títulos publicados con la población, con 134,6 títulos publicados por cada 100.000 habitantes, Galicia se encontraba en 2008 solo por debajo de Madrid, Cataluña, Navarra y Aragón. Es cierto que el hecho de contar en Galicia con una lengua propia, así como la obligación por parte de la Administración de potenciar su uso ${ }^{5}$, hacen que parte de la actividad editorial realizada lo sea con ayudas públicas, lo que puede explicar la cantidad de obras publicadas. Pero no se puede atribuir la explicación únicamente a este factor, habida cuenta de que Galicia destaca por encima de la media española en otra serie de indicadores relacionados con la lectura.

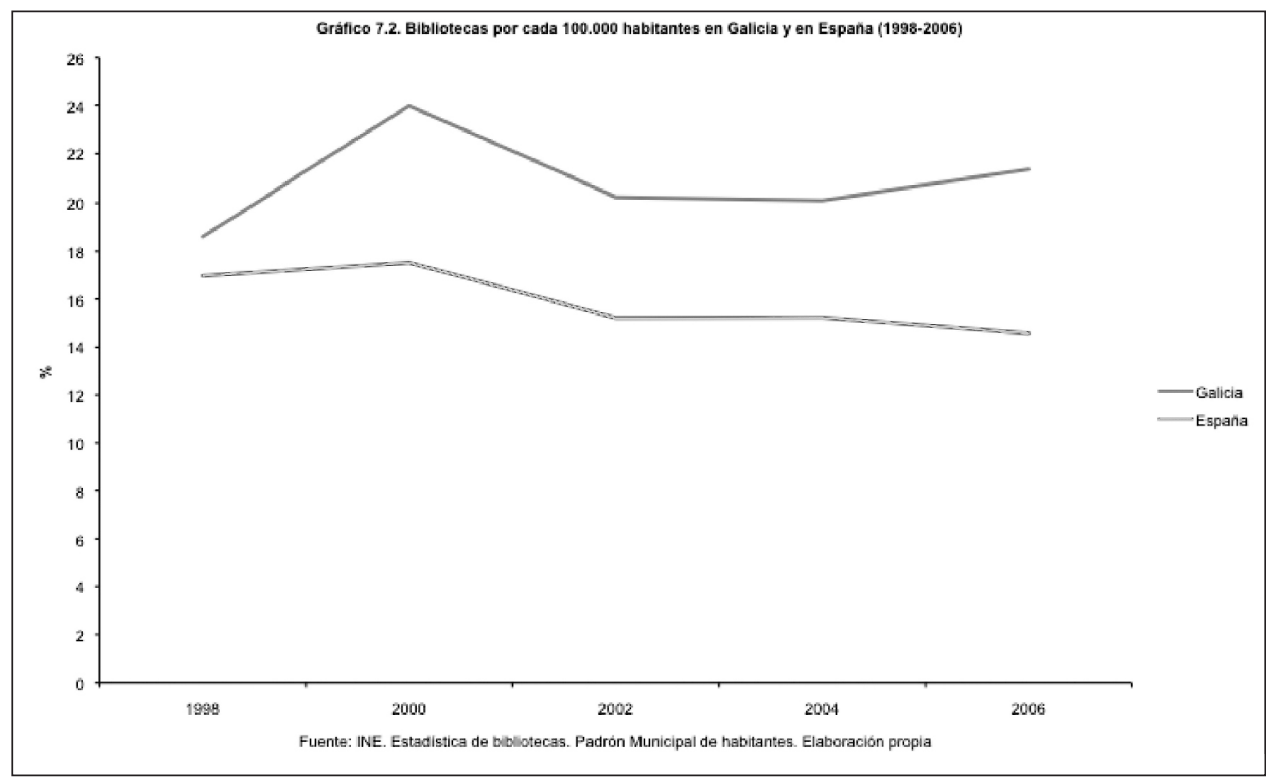

En Galicia, por ejemplo, hay una mayor dotación relativa de bibliotecas. Se pasó en 1998 de 18,6 bibliotecas por cada 100.000 habitantes a contar con 21,4 en 2006. En el caso español, y durante el mismo período, se pasó de tener 17 centros por cada 100.000 habitantes en 1998 a contar con 14,6 $6^{6}$. Aunque en esta

Artículo 5.3 del Estatuto de Galicia.

Según el IGE, que toma como fuentes el INE en su Estadística de Bibliotecas y el Padrón Municipal de Habitantes. 
situación influyen factores como la distribución de la población en el territorio ${ }^{7}$, conviene resaltar que existen otras variables que proporcionan una idea más completa de lo que ocurre. Por ejemplo, en lo que se refiere al número de préstamos efectuados a usuarios por habitante en 2006, Galicia ocupaba el puesto decimotercero, por debajo de la media estatal que se sitúa en $1,5^{8}$. Sin embargo, Galicia contaba con un valor de 4,8 en el ratio de visitantes de las bibliotecas por habitante, por encima del 4,4 de la media de España ${ }^{9}$. Y atendiendo al peso de los volúmenes existentes en las bibliotecas gallegas sobre el total de España, Galicia se sitúa en 2006 como la sexta comunidad autónoma con un 5,6\% ${ }^{10}$. Es posible que el dato de bibliotecas por habitante esté sesgado debido a la dispersión de la población por el territorio en municipios pequeños, que por ley deben contar con este tipo de centros; sin embargo, es en esos mismos municipios pequeños donde se dan los mayores porcentajes de población envejecida y con bajo nivel de estudios. Creemos, por tanto, que en Galicia los indicadores acerca de las bibliotecas (equipamientos, fondos, uso, etc.) son coherentes con la idea de una comunidad que destaca por encima de la media en este aspecto ${ }^{11}$.

Decíamos que los indicadores suelen situar a Galicia por debajo de la media, cuando no directamente en los últimos puestos y que, sin embargo, esto no siempre es así. Es el caso del uso de las nuevas tecnologías: las fuentes de información estadística habituales (el INE, IGE, etc.) ubican en sus clasificaciones a Galicia entre las últimas comunidades. No obstante, cuando en la EMVG se preguntó acerca de Internet como fuente de información y del uso del ordenador personal, en ambos casos los valores para Galicia resultaron superiores a los de la media española.

Si se toma como ejemplo el equipamiento informático de los hogares gallegos, se verá que los datos del INE ${ }^{12}$ (Tabla 7.1) colocan a Galicia en los últimos puestos para este concepto, con un 53,6\% de los hogares con algún tipo de ordenador, solo por encima de Extremadura (53,3\%) y a bastante distancia de Madrid y Cataluña (71,9\% y $71 \%$ respectivamente). Lógicamente, debido a que parte de una situación más baja, el ritmo de crecimiento entre 2004 y 2008 en Galicia es casi el doble del madrileño (27,9\% y $15,4 \%$ respectivamente).

Algo similar ocurre con respecto a la implantación de Internet. Según el INE Galicia ocupa los últimos lugares en lo que se refiere al uso de Internet (Tabla 7.2).

\footnotetext{
La Ley de bases de Régimen Local de 1985, recogía que los municipios con más de 5.000 habitantes deberían contar con una biblioteca pública. Por su parte, La Ley 14/1989, de 11 de octubre, de Bibliotecas de Galicia fue más allá y dispone que los municipios con una población superior a los 2.000 habitantes deberán disponer de una biblioteca pública. En Galicia, más de la mitad de sus municipios tienen menos de 5.001 habitantes y son los más pequeños aquellos en donde todavía no se cumple con las normas antes señaladas (Rodríguez París, 2004).

Según el INE en su Estadística de Bibliotecas.

Fuente: Instituto Nacional de Estadística. Estadística de Bibliotecas. Elaboración propia.

Fuente: Instituto Nacional de Estadística. Estadística de Bibliotecas. Elaboración propia.

11 Noticias como la publicada en La Voz de Galicia el 29/11/2009 confirman esta impresión. En ella se destaca que en Galicia la comprensión lectora de los jóvenes es superior a la media española según el informe PISA (WWW. lavozdegalicia.es/sociedad/2009/11/29/0003_8138437.htm).

12 Encuesta sobre Equipamiento y Uso de Tecnologías de la Información y Comunicación en los hogares 2008. Los datos de los siguientes párrafos se obtuvieron de esta fuente del INE.
} 
A la pregunta de si se había utilizado en los últimos tres meses respondieron afirmativamente el $67 \%$ de los madrileños y el $64,2 \%$ de los catalanes y, en los últimos lugares, el 47,6\% de los gallegos y el 43,5\% de los extremeños; el valor medio para el conjunto de España era del 56,7\%. Y si atendemos a la frecuencia del uso (personas que han utilizado Internet al menos una vez por semana en los últimos tres meses), encabezan la lista los catalanes (59,1\%) y madrileños (59\%) y la cierran gallegos y extremeños (37,9\% y 36,3\% respectivamente), siendo el valor para el conjunto de España el 49,2\%.

Tabla 7.1. Porcentaje de hogares que en 2008 estaban equipados con NTIC.

\begin{tabular}{lcccc} 
& $\begin{array}{c}\text { Algún tipo de } \\
\text { ordenador }\end{array}$ & $\begin{array}{c}\text { Acceso a } \\
\text { Internet }\end{array}$ & $\begin{array}{c}\text { de banda } \\
\text { ancha }\end{array}$ & $\begin{array}{c}\text { Teléfono } \\
\text { móvil }\end{array}$ \\
\hline Total nacional & 63,6 & 51 & 44,6 & 92,1 \\
\hline Andalucía & 59,4 & 43,7 & 38,9 & 90,1 \\
\hline Aragón & 64,2 & 51,7 & 45,2 & 90 \\
\hline Asturias (Principado de) & 63,5 & 53,1 & 47,7 & 92,7 \\
\hline Balears (Illes) & 64,6 & 54,9 & 49,9 & 91,4 \\
\hline Canarias & 65,5 & 52,5 & 45,4 & 93,9 \\
\hline Cantabria & 66,2 & 53,7 & 49,4 & 93,8 \\
\hline Castilla y León & 58,4 & 41,7 & 34,8 & 89 \\
\hline Castilla-La Mancha & 56,1 & 40,5 & 36,3 & 88,8 \\
\hline Cataluña & 71 & 60,1 & 52,5 & 94,2 \\
\hline Comunitat Valenciana & 60,5 & 48,4 & 42,5 & 93 \\
\hline Extremadura & 53,3 & 42,9 & 35,3 & 91,5 \\
\hline Galicia & 53,6 & 39,7 & 31,8 & 87 \\
\hline Madrid (Comunidad de) & 71,9 & 62,3 & 57,9 & 95,3 \\
\hline Murcia (Región de) & 57,2 & 42,3 & 35,8 & 92,3 \\
\hline Navarra (Comunidad Foral de) & 66,3 & 55,8 & 44 & 92,9 \\
\hline País Vasco & 66,4 & 57 & 43,7 & 92 \\
\hline Rioja (La) & 56,8 & 48 & 46 & 92,6 \\
\hline Ceuta & 50,6 & 45,1 & 92,6 \\
\hline Melilla & 50,2 & 45,9 & \\
\hline & 63,9 & & \\
\hline
\end{tabular}

Fuente: INE. Encuesta sobre Equipamiento y Uso de Tecnologías de la Información y Comunicación en los hogares 2008. 
Tabla 7.2. Porcentaje de individuos que en 2008 en los últimos tres meses utilizaron NTIC.

\begin{tabular}{|c|c|c|c|}
\hline & Ordenador & Internet & $\begin{array}{c}\text { Internet para } \\
\text { comprar }\end{array}$ \\
\hline Total nacional & 61 & 56,7 & 13,3 \\
\hline Andalucía & 55,5 & 50,7 & 9,7 \\
\hline Aragón & 62,7 & 55,7 & 15,7 \\
\hline Asturias (Principado de) & 60,2 & 54,9 & 11,2 \\
\hline Balears (Illes) & 63,6 & 60,6 & 20 \\
\hline Canarias & 61,4 & 57,6 & 9,8 \\
\hline Cantabria & 61,4 & 57,2 & 15,4 \\
\hline Castilla y León & 57,9 & 52,3 & 12,2 \\
\hline Castilla-La Mancha & 56,1 & 50,5 & 9,5 \\
\hline Cataluña & 68 & 64,2 & 16,2 \\
\hline Comunitat Valenciana & 58,6 & 55,6 & 10,8 \\
\hline Extremadura & 49,5 & 43,5 & 10,2 \\
\hline Galicia & 52,1 & 47,6 & 11,6 \\
\hline Madrid (Comunidad de) & 70 & 67 & 18,8 \\
\hline Murcia (Región de) & 53,4 & 48,7 & 9,1 \\
\hline Navarra (Comunidad Foral de) & 65,2 & 59 & 15,6 \\
\hline País Vasco & 63,7 & 59,5 & 15,4 \\
\hline Rioja (La) & 60 & 56,1 & 13,9 \\
\hline Ceuta & 56,5 & 54,7 & 11,3 \\
\hline Melilla & 55,8 & 48,6 & 10,8 \\
\hline
\end{tabular}

Fuente: INE. Encuesta sobre Equipamiento y Uso de Tecnologías de la Información y Comunicación en los hogares 2008.

En cuanto al porcentaje de hogares con conexión a Internet en 2008, Galicia cerraba la lista de comunidades autónomas con un 39,7\% (Tabla 7.1). La media estatal para ese año se encontraba en el 51\% y Madrid se hallaba en cabeza con un 62,3\% de hogares conectados. Pero si comprobamos la tendencia de los últimos años observaremos que entre 2004 y 2008, si en el conjunto de España los hogares conectados aumentaron en un $51,8 \%$ y los de la Comunidad de Madrid en un $46,9 \%$, el valor para Galicia es de un $88,2 \%$. En lo que se refiere 
a la conexión de calidad, los datos son peores, toda vez que Galicia ocupa el último lugar, con un 31,8\% de hogares conectados por banda ancha, mientras que Madrid tiene un 57,9\% y la media española es de 44,6\%. En lo que se refiere a los datos de los últimos años, Galicia es la sexta comunidad en la que más se incrementaron este tipo de conexiones entre 2004 y 2008 (con un 253,3\%), por detrás de Extremadura (la primera en este concepto, con un 390,3\%), y situándose la media española en un 203,4\%.

El propio INE aporta información relevante para conocer mejor lo que ocurre en Galicia, tanto en lo que se refiere al uso del ordenador como a la conexión a la Red. Preguntados los entrevistados acerca de dónde hicieron uso del ordenador en los últimos tres meses, un porcentaje muy similar afirmó hacerlo desde su vivienda (el 85,5\% de los españoles y el $82,8 \%$ de los gallegos; Gráfico 7.3). Sin embargo, en el resto de las opciones de respuesta existe una mayor proporción de gallegos que de españoles, con diferencias que oscilan entre los 2,3\% de quienes utilizaron el ordenador en el centro de estudios y el 13,2\% de quienes se fueron a otra vivienda para poder utilizarlo (destacan especialmente quienes se fueron a un cibercafé o a cualquier otro lugar, un $10,9 \%$ y un $8,1 \%$ más que en España).

Lo mismo ocurre con el uso de Internet. Fueron un $77,6 \%$ de los españoles quienes se conectaron en su casa, solo un $6,1 \%$ más que los gallegos, pero en el resto de categorías los entrevistados en Galicia superan el porcentaje medio calculado para España (Gráfico 7.4).

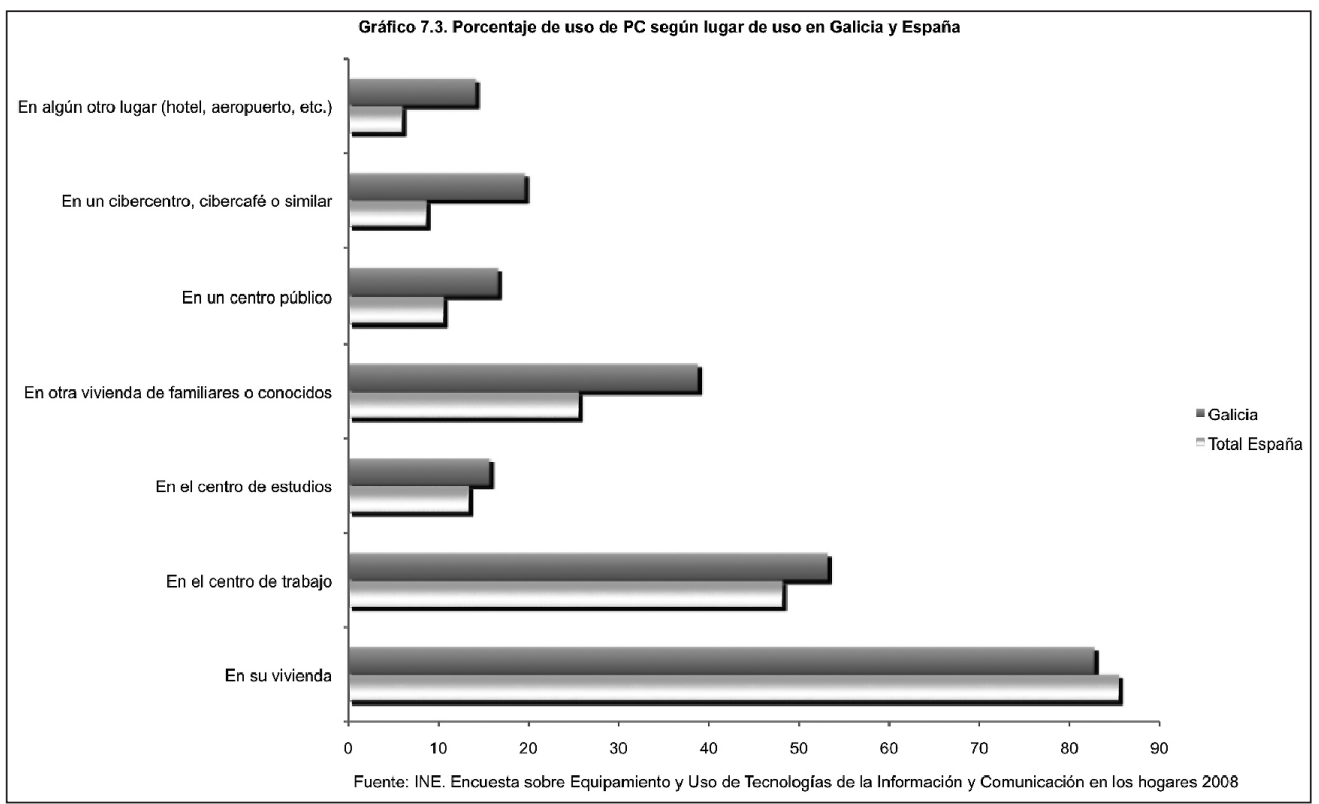




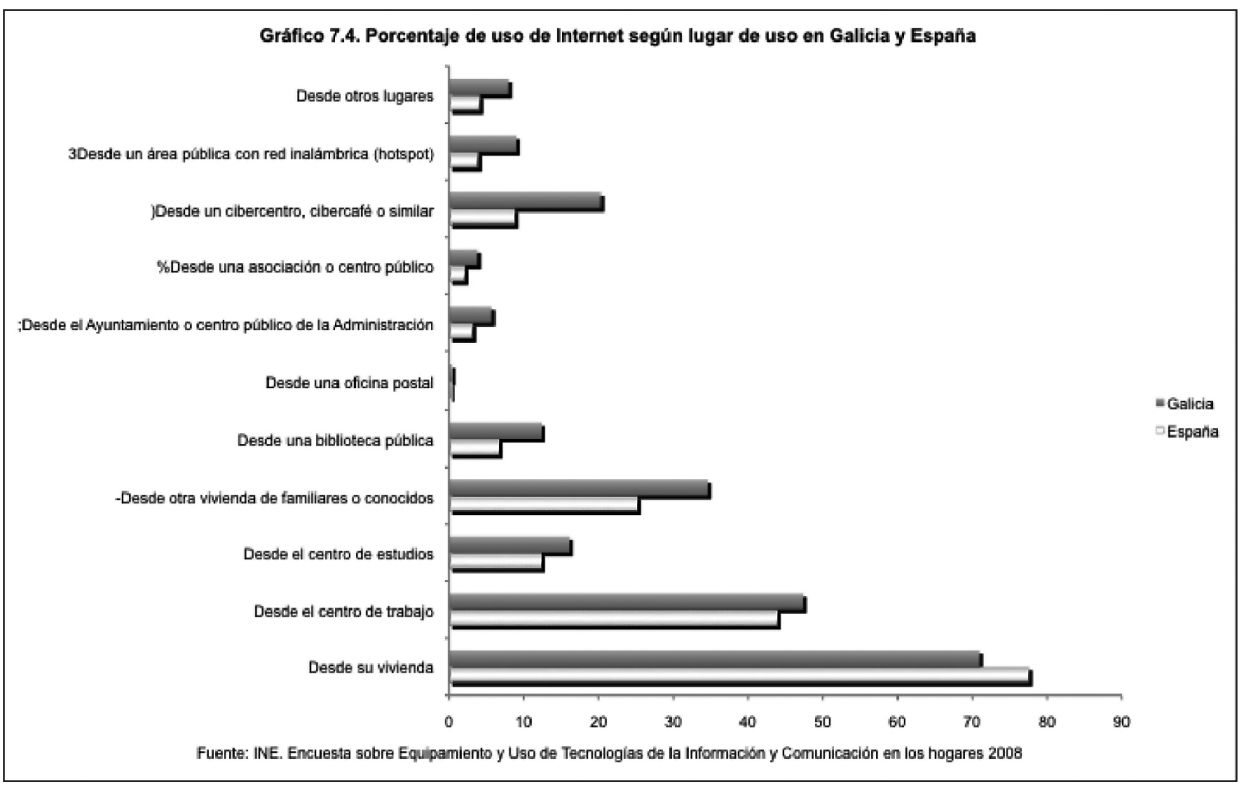

Estos datos, junto con el hecho de que en Galicia existe una operadora de cable que tiene su mercado natural en la comunidad gallega, sugiere la idea de que en el futuro Galicia convergerá con el resto de España. Y en este pronóstico hay dos indicadores que proporcionan información interesante.

El primero de estos indicadores se refiere a los niños. En líneas generales, y pensando en el conjunto de España, se constata que las próximas generaciones estarán alfabetizadas tecnológicamente, toda vez que entre la comunidad autónoma con mayor porcentaje de niños usuarios de ordenador (Navarra, con un valor del 97,7\%) y la menor (Ceuta, con un 88,5\%) existe un rango inferior al 10\% (Tabla 7.3). Galicia, también en este caso, se sitúa por debajo de la media estatal (91\% frente a un 94,1\%). Peor es el dato de los niños usuarios de Internet. En este caso el rango entre Cataluña (con un 93,5\%) y Murcia (con un 73,2\%) vuelve a ser importante, situándose Galicia en los puestos más bajos $(73,4 \%)$. Estos datos, uso de ordenadores similar al de la media pero no de Internet, sugieren la posibilidad de un fallo de la oferta, esto es, la deficitaria infraestructura de redes de datos en Galicia, debida posiblemente a factores relacionados con la distribución de la población en el territorio y el precio de conexión a Internet. Aunque la aparición de la telefonía móvil ha permitido superar en gran parte el tradicional aislamiento de la población rural en materia de conexión telefónica, Galicia es la comunidad española con menor presencia de teléfonos móviles en los hogares (87\%); solo Ceuta tiene un porcentaje inferior $(81,9 \%)$, mientras que la media estatal para este concepto se sitúa en el 92,1\%. Además, la conexión a Internet a través de este tipo 
de telefonía es muy costosa, más aún que la que se realiza a través de la red fija, una de las más caras de Europa.

Tabla 7.3. Porcentaje de niños que en 2008 y en los últimos tres meses habían usado NTIC.

\begin{tabular}{llcl} 
& Ordenador & Internet & $\begin{array}{c}\text { Teléfono } \\
\text { móvil }\end{array}$ \\
\hline Total nacional & 94,1 & 82,2 & 65,8 \\
\hline Andalucía & 90,1 & 74,5 & 64,1 \\
\hline Aragón & 95,2 & 90,4 & 63,8 \\
\hline Asturias (Principado de) & 94,9 & 82 & 71,1 \\
\hline Balears (Illes) & 95,6 & 88,2 & 68,3 \\
\hline Canarias & 90,5 & 79,4 & 66,9 \\
\hline Cantabria & 96 & 86,2 & 67,4 \\
\hline Castilla y León & 96,2 & 82 & 70,3 \\
\hline Castilla-La Mancha & 97,5 & 75,2 & 65,8 \\
\hline Cataluña & 96,5 & 93,5 & 66,2 \\
\hline Comunitat Valenciana & 96,6 & 82,5 & 69,1 \\
\hline Extremadura & 96,9 & 79,5 & 78,5 \\
\hline Galicia & 91 & 73,4 & 60,7 \\
\hline Madrid (Comunidad de) & 93,5 & 85,6 & 61,4 \\
\hline Murcia (Región de) & 94,3 & 73,2 & 60,3 \\
\hline Navarra (Comunidad Foral de) & 97,7 & 88,7 & 70,4 \\
\hline País Vasco & 97,2 & 86,9 & 71,3 \\
\hline Rioja (La) & 90,9 & 80,5 & 69,6 \\
\hline Ceuta & 96,4 & 57,7 \\
\hline Melilla & 73,9 & \\
\hline & 96,5 & \\
\hline
\end{tabular}

Fuente: INE. Encuesta sobre Equipamiento y Uso de Tecnologías

de la Información y Comunicación en los hogares 2008.

El segundo de los indicadores puede parecer anecdótico, pero no deja de ser significativo. En Galicia las compras por Internet pasaron de un 3,7\% en 2004 a un 11,6\% en 2008. A diferencia de las comunidades madrileña y catalana, que ofrecieron su valor máximo en 2007, Galicia (entre otras) 
ofrece una curva de crecimiento continuado y destaca por ser la comunidad peninsular en la que más han aumentado las compras por Internet, con un incremento del 213,5\%. Es decir, pese a que habitualmente Galicia aparece en el furgón de cola de las comunidades autónomas en materia de equipamientos y conexiones a Internet, no está entre las últimas en uno de los indicadores que habitualmente se utilizan para medir tanto la implantación de la Red como la confianza en ella; es más, en lo que se refiere a la evolución en este aspecto en los últimos años, destaca por encima del resto.

Si bien Galicia suele ofrecer valores bajos en diferentes indicadores, al hacer una lectura de varios de ellos para obtener una idea de conjunto, la imagen resultante escapa de los tópicos y ofrece una realidad compleja, de difícil aprehensión. En el origen de esto se halla, probablemente, el tipo de distribución que tiene la población gallega en el territorio, que condiciona a su vez el nivel de equipamientos e infraestructuras, junto con otras características demográficas como el envejecimiento (que es mayor cuanto más rural es el entorno), y al que están asociadas otras como la educación, la ocupación, etc. El resultado de todo ello es una imagen que en ocasiones parece contradictoria: un menor nivel de equipamiento informático y de conexiones a Internet, así como un aparente menor uso (según unas fuentes estadísticas) tanto del ordenador como de la Red se combinan con un uso más intensivo de esos mismos medios tecnológicos ${ }^{13}$. Y si se atiende a los medios de comunicación tradicionales, esa misma Galicia caracterizada por el envejecimiento de su población y por la mayor dispersión territorial con respecto a las otras comunidades, destaca más por su consumo de medios de prensa escrita que por el consumo de medios audiovisuales.

En los párrafos siguientes se analiza la influencia que tienen diferentes características como la edad, el sexo, el tamaño del hábitat, o el nivel de estudios, entre otras, sobre el consumo de medios de comunicación. Se comparan los datos existentes para Galicia y España de la Encuesta Mundial de Valores (que se encuentran recogidos en la Tabla 7.4) y, para no hacer demasiado farragosa la lectura se apuntarán solamente las tendencias más destacables. La idea que subyace es la de que si se conocen los elementos que influyen en el consumo de medios en Galicia podremos adelantarnos, aunque sea de manera indirecta y parcial, a la manera en la que la sociedad de la información se construirá en las próximas décadas. Se adelanta ya ahora que, salvo en el caso de los informativos y telediarios, y según los datos de la EMV en Galicia, se da un mayor consumo de medios que en España en prácticamente todas las categorías, por lo que usualmente los datos reflejarán lo que ocurre en esta comunidad autónoma.

13 Por ejemplo, y según los datos del INE, pese a que tanto en equipamiento de hogares como en uso de recursos informáticos Galicia ocupa los últimos lugares, si calculamos los porcentajes de individuos que compran a través del ordenador sobre aquellos que usan Internet y sobre los que usan el ordenador, los valores de Galicia se encuentran por encima de la media española. 
En lo que se refiere a la lectura de prensa escrita, los varones leen más que las mujeres (un 11,4\% más), y más quienes cuentan con un alto nivel de estudios que quienes no lo tienen (un 35,7\% más). La edad también influye, pero son los individuos con edades comprendidas entre los 25 y los 54 años quienes ofrecen porcentajes más altos de lectura. El lugar de residencia tiene que ver con el consumo de prensa, ya que, y salvo en el caso de los municipios más grandes donde el porcentaje de lectores baja con respecto a las ciudades de entre 50.001 y 200.000 habitantes, cuanto mayor es el municipio, mayor es el porcentaje de individuos que leen periódicos; en el caso de España, no obstante, la relación es lineal. La relación también existe con la asunción de valores materialistasposmaterialistas, de modo que hay mayor porcentaje de lectores de prensa entre los posmaterialistas puros y menor entre los materialistas puros.

Si se atiende a los informativos de radio y TV, como ya se dijo, no existen grandes diferencias entre las categorías de las variables contempladas, puesto que no superan el 5\% entre ellas (salvo en el caso del nivel de estudios, donde la diferencia en el consumo de estos medios por parte de quienes cuentan con un muy alto y un muy bajo nivel de estudios es del 6,5\%). Tampoco existen apenas diferencias con respecto a España.

Sí la hay en la lectura de revistas. Las mujeres se informan a través de ellas más que los varones (52,8\% por 41,7\%) en Galicia, mientras que en España apenas hay diferencias por razón de sexo. Esta práctica está relacionada también con la edad (los jóvenes leen más que los mayores), así como por el nivel de estudios (cuanto mayor es el nivel de estudios, mayor porcentaje de lectores de revistas hay). No existen grandes diferencias entre los individuos con valores materialistas y posmaterialistas puros ( $48,6 \%$ y $50,5 \%$ de lectores respectivamente), pero sí entre los que se ubican en una posición intermedia (41,8\% los mixtos materialistas y $53,2 \%$ los mixtos posmaterialistas).

Los programas de información de los medios de comunicación de masas (reportajes, documentales, etc.) son seguidos por el 57\% de los varones, un 5,6\% más que las mujeres. En lo que se refiere a la edad, hay casi una relación lineal, puesto que conforme avanza el grupo de edad aumenta también el porcentaje de quienes se informaron a través de estos programas (salvo en el colectivo de más edad, que desciende un poco con respecto al grupo anterior). En cuanto al nivel de estudios, se podría afirmar que cuanto más alto es, mayor es el porcentaje de individuos que consumen este tipo de programas, de no ser por el grupo de bajo nivel de estudios, que ofrece el valor más alto (61\%). Sí existe una relación positiva y creciente en el caso del tipo de valores en el sentido de que cuanto más posmaterialistas son los valores asumidos, mayor es el porcentaje de consumidores de programas de información de radio y televisión, existiendo además una clara diferencia entre los posmaterialistas puros $(63,4 \%)$ y los materialistas puros y mixtos ( $51,8 \%$ y $51,9 \%$ respectivamente), ubicándose los mixtos posmaterialistas en una distancia intermedia (56,2\%). 


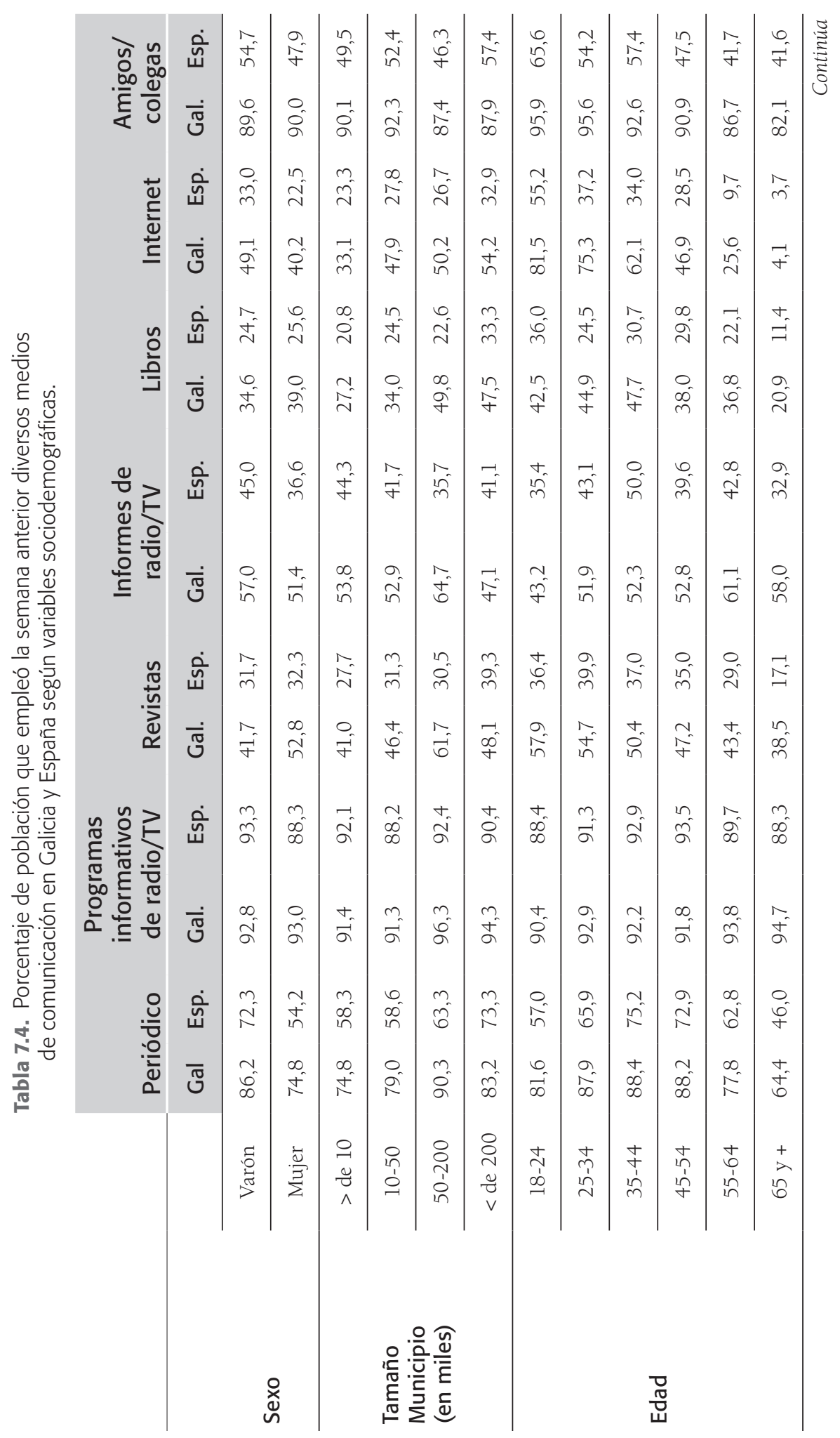

186 LA EVOLUCIÓN DE LOS VALORES SOCIALES EN GALICIA 


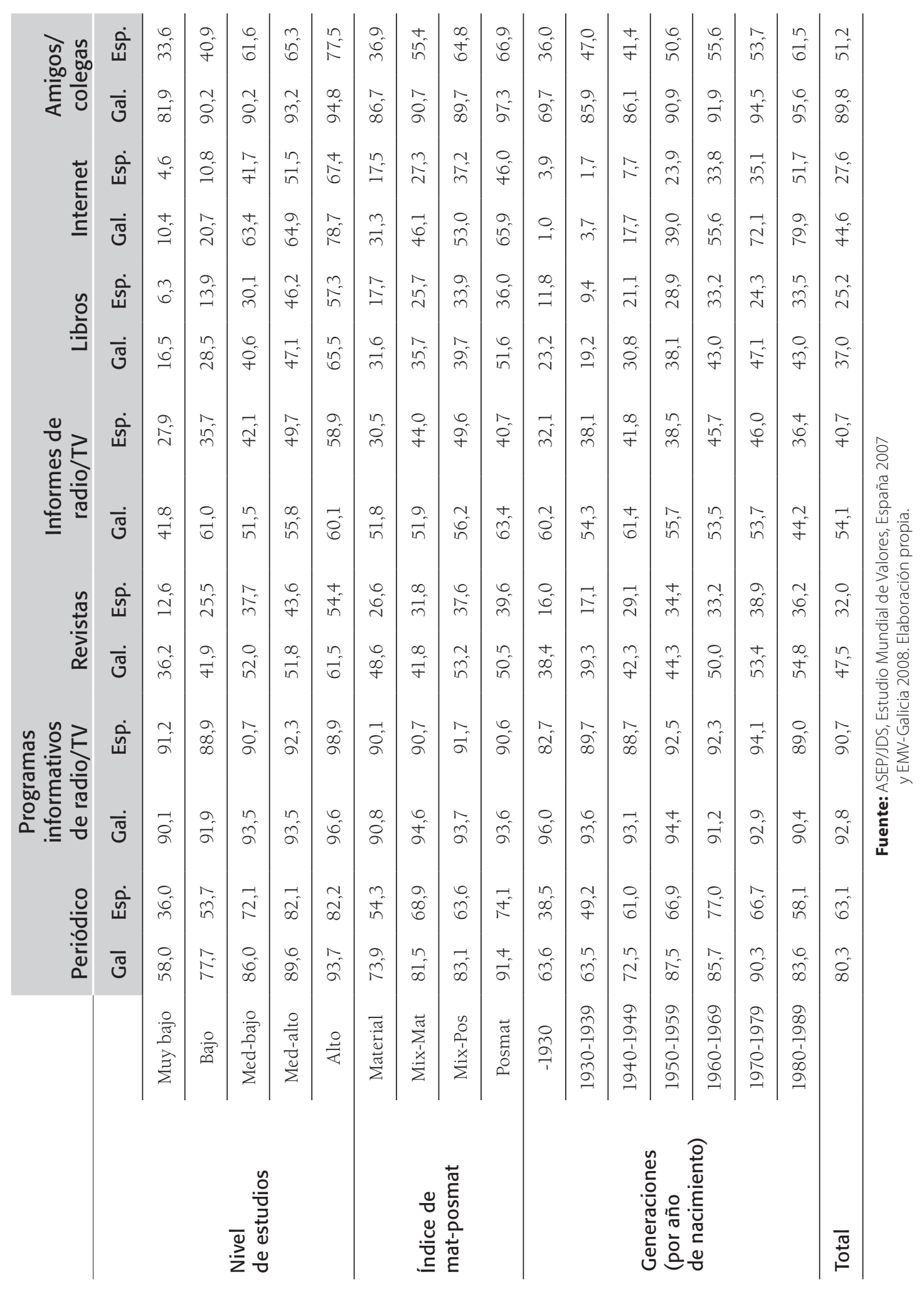


Ya se ha comentado que el consumo de libros es superior en Galicia que en España. Como en el caso de las revistas, leen más las mujeres que los varones (un 4,4\% más). El tamaño del municipio también influye, de modo que cuanto mayor es el municipio, mayor es el porcentaje de quienes leen (salvo en el caso de los municipios de más de 200.000 habitantes, A Coruña y Vigo, donde el porcentaje desciende un 2,3\% con respecto a la categoría anterior). La edad es otra variable relacionada, puesto que aumenta el porcentaje de lectores del $42,5 \%$ en el colectivo de 18 a 24 años al 44,9\% en el de 25 a 34 años y al 47,7\% en el grupo de entre 35 y 44 años para, a partir de esa franja de edad, descender progresivamente hasta el 20,9\% de los mayores de 65 años. El nivel de estudios tiene una relación lineal directa, así como los valores posmaterialistas.

En Galicia, como en España, los varones utilizan más Internet que las mujeres (49,1\% frente al 40,2\%). De los medios contemplados en el estudio, es el único que mantiene relaciones de tipo positivo y creciente con las variables explicativas, de manera que se puede decir que el empleo de la red es más alto cuanto mayor es el tamaño del municipio, el nivel de estudios, la asunción de valores posmaterialistas y el año de nacimiento.

La forma de comunicación interpersonal no mediada por las nuevas tecnologías, esto es, las tradicionales redes de colegas y de amigos, y que conforman parte del capital social vinculante (Veira, Pena y Sánchez, 207: 31) destacan en Galicia como fuente de información con respecto a España. Casi no hay diferencias por razón de sexo ni por el hecho de residir en municipios de diferente tamaño (en este caso las diferencias no exceden del 5\%). Sí la hay en lo relativo a la edad, pues a medida que aumenta menores son los porcentajes de individuos que recurrieron a sus amigos para informarse; y también en el nivel de estudios, puesto que cuanto mayor es, más individuos hablaron la semana anterior con amigos. Los valores materialistas-posmaterialistas también influyen, de modo que entre quienes tienen interiorizados valores posmaterialistas puros es muy superior el peso de quienes se informaron a través de redes de amigos (97,3\%) en comparación con quienes consideramos mixtos posmaterialistas y materialistas (alrededor del 90\% en los dos casos) y materialistas puros (68,7\%).

Hasta ahora se ha visto de qué nivel de equipamiento disponen los gallegos en cuanto a material informático y a infraestructura de comunicaciones, así como algunos de sus hábitos en el uso de las NTIC y de consumo de información en general, como datos importantes para tener una idea de cómo se puede estar implementando (y cómo será en el futuro) la sociedad de la información. Otro tipo de información relevante es la referida a cómo la población entiende y valora la ciencia y tecnología. En efecto, si las tecnologías de la información son la base estructural que posibilita el cambio social y los usos de estas tecnologías (así como de los modos de información y comunicación) son indicadores de la 
potencialidad del empleo de dichas tecnologías, tan interesante como esto es la actitud ante la ciencia y la tecnología como elementos clave en la sociedad de la información. A este tema le dedicamos el siguiente apartado.

\subsection{CIENCIA Y TECNOLOGÍA}

Es innegable el desarrollo que ha tenido Galicia en las últimas décadas. El PIB creció un 43\% entre 1995 y $2007^{14}$. Expresado en términos relativos, si en 1995 el PIB/habitante era de $8.580 €$, en 2007 pasó a ser de $20.144 €$. Y, como se puede observar en el Gráfico 7.5, la inversión realizada en materia de ciencia ofrece la misma tendencia; el porcentaje de gasto en investigación científica, técnica y aplicada con respecto al PIB creció de manera similar al del PIB/habitante (con tasas de incremento relativo del 142\% y 135\% respectivamente).

Este cambio se constata, por ejemplo, en el número de investigadores en I+D ${ }^{15}$. En 1995 no llegaban a los 2.000, mientras que en 2007 superaban los 5.400, con un incremento relativo del $176 \%$ para este período, siendo especialmente significativo que fueran las empresas las que aumentaran sus equipos de investigadores en un $859 \%$. Es necesario decir, en este sentido, que tanto las administraciones públicas como las universidades tuvieron incrementos relativos menores (del 95,6\% y 120,1\%) respectivamente, pero que ello es debido a que en 1995 estas instituciones partían de equipos de investigadores más numerosos.

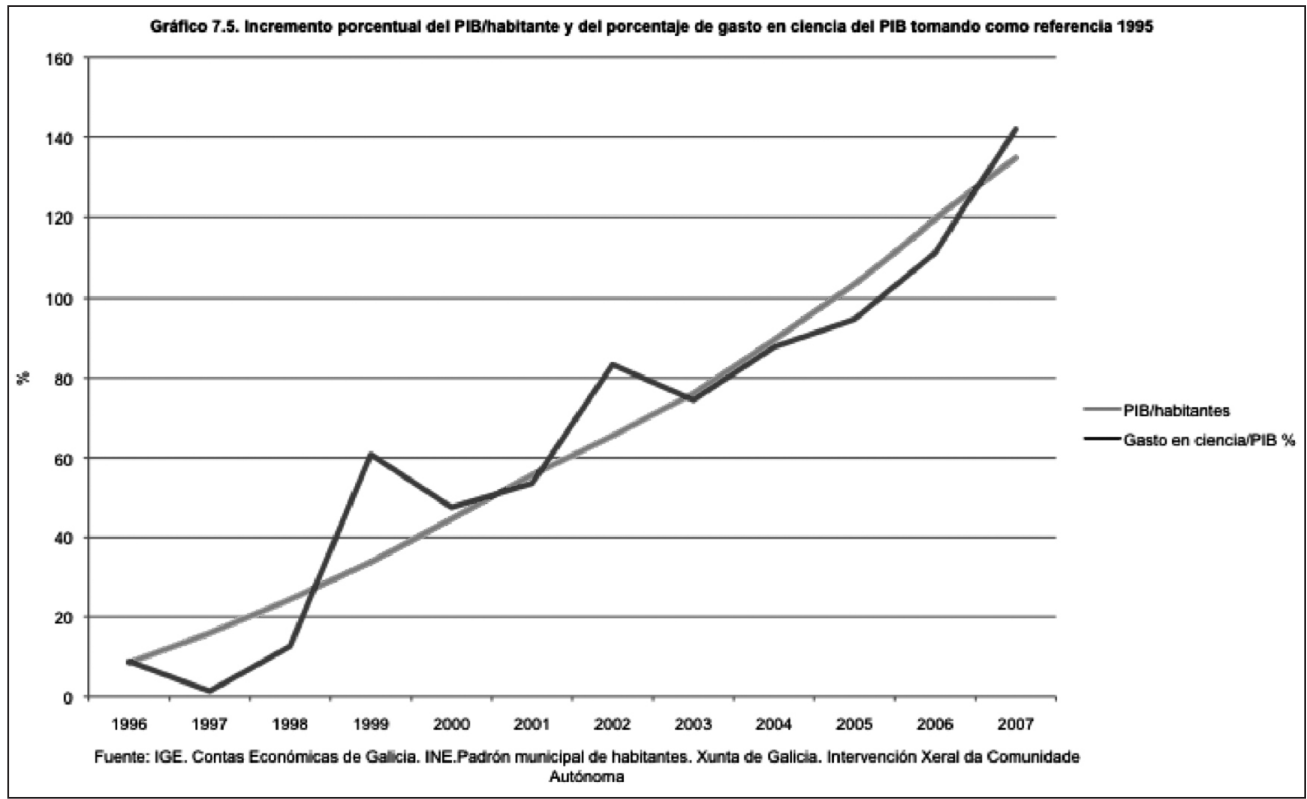

14 Valores relativos del PIB según el Instituto Galego de Estatística. Tomando como referencia 100 el año 2000, los valores de 1995 eran de 82,9 y el de 2008 de 128.

15 Datos del Instituto Galego de Estatística y del INE. Estadística sobre actividades en I+D. Resultados para Galicia. 
En realidad, Galicia no es ajena a lo que ha ocurrido en el resto de España ${ }^{16}$ ni de Europa, aunque los datos para esta comunidad reflejan especialmente la situación de la que se partía. En efecto, y por considerar solamente el último dato comentado, el incremento en España de investigadores entre 1995 y 2007 fue de un $92,8 \%$ (en las empresas se aumentó un 313,5\%, en las administraciones un $145,7 \%$ y en las universidades un $49,9 \%$ ). Si tomamos como referencia la UE-15, el incremento es notable aunque mucho menor que en los casos de España y especialmente de Galicia, ya que en los doce años referidos el número de investigadores aumentó en un 37,4\% (un 55,7\% en las empresas, un 19,4\% en las administraciones y un 27,4\% en las universidades); Francia, por ejemplo, ofrece unos valores casi idénticos a estos últimos ${ }^{17}$.

Galicia incrementó el porcentaje de recursos destinados a la ciencia, lo que, en un contexto de crecimiento económico, supuso un volumen de gasto realmente importante. Seguramente este hecho está relacionado con la forma en la que ha evolucionado, especialmente en los últimos años, la opinión de los gallegos acerca de la ciencia y de la tecnología.

En 1995, un 15,6\% de la población encuestada en Galicia opinaba que dar más importancia a la tecnología sería malo para nuestro estilo de vida (Gráfico 7.6). Este porcentaje se redujo a menos de la mitad en 2001 (un 7,2\%) y no ha variado en la última consulta de 2008. En España la variación también fue a la baja, pero menos fuerte, ya que se pasó de un 11,6\% en 1995 a un 8,7\% en 2000 y un $9,2 \%$ en 2007.

Sin embargo, el peso de quienes entendían que dar importancia a la tecnología beneficiaría el estilo de vida pasó en Galicia del 58\% en 1995 al 61,3\% en 2001 y al $72,4 \%$ en 2008. En España la evolución fue similar, ya que se pasó de un 56,6\% en 1995 a un $64,7 \%$ en 2000 y a un 68,9\% en 2007. En otras palabras, el porcentaje de quienes consideran buena la tecnología para el estilo de vida aumentó en España entre 1995 y 2007 en un 21,7\%, siendo el incremento destacable el que ocurre en la última década de los años 90 (un 14,3\% en 2000 con respecto a 1995). En Galicia, sin embargo, el porcentaje aumentó más, un $24,8 \%$, y sobre todo lo hizo en los años del nuevo siglo (un 18,1\% en 2008 con respecto a 2001).

Este optimismo hacia la tecnología, ligeramente superior en Galicia que en España, tiene su correlato en la visión que se tiene de la ciencia y en cómo ha de comportarse en el futuro en relación a la humanidad. Y el cambio es todavía más pronunciado en el caso gallego. En efecto, en España era un 26,2\% el que en 1995 entendía que a largo plazo los avances científicos perjudicarían a la humanidad, porcentaje que en 2000 se había reducido al 11,1\%, para variar ligeramente situándose en el 9,4\% en 2007. En Galicia la proporción de "pesimistas" en 1995 era mayor que en España (un 33,9\%) y se redujo a un 10,9\% en 2001, prácticamente lo mismo que en 2008.

\footnotetext{
16 Los datos recogidos en este párrafo provienen de la Estadística sobre actividades en I+D del INE. Resultados nacionales.

17 Según datos de Eurostat recogidos por el INE en 2009
} 


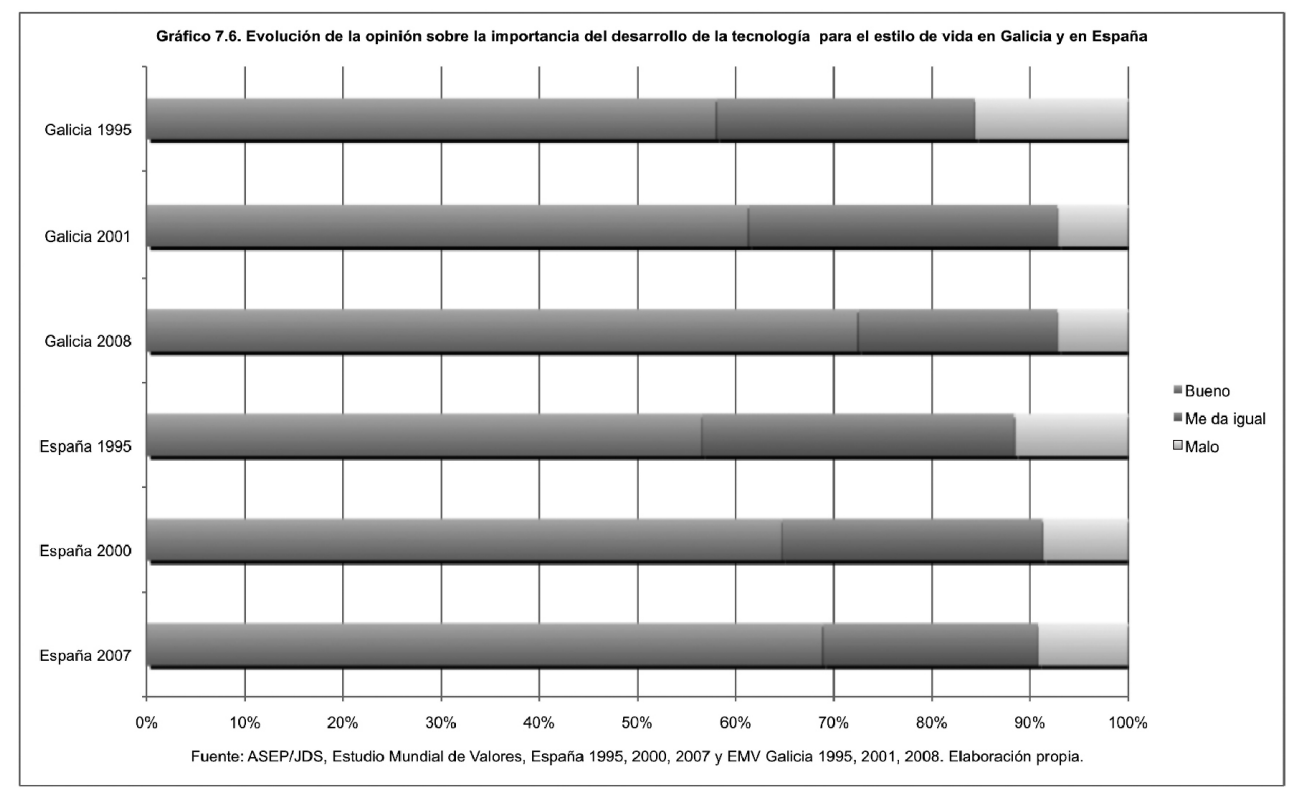

Quienes apostaban en España en 1995 por los beneficios futuros de la ciencia eran un 47,8\%, porcentaje que pasó al $66 \%$ en 2000 y al $72,1 \%$ en 2007 . El aumento de este grupo en Galicia entre 1995, 2001 y 2008 es también relevante y ocurrió especialmente en los últimos años.

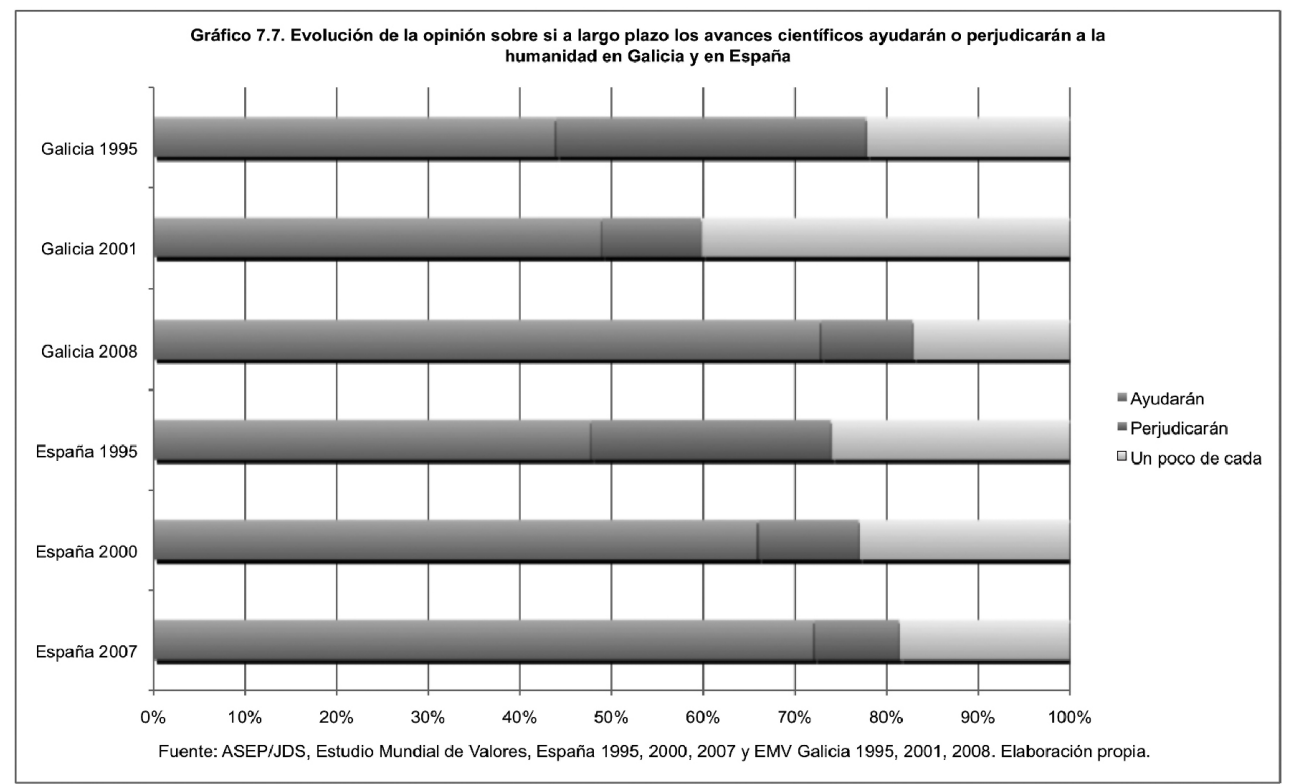


Se puede afirmar, pues, que en 2008, 7 de cada 10 gallegos valoraban positivamente los avances científicos y tecnológicos, mientras que uno de cada 10 no lo hacía; equiparándose Galicia al resto de España. A este cambio no debe ser ajeno el gasto en investigación que ha realizado la sociedad y, muy probablemente, el que se ha hecho desde las empresas y las administraciones públicas, que son quienes más han incrementado su gasto por este concepto en los primeros años del nuevo siglo, precisamente cuando los gallegos incrementaron significativamente sus actitudes favorables a la ciencia y la tecnología. Creemos también que en la más que rápida adopción de una visión positiva de la ciencia y de la tecnología se encuentra el desarrollo de la sociedad de la información. Ésta, en sus diversas formas (correo electrónico, world wide web, telefonía móvil, etc.), ha permitido superar el déficit que en materia de comunicaciones arrastraba Galicia desde los tiempos de la Revolución Industrial.

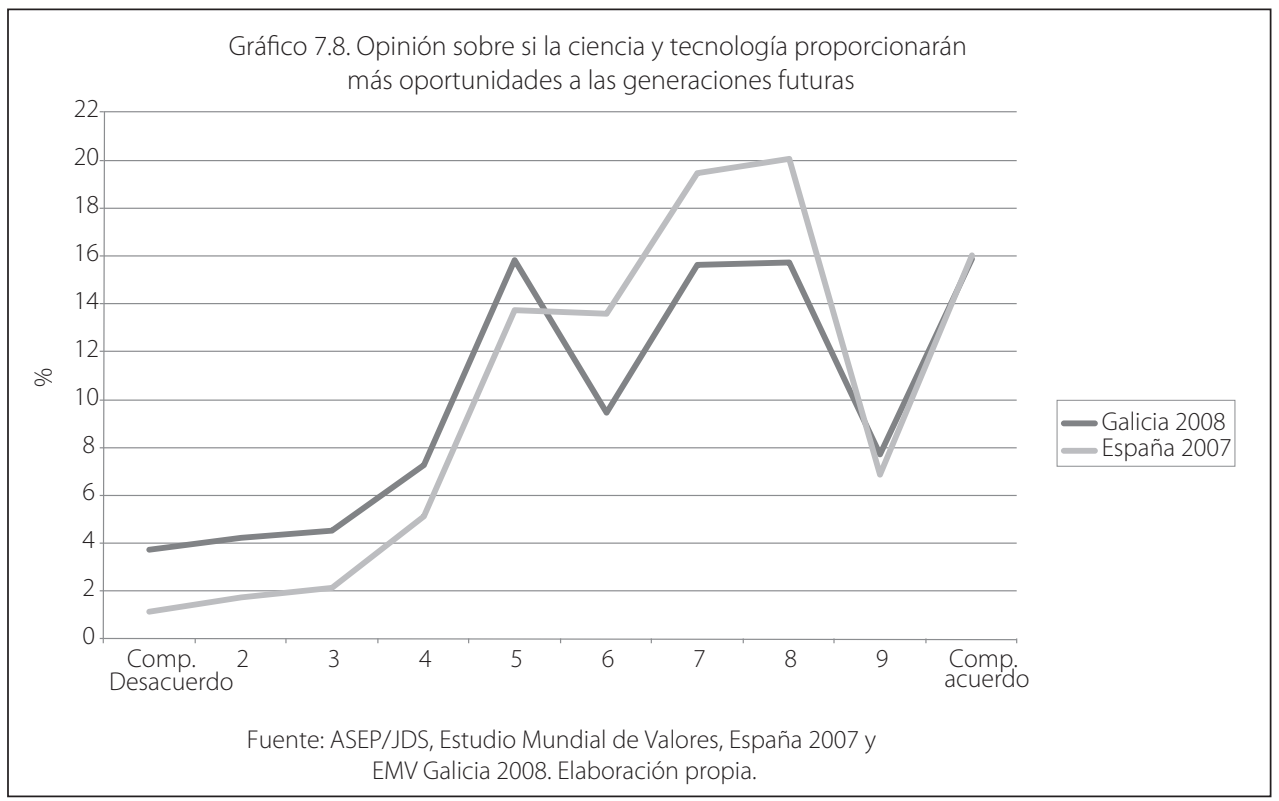

A la luz de los datos que se acaban de ofrecer, sorprende un poco que la opinión de los gallegos sea algo menos confiada que la de los españoles respecto a si la ciencia y la tecnología proporcionarán más oportunidades a las generaciones futuras. En una escala en la que 1 significa completamente en desacuerdo y 10 completamente de acuerdo con que la ciencia y la tecnología proporcionarán más oportunidades a las generaciones futuras, y como se puede observar en el Gráfico 7.8, los gallegos tienen mayores porcentajes de respuesta en las categorías de comprendidas entre el 1 y el 5 . 
No hay prácticamente diferencia alguna entre España y Galicia en las respuestas a si se está de acuerdo con la afirmación de que la ciencia y la tecnología mejoran nuestra vida haciéndolas más saludables, fáciles y confortables. Como se puede ver en el Gráfico 7.9, un 76,8\% de los gallegos expresan algún tipo de acuerdo con dicha afirmación (por un 79,4\% de los españoles).

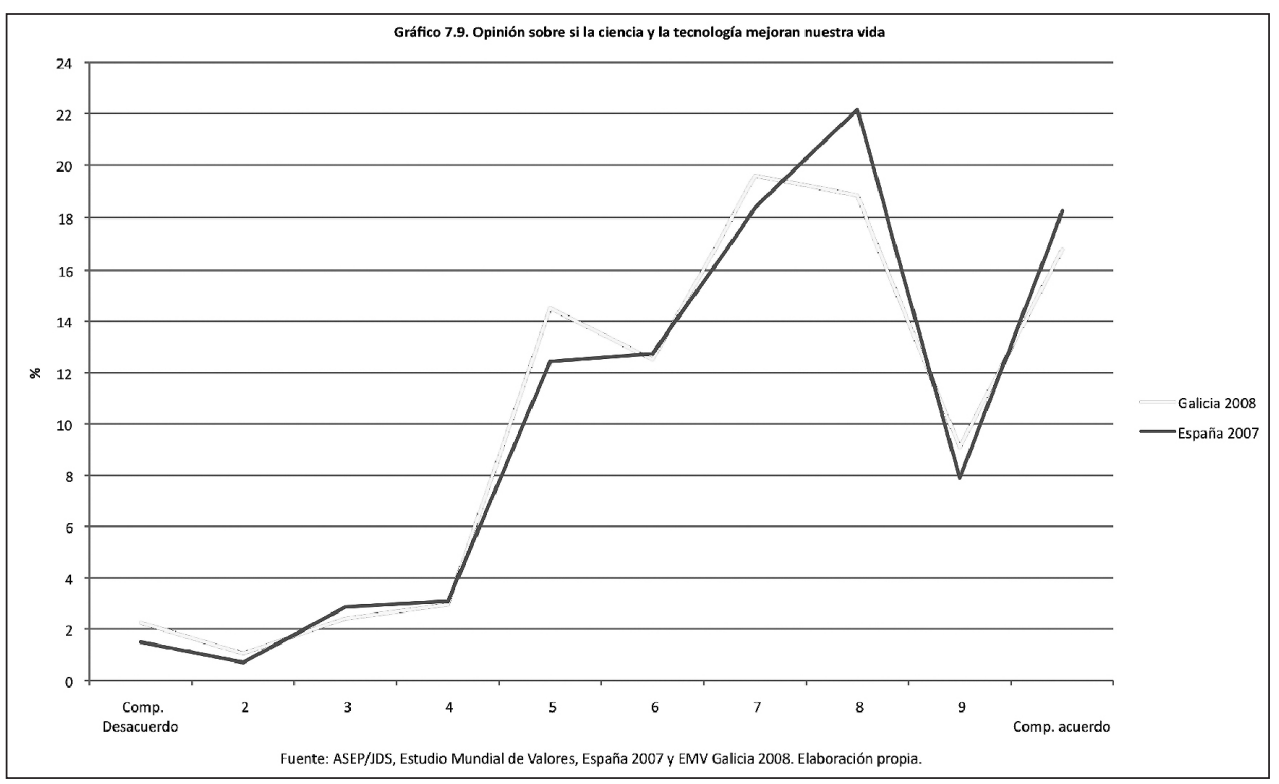

Pero los gráficos anteriores informan de que, aunque levemente, el grado de desacuerdo con las afirmaciones de que "la ciencia y la tecnología proporcionarán más oportunidades a las generaciones futuras" (Gráfico 7.8) y de que "la ciencia y la tecnología hacen que nuestras vidas sean más saludables, fáciles y confortables" (Gráfico 7.9) es superior en Galicia que en España. Para profundizar en esta cuestión hemos recodificado estas variables despreciando los valores intermedios (las puntuaciones 5 y 6 en la escala) y creando otra que sintetiza la opinión de la ciencia y la tecnología en cuatro categorías: claramente negativa, positiva hoy pero negativa de cara al futuro, negativa hoy pero positiva de cara al futuro y claramente positiva. Los resultados se encuentran detallados en la Tabla 7.5 y se observa que, si bien el peso de quienes son críticos con la ciencia y la tecnología es similar en Galicia y en España, en esta última las opiniones mixtas son marginales. En Galicia, por el contrario, existe una constatación de las bondades de la ciencia y la tecnología actualmente combinada con un cierto pesimismo (o escepticismo) con respecto a lo que puedan deparar a las generaciones del futuro. 
Tabla 7.5. Opinión sintética de la ciencia y de la tecnología a partir de las opiniones sobre si la ciencia y la tecnología mejoran nuestra vida y sobre si depararán más oportunidades a las generaciones del futuro (en porcentaje).

\begin{tabular}{lcc} 
& Galicia & España \\
\hline Negativa & 7,6 & 7,1 \\
\hline Positiva hoy, negativa de cara a futuro & 15,8 & 2,9 \\
\hline Negativa hoy, positiva de cara a futuro & 3,5 & 2,2 \\
\hline Positiva & 73,1 & 87,7 \\
\hline Total & 100 & 99,9
\end{tabular}

Fuente: ASEP/JDS, Estudio Mundial de Valores, España 2007 y EMV-Galicia 2008. Elaboración propia.

Ahora bien, iexisten factores que influyan en las opiniones que se tienen sobre la ciencia y tecnología? ¿son las mismas en Galicia y en España? La literatura sobre el tema ha demostrado que existen diferencias de género que son relevantes en este caso, toda vez que los roles desempeñados por varones y mujeres comportan un uso (y una intensidad de uso) distinto de las nuevas tecnologías (Díaz Martínez, 2009: 39) ${ }^{18}$. Estas diferencias se han ido reduciendo en los últimos años, pero se revelan todavía hoy en un mayor interés mostrado por los varones con respecto a la ciencia y a la tecnología (Díaz Martínez, 2009: 43) ${ }^{19}$. Según otros estudios (Hayes y Tariq, 2000) lo que subyace a las distintas actitudes manifestadas por los varones y las mujeres ante la ciencia son, en realidad, diferencias en el nivel de estudios y en las creencias religiosas.

Para responder a estas cuestiones se han cruzado las variables ya comentadas con otras como el sexo, la edad, el nivel de estudios, etc. y los resultados son interesantes. En efecto, en España se cumplen (parcialmente) las afirmaciones anteriores y las variables que relacionan de manera estadísticamente significativa más veces con las cuatro relativas a la ciencia y tecnología son el sexo y la asistencia a misa; siendo ambas explicativas de cada una de las cuatro. La religiosidad, por su parte, es explicativa de tres, la edad de dos, y la generación de nacimiento, el tamaño del municipio y el nivel de estudios de una.

18 Diferencia que, cuando se plasma en forma de humor, refuerza el mito de la incompetencia tecnológica de las mujeres en el discurso popular, como demuestra Justo (2004).

19 Díaz Martínez va más allá y propone una escala de actitudes prácticas hacia la ciencia y la tecnología que comprendería las categorías desinformada, crítica, pro-científica moderada, pro-científica entusiasta y sin posición definida. Las mujeres destacarían más por sus actitudes desinformadas, pro-científica moderada y sin posición definida, mientras que los varones lo harían por sus actitudes críticas y pro-científica moderadas. Además, las diferencias se extenderían al tipo de investigación que se debería priorizar; las mujeres prefieren la centrada en la salud, la medicina y la alimentación y los varones las TICs y las fuentes energéticas, con lo que se evidenciaría la importancia de los roles de género (Díaz Martínez 2009: 40-41 y 52-53). 
Pero en el caso de Galicia es diferente. Lo más destacable es que el sexo no se muestra explicativo a nivel estadístico con ninguna de ellas. La religiosidad explica el mismo número de variables referidas a la ciencia y la tecnología que en España (tres), pero la frecuencia de asistencia a misa, que en España es explicativa de las cuatro variables, solo explica dos de ellas. Igualmente destacable es que la generación de nacimiento tiene relación con las cuatro variables y que el tamaño del municipio con tres. La edad y el nivel de estudios (relacionadas con dos variables), así como el tipo de valores asumidos (relacionada con una) son las otras variables independientes que se mostraron estadísticamente significativas.

Ya se ha dicho que no se hallaron diferencias de género en relación a las opiniones con respecto a la ciencia y la tecnología en el caso de Galicia. En realidad, sí existen esas diferencias, pero son tan pequeñas en el caso gallego que no son significativas estadísticamente. Por ejemplo, ante la cuestión de si se debe dar más importancia al desarrollo de la tecnología en el futuro, en Galicia las respuestas de varones y de mujeres fueron de que eso sería bueno para el 74,2\% y $70,8 \%$ respectivamente; mientras que en el caso de España los porcentajes son del $73,9 \%$ y $64 \%$. Lo mismo ocurre en el resto de los casos.

En España la religión se asume cada vez más como un conjunto de reglas y obligaciones morales y menos como una fuente de conocimiento fidedigno de lo que ocurre en el mundo, papel que sí se le reconoce a la ciencia. Esto no obsta para que, si se indaga acerca de la valoración de la ciencia en determinados temas como la biomedicina y la salud, en los que se ponen en juego aspectos éticos (como la investigación con células madre), se rompa el consenso existente en torno a la positiva valoración de la ciencia (Fernández Prados, 2003: 331 y 332); en estos casos la religión suele ser una variable explicativa importante. Por eso, en el caso de la religiosidad, el hecho de que una persona se considere religiosa, no religiosa o atea, puede explicar alguna variación porcentual en cuanto a la valoración de la ciencia, pero no cabe esperar diferencias notables. En este sentido, incluso cuando se les plantean a los ciudadanos cuestiones como el principio de precaución (si la ciencia debe actuar con cautela y limitar el uso de la tecnología cuando se desconocen sus efectos sobre la salud), las diferencias entre ateos y creyentes practicantes oscilan entre un 5\% y un $7 \%$ (Luján López, 2006: 70).

La tendencia general, a la hora de explicar las opiniones de los encuestados sobre la ciencia en relación con su religiosidad es que las personas ateas valoran más la ciencia y la tecnología que las personas que no se consideran religiosas, y éstas más que las que son creyentes ${ }^{20}$. En Galicia, aun cuando esta variable se

\footnotetext{
20 Existe una relación entre la religiosidad, el nivel de estudios y la edad de manera que, en líneas generales, a menor edad corresponde un mayor nivel de estudios y un menor peso de la religiosidad. Creemos, no obstante, que la afirmación realizada se sostiene, ya que una vez controlado el nivel de estudios, la religiosidad sigue estando relacionada con las opiniones sobre la ciencia.
} 
mostró estadísticamente relacionada, las diferencias entre las categorías no son muy altas y nunca superan el 10\% (Tabla 7.6). En el caso de España, sin embargo, las diferencias sí son mayores (Tabla 7.7).

Las Tablas 7.6 y 7.7 permiten comparar algunas diferencias existentes entre Galicia y España. Por ejemplo, el grado de acuerdo con si "la ciencia y la tecnología hacen que nuestras vidas sean más saludables, fáciles y confortables" es muy similar en términos generales. No obstante, los gallegos que se declaran ateos suscriben esa afirmación en un 15,9\% menos que los ateos españoles. Por otro lado, y con respecto a la afirmación de que "gracias a la ciencia y a la tecnología habrá más oportunidades para las generaciones del futuro", el grado de desacuerdo es mayor en todas las categorías en Galicia y menor el de acuerdo (con diferencias que alcanzan casi el 20\% en el caso de los ateos). Creemos que la explicación a este hecho se halla en la cautela con la que se valora la ciencia y en el nivel de estudios. En efecto, Galicia es la comunidad autónoma donde el nivel de estudios correlaciona más alto, como factor explicativo, con el interés por la ciencia (Arroyo Menéndez, 2006: 24). Por otro lado, Galicia es la comunidad autónoma donde la gente es más crítica con la ciencia (Pérez Manzano, 2006: 133). En el caso que nos ocupa, los ateos gallegos tienen en mayor proporción un alto nivel de estudios $(18,6 \%$ ) que los españoles (12\%). Como veremos, el segmento de población con un mayor nivel educativo se muestra crítico con la ciencia y la tecnología en mayor medida que otros.

Tabla 7.6. Religiosidad y opiniones sobre la ciencia en Galicia (en porcentaje).

\begin{tabular}{|c|c|c|c|c|c|}
\hline & & \multicolumn{4}{|c|}{ Diría Vd. que es una persona } \\
\hline & & Religiosa & $\begin{array}{l}\text { No } \\
\text { religiosa }\end{array}$ & $\begin{array}{l}\text { Un ateo con- } \\
\text { vencido }\end{array}$ & Total \\
\hline \multirow{3}{*}{$\begin{array}{l}\text { La ciencia y tecnología hacen } \\
\text { que nuestras vidas sean } \\
\text { más saludables, fáciles y } \\
\text { confortables }\end{array}$} & Desacuerdo claro & 9,7 & 6,7 & 7,4 & 8,7 \\
\hline & $\begin{array}{c}\text { Posición } \\
\text { intermedia }\end{array}$ & 29 & 23,4 & 25 & 27,1 \\
\hline & Acuerdo claro & 61,3 & 69,9 & 67,6 & 64,3 \\
\hline Total & & 100 & 100 & 100 & 100 \\
\hline \multirow{3}{*}{$\begin{array}{l}\text { Gracias a ciencia y tecnología } \\
\text { habrá más oportunidades } \\
\text { para las generaciones } \\
\text { del futuro }\end{array}$} & Desacuerdo claro & 17,4 & 23,5 & 24,1 & 19,7 \\
\hline & $\begin{array}{c}\text { Posición } \\
\text { intermedia }\end{array}$ & 27,3 & 23,3 & 18,2 & 25,4 \\
\hline & Acuerdo claro & 55,2 & 53,1 & 57,7 & 54,9 \\
\hline Total & & 100 & 100 & 100 & 100 \\
\hline
\end{tabular}

Fuente: EMV-Galicia, 2008. Elaboración propia. 
La Tabla 7.8 pone en relación las valoraciones que se hacen en Galicia y en España con respecto a si los avances científicos ayudarán o no a la humanidad en el futuro. Se puede observar que los resultados globales son prácticamente idénticos, con un 72,6\% de gallegos que cree que sí ayudarán, un 10,2\% que opina que perjudicarán y un $17,1 \%$ que entiende que podrán ocurrir ambas cosas; los resultados en España son del 71,7\%, 9,4\% y 18,9\% respectivamente. Ahora bien, la distribución en función del nivel de estudios ofrece ciertas diferencias, como son que en Galicia hay un 13,4\% más de individuos con muy bajo nivel de estudios que son optimistas con respecto a lo que hará la ciencia en el futuro que en España, y que entre los gallegos con un elevado nivel de estudios son un $6,1 \%$ menos los optimistas y un $7,1 \%$ más los que podríamos denominar cautos, esto es, los que entienden que la ciencia puede generar problemas a la vez que resolver otros.

Tabla 7.7. Religiosidad y opiniones sobre la ciencia en España (en porcentaje).

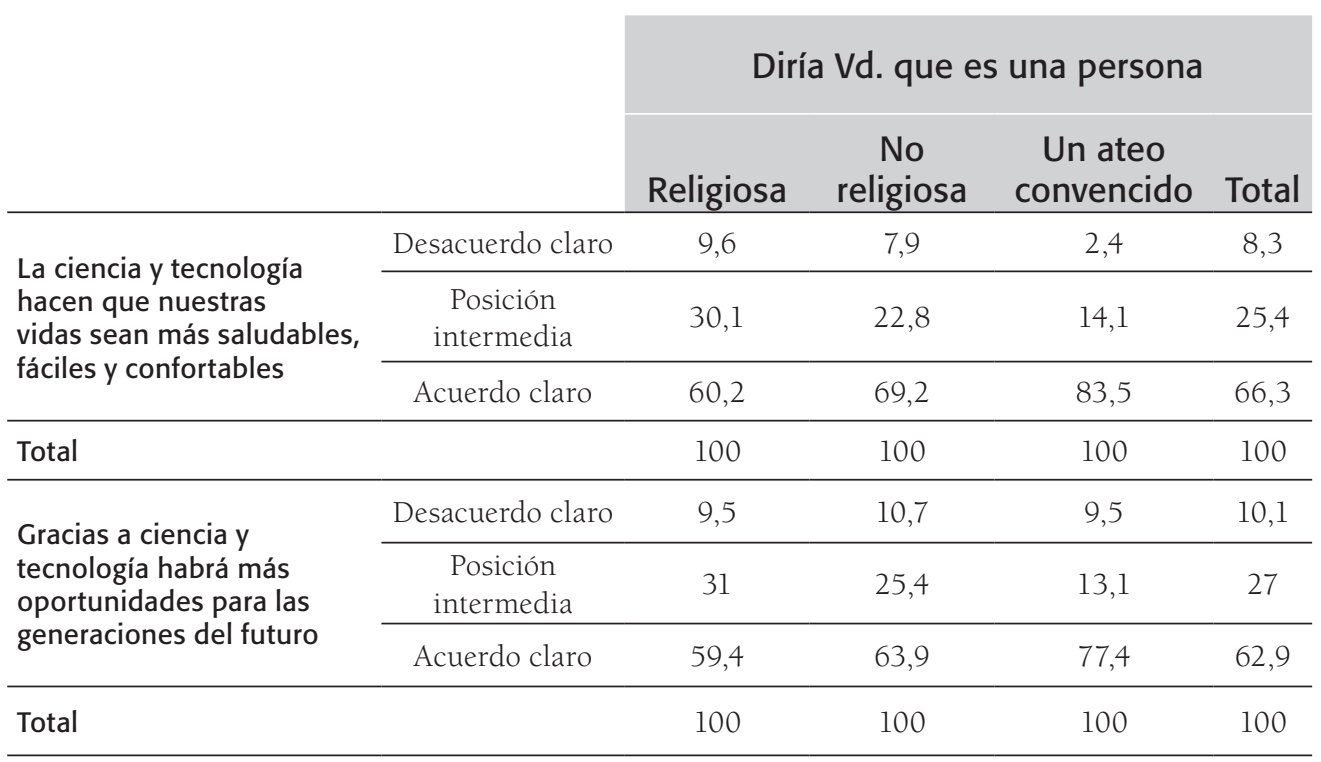

Fuente: ASEP/JDS, Estudio Mundial de Valores, España 2007 y EMV-Galicia, 2008. Elaboración propia. 
Tabla 7.8. Valoración de los avances científicos en relación al futuro de la humanidad según nivel de estudios agrupado (en porcentaje).

\begin{tabular}{|c|c|c|c|c|c|c|c|}
\hline \multirow{2}{*}{\multicolumn{2}{|c|}{ Galicia }} & \multicolumn{6}{|c|}{ Nivel de estudios agrupado } \\
\hline & & $\begin{array}{l}\text { Muy } \\
\text { bajo }\end{array}$ & Bajo & $\begin{array}{l}\text { Medio- } \\
\text {-bajo }\end{array}$ & $\begin{array}{l}\text { Medio- } \\
\text {-alto }\end{array}$ & Alto & Total \\
\hline \multirow{3}{*}{$\begin{array}{l}\text { A largo plazo, } \\
\text { a la humanidad } \\
\text { los avances } \\
\text { científicos la }\end{array}$} & Ayudarán & 68,6 & 67,8 & 73,8 & 78,9 & 77 & 72,6 \\
\hline & Perjudicarán & 11,3 & 11,4 & 10,6 & 9,1 & 6,9 & 10,2 \\
\hline & $\begin{array}{l}\text { Un poco } \\
\text { de cada }\end{array}$ & 20,1 & 20,8 & 15,6 & 12 & 16,1 & 17,1 \\
\hline Total & & 100 & 100 & 100 & 100 & 100 & 100 \\
\hline \multicolumn{8}{|l|}{ España } \\
\hline \multirow{3}{*}{$\begin{array}{l}\text { A largo plazo, } \\
\text { a la humanidad } \\
\text { los avances } \\
\text { científicos la }\end{array}$} & Ayudarán & 55,2 & 67,8 & 79,8 & 74,2 & 83,1 & 71,7 \\
\hline & Perjudicarán & 16,7 & 12,1 & 4,9 & 5,3 & 7,9 & 9,4 \\
\hline & $\begin{array}{l}\text { Un poco } \\
\text { de cada }\end{array}$ & 28,1 & 20,1 & 15,2 & 20,5 & 9 & 18,9 \\
\hline Total & & 100 & 100 & 100 & 100 & 100 & 100 \\
\hline
\end{tabular}

Fuente: ASEP/JDS, Estudio Mundial de Valores, España 2007 y EMV-Galicia 2008. Elaboración propia.

Se han explicado las razones que pueden haber llevado a la población gallega a aumentar en muy poco tiempo su visión positiva de la ciencia y de la tecnología. Creemos que la cautela puede ser explicada igualmente. En una síntesis de diversos aspectos relacionados con la valoración y percepción de la ciencia y de la tecnología (Arroyo Menéndez, 2007: 30), Galicia aparece como la segunda comunidad autónoma en la que se vincula más fuertemente dicha imagen con el ejercicio del poder y del control. En este mismo sentido, en el informe de la Fundación Española para la Ciencia y la Tecnología (FECYT) Percepción social de la ciencia y la tecnología en España 2006, la población gallega era ubicada en el colectivo denominado pro-científicos medidos ${ }^{21}$ (junto con la del País Vasco y Valencia $^{22}$. El perfil de este colectivo se describe a continuación.

21 En el sentido de comedidos o moderados. Por tratarse de una cita textual, se ha mantenido el término original.

22 Es digno de mención que a lo largo de prácticamente todo el texto, a la hora de señalar los rasgos por los que sobresalían las diferentes comunidades autónomas y al compararlas entre sí, la gallega solía ocupar los últimos puestos de los "rankings" junto con la extremeña (considerada mayoritariamente como "población sin posición definida") y la canaria (ídem, pero también como población "desinformada"). Y sin embargo, en el análisis cluster Galicia da un perfil completamente diferente al que cualquier lector atento del informe podría haberse hecho hasta entonces debido a su información descriptiva. Sirva esto como confirmación de lo que decíamos al comienzo de este capítulo. 
Demuestran unos niveles de interés altos (...) también obtienen buenas puntuaciones en cuanto al nivel informativo, que es medio-alto en la mayoría de los temas considerados. Son moderadamente escépticos ante las posibilidades de la investigación científica y tecnológica. Se muestran de nuevo moderados a la hora de hacer un balance global de la ciencia y la tecnología. Consideran mayoritariamente que beneficios y perjuicios están equilibrados.

(FECYT, 2007: 273-274)

En cuanto a sus opiniones y actitudes:

Se trata de un conglomerado crítico, especialmente si lo comparamos con el otro segmento pro-científico. Sin embargo, demuestran poseer más elementos cognitivos que los segmentos anteriores. Además, se informan a través de informativos, documentales y son los más aficionados a los debates.

En general, admiten que el conocimiento científico supone ventajas (...). Se muestran escépticos, no obstante, en relación con la mejora del medio ambiente y de las relaciones entre las personas. Por el contrario, están más de acuerdo con que la ciencia y la tecnología están creando problemas graves para el medio ambiente.

Entre sus valoraciones críticas, destaca que son quienes más de acuerdo están con que se atribuye demasiada importancia al conocimiento científico. Además, consideran que aumenta la distancia entre ricos y pobres. Aunque tienden a asociar ciencia y tecnología a nociones positivas, también son quienes más las vinculan al concepto de riesgos.

Son los más críticos con el nivel de la investigación científica en España, pero también en su comunidad autónoma.

(FECYT, 2007: 274-275)

\section{Como corolario:}

Mantienen una posición pragmática y realista, apoyada en un nivel informativo más o menos sólido. Aunque valoran positivamente la ciencia y la tecnología y admiten la importancia del conocimiento que aportan, son a la vez muy conscientes de sus riesgos y limitaciones. Sus actitudes son críticas hacia las instituciones.

(FECYT, 2007: 275)

Decíamos al comienzo del capítulo que el nuevo tipo de sociedad emergente no tiene consensuado un nombre que lo defina y que, por ello, se habla de sociedad postindustrial, posmaterialista, postmoderna, etc. Ulrich Beck (1994) aportó su personal grano de arena al introducir el término de "sociedad del riesgo", que llama precisamente la atención sobre el peligro derivado de los excesos de la ciencia 
y de la tecnología (o, mejor dicho, de la aplicación puramente instrumental del enorme poder derivado del conocimiento científico y tecnológico con el único objetivo del beneficio económico inmediato). Según los datos aportados antes, los gallegos no se caracterizan por su aceptación acrítica de las bondades de la ciencia y mantienen una posición crítica con ella, precisamente por lo que engloba el concepto de riesgo ${ }^{23}$. A continuación describiremos brevemente ese tipo de sociedad y lo que piensan los gallegos al respecto a la cuestión ecológica, central en la sociedad del riesgo.

\subsection{EL MEDIO AMBIENTE}

El concepto de la sociedad del riesgo se aplica a una etapa en la que se han superado los rasgos característicos de la sociedad moderna. Esta última ha estado caracterizada por el Estado de bienestar, que evidencia el acceso progresivo al poder de las clases trabajadoras, su mejora en el nivel de vida y cierta reducción en las diferencias sociales gracias a la redistribución de la renta (que permite la provisión de educación y sanidad con carácter más o menos universal). En la sociedad moderna el socialismo compite y convive con el liberalismo, pero la paz social no es cuestionada por los actores sociales (que se han institucionalizado), lo que redunda en la aceptación de las instituciones sociales y políticas básicas (propiedad privada, democracia formal, derechos sociales). El discurso se centra en la racionalidad y en la centralidad de la idea de progreso.

En la sociedad del riesgo, por el contrario, se cuestiona el Estado de bienestar que, al reducirse, pierde (o se ven a su vez cuestionadas) parte de las conquistas alcanzadas por las clases dependientes. Se pasa de una situación de trabajo estable a otra más flexible y se libera el capital. Esto, por un lado, aumenta más la flexibilidad del trabajo con los procesos de deslocalización productiva; por otro, y con la reducción del papel del Estado, se liberalizan sectores como la sanidad, la educación, la ciencia, etc. Se asume el riesgo en el pacto social y se pasa de una situación estable, generadora de confianza, a otro escenario de crisis ecológica, política y social, en la que predomina la incertidumbre. El discurso tradicional no se rompe, pero se cuestiona la idea de progreso y la posibilidad de la racionalidad, e irrumpen con fuerza discursos parciales (feministas, ecologistas, identitarios, etc.) ${ }^{24}$.

Una característica importante de la sociedad del riesgo es la conciencia de la crisis ecológica, de la cual el desarrollo económico y la idea de progreso (en cuya base se encuentran los avances científicos y el desarrollo tecnológico) se presentan como desencadenantes. Se puede entender, entonces, que la idea de preservar el medio ambiente, aun a costa de hacer algunos sacrificios en materia económica (pérdida de puestos de trabajo, por ejemplo, o bien un crecimiento económico más

\footnotetext{
23 De hecho, en la escala anti-progreso, que mide el posicionamiento de la gente frente a la naturaleza (si tenemos que convivir con ella o dominarla) y el grado de aceptación/rechazo de los avances científicos y tecnológicos, los gallegos se sitúan en una posición equidistante (Veira, 2007).

24 Para una visión más completa véase, además de la obra de Beck citada antes, a Giddens (1994) y a Beck (2009).
} 
lento), es una idea que refleja un cierto grado de implantación (o de asunción) de la sociedad del riesgo. En este sentido, el Gráfico 7.10 informa de que en Galicia, como en España, hay una mayoría de personas que cree que hay que dar prioridad al medio ambiente, incluso a costa de un crecimiento económico más lento y pérdida de puestos de trabajo (un 59,8\% en Galicia y un 64,2\% en España).

El mismo Gráfico 7.10 muestra cómo ha evolucionado la opinión a este respecto en los últimos años. Si en 1995 en España suscribían la afirmación ya comentada un $55,1 \%$ por un $38,3 \%$ que entendían que se debería dar prioridad al crecimiento económico y a la creación de puestos de trabajo, aun cuando esto pudiera perjudicar en cierta medida al medio ambiente, en 2000 los porcentajes fueron del $57,2 \%$ y del $41,8 \%$ respectivamente (es decir, habían aumentado ligeramente los partidarios de ambas posturas), y en 2007 los porcentajes fueron del 64,2\% y del $33,3 \%$ respectivamente (con un importante aumento de los primeros y descenso de los segundos).

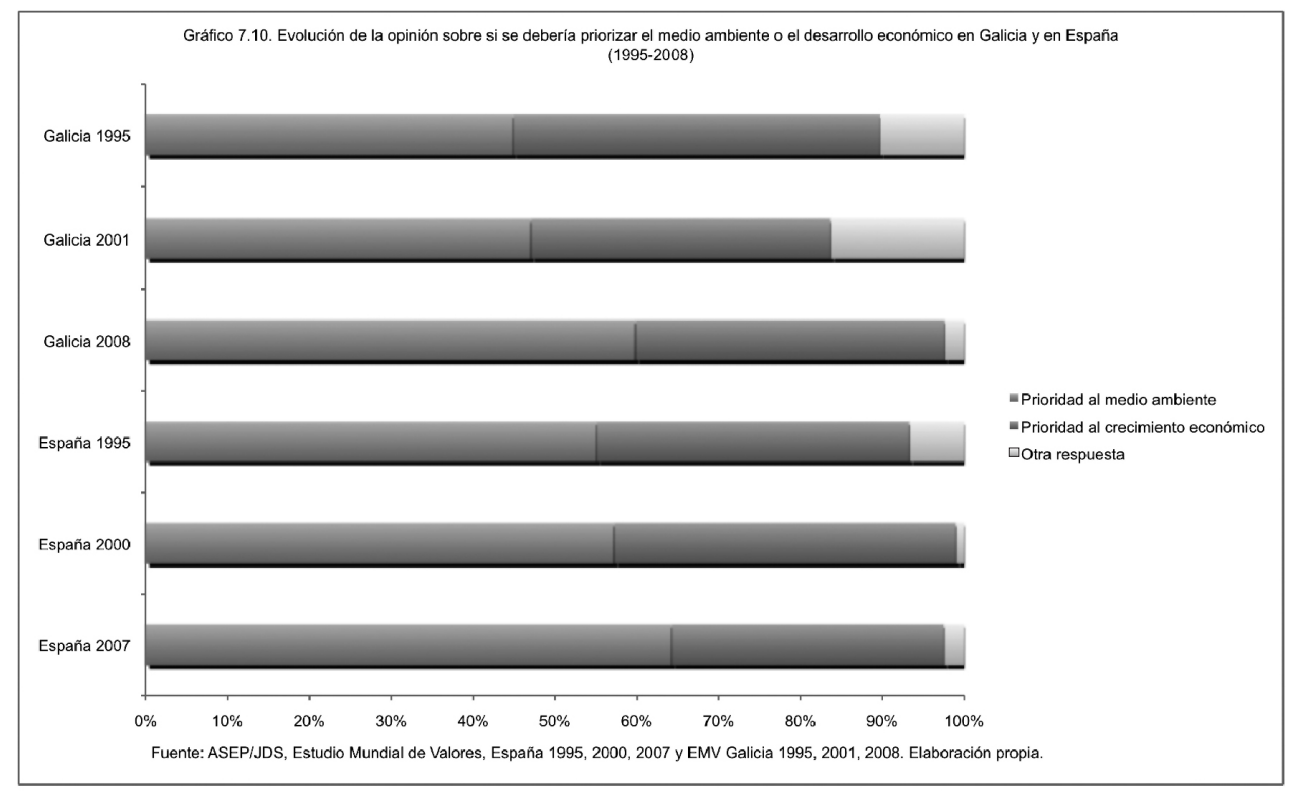

El caso de Galicia es diferente. En efecto, se pasó de una situación de equilibrio en 1995 (los que priorizaban el medio ambiente eran el 44,8\% y los que priorizaban el crecimiento económico el 44,9\%) a otra en 2001 en la que, mientras los partidarios del medio ambiente aumentaban ligeramente (47\%), los del crecimiento económico descendían significativamente (36,7\%). Finalmente, en 2008 el incremento de los pro-medio ambiente fue muy importante (se alcanzó el 59,8\%) y apenas significativo el de los pro-desarrollo económico (llegando al 37,8\%). 
El análisis de las tasas de crecimiento relativo sufrido por la categoría de quienes priorizan el medio ambiente en los últimos años, permite interpretar mejor estos datos. Entre 1995 y 2007 se incrementó en España en un 16,5\% el peso de quienes priorizarían el medio ambiente por encima del desarrollo económico; dicho incremento fue más acusado entre 2000 y 2007 (12,2\%) que entre 1995 y 2000 (3,8\%). Siendo este cambio significativo, en Galicia, sin embargo fue mucho mayor, doblando el crecimiento español entre 1995 y 2008 (33,5\%) y siendo especialmente fuerte el que ocurrió entre 2001 y 2008.

Existen dos corrientes teóricas que explican el aumento de la preocupación por los temas medio ambientales (Veira, 2007: 247). Por un lado, el modelo de la sociedad del riesgo dice que, en la medida en la que se produce un deterioro medio ambiental, aumenta la percepción de dicho deterioro como una amenaza y también la preocupación de la gente por este tema. Por otro, el aumento de la sensibilidad hacia el medio ambiente vendría dado por la implantación progresiva de un sistema de valores posmaterialistas que reemplazaría a los característicos de la modernidad (centrados en cuestiones como el crecimiento económico, el trabajo, etc.) (Inglehart, 1977 y 1998; Díez Nicolás, 1994; Veira, 2007) ${ }^{25}$. Ambas interpretaciones difieren en cuanto a las razones del origen de la sensibilidad social hacia el medio ambiente, así como en cuanto a sus consecuencias, pero en realidad no son excluyentes entre sí (Veira, 2007). En cualquier caso resulta interesante saber qué se encuentra en la base de ese incremento de la priorización del medio ambiente sobre el crecimiento económico.

Una lectura simple de los datos (que aparecen en el Gráfico 7.11) podría dar por buena la explicación de que la implantación progresiva de los valores posmaterialistas en la sociedad es lo que subyace al incremento de quienes dan más importancia al medio ambiente, aun por encima del crecimiento económico, toda vez que en 1995 el 59,7\% de los posmaterialistas priorizaban el medio ambiente, porcentaje que en 2008 se elevó al 72,3\%. No obstante, el mismo gráfico ofrece información que cuestiona la afirmación que acabamos de hacer.

En efecto, el incremento más importante no ocurre en la categoría de quienes asumen valores posmaterialistas ${ }^{26}$ sino entre los que demuestran tener unos valores netamente materialistas y los que se consideran intermedios entre ambos. Un 28,5\% de los individuos que en 1995 tenían valores materialistas priorizaba cuestiones ecológicas sobre las económicas; pues bien, ese porcentaje en 2001 fue de un 31,4\% (con una tasa de crecimiento relativo del 10,2\%) y en 2008 alcanzó un $51,6 \%$ (con una tasa de crecimiento relativo del $64,3 \%$ con respecto a 2001 y del 81\% con respecto a 1995). Dicho de otra forma, en 2008 más de la mitad de quienes son considerados materialistas, y que deberían subordinar las cuestiones

\footnotetext{
Para un desarrollo más amplio del tema, véase Veira (2007) quien, además, lo contextualiza en el caso gallego. Que, por otro lado, se reducen significativamente como colectivo entre 1995 y 2008, pasando de ser un 21,3\% en 2001 a un $11,8 \%$ en 2008.
} 
ambientales al crecimiento económico, defendían precisamente lo contrario. Normalmente los valores posmaterialistas, entre los que se encuentran la preocupación por el medio ambiente, son asumidos por quienes defienden posiciones políticas de izquierda, pero existen también grupos en la izquierda política que cabe definir como materialistas puros (un marxista ortodoxo, por ejemplo) y que, sin embargo, pueden mostrar un notable grado de preocupación por el medio ambiente.

El Gráfico 7.11 también informa de que el crecimiento de la sensibilidad medio ambiental en Galicia ocurre en el último período de tiempo, entre 2001 y 2008. Creemos que, como dice Veira (2007: 247), el caso del hundimiento del petrolero Prestige en noviembre de 2002 fue determinante para el despertar de la conciencia ecológica en Galicia.

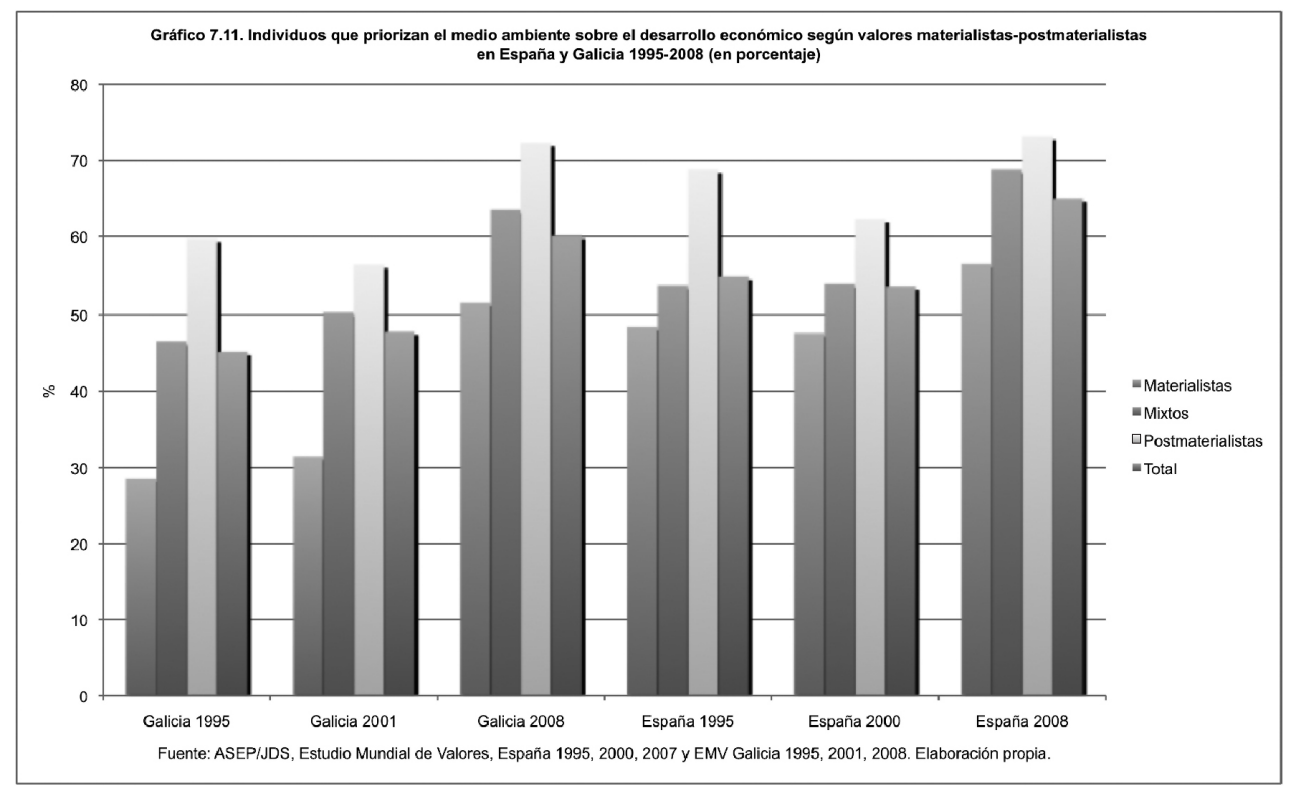

En Galicia, pues, ha aumentado de manera importante la preocupación por el medio ambiente en los últimos años. Este aumento ya había sido vaticinado (Veira, 2007: 258) y, si bien se cumplen algunos de los requisitos para que este fenómeno pudiera ser explicado desde la teoría del cambio de valores (como el importante aumento del PIB en los últimos años), curiosamente el peso de quienes se considera que asumen valores posmaterialistas ha descendido. Creemos, por tanto, que en el caso de Galicia la sensibilidad medio ambiental tiene más que ver con las tesis de la sociedad del riesgo, dramáticamente evidenciadas en la coyuntura histórica reciente, esto es, el hundimiento del Prestige.

Ahora bien, y a pesar de lo comentado hasta el momento, hay que matizar que la sensibilidad hacia el medio ambiente sea una realidad en Galicia. Lo que se ha constatado es un incremento del porcentaje de gallegos que opinan que se debe 
priorizar el medio ambiente sobre el crecimiento económico ${ }^{27}$. Sin embargo, un aumento real de dicha sensibilidad, así como de la implantación de actitudes pro-ambientalistas en Galicia, debería venir acompañado también de un cambio en otras dimensiones; y esto no ocurre, más bien lo contrario.

Ante la afirmación de "daría parte de mis ingresos si estuviera seguro de que el dinero se utilizaría para prevenir la contaminación del medio ambiente", en 2008 son más en Galicia quienes manifiestan su desacuerdo (un 54,8\%; un 40,3\% está en desacuerdo y un 14,5 muy en desacuerdo; Gráfico 7.12) que quienes la suscriben (un 45,1\%; un 37,8\% está de acuerdo y un 8,6\% muy de acuerdo). En lo que se refiere a España (en 2007) los datos son similares, aunque ofrecen un mayor equilibrio. Y esto es tanto más llamativo por cuanto se viene de una situación en la que los consultados habían manifestado mayoritariamente estar más bien de acuerdo con sufragar el coste de prevenir la contaminación (62,8\% en el caso de Galicia en 2001 y 59,5\% en el de España en 2000).

La negativa a que sea el ciudadano quien pague la factura de la prevención de la contaminación aumenta si la institución mediadora propuesta para encargarse de ello es el Estado. Efectivamente, si en 1995 un 74\% de gallegos declaraba estar dispuesto a que se aumentaran los impuestos para prevenir la contaminación, este porcentaje bajaba al 56,2\% en 2001 y al 39,6\% en 2008 (Gráfico 7.13). Los porcentajes para España son del 68\% en 1995, del 50,6\% en 2000 y del 47,3\% en 2007.

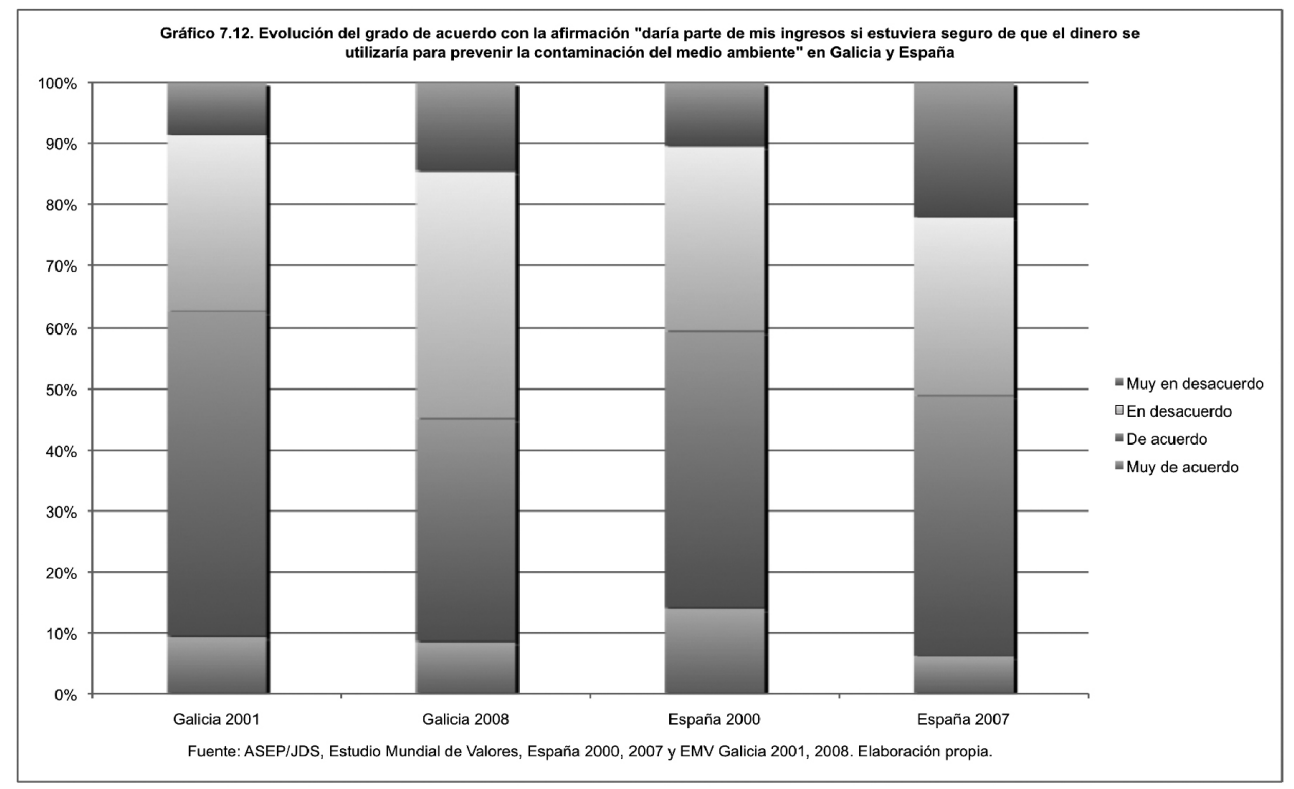

27 En el desarrollo argumental seguido hasta el momento, y por razones de estilo y para agilizar la lectura, hemos sustituido en ocasiones esta construcción por las de "sensibilidad medio ambiental", "actitudes hacia el medio ambiente", etc. 

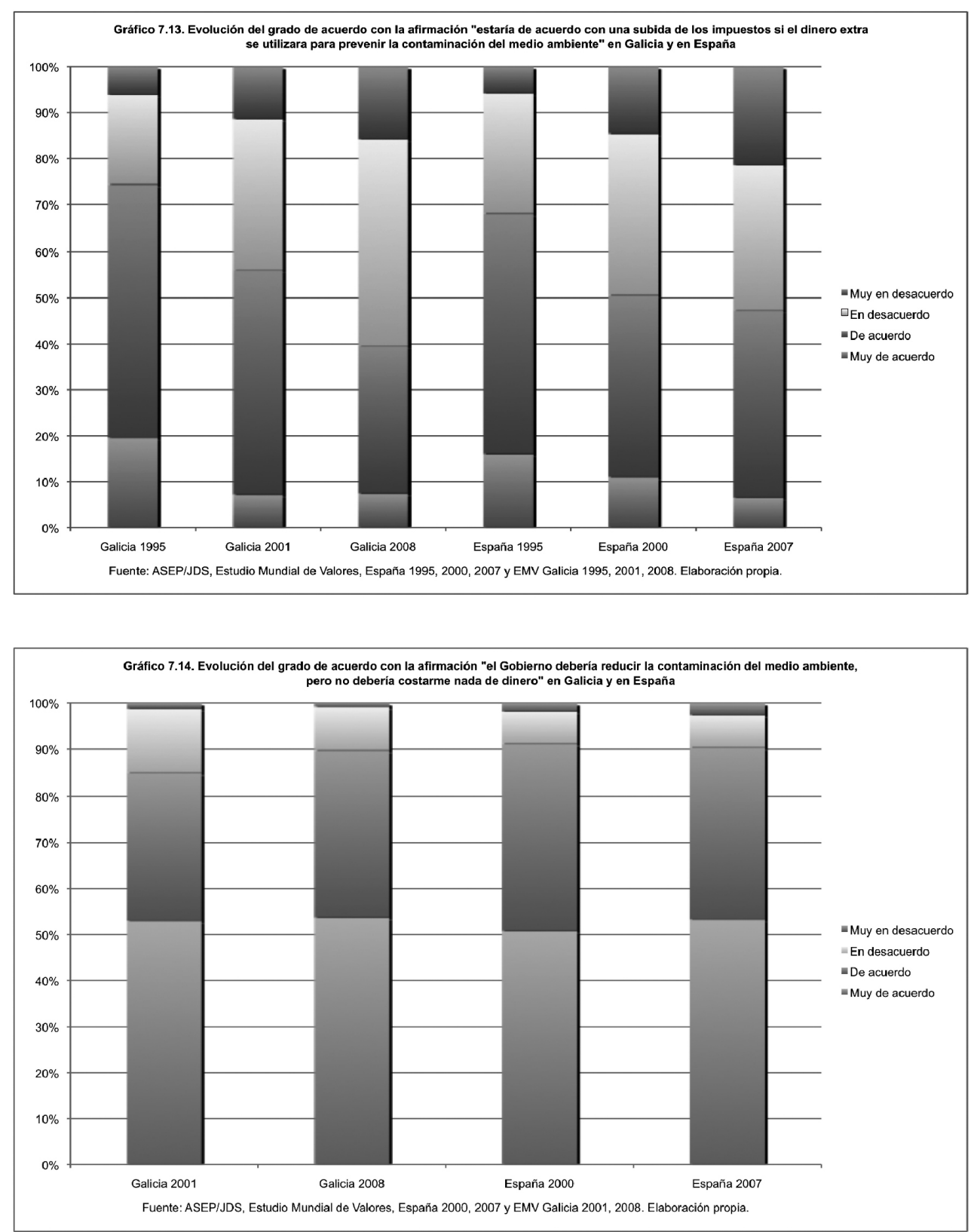

En realidad, y como se pone de manifiesto en el Gráfico 7.14, tanto en Galicia como en el conjunto de España se espera que los problemas medio ambientales (entendidos en este caso como contaminación medio ambiental) sean solucionados por el Estado. Esto concuerda con otros estudios (Díez Nicolás, 2004: 127), pero lo llamativo del caso es que la pretensión de que se haga a un coste cero para el ciudadano/individuo haya aumentado de manera tan significativa en los 
últimos años. Creemos que es cierta la afirmación de Díez Nicolás (2004: 126) referida a que el pro-ambientalismo no se trata de una actitud muy cristalizada sino, más bien, a la expresión de opiniones políticamente correctas.

Que se reduzca el peso de quienes estarían dispuestos a asumir el coste de la prevención de la contaminación medio ambiental a través de los impuestos, puede estar relacionado con el aumento de la presión fiscal en nuestro país (Eurostat, 2009). Pero también, si el caso Prestige ha influido realmente en el crecimiento de la sensibilidad medio ambiental, podría tener que ver con la percepción de que es el Estado quien debe asumir principalmente el pago de la factura debido a su responsabilidad en la crisis. La sociedad civil dedicó mucho tiempo y esfuerzo a resolver los problemas generados a raíz del hundimiento del buque ( 233.730 jornadas de trabajo de voluntarios solo los tres primeros meses, que fueron muchas más si tenemos en cuenta que se prolongaron cinco meses más hasta un total de ocho, según datos del MMA, 2005) ${ }^{28}$, por lo que parece razonable pensar que se vuelve progresivamente reacia a asumir también su coste económico.

Más allá de las cuestiones acerca de quién debe pagar la factura, si en Galicia, como se ha dicho, ha aumentado la preocupación por el medio ambiente, cabría esperar una mayor confianza en las organizaciones ecologistas, como agentes de la sociedad civil que se encargan de operativizar precisamente dicha preocupación en demandas concretas.

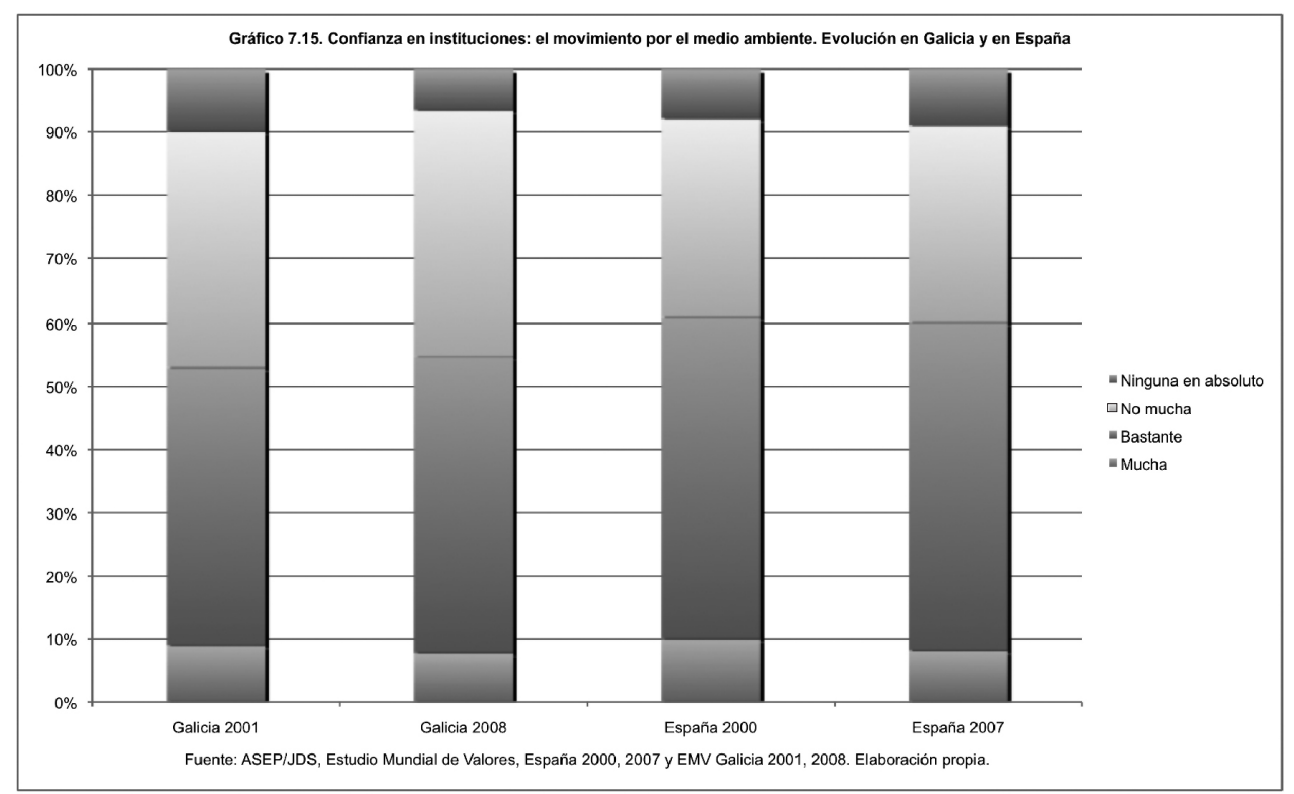

28 Estimación propia a partir de los datos de Ministerio de Medio Ambiente (MMA, 2005) de una media de 2.597 voluntarios trabajando diariamente, solamente durante los tres primeros meses. 
El Gráfico 7.15 informa de que, en los últimos años, apenas ha habido cambios en la confianza que despiertan las organizaciones para el medio ambiente, si bien parecen aumentar ligeramente en Galicia. Este tipo de grupos gozaba de la confianza del 53\% de los gallegos en 2001 (un 9\% tenía mucha confianza y un $44 \%$ bastante) y del 60,9\% de los españoles (un 8,1\% tenía mucha confianza y un $52 \%$ bastante). Este porcentaje descendió ligeramente en España, hasta el 60,1\% (aumentando un poco la desconfianza, que pasó del 39\% al 39,9\%) y aumentó un poco en Galicia hasta situarse en el 54,7\% (donde sí disminuye la desconfianza del $47 \%$ hasta el 45,2\%).

En lo que resta de apartado se analizará qué elementos influyen en que los individuos prioricen el medio ambiente sobre el crecimiento económico o a la inversa. Según Díaz Nicolás (2004: 90) son las variables sociodemográficas las que contribuyen a explicar las diferencias en materia de cultura medio ambiental entre los españoles, en mayor medida que las socioeconómicas, las actitudinales y la información medio ambiental. Así, los hombres, los jóvenes, los de mayor nivel educativo (...) y quienes residen en núcleos metropolitanos muestran (...) más preocupación por el medio ambiente (Díez Nicolás, 2004: 90). Esta afirmación se cumple (parcialmente ${ }^{29}$ ) según los datos que disponemos de España, pero no tanto para el caso de Galicia. En efecto, el sexo no resultó ser una variable significativa estadísticamente ${ }^{30}$.

En lo que se refiere a la edad, el colectivo más joven prioriza el medio ambiente en menor medida que lo que lo hacen los grupos de edad siguientes y siendo un porcentaje mucho menor en Galicia que en España. Esta tendencia se acentúa cuando la edad se presenta en la variable generación. En España son las personas nacidas en la década de los años 80 los que en mayor medida priorizan el medio ambiente (71,3\%), seguidas de los que nacieron en los 70 , en los 60 y en los 50 (69,3\%, 65,6\% y 60,1\% respectivamente). Sin embargo, en Galicia, los nacidos en la década de los 80 que priorizan el medio ambiente son un $58,7 \%$, un porcentaje significativamente menor que sus coetáneos en España y menor también que las generaciones que los precedieron (un 65,1\% de quienes nacieron en los 70, un $62,1 \%$ de quienes nacieron en los 60 y un $59,1 \%$ de quienes nacieron en los 50). De igual modo, el 35,6\% de los nacidos en los 80 en Galicia priorizan el crecimiento económico, un porcentaje superior al de las dos generaciones que los anteceden y también superior al de sus coetáneos españoles (25\%).

29 El tamaño del municipio no es explicativo para el caso de España, según ASEP/JDS-Estudio Mundial de Valores. Ésta es la razón de que no lo hayamos incluido en la Tabla 7.9, donde únicamente aparecen las variables que estadísticamente tienen significación tanto en Galicia como en España.

30 Tampoco en el caso de España, aunque como el propio Díez Nicolás matiza, las diferencias entre hombres y mujeres desaparecen cuando se compara a hombres y mujeres con igual edad, nivel educativo, etc. En nuestro caso, para España y Galicia, el sexo no es una variable explicativa ni siquiera considerando los datos en conjunto. 
Tabla 7.9. Porcentaje que da prioridad al medio ambiente o al crecimiento económico en Galicia (2008) y en España (2007) según nivel de estudios y edad recodificada en generaciones.

\begin{tabular}{|c|c|c|c|c|c|c|c|}
\hline & & \multicolumn{2}{|c|}{$\begin{array}{c}\text { Prioridad al } \\
\text { medio } \\
\text { ambiente }\end{array}$} & \multicolumn{2}{|c|}{$\begin{array}{l}\text { Prioridad al } \\
\text { crecimiento } \\
\text { económico }\end{array}$} & \multicolumn{2}{|c|}{$\begin{array}{c}\text { Otra } \\
\text { respuesta }\end{array}$} \\
\hline & & Gal. & Esp. & Gal. & Esp. & Gal. & Esp. \\
\hline \multirow{5}{*}{$\begin{array}{l}\text { Nivel } \\
\text { de estudios } \\
\text { agrupado }\end{array}$} & Muy bajo & 54,5 & 65,9 & 45,2 & 29,5 & 0,3 & 4,5 \\
\hline & Bajo & 59,3 & 59,4 & 40,0 & 37,8 & 0,7 & 2,8 \\
\hline & Medio-bajo & 62,7 & 63,2 & 34,3 & 35,0 & 3,1 & 1,8 \\
\hline & Medio-alto & 56,1 & 71,2 & 39,6 & 26,0 & 4,3 & 2,8 \\
\hline & Alto & 71,2 & 73,2 & 23,5 & 26,8 & 5,3 & 0,0 \\
\hline \multirow{7}{*}{$\begin{array}{l}\text { Generaciones } \\
\text { (por año } \\
\text { de nacimiento) }\end{array}$} & Antes de 1930 & 52,7 & 56,4 & 47,3 & 41,0 & 0,0 & 2,6 \\
\hline & 1930-1939 & 51,6 & 62,6 & 48,4 & 36,4 & 0,0 & 1,0 \\
\hline & $1940-1949$ & 62,0 & 59,1 & 35,6 & 35,7 & 2,3 & 5,2 \\
\hline & 1950-1959 & 59,1 & 60,1 & 38,3 & 37,2 & 2,6 & 2,7 \\
\hline & 1960-1969 & 62,1 & 65,6 & 35,3 & 33,3 & 2,6 & 1,0 \\
\hline & 1970-1979 & 65,1 & 69,3 & 32,6 & 29,1 & 2,3 & 1,6 \\
\hline & 1980-1989 & 58,7 & 71,3 & 35,6 & 25,0 & 5,7 & 3,7 \\
\hline Total & & 59,8 & 64,2 & 37,8 & 33,3 & 2,4 & 2,5 \\
\hline
\end{tabular}

Fuente: ASEP/JDS, Estudio Mundial de Valores, España 2007 y EMV-Galicia 2008. Elaboración propia.

En cuanto al nivel de estudios, se cumple lo dicho por Díez Nicolás, toda vez que los individuos con nivel de estudios más alto enfatizan el medio ambiente sobre el crecimiento económico en un porcentaje similar en España y en Galicia $(73,1 \%$ y $72,3 \%$ respectivamente). La relación entre el nivel de estudios y la variable a explicar es casi lineal, ya que (salvo algún grupo concreto) conforme desciende el nivel de estudios baja también el peso de quienes suscriben priorizar el medio ambiente. Pero destaca en Galicia el colectivo con un nivel de estudios medio-alto, que prioriza el medio ambiente menos de lo que lo hace el de estudios medios anterior (6,6\% menos) y mucho menos de lo que lo hace el de nivel de estudios más alto (15,1\% menos), diferenciándose también en más de 15 puntos con respecto a cómo se comporta ese mismo colectivo en España (un $56,1 \%$ en Galicia por un $71,2 \%$ en España). Es este mismo grupo el que pone 
el énfasis en el desarrollo económico en mayor medida en Galicia (39,6\%) que en España (26\%), destacando también en este sentido el colectivo menos formado (45,2\% en Galicia por el 29,5\% en España).

El lugar de residencia influye también en que se dé más importancia al medio ambiente o no, pero solo en Galicia esta relación es significativa. En la Tabla 7.10 se observa que quienes más priorizan el medio ambiente son los que viven en las grandes urbes $(72,4 \%)$ y que son asimismo los que menos importancia dan al crecimiento económico (21,9\%). Quienes viven en los municipios más pequeños ofrecen la misma tendencia, aunque menos pronunciada (63\% y $36,2 \%$ respectivamente), seguidos de los vecinos de municipios de entre 50.001 y 200.000 $(55,7 \%$ y $42,4 \%)$ y, finalmente, son quienes viven en municipios de entre 10.001 y 50.000 habitantes los que ofrecen porcentajes muy similares en cuanto a sus prioridades (49,9\% y 47,5\%). Posiblemente en el primer caso las respuestas dejan traslucir lo que se echa de menos en las grandes ciudades gallegas, mientras que en el segundo la priorización del medio ambiente denota una preocupación por sus condiciones materiales de vida. En el caso de los municipios intermedios, especialmente el de entre 10.001 y 50.000 habitantes, el mayor peso relativo otorgado al crecimiento económico puede estar relacionado con el escaso nivel de servicios e infraestructuras existente en el municipio.

Tabla 7.10. Porcentaje que da prioridad al medio ambiente o al crecimiento económico en Galicia (2008) según tamaño de municipio.

\begin{tabular}{lcccc} 
& $\begin{array}{c}\text { Prioridad } \\
\text { al medio } \\
\text { ambiente }\end{array}$ & $\begin{array}{c}\text { Prioridad } \\
\text { al crecimiento } \\
\text { económico }\end{array}$ & $\begin{array}{c}\text { Otra } \\
\text { respuesta }\end{array}$ & Total \\
\hline Menos de 10.001 hab. & 63,0 & 36,2 & 0,7 & 100 \\
\hline $\mathbf{1 0 . 0 0 1 - 5 0 . 0 0 0 ~ h a b . ~}$ & 49,9 & 47,5 & 2,6 & 100 \\
\hline 50.001-200.000 hab. & 55,7 & 42,4 & 1,9 & 100 \\
\hline Más de 200.000 hab. & 72,4 & 21,9 & 5,6 & 100 \\
\hline Total & 59,7 & 37,8 & 2,4 & 100 \\
\hline
\end{tabular}

Fuente: EMV-Galicia 2008. Elaboración propia.

Otro indicador que puede dar cuenta del cambio de actitudes de los gallegos en relación al medio ambiente es el de la participación en asociaciones que persiguen su conservación. En realidad, el de la participación en organizaciones de la sociedad civil, ya sean ecologistas o de otro tipo y conocidas en su conjunto como Tercer Sector, es un indicador de la vitalidad del tejido social que, en el marco de la modernización reflexiva, adquiere una especial importancia. En efecto, los individuos tratan de recuperar el espacio 
cedido a las burocracias, al menos en lo que a la conformación de la agenda se refiere, sobre todo porque perciben que lo que puede ser importante para ellos no lo es en la misma medida para las administraciones ni para quienes las gobiernan. Ahora bien, la participación de los ciudadanos puede tener múltiples direcciones y ser diversa en cuanto a sus formas. De hecho, se presenta aparentemente desconectada de cualquier cuestión política y, sin embargo, en determinadas circunstancias, puede servir como medio de transmisión de la información y como espacio para generar debate público y para articular demandas políticas ${ }^{31}$ ya que, en la sociedad del riesgo, los grupos de ciudadanos son capaces de tomar la iniciativa temática llevando a la agenda social los temas de un mundo amenazado en contra de la resistencia de los partidos establecidos (Beck, 2009: 107). Por esta razón concluiremos este capítulo haciendo un repaso de la estructura de la participación en las organizaciones sociales que componen el Tercer Sector en Galicia.

\subsection{LA ESTRUCTURA DEL ASOCIACIONISMO EN GALICIA}

Finalizábamos el apartado anterior con una cita de Ulrich Beck que pone de manifiesto la importancia que se le atribuye hoy en día a la participación social. Debemos aclarar que, no siendo su función principal, el Tercer Sector puede llegar a asumir el papel señalado por Beck. Dicho papel es el propio de los grupos de ciudadanos articulados en un movimiento social, puesto que es a los movimientos sociales a quienes se les suele reconocer esa potencialidad de acción y de cambio social (Habermas, 1989; Castells, 1997; Kellner, 1989).

El término Tercer Sector suele emplearse para referirse al conjunto de organizaciones que, siendo de titularidad privada, realizan su acción en el ámbito de lo público y además, y esto es importante, sin tener ánimo de lucro. Se consideran entidades del Tercer Sector las ONG, las asociaciones culturales, las recreativas, las ecologistas, y también las fundaciones ${ }^{32}$. Tanto los movimientos sociales como el Tercer Sector no tienen una definición consensuada y, aunque ambos se nutren de la misma sociedad civil, suele emplearse el concepto de movimiento social cuando se quiere enfatizar la dimensión explícitamente política de aquélla y el de Tercer Sector para referirse a la constelación de organizaciones que la componen normalmente. En cualquier caso, probablemente la diferencia entre ambos conceptos no sea muy relevante. No, al menos, en el presente caso. En efecto, la plataforma social que articuló la protesta social generada a raíz de la

Véase como, ejemplo, la nota número 33

Hay autores que incluyen a los partidos y a los sindicatos en el Tercer Sector porque son de titularidad privada, no persiguen el lucro y desarrollan su actividad en la esfera pública (Salamon y Anheier, 1992; Olabuénaga, 2000). Sin embargo, ésta es una cuestión polémica por cuanto los partidos políticos tienen como fin el alcanzar el poder para gestionarlo, por lo que se pueden considerar como instituciones cuasi estatales, y los sindicatos son organizaciones de defensa de los trabajadores que persiguen cuotas de poder dentro de las empresas y que compiten por el control de parte del gasto público. 
crisis del Prestige, Nunca Máis, estaba compuesta por un gran número de organizaciones del Tercer Sector, así como por innumerables individuos ${ }^{33}$.

A continuación se analizará a qué tipo de las organizaciones se afilian los gallegos y se comparará dicha pertenencia con la que ocurre en España ${ }^{34}$. Posteriormente se ofrecerá más información sobre el grupo que se muestra más participativo y se elaborará un perfil de los más activos.

El rasgo más destacable es que casi dos de cada tres gallegos dice pertenecer a asociaciones de iglesia u organizaciones religiosas. Muy probablemente esta respuesta refleja, más que la participación en asociaciones de tipo religioso, la pertenencia a la Iglesia Católica. Independientemente de que se deba o no considerar a ésta dentro del Tercer Sector ${ }^{35}$, hemos de decir que este tipo de pertenencia ha bajado en casi un $11 \%$ en los últimos trece años, siendo la caída de un 33,3\% entre quienes se consideran miembros activos y habiéndose incrementado en un 15,7\% el peso de los que se consideran no activos. En España el porcentaje de quienes afirmaban pertenecer a este tipo de entidades es del $21,2 \%$ (un 50,9\% menos que en 1995; un 35,4\% menos en lo que se refiere a los miembros activos, y un 43,7\% menos los no activos).

El siguiente tipo de entidades más populares son las deportivas o de ocio, que son las elegidas por el 34,7\% de los gallegos (por un 14,4\% en España), seguidas

33 En concreto, 68 asociaciones culturales y juveniles; 31 vecinales y también asociaciones que agrupan a éstas; 43 asociaciones de empresarios; 22 asociaciones de profesionales; 11 asociaciones de mujeres y de amas de casa (algunas de las cuales eran plataformas que representaban a más colectivos); 17 asociaciones deportivas; 3 ateneos, 4 organizaciones de iglesia, 1 de consumidores; también había, con respecto a las relacionadas con la educación, la docencia y la investigación, 6 APAs individuales, la Confederación Galega de APAS de Centros Públicos (CONFAPA-Galicia); 9 asociaciones estudiantiles; 3 consejos escolares; 13 organizaciones de docentes —incluyendo algún departamento universitario-; y 4 Facultades universitarias. Había ONG: 33 ecologistas y otras 33 solidarias/de salud, además de plataformas y coordinadoras de las mismas, como la Coordinadora Galega de ONGD (en la que están Medicus Mundi, Manos Unidas, Intermón, etc.) y Ecologistas en Acción. Había también 10 organizaciones sindicales (UGT, CIG, CC. OO., USO, CGT y CNT, junto con otras minoritarias y comités de empresa). Finalmente, estaba el partido nacionalista (BNG), pero también otras 20 agrupaciones políticas entre las que destacan IU, la organización juvenil del PSOE así como 4 agrupaciones locales de este mismo partido (el PSOE como tal no formó parte de la plataforma). Información tomada de http://nuncamais.vieiros.com el 5/05/2004. Creemos que con este ejemplo se demuestra la importancia de las organizaciones del Tercer Sector (entendido en su sentido más amplio) como canalizadoras de la acción social que, en ocasiones, puede adquirir tintes políticos y, por eso mismo, la inutilidad de tratar de establecer definiciones del Tercer Sector y de los movimientos sociales que, por ser mutuamente excluyentes, y llegado el caso, no se correspondan con la realidad.

34 Hemos de advertir que los datos que compararemos a continuación son los de las encuestas realizadas en 1995 (en España y en Galicia), así como las de 2007 (en España) y 2008 (en Galicia). Las preguntas de cuestionario en ambas oleadas son coincidentes (salvo que en 1995 no se preguntó por las asociaciones de consumidores, por lo que dicho ítem se retiró de este análisis), no así las que se hicieron en 2000 y 2001. En estas últimas las preguntas se formularon de manera diferente; dos, la primera a modo de filtro, con dos opciones de respuesta cada una. En 1995, 2007 y 2008 se realizó una sóla pregunta con tres opciones de respuesta, lo que, creemos, induce a los entrevistados a aumentar su respuesta (como le ocurre a Torre Prados, 2005, aunque en su investigación se ofrecían cuatro opciones de respuesta). Diremos, en este sentido, que los resultados de 1995, 2007 y 2008 , ofrecen valores más elevados con respecto a otras fuentes estadísticas que se puedan manerjar (seguramente derivados de la formulación de la pregunta) y que son consistentes entre sí. Los resultados de la encuesta de 2000 en España y 2001 en Galicia se pueden consultar en Veira, Pena y Sánchez (2007).

35 A la hora de estudiar el Tercer Sector, existe la posibilidad de considerar las organizaciones y asociaciones religiosas como propias del mismo o no. Víctor Pérez Díaz (Pérez Díaz y López Novo, 2005) las tuvo en cuenta en su estudio sobre el Tercer Sector en Galicia, debido a razones de tipo histórico y a que entiende que realizan una oferta de servicios de carácter social, cultural o espiritual, además del estrictamente religioso (Pérez Díaz y López Novo, 2005: 101). Sin embargo, Ruiz de Olabuénaga en su estudio sobre el Tercer Sector en España, y pese a trabajar en el marco del Third Sector Project de la Universidad Johns Hopkins y utilizar la Clasificación Internacional de Organizaciones No Lucrativas (INCPO, que en su categoría no 10 recoge a las iglesias), decidió no incluirlas. 
de las artísticas, culturales o educativas (con un 22,1\% en Galicia y un 9,3\% en España), las humanitarias o caritativas (con un 17,5\% en Galicia y un 9,4\% en España), las de tipo profesional (un 14\% en Galicia y un 6,6\% en España) y los sindicatos (13,6\% en Galicia y 7,6\% en España). El resto de entidades puntúan en Galicia con un porcentaje inferior al 10\%; así, los partidos políticos con un 9,6\% (4,7\% en España) y las organizaciones medio ambientales con un 9,1\% (un 4,7\% en España). Estos datos, detallados según pertenencia activa o no activa, se encuentran en la Tabla 7.11.

En conjunto, y sobre todo, hay que destacar la mayor pertenencia a asociaciones del Tercer Sector manifestada en Galicia con respecto a España. Posiblemente lo que subyace a este hecho, que rompe con otro de los tópicos con respecto a la sociedad gallega, es el desarrollo institucional que ha acompañado a la puesta en marcha del Estado de Bienestar, especialmente en los niveles locales (ayuntamientos y comarcas) ${ }^{36}$. La construcción de piscinas y polideportivos, la disponibilidad de locales para reuniones y ensayos, así como la necesidad de los gobiernos locales de contar con interlocutores sociales, ha propiciado el asociacionismo. En cualquier caso, hay autores como Torre Prados (2005) para quien en la sociedad española existe un grado de pertenencia asociativa de mayor entidad y amplitud que los niveles reconocidos hasta ahora (Torre Prados, 2005: 49); de hecho, en dicho estudio solo el 39\% de los encuestados afirmaron no pertenecer a ningún tipo de asociación, porcentaje que en el caso de Galicia roza el 48\% y en España supera el 73\%.

Otro elemento llamativo es el tipo de entidades que han visto incrementada o reducida su importancia relativa en los últimos años en Galicia. En efecto, y además de las religiosas, son las organizaciones medio ambientales y humanitarias, esto es, las conocidas normalmente como ONGs, las que perdieron peso $(1,1 \%$ y $2,9 \%$ respectivamente), especialmente entre su base social activa ( $0,8 \%$ y $2,1 \%$ respectivamente). Por el contrario, las organizaciones que canalizan las aficiones personales, los aspectos más lúdicos y de ocio, aumentaron notablemente (en consonancia con la idea de la individualización); así, las deportivas y de ocio se incrementaron en un 5\% en trece años (en un 3,9\% la membresía activa y en un $1,2 \%$ la no activa) y las culturales, musicales y educativas en un $1,4 \%$ (3,4\% los miembros activos, descendiendo los no activos en un 2,1\%). Igualmente destacable es que las organizaciones de representación institucional, ya sea de tipo político como los partidos, o de tipo laboral como los sindicatos y asociaciones profesionales, hayan incrementado su importancia aunque sea de manera muy leve $(0,1 \%, 1,9 \%$ y $0,3 \%$ respectivamente), aunque en este caso el aumento se centró en la membresía no activa (los miembros activos en estas organizaciones descendieron porcentualmente con respecto a 1995).

36 Por otro lado, no se debe olvidar el hecho de que en Galicia, hay 2.900 comunidades de montes de mancomún, repartidos por 248 de los 316 municipios gallegos, según la Organización Galega de Comunidades de Montes Veciñais en Man Común (www.orgaccmm.org/xORGANIZACION /ORGA-1.htm, consulta realizada el 22/2/2010). 


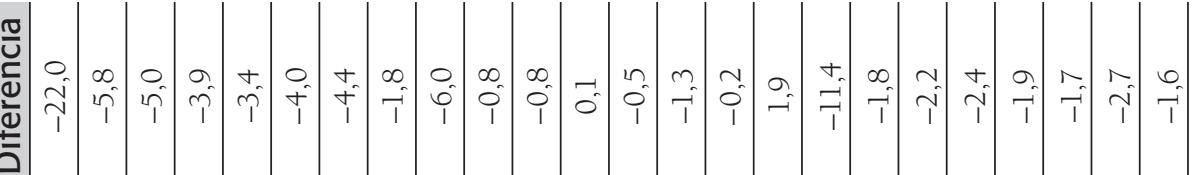

फिं

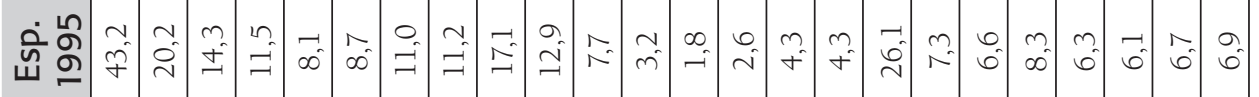

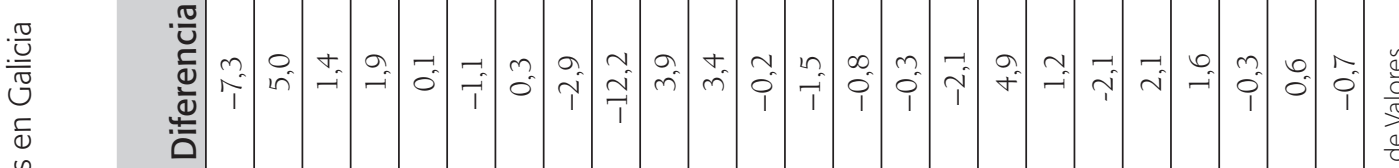

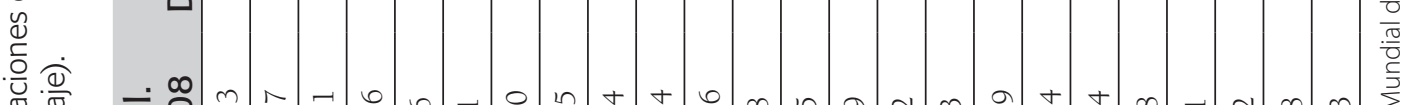

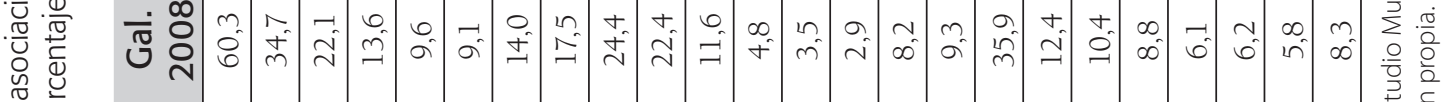

ช

는 $\frac{\mathrm{c}}{\mathrm{C}}$

至 $\infty$

उु

岀: 을

塎

중

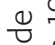

든 든

공

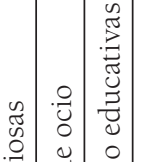

$\frac{\pi}{\frac{\pi}{\pi}}$

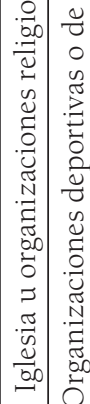

0
0
0

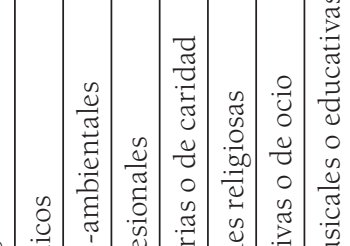

胥

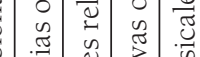

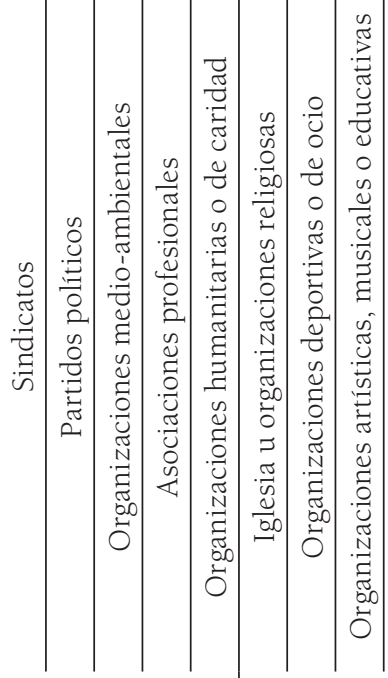

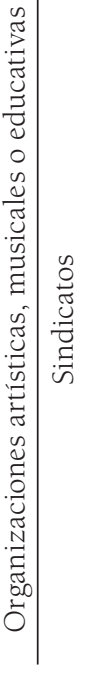
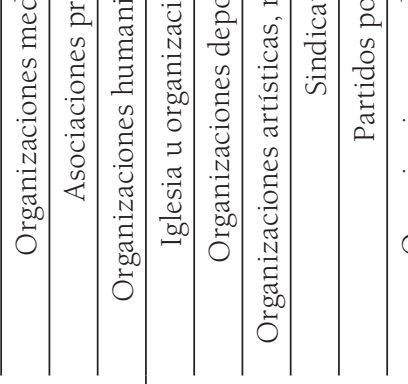

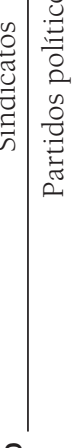

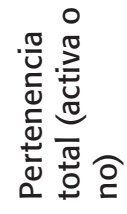

号

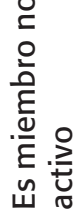


Es interesante conocer el perfil de los individuos que se muestran más participativos en las entidades del Tercer Sector. En la Tabla 7.12 se muestran los cruces de diferentes variables con una que sintetiza la pertenencia a las asociaciones del Tercer Sector ${ }^{37}$. En esta tabla se puede comprobar que la mayor parte de los varones pertenecen a alguna asociación y que la mayoría de las mujeres no pertenece a ninguna; dicho esto, la diferencia en los dos sexos en cuanto a pertenencia apenas supera el $8 \%$ y el $10 \%$ en cuanto a no pertenencia. El tamaño del municipio ofrece información relevante por cuanto no hay casi diferencias entre los municipios más pequeños y más grandes (en ambos casos, alrededor del 53\% no pertenece a asociación alguna y alrededor del 38\% tiene una pertenencia intensa). Son los municipios de entre 50.001 y 200.000 habitantes los que demuestran tener un Tercer Sector más implantado en la comunidad, ya que el 59,1\% dice tener una pertenencia que entendemos como intensa y solo el 33,1\% no pertenece a ninguna asociación. Por su parte, en los municipios de entre 10.001 y 50.000 habitantes los niveles de asociacionismo no alcanzan los comentados, pero superan claramente a los de los municipios más grandes y más pequeños.

El nivel de estudios es una variable que se relaciona de manera muy clara con la pertenencia a asociaciones. El 21,2\% de quienes tienen un muy bajo nivel de estudios pertenece a una asociación, porcentaje que asciende al $40 \%$ si el nivel es bajo, al $53,8 \%$ si el nivel es medio, al $49 \%$ si es alto y al $67,2 \%$ si es muy alto, más del triple con respecto a la primera categoría.

Pero la variable que ofrece una relación lineal con la pertenencia a asociaciones es la edad, tanto recodificada en grupos como en generaciones. Son los más jóvenes los que pertenecen en mayor medida a entidades del Tercer Sector (un 61,6\% los individuos de entre 18 y 24 años tienen una participación intensa). Por el contrario, un 67,3\% de los mayores de 65 años no pertenecen a ninguna asociación.

Finalmente, también la asunción de valores materialistas o posmaterialistas influye en la participación. Los materialistas puros son los que menos participan (un $62,1 \%$ no pertenece a ninguna asociación, el doble de los que tienen una participación intensa), seguidos de los mixtos-materialistas (un 41,1\% no participa y un 49,9\% lo hace de manera intensa). Los mixtos posmaterialistas y los posmaterialistas puros son bastante más participativos, aunque ligeramente más los primeros que los segundos.

\footnotetext{
En esta variable de síntesis se ha excluido la que se refería a la pertenencia a la Iglesia por las razones comentadas anteriormente. La pertenencia moderada se define como membresía no activa en una organización y la intensa como, por lo menos, la membresía activa en una o la no activa en dos. Todos los cruces se han mostrado estadísticamente significativos.
}

\section{LA EVOLUCIÓN DE LOS VALORES SOCIALES EN GALICIA}


Tabla 7.12. Perfiles sociodemográficos según participación en organizaciones del Tercer Sector en Galicia (en porcentaje).

\begin{tabular}{|c|c|c|c|c|c|}
\hline & & $\begin{array}{c}\text { No pertenece } \\
\text { a ninguna }\end{array}$ & $\begin{array}{c}\text { Pertenencia } \\
\text { moderada }\end{array}$ & $\begin{array}{c}\text { Pertenencia } \\
\text { intensa }\end{array}$ & Total \\
\hline \multirow{2}{*}{ Sexo } & Varón & 42,2 & 8,9 & 48,9 & 100 \\
\hline & Mujer & 52,6 & 6,7 & 40,6 & 100 \\
\hline \multirow{4}{*}{$\begin{array}{l}\text { Tamaño } \\
\text { Municipio }\end{array}$} & $\begin{array}{l}\text { Menos de } \\
10.001 \text { hab. }\end{array}$ & 54,2 & 7,9 & 37,9 & 100 \\
\hline & $\begin{array}{c}\text { 10.001-50.000 } \\
\text { hab. }\end{array}$ & 44,6 & 7 & 48,4 & 100 \\
\hline & $\begin{array}{c}50.001-200.000 \\
\text { hab. }\end{array}$ & 33,1 & 7,8 & 59,1 & 100 \\
\hline & $\begin{array}{c}\text { Más de } 200.000 \\
\text { hab. }\end{array}$ & 52,5 & 8,5 & 38,9 & 100 \\
\hline \multirow{6}{*}{$\begin{array}{l}\text { Edad } \\
\text { por grupos }\end{array}$} & $18-24$ & 32,9 & 5,5 & 61,6 & 100 \\
\hline & $25-34$ & 36,2 & 8,7 & 55 & 100 \\
\hline & $35-44$ & 37,7 & 8,5 & 53,9 & 100 \\
\hline & $45-54$ & 42,7 & 8,2 & 49 & 100 \\
\hline & $55-64$ & 54,7 & 5,8 & 39,6 & 100 \\
\hline & $65 y+$ & 67,3 & 8,4 & 24,4 & 100 \\
\hline \multirow{5}{*}{$\begin{array}{l}\text { Nivel de } \\
\text { estudios } \\
\text { agrupado }\end{array}$} & Muy bajo & 73 & 5,8 & 21,2 & 100 \\
\hline & Bajo & 52,1 & 7,9 & 40 & 100 \\
\hline & Medio-bajo & 35,3 & 11 & 53,8 & 100 \\
\hline & Medio-alto & 44,2 & 6,8 & 49 & 100 \\
\hline & Alto & 27,6 & 5,2 & 67,2 & 100 \\
\hline \multirow{4}{*}{$\begin{array}{l}\text { Índice de mat- } \\
\text { posmaterialismo }\end{array}$} & Materialista & 62,1 & 6,9 & 31 & 100 \\
\hline & Mixto-Mat & 41,1 & 9,3 & 49,6 & 100 \\
\hline & Mixto-Posmat & 36,2 & 7,3 & 56,5 & 100 \\
\hline & Posmaterialista & 38 & 7 & 55,1 & 100 \\
\hline Total & & 47,5 & 7,8 & 44,7 & 100 \\
\hline
\end{tabular}

Fuente: EMV-Galicia 2008. Elaboración propia. 
Un estudioso del asociacionismo en Galicia afirmó, no hace tanto tiempo, que lejos nos hallamos (...) de la posibilidad de que uno de cada tres de nuestros ciudadanos se adhiera formalmente a una asociación (Bouzada, 1994: 200). Los datos aquí expuestos dan idea del camino que ha recorrido la sociedad gallega en los últimos años. De mantenerse las tendencias aquí detectadas y expuestas, Galicia verá incrementado su nivel de asociacionismo y robustecido su Tercer Sector, habida cuenta de que son los más jóvenes quienes más desarrollan los vínculos asociativos, de que no hay grandes diferencias entre los entornos más urbanos y los más rurales, de que la pertenencia a asociaciones es intensa en los municipios de tamaño intermedio, y de que en la medida en la que aumente el nivel de estudios, así lo hará la vinculación con organizaciones del Tercer Sector.

\subsection{CONCLUSIONES}

Este capítulo comenzaba estableciendo un paralelismo entre la situación actual, en los albores de la sociedad de la información, y la que se vivió en Galicia cuando la sociedad industrial era incipiente. La historiografía moderna ha demostrado que en aquella época Galicia se encontraba en buenas condiciones para acometer el cambio económico y social derivado de la industrialización pero que, por diversas circunstancias, en gran parte ajenas a la propia realidad gallega, ésta ocurrió tarde y con dramáticas consecuencias sociales (muestra de lo cual fue la emigración sufrida desde el siglo XIX). En los inicios de la sociedad de la información, en la que "las claves" son las personas y el uso que hagan de la información y de las nuevas tecnologías en función de su conocimiento e imaginación, Galicia se encuentra ante una situación semejante de posibilidades y de retos, así como de incertidumbres.

Se ha constatado que el déficit en materia de infraestructuras tecnológicas es mayor en Galicia que en otras partes de España, lo cual repercute seguramente en un menor uso de las NTIC; pero también que los gallegos solventan esta situación haciendo una intensidad de uso diferente o, al menos, un aprovechamiento diferente de las posibilidades de la Red (como muestra su uso en lugares diferentes a los habituales de hogar y lugar de trabajo o su empleo para, por ejemplo, realizar compras). Asimismo, se ha mostrado la imagen de una sociedad gallega preocupada por informarse, en mayor medida que la media española, y de emplear para ello cualquier medio (ya sea de masas, interpersonal o tecnológico).

Ha ocurrido un cambio de la actitud en Galicia ante la ciencia y la tecnología, incrementándose notablemente en los últimos años la valoración que se hace de aquéllas hasta alcanzar valores similares a los del resto de España. Pero, y a diferencia de lo que ocurre en el resto de España, los segmentos poblacionales que cabría hallar como más favorables al conocimiento científico y a los avances tecnológicos que posibilita, demuestran mantener una cierta distancia que se ha identificado con la cautela. Este hecho, que coincide con los resultados de otros estudios, sugiere la idea de que en Galicia existe la conciencia de vivir en 
la sociedad del riesgo. A dicha conciencia no deben ser ajenas las catástrofes ecológicas provocadas a lo largo de 30 años por los siete naufragios ocurridos en sus costas, de las cuales la del Prestige es la más reciente. Es probable que esta conciencia del riesgo origine la base de la priorización que, mayoritariamente, la sociedad gallega afirma hacer del medio ambiente sobre el crecimiento económico, aunque también hay elementos para pensar que los valores ecologistas no están muy consolidados en la sociedad.

En cualquier caso, la misma crisis del Prestige evidenció ante las cámaras de televisión de todo el mundo cómo la sociedad gallega era capaz de organizarse y articular demandas ante los fallos de control en la sociedad del riesgo, a través de la plataforma Nunca Máis que, formada por un gran número de asociaciones del Tercer Sector, a su vez rompió el tópico de que en Galicia apenas hay asociacionismo. Por el contrario, la voluntad asociativa existente en Galicia, al ser más intensa en los gallegos más jóvenes (que además de alfabetizados en las NTIC son los que cuentan con mayores niveles de educación), ofrece ciertas garantías de que en el cambio a la sociedad de la información (y del riesgo) no ocurrirá lo mismo que en el pasado tránsito a la sociedad industrial.

\subsection{REFERENCIAS BIBLIOGRÁFICAS}

Anderson, P. (2000): Los orígenes de la postmodernidad. Madrid, Anagrama.

Alonso Álvarez, L. (2005): "La crisis de la economía tradicional: continuidad y cambio en la Galicia del siglo XIX" en Jesús de Juana y Julio Prada (Coords.) Historia contemporánea de Galicia, Madrid, Ariel.

Arroyo Menéndez, M. (2007): "Diferencias en percepción y seguimiento de la ciencia y la tecnología por comunidades autónomas" en VV. AA., Percepción social de la ciencia y la tecnología en España 2006. Análisis de la Tercera Encuesta Nacional sobre Percepción Social de la Ciencia y la Tecnología, Madrid, Fundación Española para la Ciencia y la Tecnología: 17-38.

Baigorri, A. et. al. (2005): "Estrategias de inserción en la sociedad de la información de las empresas". Comunicación presentada en las XIII Jornadas de la Asociación Española de Profesores Universitarios de Matemáticas para la Economía y la Empresa (ASEPUMA). A Coruña, 15 y 16 de septiembre.

Baudrillard, J. et al. (2000): La postmodernidad. Barcelona, Kairós.

Beck, U. (1994): La sociedad del riesgo. Hacia una nueva modernidad, Barcelona, Paidós.

Beck, U. (1999): "Reflexive Modernisierung" en Archplus, 146: 18-19. Consultado en www.criterios.es/pdf/ archplusbeckmoder.pdf el 12/04/10. Texto traducido por Orestes Sandoval López.

Beck, U. (2009): La sociedad del riesgo global, Madrid, Siglo XXI.

Beck, U., Giddens, A. y Lash, S. (2001): Modernización reflexiva. Política, tradición y estética en el orden social moderno, Madrid, Alianza Universidad. 
Bell, D. (1991): El advenimiento de la sociedad postindustrial un intento de prognosis social, Madrid, Alianza.

Bouzada Fernández, X. (1994): "La Galicia desconocida de las asociaciones" en Documentación Social 94: 197-212.

Carmona Badía, X. y Nadal Oller, J. (2005): El empeño industrial de Galicia. 250 años de historia (1750-2000), A Coruña, Fundación Pedro Barrié de la Maza.

Castells, M. (1997): La era de la Información vol. II El poder de la identidad. Madrid, Alianza.

Castells, M. (2001): La era de la Información vol. I La sociedad red. Madrid, Alianza.

Chaves Carrillo, M. ${ }^{a}$ del M. (2004): "El modelo de urbe global" en Aposta. Revista de Ciencias Sociales 4: 1-15.

Díez Nicolás, J. (1994): "Posmaterialismo y desarrollo económico" en J. Díez Nicolás y R. Inglehart, Tendencias mundiales de cambio en los valores sociales y políticos, Madrid, Fundesco: 125-155.

Díez Nicolás, J. (2004): El dilema de la supervivencia: los españoles ante el medio ambiente, Madrid, Obra social de Caja Madrid.

Díaz Martínez, J. A. (2009): "Actitudes prácticas de la sociedad ante la ciencia y la tecnología" en Sistema 213: 37-54.

Eurostat (2009): Taxation Trends in the European Union, Julio de 2009.

FECYT (2007): Percepción social de la ciencia y la tecnología en España 2006. Análisis de la Tercera Encuesta Nacional sobre Percepción Social de la Ciencia y la Tecnología, Madrid, Fundación Española para la Ciencia y la Tecnología.

Fernández Prados, J. S. (2006): "El valor de la ciencia y de la tecnología en la cultura española contemporánea" en Eduardo Bericat Alastuey (Dir.), El conflicto cultural en España. Acuerdos y desacuerdos entre los españoles, Madrid, CIS: $328-386$.

Giddens, A. (1990): Consecuencias de la modernidad, Madrid, Alianza.

Habermas, J. (1989): El discurso filosófico de la modernidad, Madrid, Taurus.

Hayes, B. C. y Tariq, V. N. (2000): "Gender differences in Scientific Knowledge and attitudes toward science: a comparative study of four Anglo-American nations" en Public Understanding of Science 9: 433-447.

Inglehart, R. (1977): The silent revolution: Changing Values and political styles. Princeton, Princeton University Press.

Inglehart, R. (1998): Modernización y postmodernización: el cambio cultural, económico y político en 43 sociedades avanzadas, Madrid. CIS.

Jameson, F. (1991): El posmodernismo o la lógica cultural del capitalismo avanzado, Barcelona, Paidós.

Justo Suárez, C. (2004): "El mito de la incompetencia tecnológica de las mujeres a través del humor" en Debats 85: 68-77.

Kellner, D. (1989): Critical Theory, Marxism and Modernity, Baltimore, Johns Hopkins University Press. 
Luján López, J. L. (2007): "El principio de precaución y la imagen social de la ciencia" en VV. AA., Percepción social de la ciencia y la tecnología en España 2006. Análisis de la Tercera Encuesta Nacional sobre Percepción Social de la Ciencia y la Tecnología, Madrid, Fundación Española para la Ciencia y la Tecnología: 65-80.

MMA (2005): La catástrofe del Prestige: Limpieza y restauración del litoral norte Peninsular, Madrid, Ministerio de Medio Ambiente y CEPRECO (Ministerio de la Presidencia).

Murado, M.-A. (2008): Otra idea de Galicia, Barcelona, Debate.

Pérez Díaz, V. y López Novo, J. P. (2005): El Tercer Sector, presente y promesa. Un análisis de su problemática general y de su realidad en Galicia, Obra Social de Caixa Galicia.

Pérez Manzano, A. (2007): "Jóvenes jugando en las orillas de la ciencia y la tecnología" en VV. AA., Percepción social de la ciencia y la tecnología en España 2006. Análisis de la Tercera Encuesta Nacional sobre Percepción Social de la Ciencia y la Tecnología, Madrid, Fundación Española para la Ciencia y la Tecnología: 105-138.

Radl Philipp, R. (2007): "Percepción social de la ciencia y la tecnología y género" en VV. AA., Percepción social de la ciencia y la tecnología en España 2006. Análisis de la Tercera Encuesta Nacional sobre Percepción Social de la Ciencia y la Tecnología, Madrid, Fundación Española para la Ciencia y la Tecnología: 161-184.

Rodríguez París, E. (2004): La aportación bibliotecaria a la implantación de la sociedad de la información en Galicia. Proyecto de DEA leído en el Dpto. de Socioloxía, Ciencia Política e da Administración el 30 de septiembre de 2004.

Ruíz de Olabuénaga, J. I. (Dir.) (2000): El sector no lucrativo en España. Bilbao. Fundación BBV.

Salamon, L. M. y Anheier, H. K. (1992): "In search of the non-profit sector I: The question of definitions" en Voluntas 3/2: 125-151.

Toffler, A. (1980): La tercera ola, Plaza \& Janés, Barcelona.

Torre Prados, I. de la (2005): Tercer Sector y participación ciudadana en España, Madrid, CIS.

Veira Veira, J. L. (2007): "Valores verdes" en José Luis Veira Veira (Dir.) Las actitudes y los valores sociales en Galicia, Madrid, CIS: 246-259.

Veira Veira, J. L., Pena López, J. A. y Sánchez Santos, J. M. (2007): "Capital social" en J. L. Veira Veira (Dir.) Las actitudes y los valores sociales en Galicia, Madrid, CIS: 30-59. 


\section{LA CULTURA DEL TRABAJO EN GALICIA}

Celia Muñoz Goy

\subsection{INTRODUCCIÓN}

El trabajo y los valores que se le asocian han sido temas de estudio a los que se ha concedido gran importancia en el campo de las ciencias sociales. Es lógico que se preste mucha atención a una actividad que ocupa gran parte de la vida de las personas, no solo en el desempeño efectivo del trabajo sino también en la preparación y el entrenamiento para su realización. El trabajo concierne a toda la población, activa o no. Tal vez por esta razón, todas las personas tienen una opinión sobre el tema, sea porque ejercen actualmente un trabajo, porque lo han ejercido antes, o porque lo ejercerán en el futuro. Incluso si una persona nunca ha trabajado puede tener opiniones sobre el trabajo.

En las sociedades desarrolladas, el concepto de trabajo suele estar vinculado al mercado laboral. Además del trabajo remunerado existen otros tipos de actividades que pudieran incluirse bajo el mismo término, como el trabajo voluntario, el trabajo doméstico o, incluso, las aficiones. Sin embargo, los términos trabajo y empleo suelen utilizarse como sinónimos, tanto en el lenguaje coloquial como en el usado en las ciencias sociales (Jahoda, 1987: 25), por ello en este capítulo se empleará la definición de trabajo como una actividad remunerada que se realiza en el ámbito del mercado laboral.

Aunque algunos autores afirman que el trabajo es un valor en vías de extinción (Méda, 1998) y que se avecina su fin (Rifkin, 1996), para otros parece más plausible que en realidad estemos ante un proceso de cambio en el ámbito laboral (Harding y Hikspoors, 1995; Zanders, 1994). Los cambios que están afectando al trabajo tienen lugar en un doble plano.

Por una parte, se está alterando la expresión más institucionalizada del trabajo, es decir el contrato laboral. Los contratos se han flexibilizado de modo que ya no abundan las trayectorias vitales vinculadas a un único empleo a tiempo completo y prácticamente de por vida, sino que los empleos se están volviendo más flexibles, a tiempo parcial y sin continuidad asegurada en el tiempo (Alonso, 2000 y 2004). 
Por otra parte, es posible que el significado y los valores del trabajo estén modificándose como consecuencia de un proceso más general de cambio de valores (Inglehart, 1991 y 1998; Yankelovich, 1985 y 1994). En consonancia con los valores expresivos o posmodernos, que hacen hincapié en la calidad de vida, algunos autores vaticinan que en el ámbito laboral se dará cada vez más importancia a que el desempeño de un trabajo permita no solo conseguir unos ingresos sino también acceder a una experiencia laboral enriquecedora, que propicie la autorrealización y el logro personal.

Para ofrecer un marco de referencia y por las posibles implicaciones que pudiera tener en las opiniones y valoraciones de los entrevistados acerca del trabajo, este capítulo comenzará con una descripción de la evolución del mercado laboral en los últimos treinta años. A continuación se analizarán los datos de la Encuesta Mundial de Valores, que ofrecen información sobre la centralidad, la ética, las orientaciones hacia el trabajo y la individualización en la esfera laboral. Para cada una de las variables consideradas se presentarán los resultados de la última edición de esta Encuesta para el conjunto de los países del mundo y para los países europeos con mayor índice de desarrollo humano, con el propósito de disponer de un punto de comparación. Tras ello se analizará la evolución temporal en España y Galicia de los aspectos relacionados con el trabajo en las tres recogidas de datos disponibles. En general, todas las evoluciones temporales de las variables dependientes son estadísticamente significativas, en caso contrario se mencionará explícitamente.

Para los datos de Galicia se realizó un análisis a nivel micro (individual) más pormenorizado, explorando la relación entre cada una de las variables dependientes y las siguientes variables sociodemográficas ${ }^{1}$ : las relacionadas con la edad y el momento de realización de la encuesta, índice de materialismo/posmaterialismo, nivel de estudios, nivel de ingresos del hogar, grado de satisfacción con la situación económica del hogar, género y situación laboral.

Las variables relacionadas con la edad y el momento de realización de la encuesta son consideradas importantes por diversos estudios a la hora de describir el cambio de valores o las diferencias en las opiniones sobre los valores laborales entre los distintos grupos de edad. Algunos autores —Inglehart (1991 y 1998), Inglehart y Welzel (2006), Abramson e Inglehart (1992) y Yankelovich (1985 y 1994) — sostienen que el reemplazo generacional es el mecanismo por el que se produce el cambio en los valores de una población, mientras que otros —Goldthorpe et al. (1968), MOW (1987) y Sverko y Super (1995) — señalan que es la posición en el ciclo vital la que explicaría las diferencias en los valores laborales que presentan los distintos grupos de edad. En cualquier caso se prevé

Para cada variable dependiente se calculó el grado de asociación —empleando medidas de asociación $V$ de Cramer o Tau-B, según los niveles de medición de las variables consideradas en cada caso - con las distintas variables sociodemográficas y se seleccionó la relación más intensa y consistente a lo largo de las tres encuestas, cuyos datos se comentan detalladamente en cada apartado. 
que habrá diferencias en los valores laborales de los grupos definidos por año de nacimiento. No obstante, no debe olvidarse que al comparar encuestas de distintos años es posible que se produzca un efecto período, que tiene que ver con el impacto de la coyuntura socioeconómica del momento de recogida de los datos en las opiniones de las personas encuestadas.

Tanto desde las perspectivas más teóricas como en los estudios más empíricos (Cherrington, 1980; Rose, 1985; Yankelovich, 1985 y 1994; Inglehart, 1991 y 1998; Zanders, 1994; Russell, 1998; Ros, Schwartz y Surkiss, 1999), existe un amplio consenso acerca de la coherencia entre los valores laborales y los valores a nivel más general. Como medida resumen de dichos valores a nivel general se ha incluido entre las variables explicativas el índice de materialismo/posmaterialismo.

En cuanto al nivel educativo, en diversos estudios —Yankelovich (1985), Zanders (1994) y Russell (1998) — se han encontrado claras relaciones entre dicha variable y los valores laborales, especialmente en el sentido de que las personas con mayores niveles de estudios suelen orientarse con mayor frecuencia hacia los valores intrínsecos o expresivos.

Algunos autores como Yankelovich (1985 y 1994), Inglehart (1991 y 1998) y Rokeach (1973), señalan que entre las personas que se encuentran en mejor situación económica cabría esperar una orientación más expresiva, pues, al tener sus necesidades básicas cubiertas, pueden verse libres para aspirar a una experiencia laboral creativa, enriquecedora e interesante. Para dar cuenta de la situación económica a nivel individual se han considerado las variables que recogen el nivel de ingresos del hogar y el grado de satisfacción con la situación económica del hogar.

Las justificaciones teóricas para explicar las diferencias por género en los valores laborales se pueden agrupar, como señalan Rowe y Snizek (1995), en dos enfoques: el modelo de la socialización y el modelo estructural. El modelo de la socialización sostiene que las diferencias observadas en los valores laborales reflejan los patrones tradicionales asignados a cada género, mientras que, por el contrario, el modelo estructural afirma que tales diferencias son un reflejo del acceso diferencial de varones y mujeres al sistema de recompensas laborales y a las posiciones jerárquicas. En nuestro caso se ha explorado la relación del género con las variables dependientes, a pesar de que en distintos estudios sobre el tema (Dex, 1988; Vaus y McAllister, 1991; Rowe y Snizek, 1995 y Abu-Saad, 1997) se concluye que los estereotipos sobre las orientaciones hacia el trabajo de varones y mujeres resultan inapropiados, bien porque las diferencias encontradas son muy escasas o bien porque, en caso de existir, se debilitan al establecer controles por distintas variables relacionadas con el modelo de la socialización o, sobre todo, con el modelo estructural.

Por último, en diversas investigaciones — Pino y Bericat, 1996; Ayerbe, 2000—se ha encontrado que la situación laboral permite establecer diferencias en las actitudes 
hacia el trabajo. Dichas diferencias pueden deberse a las distintas posiciones que el trabajo ocupa en la vida - lo que llevaría a establecer una diferencia entre la población activa y el resto-, o como consecuencia de la relación que tiene la situación laboral con la edad y esta con el momento en el ciclo vital de las personas.

\subsection{LA EVOLUCIÓN DEL EMPLEO}

Para contextualizar las opiniones de los encuestados sobre distintos aspectos relacionados con el trabajo se presentan en este apartado algunos datos sobre el mercado laboral en los últimos treinta años en Galicia y España. En concreto, se analizará la evolución de las tasas de actividad, paro y temporalidad a lo largo de dicho período.

La tasa de actividad — calculada como el porcentaje de población activa respecto a la población total-, tanto en España como en Galicia, se ha mantenido por encima del 49\% durante todo este período (Gráfico 8.1). En España, dicha tasa ha ido descendiendo desde el 50,67\% de 1979 hasta el 49\% de 1985, momento en que comienza a recuperase para ascender, con algunas oscilaciones, hasta el 59,8\% de 2008. En cuanto a Galicia, se ha seguido una evolución semejante, aunque partiendo de un valor superior en 1979 (57,7\%) que, con oscilaciones, alcanza el mínimo en 1997, con un 49,8\%, momento a partir del cual se inicia la recuperación para finalizar en el 55,1\% de 2008. De estos datos se desprende que la caída de la tasa de actividad ha sido mucho más acusada en Galicia que en España y que tras la fase de recuperación no ha llegado a equipararse con los valores de España.

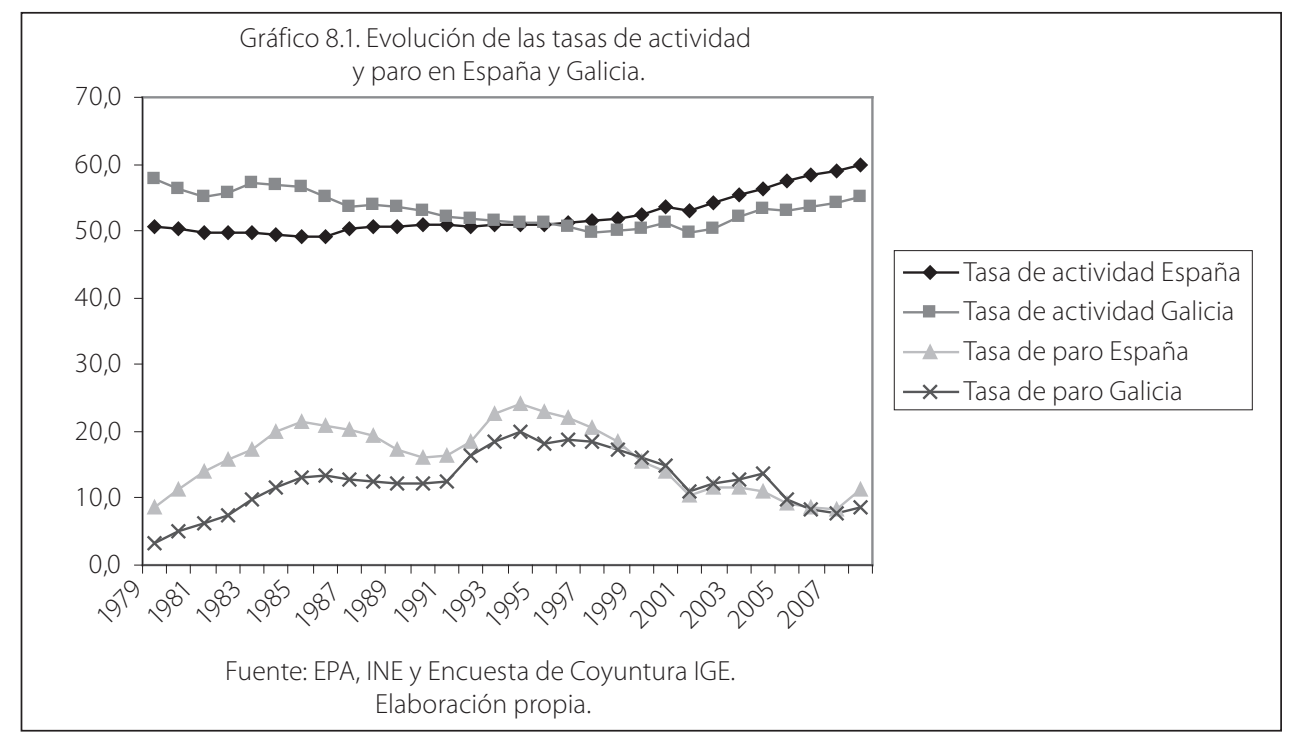

Precisamente en 1995, año en que se realizó la primera de las encuestas que se comentan en este capítulo, la tasa de actividad en Galicia y España eran 
prácticamente iguales (51,1\% y $51 \%$ respectivamente) y a partir de ese momento la tasa de actividad de Galicia se encuentra permanentemente por debajo de la de España. La igualdad en las cifras de 1995 no supone que la evolución previa haya sido similar pues mientras que en España en los años anteriores a la encuesta de 1995 se aprecia un período de relativa estabilidad de la tasa de actividad, en Galicia la situación es bien diferente, al haberse producido un claro descenso de dicha tasa. En el momento de realización de la segunda encuesta (2000 en España y 2001 en Galicia) la tasa de actividad era claramente superior para España $(53,6 \%)$ que para Galicia (49,7\%). En la última encuesta (2007 en España y 2008 en Galicia) se mantiene la diferencia a favor de España aunque en valores más elevados (58,9\% y $55,1 \%$ respectivamente).

En cuanto a la tasa de paro, la evolución en Galicia y España sigue un patrón con oscilaciones similares. En España se parte de una tasa de paro del 8,6\% en 1979 que aumenta hasta un primer máximo del 21,5\% en 1985, a partir de este punto desciende hasta el 16,2\% en 1990 para volver a aumentar hasta un máximo histórico del 24,1\% en 1994 y a continuación se produce una reducción hasta el año 2000 en el que se alcanza una cifra de cerca del 14\%. Si bien en 2001 la cifra de paro $(10,6 \%)$ es incluso menor que en el año anterior, hay que recordar que a partir de ese año se emplea una nueva definición de parado siguiendo el Reglamento 1897/2000 de la CE, que hace que desde 2001 los datos de paro no sean directamente comparables con los de períodos anteriores. Desde este momento se suceden una serie de altibajos en cifras reducidas, pasando de los valores cercanos al 11\% del principio de la década del 2000 a valores inferiores que llegan hasta el 8,3\% en 2007, para experimentar un repunte en 2008 que sitúa la cifra final de paro en el 11,3\%.

Con respecto a Galicia, la tasa de paro ha aumentado desde un mínimo del 3,4\% en 1979 hasta un primer máximo del 13,5\% en 1986, experimenta un ligero descenso y vuelve a aumentar hasta su máximo histórico del 19,9\% en 1994. Desde ese momento la cifra se reduce hasta el 14,9\% de 2000. Al igual que en España, en 2001 la tasa de paro se reduce claramente hasta el 11\%, pero de nuevo hay que tener en cuenta el cambio de legislación que afecta al modo de medirla. Desde este año se eleva la tasa hasta el 13,6\% de 2004 para descender hasta el 7,6\% de 2007 y ascender ligeramente hasta el 8,7\% de 2008.

En general, se observa que la tasa de paro de Galicia se mantiene por debajo de la de España hasta 1999. Desde ese año hasta 2005 las tasas de paro en Galicia son superiores, en 2006 son iguales en los dos ámbitos y hasta el final del período las tasas de Galicia vuelven a ser inferiores a las de España.

En 1995, momento de realización del la primera encuesta, la tasa de paro de España se situaba en casi el 23\% y en Galicia en 18\%, pero hay que destacar que precisamente en el año anterior se habían alcanzado las cifras máximas de los 
últimos treinta años, tal como se mencionó más arriba. En el año 2000, cuando se llevó a cabo la segunda encuesta para España la cifra se había reducido hasta el 13,9\%. En Galicia la segunda encuesta se realizó en el año 2001 que coincide con el momento del cambio de metodología en la medición, por lo que la cifra de ese año es aún más reducida que la de España y se coloca en el 11\%. En el momento de realización de la última consulta los valores de la tasa de paro en España (2007) y Galicia (2008) son los mínimos de las tres encuestas, situándose en el 8,3\% y $8,7 \%$ respectivamente.

En respuesta a las elevadas cifras de paro que se experimentaron en España en los años centrales de las décadas de 1980 y 1990 se produjeron dos reformas laborales, en 1984 y 1994, cuyo objetivo prioritario era crear empleo. En dichas reformas se introducen nuevas modalidades de contratación como contratos formativos (en prácticas o aprendizaje), contratación a tiempo parcial y contratación temporal, que, aunque inicialmente persiguen incrementar el empleo, acabarán desvirtuándose y conduciendo a la sustitución de empleos a tiempo completo y estables por otros de peor calidad. La consecuencia de estas reformas se reflejó en el incremento de la tasa de temporalidad — calculada como el porcentaje de asalariados con contrato temporal respecto al total de asalariados- en los últimos veinte años, pues aunque las reformas posteriores, de 1997, 2001 y 2006, intentaron disminuir la temporalidad impulsando la contratación indefinida, no consiguieron resultados significativos (Gráfico 8.2).

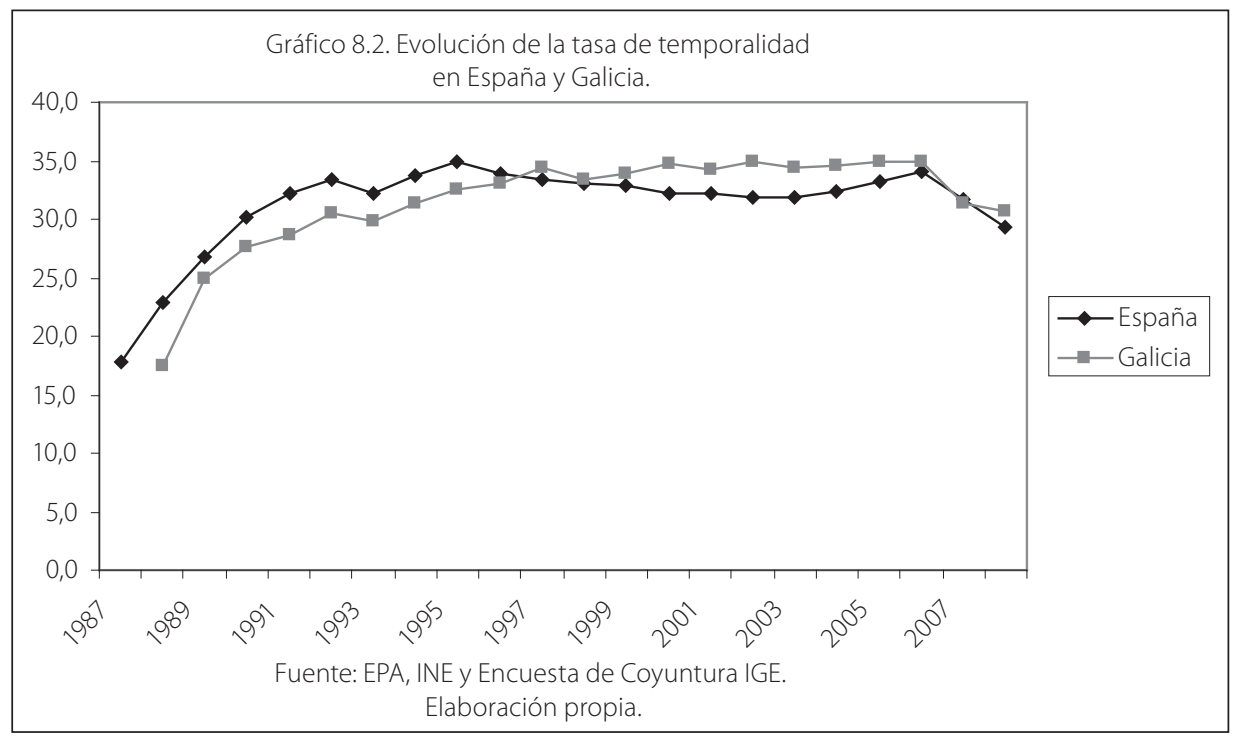

En 1987 el valor de la tasa se situaba para España en el 17,8\% y desde ese momento se produce un ascenso hasta prácticamente duplicarse $(34,8 \%)$ en 1995. A partir de entonces la tasa se mantiene estable con un ligero descenso y 
posterior repunte en 2006 (34\%) para volver a disminuir en los dos años posteriores aunque manteniéndose en torno al 30\%.

Para Galicia se observa un comportamiento de la temporalidad bastante similar al de España, si bien antes de 1996 las cifras para Galicia eran algo inferiores que las de España y a partir de dicho año los porcentajes de Galicia superan ligeramente a los de España, situándose dos o tres puntos por encima de estos.

En resumen, las tasas de temporalidad se colocan desde 1995 en torno al 33\% tanto en Galicia como en España, es decir que uno de cada tres asalariados tiene un contrato temporal, o de prácticas, o mantiene un contrato con una empresa de trabajo temporal. La tasa de temporalidad española es la más elevada de la Europa de los 15, con una diferencia en torno a los 17 puntos. Esta situación de temporalidad tendrá efectos negativos sobre la calidad del empleo, repercutiendo, por ejemplo, en una menor satisfacción en el trabajo y una productividad media inferior.

En el momento en que se lleva a cabo la primera de las encuestas, año 1995, se acaba de producir la reforma laboral de 1994, en una situación de importante crisis económica y con la tasa de temporalidad más alta de las registradas en España $(34,8 \%)$ y con un valor algo inferior en el caso de Galicia (32,4\%). En el período correspondiente a la segunda encuesta, tras la tercera reforma laboral de 1997 y casi coincidiendo con la cuarta (2001) la tasa de temporalidad de España había descendido ligeramente $(32,2 \%)$, mientras que se había incrementado en Galicia (34,2\%). La situación de la temporalidad en la tercera encuesta es muy semejante en los dos ámbitos, manteniéndose en torno al 30\%.

Los datos aquí presentados muestran que el mercado de trabajo en España, como señalan Garrido Medina y González (2008: 95), está caracterizado por un problema de escasez de empleo de carácter crónico y una elevada tasa de temporalidad. Las mismas características pueden emplearse para resumir la situación en Galicia.

\subsection{LA CENTRALIDAD DEL TRABAJO}

El trabajo, en tanto que satisface necesidades primarias y secundarias, ha sido considerado como uno de los ejes principales en la vida de las personas y por ello se emplea el término "centralidad" para aludir al elevado grado de importancia que se le concede. Existen distintos modos de medir la centralidad, desde medidas absolutas del grado de importancia que tiene el trabajo hasta medidas de tipo relativo, que, en algunos casos, implican la elección del trabajo como la esfera vital prioritaria aun a costa de sacrificar otros ámbitos.

En los análisis de datos sobre la centralidad en cualquiera de sus vertientes (MOW, 1987; Zanders, 1994; Harding y Hikspoors, 1995; Sverko y Super, 1995; Russell, 1998), el trabajo se muestra como una actividad de gran importancia en la vida de las personas. Si el trabajo se entiende como la condición material de la 
supervivencia es probable que sea central, esto es, muy importante, para amplios sectores de la población y, desde este punto de vista, la preocupación por el tema de la centralidad podría considerarse trivial, como señala Noguera (2002: 147).

Sin embargo, no todas las personas dan la misma importancia al trabajo $\mathrm{y}$, considerando los resultados agregados, no en todos los países se coloca al trabajo en el mismo lugar en la escala de importancia de distintos aspectos vitales, apreciándose una menor centralidad en los países más ricos y desarrollados. La existencia de tales diferencias podría interpretarse como que se está experimentando un descenso de la centralidad del trabajo en las sociedades más avanzadas, quizá debido a la emergencia de otras esferas vitales, como el ocio, que están adquiriendo una importancia creciente (Veira Veira y Muñoz Goy, 2004: 60-62).

Como se ha señalado más arriba, algunos autores sostienen que el trabajo está perdiendo importancia tanto en la vida de las personas como en el ámbito de la organización social (Rifkin, 1996) o que el valor del trabajo se encuentra en peligro de extinción (Méda, 1998). Desde una perspectiva más moderada, otros autores señalan que está llegando el fin de la cultura del trabajo (Ayllón Trujillo, et al., 2002) o, en todo caso que las sociedades actuales se dirigen hacia una nueva cultura del trabajo (Veira Veira, 2002), puesto que la noción del trabajo y el valor que se le atribuye, al ser construcciones sociales, son dinámicas y cambiantes y han de adaptarse al entorno variable de cada momento histórico.

En las anteriores ediciones de la Encuesta Mundial de Valores y de la Encuesta Europea de Valores, en las que se emplea una medida de centralidad absoluta del trabajo, se respaldaba la posición central, pues en la mayoría de los países el trabajo era el segundo aspecto vital en orden de importancia, por detrás de la familia. Un resultado similar a nivel mundial se ha obtenido en la última edición de la Encuesta Mundial de Valores (Tabla 8.1). Sin embargo, al tener en cuenta solo los diez países europeos con un índice de desarrollo humano (IDH) elevado se observan ciertos cambios en el modo de ordenar las esferas vitales. En cuanto al conjunto de estos diez países, el trabajo se sitúa en tercer lugar, pues el porcentaje de respuestas que señalan que el trabajo es "muy importante" es inferior a los correspondientes a la familia y los amigos. El porcentaje de españoles que dicen que el trabajo es muy importante se asemeja al obtenido por los noruegos, suecos, suizos y alemanes. Pero si se tiene en cuenta el orden respecto a los otros aspectos vitales, en Reino Unido, Países Bajos, Finlandia y Suecia el trabajo se relega a la cuarta posición; en Noruega, Suiza y Alemania a la tercera y la ordenación de España es más similar a la de los otros países del Sur de Europa, pues junto con Francia e Italia son los tres países que colocan el trabajo en segundo lugar, solo por detrás de la familia.

\section{LA EVOLUCIÓN DE LOS VALORES SOCIALES EN GALICIA}


Tabla 8.1. Porcentajes de respuestas que valoran como "muy importante" una serie de aspectos vitales, en los países europeos con mayor IDH.

\begin{tabular}{lcccccc} 
& Familia & Amigos & $\begin{array}{c}\text { Tiempo } \\
\text { libre }\end{array}$ & Política & Trabajo & Religión \\
\hline Alemania & 81,8 & 52,6 & 30,0 & 9,5 & 52,2 & 11,2 \\
\hline España & 89,1 & 49,4 & 43,6 & 7,7 & 52,2 & 14,9 \\
\hline Finlandia & 87,5 & 62,3 & 43,0 & 2,6 & 41,7 & 17,6 \\
\hline Francia & 86,4 & 58,8 & 37,7 & 11,9 & 64,6 & 13,0 \\
\hline Italia & 93,3 & 47,3 & 31,4 & 9,4 & 61,9 & 34,4 \\
\hline Noruega & 90,1 & 65,0 & 48,8 & 9,9 & 52,9 & 10,5 \\
\hline Países Bajos & 81,0 & 57,6 & 55,7 & 7,1 & 32,7 & 12,5 \\
\hline Reino Unido & 93,6 & 68,8 & 45,9 & 9,2 & 39,0 & 21,0 \\
\hline Suecia & 92,2 & 71,3 & 53,6 & 15,5 & 53,4 & 9,3 \\
\hline Suiza & 85,5 & 58,9 & 37,6 & 12,5 & 53,0 & 17,2 \\
\hline $\begin{array}{l}\text { Media países } \\
\text { elevado IDH }\end{array}$ & 87,5 & 58,5 & 41,6 & 9,5 & 50,6 & 15,7 \\
\hline $\begin{array}{l}\text { Media países del } \\
\text { mundo }\end{array}$ & 90,3 & 47,6 & 35,4 & 14,6 & 63,2 & 49,1 \\
\hline
\end{tabular}

Fuente: ASEP/JDS, Estudio Mundial de Valores Oleada 5 (2005-2008). Elaboración propia.

Esta situación se produce tanto en España como en Galicia en las tres encuestas realizadas desde 1995 (Tabla 8.2). En efecto, el trabajo obtiene en todos los casos el segundo porcentaje más alto en la categoría de "muy importante". Sin embargo, y de acuerdo con las referencias antes mencionadas, también se observa que dichos porcentajes están experimentado un claro descenso, a la vez que se producen aumentos en otras esferas vitales como el tiempo libre.

Si se analiza más detalladamente la evolución del grado de importancia del trabajo en España se detecta que al pasar de 1995 a 2000 desciende el porcentaje de los que señalan que el trabajo es muy importante, casi en la misma medida en la que aumentan los que creen que es bastante importante, y al pasar a 2007 también se observa una reducción en la categoría "muy importante" junto con un aumento de la categoría "bastante importante", pero de menor magnitud (Gráfico 8.3). En Galicia, la evolución de 1995 a 2001 es semejante a la de España y al pasar a 2008 se reducen ambos porcentajes, en mayor medida el de los que dicen que el trabajo es muy importante. Aunque se aprecia que la evolución de la importancia del trabajo es semejante en Galicia 
y en España, hay que destacar el hecho de que las categorías que califican el trabajo como muy o bastante importante arrojan resultados superiores en Galicia que en España.

Tabla 8.2. Porcentajes de respuestas que valoran como "muy importante" una serie de aspectos vitales, en Galicia y España.

\begin{tabular}{lcccccc} 
& $\begin{array}{c}\text { Galicia } \\
\mathbf{1 9 9 5}\end{array}$ & $\begin{array}{c}\text { España } \\
\mathbf{1 9 9 5}\end{array}$ & $\begin{array}{c}\text { Galicia } \\
\mathbf{2 0 0 1}\end{array}$ & $\begin{array}{c}\text { España } \\
\mathbf{2 0 0 0}\end{array}$ & $\begin{array}{c}\text { Galicia } \\
\mathbf{2 0 0 8}\end{array}$ & $\begin{array}{c}\text { España } \\
\mathbf{2 0 0 7}\end{array}$ \\
\hline Familia & 85,2 & 81,8 & 91,4 & 85,5 & 91,9 & 89,1 \\
\hline Amigos & 54,4 & 40,9 & 51,7 & 47,2 & 56,4 & 49,4 \\
\hline $\begin{array}{l}\text { Tiempo } \\
\text { libre }\end{array}$ & 33,7 & 30,5 & 37,5 & 38,5 & 48,3 & 43,6 \\
\hline Política & 6,4 & 8,0 & 3,4 & 7,4 & 7,0 & 7,7 \\
\hline Trabajo & 67,3 & 59,3 & 62,8 & 55,9 & 58,7 & 52,2 \\
\hline Religión & 30,1 & 25,4 & 22,6 & 22,1 & 19,3 & 14,9 \\
\hline
\end{tabular}

Fuente: EMV-Galicia 1995, 2001, 2008 y ASEP/JDS, Estudio Mundial de Valores,

España 1995, 2000, 2007. Elaboración propia.

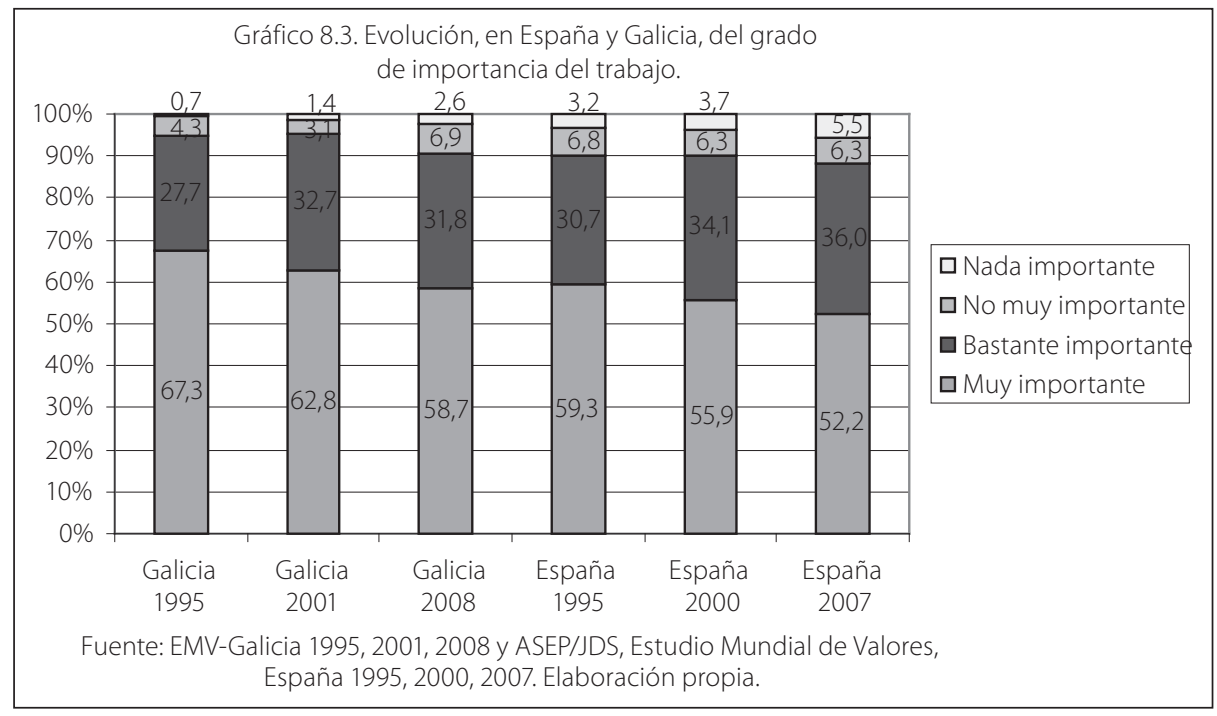

En cuanto al análisis a nivel individual en Galicia, se ha encontrado que la variable que muestra una relación más consistente con el grado de centralidad en las tres encuestas es la generación por año de nacimiento. Si a nivel agregado se está produciendo una disminución de la importancia del trabajo y dicha disminución es causada por el cambio generacional, cabría esperar que las generaciones 
de personas de más edad diesen mayor importancia al trabajo y que dicha importancia fuese disminuyendo para las generaciones de personas que han nacido posteriormente, lo que gráficamente se traduciría en una línea decreciente. Sin embargo, al analizar los datos que relacionan la importancia del trabajo con la generación, la relación no sigue esta tendencia ya que las líneas descienden en los extremos, lo que indica que la centralidad del trabajo es menor para las generaciones más jóvenes y las de más edad, y mayor para las generaciones intermedias (Gráfico 8.4). Este comportamiento se observa en los datos de las tres encuestas, aunque en el caso de 1995 la curva se coloca en posiciones superiores para todas las generaciones, lo que parece indicar que hay un efecto período de descenso generalizado de la importancia del trabajo, sea cual sea el año de nacimiento (excepto en la generación de 1950-59). También llama la atención el porcentaje alcanzado por la generación más joven (1980-89) en la encuesta de 2008 que obtiene una puntuación semejante a la generación anterior y muy por encima del valor alcanzado en la encuesta de 2001; tal vez este resultado se deba al impacto de la crisis económica actual en la opinión de los más jóvenes, de modo que le dan más importancia al trabajo por ser cada vez más escaso e inseguro.

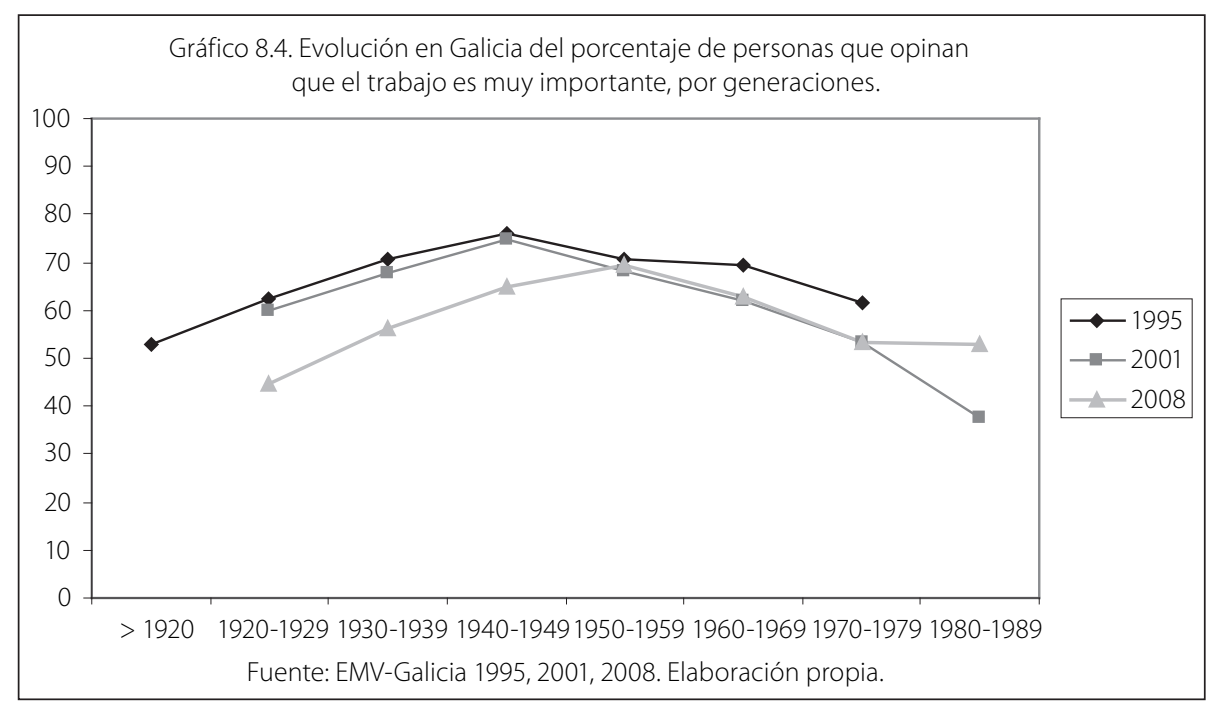

No cabe duda de que la situación laboral de las personas puede explicar en cierta medida la importancia que ocupa el trabajo en su vida, pues para los estudiantes o los jubilados el trabajo no ocupará un lugar tan importante como para los que están desempeñando un trabajo remunerado o para los que lo buscan activamente, aunque solo sea por la cantidad de tiempo que diariamente le dedican estos dos últimos grupos. Por esa razón, merece la pena diferenciar 
las opiniones de la muestra completa, que representa a la población total, y, por otra parte, las opiniones de la parte de la muestra que representa a la población activa, es decir a los ocupados y los parados.

Al considerar solamente a los encuestados que pertenecen a la población activa, se mantiene la relación entre la centralidad del trabajo y la generación ${ }^{2}$ (Gráfico 8.5), si bien ahora sí se manifiesta un descenso del grado de centralidad en las generaciones más jóvenes. Las generaciones anteriores a 1970 arrojan valores cercanos en las tres encuestas y se aprecian mayores distancias en las generaciones más jóvenes. En concreto, la generación de 1970-79 mostraba un porcentaje de importancia del trabajo mucho más elevado en 1995 (70,7\%) que en 2001 (56,8\%) y 2008 (53,3\%) y la generación más joven, 1980-89, presenta un repunte de la centralidad del trabajo al pasar de 2001 a 2008 (42,1\% y 57,2\% respectivamente). Cabe preguntarse si este repunte de la centralidad obedece a la percepción de que en una situación de crisis económica el trabajo puede escasear, y por ello los jóvenes — que suelen verse más afectados por el paro— lo valoran más que en etapas anteriores.

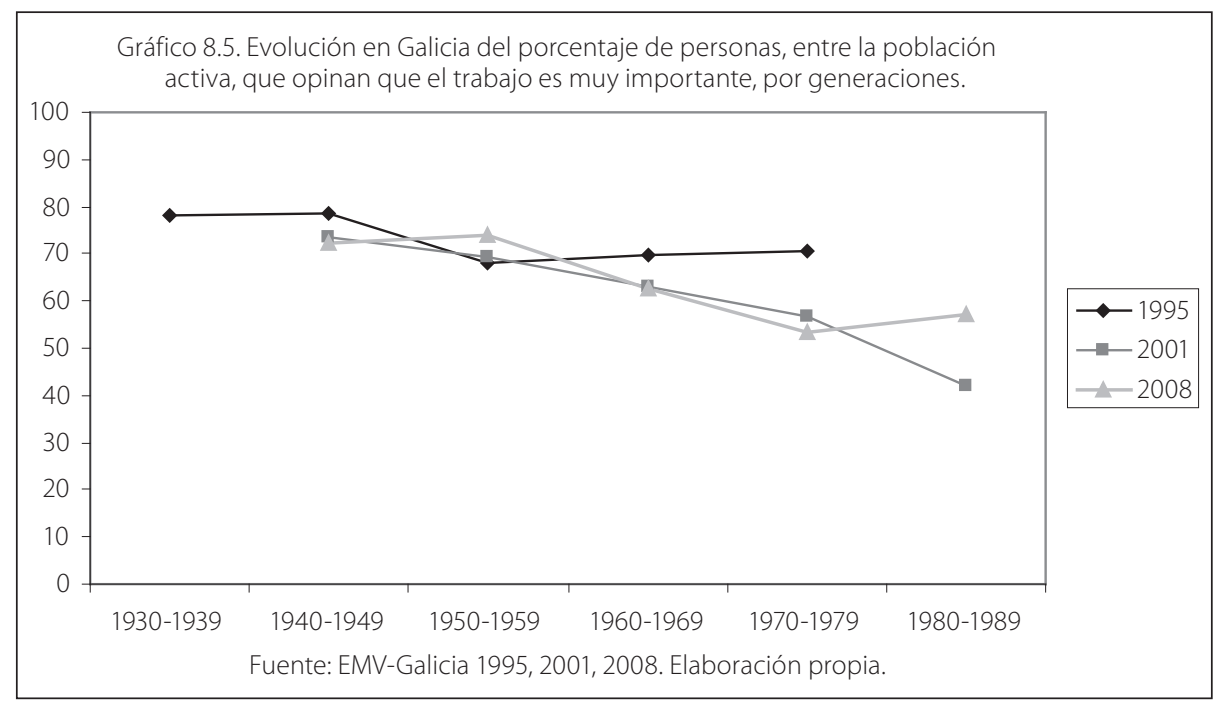

Un enfoque diferente para analizar la centralidad del trabajo se obtiene a través de las opiniones de los entrevistados sobre si sería bueno o malo que nuestro estilo de vida cambiase, de modo que en el futuro se le diese menos importancia al trabajo en nuestras vidas. En una situación de pérdida de centralidad del trabajo cabría esperar opiniones favorables respecto a ese supuesto

2 Al tener en cuenta solo la parte de la muestra que representa a la población activa, la relación entre la importancia del trabajo y la generación resultó ser estadísticamente significativa en los años 2001 y 2008, pero no en 1995. De todos modos, en la parte de la muestra que representa a la población activa, la generación es la variable sociodemográfica que mantiene una relación más consistente con la importancia del trabajo en los tres años analizados. 
cambio en el futuro. Sin embargo, al analizar los datos de Europa no parece haber una tendencia común (Tabla 8.3). Tomando como referencia el conjunto de todos los países del mundo disponibles en la última oleada de la Encuesta Mundial de Valores, un cambio en el estilo de vida futuro que supusiese darle menos importancia al trabajo se percibe como algo malo, pues el porcentaje de esta opción de respuesta es más del doble de los que dicen que sería bueno (57,6\% frente al 24,5\%). En el conjunto de los países europeos con elevado índice de desarrollo humano también se considera malo dicho cambio futuro, aunque en este caso las diferencias de porcentajes son mucho menores (42,5\% frente a $35,3 \%$ ). Considerando cada uno de los países por separado, prevalece la idea de que el cambio propuesto es malo en Italia, Noruega, Finlandia y Alemania; en Francia, Reino Unido y Suecia se opina lo contrario; y en los Países Bajos y España casi se produce un empate entre los que creen que sería bueno y los que opinan que sería malo darle menos importancia al trabajo en el futuro.

La evolución temporal de esta variable en España muestra que se han producido cambios de distinta dirección al pasar de unos años a otros (Gráfico 8.6). En 1995 la elección más frecuente es que sería malo darle menos importancia al trabajo en el futuro, aunque el porcentaje de esta respuesta no es muy superior al de los que optaron por calificar como bueno dicho cambio futuro $(40,3 \%$ frente a 37,5\%). En 2000 se obtiene la situación inversa, los que creen que sería bueno que disminuyese la importancia del trabajo en el futuro aventajan a los que creen que sería malo (48,6\% frente a 34,2\%). Y en 2007 se produce prácticamente un empate entre las dos opciones.

En Galicia se observa una evolución similar a la experimentada en España en los dos primeros años. En 1995 también es mayoritaria la opinión de que sería malo darle menos importancia al trabajo en el futuro (Gráfico 8.6). Al pasar de 1995 a 2001 aumenta el porcentaje de las personas que señalan que la disminución futura de la importancia del trabajo sería buena (de 28,1\% a 41,4\%) y sobre todo se reduce notablemente el porcentaje de los que señalan que dicha disminución sería mala (60,9\% a 35,1\%). Sin embargo, en 2008 se produce un ligero retroceso en el porcentaje a favor de la disminución de la importancia del trabajo (de $41,4 \%$ a $37,9 \%$ ) y un aumento más notable en el porcentaje de los que se posicionan en contra del cambio propuesto (de $35,1 \%$ a $51,1 \%$ ). No obstante, los valores de 2008 son más favorables a la disminución de la importancia del trabajo en el futuro que en 1995, aunque no tanto como en 2001. Tal vez la mala situación económica y las previsiones de un aumento en las tasas de paro en 2008 hayan provocado este cambio en la tendencia, respecto a 2001, llevando a los entrevistados a valorar más un bien escaso. 
Tabla 8.3. Opinión sobre si sería bueno o malo que en el futuro disminuyese la importancia concedida al trabajo en nuestras vidas, en los países europeos con mayor IDH.

\begin{tabular}{llll} 
& Bueno & No importa & Malo \\
\hline Alemania & 24,8 & 20,5 & 54,7 \\
\hline España & 41,1 & 17,6 & 41,3 \\
\hline Finlandia & 33,3 & 11,5 & 55,2 \\
\hline Francia & 51,5 & 23,8 & 24,7 \\
\hline Italia & 30,5 & 21,5 & 48,0 \\
\hline Noruega & 19,9 & 25,2 & 54,9 \\
\hline Países Bajos & 34,4 & 34,5 & 31,1 \\
\hline Reino Unido & 42,8 & 34,9 & 36,8 \\
\hline $\begin{array}{l}\text { Suecia } \\
\text { Media países }\end{array}$ & 50,1 & 13,0 & 42,5 \\
\hline elevado IDH & 35,3 & 22,2 & 57,6 \\
\hline $\begin{array}{l}\text { Media países del } \\
\text { mundo }\end{array}$ & 24,5 & 18,0 &
\end{tabular}

Fuente: ASEP/JDS, Estudio Mundial de Valores Oleada 5 (2005-2008). Elaboración propia.

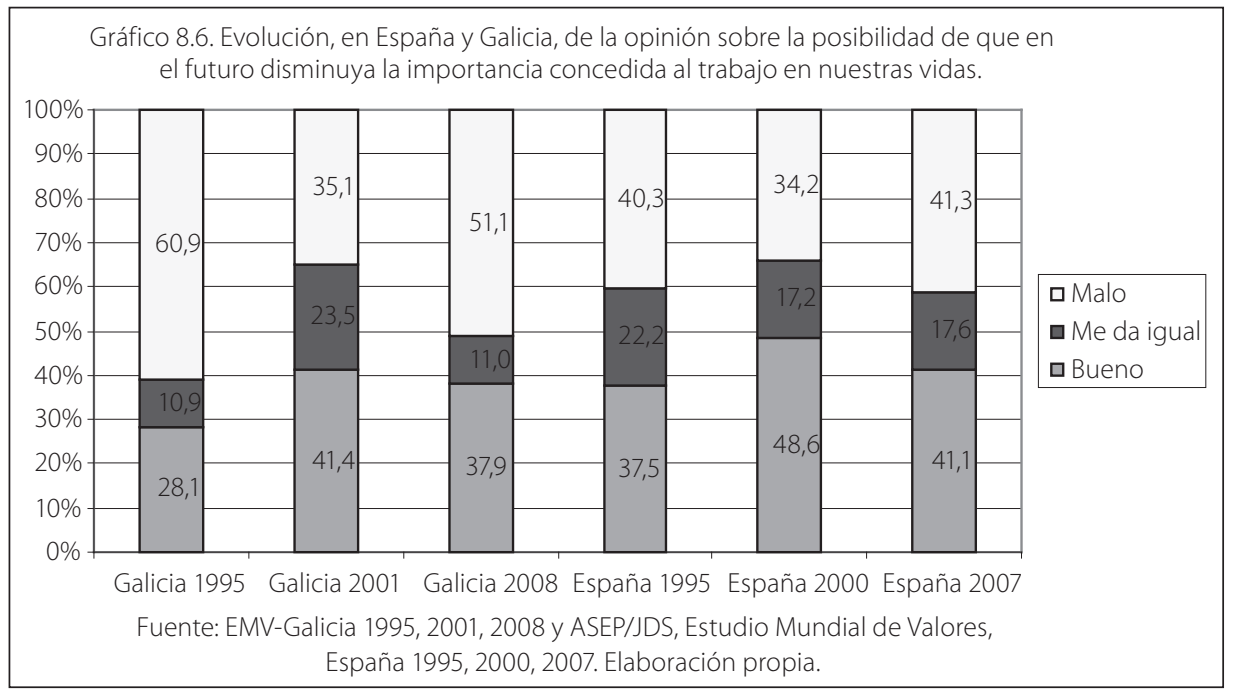

En el análisis a nivel individual para Galicia, la generación por año de nacimiento es la variable más fuertemente asociada con las opiniones sobre 
la disminución de la importancia del trabajo en el futuro. Cabría esperar que los cambios a nivel agregado se reflejasen en que las generaciones más jóvenes fuesen más proclives a apoyar la disminución de la importancia del trabajo en nuestras vidas. En términos generales, se comprueba que dicha relación se mantiene, si bien con ligeros altibajos, sobre todo en las generaciones más jóvenes y en las de mayor edad (Gráfico 8.7). Para las generaciones de las personas nacidas antes de 1960 el porcentaje de los que opinan que sería mala la disminución de la importancia futura del trabajo es superior al de los que opinan que sería buena, pero las diferencias van reduciéndose a medida que se consideran las generaciones más jóvenes. Para las generaciones de los nacidos a partir de 1960 los porcentajes de los que creen que dicha disminución sería buena aventajan a los de los que piensan que sería mala, con diferencias más amplias en la encuesta de 2001 que en la de 2008, con una única excepción que es la de los nacidos en la generación de 1980-89, para los que la relación entre los porcentajes se invierte.

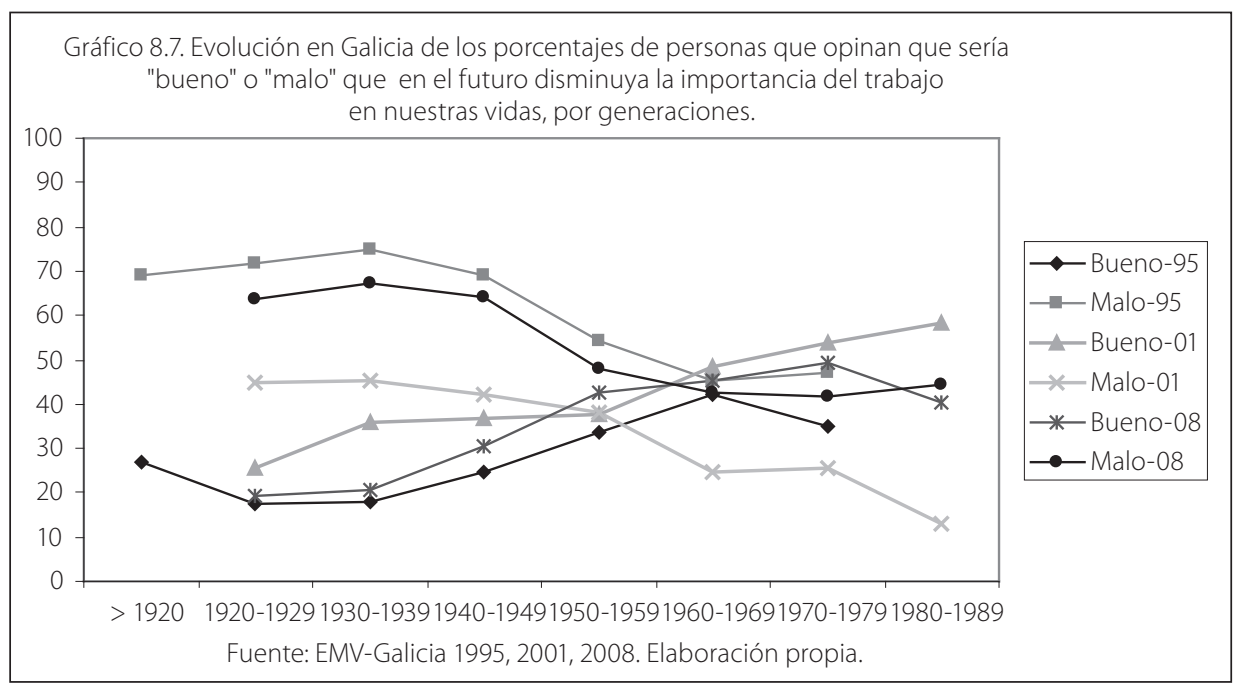

La curva de la opinión de que la disminución de la importancia futura del trabajo sería "mala" de 2008 se coloca entre la de 1995 y 2001, si bien es mucho más cercana a la de 1995. La curva de que dicha disminución sería "buena" en 2008 también se coloca entre la de 1995 y 2001 y aunque en general es más cercana a la 1995, en algún punto se acerca e incluso sobrepasa a la de 2001. El gráfico parece mostrar una consistencia en la opinión de las generaciones, pues las curvas de las tres encuestas siguen una tendencia similar, pero se sitúan en posiciones diferentes para cada oleada lo que, de nuevo, indica un efecto período que concuerda con lo comentado a nivel agregado. 
En resumen, la centralidad del trabajo en Galicia —-medida como el grado de importancia del trabajo en la vida de las personas- es elevada, más que en España y que en la mayoría de los países europeos con elevado IDH. Pero dicha centralidad se ha ido reduciendo desde 1995 hasta 2008. El trabajo es más importante para las generaciones intermedias, que suelen agrupar a los miembros de la población activa; si se analiza solo a la parte de la muestra que representa a la población activa se encuentra que hay una relación inversa entre el año de nacimiento y la importancia del trabajo: los más jóvenes le dan menos importancia al trabajo. Sin embargo, este hallazgo no permite aventurar que en el futuro la importancia del trabajo vaya a disminuir a causa del reemplazo generacional, porque las diferencias por generaciones pueden estar reflejando simplemente un efecto del ciclo vital y porque la relación inversa entre la importancia del trabajo y el año de nacimiento solo se sostiene en la parte de la muestra que representa a la población activa y no al considerar la muestra total.

Si se emplea otra medida de centralidad del trabajo, consistente en evaluar si sería bueno o malo que en el futuro disminuyese la importancia del trabajo en nuestras vidas, Galicia obtiene en 2008 un grado de centralidad superior que España y el conjunto de países europeos con elevado IDH. Pero la trayectoria de esta variable ha tenido ciertos altibajos en las tres encuestas realizadas en Galicia. Tanto en 1995 como en 2008 son mayoría los que creen que sería malo dar menos importancia al trabajo en el futuro, mientras que en 2001 se producía la situación contraria; de todos modos, la mayoría alcanzada en 2008 no llega al nivel de la obtenida en 1995. Por otra parte, se constata que hay una menor centralidad del trabajo entre las generaciones más jóvenes ya que son las más proclives a considerar que sería "bueno" disminuir la importancia futura del trabajo, mientras que las generaciones de más edad se inclinan por considerar este cambio como algo "malo".

\subsection{LA ÉTICA DEL TRABAJO}

Según Cherrington, la ética del trabajo en un sentido amplio se refiere a la ética protestante, tal como la define Max Weber en su análisis sobre la ética protestante y el espíritu del capitalismo. Esta visión amplia de la ética del trabajo incluye uno o varios de los siguientes elementos: la obligación moral de trabajar; una dedicación del tiempo casi exclusiva al trabajo en detrimento del ocio; formalidad en la asistencia al trabajo y corrección en el desempeño de las tareas; elevada productividad; compromiso del empleado hacia su profesión, su organización y su grupo de trabajo; orientación de los trabajadores hacia el logro, las promociones y ascensos; y el trabajo como única fuente lícita para conseguir ingresos (Cherrington, 1980: 20). 
A continuación se comentará una serie de aspectos relacionados con la ética del trabajo, analizando una pregunta incluida en las dos últimas oleadas de la Encuesta Mundial de Valores, en la que se consulta sobre el grado de acuerdo o desacuerdo de los entrevistados con algunas afirmaciones sobre el trabajo ${ }^{3}$. En concreto, se recogen las opiniones relativas a dos indicadores de la obligación moral de trabajar - "el trabajo es un deber hacia la sociedad" y "la gente que no trabaja se vuelve perezosa"-, del papel del trabajo como generador de ingresos — "es humillante recibir dinero sin tener que trabajar para conseguirlo"-, como ámbito que permite la autorrealización — "para poder desarrollar completamente el talento, es necesario tener un trabajo"- y con su función de estructuración del tiempo - "el trabajo debería ser siempre lo primero, incluso si ello implica menos tiempo libre"-

La frase que recoge el mayor número de respuestas positivas, tanto en el conjunto de los países del mundo como en los países europeos con elevado índice de desarrollo humano, es la que se refiere a que "el trabajo es un deber hacia la sociedad", con porcentajes que se acercan al $88 \%$ y $82 \%$ respectivamente (Tabla 8.4). Entre los países europeos, el que mayor grado de acuerdo muestra con esta frase es Noruega y el que menor apoyo le da es Suecia; España se acerca más bien a los valores inferiores. No obstante, es claro el fuerte respaldo de que el trabajo tiene un carácter de deber hacia la sociedad, pues aun en los países con menor número de respuestas positivas, más de tres de cada cuatro personas están de acuerdo con esta idea.

En cuanto a la evolución temporal, en España el grado de apoyo a esta frase prácticamente no varía al pasar de 2000 a 2007, con porcentajes aproximados de respuestas a favor del $78 \%$ y $79 \%$ respectivamente ${ }^{4}$ (Gráfico 8.8). En Galicia tampoco hay grandes cambios, solo se aprecia un ligero descenso en el grado de acuerdo con la idea de que "el trabajo es un deber hacia la sociedad", con porcentajes de respuestas de positivas del 75\% en 2001 y del 71\% en 2008. Pero hay que destacar que en Galicia esta afirmación se sitúa en la segunda posición en cuanto a respuestas a favor, a diferencia del primer lugar que ocupa para España y Europa.

Esta pregunta se incluyó en los cuestionarios de la EMV solo a partir de 2000. Además, hay que precisar que se produjo un cambio en la redacción de la posición central en la escala propuesta para esta pregunta. Mientras que en la escala de las encuestas de 2000-2001 el punto central se denominaba "Ni de acuerdo ni en desacuerdo", lo que podía interpretarse como una posición neutra respecto a la afirmación, en la escala de 2007-2008 el punto central pasó a denominarse "no tiene opinión", lo que podría asimilarse al "no sabe no contesta". Este cambio en la escala, que provocó un descenso de los porcentajes de elección del punto central de la escala, mucho más notable en Galicia que en España, impide una comparación directa de los resultados de los dos años. Para poder llevar a cabo dicha comparación, los porcentajes se recalcularon eliminando el punto central de la escala — considerándolo como no respuesta válida—. Esta transformación se llevó a cabo también en los datos disponibles de los países europeos para poder comparar sus resultados con los de Galicia y España.

4 No se encontraron diferencias estadísticamente significativas entre resultados de las dos encuestas ni en Galicia ni en España. 
Tabla 8.4. Porcentaje a favor ${ }^{5}$ de distintas afirmaciones sobre el trabajo, en los países europeos con mayor IDH.

\begin{tabular}{lccccc} 
& $\begin{array}{c}\text { El trabajo } \\
\text { es un deber } \\
\text { hacia la } \\
\text { sociedad }\end{array}$ & $\begin{array}{c}\text { El trabajo es } \\
\text { necesario para } \\
\text { desarrollar el } \\
\text { talento }\end{array}$ & $\begin{array}{c}\text { Los que no } \\
\text { trabajan } \\
\text { se vuelven } \\
\text { perezosos }\end{array}$ & $\begin{array}{c}\text { El trabajo } \\
\text { siempre lo } \\
\text { primero frente } \\
\text { al tiempo libre }\end{array}$ & $\begin{array}{c}\text { Es } \\
\text { humillante } \\
\text { recibir dinero } \\
\text { sin trabajar }\end{array}$ \\
\hline Alemania & 84,6 & 89,9 & 63,2 & 80,8 & 55,6 \\
\hline España & 79,2 & 71,6 & 73,2 & 58,3 & 56,0 \\
\hline Finlandia & 78,7 & 68,1 & 73,6 & 44,8 & 53,5 \\
\hline Italia & 83,9 & 79,5 & 85,0 & 64,5 & 79,1 \\
\hline Noruega & 89,4 & 74,1 & 66,9 & 57,5 & 65,2 \\
\hline Suecia & 77,4 & 55,1 & 50,3 & 44,9 & 41,6 \\
\hline Suiza & 79,4 & 84,9 & 64,4 & 56,9 & 56,2 \\
\hline $\begin{array}{l}\text { Media países } \\
\text { elevado IDH }\end{array}$ & 82,1 & 77,2 & 67,9 & 60,5 & 57,7 \\
\hline $\begin{array}{l}\text { Media países } \\
\text { del mundo }\end{array}$ & 87,7 & 84,6 & 83,6 & 76,6 & 72,4 \\
\hline
\end{tabular}

Fuente: ASEP/JDS, Estudio Mundial de Valores Oleada 5 (2005-2008). Elaboración propia.

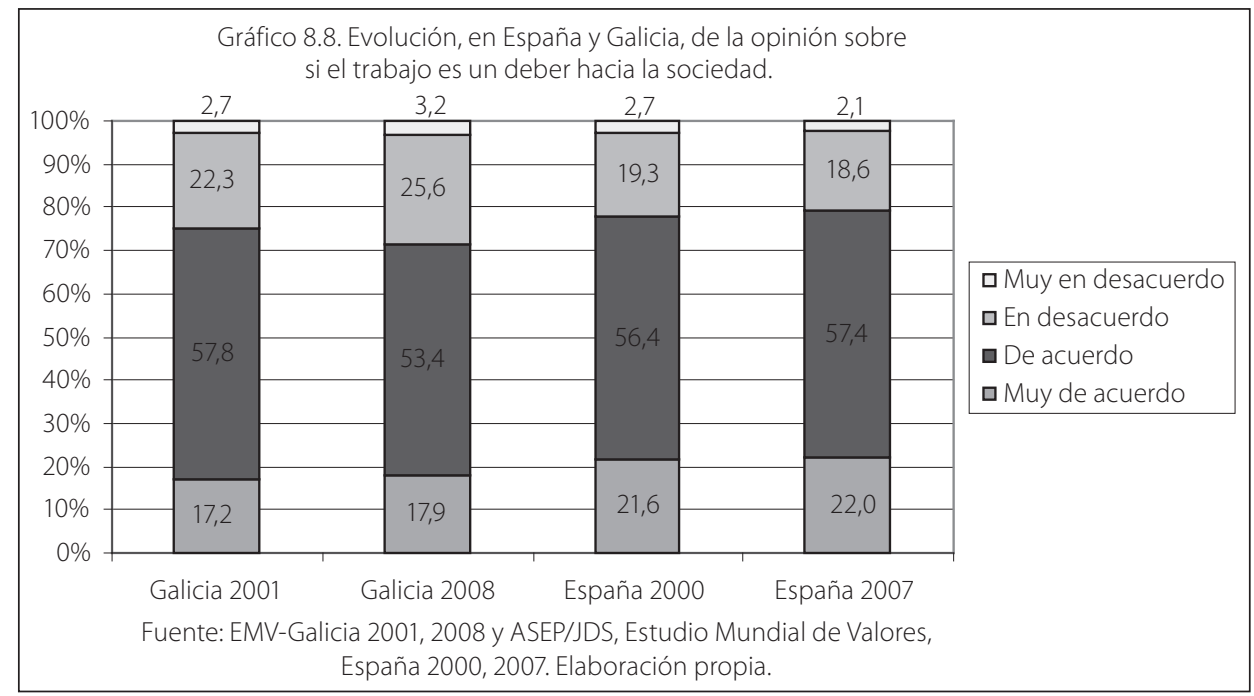

El porcentaje a favor se refiere a la suma de las respuestas "muy de acuerdo" y "de acuerdo" con cada una de las frases. Estos porcentajes se han calculado sobre los resultados recodificados de acuerdo con la nota 3, es decir que la suma de los porcentajes a favor y en contra (que ya no se presentan en esta tabla) suman el 100\%, al haberse excluido el punto central de la escala. El número de países europeos que se incluyen en esta tabla es inferior al de las tablas anteriores puesto que en algunos países no se incluyó esta pregunta en el cuestionario. 
En Galicia, la variable sociodemográfica que tiene mayor relación con el grado de acuerdo con esta frase es la generación. Entre los grupos definidos por año de nacimiento se observa que las generaciones de más edad se muestran mucho más a favor de que el trabajo sea un deber hacia la sociedad que las generaciones más jóvenes (Gráfico 8.9). De hecho, en 2001 las personas nacidas entre 1970 y 1979 muestran un porcentaje en contra de la frase propuesta ligeramente superior al de las que están a favor; en la generación posterior, los nacidos entre 1980 y 1989 , el porcentaje a favor supera al porcentaje en contra, pero en una medida mucho menor que para las generaciones de más edad. Esta tendencia se aprecia también en 2008, aunque de manera suavizada, pues en las generaciones de más edad se ha reducido la distancia entre los porcentajes a favor y en contra, mientras que en las generaciones más jóvenes hay una mayor diferencia entre dichos porcentajes que en los datos de la encuesta anterior. Se observa que las generaciones de más edad están más a favor de que "el trabajo es un deber hacia la sociedad", pero las diferencias entre generaciones son más acusadas en 2001 que en 2008.

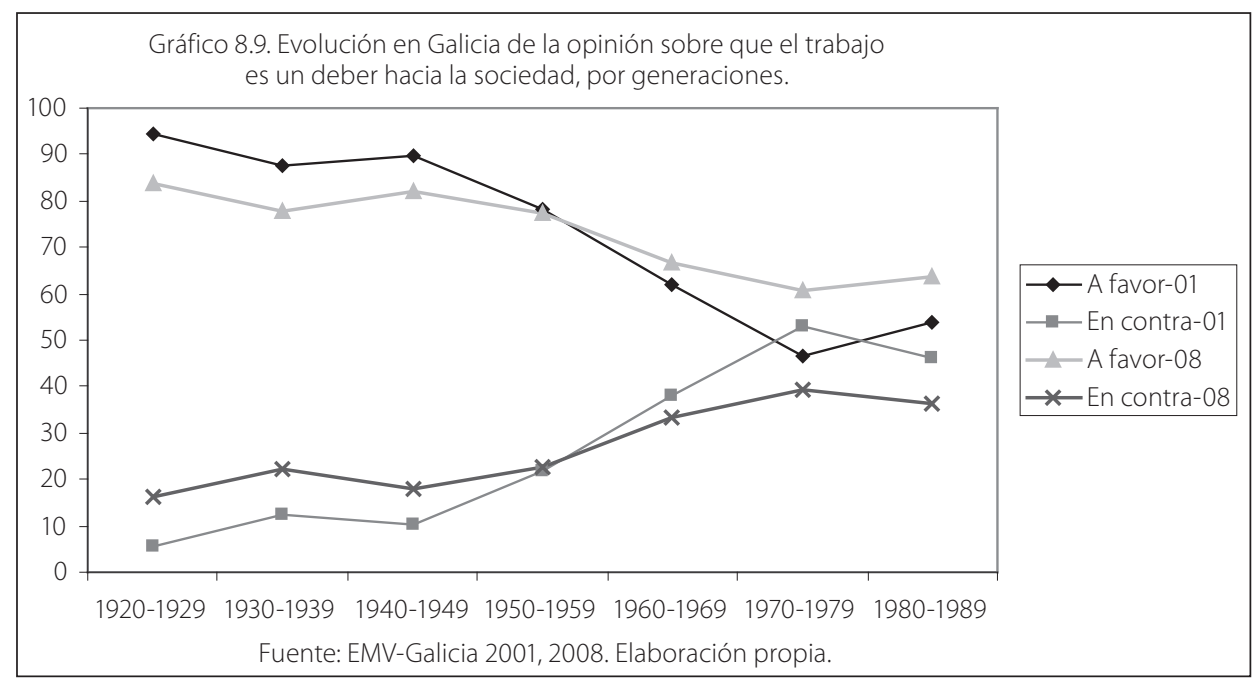

La frase que se coloca en segundo lugar en cuanto al grado de apoyo, tanto en el conjunto del mundo como en los países europeos, es la que señala que "para desarrollar el talento completamente es necesario tener un trabajo" (Tabla 8.4). A pesar de que en todos los países considerados hay mayoría de respuestas a favor de esta frase, es decir que en todos los casos los porcentajes de acuerdo superan a los en desacuerdo, se aprecian notables diferencias entre ellos: mientras que en Alemania hay casi un 90\% de respuestas a favor, en Suiza se llega casi al 85\% y en Italia al 80\% — de hecho en Alemania y Suiza esta frase es la que recibe mayor grado de acuerdo-; en Noruega y España no se llega al 75\% y Finlandia se sitúa por debajo del $70 \%$. El caso más destacado es el de Suecia, donde el acuerdo con esta frase solo alcanza el 55\%. 
En España esta afirmación no ocupa el segundo puesto sino el tercero. En su evolución temporal, el grado de apoyo se mantiene, como muestran los porcentajes a favor de la frase, que se sitúan en torno al $72 \%$ en ambos años ${ }^{6}$ (Gráfico 8.10). En Galicia esta frase también aparece en tercera posición, pero obtiene un respaldo inferior que en España, a juzgar por los porcentajes positivos claramente menores. Además, el grado de acuerdo con que sea necesario un trabajo para desarrollar el talento disminuyó en Galicia de 2001 a 2008, pues mientras que en el primer año considerado las respuestas a favor casi llegaban al 67\%, dicho porcentaje desciende hasta el $57 \%$ en el segundo año.

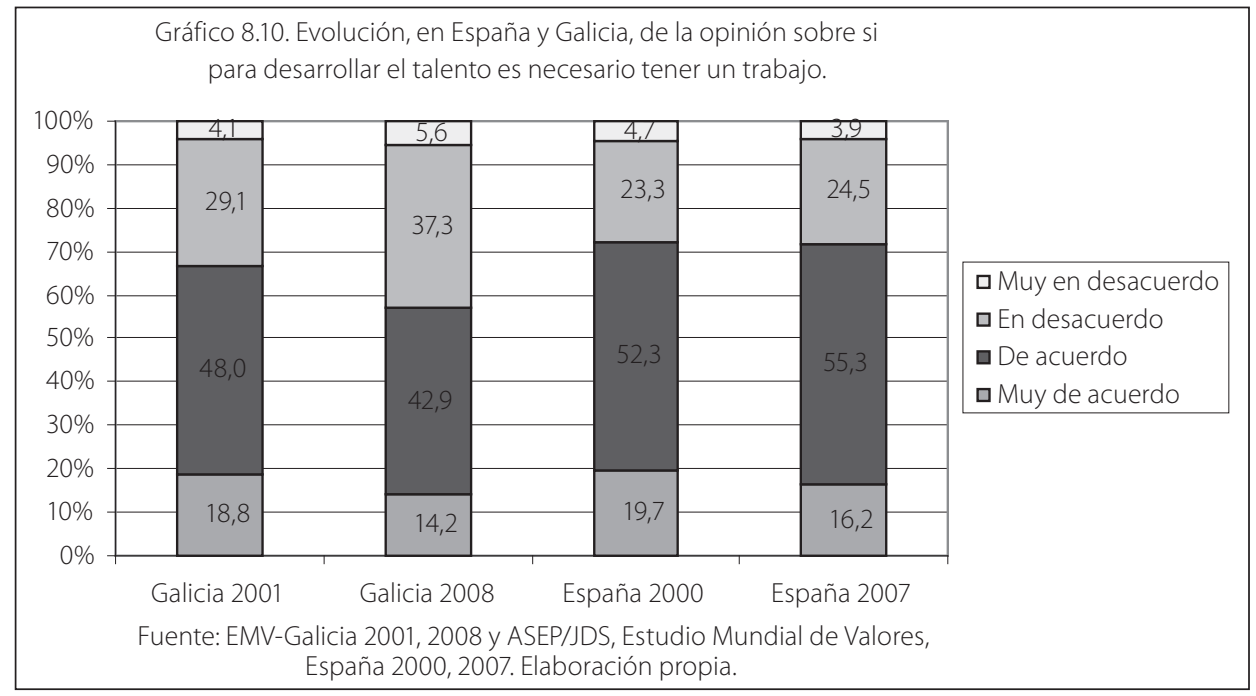

De nuevo, en Galicia, la generación por año de nacimiento es la característica sociodemográfica que ofrece la mayor asociación con esta variable dependiente. Las generaciones de más edad son más proclives a apoyar la frase propuesta que las generaciones más jóvenes (Gráfico 8.11). En 2001, las dos primeras generaciones, 1920-29 y 1930-39, arrojan porcentajes a favor que superan el $80 \%$. A medida que se avanza hacia las generaciones más jóvenes se observa cómo se reducen las distancias entre los que están de acuerdo y los que están en desacuerdo y, de hecho, en la generación de los nacidos entre 1970 y 1979 prácticamente se da un equilibrio entre las opiniones a favor y en contra, para encontrar que en la generación más joven, 1980-89, los porcentajes en contra llegan al 58\%, superando claramente a los porcentajes a favor. Esta situación se repite en 2008, aunque con diferencias menos notables entre las generaciones, como ya sucedía con la frase anterior. En este año las respuestas positivas en la generación de más edad ascienden al 74\% y van disminuyendo hasta alcanzar el equilibrio en la generación de 1960-69; a partir de esta generación, en las dos

No se encontraron diferencias estadísticamente significativas entre resultados de las dos encuestas para España. 
siguientes, se observa que en un caso hay más respuestas de acuerdo y en el otro en desacuerdo, pero las diferencias entre los porcentajes a favor y en contra no superan el 5\%.

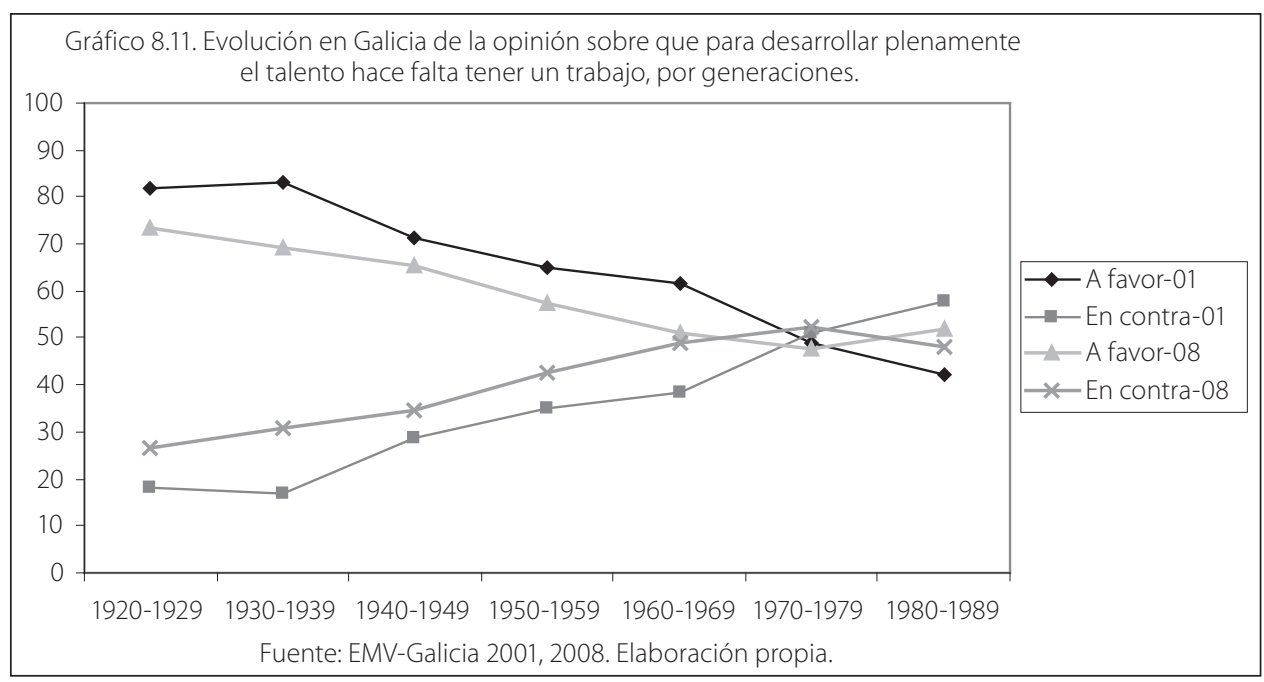

Tanto el grupo de los países europeos con elevado índice de desarrollo humano como el conjunto del mundo sitúan en tercer lugar la frase que señala que "la gente que no trabaja se vuelve perezosa", con porcentajes de respuestas a favor de cerca del $68 \%$ y $84 \%$ respectivamente (Tabla 8.4 ). Al analizar los resultados para cada uno de los países europeos, Italia destaca como el que le da mayor apoyo; en el otro extremo se encuentra Suecia, donde se obtienen casi tantas respuestas de acuerdo como en desacuerdo. España y Finlandia muestran un grado similar de apoyo a esta frase, con porcentajes a favor en torno al 73\%, mientras que en Noruega, Suiza y Alemania se obtienen resultados que muestran menor acuerdo con esta idea, con respuestas positivas alrededor del 65\%.

En España, a diferencia del tercer lugar que ocupa esta frase en Europa y el mundo, la idea de que las personas que no trabajan se vuelven perezosas ocupa el segundo lugar, con porcentajes a favor, en ligero descenso, del 76\% en 2000 y 73\% en 2007 (Gráfico 8.12). Esta frase es la que cuenta con el mayor grado de apoyo en Galicia, donde las respuestas a favor llegaron casi al 79\% en 2001 y al 76\% en 2008.

En Galicia, la asociación más consistente con esta afirmación se obtiene con los grupos definidos por año de nacimiento. Aunque en todas las generaciones el porcentaje a favor de esta frase supera al porcentaje en contra, el grado de acuerdo se va reduciendo entre las generaciones más jóvenes (Gráfico 8.13). En 2001, las opiniones a favor de la frase llegan a cerca del 92\% para la generación de más edad, mientras que en la generación más joven solo rozan el 57\%. Estas fuertes diferencias entre generaciones se reducen en el año 2008, cuando las opiniones a 
favor entre la generación de mayor edad se acercan al 90\% y para los más jóvenes son aproximadamente del $75 \%$. Como puede observarse, el comportamiento de las generaciones de los nacidos antes de 1970 son bastante similares para 2001 y 2008, pero las dos generaciones más jóvenes están menos a favor de la frase propuesta en 2001 que en 2008. Por tanto, en 2008 las generaciones de mayor edad apoyan en mayor medida la frase propuesta que las generaciones más jóvenes, aunque las diferencias generacionales no son tan notables como en 2001.
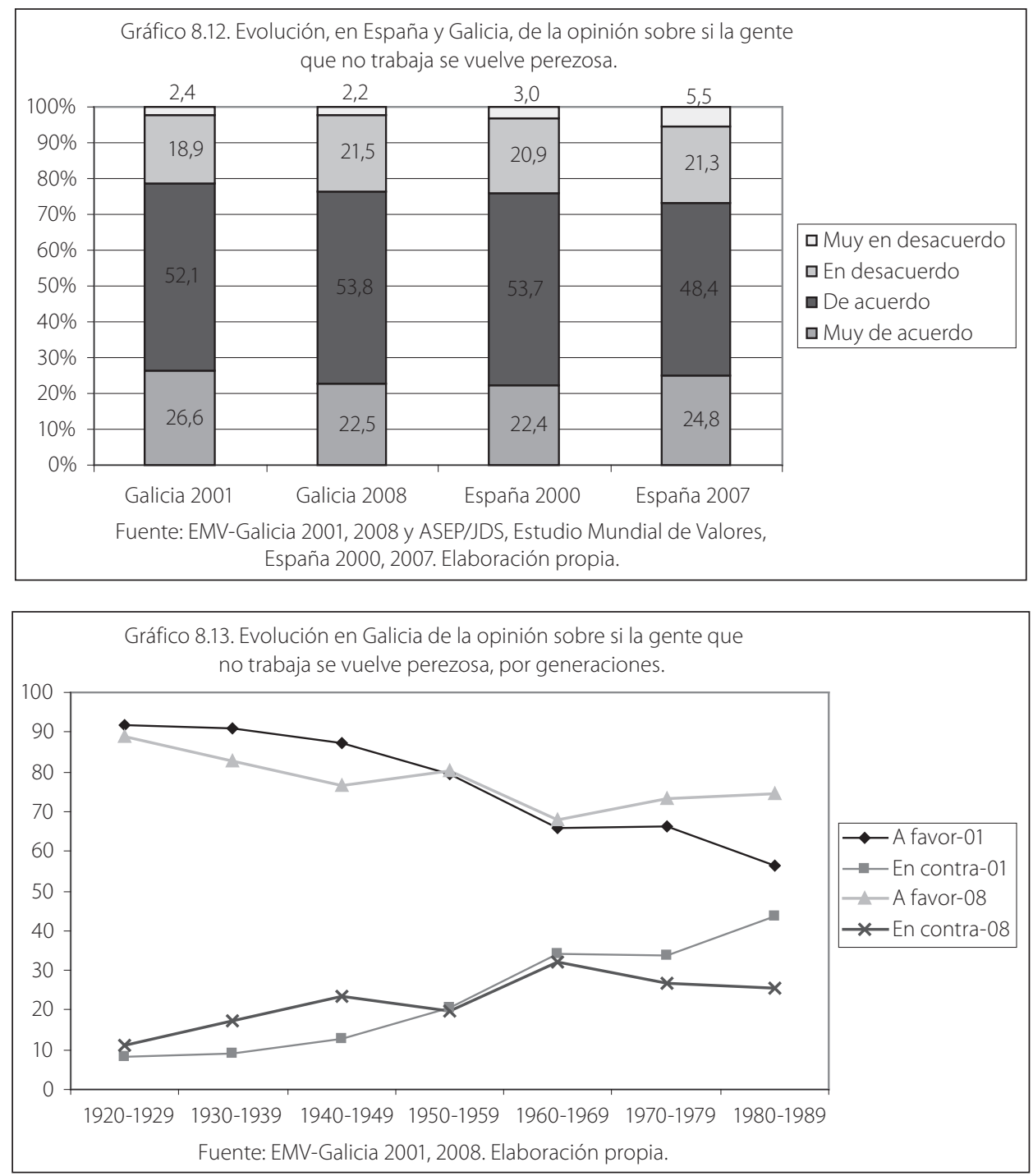

En cuarto lugar, de acuerdo con el porcentaje a favor que le otorgan tanto el grupo de los países europeos con elevado índice de desarrollo humano como el conjunto del mundo, se encuentra la afirmación que sostiene que "el trabajo 
debería ser siempre lo primero, incluso si ello implica menos tiempo libre" (Tabla 8.4). Esta frase se analiza aquí para poder comparar el grado de apoyo que recibe con el de las otras frases sobre el trabajo, pero también puede interpretarse como una medida de centralidad relativa, pues presenta una comparación o elección entre el trabajo y otro ámbito vital, como es el tiempo libre. El grado de centralidad relativa en el conjunto de los países del mundo es claramente superior al de los países europeos con elevado índice de desarrollo humano, si bien en estos países todavía hay mayoría de respuestas a favor del trabajo ( $76,6 \%$ y $60,5 \%$ respectivamente). De todos modos se aprecian claras diferencias entre los países: Alemania destaca por ofrecer el mayor porcentaje de centralidad relativa, le siguen Italia, España, Noruega y Suiza. En estos países hay mayoría de personas que están muy de acuerdo o de acuerdo con que el trabajo debe ser siempre lo primero, mientras que en el resto -Finlandia y Suecia— hay mayor porcentaje de respuestas en contra.

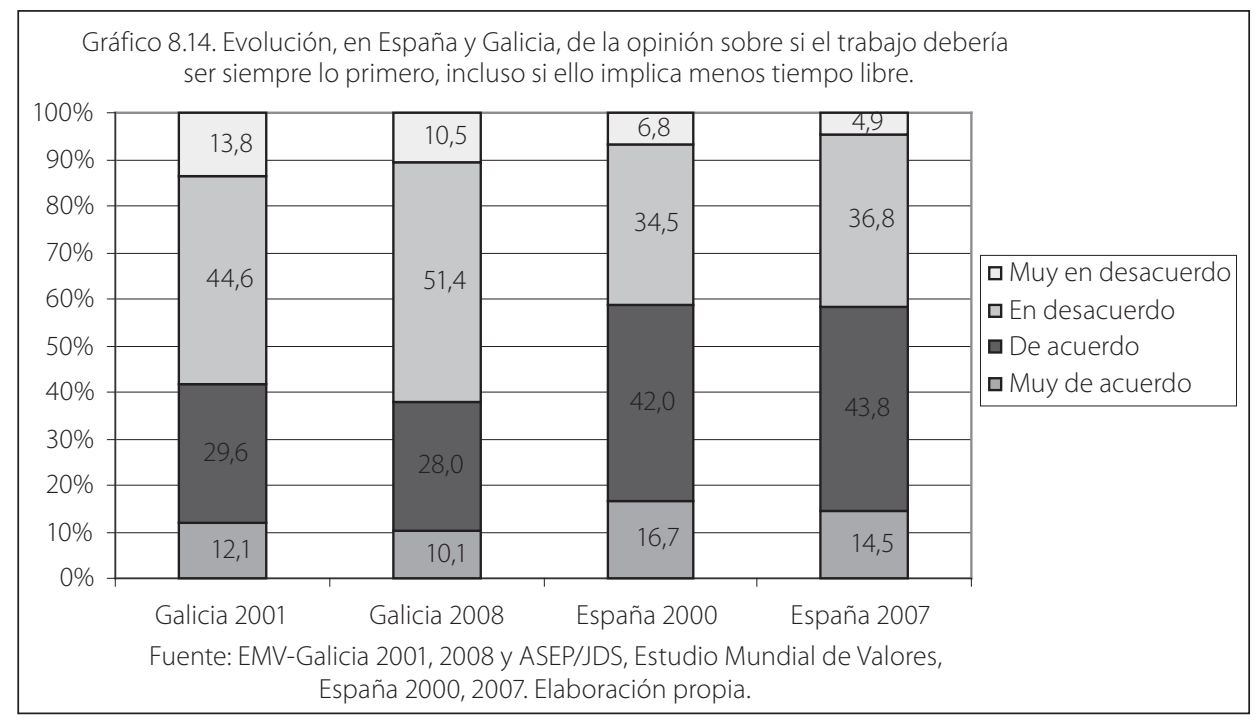

De acuerdo con la idea del descenso de la centralidad del trabajo cabría esperar que fuese en aumento el porcentaje de desacuerdo con la afirmación propuesta. En España, al comparar los datos de las dos encuestas mas recientes, no se aprecian cambios en las opiniones respecto a la frase propuesta ${ }^{7}$, que obtiene respuestas a favor del 58,7\% en 2000 y 58,3\% en 2007 (Gráfico 8.14). Además cabe mencionar que mientras que en 2000 la afirmación se colocaba en el quinto y último lugar en cuanto al grado de apoyo, en 2007 asciende a la cuarta posición. En Galicia, la centralidad relativa del trabajo es claramente inferior que en España. Esta frase es la que menor acuerdo suscita en Galicia en los dos años considerados, con porcentajes a favor que se reducen ligeramente,

\footnotetext{
No se encontraron diferencias estadísticamente significativas entre los resultados de las dos encuestas para España ni para Galicia.
} 
pasando de cerca del 42\% en 2001 al 38\% en 2008. Por tanto, en los dos años se aprecia que hay mayoría de personas en contra de la afirmación propuesta. Estos datos resultan sorprendentes si se tiene en cuenta que en el caso de la centralidad absoluta Galicia presentaba valores superiores a los de España, pero en cuanto a la centralidad relativa los porcentajes indican que los gallegos no están dispuestos a sacrificar parte de su tiempo libre en beneficio del trabajo. De hecho, el porcentaje de acuerdo con esta frase en Galicia es inferior al obtenido por el resto de los países europeos con índice de desarrollo humano alto para los que existen datos disponibles en la última edición de la Encuesta Mundial de Valores.

Si se analizan los datos de Galicia en relación al comportamiento de esta variable a nivel individual, de nuevo resulta que la generación de nacimiento es el factor que ofrece una mayor explicación en las dos encuestas disponibles. La frase propuesta suscita un fuerte rechazo entre las generaciones más jóvenes, que se va suavizando a medida que se avanza hacia los grupos de personas nacidas con anterioridad y, en el caso de las generaciones de más edad, se llega a una situación inversa, pues los porcentajes de los que están a favor superan a los de los que están en contra (Gráfico 8.15). En el año 2001, la generación de los nacidos entre 1950 y 1959 muestra casi un equilibrio entre los porcentajes a favor y en contra de que el trabajo deba ser siempre lo primero, pero se inclinan ligeramente más hacia la posición en contra de la afirmación. A partir de esta generación se incrementan los porcentajes en contra, situándose aproximadamente en el 85\%. El fenómeno contrario se observa al considerar las generaciones de más edad, que están más a favor de la frase propuesta, especialmente los nacidos entre 1920 y 1929. En 2008 se produce una situación similar, pero la generación de 1950-59 se muestra algo más en contra de la frase que en el año 2001. Aunque en 2008 no se obtienen diferencias tan claras entre los porcentajes a favor y en contra en las generaciones extremas, se mantiene el comportamiento generacional frente a la centralidad relativa.

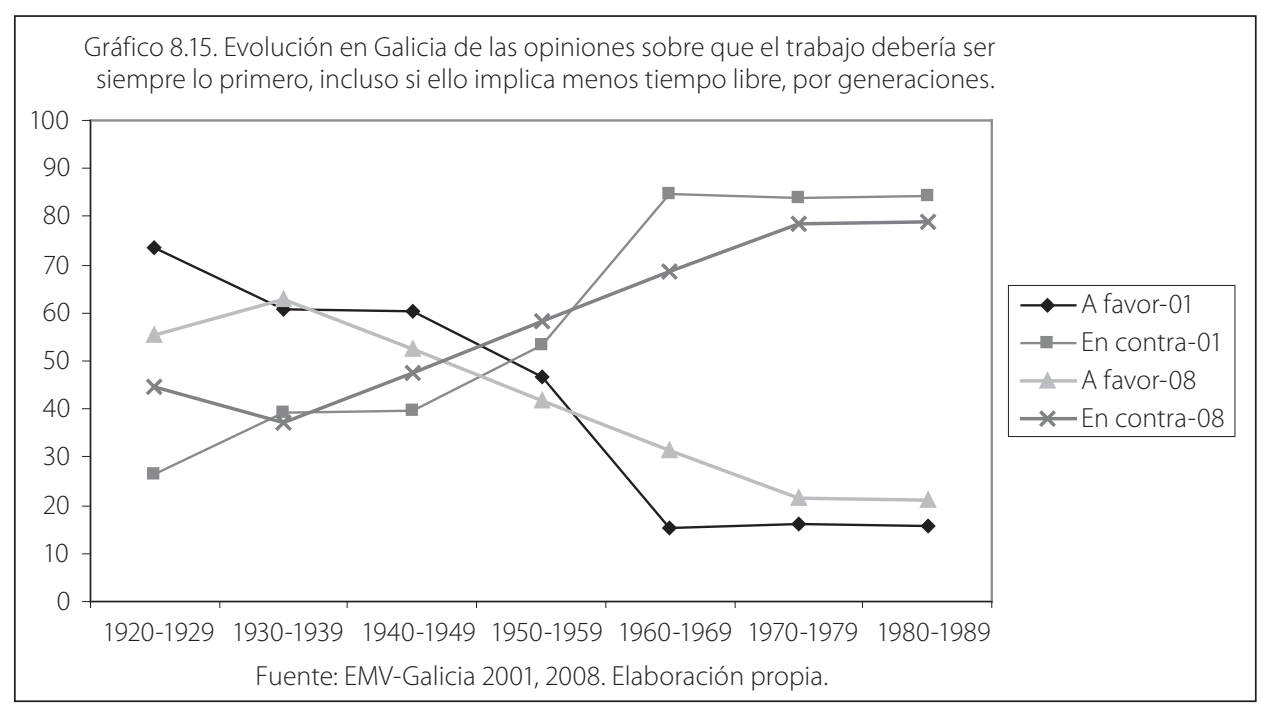

244 LA EVOLUCIÓN DE LOS VALORES SOCIALES EN GALICIA 
La afirmación sobre el trabajo que menor grado de acuerdo suscita, tanto en Europa como en el conjunto del mundo, es la que señala que "es humillante recibir dinero sin tener que trabajar para conseguirlo"; aun así el $72 \%$ de la población mundial y el 58\% de los europeos la respaldan (Tabla 8.4). Italia es el país europeo más de acuerdo con esta frase, seguido a bastante distancia por Noruega, con porcentajes a favor del 79 y $65 \%$ respectivamente. Con porcentajes de respuestas positivas ligeramente por encima del 55\% se encuentran Suiza, España y Alemania, siendo el de Finlandia de aproximadamente el 54\%. De nuevo, Suecia destaca por ser el país con menor respaldo de la frase propuesta, pues solo cerca del $42 \%$ se mostró de acuerdo o muy de acuerdo con que el trabajo es el único modo legítimo de obtener ingresos.

En España, esta frase obtiene porcentajes a favor que se han reducido del 63,5\% al 56\% al pasar de 2000 a 2007. De hecho, la idea de que "es humillante recibir dinero sin tener que trabajar para conseguirlo" ocupaba en 2000 la cuarta posición en cuanto al apoyo recibido por los españoles y cae al quinto puesto en 2007, aun así la mayoría está de acuerdo o muy de acuerdo con la frase propuesta (Gráfico 8.16). En Galicia, esta es también una de las frases que suscita menor acuerdo y, a pesar de que aparece en la cuarta posición en las dos encuestas, recibe menor porcentaje de apoyo que en España. En 2001 se produce casi un equilibrio entre las opciones a favor y en contra de dicha frase, aunque el acuerdo aventaja escasamente al desacuerdo. En 2008 también las opiniones a favor y en contra alcanzan porcentajes similares, pero, en este caso, las respuestas en contra superan a las respuestas a favor, lo que indica un ligero desacuerdo con la idea de que sea humillante percibir ingresos sin trabajar, lo que no resulta muy extraño si consideramos los efectos de una situación de crisis económica en la que presumiblemente aumentarán las tasas de paro y, en consecuencia, muchas personas habrán de contar con un subsidio de desempleo ${ }^{8}$.

En Galicia, la variable explicativa que mejor diferencia las opiniones respecto a esta frase es, una vez más, la generación por año de nacimiento. En 2001 las tres generaciones de más edad se muestran a favor de que "es humillante recibir dinero sin trabajar", pero el grado de apoyo de esta idea va disminuyendo a medida que avanza el año de nacimiento, para llegar en la generación de 1950-59 a un punto cercano al equilibrio entre los que están a favor y en contra (Gráfico 8.17). En las generaciones de los nacidos a partir de 1960 los porcentajes de los que están en contra de esta frase alcanzan porcentajes superiores al 60\%, es decir que ya son mayoría los que opinan que no es humillante recibir dinero sin trabajar. El patrón de comportamiento de las generaciones en 2008 sigue mostrando que los nacidos de 1960 en adelante están más bien en contra de la frase propuesta, pero la ventaja de los porcentajes en contra sobre los porcentajes a favor es muy

De todos modos hay que matizar que no se encontraron diferencias estadísticamente significativas entre resultados de las dos encuestas para Galicia. 
inferior a la obtenida en 2001. Entre los nacidos antes de 1960, algunas generaciones se muestran más bien a favor y otras en contra de la frase propuesta, sin seguir la misma pauta que en 2001 y con distancias entre porcentajes inferiores a los de dicho año.
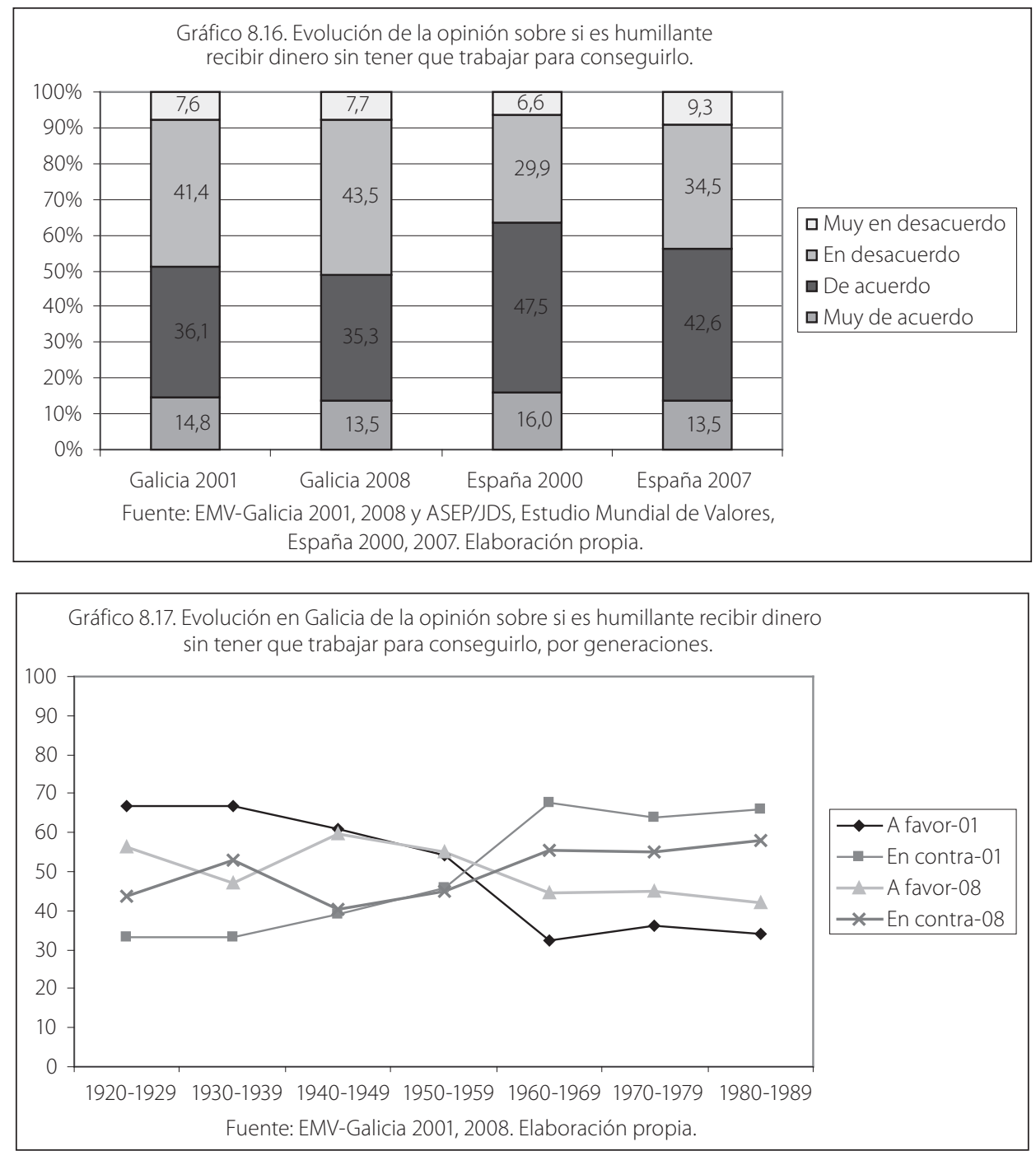

De los datos aquí presentados se desprende que la valoración de distintos aspectos relacionados con la ética del trabajo es diferente en Galicia que en España y en el conjunto de los países europeos considerados. Por una parte, destaca el elevado apoyo que se le da en Galicia a la idea de que "las personas que no trabajan se vuelven perezosas", que es la que recibe el mayor apoyo en Galicia, mientras que en España ocupa el segundo lugar y el tercero en el conjunto de Europa con elevado IDH. El resto de las afirmaciones reciben porcentajes de apoyo inferiores 
en Galicia que en España y en el conjunto de los países europeos. La idea que menor grado de acuerdo recibe en Galicia es que "el trabajo debería ser siempre lo primero, incluso si ello implica menos tiempo libre", a diferencia de España y el conjunto de Europa, que la colocan en cuarto lugar. Esta frase puede interpretarse como una medida de centralidad relativa y resulta muy llamativo el poco respaldo que recibe en Galicia, donde la centralidad absoluta, sobre todo como el grado de importancia del trabajo en la vida de las personas, era muy elevado.

En Galicia, todos los aspectos mencionados de la ética del trabajo tienen un mayor grado de apoyo entre las generaciones de más edad que se debilita entre las generaciones más jóvenes, llegando incluso a rechazar las frases propuestas. De todos modos, las diferencias entre generaciones no son tan intensas en 2008 como en 2001.

\subsection{LAS ORIENTACIONES HACIA EL TRABAJO}

En los análisis e investigaciones sobre las percepciones que las personas tienen del trabajo, del modo en que valoran su utilidad y las recompensas que de él obtienen, se emplean diversas clasificaciones de las orientaciones y de los valores laborales. Sin embargo, a pesar de las diferencias, en todas estas clasificaciones hay alguna dimensión, orientación o eje que se refiere a una visión instrumental, extrínseca, calculadora o económica del trabajo y alguna dimensión, orientación o eje que se refiere a una visión expresiva o intrínseca (Muñoz Goy, 2005: 109-114).

La orientación instrumental hace referencia a una visión del trabajo que valora las recompensas materiales y económicas del trabajo, especialmente el salario, y otro tipo de recompensas que no tienen por qué ser exclusivamente económicas, como puede ser la estabilidad del puesto de trabajo. Por otra parte, la orientación expresiva se refiere a la valoración de las recompensas intrínsecas al propio desempeño de la tarea, que posibilitan el desarrollo y la realización personal y, además, aquellas características del trabajo que permiten la interacción social de los trabajadores.

El hecho de que a la hora de hablar del trabajo se sobreentienda que se trata de trabajo remunerado pone las bases para entender que la oferta de mano de obra se produce en una situación de mercado, lo que hace prácticamente imposible desvincular la idea del trabajo de una cierta propensión al cálculo que implica una visión instrumental. De ahí que, como se desprende del estudio de Goldthorpe et al. (1968), siempre habrá algún componente instrumental en cualquier orientación hacia el trabajo. Por ello, cuando se alude a que ciertas personas tienen orientaciones distintas de las instrumentales, no debe suponerse que no valoran este tipo de recompensas del trabajo, sino que dan prioridad o mayor importancia a otras recompensas como pueden ser las condiciones laborales que les permitan desarrollar su potencial personal, que les planteen retos y que, en definitiva, contribuyan a mejorar su calidad de vida. 
La tendencia a situar las orientaciones instrumentales y expresivas del trabajo como contrapuestas deriva, en numerosas ocasiones, de la forma en que se miden los aspectos relativos al trabajo. Muchas veces se realiza una elección entre distintos resultados o recompensas del trabajo, lo que puede llevar a pensar que los que prefieren las recompensas de tipo no instrumental es porque no perciben que estas sean necesarias o importantes. Sin embargo, esta interpretación no sería correcta pues en realidad lo que estaríamos apreciando es que dicha persona antepone las recompensas expresivas a las instrumentales, aunque estas también puedan ser importantes, pero a la hora de decantarse por una preferencia su orientación es más expresiva que instrumental.

En el análisis de las orientaciones hacia el trabajo existen dos perspectivas o teorías en competencia. Por una parte, puede suponerse que el subsistema social económico es, por definición, el ámbito de la escasez (Goldthorpe et al. 1968). Por esta razón cabría esperar que en el mundo laboral se deje notar la influencia de los valores fuertemente asociados a las necesidades básicas de supervivencia y seguridad, es decir, valores de tipo materialista que se corresponderían con un puesto de trabajo estable, seguro y con un buen sueldo, o lo que es lo mismo, que en las orientaciones laborales siempre habrá un fuerte componente instrumental.

Por otra parte, algunos autores (Inglehart, 1991 y 1998; Yankelovich, 1985; Zanders, 1994; Harding y Hikspoors, 1995 y Russell, 1998) señalan que en el ámbito laboral se está produciendo un cambio de valores acorde con el experimentado en el ámbito general, por lo que se espera un auge de los aspectos

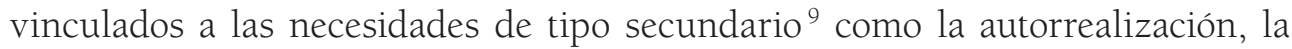
afiliación o el espíritu de logro, esto es, valores de tipo posmaterialista, que en el ámbito del trabajo se reflejarían en orientaciones de tipo expresivo.

Esta perspectiva, que propone que la evolución de los valores laborales seguirá la misma dirección que los valores en el ámbito general, implicaría que a nivel macro o agregado, en tanto que se da por supuesta la cobertura de las necesidades primarias, haya una tendencia hacia una mayor elección de las orientaciones laborales expresivas a lo largo del tiempo.

Además, en distintos análisis sobre el cambio de valores, tanto en el ámbito general como en la esfera laboral, se señala que dicho cambio es más intenso entre los más jóvenes y las personas con mayor nivel educativo, como se recoge en la introducción de este capítulo. En el caso de la edad, la razón de que los nuevos valores se encuentren más extendidos entre los más jóvenes se debería, precisamente, a que estos han sido socializados en épocas de mayor estabilidad

La diferencia entre necesidades primarias y secundarias se basa en la conocida jerarquía de las necesidades de Maslow (1954), de modo que las necesidades de tipo primario engloban las necesidades fisiológicas y de seguridad, mientras que las de tipo secundario se corresponden con las necesidades sociales o de afiliación, las de estima y las de autorrealización. 
y mejores condiciones económicas, lo que les permite dar por supuesta la cobertura de las necesidades primarias. La influencia del nivel de estudios sobre las orientaciones laborales podría explicarse por el hecho de que los más educados son, justamente, los que pueden permitirse aspirar a unos puestos de trabajo más acordes con las exigencias de la autorrealización. También pudiera ser que el nivel de estudios refleje de manera aproximada la situación socioeconómica del entrevistado durante sus años formativos (Díez Nicolás, 1994: 149). Asimismo, es posible que al recibir una educación formal prolongada se "aprenda" que es deseable la autorrealización y, además, que se puede buscar en el ámbito del trabajo. Por lo tanto, a nivel micro o individual cabría esperar que entre las personas con mayores niveles de estudios se encuentren mayores porcentajes de orientaciones expresivas y que dichas orientaciones estén más extendidas entre las generaciones más jóvenes.

Los datos de la última edición de la Encuesta Mundial de Valores muestran que, al considerar el conjunto de todos los países del mundo, la característica prioritaria del trabajo ${ }^{10}$ es el salario, seguida muy de cerca por la seguridad del puesto de trabajo, con porcentajes aproximados del 36\% y 34\% respectivamente, es decir que las dos opciones que se eligen en mayor medida son las de tipo instrumental (Tabla 8.5). Sin embargo, dicho orden no se mantiene al tener en cuenta solo a los países europeos con mayor índice de desarrollo humano; entre estos la característica prioritaria es el hecho de que el trabajo desempeñado permita la realización personal (32,8\%), seguida de la estabilidad laboral (31,8\%). Pero no en todos los países europeos prima la autorrealización sobre las otras características del trabajo, esto es así en los Países Bajos, Noruega, Suecia y especialmente en Suiza, donde más de la mitad de los entrevistados mencionaron la autorrealización como la característica más deseable en caso de que estuviesen buscando un trabajo. El caso de Suecia también es muy llamativo, pues es el único de los países analizados en el que las dos características que reciben el mayor porcentaje de apoyo son las de tipo expresivo. En otros cinco países la característica más mencionada es que el trabajo sea seguro y no comporte riesgos de desempleo; se trata de España y Alemania — que presentan como segunda opción el salario- y Finlandia, Italia y Francia — cuya segunda opción es que el trabajo permita la realización personal- Reino Unido es el único país en el que se menciona como característica prioritaria del trabajo el salario, si bien casi con la misma intensidad que la realización personal.

10 En la pregunta del cuestionario se pedía a los entrevistados que señalasen cuál de entre las cuatro características presentadas pondrían en primer y segundo lugar, en caso de estar buscando un trabajo. Puesto que se han analizado las respuestas a la elección realizada en primer lugar, se utilizará el término "característica prioritaria del trabajo". 
Tabla 8.5. Opiniones, en porcentaje, sobre la característica prioritaria del trabajo, en los países europeos con mayor IDH.

\begin{tabular}{|c|c|c|c|c|}
\hline & $\begin{array}{l}\text { Un buen sueldo, } \\
\text { de manera que } \\
\text { no tuviese } \\
\text { preocupaciones } \\
\text { respecto al dinero }\end{array}$ & $\begin{array}{l}\text { Un trabajo } \\
\text { seguro que } \\
\text { no comporte } \\
\text { riesgos de } \\
\text { cierre o de } \\
\text { desempleo }\end{array}$ & $\begin{array}{l}\text { Trabajar con } \\
\text { gente que } \\
\text { sea de su } \\
\text { gusto }\end{array}$ & $\begin{array}{l}\text { Hacer un trabajo } \\
\text { importante } \\
\text { que le haga } \\
\text { sentirse realizado }\end{array}$ \\
\hline Alemania & 20,1 & 53,8 & 6,8 & 19,4 \\
\hline España & 29,0 & 41,8 & 15,0 & 14,2 \\
\hline Finlandia & 16,0 & 34,8 & 19,2 & 30,0 \\
\hline Francia & 19,7 & 37,7 & 17,6 & 25,0 \\
\hline Italia & 21,9 & 38,4 & 8,8 & 30,8 \\
\hline Noruega & 12,6 & 25,7 & 13,6 & 48,1 \\
\hline Países Bajos & 28,1 & 15,8 & 22,3 & 33,7 \\
\hline Reino Unido & 34,9 & 17,6 & 13,6 & 33,9 \\
\hline Suecia & 11,3 & 11,9 & 27,7 & 49,1 \\
\hline Suiza & 9,8 & 19,3 & 15,2 & 55,7 \\
\hline $\begin{array}{l}\text { Media países } \\
\text { elevado IDH }\end{array}$ & 20,2 & 31,8 & 15,1 & 32,8 \\
\hline $\begin{array}{l}\text { Media países } \\
\text { del mundo }\end{array}$ & 35,7 & 34,4 & 10,3 & 19,7 \\
\hline
\end{tabular}

Fuente: ASEP/JDS, Estudio Mundial de Valores Oleada 5 (2005-2008).

Elaboración propia.

Si se analiza la evolución de la característica prioritaria del trabajo en España, no se observa la supuesta transición hacia las orientaciones expresivas, recogidas en las opciones que se refieren al hecho de trabajar con gente agradable o sentirse realizado con el trabajo. La característica prioritaria del trabajo fue la seguridad del empleo tanto en 1995 como en 2007, mientras que en 2000 experimentó un descenso y el primer lugar lo ocupó la opción de "un buen sueldo", aunque los porcentajes de las dos opciones instrumentales durante ese año fueron prácticamente iguales (Gráfico 8.18). Por otra parte, la característica de que el trabajo ofrezca la posibilidad de sentirse realizado perdió terreno desde 1995 hasta 2007, de modo que en el último año fue la opción menos elegida por los españoles. 


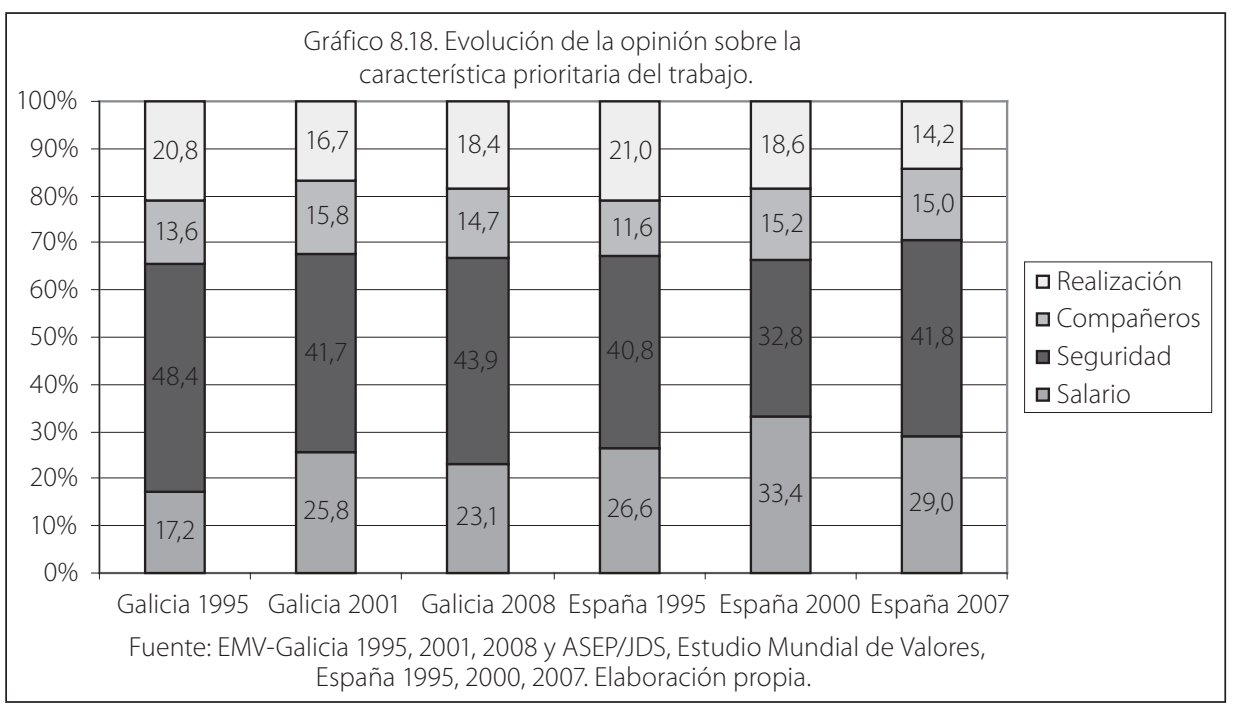

Tampoco en Galicia se aprecia una tendencia hacia las orientaciones expresivas en el trabajo. Dichas opciones fluctúan en los años considerados pero no se consolidan ni ganan terreno a las opciones más instrumentales. La estabilidad laboral es la característica del trabajo más apreciada por los gallegos en cualquiera de las encuestas llevadas a cabo, aunque en 2001 se produce un descenso hay un repunte en 2008, tal vez como consecuencia de un mercado laboral más incierto en el que comenzaban a preverse los incrementos en la tasa de paro. La otra característica instrumental, el sueldo, pasa de ser la tercera opción elegida en 1995 a ser la segunda elección tanto en 2001 como en 2008.

Al comparar los datos de Galicia y España se observa que en Galicia los porcentajes de respuestas a favor del sueldo son inferiores a los de España, mientras que en cuanto a la seguridad del empleo sucede lo contrario, se obtienen porcentajes superiores en Galicia que en España. Las dos opciones expresivas — autorrealización y trabajar con compañeros agradables— tienen un comportamiento similar en Galicia y en España.

No es de extrañar que la búsqueda de un empleo estable sea una demanda recogida por un elevado número de personas si se tiene en cuenta la situación del mercado de trabajo tanto en Galicia como en España. La tasa de temporalidad se ha mantenido en valores muy elevados desde 1990, tanto en relación a los valores precedentes como en comparación con otros países de la Unión Europea. De hecho, junto con la reducción de la tasa de paro, la reducción de la temporalidad ha sido una de las metas que se han propuesto las diferentes reformas laborales que se han llevado a cabo desde 1994 - la primera reforma laboral de 1984 se propuso reducir una elevadísima tasa de paro, que no había tenido precedentes en España y, aunque lo consiguió en 
parte durante los primeros años, fue a costa de incrementar la temporalidad, que desde comienzos de la década de 1990 se colocó en tasas superiores al 30\% de la población activa-.

En Galicia el nivel de estudios es la variable sociodemográfica que tiene una mayor y más consistente relación con la característica prioritaria del trabajo. En 1995 se aprecia que, en términos generales, a medida que aumenta el nivel de estudios disminuye la importancia de la seguridad del trabajo y aumenta la de que el trabajo permita la realización personal (Gráfico 8.19). Además, los que tienen el nivel de estudios más bajo hacen más hincapié que los otros grupos en la importancia del salario. Llama la atención cómo el orden de las características del trabajo varía en los dos grupos extremos definidos por nivel de estudios: mientras que para los de menor nivel de estudios la primera opción es la seguridad, seguida del salario, trabajar con compañeros agradables y, por último, la posibilidad de realizarse en el trabajo, entre los de mayor nivel de estudios el orden de las características es primero la realización, seguida de la seguridad, el trabajar con compañeros agradables y, por último, el salario.

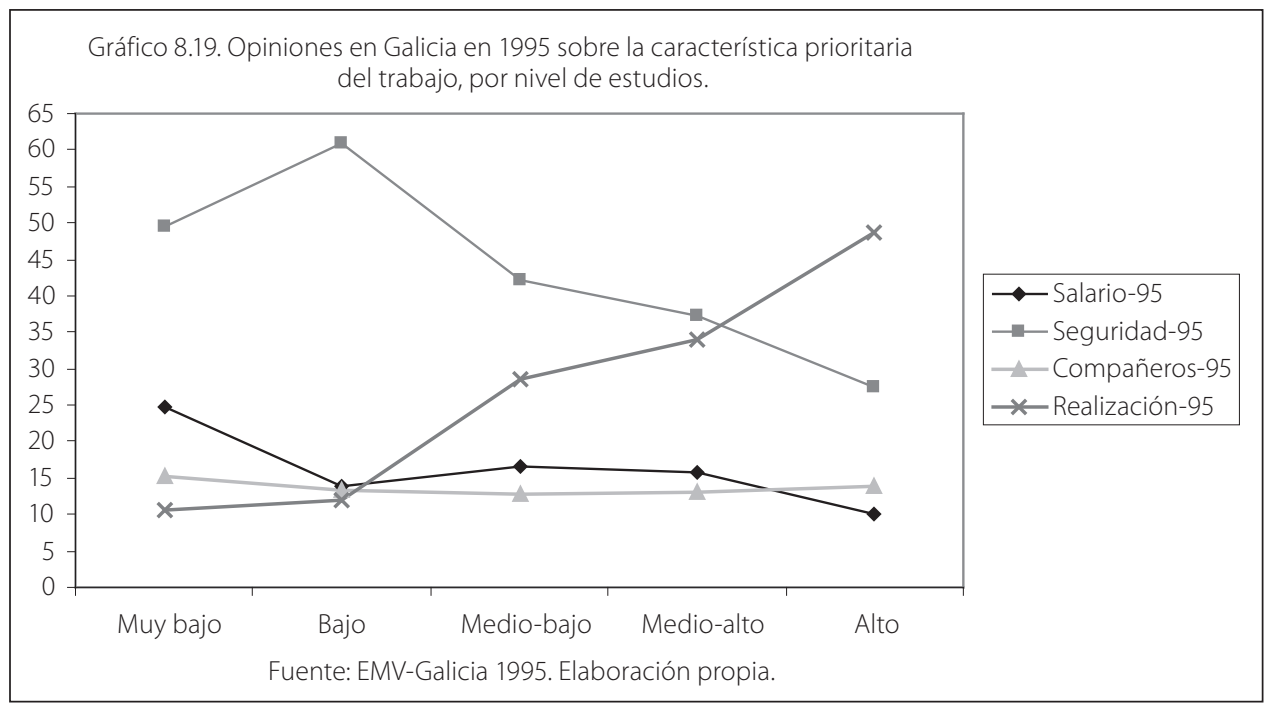

La relación entre el nivel de estudios y las características del trabajo ya no es tan intensa en 2001. De nuevo se aprecia que la seguridad y el salario son algo más importantes cuanto menor es el nivel de estudios y que a medida que este aumenta también crece la búsqueda de la realización en el trabajo, pero las diferencias entre los porcentajes obtenidos para cada característica entre los distintos grupos no son tan fuertes como en 1995 (Gráfico 8.20). Además, mientras que en 1995 la autorrealización fue la segunda opción para las personas con nivel de estudios medio-bajo 
y medio-alto, en 2001 solo alcanza la segunda posición para el grupo con nivel de estudios medio-bajo. También destaca el hecho de que en 1995 para el grupo de nivel de estudios alto la realización superaba con mucho a la seguridad (49\% frente a 28\%), pero en 2001 las dos opciones están mucho más cerca (40\% frente a 33\%).

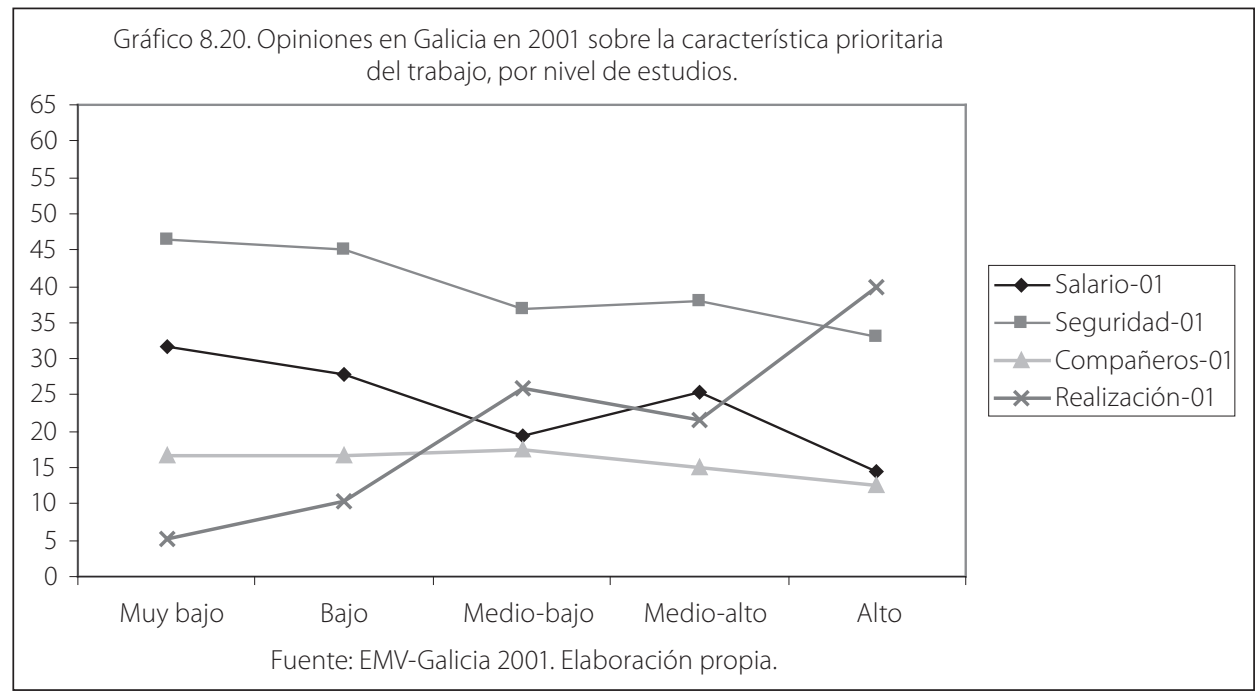

La disminución de la intensidad de la capacidad explicativa del nivel de estudios es todavía más patente en 2008 (Gráfico 8.21). Aunque entre las personas con mayor nivel de estudios se obtiene el porcentaje más alto de elecciones de la "realización en el trabajo", ni siquiera para este grupo dicha característica ocupa la primera posición. En las otras categorías definidas por nivel de estudios, la característica más importante es la seguridad, seguida del salario. Parece haber un impacto de la situación de crisis económica y de incertidumbre respecto a la estabilidad del puesto de trabajo que hace primar la conservación del empleo sobre todas las demás características, aun entre aquellas personas que pudieran estar más protegidas frente al desempleo por su cualificación.

Al comparar la evolución de cada una de las características en las tres encuestas se observa que el salario fue elegido en mayor medida en 2001 que en 1995 por todos los grupos de nivel de estudios, mientras que en 2008 se produce un ligero retroceso en algunos grupos y un cierto aumento en otros, pero siempre en niveles superiores a los de 1995. En cuanto a la seguridad, al pasar de 1995 a 2001 los grupos con niveles de estudios más bajos descienden en sus porcentajes de mención de esta característica, mientras que se da un aumento en los grupos de mayor nivel de estudios. En 2008 se observa un incremento en la elección de la seguridad para todos los grupos, que es algo 
más intenso entre los colectivos con niveles de estudios medios y altos, de modo que se produce una homogeneización en los porcentajes de los distintos grupos de nivel de estudios. Las oscilaciones en cuanto a la opción de trabajar con compañeros agradables son muy reducidas en los tres años considerados, pues esta característica es la que menos varía con el nivel de estudios. La elección de la realización personal en el trabajo disminuye para todos los grupos de nivel de estudios al pasar de 1995 a 2001, con más intensidad entre los grupos con niveles de estudios más altos; en 2008 sigue disminuyendo para los tres colectivos con niveles de estudios más altos al tiempo que aumenta para los dos grupos de niveles de estudios bajos, de modo que se produce un acercamiento en los porcentajes de elección de esta característica entre los diferentes niveles de estudios. Esta convergencia en las opiniones de los grupos produce una disminución de la intensidad de la asociación existente entre las dos variables.

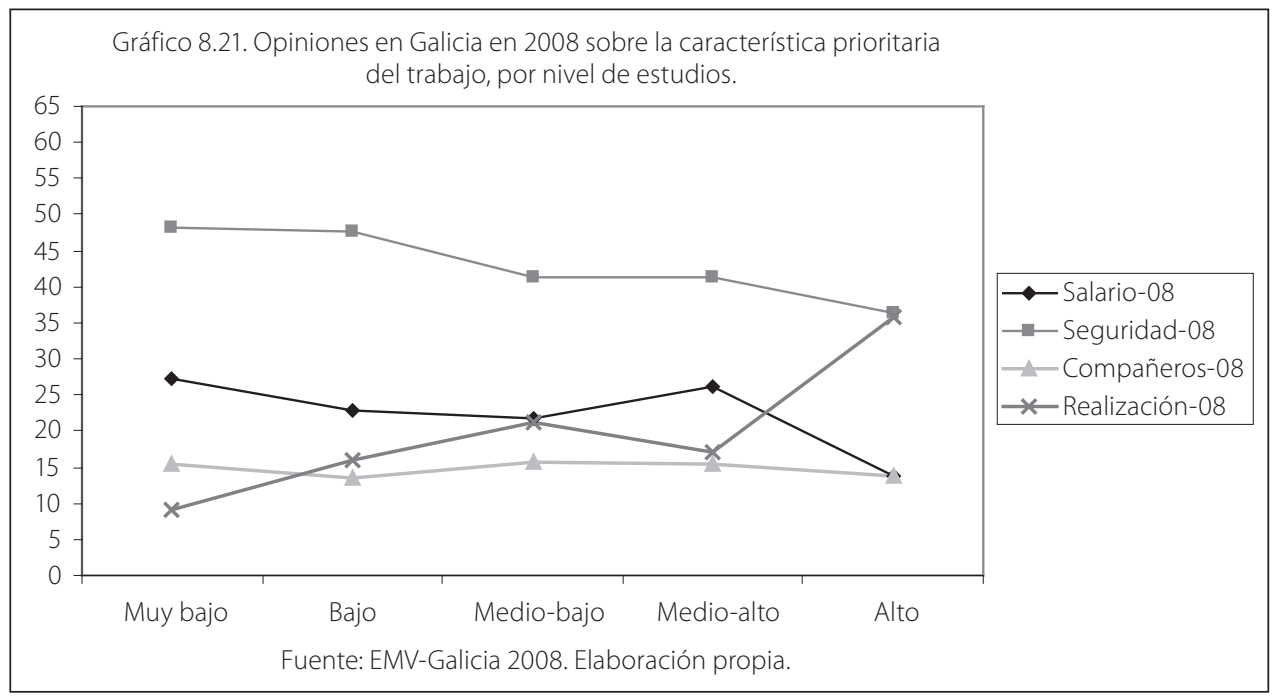

En resumen, no se aprecia en Galicia un aumento de las opciones expresivas al elegir la característica prioritaria del trabajo. En la Europa con elevado IDH se sitúa primero la autorrealización, seguida de la estabilidad en el empleo, el salario y trabajar con gente agradable. En España, el orden en la última encuesta coloca en primer lugar la estabilidad laboral, seguida del salario, trabajar con compañeros agradables y la autorrealización; en Galicia, el orden es el mismo a excepción de las dos últimas opciones que aparecen en orden inverso. En Galicia se constata que los que tienen mayor nivel de estudios tienden a elegir en mayor medida la autorrealización, pero las diferencias entre los grupos con diferentes niveles de estudios se han reducido de 1995 a 2008. 
La evolución de las orientaciones laborales en Galicia no sigue la trayectoria propuesta teóricamente de un incremento de la apreciación del trabajo como una fuente de satisfacciones intrínsecas. Como ya se ha señalado (Muñoz Goy, 2007: 134), es posible que la causa de que no se valoren cada vez más las recompensas intrínsecas sea un entorno laboral con escasez de puestos de trabajo y, sobre todo, con empleos que no permiten lograr una experiencia laboral enriquecedora, que propicie la autorrealización y el logro personal. Aunque, en consonancia con los nuevos valores posmaterialistas, las personas se planteasen la búsqueda de las recompensas de tipo intrínseco, es posible que al encontrarse con que la mayoría de puestos de trabajo no están diseñados de acuerdo con tales inquietudes, sufriesen el fenómeno que Alderfer (1972) denomina como "frustración-regresión", de modo que cuanto menos satisfechas estén las necesidades de nivel superior más se deseará la satisfacción de necesidades de nivel inferior. Es decir, que cuando la satisfacción de las necesidades superiores se ve frustrada se pondrá más énfasis en las necesidades inferiores aunque estén satisfechas y aún más si se prevé que algunas recompensas — como la estabilidad laboral— pueden estar siendo amenazadas.

\subsection{LA INDIVIDUALIZACIÓN EN EL ÁMBITO LABORAL}

En su análisis sobre el cambio en los valores del trabajo, Zanders parte del supuesto de que el ámbito valorativo laboral puede verse influido por el proceso de modernización. Dicho proceso, que se refiere a la diferenciación e individualización, implica que los valores serán menos dependientes de la tradición y de las instituciones sociales que en el pasado, convirtiéndose en la actualidad en elecciones personales. En el ámbito laboral, la individualización se refleja, entre otros aspectos, en un mayor énfasis en la relación directa entre el logro personal y las recompensas obtenidas (Zanders, 1994: 146).

En la Encuesta Mundial de Valores se incluye una pregunta que relaciona la remuneración y el modo en que se desempeñan las tareas. En ella se propone una hipotética situación en la que dos personas realizan prácticamente el mismo trabajo, pero una de ellas, que es más eficiente, rápida y fiable, cobra más que la otra y se les pide a los encuestados que valoren si esta situación es justa o no. Es decir, se propone una elección implícita entre los criterios de la adscripción, más propios de las sociedades tradicionales, y los criterios meritocráticos, típicos de las sociedades modernas, que procuran que los criterios de asignación y distribución de la renta se basen en el esfuerzo y las capacidades adquiridas por los individuos (Pino y Bericat, 1998: 159-160). 
Tabla 8.6. Opiniones, en porcentaje, sobre si es o justa o no la remuneración de acuerdo con el rendimiento, en los países europeos con mayor IDH.

\begin{tabular}{lcc} 
& Injusta & Justa \\
\hline Alemania & 17,1 & 82,9 \\
\hline España & 27,7 & 72,3 \\
\hline Finlandia & 20,2 & 79,8 \\
\hline Italia & 27,2 & 72,8 \\
\hline Noruega & 44,3 & 55,7 \\
\hline Suecia & 17,5 & 82,5 \\
\hline Suiza & 12,4 & 87,6 \\
\hline Media países & 22,8 & 77,2 \\
elevado IDH & 23,1 & 76,9 \\
\hline $\begin{array}{l}\text { Media países } \\
\text { del mundo }\end{array}$ &
\end{tabular}

Fuente: ASEP/JDS, Estudio Mundial de Valores Oleada 5 (2005-2008). Elaboración propia.

Tanto en el conjunto de países del mundo como en los países europeos con elevado índice de desarrollo humano, más del 75\% de los encuestados consideran justo que se remunere a las personas de acuerdo con su rendimiento (Tabla 8.6). En los países europeos esta idea es más firmemente apoyada por suizos, alemanes, suecos y finlandeses y algo menos por italianos y españoles, si bien en todos los casos el porcentaje de respaldo supera el $70 \%$. Por otra parte, destacan los noruegos, entre los que solo el 56\% cree que se debe pagar más a los trabajadores que desempeñan mejor su trabajo.

En España, la opinión de que es justa la remuneración de acuerdo con el rendimiento ha sido mayoritaria en las tres encuestas, aunque los porcentajes de apoyo a esta idea presentan algunas fluctuaciones (Gráfico 8.22). El año en que se alcanza el menor grado de acuerdo es el intermedio, aún así en 2000 casi el $62 \%$ de los encuestados cree que es justo pagar más a las personas que mejor trabajan; este porcentaje ascendía al 67\% en 1995 y a más del 72\% en 2007. En Galicia, la respuesta ha sido siempre muy favorable a la remuneración en función del rendimiento, con porcentajes superiores a los de España. El año en que se obtiene un porcentaje más contundente es 2001, en el que el grado de acuerdo alcanza el 80\%; en 1995 ya se había obtenido una cifra superior al 77\%, y el acuerdo disminuye ligeramente en 2008, aunque sigue habiendo una clara mayoría a favor de la diferencia de salarios, pues piensan así tres de cada cuatro personas (74,5\%). El momento en que los datos de España 
y Galicia se asemejan más es en la última recogida de datos (2007-2008), en el que más de siete de cada diez personas respaldan la opinión de que es justo pagar más al que trabaja mejor.

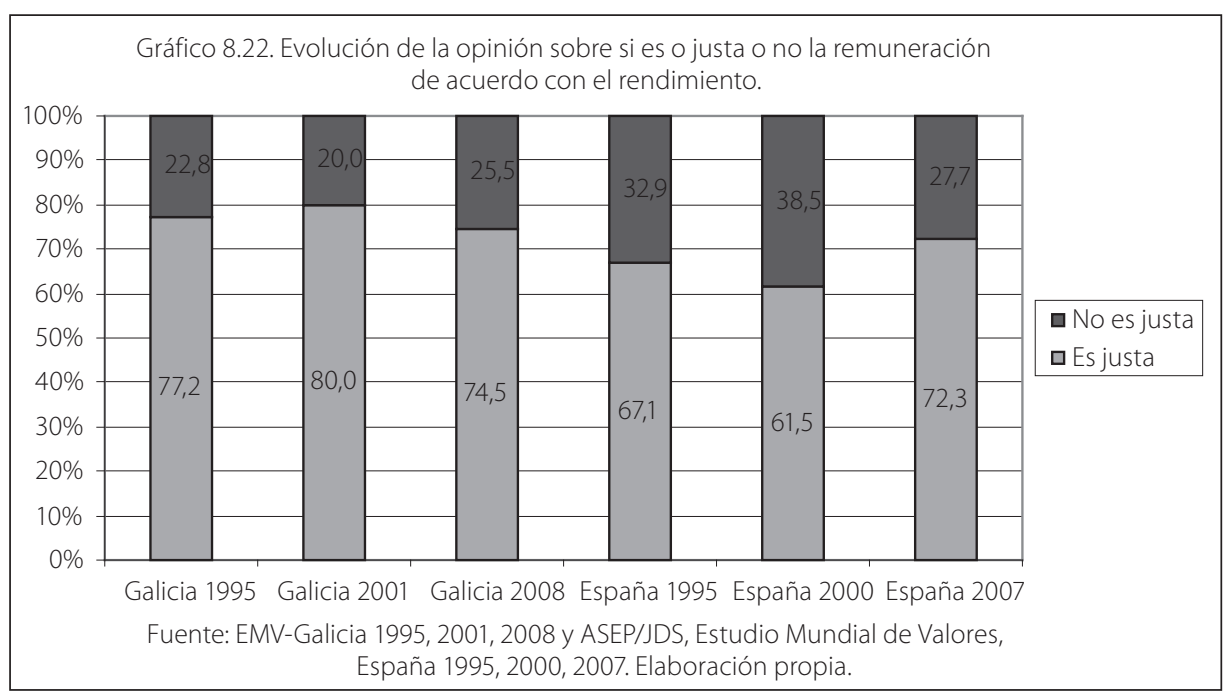

En el análisis a nivel individual en Galicia, la característica sociodemográfica que mejor permite diferenciar las opiniones sobre la remuneración de acuerdo con el rendimiento es el nivel de ingresos del hogar (Gráfico 8.23). En las tres ediciones de la encuesta se aprecia que a medida que aumenta el nivel de ingresos del hogar hay un grado de apoyo ligeramente superior a que se pague más a quien mejor trabaja, con la única excepción de que en 2001 el grupo con mayor porcentaje de acuerdo con esta idea es el de ingresos altos en lugar del grupo de ingresos muy altos.

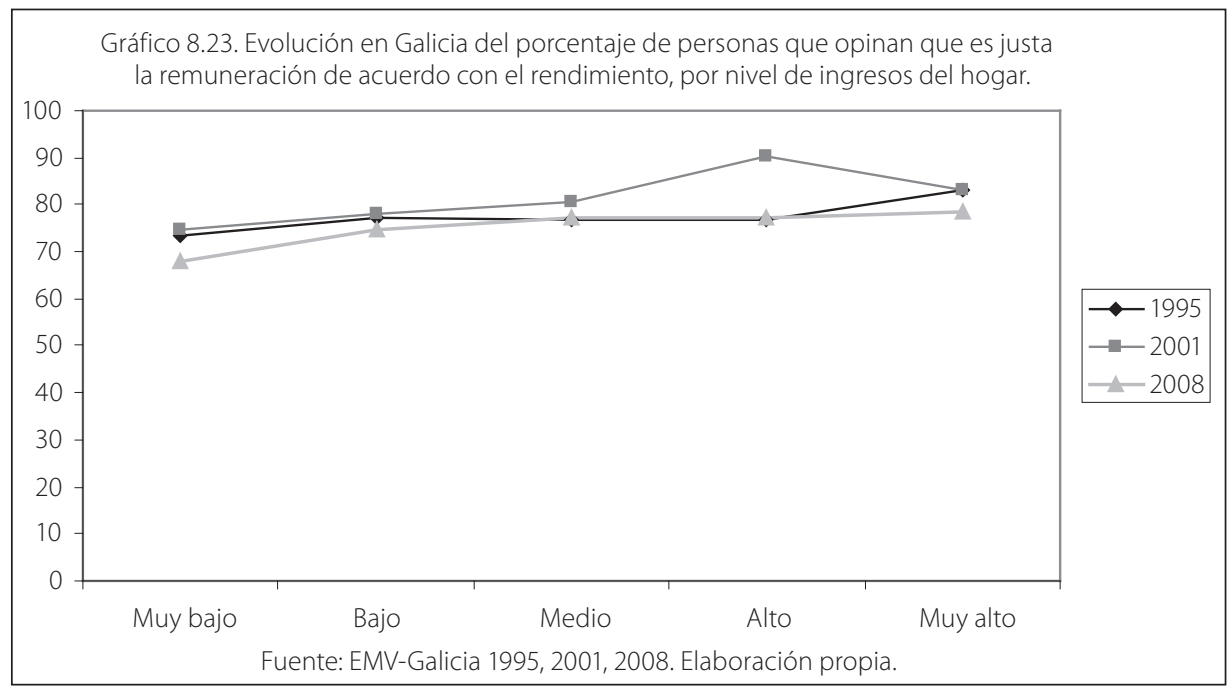


Otro modo de valorar las percepciones de los criterios meritocráticos consiste en analizar las opiniones sobre si la clave del éxito es el esfuerzo personal o si el éxito puede conseguirse por medios externos al individuo. Para ello se analizó una pregunta incluida en los cuestionarios de 1995 y 2007-2008, sobre si "a la larga, esforzarse en el trabajo suele llevar a una vida mejor" (punto 1 en la escala) o si "esforzarse en el trabajo no suele llevar al éxito, eso depende más de la suerte y los enchufes" (punto 10 en la escala). Por tanto, las puntuaciones 5 y 6 son los valores centrales en la escala y las puntuaciones de 1 a 4 pueden considerarse más cercanas a la idea de que el trabajo es la clave del éxito, mientras que las puntuaciones 7 a 10 se inclinan por creer que es la suerte o los enchufes lo que puede ayudarnos a alcanzar el éxito.

Según los datos de la última oleada de la Encuesta Mundial de Valores, en el conjunto de los países de mundo se opina mayoritariamente que el modo de conseguir el éxito en la vida es a través del trabajo (Tabla 8.7). En los países europeos con elevado índice de desarrollo humano también esta es la opinión dominante, si bien el porcentaje de los que creen que el trabajo es la clave del éxito es algo inferior que en el conjunto del mundo. El país que destaca por su convencimiento de que el trabajo es la clave del éxito es Finlandia, donde casi tres de cada cuatro personas sostienen esta opinión. En España, Reino Unido, Suecia y Alemania también son mayoría absoluta los que señalan que la vía del éxito es el trabajo (con porcentajes del 56,7\%; $52,4 \% ; 52,3 \%$ y $50,2 \%$ respectivamente). El apoyo de esta idea desciende en el resto de los países: en Suiza y los Países Bajos los porcentajes son del 42 y 44,5\% y en Francia e Italia del 37 y 36\%. De hecho, en Francia se produce casi un empate entre el número de respuestas a favor del trabajo y de la suerte y en Italia las opiniones se distribuyen de modo prácticamente uniforme entre las tres posiciones en que se han agrupado los valores de la escala de esta pregunta.

Al analizar la evolución temporal de esta variable en España, se observa que en 1995 los encuestados que se decantan por el trabajo son la mayoría, alcanzando el 55\%, mientras que los que ocupan las posiciones intermedias y los que confían en la suerte obtienen porcentajes parecidos, 20\% y 25\% aproximadamente (Gráfico 8.24). En 2007 se reafirma ligeramente la convicción de que el trabajo lleva al éxito, pues el bloque de los que se acercan más al principio de la escala se incrementa hasta el 57\% y aumentan los que se sitúan en las posiciones intermedias de la escala hasta el 28\%, mientras que los que confían en la suerte y los enchufes descienden en diez puntos.

Los datos para Galicia en 1995 señalan que los que creen en el esfuerzo en el trabajo son un 58\%, los que ocupan las posiciones intermedias alcanzan 
cerca de un $18 \%$ y los que confían en la suerte un $24 \%$, es decir que los gallegos se inclinan más hacia el esfuerzo en el trabajo a la hora de conseguir el éxito en la vida (Gráfico 8.24). Los datos de 2008 muestran un incremento en el grupo de puntuaciones centrales, que ahora alcanza el 23\% y el descenso de los que señalan el trabajo como base del éxito, que se sitúan cerca del $52 \%$; los que creen en la suerte apenas varían respecto al año anterior pues se acercan al 25\%. Es decir, que en 2008 se sigue creyendo que el esfuerzo en el trabajo conduce al éxito en la vida, pero de un modo menos intenso que en 1995. Así pues, la creencia de que el esfuerzo en el trabajo es la clave del éxito parece haber seguido una evolución inversa en España y en Galicia, incrementándose algo en el primer caso y disminuyendo en el segundo.

Tabla 8.7. Opiniones, en porcentaje, sobre si el éxito se consigue por el trabajo duro o por la suerte, en los países europeos con mayor IDH.

\begin{tabular}{lccc} 
& Trabajo & Intermedio & Suerte/enchufes \\
\hline Alemania & 50,2 & 23,5 & 26,3 \\
\hline España & 56,7 & 28,1 & 15,2 \\
\hline Finlandia & 74,0 & 14,2 & 11,8 \\
\hline Francia & 37,0 & 27,8 & 35,2 \\
\hline Italia & 36,0 & 30,1 & 33,9 \\
\hline Noruega & 46,0 & 25,5 & 28,5 \\
\hline Países Bajos & 44,5 & 27,5 & 28,0 \\
\hline Reino Unido & 52,4 & 21,7 & 21,3 \\
\hline Suecia & 52,3 & 26,4 & 35,7 \\
\hline Suiza & 42,1 & 22,2 & 26,2 \\
\hline $\begin{array}{l}\text { Media países } \\
\text { elevado IDH }\end{array}$ & 49,3 & 24,5 & 23,8 \\
\hline $\begin{array}{l}\text { Media países } \\
\text { del mundo }\end{array}$ & 55,7 & 20,5 & 2008,9 \\
\hline
\end{tabular}

Fuente: ASEP/JDS, Estudio Mundial de Valores Oleada 5 (2005-2008).

Elaboración propia. 


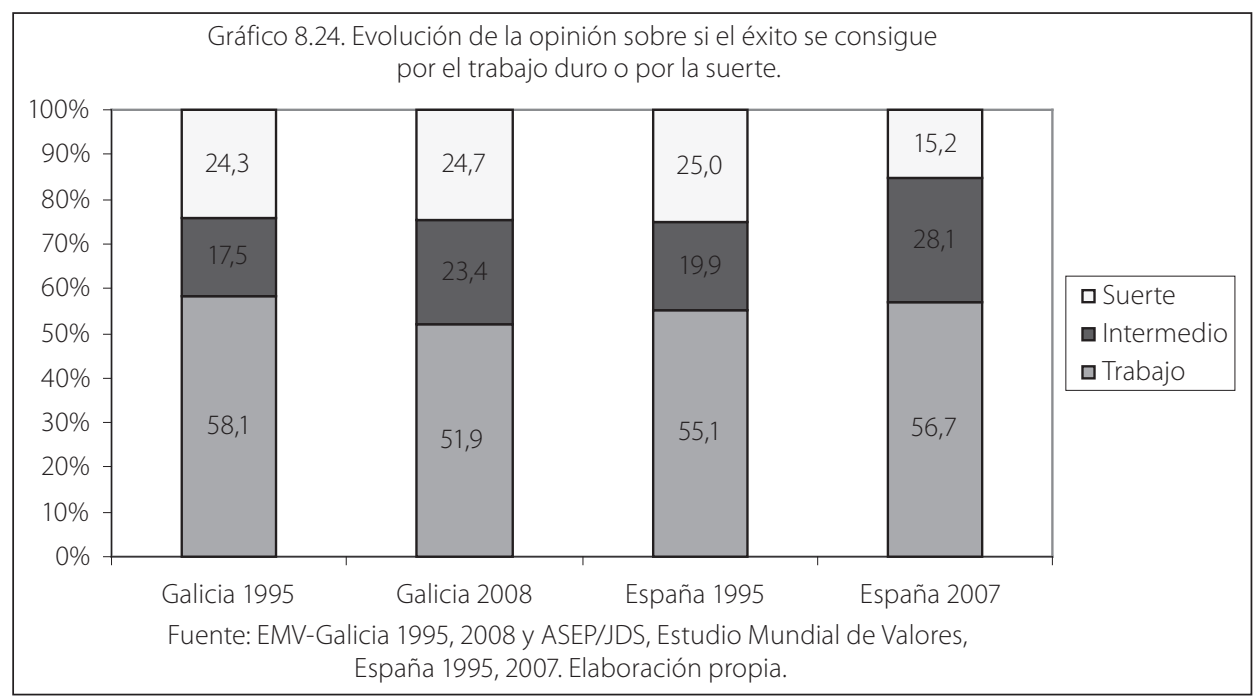

Una vez más, en Galicia la generación permite establecer diferencias significativas en las respuestas a esta pregunta, con una tendencia inversa entre el año de nacimiento y la creencia de que el éxito se consigue a través del esfuerzo en el trabajo (Gráfico 8.25). Tanto en 1995 como en 2008, el porcentaje de los que confían en el trabajo duro como clave del éxito personal es más alto entre las generaciones de más edad que entre las más jóvenes. Llama especialmente la atención el elevado valor que le dan al esfuerzo los nacidos antes de 1920. También es llamativo el ligero repunte en los porcentajes que se produce en las últimas generaciones consideradas en los dos años. De hecho, la forma de las curvas parece sugerir más bien un efecto ciclo vital que un efecto generación, pues las dos son prácticamente paralelas con un desplazamiento horizontal.

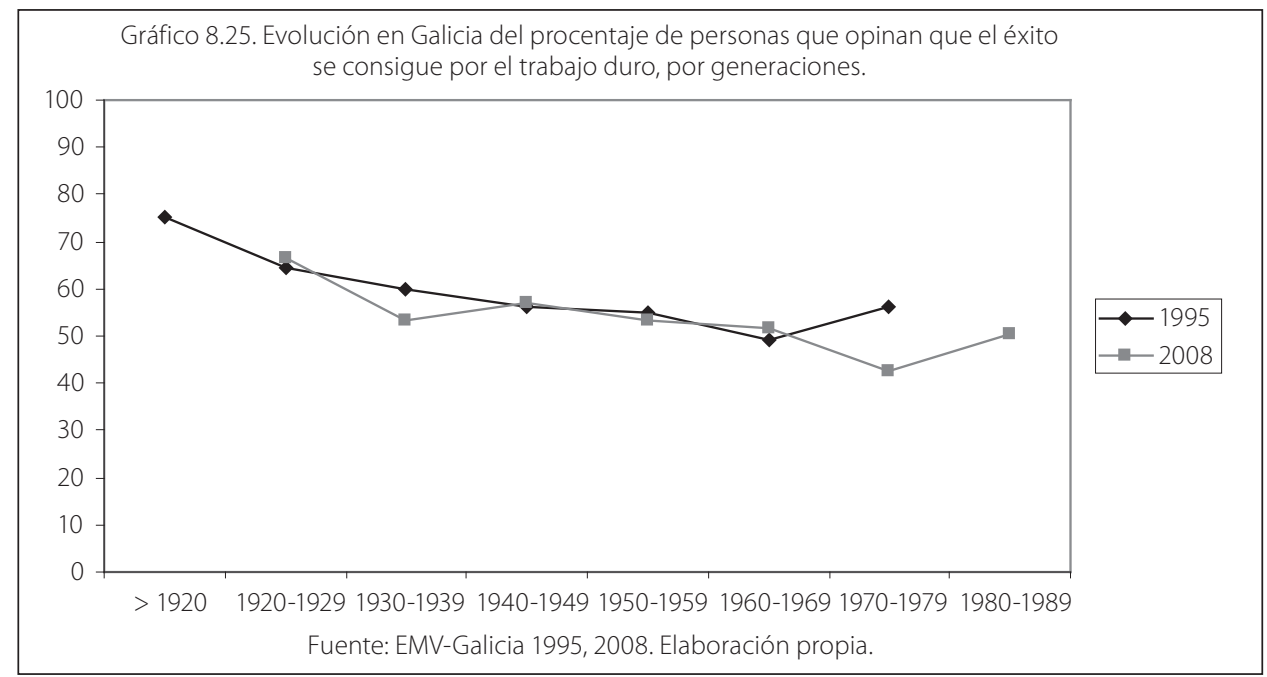


En resumen, en Galicia hay un fuerte apoyo a la remuneración de acuerdo con el rendimiento, algo superior que en España y la media de los países de Europa con elevado IDH. El apoyo de esta opinión ha descendido respecto a 1995 y, sobre todo, en relación a 2001. El respaldo de esta idea está más extendido entre las personas con mayores ingresos del hogar.

Para la mayoría de los gallegos la clave del éxito es el trabajo y no la suerte, también opinan así los españoles y europeos. Sin embargo, en Galicia esta mayoría se reduce al pasar de 1995 a 2008. Las personas que más confían en que el esfuerzo en el trabajo es la clave del éxito en la vida son las pertenecientes a las generaciones de más edad.

\subsection{CONCLUSIONES}

Durante los últimos treinta años, la evolución del mercado laboral en Galicia ha sido semejante a la de España, caracterizada por una constante escasez de empleo y elevadas tasas de temporalidad. No obstante, aunque Galicia partía de mejores condiciones que España, en el transcurso de este período, se produjo un retroceso en la tasa de actividad y una equiparación en la tasa de paro.

En Galicia existe una elevada centralidad absoluta del trabajo, ya que este es considerado como una esfera vital muy importante y predomina la creencia de que sería malo que en el futuro disminuyese la importancia del trabajo en nuestras vidas. En cualquiera de estas dos medidas, Galicia ofrece puntuaciones más elevadas que las de España y la mayoría de los países europeos con elevado IDH.

En cuanto a la ética del trabajo, en Galicia se le da más importancia que en España y el conjunto de países europeos a uno de los indicadores de la obligación moral de trabajar - "la gente que no trabaja se vuelve perezosa"-. Por el contrario, tanto el otro indicador de la obligación moral de trabajar - "el trabajo es un deber hacia la sociedad" - como el resto de los componentes de la ética del trabajo reciben menor apoyo en Galicia que en los otros ámbitos geográficos analizados. Destaca, especialmente, que los gallegos se muestran en contra de que haya que anteponer el trabajo al tiempo libre, lo que indica que en Galicia existe una baja centralidad relativa del trabajo, en contraposición a la elevada centralidad absoluta.

Las orientaciones laborales predominantes en Galicia son de tipo instrumental y no se observa una tendencia hacia el incremento de las opciones expresivas, tal como cabría esperar de acuerdo con algunas propuestas teóricas que asumen que en el mundo del trabajo ya no primarán los valores vinculados a las necesidades primarias de supervivencia y seguridad sino los vinculados a las necesidades secundarias de afiliación y autorrealización. En este sentido, los resultados de Galicia se asemejan a los de España, pero difieren de los países europeos con elevado IDH, en los que sí se da algo más de importancia a alguna de las opciones de tipo expresivo. 
En Galicia se respalda ampliamente la idea de que es justa la remuneración de acuerdo con el rendimiento, en mayor medida que en España y en los países europeos con elevado IDH. La mayoría de los gallegos cree que el esfuerzo en el trabajo es la clave del éxito en la vida y esta mayoría aventaja a la de los países europeos pero no a la de España.

En términos generales, en Galicia los aspectos de la cultura del trabajo que aquí se han analizado a nivel individual tienen una clara relación con el año de nacimiento. Las generaciones de mayor edad tienden a presentar actitudes más favorables hacia el trabajo que los grupos más jóvenes. Por tanto, cabría esperar que el reemplazo generacional produjese un declive de la cultura del trabajo en Galicia, siempre y cuando las distintas generaciones mantuviesen su modo de pensar en el futuro. Sin embargo, los datos muestran que la influencia de la generación de nacimiento está perdiendo intensidad en el tiempo, para dar lugar a una situación de convergencia en las opiniones sobre el trabajo de las distintas generaciones, y que los cambios en un buen número de variables parecen responder a la influencia de un efecto período.

El análisis de la evolución temporal parece indicar que la cultura del trabajo en Galicia está debilitándose, pues se aprecia un descenso en todos los indicadores utilizados. Han disminuido la centralidad absoluta y todos los aspectos de la ética del trabajo —incluida la centralidad relativa-, así como la creencia en que los criterios meritocráticos justifican la remuneración de acuerdo con el rendimiento y la idea de que el trabajo duro es la clave del éxito en la vida. Además, no se observa la transición propuesta teóricamente hacia las orientaciones expresivas en el trabajo, sino que siguen primando las orientaciones instrumentales.

\subsection{REFERENCIAS BIBLIOGRÁFICAS}

Abramson, P. R. e Inglehart, R. (1992): "Generational Replacement and Value Change in Eight West European Societies" en: British Journal of Political Science, 22: $183-228$.

Abu-Saad, I. (1997): "Gender as a Determinant of Work Values among University Students in Israel" en: Journal of Social Psychology, 137: 749-763.

Alderfer, C. P. (1972): Existence, Relatedness and Growth: Human Needs in Organizational Settings, Nueva York, Free Press.

Alonso, L. E. (2000): Trabajo y posmodernidad: el empleo débil, Madrid, Editorial Fundamentos.

Alonso, L. E. (2004): "La sociedad del trabajo: debates actuales. Materiales inestables para lanzar la discusión" en Revista Española de Investigaciones Sociológicas, 107: 21-48.

Ayerbe, M. (2000): "El trabajo" en: Orizo, F. A. y Elzo, J. (Dirs.): España 2000, entre el localismo y la globalidad. La Encuesta Europea de Valores en su tercera aplicación, 1981-1999. Madrid, Universidad de Deusto. Fundación Santa María: 157-179. 
Ayllón Trujillo, M. T.; Vieyra Medrano, A.; Rubio González, R. y Rey Álvarez, I. (2002): "Cambios en el mercado laboral, en el valor del trabajo y en las identidades. Una aproximación desde el análisis del discurso" en: Scripta Nova, Revista Electrónica de Geografía y Ciencias Sociales, Universidad de Barcelona, 119 (120).

Cherrington, D. J. (1980): The Work Ethic. Working Values and Values that Work, New Cork, Amacom.

Dex, S. (1988): Women's Attitudes towards Work, Nueva York, St. Martin's Press.

Díez Nicolás, J. (1994): "Posmaterialismo y desarrollo económico en España" en: Díez Nicolás, J. e Inglehart, R. (Eds.): Tendencias mundiales de cambio en los valores sociales y políticos, Madrid, Fundesco: 125-155.

Garrido Medina, L. y González, J. J. (2008): "Mercado de trabajo, ocupación y clases sociales" en: González, J. J. y Requena, M. (Eds.): Tres décadas de cambio social en España (2 ed.), Madrid, Alianza Editorial: 89-134.

Goldthorpe, J. H.; Lockwood, D.; Bechhofer, F. y Platt, J. (1968): The Affluent Worker: Industrial Attitudes and Behaviour, Cambridge, Cambridge University Press.

Harding, S. D. Y Hikspoors, F. J. (1995): "New Work Values: in Theory and in Practice" en: International Journal of Social Sciences, 145: 441-455.

Inglehart, R. (1991): El cambio cultural en las sociedades industriales avanzadas, Madrid, Centro de Investigaciones Sociológicas.

Inglehart, R. (1998): Modernización y posmodernización. El cambio cultural, económico y politico en 43 sociedades, Madrid, Centro de Investigaciones Sociológicas.

Inglehart, R. y Welzel, C. (2006): Modernización, cambio cultural y democracia: la secuencia del desarrollo humano, Madrid, Centro de Investigaciones Sociológicas.

Jahoda, M. (1987): Empleo y desempleo: un análisis socio-psicológico, Madrid, Ediciones Morata ( $1^{a}$ Edición en inglés 1982).

Maslow, A. H. (1954): Motivation and personality, Nueva York, Harper and Row.

Méda, D. (1998): El trabajo. Un valor en peligro de extinción, Barcelona, Gedisa Editorial.

MOW International Research Team (1987): The Meaning of Working, Londres, Academic Press.

Muñoz Goy, C. (2005): Las orientaciones laborales en España y sus determinantes sociodemográficos, Santiago de Compostela, Universidad de Santiago de Compostela, Servicio de Publicaciones e Intercambio Científico.

Muñoz Goy, C. (2007): "Los valores del trabajo" en Veira Veira, J. L. (Dir.): Las actitudes y los valores sociales en Galicia, Madrid, Centro de Investigaciones Sociológicas: 106-137.

Noguera, J. A. (2002): "El concepto de trabajo y la teoría social crítica" en: Papers, 68: 141-168.

Pino Artacho, J. del y Bericat Alastuey, E. (1998): Valores sociales en la cultura andaluza: encuesta mundial de valores, Andalucía 1996, Madrid, Centro de Investigaciones Sociológicas. 
Rifkin, J. (1996): El fin del trabajo. Nuevas tecnologías contra puestos de trabajo: el nacimiento de una nueva era, Barcelona, Paidós.

Rokeach, M. (1973): The Nature of the Human Values, Nueva York, The Free Press.

Ros, M.; Schwartz, S. H. y Surkiss, S. (1999): "Basic Individual Values, Work Values, and the Meaning of Work" en: Applied Psychology, 48: 49-71.

Rose, M. (1985): Re-working the Work Ethic. Economic Values and Socio-Cultural Politics, Londres, Batsford Academic and Educational.

Rowe, R. y Snizek, W. E. (1995): "Gender Differences in Work Values" en: Work E Occupations, 22 : 215-230.

Russell, H. (1998): "The Rewards of Work", en: Roger Jowell, R.; Curtice, J.; Park, A.; Brook, L.; Thomson, K. y Bryson, C. (Eds.): British — and EuropeanSocial Attitudes. How Britain Differs. The $15^{\text {th }}$ Report, Adershot, England, Social and Community Planning Research. Ashgate Publishing Limited: 77-100.

Sverko, B. y Super, D. E. (1995): "The Findings of the Work Importance Study" en: Super, D. E. y Sverko, B. (Eds.): Life Roles, Values, and Careers. International Findings of the Work Importance Study, San Francisco, Jossey-Bass: 349-358.

Vaus, D. de y Mcallister, I. (1991): "Gender and Work Orientation" en: Work and Occupations, 18: 72-94.

Veira Veira, J. L. (2002): "Valores y actitudes laborales: hacia una nueva cultura del trabajo" en Pérez Vilariño J. y Bouzada Fernández, X. (Eds.): Las encrucijadas del cambio social: homenaje al profesor José Luis Sequeiros Tizón, Vigo, Servicio de Publicaciones de la Universidad de Vigo y Centro de Investigaciones Sociológicas: 99-113.

Veira Veira, J. L. y Muñoz Goy, C. (2004): "Valores y actitudes hacia el trabajo en Europa Occidental” en: Revista Española de Sociología, 4: 51-66.

Yankelovich, D.; Zetterberg, H.; Strümpel, B. y Shanks, M. (1985): The World at Work. An International Report on Jobs, Productivity and Human Values, Nueva York, Octagon Books.

Yankelovich, D. (1994): "How Changes in the Economy are Reshaping American Values" en: Aaron, H. J.; Mann, T. E. y Taylor, T.: Values and Public Policy. Washington, Brookings Books.

Zanders, H. (1994): "Changing Work Values" en: Ester, P.; Halman, L. y De Moor, R. (Eds.): The Individualizing Society. Value Change in Europe and North America, Tilburg, The Netherlands, Tilburg University Press: 129-153. 


\section{LA EVOLUCIÓN DEL CAPITAL SOCIAL EN GALICIA}

José Atilano Pena López

Pablo Castellanos García

\subsection{INTRODUCCIÓN}

El interés de las investigaciones sobre el capital social radica en la posible influencia de esta variable sobre el crecimiento y distribución de la renta, la calidad de la vida en general e incluso en la evolución de la estructura e identidad social. No obstante, pese a que la noción de capital social ha pasado a ser objeto de atención prioritaria tanto en el ámbito de la Sociología como en el de la Economía, presenta una falta de delimitación, tanto conceptual como en su medición. El referente más directo de dicho concepto podría ser la generalización de normas, la extensión de redes asociativas e incluso tiende a identificarse tautológicamente con la confianza general. Respecto a esta última, un denominador común en la literatura sobre el tema es la idea de que la confianza y la interiorización de normas conducentes a comportamientos cooperativos y prosociales constituye un pilar esencial para el funcionamiento de la economía y de la sociedad en general (Esser, 2008). Prueba de ello es que en una comunidad integrada los costes de transacción, información o cooperación se ven sensiblemente reducidos por la extensión de redes de colaboración individual y grupal ${ }^{1}$.

A lo largo de la evolución del pensamiento social y económico surgen nociones muy semejantes a las de capital social como intentos de captar el etéreo mundo de los lazos sociales cooperativos y, en particular, sus efectos en la esfera económica ${ }^{2}$. Aunque la preocupación por este tema se remonta a los años veinte del pasado siglo, no es hasta los estudios de R. Putnam sobre las regiones italianas en los años ochenta y noventa cuando adquiere carta de naturaleza como un aspecto esencial del desarrollo económico y social. Los resultados de la investigación llevada a cabo por este autor apuntaban a

Este es el caso, por ejemplo, del fenómeno conocido como distrito industrial marshalliano (Becattini, 2002).Este tema ha recibido una especial atención en los estudios sobre culturas organizativas comunes y desarrollo local.

Autores como Smith, Tocqueville, Marshall, Durkheim o Weber ofrecen en sus obras conceptos que serían perfectamente traducibles por capital social. 
que la causa del sensible diferencial de crecimiento entre el sur y el norte de Italia radicaba en lo que Maquiavelo denominaba la virtu civile (virtud civil), es decir, la tendencia a generar asociaciones horizontalistas de pequeña escala, que constituían una base para el desarrollo económico y social, especialmente cuando éstas no son políticas o económicas. En este sentido Putnam llega a afirmar que "el buen gobierno en Italia es un subproducto de las sociedades corales y los clubes de fútbol" (Putnam, 1993).

En el presente capítulo abordaremos la evolución y las características del capital social existente en Galicia, así como sus determinantes. Dado el problema de indefinición al que antes aludíamos, en primer lugar realizaremos una aproximación al concepto de capital social, sus dimensiones y efectos, estudiando en particular el problema de la confianza social. En el segundo bloque, partiendo de la Encuesta Mundial de Valores, analizaremos la evolución de las variables ligadas a esta dimensión social proponiendo los factores explicativos de la misma. En definitiva, tras resituar las definiciones más extendidas de capital social buscamos explicar la trayectoria, en algún caso aparentemente paradójica, de las variables ligadas al entramado de redes sociales en el caso gallego.

\subsection{EL CAPITAL SOCIAL COMO UNA FORMA DE CAPITAL COMUNITARIO}

La Economía distingue cuatro categorías de capital que describen los diversos tipos de recursos a los que tiene acceso una comunidad. Dichos recursos son accesibles a individuos o empresas y pueden ser aplicados a la producción de bienes y servicios, incluyendo aquellas condiciones, sean o no "poseídas" por estos, que facilitan tanto la producción como la coordinación entre las partes intervinientes en una transacción. Dos de ellos son relativamente convencionales: el capital natural o los recursos naturales del entorno y el capital económico generado o capacidad productiva instalada, al que nos referimos como capital físico. No obstante, ninguno de los anteriores recoge la singularidad del ser humano, sus capacidades y relaciones. Por esta razón, la clasificación se completa con los conceptos de capital humano, concerniente a capacidades y conocimientos, y el capital social, relativo a las estructuras relacionales, que completan el análisis de las dotaciones de una comunidad concreta.

En lo que se refiere al capital social existe una notable variedad de definiciones que tratan de dar cuenta del concepto. Entre éstas podemos destacar la de Coleman (1988), la clásica de Putnam (1995) y la reinterpretación crítica de Bourdieu $(1986,2001)$. Para el primero de ellos, desde una perspectiva más sociológica, el capital social se define como aspectos consistentes de la estructura social, obligaciones y expectativas, canales de información, conjuntos de normas y sistemas de sanción que restringen o animan ciertos tipos de comportamientos constructivos social y económicamente. Putnam, en cambio, se centra en la generación de comportamientos prosociales, rasgos o características de las organizaciones sociales 
como normas, redes y confianza que facilitan la cooperación y coordinación para el beneficio mutuo. Abundando en esta última caracterización, la Organización Mundial de la Salud propuso una variante de la misma en la que se hace hincapié en la identidad colectiva, de forma que el capital social representa el grado de cohesión social que existe en las comunidades. Se refiere, por tanto, a los procesos entre individuos que establecen redes de relación, normas y confianza social y que facilitan la coordinación y la cooperación (Winter, 2001) ${ }^{3}$.

Tomando como punto de partida los elementos comunes a estas definiciones se puede concluir que el capital social se conforma de redes y normas sociales. En primer lugar, de redes sociales en las que se insertan los individuos, redes de comunicación, apoyo social y económico y, en segundo lugar, de unas reglas sociales de reciprocidad o expectativas mutuas de cooperación, en definitiva, de confianza y desarrollo de proyectos comunes.

Esta caracterización de síntesis pone de manifiesto la existencia de una serie de peculiaridades que merecen ser destacadas (Sobel, 2002):

(i) Desde el punto de vista económico, el capital social no es una propiedad exclusiva de un individuo o de un grupo en particular y, en la medida en que todos los individuos de un colectivo tienen posibilidades de acceder al mismo, podría constituir un bien público. Ahora bien, dado que ciertos colectivos pueden controlar el acceso, le corresponde de modo más ajustado el calificativo de bien de club o de grupo de interés e incluso, en muchos casos, con rasgos de bien individual. Igualmente, este capital es un producto de una inversión social de tiempo y esfuerzo, pero de un modo más indirecto que el capital humano, ya que se trata de un proceso histórico, social y cultural que da lugar al nacimiento de normas, valores y relaciones, que generan redes de acción colectiva. Además, evidencia una fuerte asimetría en lo que respecta a la capitalización y descapitalización, puesto que su constitución conlleva un largo proceso de inversión grupal e individual que puede ser rápidamente destruido por conflictos, disensiones, etc. No obstante, esta forma de capital no experimenta obsolescencia con su uso, sino, por el contrario, con su abandono y la consecuente pérdida de las redes generadas.

(ii) Existe un cierto potencial de intercambio entre las distintas formas de capital, al igual que relaciones de interdependencia entre las mismas. En la medida que un individuo, una comunidad o incluso una empresa puede plantearse una elección sobre qué tipo de capital desarrollar, potenciar una expresión concreta puede reforzar o tener un coste en términos de otras. Concretamente, los capitales sociales y culturales desempeñan un papel crucial

Merecen una mención aparte los trabajos de Bourdieu (2001). Este, en clave marxista, alude al capital social como recursos en manos de las comunidades para acceder a bienes de grupo. Esto es, redes y vínculos que constituyen un recurso en manos de los individuos para ejercer una forma de dominio. En cierta medida es un sistema de preservación de la estratificación social, al mismo tiempo que una inversión de los individuos en redes de relaciones (influencias) transformable en cualquier otra forma de capital. 
en la generación de capital humano y viceversa. Por su parte, el propio capital social influye en la toma de decisiones de inversión en capital físico o humano (Szretzer, 2000).

(iii) La definición genérica que hemos adoptado engloba al menos tres formas de capital social bajo el mismo concepto, dado que éste es esencialmente multidimensional. De una parte, existe un capital relacional de lazos familiares o con semejantes (bonding), miembros de una misma familia o grupo étnico. También se puede hablar de un capital de puenteado (bridging) o de relaciones con miembros de otros grupos, tanto en cuestiones étnicas como socio-económicas. Finalmente, existe un importante capital de enlace institucional (linking) o de relación entre los individuos y las agrupaciones de individuos con cualquier forma de autoridad (Woolcock, 2001). De esta manera, se distinguen al menos tres niveles de generación de entramados relacionales: microanalítico (o de enlaces entre semejantes), mesoanalítico (o de unidades corporativas) y macroanalítico (o de instituciones sociales) (Figura 9.1).

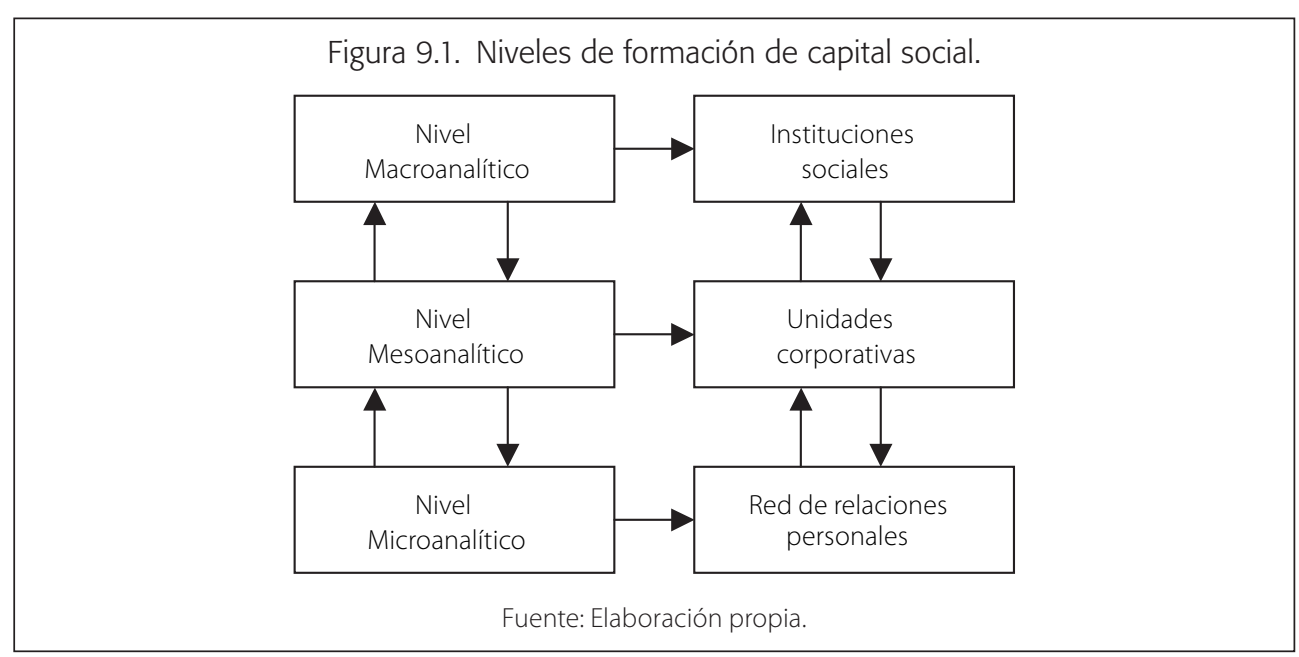

La distinción entre estos tipos de capital es también una separación de los lazos sociales fuertes y débiles, asimilable a la diferencia entre bonding y linking. En conjunto, la situación óptima para una comunidad sería aquella en la que se lograse un equilibrio entre las tres dimensiones de capital social, si bien, como veremos, las expresiones más generalistas (bridging y linking) parecen ser más determinantes de cara a un mejor funcionamiento de las instituciones sociales que las particularistas o de grupo estrecho (bonding) ${ }^{4}$.

(iv) El concepto de capital social hace también referencia a las relaciones formales o informales que constituyen la "sociedad civil". Si bien el papel

4 Por ejemplo, el predominio de los lazos con semejantes se traduce en la carencia de confianza social fuera del ámbito del vínculo familiar (familismo amoral). Este es el caso de asociaciones del tipo de las "mafias", en las que existen elevados niveles de confianza interna sin traducción exterior al grupo (Portes y Landolt, 1996). 
desempeñado por la confianza parece decisivo, el de la actividad asociativa resulta notablemente ambiguo, pese a la aparente identidad que asumen como punto de partida la mayor parte de los estudios sobre capital social. Para Putnam (1993) y buena parte de los teóricos del capital social, el mayor éxito de regiones y países en términos de crecimiento económico es atribuido parcialmente a la existencia de un fuerte entramado asociativo. Dicho entramado desarrolla en los individuos hábitos de cooperación, solidaridad y preocupación por lo público, básicos para la resolución de problemas colectivos.

No obstante, y siguiendo una perspectiva olsoniana, puede hacerse una lectura totalmente opuesta de lo planteado por Putnam, ya que si los intereses de alguno de estos grupos organizados entran en conflicto con los de otros o con los de los grupos desorganizados en general, el efecto conjunto sobre la actividad social y económica puede llegar a ser negativo. En cierta medida, la economía y la sociedad en general podrían verse capturadas por los conflictos entre grupos de interés organizados. En este sentido, Olson $(1982,2000)$ insistía en que las organizaciones sociales pueden limitar las posibilidades de crecimiento cuando actúan como grupos de interés especializados (lobbies) a la captura de políticas preferenciales. En la misma línea, Keefer y Knack (1997) encuentran evidencias de la naturaleza conflictiva de la relación existente entre la actividad asociativa y el crecimiento, en particular, como consecuencia de la relación existente entre los grupos de interés y el gobierno. La salida de esta aparente aporía está ligada al tipo de entramado asociativo al que hagamos referencia. El asociacionismo horizontal constituye la base del funcionamiento de la sociedad civil y es capaz de establecer vínculos de confianza; por el contrario, el vertical está directamente vinculado a la captación de políticas preferenciales y no puede ser considerado como equiparable al anterior (Pena y Sánchez, 2007).

\subsubsection{La medición del capital social: confianza y redes sociales}

Una vez aclaradas algunas de las especificidades más significativas de la noción de capital social, cabe plantear la tarea de estructurar e incluso deconstruir los componentes de la definición de síntesis que hemos propuesto en el apartado anterior para establecer algún modo de cuantificación de su stock o dotación.

A partir de lo señalado, de un lado nos encontramos con aquellos enfoques que ponen de relieve la confianza social (social trust) y de otro, los centrados en la generación de redes sociales (social networks). Para un amplio conjunto de autores el capital social se confunde directamente con la idea de confianza al considerarlo como habilidades personales para desarrollar una tarea voluntaria con un grupo (Coleman, 1988; Fukuyama, 1995; Dasgupta, 1999) ${ }^{5}$. Aunque es posible

En particular, Fukuyama plantea una vía negativa de acercamiento a través de los niveles delictivos, es decir, una aproximación a través de las disfuncionalidades sociales derivadas de su carencia: corrupción, delincuencia, etc. Este acercamiento presenta un importante error metodológico, ya que por esta vía se estarían confundiendo los efectos con los orígenes. 
establecer distinciones lógicas entre ambos conceptos, es innegable el hecho de que se encuentran íntimamente relacionados. Si bien la confianza facilita la cooperación, puede establecerse igualmente la relación inversa, es decir, ésta puede constituirse a través de la propia cooperación.

El problema que se deriva de la tautología anterior impone la búsqueda de un referente más sólido. El análisis de las redes sociales o la denominada perspectiva sociológica es una alternativa viable al estudio del complejo confianza-cooperación. Estas redes están constituidas por lazos de muy diverso signo (familiares, laborales...), cuyo mantenimiento supone un coste efectivo. Consecuentemente, en términos económicos cabría plantearse la existencia de un nivel óptimo de relaciones en términos de un análisis coste-beneficio y de un proceso de capitalización (Glaeser et al., 2002).

De acuerdo con esta visión, Putnam (1993) sostiene que la mejor aproximación estadística a la dotación de capital social es la densidad de organizaciones voluntarias en un colectivo determinado, ya que la presencia de este tipo de instituciones manifiesta la existencia de confianza y cooperación. Ahora bien, es preciso considerar la implicación real o compromiso efectivo de los individuos en dichas organizaciones. Consecuentemente, desde esta perspectiva, el capital social sería el monto de redes construidas por una persona o un colectivo de personas. Sin embargo, no parece razonable admitir una identificación directa entre redes sociales y redes de asociaciones voluntarias, porque éstas no constituyen la única vía de relación, ni siquiera la predominante (Nam, 1999 y 2008). Esta identidad "a la Putnam" puede considerarse una proxy, aunque sesgada y con algunos problemas asociados. En primer lugar, las fronteras entre las asociaciones voluntarias, las gubernamentales y las privadas son extremadamente difusas. Además, aparece el problema de la intensidad o calidad de los contactos. Por lógica, aquellas agrupaciones en las que la participación sea barata en costes de tiempo, dinero, normas, etc. tienden a presentar mayores niveles de asociación. A todo ello habría que añadir que no es posible asegurar que cualquier modo de asociación voluntaria sea socialmente benigna (asociaciones criminales, racistas...) ${ }^{6}$.

Este complejo entramado de indicadores (Figura 9.2) no es más que el resultado del análisis de un fenómeno social a través de diversas facetas mutuamente interrelacionadas a las que aludíamos al plantear una definición de capital social. Así, de un lado nos encontramos con las definiciones vinculadas al concepto de confianza y su vinculación directa con la cooperación; de otro lado, la extensión de redes sociales también guarda una relación directa con las más diversas formas de cooperación e incluso de confianza social.

\footnotetext{
Los planteamientos previos se centran exclusivamente en un estudio micro, por lo que la traducción de los mismos a escala macrosocial precisa de otro tipo de indicadores, como la medición de niveles de democracia y derechos políticos (índices $\phi$ ), protección legal del individuo y su propiedad, transparencia del sistema judicial, etc.
} 


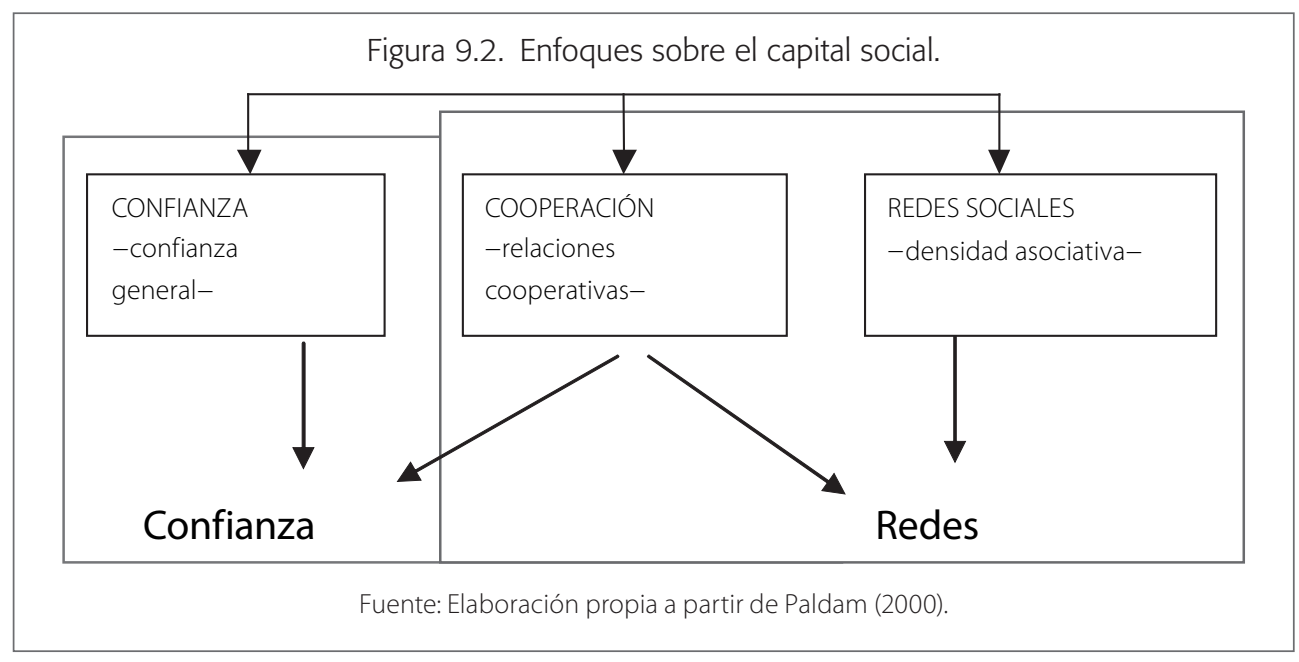

En lo que respecta a otros indicadores proxy, algunos estudios recurren a variables vinculadas a la preocupación por temas comunitarios (lectura de prensa local, participación en votaciones, respeto de normativas...) o a evaluar la red asociativa de una determinada localización (Krishna y Schrader, 1999). Sin embargo, la medida más pura, aunque difícilmente aislable, es la variable "confianza general" o confianza en el conjunto de la población y la "confianza institucional", lo que capacitaría al individuo para el desarrollo de tareas colectivas y haría más eficiente el funcionamiento del entramado administrativo. No obstante, las deficiencias inherentes a los sistemas de medición mencionados conllevan la necesidad de recurrir a una valoración personal directa a través de encuesta.

La Encuesta Mundial de Valores (World Values Survey, WVS) (Inglehart et al., 1981, 1990, 1995, 2000) nos proporciona un análisis intercultural de los comportamientos y las valoraciones sociales que puede sernos particularmente útil en este sentido. En concreto, la medida que utilizamos está constituida por el porcentaje de entrevistados que se adhieren a la afirmación de que "la mayor parte de la población es objeto de confianza" frente a "no conviene ser confiado en el trato con los otros". Estos resultados han sido contrastados por otras medidas alternativas de confianza, observándose una correlación cercana a la identidad ${ }^{7}$.

Aunque se trata de una respuesta a una pregunta ambigua, la introducción del concepto genérico de "población" está cuestionando la percepción del nivel de confianza general más allá del estrecho campo familiar. En definitiva, nuestra variable captura la confianza generalizada como opuesta a la específica

\footnotetext{
Por ejemplo, guardan una estrecha relación con los porcentajes de devolución de objetos perdidos, niveles de corrupción, etc. (Knack y Keefer, 1997). Igualmente recogen las evidencias expresadas en los estudios de Putnam (Putnam, 1993).
} 
o estrecha, es decir, aquella que se refiere a los casos en que existen interacciones repetidas o ligada a relaciones de proximidad. En términos de Teoría de Juegos, esta variable se define como la actitud hacia la cooperación con sujetos anónimos en situaciones análogas a la del "Dilema del Prisionero" o como la existencia de un enfoque cooperativo de los juegos no limitado a una determinada agrupación social. Por tanto, también expresa la expectativa de que otros no actúen oportunistamente ${ }^{8}$.

\subsubsection{Factores determinantes del capital social}

Nuestro interés se centra en el estudio de la causalidad de la confianza en orden a analizar las actuaciones políticas planteadas sobre los procesos de capitalización social. Los determinantes de la confianza son de muy diversa índole (Glaeser et al., 1999; Alesina y La Ferrara, 2000). En primer lugar, la confianza en los otros puede ser el resultado de la actividad moral y cultural. Consecuentemente, se vería fuertemente influenciada tanto por características individuales como por el nivel y tipo de educación recibida, las creencias religiosas, etc. De igual manera, abundando en las relaciones de proximidad, uno puede confiar más en aquellos con los que guarda una semejanza en formación o con los pertenecientes a una misma agrupación social o religiosa. Así, aquella sociedad con una fuerte diversidad en su composición manifestará bajos niveles de confianza y se asentará primordialmente en las relaciones familiares. A su vez, una comunidad en la que existen instituciones consolidadas de persecución de los comportamientos desviados se mostrará más confiada al sentirse efectivamente protegida.

Tradicionalmente, la literatura sobre el tema ha insistido en el papel de las asociaciones cívicas, marginando la familia y las asociaciones no vinculadas a una acción social directa (asociaciones recreativas, culturales, etc.). Fruto de este sesgo, en el análisis existe una infravaloración de las expresiones asociativas más recientes, en muchos casos informales, como generadoras de esta forma de capital. Teniendo en cuenta esta multiplicidad de fuentes, es necesario analizar los efectos derivados de la actividad asociativa, la desigualdad en los niveles de renta, la polarización étnica, las instituciones formales de protección de los derechos individuales, los ingresos per cápita y los niveles educativos.

Partiendo de los resultados obtenidos de la Encuesta Mundial de Valores (World Values Survey) en su última oleada (2008) nos encontramos con una amplia evidencia sobre la interrelación existente entre valores sociales, estructuras y confianza social. Para determinar la causalidad de la confianza generalizada, hemos

Su recorrido es muy amplio. La media mundial del conjunto de respuestas, 35,8\%, está ocultando la existencia de una fuerte variabilidad que va desde un 5\% en Perú a un 65\% en Noruega. 
recurrido a un modelo de regresión logística ${ }^{9}$ sobre las afirmaciones referentes a la confianza generalizada por parte de los entrevistados.

Las variables que hemos encontrado significativas para explicar los niveles de confianza generalizada en Galicia (Tabla 9.1) a partir de los resultados de la encuesta muestran una sustantiva diferencia con relación a los modelos que se pueden construir a partir de las oleadas previas de la EMV. Ahora bien, esta misma diferencia puede considerarse explicativa de la reducción de los niveles de confianza que se observan tanto a escala regional como nacional. En los trabajos previos, los resultados mostraban una clara coincidencia con lo recogido por la teoría de Putnam (1993), sobre la importancia decisiva del asociacionismo horizontal a la hora de explicar las dotaciones de capital social entendido como confianza generalizada. Sin embargo, nuestro análisis sobre el caso gallego no encuentra vínculos relevantes con las diversas formas de asociacionismo y la confianza generalizada.

En el modelo explicativo actual, desde una perspectiva axiológica, aquellos individuos que manifiestan una mayor confianza generalizada presentan un notable activismo político reflejado en el reconocimiento de la importancia de esta dimensión y en la participación en iniciativas políticas. Es decir, se trata de sujetos implicados en los procesos sociales de toma de decisiones. Paralelamente, se trata de individuos que relativizan la importancia del trabajo y dedican una parte significativa de su tiempo al sostén de relaciones sociales, esto es, la generación de una red de relaciones constituye una inversión personal. En otro orden de cosas, tal y como veremos, este grupo se encuentra integrado por individuos con un mayor nivel de estudios e ingresos. En definitiva, la confianza parece ligada a un grupo social de ingresos más elevados, más activo social y políticamente, pero no especialmente vinculado a ningún tipo de asociación. Lo que es más, resulta relevante la no pertenencia a asociaciones de tipo religioso.

Al mismo tiempo la confianza generalizada tiene vínculos con algunas formas de confianza institucional. Así, aquellos que se sitúan entre los que presentan confianza social tienden a presentar confianza con grupos ajenos e instituciones sociales (linking y bridging social capital). Este es el caso de las variables confianza en el sistema judicial y confianza en gente de otras nacionalidades. Ahora bien, este grupo parece guardar una cierta actitud "hostil" hacia instituciones de carácter religioso o de mercado ${ }^{10}$.

\footnotetext{
La opción por este tipo de metodología se deriva del hecho de que la variable explicada es binaria discreta (confía o no confía) y las explicativas son ordinales discretas. En lo que respecta a la capacidad explicativa del modelo, ésta es óptima (capaz de clasificar correctamente un $70 \%$ de los casos).

10 En cierta medida podrían encontrarse también vínculos entre estas variables y posicionamientos políticos. De hecho, aunque no aparecen en el modelo, existen importantes correlaciones con la pertenencia a sindicatos y orientaciones más de corte de partidos de izquierdas.
} 
Tabla 9.1. Factores determinantes de la confianza generalizada en Galicia.

\begin{tabular}{cc} 
Variable & Coeficiente \\
\hline Importancia del tiempo libre & $0,37056^{* *}$ \\
\hline Importancia de la política & $0,26309^{* *}$ \\
\hline Importancia del trabajo & $-0,45877^{* *}$ \\
\hline Miembro de Iglesia & $-0,39055^{* *}$ \\
\hline Situación económica del hogar & $0,12902^{* *}$ \\
\hline Confía en gente que no conoce & $0,73984^{* *}$ \\
\hline Confía en gente de otra nacionalidad & $0,56767^{* *}$ \\
\hline Confía en la Iglesia & $-0,23920^{* *}$ \\
\hline Confía en sistema judicial & $0,47657^{* *}$ \\
\hline Confía en grandes empresas & $-0,39870^{* *}$ \\
\hline Nivel de estudios & $0,12110^{* *}$ \\
\hline Constante & 0,96357 \\
\hline Significativo al $0,01$. &
\end{tabular}

Fuente: Elaboración propia a partir de EMV-Galicia 2008.

Tal y como señalamos anteriormente, la evolución de este modelo puede guardar una relación directa con la sorprendente marcha de los datos de confianza generalizada. Concretando más, su drástica reducción. Por una parte, variables de carácter coyuntural pueden explicar su caída pero, desde una lectura en negativo, la mayor "desconfianza" guarda relación con un cierto descrédito de la política o la justicia, al mismo tiempo que con los problemas ligados a una sociedad crecientemente heterogénea. No obstante, es aventurado señalar las causas de un movimiento tan complejo como el de esta variable.

En otro orden de cosas, merece la pena un breve análisis de la relación observada entre renta, capital humano y capital social. Un importante conjunto de autores situados dentro del individualismo metodológico insiste en el carácter económico del capital social (Glaeser et al., 1999, 2002). Éste, al igual que cualquier forma de capital, podría ser explicado por un modelo de decisiones óptimas de inversión. Esta aproximación, que ha sido denominada "capital social individual" o Rolodex Capital ${ }^{11}$, considera que el agregado o stock de capital social es el resultado de la suma de los capitales sociales individuales y sus externalidades o los efectos colaterales generados. Dicho de otro modo, esta teoría defiende que la acumulación de capital social sigue patrones consistentes con la elección racional en un proceso de inversión, de forma que experimenta la influencia de los mismos determinantes que sufriría un mercado de este tipo.

11 Con esta expresión se alude al hecho de que el capital social sería identificable con la red de influencia de un individuo, su red de vínculos sociales fuertes y débiles que podría quedar aproximada por su agenda personal (Rolodex). 
Una evidencia observada que se acomoda a esta hipótesis es la relación existente entre capital social (confianza), nivel de renta y capital humano. Tal y como se observa en los determinantes de la confianza general (Figura 9.3), existe una relación directa entre confianza y nivel de renta, pero no entre esta última y asociacionismo. Los grupos de elevados ingresos presentan una mayor inversión en este tipo de redes en razón de unos mayores rendimientos contractuales esperados pero, muy probablemente, utilizando formas de asociacionismo más informal. De igual modo, la relación entre capital humano y social es bidireccional y, sin duda alguna, constituye uno de los resultados empíricos más constantes en la literatura. Aquellos sujetos que disponen de una mayor dotación de capital social presentan mayores logros en términos de capital humano y viceversa.

En lo que respecta a este vínculo, planteado a escala macroeconómica, podemos obtener evidencias sobre la relación existente entre el desarrollo económico y social y la evolución y estructura del asociacionismo. Por una parte, tal y como viene remarcando la extensa literatura sobre el capital social, se hace patente, que existe una clara vinculación biunívoca entre desarrollo económico (PIBpc) y nivel asociativo. Sin embargo, es preciso analizar los entresijos de esta relación, en lo que respecta a cambios en la estructura asociativa. Este hecho se hace más evidente si nos centramos en un índice más expresivo del nivel de desarrollo socioeconómico alcanzado por una nación, como es el IDH ${ }^{12}$.

Figura 9.3. Variables relacionadas con la generación de confianza generalizada.

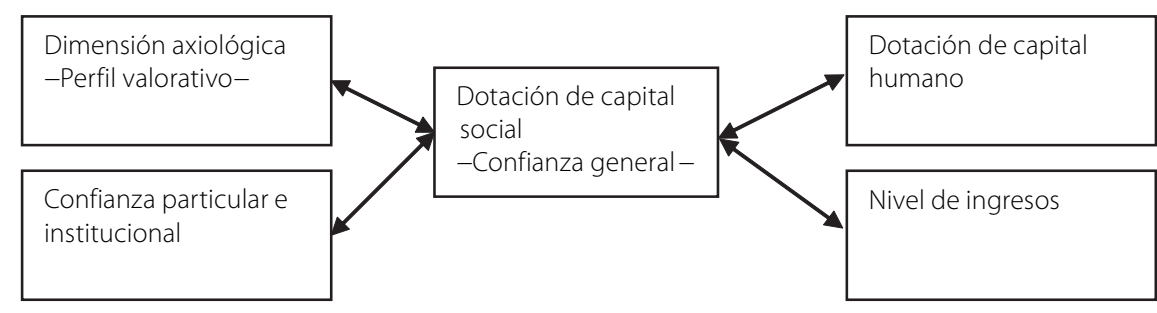

Fuente: Elaboración propia.

\subsubsection{Los efectos del capital social}

La dotación de capital social de una comunidad constituye una variable explicativa clave de determinados aspectos que escapan del ámbito de las variables socioeconómicas e indicadores demográficos convencionales. La relevancia del estudio del capital social radica, en que se trata de una dimensión social que incide no solo sobre los niveles de bienestar personal, sino también sobre un amplio conjunto de

12 Este índice pondera tres dimensiones esenciales del desarrollo: el nivel de PIB per cápita, la esperanza de vida y los niveles de escolarización. 
variables económicas y sociales en general, que van desde los niveles de crecimiento, el funcionamiento del mercado de trabajo, los logros educativos, las mejoras en los niveles sanitarios, etc., hasta un mejor manejo institucional.

Si estructurásemos la división de los efectos bajo el criterio del ámbito personal o social de actuación, evidenciaríamos tres niveles. A escala individual, nos encontramos con los efectos derivados de la existencia de una mayor red personal de soporte individual; a escala intermedia o comunitaria están los efectos de derrame (spillover) consecuencia de vivir en una comunidad en la que hay fuertes vínculos; finalmente y en el macronivel, están los efectos derivados de la existencia de una mayor riqueza asociativa, que pueden ir desde el crecimiento económico hasta la mejora de los niveles generales de desarrollo humano.

Como es obvio, las dimensiones de capital social a las que antes aludíamos no operan conjuntamente o en idénticas direcciones (Figura 9.4). Por ejemplo, en el caso concreto de la educación y la salud (Kawachi et al., 1997) el papel crucial lo desempeña el capital social de lazos con semejantes (bonding), en los que la institución familiar constituye el principal soporte o sistema de aseguramiento, tanto en las edades tempranas como en la ancianidad.

Igualmente, el capital social conectivo (bridging) entre diversos grupos, reviste una especial importancia para el funcionamiento del mercado de trabajo. En este caso la amplitud y profundidad de las redes supone una ganancia en eficiencia y podría generar al individuo mayores niveles de ingresos o un más fácil acceso a bienes comunes (Barbieri et al., 2000; Granovetter, 1973).

A su vez, el capital social de enlace institucional (linking) influye en la capacidad para afrontar las tareas colectivas a las que hacíamos mención, como la gobernabilidad, identidad de grupo, etc. En este contexto, por ejemplo, un mayor nivel de capital social se traduce en la extensión de las actividades de voluntariado y tercer sector.

En general, tener acceso a las diferentes expresiones del capital social es una cuestión esencial para la mejora de la calidad de vida en cualquiera de sus formas.

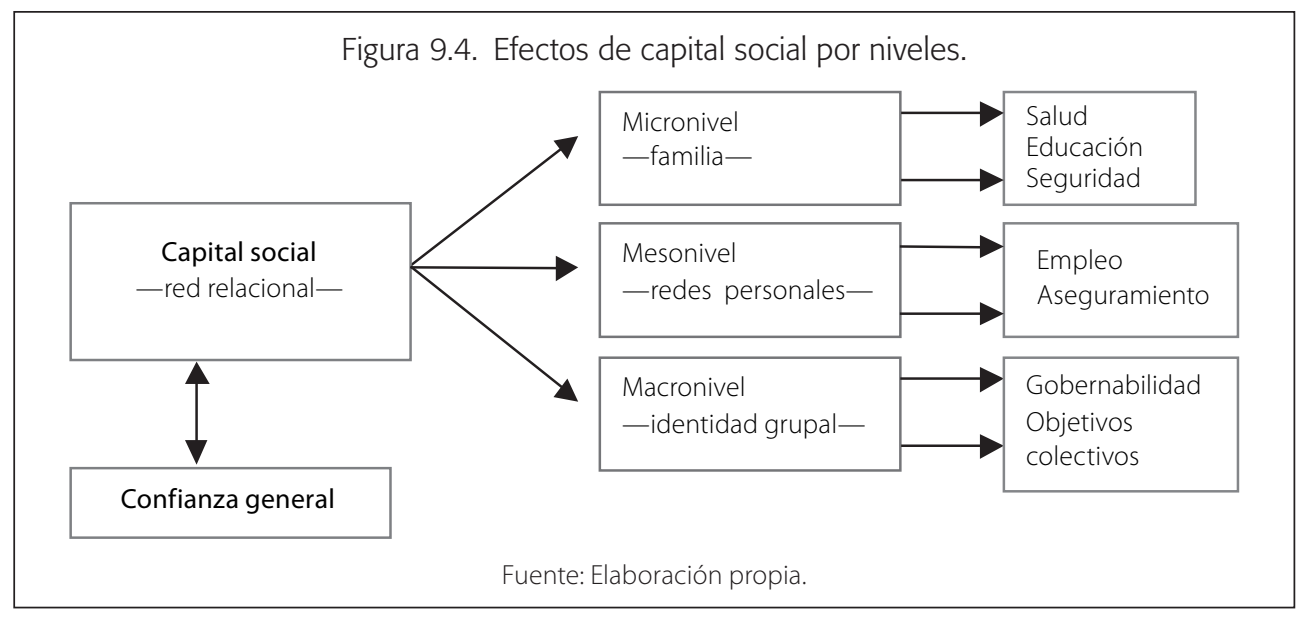


Si nos centramos en los aspectos económicos, ante la constancia de que ni la ley ni el mercado por sí solos son suficientes para regular los comportamientos organizativos, ha ido ganando adeptos la idea de que gran parte de los problemas de desarrollo económico aparecen asociados a la falta de confianza (Fukuyama, 1995). La confianza resulta clave tanto para empresas como para la economía en general por el carácter esencial de la división del trabajo para el crecimiento, al facilitar la formación de grandes organizaciones (LaPorta, 1997). La razón reside en que el crecimiento de una sociedad o una economía supone una expansión exponencial del número de relaciones de agencia ${ }^{13}$, contractuales o no, con los problemas que estas conllevan (costes de vigilancia, asimetría informativa...). Por consiguiente, una de las alternativas para elevar la eficiencia del sistema económico implica encontrar un modo efectivo de resolución de este tipo de problemas. En este sentido, la mayoría de los estudios que abordan la cuestión del capital social han puesto de manifiesto cómo la confianza, asentada en el establecimiento de relaciones de simpatía y la extensión de las diversas formas de asociacionismo, contribuye a reducir los costes de transacción (costes de información, de vigilancia de contratos, de conflicto, etc.).

El valor de la confianza se sustenta sobre el principio de reciprocidad que debe regir las relaciones sociales. Confiamos en los demás en la medida que esperamos de ellos una cierta correspondencia a nuestras expectativas, aunque nunca llegue a concretarse. Nos basta con sentir que esta reciprocidad es esperable, sin necesidad de que sea efectiva. La confianza reduce los costes de transacción en la interacción social y facilita el acceso a la información. Sin un determinado nivel de confianza en los demás sería muy costosa toda transacción o interacción social. En suma, necesitamos confiar en los demás para que la vida social fluya sin grandes brusquedades y precisamos creer que el engaño es la excepción y no la norma.

Traducido al ámbito de la economía regional, los sistemas empresariales locales se asientan en la existencia de redes sociales (Sabatini, 2006). La ausencia de este capital de redes conduce a una forma jerárquica de comprensión de los entramados de relaciones, caracterizada por una cultura del secreto. Adicionalmente, y éste es un aspecto que reviste un especial interés, los estudios más recientes han puesto de relieve la relación existente entre determinadas expresiones de capital social, en particular la participación en actividades deportivas y culturales en general, y el desarrollo de una identidad colectiva, la cohesión social e incluso la gobernabilidad. La participación en este tipo de actividades genera en los individuos un sentimiento de pertenencia y de existencia de objetivos comunes que denominamos perspectiva o enfoque

13 Una relación de agencia funciona bajo un simple esquema principal-agente o, lo que es lo mismo, la existencia de una actividad delegada por un principal a un agente, formal o informalmente. Evidentemente éste es el marco de una relación contractual de cualquier tipo. Esta situación conlleva la existencia de una serie de asimetrías dado que el principal no puede tener un control absoluto de las tareas desarrolladas por el agente. 
comunitario (community focal point). En esta línea, Putnam ha demostrado cómo estados y regiones con elevada implicación en instituciones horizontales tienden a presentar una mejor calidad de gobierno en tres sentidos (Putnam, 1993). Por una parte, fortalece los comportamientos "comunitaristas" al hacer a los ciudadanos más orientados hacia la comunidad y cooperativos con las instituciones; igualmente, los convierte en unos sofisticados consumidores de políticas, al ofrecer canales de presión política y de generación de opinión y, finalmente, facilita la cooperación con burócratas y políticos para el desarrollo de políticas públicas.

En lo que respecta al crecimiento económico, la evidencia obtenida respecto al crecimiento sostenido de los niveles de vida constituye la base de la construcción de los modelos de crecimiento endógeno. En éstos, frente a los modelos neoclásicos, la atención pasa al papel desempeñado por la evolución de la productividad (Lucas, 1989; Romer, 1990) y el capital es considerado como reproducible, en especial el humano y el social, con lo que no aparecen necesariamente rendimientos decrecientes. De esta manera, junto a las variables tradicionales de los modelos de crecimiento, como las dotaciones de capital físico iniciales y procesos de inversión (Barro, 1991; Mankiw, 1992; Helliwell, 1994; Granato et al., 1996), se incluyen un amplio conjunto de otros factores, que van desde el nivel de inversión en capital humano, hasta índices de delincuencia, corrupción, confianza, etc. Mediante esta metodología, el estudio de Knack y Keefer (1997) constata la existencia de una relación positiva entre una medida de confianza interpersonal y el crecimiento del PIB, una vez que se neutralizan los efectos derivados de las distintas dotaciones de capital humano. Otros trabajos reconocen la influencia de la confianza en la reducción de la prima de riesgo asociada a la inversión (Guiso et al., 2000). Tomando como ejemplo el caso italiano, aquellas regiones con un mayor nivel de desarrollo comunitario, observable en índices de red asociativa, lectura de periódicos, etc., manifestaron mayores niveles de crecimiento (Helliwell y Putnam, 1995; Helliwell, 1996) ${ }^{14}$.

Abundando en esta relación, resulta difícil demostrar el vínculo causal existente entre capital social y bienestar económico y social, dado que la relación es bidireccional. Tal y como recogen los recientes trabajos de Putnam, capital social e igualdad económica van conjuntamente y se refuerzan mutuamente, al igual que la desigualdad económica y la falta de colaboración social (Bush y Bann, 2001). Igualmente, en lugar de caracterizar al capital social como un input fundamental para el crecimiento económico, algunos autores se plantean el efecto del crecimiento económico sobre el capital social (Routledge y von

14 Concretamente, las regiones del norte de Italia presentan un denso entramado de relaciones sociales e institucionales, frente a las regiones del sur, en las que dominan las relaciones de autoridad vertical y la desconfianza fuera del ámbito familiar. 
Amsberg, 2003). La idea central es simple: las sociedades que registran elevadas tasas de crecimiento suelen experimentar importantes "shocks" tecnológicos que generan presión sobre la movilidad laboral para ocupar los nuevos puestos de trabajo, por ejemplo, en las áreas urbanas más pujantes. La movilidad residencial resultante aumenta la productividad del trabajo al poner en contacto trabajadores con cualificaciones específicas con los empleadores que necesitan dichas cualificaciones. Ahora bien, esa movilidad también tiene efectos menos favorables. La confianza y el capital social pueden verse socavados, porque los individuos ya no son capaces de involucrarse en relaciones recíprocas a largo plazo que alimentan la cooperación en el seno de una comunidad. En suma, aunque el capital social es un factor fundamental en la promoción del crecimiento económico, dicho crecimiento también puede destruir capital social.

\subsection{EL CAPITAL SOCIAL EN GALICIA: UNA APROXIMACIÓN EMPÍRICA}

Como hemos visto, la amplitud y naturaleza del concepto de capital social dificultan su medición empírica a través de datos de encuesta. No obstante, hemos podido seleccionar en el presente estudio cuatro grandes dimensiones del capital social en Galicia, como son el grado de confianza general y particular, la confianza en las instituciones y el nivel de asociacionismo.

\subsubsection{La evolución de la confianza generalizada y la particular}

A partir de los resultados de la EMV en Galicia podemos observar una evolución paradójica en el último período (Gráfico 9.1). Tal y como señalamos anteriormente, nos centramos en la evolución de la variable confianza generalizada medida a través del porcentaje de entrevistados que se adhieren a la afirmación de que "la mayor parte de la población es objeto de confianza" frente a "no conviene ser confiado en el trato con los otros".

En una primera lectura de los datos, aparentemente nos encontramos en Galicia (como de hecho se ha mostrado también en España) con una muy considerable descapitalización a escala general y, simultáneamente, una elevación de lo que podríamos denominar expresiones más de tipo particularista de esta forma de capital.

Sobre el gráfico se aprecia el notable cambio de tendencia y una muy fuerte reducción de los niveles de confianza generalizada. En un período de algo menos de siete años se ha producido una reducción de los niveles de confianza generalizada a la mitad de los observados en 2001. Esta trayectoria tan abrupta podría asemejarse a una anomalía estadística si no fuese acompañada por una evolución semejante en los resultados de todo el conjunto español (Gráfico 9.2). En ambos casos, tras una etapa de crecimiento moderado que situaba a España y a Galicia en la media de los países europeos, se experimenta un recorte sustancial. 

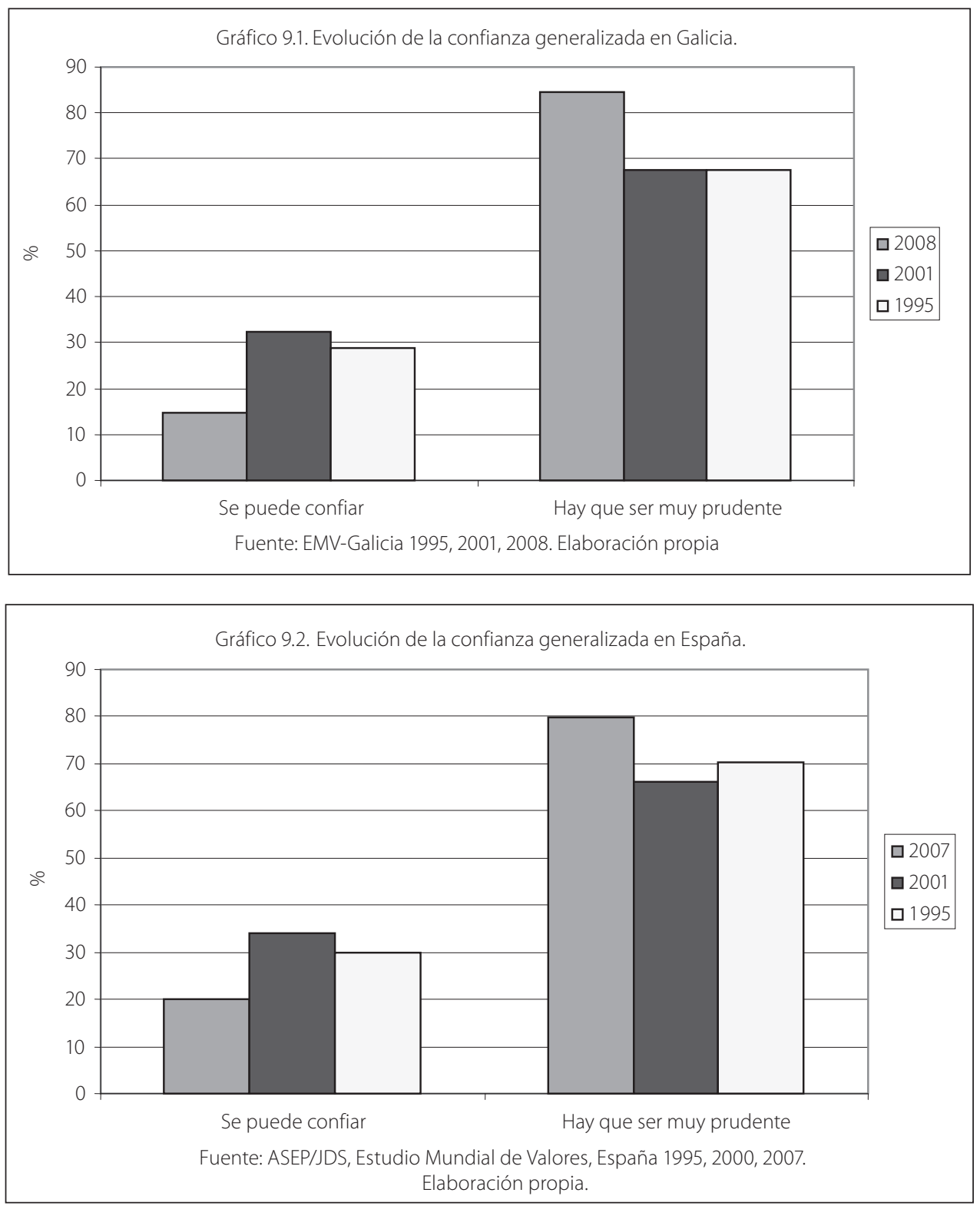

Las razones de esta evolución pueden ser de índole diversa y van desde factores coyunturales, como el deterioro de la situación económica y laboral, hasta los procesos de inmigración y la mayor heterogeneidad social. Por otra parte, conviene recalcar que una de las particularidades evidentes del capital social es la asimetría de los procesos de inversión y desinversión. Si bien es evidente que los procesos de creación son largos y lentos, los de destrucción pueden ser sorprendentemente rápidos. La generación de un clima de desconfianza generalizada puede verse acelerada por múltiples causas y aunque esto no suponga la 
destrucción de redes de relaciones, sí puede traslucir una mayor dificultad para establecer vínculos (bridging y linking) con grupos que vayan más allá de los lazos más estrechos (bonding).

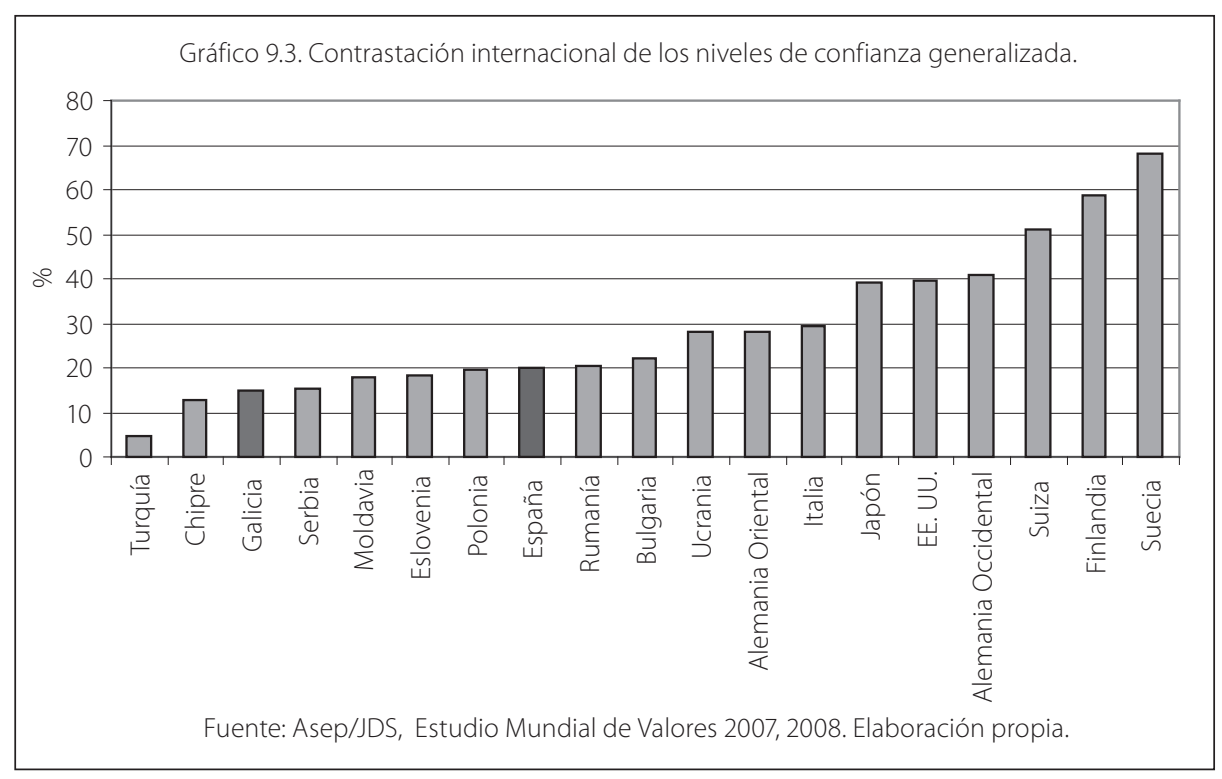

En el contexto general de Europa y las principales economías mundiales (EE. UU. y Japón) la sociedad gallega ha retrocedido notablemente en niveles de confianza generalizada, hasta el punto de situarse en el vagón de cola del conjunto, partiendo de posiciones por encima de la media (Gráfico 9.3). Este proceso ha sido más acusado que en el caso general español.

A modo de contraste, la encuesta realiza también la cuestión sobre confianza planteándola en términos negativos, preguntando a los individuos si, en el supuesto de que tuviesen oportunidad, intentarían aprovecharse o, por el contrario, tratarían de ser justas. Los resultados en este caso muestran una mayor similitud con los de las encuestas previas y parecen reflejar una mayor estabilidad de los niveles de capital social de la que podría derivarse de la anterior variable (Gráfico 9.4).

Así, en torno a un 38\% de los encuestados se sitúa en posiciones donde considera que la mayoría de la gente trataría de ser justa (posiciones de 6 a 10). Este nivel de respuesta coincide prácticamente con el obtenido en la oleada previa, donde un $37 \%$ de la población se manifestaba como confiado en que la gente trataría de ser justa ${ }^{15}$.

No obstante, es preciso tener en cuenta que estos resultados no son necesariamente contradictorios. Ambas cuestiones no tienen un mismo referente, ya que la

15 Esta pregunta ha sido planteada de forma distinta en ambas oleadas. Si bien en la última oleada es una gradación entre 1 y 10, en la previa era una cuestión del tipo sí/no. 
segunda alude más a lo que podríamos denominar capital moral, esto es, el respeto a las normas morales.

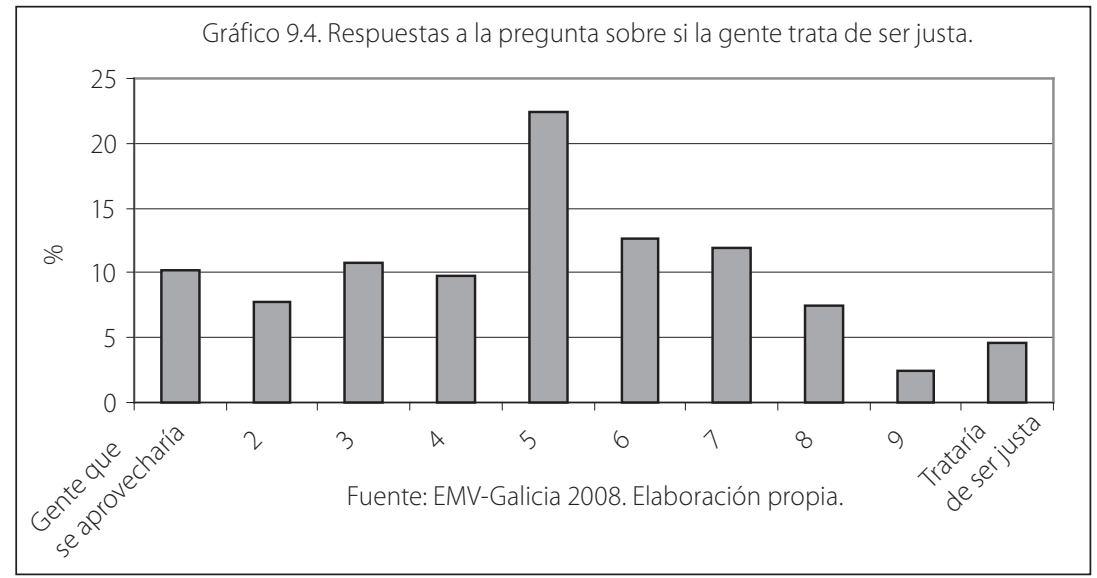

Paralelamente a esta reducción de la confianza generalizada se comprueba un fortalecimiento de la confianza particularista (Gráfico 9.5). En conjunto, se observa que existe un claro consenso valorativo en dar una prioridad a la institución familiar y a los grupos de vínculos fuertes o de elevada proximidad social en términos de confianza. De este modo, el capital social de lazos fuertes (bonding social capital) puede considerarse predominante. Este es uno de los rasgos propios de lo que podríamos denominar, en terminología de Tönnies, sociedades cálidas, muy ligadas a los países del sur de Europa de tradición católica, en las que se observa un claro predominio de los vínculos de consanguinidad y de proximidad.

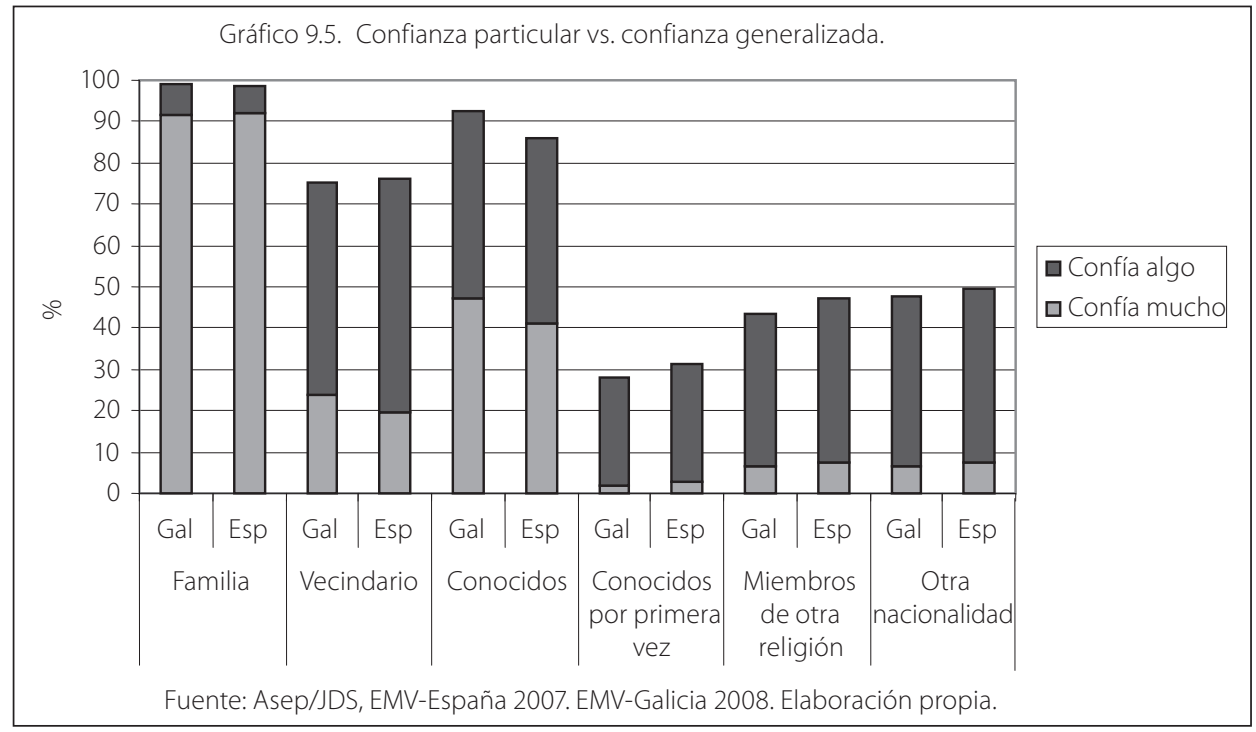


La confianza en la institución familiar es prácticamente total, superando niveles del 90\% tanto en Galicia como en España. La existente respecto a los conocidos es sensiblemente inferior, especialmente en lo referido a niveles de "mucha confianza" (entre el 40 y el 50\% en España y algo superior en Galicia). Frente a ambas, la confianza en el vecindario se reduce a niveles próximos al 20\% en ambos casos, si bien alcanza el entorno del $75 \%$ si consideramos los que responden que confían algo y se sitúa en niveles inferiores al 10\% para los referidos a conocidos por primera vez, miembros de otra religión y de otras nacionalidades (menos de un 50\% para el agregado de los que confían mucho y algo). Estos bajos niveles de confianza respecto a los entornos más amplios pueden evidenciar uno de los efectos de la transformación de la sociedad española y gallega en un conjunto más heterogéneo en un muy corto período de tiempo.

Si adoptamos una perspectiva diacrónica, nos encontramos que tanto la familia como las redes de amistad han ido incrementando su importancia a lo largo del período de estudio. Contrastando los resultados de las encuestas de la última con la primera oleada (Gráfico 9.6) se observa un incremento significativo en el grupo de aquellos que consideran a los lazos fuertes como esenciales.

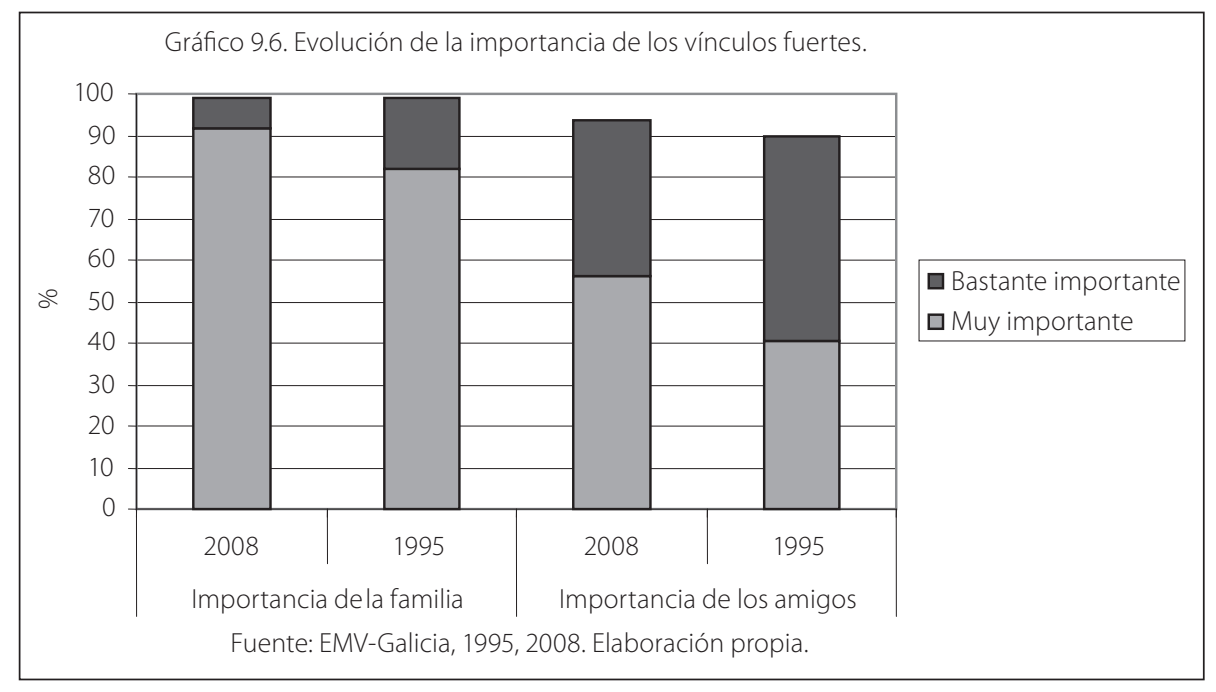

Este repliegue hacia los núcleos de confianza particular puede tener efectos en varios sentidos. Por una parte, es obvio que en la sociedad gallega la familia cumple un papel clave. Tal y como señalamos anteriormente, los lazos fuertes son esenciales tanto en los procesos de generación de capital humano, como en aseguramiento personal. La familia constituye un sistema de cobertura en lo que se refiera a prestaciones sanitarias y económicas, hasta el punto que puede considerarse como notablemente más efectivo que el generado por el propio Estado. 
Consecuentemente, en una situación de crisis es lógico que gane importancia la institución familiar, ya que ésta se convierte en un recurso particularmente necesario. Por otra parte, también podría mencionarse el papel que la creciente heterogeneidad social puede ejercer sobre los vínculos fuertes o lo que hemos venido denominando como bonding social capital. De este modo, no puede hablarse de una institución en crisis, sino que ha ido ganando en importancia y, pese a los procesos de individuación, sigue siendo la pieza clave del sistema social. Ahora bien, según hemos indicado, parte de este movimiento puede ser coyuntural.

Tabla 9.2. Correlaciones entre las formas de confianza particular y general en Galicia.

\begin{tabular}{|c|c|c|c|c|c|c|}
\hline & $\begin{array}{c}\text { Confianza } \\
\text { general }\end{array}$ & $\begin{array}{l}\text { Confía } \\
\text { en: } \\
\text { familia } \\
\end{array}$ & $\begin{array}{c}\text { Confía } \\
\text { vecindario }\end{array}$ & $\begin{array}{c}\text { Confía } \\
\text { conoce } \\
\text { personalmente }\end{array}$ & $\begin{array}{l}\text { Confía en: } \\
\text { gente que } \\
\text { conoce por } \\
\text { primera vez } \\
\end{array}$ & $\begin{array}{l}\text { Confía } \\
\text { en: gente } \\
\text { de otra } \\
\text { religión }\end{array}$ \\
\hline $\begin{array}{l}\text { Confía en: } \\
\text { familia }\end{array}$ & 0,0437 & & & & & \\
\hline $\begin{array}{l}\text { Confía en: } \\
\text { vecindario }\end{array}$ & $0,0914 * *$ & $0,2295^{* *}$ & & & & \\
\hline $\begin{array}{l}\text { Confía en: } \\
\text { gente que } \\
\text { conoce } \\
\text { personalmente }\end{array}$ & $0,0958^{* *}$ & $0,2119^{* *}$ & $0,3282 * *$ & & & \\
\hline $\begin{array}{l}\text { Confía en: } \\
\text { gente que cono- } \\
\text { ce por primera } \\
\text { vez }\end{array}$ & $0,2061^{* *}$ & $0,0679 * *$ & $0,3781^{* *}$ & $0,2849 * *$ & & \\
\hline $\begin{array}{l}\text { Confía en: } \\
\text { gente de otra } \\
\text { religión }\end{array}$ & $0,1693 * *$ & $0,1162^{* *}$ & $0,2580 * *$ & $0,2956^{* *}$ & $0,4867 * *$ & \\
\hline $\begin{array}{l}\text { Confía en: } \\
\text { gente de otra } \\
\text { nacionalidad }\end{array}$ & $0,1954 * *$ & $0,1154 * *$ & $0,2072 * *$ & $0,2791^{* *}$ & $0,4362 * *$ & $0,8027^{* *}$ \\
\hline
\end{tabular}

* Significativo al 0,05.

** Significativo al 0,01.

Fuente: EMV-Galicia 2008. Elaboración propia.

Si pasamos a considerar los efectos, un análisis de las correlaciones existentes entre las respuestas a las cuestiones sobre las distintas formas de confianza pone de manifiesto la escisión de las expresiones más particulares respecto a las de carácter más general (Tabla 9.2). La confianza general guarda una 
relación directa y significativa con todas las expresiones de confianza salvo con la confianza en la familia. Este resultado nos lleva a afirmar la existencia de un cierto trade off o intercambio entre la confianza general y la confianza particular o centrada en los vínculos fuertes. Este dato ya ha sido evidenciado en investigaciones previas ligadas a lo que ha sido denominado "familismo amoral", como una de las bases de asentamiento de los fenómenos de corrupción. El predominio de capital social de vínculos fuertes o bonding social capital puede constituir un seguro frente a la inestabilidad social o desconfianza en la sociedad en su conjunto, hasta el punto de que los únicos contratos sociales fiables son los establecidos entre aquellos para los que los vínculos son fuertes o integran el círculo personal de confianza (ring of trust) (Lambsdorff, 2007). No obstante, pese a que no puede hablarse que ése sea el caso de la sociedad gallega, el fenómeno coyuntural que parecen reflejar los datos es un repliegue sobre aquellas instituciones sociales más sólidas, en este caso la familia, y una sensible reducción de la confianza generalizada.

\subsubsection{Confianza en las instituciones}

Una de las vertientes de la confianza generalizada es la confianza institucional. Ésta traduce una de las variantes del capital social que hemos denominado linking social capital o capital social institucional. Prácticamente todos los autores coinciden en afirmar que un clima de confianza en las instituciones es una de las bases primordiales para el desarrollo económico. La confianza en los gobiernos, en las empresas y en las instituciones educativas y religiosas es un requisito ineludible para el crecimiento, en la medida en que facilita la confianza generalizada y solventa los problemas de agencia colectivos, favoreciendo la gobernanza. Ahora bien, no debe confundirse la confianza general con la denominada confianza institucional. La confianza en las instituciones políticas, religiosas, económicas, etc., sigue una dinámica diversa, y en ocasiones contraria, a la general. El asociacionismo al que hacíamos referencia bajo el capital social general (bridging) y en algún caso el bonding o particularista facilita un tipo de integración social más favorecedor del desarrollo social y económico, al tratarse de una integración horizontal, no jerárquica, en tanto que esta forma de confianza establece vínculos primordialmente verticales que tienen su traducción en las formas de gobierno y en el ejercicio y eficiencia de la gobernanza.

En Galicia, considerando las diversas consultas, ninguna institución presenta elevados niveles de confianza para la mayoría de la población. En general, para el caso de los que manifiestan "mucha confianza", todas se sitúan por debajo del 15\% de la población. Consecuentemente podría afirmarse que no existen instituciones capaces de generar un alto clima de confianza en el momento presente, si no 
fuera porque tampoco ninguna institución merece "ninguna confianza" para la mayoría. Individualmente sigue destacando el hecho de que la Iglesia es la institución que muestra un mayor porcentaje de "mucha confianza", seguida por las fuerzas armadas, esto es, dos instituciones tradicionales.

Bajo una perspectiva diacrónica, todas las instituciones han bajado con la única excepción de las fuerzas armadas y la policía. Si agregamos al porcentaje de "mucha confianza", el de aquellos que manifiestan "bastante confianza" puede observarse (Gráfico 9.7) que las únicas instituciones que superan el 50\% de la población son la policía, las fuerzas armadas, las organizaciones no gubernamentales y la Unión Europea. Esta suma es legítima porque tampoco se puede exigir extrema confianza a la mayoría de la población en una sociedad donde el pluralismo y el disenso normativo están institucionalizados en gran medida. Agrupando los resultados, las instituciones más sólidas en términos de confianza son, nuevamente, las ligadas a la función de orden y protección social (la policía y las fuerzas armadas), unidas a las organizaciones medioambientales y la Unión Europea. A su vez, en niveles por encima del 40\% encontramos instituciones tales como la justicia, el gobierno, el parlamento, las organizaciones feministas, las organizaciones de caridad, la Xunta y los ayuntamientos. En el extremo contrario, las instituciones peor valoradas por los gallegos en términos de confianza siguen siendo los partidos políticos.

El análisis de la evolución de estos agregados a lo largo del período 1995-2008 puede poner de manifiesto cuáles se están convirtiendo en las instituciones más sólidas. Tal y como señalamos, la policía y las fuerzas armadas han experimentado considerables incrementos en los niveles de confianza institucional, hasta el punto de duplicarse en la primera en estos casi 25 años. Ha habido también leves incrementos en la confianza en el gobierno, el parlamento, los partidos, las organizaciones feministas y la Unión Europea. Frente a éstos, la Iglesia continúa un proceso de declive en términos de confianza, lo que tendrá su traducción también en las cifras de pertenencia que analizaremos más adelante. Junto a ella, los medios de comunicación (prensa y televisión), unidos a las organizaciones sindicales y las grandes empresas.

En conjunto, la población gallega no otorga altos márgenes de confianza a sus instituciones o mantiene una actitud de cautela ante su actuación, siempre bajo cierta sospecha. De igual modo, ante este resultado es de notar la ausencia de las instituciones políticas y sindicales dentro del listado de las que merecen más confianza. Por otra parte, en el movimiento verde o las organizaciones de tipo altruista que representan la difusión cuasi-institucionalizada de unos valores en alza como son los de respeto a la naturaleza, el cuidado del medio ambiente y la solidaridad, existen leves incrementos. 


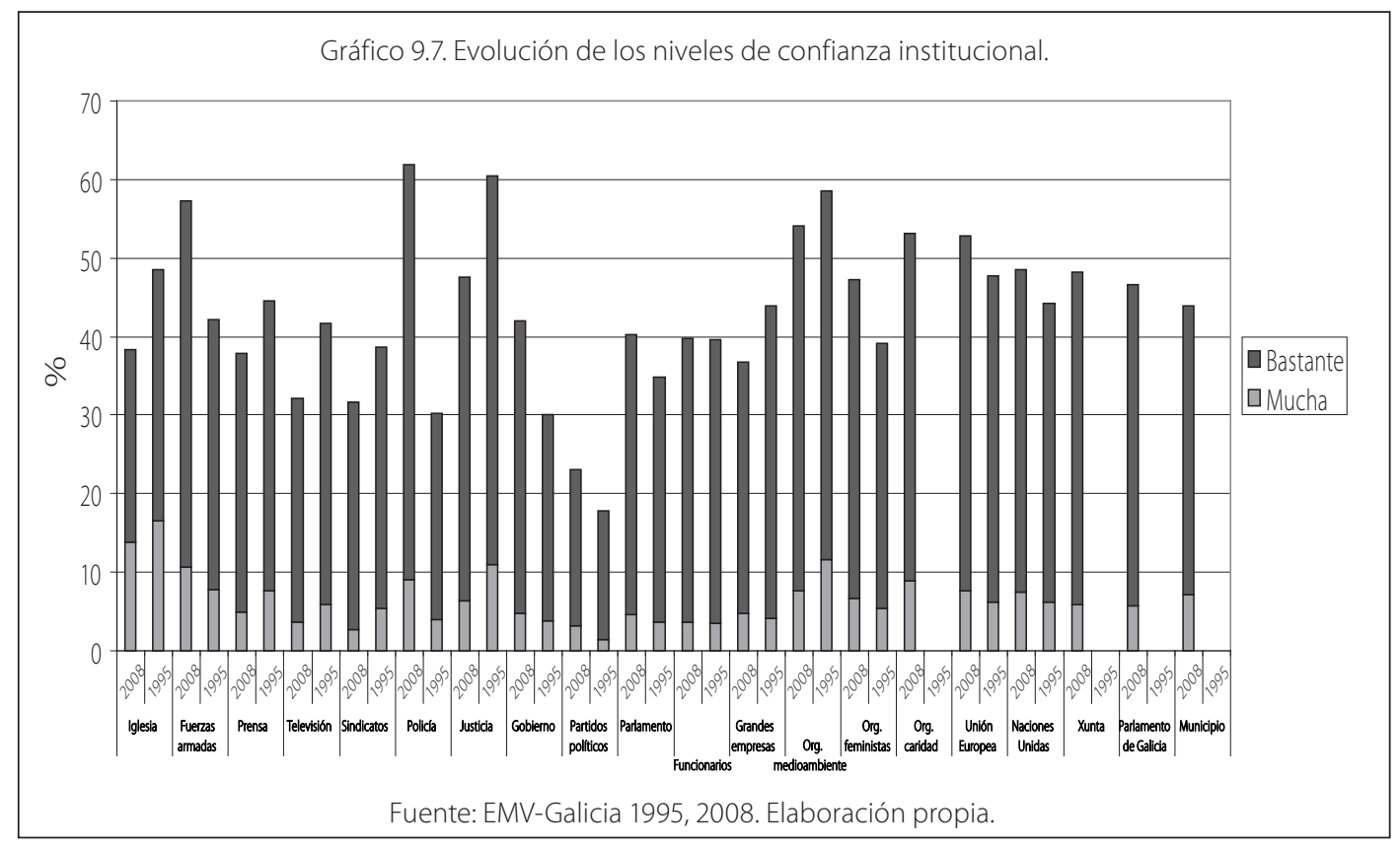

Como conclusión general puede decirse que determinadas instituciones esenciales para el buen funcionamiento de la democracia y del sistema de valores en general, como son, entre otras, el gobierno, los partidos políticos, los sindicatos, los medios de comunicación y la Iglesia, no gozan de la suficiente confianza como para que podamos afirmar que en Galicia tenemos un alto capital social institucional o linking. Si esto representa un lastre para nuestro desarrollo económico y social es algo que debemos por el momento dejar formulado a manera de hipótesis, en espera de futuras verificaciones. No obstante, la "Teoría del capital social" ha mantenido esta afirmación como cierta, esto es, que un clima de baja confianza institucional dificulta el desarrollo social y económico de una sociedad.

Debe señalarse, por otra parte, que este distanciamiento entre ciudadanía e instituciones políticas no es algo exclusivo o diferencial de Galicia, sino común a las sociedades de nuestro entorno cultural democrático, aunque existe diversidad entre los distintos países. Concretamente, hay una enorme similitud con los datos, derivados de la encuesta a escala nacional (Gráfico 9.8). Sin embargo, este hecho no debe justificar la pasividad de los agentes sociales ante este distanciamiento. La búsqueda de la eficiencia de las instituciones debe ser un objetivo común y compartido, para que las mismas alcancen un alto grado de confianza.

En lo que respecta a los lazos entre la confianza institucional y la confianza generalizada, observamos dos claras tendencias al analizar las correlaciones internas entre dichas variables. En primer lugar, tal y como predice la teoría, no 
existe una relación directa entre confianza general y confianza institucional y, en segundo lugar, dentro de esta confianza institucional, la presencia de un elevado nivel de correlación interna entre las distintas expresiones de esta última con la excepción de los vínculos entre Iglesia, sindicatos y partidos políticos.

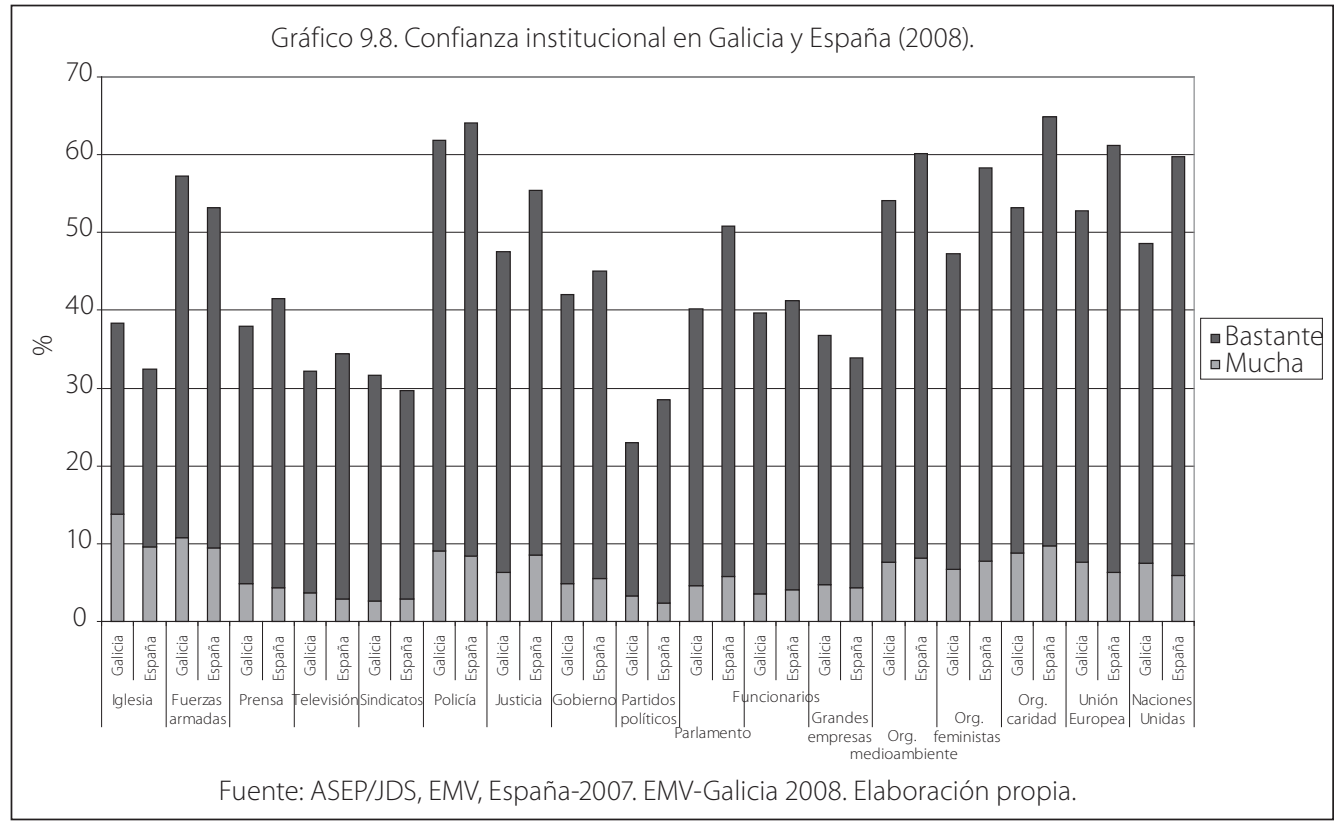

\subsection{LA EVOLUCIÓN DEL ASOCIACIONISMO}

La ya señalada perspectiva de Putnam (1993) insiste en la importancia del asociacionismo en la generación de capital social. De este modo, el mayor éxito de regiones y países en términos de crecimiento económico podría estar ligado, al menos parcialmente, a la existencia de un fuerte entramado asociativo. Éste desarrolla en los individuos hábitos de cooperación, solidaridad y preocupación por lo público, así como la ya aludida confianza general. De acuerdo con esta visión, la mejor aproximación estadística a la dotación de capital social es la densidad de organizaciones voluntarias en un colectivo determinado, ya que la presencia de este tipo de instituciones manifiesta la existencia de confianza y cooperación. Ahora bien, como veremos, es preciso tener en cuenta tanto la naturaleza de las asociaciones como los vínculos generados.

Algunos trabajos más generales obtuvieron evidencias sobre la relación existente entre desarrollo económico y social y la evolución y estructura del asociacionismo (Sánchez Santos et al., 2003) e igualmente, según viene remarcando la extensa literatura sobre el capital social, se hace patente que existe una clara vinculación biunívoca entre desarrollo económico (PIB per cápita) y nivel asociativo. Sin embargo, es preciso analizar los entresijos de esta relación, en lo que respecta 
a cambios en la estructura asociativa y, al mismo tiempo, el paradójico aparente declive en los niveles de asociacionismo y en las dotaciones de capital social en las economías más desarrolladas.

El capital social es visto como mecanismo básico de articulación de la sociedad. La copertenencia a organizaciones sociales configura una estructura/red social cuyas funciones fundamentales son: articular a la sociedad; convertirse en mecanismo de creación de identidad y de valores; ser un cauce para la acción individual y la acción colectiva; y ser la vía fundamental de acceso diferencial a bienes y servicios. Tal y como señalamos, el capital social puede ser visto desde el punto de vista individual, es decir, considerar el número de organizaciones a las que cada individuo accede de forma directa (que sería la base de los indicadores usualmente utilizados), junto al capital social organizativo, es decir, las organizaciones a las que cada organización está a su vez conectada. La forma y dinámica de las redes en que los actores están insertos condicionará a la vez que potenciará su vida individual y colectiva. Dichas redes se convierten en agentes colectivos de creación de valores y de acción tanto social como política.

No obstante, debemos ser precavidos a la hora de utilizarlo como indicador único de capital social de un país, ya que otras formas de capital menos formalizadas y organizadas pueden ser relevantes y desempeñar un papel también importante en la acción social.

Procesos históricos, políticos, culturales o religiosos pueden dar lugar a variaciones en la preponderancia de una forma de capital u otra (formal o informal) en la acción social y en la configuración de la sociedad que no necesariamente supone que unas sociedades (las más organizadas) sean más activas y democráticas que las otras (menos organizadas). La sociedad civil organizada que ocupa espacios históricamente no controlados por el Estado (el religioso, el deportivo y el artísticocultural), mantiene todavía un peso importante en sus espacios propios, pero que han sido progresivamente profesionalizados y regulados por el Estado (caridad, asistencia social y humanitaria), y crea nuevos espacios de acción en áreas de importancia para las nuevas clases medias y para la calidad de vida de las sociedades ricas (medio ambiente, paz, mujer). Esta situación refleja procesos históricos de división de tareas entre el Estado y la sociedad tendentes a la complementariedad (cultura y deporte), a la vez que muestra también los espacios históricos de confrontación (asistenciales) y las nuevas problemáticas y retos sociales planteados por la sociedad global ante los que el Estado nacional parece ineficiente (medio ambiente, paz, Tercer Mundo). En estos ámbitos, la sociedad organizada y, especialmente, las redes globales de organizaciones, podrían ser más eficaces por su capacidad de sobrepasar fronteras nacionales (Rodríguez et al., 2003).

En general, lo que analizamos en este apartado es cómo los elementos del tejido social de una comunidad concreta (sus personas, colectivos, líderes naturales...) se relacionan entre sí establemente, con conexiones y desconexiones que 
forman redes de relación. Estos vínculos son muy intensos en algunas zonas de la malla social mientras que son casi inexistentes en otras.

A partir de los resultados recogidos en la secuencia de encuestas realizadas, en Galicia se observa (Gráfico 9.9) una reducción de los niveles de asociacionismo en el período más amplio 1995-2008, coherente con los resultados obtenidos en el primer indicador de capital social, esto es, la confianza generalizada. Sin embargo, conviene aclarar que en el caso gallego podríamos hablar más bien de una substitución entre formas de asociacionismo que de una reducción significativa.

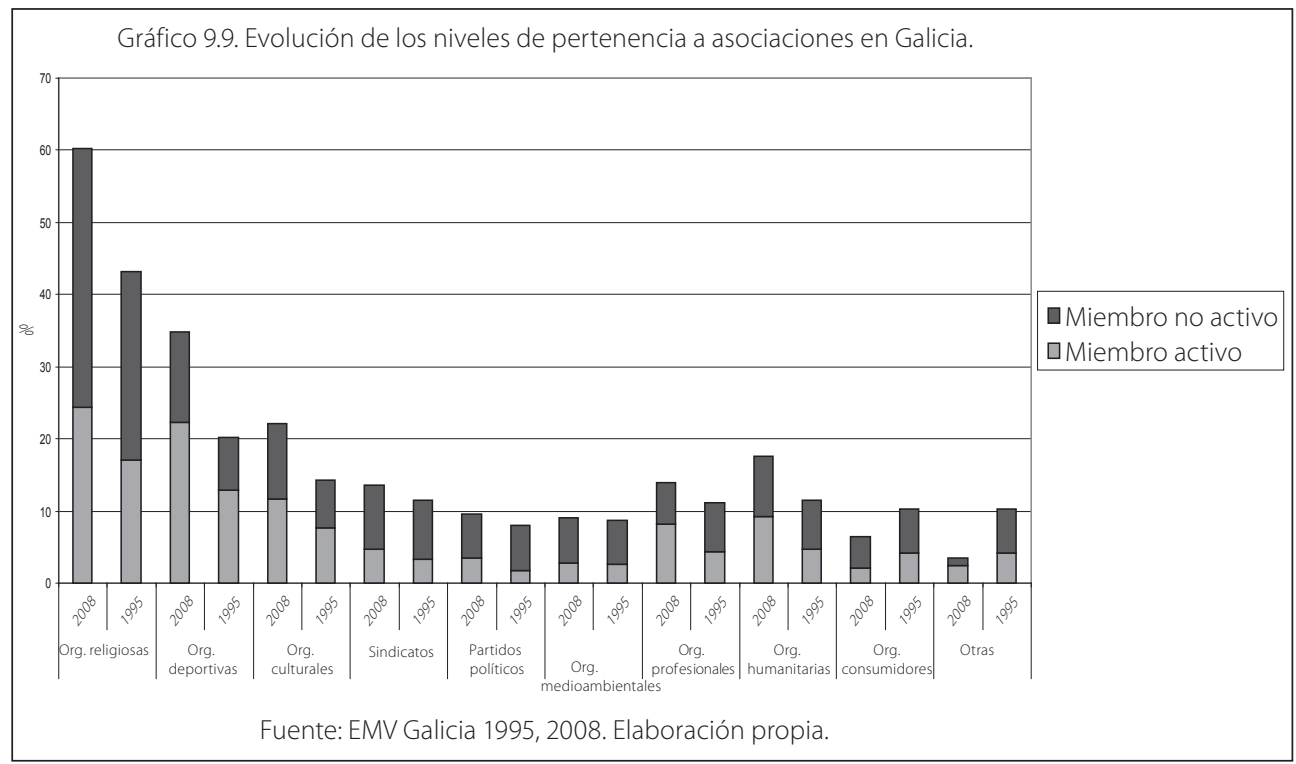

En cuanto a los datos, es relevante la pérdida de importancia del asociacionismo religioso, que en el pasado llegó a constituir el factor sinérgico de todo el entramado social. Concretamente, éste cae casi un $8 \%$ de la población, pero más de un $10 \%$ si nos fijamos exclusivamente en los miembros activos. Ahora bien, estamos hablando de una organización que todavía es capaz de generar identidad para un $60 \%$ de la población encuestada y de movilizar a casi un $25 \%$. Sin duda alguna, sigue siendo la organización social más relevante pese a este declive experimentado. El referente cultural católico persiste como rasgo identificativo para buena parte de la población, aunque los vínculos reales con la institución sean débiles o prácticamente inexistentes.

El asociacionismo deportivo constituye la expresión asociativa con un mayor crecimiento relativo. Estos grupos logran una elevada implicación de sus miembros; de hecho, más de un 50\% son activos dentro de la organización. El caso del asociacionismo cultural es notablemente semejante. El crecimiento de ambas expresiones está ligado al auge de lo que podríamos denominar civilización del ocio. En este sentido, podría ponerse en cuestión el tópico sobre el declive de las 
redes sociales o del capital social en general, puntualizando que la percepción de ese deterioro proviene del sistema de medición. Las asociaciones deportivas, habitualmente consideradas como informales o no integrables en la medición de este capital, revisten un carácter sustitutivo normal, es decir, reemplazan a otros modos de asociacionismo como el sindical, profesional o económico, a medida que la renta se incrementa, y aunque resulte paradójico, conforme aumenta el nivel educativo de la población (Sánchez Santos et al., 2003). Las causas determinantes en este proceso son de muy diversa índole y van desde los cambios de modo de vida, la movilidad geográfica, las variaciones en los patrones de vida familiar... hasta la elevación de los niveles de renta (Putnam, 2000).

Este tipo de asociacionismo, menos formal que las restantes expresiones de capital social, guarda una relación significativa y fuerte con el nivel del PIB per cápita y, en el caso más concreto del IDH, es la única que se caracteriza por una relación positiva (o directa) y significativa ${ }^{16}$. No obstante, en este ámbito continúa abierto el debate sobre el vínculo directo entre confianza y asociacionismo que se presupone en el concepto de capital social (controversia Olson-Putnam), puesto que no todas las formas de asociacionismo generan confianza, tal y como señalamos en el apartado previo. La naturaleza de la relación entre ambas variables, requiere de un análisis más profundo que excede los objetivos del presente estudio (Pena y Sánchez, 2007).

Paralelamente sufren ligeras reducciones el asociacionismo de corte humanitario y medioambiental, en tanto que el profesional permanece prácticamente estable. Merece una mención especial el caso del asociacionismo político y sindical. Ambos grupos parecen incrementarse levemente; sin embargo, este dato oculta la existencia de caídas en los miembros que se consideran a sí mismos como activos.

La integración en actividades voluntarias es todavía más modesta; así, son destacables los bajos niveles de participación en actividades sindicales, partidos, asociaciones locales, ONG, etc. No es éste el lugar para debatir las causas de este bajo asociacionismo, tan solo cabe destacar que la participación en tareas voluntarias o cívicas es un componente esencial del capital social, y por este motivo debemos concluir que en Galicia existe un déficit notable en este sentido. El vigor de una sociedad civil reside en gran parte en su nivel de asociacionismo y compromiso con las virtudes cívicas. En otro orden de cosas, cabe tener presente que la solidez de los entramados relacionales tradicionales (familia, religión, etc.) no constituye necesariamente y en sí misma un soporte de la confianza social. De hecho, según indicamos anteriormente, el denominado "familismo amoral" o predominio de los vínculos familiares o grupales estrechos sobre los generales puede constituir un importante freno al desarrollo económico y social.

Un contraste del caso gallego con el español evidencia algunas diferencias significativas. Para este último, la pérdida de importancia del asociacionismo

6 No deja de resultar llamativo que la otra relación significativa sea el declive de las organizaciones religiosas, que viene a reafirmar la hipótesis de la secularización de las sociedades desarrolladas. 
general ha sido notablemente superior y se manifiesta en todas sus expresiones. Particularmente relevante es el declive en la significación del asociacionismo religioso, hasta el punto de que en el período ha quedado reducido a menos de la mitad, unida a las caídas en el asociacionismo deportivo y cultural, así como el sindical y político. Consecuentemente, nos encontramos con una pérdida de capital social o, mejor dicho, asociativo más ostensible que en el caso gallego.

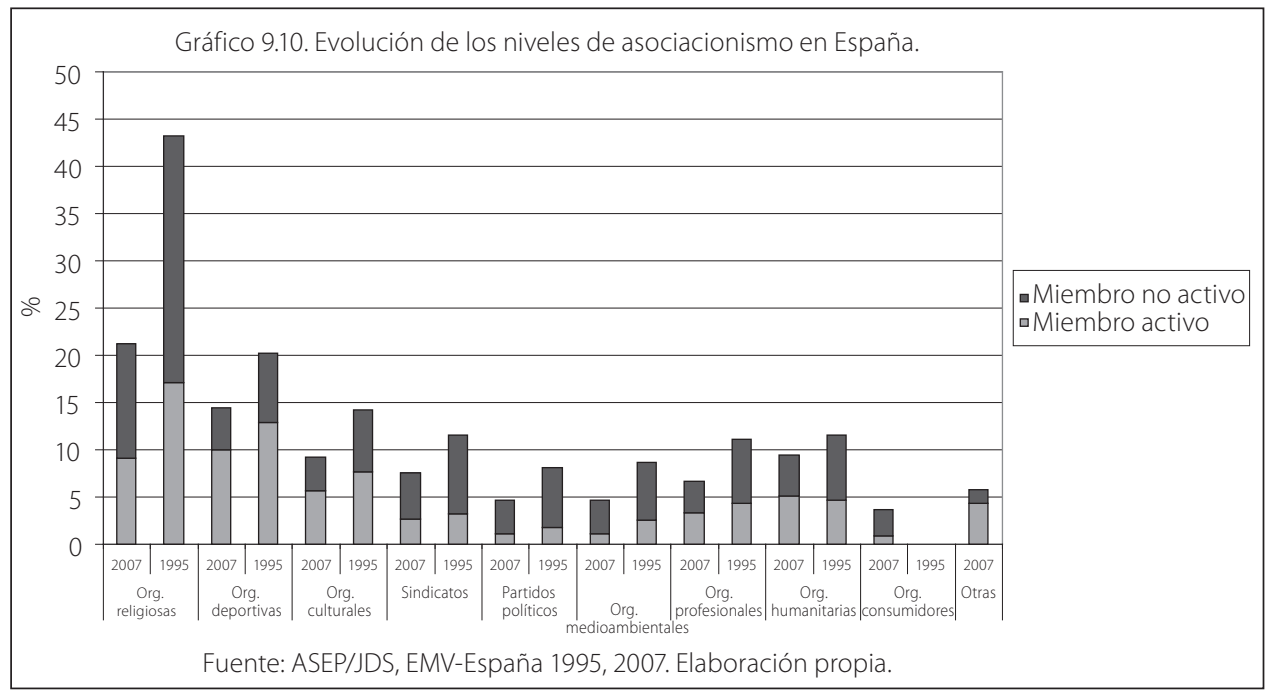

Si tomamos como marco de referencia la estructura del asociacionismo en el caso español (Gráfico 9.10), nos encontramos con un ejemplo claro de lo señalado anteriormente. Solo existen tres modos de asociacionismo auténticamente significativos: el deportivo, el religioso y el cultural. La participación activa en asociaciones de tipo religioso todavía resulta particularmente relevante, aunque ha experimentado una rápida caída en los últimos 20 años, dado que en el pasado la Iglesia Católica constituía la institución clave en la generación de este tipo de capital, incluso en el establecimiento de cualquier forma de vínculo social ${ }^{17}$. Comparativamente, la participación asociativa en Galicia es superior en todas las expresiones del mismo. Las restantes actividades asociativas resultan poco significativas, tanto las de corte económico como las de carácter político.

En este punto es conveniente recalcar la necesidad de una lectura prudente de estos datos en la medida en que se trata de apreciaciones subjetivas de pertenencia. Concretamente, los individuos pueden afirmar sentirse vinculados de forma no activa cuando muy probablemente exista solo una vinculación identitaria o afectiva. No obstante, sigue siendo una respuesta relevante a la hora de identificar las entidades sociales más representativas.

17 A título de ejemplo, hasta los años 70 España mantenía los niveles de práctica religiosa activa más elevados del mundo. 


\subsubsection{La vertebración del asociacionismo}

La actividad social de la población gallega reflejada en la encuesta muestra una red entre organizaciones que parece indicar un sensible cambio estructural e incluso una cierta diferenciación del contexto general español.

En esa red, se conectan con intensidades diferenciales prácticamente todos los tipos de organizaciones, con unos núcleos vertebradores que definen lo que es el centro neurálgico de la sociedad civil, formada por los ciudadanos más activos ligando las diversas organizaciones que la componen.

Trabajos previos han constatado para la realidad social española la existencia de tres tríadas de redes asociativas o subestructuras de relaciones recíprocas, cada una de las cuales se vincula a un modelo social: el mundo social de la Iglesia, y su relación con la caridad y la asistencia social; el eje formado por Iglesia/ Cultura/Deporte; o bien, un modelo que podría calificarse como más moderno formado por el eje Sindicatos/Cultura/Deporte (Rodríguez et al., 2003).

El eje formado por Iglesia/Cultura/Deporte ha sido históricamente el centro de la actividad de la sociedad española. En este caso es importante notar la alta intensidad relacional entre las organizaciones culturales-artísticas y las deportivas, que son los dos espacios más relevantes de acción al margen de la Iglesia.

La Iglesia todavía representa un papel central, aunque en declive, en la red de la sociedad civil española, ligada a todas las organizaciones a excepción de los sindicatos. De este modo, pervive un cierto papel influyente de las organizaciones de la Iglesia sobre una parte sustancial de la sociedad organizada, en gran medida por la existencia de un escaso nivel de asociacionismo horizontal o espontáneo. El espacio de acción históricamente ocupado por la Iglesia, representado por la tríada superior (junto con organizaciones de caridad y de asistencia), sigue siendo un espacio de acción destacado a pesar del desarrollo del Estado del bienestar y de la envergadura de la acción asistencial pública.

A la larga tradición histórica de organizaciones religiosas (y al papel de la Iglesia como gran poder antes de la aparición del Estado moderno y perviviendo con éste) se unen las tradiciones algo más modernas de las organizaciones culturales y de las deportivas, configurando un espacio propio donde además la intervención pública ha sido mínima.

La tríada inferior representa el espacio social más moderno donde se combinan la acción cultural-artística y deportiva con la acción sindical o política.

Estas tres subestructuras reflejan también tres modelos diferenciados de acción social:

- El modelo caritativo/asistencial de orientación religiosa, herencia del papel de la Iglesia y la religión como proveedora de servicios a los necesitados y que sobrevive representando un papel fundamental de complementariedad a la acción pública del Estado. 
- El modelo asociativo clásico moderno promotor de la cultura y facilitador o canalizador de la actividad deportiva.

- El modelo sindical para la articulación y defensa de los intereses laborales, fundamentalmente de las clases trabajadoras.

Sobre los datos derivados de la encuesta observamos que la sociedad gallega se encuentra en una fase de transición entre dos de los modelos señalados (Tabla 9.3). Si analizamos las correlaciones existentes entre las pertenencias a diversas organizaciones, se evidencia que el principal sistema asociativo es todavía de corte tradicional y centralizado en organizaciones de carácter religioso y con derivaciones significativas, pero cada vez más débiles, en organizaciones humanitarias y culturales. Simultáneamente, puede apreciarse la existencia de un segundo grupo en el entorno de las organizaciones deportivas y con correlaciones significativas y más elevadas con las restantes formas asociativas. Este eje puede considerarse emergente y sustitutivo del anterior. Por otra parte, si consideramos en este análisis el otro gran indicador de capital social (la confianza generalizada), el primer eje con centro en instituciones religiosas parece vincularse más a formas de confianza particularista, en tanto que el segundo, más ligado a un asociacionismo horizontalista, guarda un claro vínculo con expresiones de confianza generalizada.

\subsubsection{El asociacionismo y el declive del capital social}

Una simple lectura de los datos sobre la evolución del asociacionismo en Galicia nos permite afirmar la existencia de un declive tanto en la participación como en la misma afiliación. Esto nos llevaría a reconocer que hay un grave problema derivado de la pérdida de entidad de las organizaciones representativas o que existe una fuerte caída de la solidez del entramado social (Putnam, 1999) con indudables repercusiones tanto en la esfera social como económica, en especial por los costes en términos de confianza general. Sin embargo, tal y como señalamos en el apartado previo, podrían resultar más frecuentes otras expresiones de asociacionismo no consideradas por los enfoques tradicionales, de forma que los niveles de capital asociativo permanezcan constantes en el largo plazo.

La calidad de las evidencias en los distintos países avanzados difiere notablemente. No obstante, parece observarse una serie de tendencias comunes. En primer lugar, la participación en organizaciones tradicionales tales como sindicatos, agrupaciones religiosas y políticas, ha experimentado un fuerte declive que solo ha sido parcialmente cubierto por la expansión de nuevos movimientos formales, tales como las asociaciones deportivas. Paralelamente, las conexiones sociales se han convertido en menos intensas y más transitorias o de tipo individualista, es decir, se renuncia a formas directas de compromiso comunitario. Junto a ello, la confianza en las instituciones políticas ha sufrido un fuerte declive, en particular, entre las nuevas generaciones. 


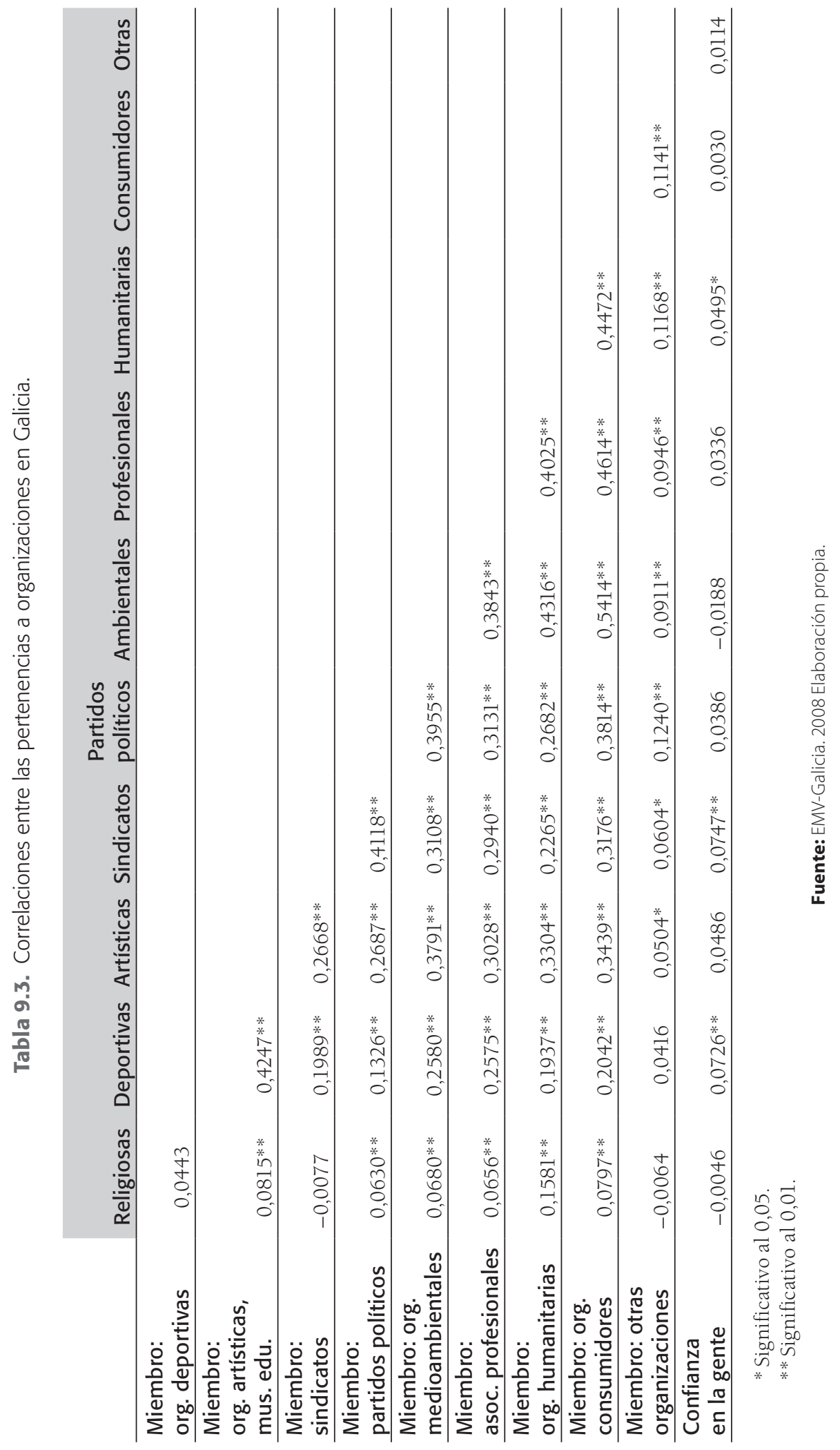

LA EVOLUCIÓN DEL CAPITAL SOCIAL EN GALICIA 295 
Entre los factores causantes de dicho declive se encuentran las tendencias actuales de los mercados de trabajo en lo referente a movilidad, las desigualdades económicas, los cambios en los hábitos de vida y la extensión paralela de valores individualistas, que ha tenido también una particular traducción en la denominada privatización del ocio. Junto a ello, la expansión del Estado del Bienestar parece tener un sensible efecto deletéreo sobre la sociedad civil, al eliminar del ámbito de la familia los sistemas sociales de aseguramiento.

En su celebrada obra Bowling alone, Putnam expresaba su preocupación ante las evidencias de pérdida de capital social y las consecuencias derivadas sobre el funcionamiento de la sociedad civil (Putnam, 2000). Las afirmaciones de este autor han dado lugar a un acalorado debate (Warren, 1999) sobre este supuesto declive. Estas diferentes visiones provienen de las distintas perspectivas sobre el objeto de análisis que medimos como integrante o generador de capital social (el asociacionismo) y de considerar ese declive señalado como un proceso natural de mutación resultado de los cambios económicos y sociales (Lemman, 1996) ${ }^{18}$. Los escasos estudios realizados en Europa vienen a confirmar una cierta vitalidad de algunas expresiones del movimiento asociativo, muy en particular en el ámbito recreativo y deportivo, en el que se sitúan prácticamente la mitad de los encuestados. De esto último parece poder deducirse que el deterioro de algunas formas de asociación no tiene porque conllevar una pérdida de capital acumulado, sino tan solo su transformación hacia expresiones adaptadas a los nuevos contextos socioculturales.

La cuestión que surge de modo inmediato es si los miembros de asociaciones deportivas son generadores de capital social. Como resulta evidente, esta afirmación exige una contrastación. Si nos retrotraemos a la definición de capital social, cualquier actividad que suponga una tarea colectiva o cooperativa tiene derivaciones en cuanto a generación de capital social, es decir, cualquier modo de relación que genere alguna forma de confianza. De este modo podrían incluirse desde las relaciones familiares a las agrupaciones religiosas, pasando por las asociaciones deportivas y profesionales. Así, un grupo está incrementando su dotación de capital social siempre que desarrolle alguna tarea colectiva, no autoritaria o coercitiva, en la que se sientan implicados un conjunto de individuos.

Por lo tanto, las mediciones tradicionales resultan demasiado estrechas, ya que los acumuladores de capital social funcionan mejor como sistemas abiertos heterogéneos e incluso informales, que se agrupan en torno a una institución formal, como puede ser un club de fútbol. Expresado de otro modo, el capital social parece encontrar otras vías especialmente eficientes de generación a través de asociaciones espontáneas, abiertas y, sobre todo, no jerárquicas que vinculan a los individuos ante un acontecimiento social determinado. Estas

18 Este autor ya había puesto en cuestión los resultados de Putnam para el caso americano, observando el espectacular crecimiento de asociaciones tales como la liga de fútbol (soccer) aficionado.

\section{LA EVOLUCIÓN DE LOS VALORES SOCIALES EN GALICIA}


redes informales se ajustan al modelo de Putnam de estructuras horizontales, reticulares e igualitaristas que ofrecen la oportunidad de una experiencia de compartir una identidad y una tarea común.

\subsection{CONCLUSIONES}

El concepto de capital social presenta un claro problema de indefinición. El referente más directo de dicho concepto podría ser la generalización de normas, la extensión de redes asociativas e incluso tiende a identificarse tautológicamente con la confianza general. Sus efectos en las esferas microsocial y macrosocial, van desde la creación de una red de cobertura o seguro personal y una reducción de los costes de transacción y agencia, a un mejor funcionamiento institucional e incluso un mayor crecimiento económico.

En nuestro análisis de la sociedad gallega hemos observado a través del estudio de los indicadores de confianza y asociacionismo, la existencia de una dotación media-baja de capital social, unida a un aparente proceso de descapitalización y, simultáneamente, una elevación de lo que podríamos denominar expresiones más de tipo particularista de esta forma de capital. En un período de algo menos de siete años se ha producido una reducción de los niveles de confianza generalizada a la mitad de los observados en 2001. Esta trayectoria tan abrupta es prácticamente homogénea con el conjunto del Estado. En ambos casos, tras una etapa de crecimiento moderado que situaba a España y a Galicia en la media de los países europeos, se experimenta un recorte sustancial. Esta mayor "desconfianza" guarda relación con un cierto descrédito de la política o la justicia, al mismo tiempo que con los problemas ligados a una sociedad crecientemente heterogénea tanto en lo axiológico como en lo cultural. No obstante, es aventurado señalar las causas de un movimiento tan complejo como el de esta variable.

Sobre la causalidad de la confianza generalizada, proponemos un modelo estadístico en el que constatamos que el grupo que se asocia a esta actitud es de ingresos más elevados, más activo social y políticamente, pero no está especialmente vinculado a ningún tipo de asociación y desde un punto de vista valorativo, considera importante la inversión en ocio y relaciones personales. Por otra parte, la confianza generalizada tiene vínculos con algunas formas de confianza institucional. Así, aquellos que se sitúan entre los que presentan confianza social tienden a presentar confianza con grupos ajenos e instituciones sociales (linking y bridging social capital). Este es el caso de las variables confianza en el sistema judicial y confianza en gente de otras nacionalidades. Ahora bien, este grupo parece guardar una cierta actitud "hostil" hacia instituciones de carácter religioso o de mercado.

Si adoptamos una perspectiva diacrónica nos encontramos que tanto la familia como las redes de amistad han ido incrementando su importancia a lo largo del 
período de estudio. De este modo, no puede hablarse de la familia como una institución en crisis, sino que ha ido ganando en importancia y, pese a los procesos de individuación, sigue siendo la pieza clave del sistema social.

En lo que respecta a las instituciones, la sociedad gallega mantiene una actitud de cautela ante su actuación. Tan solo aquellas ligadas a la seguridad (policía y fuerzas armadas) presentan elevados y crecientes niveles de confianza y, junto a ellas, algunas organizaciones de carácter humanitario.

Respecto al otro gran indicador de la dotación de capital social, el nivel de asociacionismo, podríamos hablar de una reducción de los niveles de pertenencia, de modo semejante al caso español más general; no obstante, se aprecia también un trade off o intercambio entre expresiones asociativas. Sobre los datos es relevante la pérdida de importancia del asociacionismo religioso, que en el pasado llegó a constituir el factor sinérgico de todo el entramado social, hacia el asociacionismo deportivo y cultural. Este hecho expresa un giro en la vertebración social de la población de Galicia. En este sentido, el asociacionismo manifiesta una evolución hacia formas más horizontales, en la medida en que pierden relevancia las expresiones religiosas y políticas.

\subsection{REFERENCIAS BIBLIOGRÁFICAS}

Alesina, A. y E. La Ferrara (2000): The determinants of trust, National Bureau of Economic Research, working paper 7621, Cambridge, NBER.

Barbieri, P., Paugam, S. y Russell, H. (2000): "Social capital and exits from unemployment" en Gallie, D. and Paugam, S. (Eds.) Welfare regimes and the experience of unemployment in Europe, Oxford, Oxford University Press.

Becattini, G. (2002): Desarrollo local, teorias y estrategias, Madrid, Civitas.

Bourdieu, P. (1986): "Forms of capital" in: Richardson, J. (Ed.):. Handbook of theory and research for the sociology of education. Westport, Greenwood Press, 241: 260.

Bourdieu, P. (2001): "The forms of capital" en: Granovetter, M. y Swedberg, R., The sociology of economic life. Oxford, Westview press, $2^{\mathrm{a}}$ ed.: 97-111.

Bush, R. y Baum, P. (2001): "Health, inequalities, community and social capital" en Eckersley, R. et al. The social origins of wellbeing, Cambridge, Cambridge University Press: 189-204.

Coleman, J. (1988): "Social capital in the creation of human capital" American Journal of Sociology, 94: 95-120.

Dasgupta, P. (1999): "Economic progress and the idea of Social Capital" en Dasgupta, P. and Serageldin, I., op. cit.: 325-424.

Dasgupta, P. y Serageldin, I. (1999): Social capital, a multifaceted approach. Washington, World Bank.

Esser, H. (2008): "The two meanings of Social Capital" en Castiglione, D., Van Deth, J. y Wooleb, G. (2008): The Handbook of social capital, Oxford, Oxford University Press: 22-50. 
Fukuyama, F. (1995): Trust, the social virtues and the creation of prosperity. Londres, Hamish Hamilton.

Glaeser, E., Laibson, D. y Sacerdote, B (2002): "An economic approach to social capital", Economic Journal, 112: 437-458.

Granato, J., Inglehart, R., y Leblang, D. (1996): "The effect of cultural values on economic development: theory, hypotheses, and some empirical test" American Journal of Political Science, 40 (3): 608-611.

Granovetter, M. (1973): "The strength of weak ties", American journal of sociology, 78: 1360-1380.

Guiso, L. y Sapienza, P. (2000): "The role of social capital in financial development." NBER, Cambridge.

Helliwell, J. (1996): "Do borders matter for social capital? Economic growth and civic culture in U.S. States." NBER, W.P., 5863, Cambridge, NBER.

Helliwell, J. y Putnam, R. (1995): "Economic growth and social capital in Italy", Eastern Economic Journal, XXI: 295-307.

Inglehart, R. (Coord.) (1981): "World values surveys and European values surveys." ICPSR Study, Ann Arbor, Institute for Social Research, University of Michigan [oleadas sucesivas, 1990, 1995, 2000].

Kawachi, R., Kennedy, B., Lochner, K. y Prothrow, S. (1997): "Social capital, income equality and mortality." American Journal of Public Health, 87 (9): 1491-1497.

Knack, S. y Keefer, Ph. (1997): "Does social capital have an economic pay off? A cross country investigation" Quarterly Journal of Economics, 112: 1251-1288.

Krishna, A. y Shrader, E. (1999): "Social Capital Assessment Tool" The World Bank, Social Capital Initiative, Working Paper No. 22

Lambsdorff, J.(2007): The institutional economics of corruption and reform: Theory, evidence and policy, Cambridge, Cambridge University Press.

Lemann, N. (1996): Kicking in Groups en Baron, S. Field, J. Schuller, T. (Eds.) Social Capital - Critical Perspectives, Oxford, Oxford University Press

Lucas, R., (1989): "On the mechanics of Economic Development" Journal of Monetary Economics 1: 3-32.

Nam, L. (2008): "A Network theory of Social Capital" en Castiglione, D., Van Deth, J. y Wooleb, G. The Handbook of social capital, Oxford, Oxford University Press: $50-70$.

Olson, M., (1982): The rise and decline of nations: economic growth, stagflation and social rigidities. New Haven, Yale.

Olson, M., (2000): Power and prosperity, New York, Basic Books.

Paldam, M. (2000): "Social capital: one or many? Definition and measurement" Journal of Economic Surveys, 14 (5): 629-653.

Pena López y Sánchez Santos, J.M. (2007): "The Olson-Putnam controversy: some empirical evidence" Economics Bulletin 26 (4): 1-10. 
Portes A. y Landolt P. (1998): "Unsolved mysteries: the Tocqueville files", The American Prospect online, 7: 20-26.

Putnam, R. (1993): Making democracy work: civic traditions in modern Italy. Princeton, Princeton University Press.

Putnam, R. (1995): "Bowling alone: America's declining social capital" Journal of Democracy, 6: 65-78.

Putnam, R. (2000): Bowling alone, the collapse and revival of American community, Nueva York, Simon and Schuster.

Putnam, R. (2003): El declive del capital social, Barcelona, Galaxia Gutemberg.

Rodríguez, J. A., Bosch, J. y Mérida, F. (2003): Capital Social como vertebrador de la sociedad, W.P., Barcelona, Universidad de Barcelona.

Romer, P. (1990): "Endogenous technological change." Journal of Political Economy 98: 71-102.

Routledge, B. R. y Amsberg, J. von. (2003): "Social capital and growth" Journal of Monetary Economics, 50: 167-193.

Sabatini, F. (2007): The role of social capital in economic development, Working paper $n^{\circ} 47$, Sienna, University of Sienna.

Sánchez Santos, J.M., Castellanos, P. y Pena López, J.A. (2003): Economía, fútbol y bienestar social, A Coruña, Diputación de A Coruña.

Sobel, J. (2002): “Can we trust social capital?" Journal of Economic Literature, 40: 139-154.

Stolle, D. (1998): "Bowling together, bowling alone, the development of generalized trust in voluntary associations" Political sociology, 19 (3): 497-526.

Szretzer, P. (2000): "Social capital, the economy and education in historical perspective." Baron, S., Field, J. y Schuller, T. Social capital, critical perspectives, Oxford, Oxford University Press.

Warren, M. (1999): "Democratic theory and trust" en Warren, M. (Ed.): Democracy and Trust. Cambridge: Cambridge University Press: 346-260.

Winter, I. (2001): Toward a theorized understanding of family life and social capital, Working paper no 21, Melbourne, Melbourne University.

Woolcock, M. (2001): "The place of social capital in understanding social and economic outcomes" Canadian Journal of Policy Research, 2 (1): 1492-1525. 


\section{FELICIDAD, BIENESTAR SUBJETIVO Y SATISFACCIÓN EN LA SOCIEDAD GALLEGA}

José Atilano Pena López José Manuel Sánchez Santos

\subsection{INTRODUCCIÓN}

En los últimos 25 años ha surgido un interés creciente en el estudio de la felicidad desde la perspectiva del bienestar subjetivo por parte de las ciencias sociales. La investigación sobre esta temática se ha desarrollado tanto en el campo de la Psicología (Kahneman et al., 1999), como de la Sociología (Venhoveen, 1993) y muy particularmente de la Economía (Bruni, 2004 y 2005; Frey y Stutzer, 2000 y 2002). En la mayoría de estos trabajos subyace como trasfondo común la pretensión de explicar desde diversos enfoques metodológicos las condiciones que permiten a los individuos desenvolverse como personas felices, socialmente implicadas y miembros de comunidades más prósperas y satisfechas.

Los imaginarios colectivos que caracterizaron el desarrollismo partían de la creencia de que mayores niveles de riqueza y de renta configuraban una realidad social con unas condiciones de vida mejores, mayor bienestar y, por extensión, mayor felicidad. Dicho de otra manera, la ciencia económica tendía a asumir que el bienestar material es una condición previa de la satisfacción subjetiva y que los cambios en la "felicidad" están directamente relacionados con los cambios en el poder adquisitivo. La aceptación de este supuesto tenía claras implicaciones en los planteamientos de las políticas económicas y sociales, de tal modo que la evolución del PIB constituía el objetivo prioritario de las mismas. No obstante, una amplio conjunto de estudios desarrollados bajo la denominación genérica de "paradojas de la felicidad" ponen en duda la validez de dichas hipótesis de partida. Concretamente, sería lógico pensar que la mejora del bienestar económico en términos diacrónicos no condujese a incrementos paralelos en los niveles de felicidad de la misma magnitud, pero no la constancia de los mismos, ni, por supuesto su disminución. La existencia de relaciones de trade off o intercambio entre ambos objetivos (renta y felicidad) es lo que ha venido a denominarse "paradoja de Easterlin" (Easterlin, 1974), y pone en cuestión buena parte de los 
supuestos tradicionales de la Economía. Esta evidencia disonante subraya la necesidad de analizar la felicidad y sus determinantes desde una perspectiva más amplia que la habitual, así como la incorporación de la misma a los fines últimos de la política económica ${ }^{1}$.

En el presente trabajo, a partir de las propuestas de lo que se ha dado en llamar "Economía de la Felicidad", planteamos una visión más holística de los factores influyentes en esta variable que identificamos con el bienestar subjetivo revelado. Concretando, a nivel empírico y tomando como base los resultados de la Encuesta Mundial de Valores para Galicia proponemos la construcción de una función microeconométrica que incorpore aquellos factores explicativos de la felicidad. Al mismo tiempo, analizaremos la evolución de los niveles de satisfacción subjetiva revelada (felicidad) y sus determinantes para obtener una visión general de la sociedad gallega. En definitiva, la vinculación de las diferencias interindividuales a las características sociodemográficas nos permitirá encontrar factores potencialmente explicativos de la configuración de dicha experiencia a través de sus determinantes biológicos (edad, personalidad...), estructura social (posición en las jerarquías, redes de pertenencia, nivel de renta...) y fuerzas sociales (libertad, capacidades, oportunidades vitales...). Adicionalmente, la pregunta que cabe plantearse es si la evolución de la percepción de la felicidad por la sociedad gallega se ajusta a las predicciones de la paradoja de Easterlin, es decir, se trata de verificar si se observa una tendencia al estancamiento en los niveles de bienestar paralela al incremento en los niveles de renta.

La estructura de este capítulo se puede resumir como sigue. En el siguiente apartado se procede a una delimitación del concepto de felicidad junto con la correspondiente justificación de la utilización del bienestar subjetivo revelado como indicador básico para el posterior análisis estadístico-econométrico. A continuación se aborda la naturaleza paradójica de la relación entre renta y felicidad, así como las posibles explicaciones de la misma. Posteriormente se propone una visión más holística del concepto de felicidad. Esta revisión nos permite fundamentar la construcción de una función que identifique los principales determinantes de la felicidad a partir de los datos extraídos de la EMV en su oleada del 2008 en Galicia. Para concluir, a modo de corolario del modelo general, se ahonda en las relaciones observadas entre felicidad y sus variables explicativas a lo largo del período que abarca el estudio (1995-2008). Finalmente, se resumen las principales conclusiones.

El último ejemplo que constituye un claro exponente de los intentos de buscar alternativas a la medición del bienestar o incluso de la felicidad (una noción que en algún momento parecía absurdo cuantificar) es la publicación del Report by the Commission on the Measurement of Economic Performance and Social Progress, publicado el 14 de septiembre de 2009, coordinado por J. Stiglitz, A. Sen y J. P. Fitoussi y que fue elaborado por una comisión formada por 25 destacados científicos sociales entre los que se incluyen 5 premios Nobel de Economía 


\subsection{FELICIDAD: CONCEPTO Y MEDICIÓN}

Como punto de partida de nuestro análisis se impone el realizar algunas precisiones conceptuales con el fin de evitar la confusión que se puede derivar de la plena equiparación de conceptos entre los que existe un vínculo evidente, pero que no son sinónimos: calidad de vida, bienestar y felicidad.

La calidad de vida alude a "la percepción que un individuo tiene de su lugar en la existencia, en el contexto de la cultura y del sistema de valores en los que vive y en relación a sus objetivos y expectativas, sus normas y sus inquietudes. Se trata de un concepto muy amplio que está influido por la salud física del sujeto, su estado psicológico, su nivel de independencia, sus relaciones sociales, así como su relación con los elementos esenciales de su entorno" (WHOQOL Group, 1995). En esta línea, el Programa de las Naciones Unidas para el Desarrollo (PNUD) viene calculando el Índice de Desarrollo Humano, basado en los trabajos de A. K. Sen (1999). Este indicador estadístico, introduce variables en las tres dimensiones que se han revelado como esenciales: renta, educación y salud. Ahora bien, si desgranamos la definición previa debemos distinguir dentro del concepto de calidad de vida dos vertientes: la presencia de las condiciones consideradas necesarias para una vida buena y la práctica del vivir en cuanto tal. La calidad de vida a escala social solo puede entenderse bajo el prisma del primero de los significados. En cambio, si la aplicamos a escala individual el término puede usarse en ambas acepciones: disfrutar de las condiciones adecuadas en una vida realizada. Esto nos lleva directamente a las valoraciones individuales sobre las condiciones personales de vida como indicador social, esto es, el problema del bienestar subjetivo y la felicidad.

El concepto de bienestar es un constructo abstracto con connotaciones subjetivas, pero que está correlacionado con factores económicos objetivos. Así, el bienestar individual alude a la conciencia que tiene cada individuo de haber cubierto sus necesidades privadas. Por su parte, el bienestar social estaría originado por el hecho de que un elevado porcentaje de los individuos, que se integran en un determinado grupo social, satisfagan sus necesidades. En la medida en que esta noción de bienestar tiende a sustentarse en perspectivas de corte individualista y subjetivo, se puede aproximar a través de la percepción o valoración que los sujetos hacen de sus propias vidas. A su vez, dentro de esta percepción general se distinguen varias dimensiones del bienestar subjetivo: bienestar económico, bienestar psicológico y bienestar social. En cada una de estas vertientes se resalta la valoración que el individuo realiza de su situación económica, de los estados afectivo-emocionales y psicológicos o de su funcionamiento social, respectivamente.

Uno de los objetivos sociales en la mayor parte de las economías avanzadas es lograr progresos en lo que denominamos Estado del Bienestar. Sin embargo, esta expresión induce a una importante confusión, ya que traduce la inglesa 
welfare que no es directamente equivalente, sino que se refiere a la sensación de seguridad o placer derivada de tener cubiertas buena parte de las carencias o necesidades sentidas, de modo que nos estaríamos refiriendo, más concretamente, a un Estado benefactor en la medida en que éste garantice unas necesidades básicas mediante un conjunto de actuaciones. El bienestar subjetivo (wellbeing), en cambio, alude a una valoración que del bienestar personal hace un sujeto vía encuesta.

En cuanto a la noción de felicidad, el primer problema que se plantea es la definición de lo que ésta constituye propiamente. En este sentido, Easterlin $(1995,2001)$ establece, como vía de simplificación, una identidad entre la felicidad y el bienestar subjetivo revelado o satisfacción expresada.

En general, para los economistas la palabra felicidad o bienestar subjetivo no es más que una valoración de la propia vida en sí misma, al margen de los juicios psicológicos sobre el placer momentáneo, esto es, hace referencia a cómo el individuo evalúa la calidad global de su vida (Veenhoven, 2000). Consecuentemente, el posicionamiento de los individuos dependerá íntegramente de una percepción individual $^{2}$ y está ligado directamente a los dos conceptos previos de calidad de vida y bienestar.

La Psicología por su parte, huyendo de las simplificaciones, ha tratado de delimitar las diversas dimensiones que componen el complejo que denominamos "felicidad". Esto le lleva a distinguir un componente cognitivo de autopercepción de la satisfacción vital, una dimensión afectiva o de vínculos relacionales del individuo y el bienestar subjetivo. Este último se identifica con un estado de bienestar general y permanente que incluye las dimensiones afectiva y cognitiva y sería, por tanto, sintético e identificable con la noción más estricta de felicidad (Ahuvia y Friedman, 1998). Ahora bien, en sentido estricto se pueden establecer diferencias entre la felicidad y la satisfacción subjetiva. Si bien la felicidad, al igual que la satisfacción, es una apreciación subjetiva de un individuo sobre su propia vida, la primera tiene una carga afectiva relativamente mayor (Argyle, 2002). No obstante, a pesar de las mencionadas diferencias, ambas variables manifiestan una elevada correlación.

En suma, la felicidad es un concepto más exigente e íntimo que el bienestar subjetivo y que la calidad de vida. Se trata de un estado personal extremadamente difícil de concretar, pero tal y como plantean Nussbaum y Sen (1993), es recomendable evitar el relativismo absoluto para converger en aquellas dimensiones de la vida que permitan aflorar lo que se suele considerar plenamente humano (educación, salud, libertad...). La realización humana conlleva el acceso a unos bienes materiales, a una educación, a una red de relaciones, para poder llevar el tipo de vida que, por la razón que sea, deseamos. Este progreso en la realización

Este punto la convierte en objeto de crítica por buena parte de los economistas neoclásicos e incluso algunos de orientación humanista (Sen). 
personal o humana redunda, como veremos, tanto en términos de felicidad como de libertad o dominio de la propia vida. Expresado de un modo simplificado, entendemos por felicidad sentirse bien, disfrutar de la vida y desear que ese sentimiento se mantenga. Por el contrario, aquellos que se manifiestan como poco felices revelan el deseo de un cambio decisivo de situación.

En principio, y de acuerdo con las anteriores consideraciones, podría pensarse que la felicidad, en la medida en que se trata de algo individual y propio de las circunstancias de cada sujeto, es algo que solo tangencialmente corresponde al análisis social. Sin embargo, si se reflexiona sobre los elementos intersubjetivos es posible delimitar un campo de análisis en donde los individuos son los mejores jueces sobre su situación personal.

A estos efectos, la Encuesta Mundial de Valores ofrece una amplia serie de indicadores de bienestar subjetivo o de felicidad revelada que resultan esclarecedores en tanto que permiten una cierta aproximación a la evaluación global que los individuos realizan de sus circunstancias personales y de toda la sociedad en su conjunto.

La citada encuesta constituye un referente contrastado esencial para el análisis de la evolución de las percepciones valorativas de cualquier sociedad. En la actualidad se dispone de una muy amplia base de datos a escala internacional (80 países) para un período superior a 25 años en oleadas de cinco años. Para el caso gallego, en el que nos centraremos, disponemos ya de tres oleadas $(1995,2001,2008)$ lo que nos permite tener una perspectiva temporal lo suficientemente amplia para analizar las trasformaciones socioeconómicas habidas en el último período ${ }^{3}$. En lo relativo a las variables en las que centraremos nuestro análisis empírico, la felicidad y satisfacción en sus diversos niveles queda recogida en un conjunto de cuestiones categóricas ordinales. Así, por ejemplo, la felicidad es abordada a través de la cuestión (v10) ¿Diría usted que es...". A esta cuestión caben cuatro respuestas gradadas: muy feliz, bastante feliz, no muy feliz y nada feliz.

Respecto a las dudas que pudieran surgir sobre la validez de las respuestas a este tipo de preguntas, hay que tener en cuenta que los individuos son conscientes de cómo se sienten ellos mismos y, además, la empatía les dota de la capacidad de analizar cómo se sienten los demás. Adicionalmente, conviene subrayar que los individuos, al responder a este tipo de preguntas, adoptan visiones de largo plazo. Es decir, implícitamente están considerando la situación media o las sensaciones permanentes. Por otra parte, al tratar la felicidad como una variable con una dimensión única, los individuos pueden situarse dentro de un continuum reflejando como se encuentran respecto a su vida en conjunto.

El universo de la EMV-Galicia es la población gallega mayor de 18 años. El tamaño muestral es 1.200 entrevistas (error muestral 2,9\%). 
Este sistema por el que optamos, por tanto, frente a las tradiciones de imputación y apriorísticas, como es el mismo $\mathrm{IDH}^{4}$, constituye una alternativa en la que se prioriza la valoración que el propio individuo realiza de su vida. Se trata de un enfoque propio del individualismo metodológico ya que, tanto la concepción del bienestar, la medición del mismo y los presupuestos dan la primacía a la propia valoración individual del bienestar. En definitiva, la investigación sobre las fuentes del bienestar individual revelado exige asumir un simple supuesto: que los individuos son capaces de evaluar su utilidad tomando en consideración sus circunstancias individuales, su posición respecto a otros, su experiencia pasada y sus expectativas de cara al futuro.

\subsection{LA NATURALEZA PARADÓJICA DE LA RELACIÓN ENTRE FELICIDAD E INGRESOS}

La relación entre riqueza, satisfacción y felicidad se ha convertido en una de las líneas esenciales de investigación en el campo de la socioeconomía. Desde una perspectiva puramente económica, la relación de la felicidad con la renta y el crecimiento económico ha resultado un tema, cuando menos, controvertido. En concreto, la evidencia empírica general sugiere una pérdida de significatividad del crecimiento económico y de la renta como variables determinantes de la felicidad, lo cual requiere ser explicado ${ }^{5}$.

Aunque pueda parecer más o menos evidente que el dinero no da la felicidad, el análisis económico tiende a asumir el axioma de la no saturación, que en su formulación más simple consiste en afirmar que siempre hay un bien para el que es preferible tener más que menos. Consecuentemente, los individuos con más renta real pueden acceder a paquetes de bienes superiores, lo que les permitiría mejorar en su nivel de bienestar. Sin embargo, los estudios realizados para un amplio conjunto de países arrojan resultados un tanto contraintuitivos.

Por ejemplo, la tendencia dominante en los EE. UU. y Japón es hacia la estabilización o incluso al leve decrecimiento de los niveles de bienestar subjetivo percibido y para las más importantes economías europeas se aprecian leves incrementos y en algún caso también estancamiento y reducción con escasa significatividad estadística (DiTella et al., 1999). En general, las poblaciones de sociedades más ricas revelan niveles de bienestar subjetivo superiores, aunque se produce una considerable igualación de los mismos a partir de un determinado umbral de riqueza.

En la imputación se recurre de modo apriorístico a una estimación a partir de indicadores objetivos externos del bienestar individual y social. En estos métodos partimos de un presupuesto sobre los determinantes de la felicidad e imputamos a los individuos un determinado nivel de bienestar subjetivo en razón de variables objetivas. Nuestro método, por el contrario, es inferencial, ya que a partir de las respuestas de los individuos derivamos la construcción de una función de bienestar subjetivo.

5 Véanse al respecto Kahneman, Diener y Schwarz (1999); Frey y Stutzer (2000), Easterlin (1974 y 2001), Oswald (1997) y Putnam (2000). 
En esta línea, los estudios desarrollados por Layard (2005) ponen de manifiesto que, aunque existe un tendencia a que los países más ricos tengan índices de felicidad más altos $\left(R^{2}=0,72\right)$, es posible identificar un numeroso conjunto de países con renta per cápita más baja que se sitúan por encima de otros con rentas superiores. Asimismo, aquellos países con importantes crecimientos en su renta han experimentado mejoras en sus niveles medios de felicidad (México, India, Brasil...) pero no directamente proporcionales sino sometidos a la "ley de rendimientos decrecientes" ${ }^{6}$. En este sentido, Layard concluye que los ingresos adicionales son significativamente valiosos cuando sirven para elevar a las personas por encima del umbral de la verdadera pobreza física. Dicho de otro modo, la ley de los rendimientos marginales decrecientes se puede aplicar tanto a la renta como a todo lo que la renta puede comprar, esto es, aumentos sucesivos en los niveles de renta generan elevaciones progresivamente menores del bienestar subjetivo, hasta el punto que se podrían justificar niveles de incremento cero o negativos (desutilidad).

Otro de los resultados más destacables que arroja la evidencia empírica disponible es la existencia de un claro vínculo entre nivel de renta y bienestar subjetivo revelado dentro de cada economía y particularmente, cuando ésta es poco desarrollada. La riqueza de un país presenta una relación directa con la capacidad de satisfacción de las necesidades básicas cotidianas, por esta misma razón, el vínculo entre bienestar y renta es notablemente más claro en los países menos desarrollados que en los de mayor nivel de renta. Esta constatación sugiere que una vez alcanzada la satisfacción material básica las relaciones entre las variables mencionadas se tornan notablemente más complejas.

Ahora bien, a efectos de evitar posibles interpretaciones erróneas, es importante aclarar que en un país determinado y en un momento dado, la correlación entre nivel de ingresos y felicidad es sólida. Es decir, quienes tienen más renta se declaran porcentualmente más felices que quienes tienen menos renta. Esta relación se mantiene, aunque de forma sensiblemente más débil, cuando otros factores ligados a la renta son controlados (salud, educación...).

Realizadas las anteriores consideraciones estamos en condiciones de introducir la paradoja de Easterlin, cuya formulación es bastante simple: en las sociedades desarrolladas las elevaciones de los niveles de renta no generan un incremento en los niveles generales de bienestar de los individuos ni del colectivo, aunque existe una relación directa entre niveles de bienestar individual e ingreso personal.

Para explicar esta aparente paradoja se han avanzado una serie de hipótesis que atacan, desde la heterodoxia más próxima a la socioeconomía, las limitaciones consustanciales al enfoque predominante (mainstream) de la ciencia económica. Este último se concentra en las variables de tipo material (ingreso, consumo,

A título de ejemplo, se observa que a partir de los 20.000 dólares per cápita los incrementos sucesivos de renta no implican incrementos significativos en los niveles de felicidad.

FELICIDAD, BIENESTAR SUBJETIVO... 307 
riqueza) y abandona, por su difícil formalización o no ser directamente controlables, las de tipo social (aspiraciones, libertad, capital social, salud...). A continuación se sintetizan aquellas propuestas que consideramos más destacables.

Inglehart (1996), por ejemplo, ha avanzado como explicación la hipótesis de que las sociedades que presentan esta paradoja están en una fase de transición entre dos visiones del mundo: la materialista y la posmaterialista. Detrás de esta sustitución en los sistemas de valores se encuentra la combinación de elevadas tasas de crecimiento económico y los notables progresos en el Estado del Bienestar. Tal y como afirma este autor, para una nueva generación el crecer con la conciencia de que la supervivencia está garantizada se traduce en una sensación de seguridad existencial que, unida a la disposición de mayores niveles de renta, constituye la variable clave a la hora de explicar la emergencia del posmaterialismo. Éste fenómeno se ha venido evidenciando en las economías desarrolladas desde los años setenta del siglo pasado, cuando se incorporaron a la edad adulta las primeras generaciones que vivieron estos nuevos contextos. Para este grupo social las mejoras económicas adicionales no generan incrementos significativos en el bienestar si este aumento conlleva caídas en los componentes no-materiales de la calidad de vida.

En una línea similar, Hirschman (1982) sugiere la idea de la existencia de un ciclo generacional de carácter pendular. La generación siguiente asume como naturales los niveles de bienestar y logros materiales de la precedente, por consiguiente, las aspiraciones surgen en otros ámbitos (por ejemplo, lo político o lo social). No obstante, los progresos en estas áreas tropiezan con el mismo problema de rendimientos decrecientes, de forma que las generaciones futuras pueden retornar sobre objetivos de corte materialista, abandonando pretensiones políticas o sociales.

En conjunto, al margen de las dificultades de contrastación de las citadas hipótesis, lo que puede afirmarse es la decreciente capacidad de la renta en términos agregados para proporcionar mayores cotas de bienestar. Además, por encima de los niveles de pobreza, las diferencias de bienestar dentro de un país presentan una relación más tenue con los niveles de renta de lo que cabría esperar. De hecho, los más ricos solo manifiestan una ligera mayor propensión a considerarse felices.

Esta constatación es coherente con la máxima de que la felicidad parece guardar más relación con desear lo que se tiene que con obtener lo que se desea. Para explicar este resultado la literatura sobre el posmaterialismo habla de la "noria hedónica" (hedonic treadmill) o el binomio logros-aspiraciones. Esto significa básicamente que a medida que aumentan los logros del individuo también lo hacen sus aspiraciones, con lo cual el nivel de satisfacción se mantendría inalterado. En otras palabras, una parte de la población podría optar por incrementar su renta como medio para incrementar su nivel de bienestar subjetivo, sin tener en cuenta 
los costes derivados en otras dimensiones. De modo semejante, si se adopta la perspectiva del bienestar psicológico, los datos vienen a confirmar que cuanta más importancia se le confiere a los objetivos materiales o financieros menor es el bienestar subjetivo, mientras que, por el contrario, el progreso en el logro de objetivos de índole más intrínseca lo aumenta (Ryan y Deci, 2001).

La teoría de la renta relativa desarrollada por Duesenberry (1949) afirma que la satisfacción que una persona obtiene de sus ingresos no depende del nivel absoluto de los mismos, sino de su nivel relativo. De este modo, la satisfacción o bienestar subjetivo de una persona estaría positivamente relacionada con su nivel de ingresos y negativamente con los ingresos de los demás. Por lo tanto, en un contexto extremo en el que solo importen los ingresos relativos, los efectos de una elevación de la renta personal podrían verse disminuidos e incluso eliminados, si estos fuesen asociados a una elevación general del nivel de renta. Concretamente, los resultados aportados por Layard (2005) ponen de manifiesto que si los ingresos generales se incrementan a la par, nuestra felicidad ascendería, pero solo dos tercios de lo que lo hubiese hecho si solo se incrementase nuestra renta (Layard, 2005). Si ligamos esta explicación con la noria hedónica, nuestra felicidad dependerá fundamentalmente de nuestros ingresos en relación a nuestras aspiraciones y éstas, a su vez, dependen de los ingresos medios de las personas de nuestro entorno. No obstante, conviene aclarar que este efecto no solo es generado por las comparaciones de sesgo envidioso, sino también por la pugna por el logro de bienes posicionales, es decir, bienes de lujo con oferta inelástica en el largo plazo y elevada elasticidad renta (automóviles de lujo, obras de arte...). Estos bienes escasos, cuya posesión marca las jerarquías sociales, ven incrementada su demanda exponencialmente cuando se incrementa el crecimiento económico.

Un último tipo de explicación a la paradoja de Easterlin tiene que ver con las características de los bienes consumidos. Es preciso distinguir entre bienes defensivos y bienes creativos. Los primeros son productos destinados a impedir o remediar daños y, los segundos, productos destinados a generar una satisfacción. Aunque esta división puede resultar un tanto ambigua, sin embargo, puede afirmarse que conforme crece el PIB, crece la carga de bienes defensivos como consecuencia del crecimiento del ámbito del mercado en la vida social.

Teniendo en cuenta todo lo anterior, podríamos afirmar que cada individuo tiene unas características más o menos innatas y que en función de las mismas alcanza un determinado nivel de felicidad que experimenta leves variaciones a lo largo de toda su vida. Cuando el nivel de renta aumenta se produce un incremento de bienestar subjetivo durante algún tiempo para, una vez adaptados a la nueva situación, retornar al nivel de satisfacción de referencia. Así, tal y como señala Easterlin, aunque en el corto plazo los que poseen más ingresos son más felices, si consideramos el ciclo vital en su conjunto, la felicidad media de un 
grupo permanece constante, aunque exista un incremento notable en su nivel de ingresos (Easterlin, 2001). Los individuos una vez alcanzados sus objetivos, modifican al alza sus aspiraciones para retornar nuevamente a las posiciones de partida en cuanto a nivel de satisfacción. Layard (2005), llega a concretar que el grado de adaptación puede llegar a alcanzar el 40\% del incremento de satisfacción generado por una elevación de la renta. Consecuentemente, el ingreso al que se aspira, el que podría ser considerado como suficiente para satisfacer las necesidades de la familia, es endógeno al ingreso del que se disfruta y se incrementa conforme éste aumenta. De este modo, la brecha aspiracional no se reduce conforme el ingreso se eleva. Así, es posible encontrar personas con elevados niveles de ingreso con una brecha aspiracional porcentualmente mayor que individuos de bajos ingresos (Stutzer, 2004).

En síntesis, los individuos dedican demasiados recursos a aumentar los ingresos porque creen que así mejorará su nivel de vida y de satisfacción personal, resultando que dichos recursos se utilizan ineficientemente, no solo porque se da una adaptación a la nueva situación, sino que además existen efectos colaterales negativos. Los individuos no dejan de percibir que, a causa de la adaptación hedónica y de la pugna social, las aspiraciones se modifican en función de las circunstancias efectivas. Por consiguiente, se dedica una cantidad de tiempo desproporcionada a la obtención de objetivos monetarios, a expensas de la vida familiar y la salud, disminuyendo el bienestar subjetivo respecto al nivel esperado. Un cambio de asignación del tiempo que diera preeminencia a la vida familiar y a la salud aumentaría el bienestar subjetivo.

De lo señalado anteriormente resulta en extremo difícil ofrecer un modelo integrador que permita dar cuenta de la variada casuística existente. Ryan y Deci (2001) concluyen que lo único que es posible afirmar es que evitar la pobreza, vivir en un país desarrollado y tener objetivos vitales no directamente relacionados con logros materiales está directamente asociado a mayores niveles de felicidad y que, a partir de un cierto umbral, los incrementos de renta tienen escasa traducción en los niveles de bienestar subjetivo revelado.

\subsection{UNA PERSPECTIVA HOLÍSTICA: RETORNANDO A ARISTÓTELES}

La práctica totalidad del pensamiento filosófico clásico premoderno desde Aristóteles sostuvo el carácter de la felicidad, entendida como "vida buena", como fin último de la acción humana. Ahora bien, la felicidad no era concebida como una realidad estática, sino como una actividad (Ética a Nicómaco, 9) o, tal y como lo interpreta MacIntyre (1988), como la condición del estar bien y del hacer estando bien. Es claro que esta definición tiene un evidente componente ético y no puede identificarse con el reduccionismo hedonista. 
Para esta aproximación clásica la felicidad presenta al menos dos rasgos paradójicos: la socialidad y la calidad de la felicidad.

Desde la perspectiva aristotélica el hombre es esencialmente un ser social, con lo que la felicidad tiene una dimensión relacional, es decir, depende también de relaciones sociales, lo que denominaremos bienes relacionales (Nussbaum, 1993). Consecuentemente, este objetivo vital (la felicidad) no puede lograrse de modo instrumental, sino que surge como resultado indirecto de acciones que se apartan de la necesidad estricta. Es decir, aunque el objetivo esencial de ser feliz es de carácter individual, el logro del mismo no es resultado exclusivo de una actividad del individuo orientada a tal efecto. Este problema podría ser enunciado como la fragilidad de la eudemonía ${ }^{7}$, puesto que depende de los otros (bienes relacionales) y de la libertad.

Además, nos enfrentamos al problema de la calidad de la felicidad. Tal y como planteaba Stuart Mill (1851), la felicidad guarda relación con el desarrollo cultural y, en particular, con el capital humano, con lo que puede variar tanto en cantidad como en calidad en función del tipo de experiencia individual. En la medida en que calidad y cantidad de felicidad no son perfectamente sustituibles, ambas han de tenerse en consideración. De hecho, menor cantidad de una clase más elevada es preferible a una mayor cantidad de una clase más baja y la determinación del grado de calidad queda establecida por la preferencia de quienes tienen conocimiento de ambas. Recogiendo el ejemplo de Mill, Sócrates preferiría ser un Sócrates insatisfecho a un cerdo satisfecho; el cerdo probablemente no; pero el cerdo solo conoce un lado de la cuestión, y Sócrates conoce ambos.

La idea de felicidad que está proponiendo Stuart Mill pasa a formar parte de toda la tradición clásica en el ámbito de la economía hasta Keynes y podría quedar recogida en la siguiente afirmación: la felicidad depende de un complejo conjunto de variables extraeconómicas que van desde la religión y el problema del sentido de la vida hasta las relaciones personales, por tanto, es un fenómeno de naturaleza social. No obstante, aunque la extrema pobreza no significa automáticamente la infelicidad, dificulta de hecho las condiciones objetivas que hacen posible desarrollar aquellas dimensiones vitales de las que depende. Este supuesto elemental y la orientación cuantitativista de la Economía dieron lugar a una limitación del enfoque a las cuestiones materiales marginando otras más difícilmente cuantificables que ya hemos mencionado.

Frente a este reduccionismo, la perspectiva de las capabilities de Sen opta por distinguir en el más puro sentido aristotélico entre felicidad, como equivalente a satisfacción material, y eudamonía como cumplimiento de la naturaleza

El término eudemonía es central en la ética aristotélica al plantear que el único objetivo de la vida humana es el logro de una "vida buena". 
humana (human flourishing) (Nussbaum y Sen, 1993 y 1999). A partir de este planteamiento, este autor cuestiona el verdadero contenido informativo de los indicadores económicos tradicionales como reveladores del nivel de vida. Consecuentemente, la concepción del desarrollo evoluciona desde una identificación del mismo con los ingresos hacia una visión que lo asocia más bien a la ampliación de capacidades o posibilidades en manos de los ciudadanos, lo cual puede ser interpretable incluso en términos de libertades. Así, el desarrollo humano posee una doble dimensión ${ }^{8}$ : en primer lugar, la formación de las capacidades humanas (renta, salud y conocimientos) y, por otra parte, el uso que la población hace de esas capacidades adquiridas (descanso, producciones y actividades culturales, sociales y políticas). Por lo tanto, el análisis del desarrollo a través de la renta es una posible vía de aproximación pero no excluyente. En una línea similar, Rawls (1971) analiza y define los bienes primarios como aquellos que precisan los individuos cualesquiera que sean sus fines. Concretamente, se trata de medios de uso general que ayudan a todos los miembros a promover sus objetivos vitales y comprenden las libertades, las oportunidades, la renta y las bases sociales del respeto a uno mismo.

En general, los trabajos de estos autores son pioneros en el reenfoque de este problema reclamando el carácter eudemonista de cualquier ciencia humana o social. Este tipo de estudios divergentes de la metodología económica más convencional permite adoptar un nuevo enfoque sobre problemas esencialmente económicos que precisan una aproximación más holística. En concreto, esta revisión es trascendental desde el punto de vista de la política económica, en la medida en que un replanteamiento de los objetivos últimos de toda actuación pública puede suponer alterar tanto la dirección de los instrumentos manejados como los propios instrumentos.

\subsection{UNA APROXIMACIÓN EMPÍRICA A LA FUNCIÓN DE FELICIDAD DE LOS GALLEGOS}

En el marco de esta línea revisionista de los vínculos entre renta, ingreso o crecimiento económico con desarrollo o bienestar, el estudio de bienestar subjetivo declarado resulta especialmente significativo, en orden a identificar una función microeconométrica de bienestar o felicidad, en la que se incorporen determinantes de muy diverso carácter: sociales, individuales, económicos, políticos, etc.

Como ya hemos señalado, parece obvio afirmar que la naturaleza última del ser humano es su carácter social o relacional y en consecuencia, que nuestra felicidad o infelicidad va a depender en buena medida de la cantidad y calidad

8 Realmente, Sen participa de una amplia tradición de pensamiento que puede remontarse hasta Aristóteles y en la que la prosperidad se identifica con capacidades y posibilidades más que con la renta. La vertiente más reciente de esta tradición es el Programa de las Naciones Unidas para el Desarrollo, (PNUD) en sus informes desde 1990. 
de las relaciones establecidas con los otros. Es precisamente en este punto, donde se hacen más evidentes las limitaciones del enfoque tradicional de la ciencia económica centrado en la existencia de un agente individual separado (in-dividuum) y que considera la dimensión relacional de la existencia humana como algo extrínseco, accidental o instrumental (Peiro, 2004). Junto a este factor clave, la literatura teórica sobre el tema (Frey y Stutzer, 2002; Layard, 2003 y 2005; Veenhoven, 1993; 2000 y 2001; Easterlin, 1974; Frey y Stutzer, 2000) ha identificado los siguientes determinantes socioeconómicos de la felicidad de los individuos:

- La salud individual y del entorno familiar presenta una fuerte relación bidireccional.

- La existencia de una red de relaciones sociales o el capital social y los bienes relacionales. En concreto el estado civil parece guardar una relación fuertemente directa con el nivel de bienestar.

- La situación laboral, esto es, la incorporación o no al mercado de trabajo ha resultado determinante, tanto por su capacidad de generación de ingresos como por el desarrollo de las capacidades creativas y sociales.

- La edad. La felicidad no es constante a lo largo de la vida, la interrelación con otras variables como la salud y los ingresos apunta a un decrecimiento de la felicidad con la edad.

- La estabilidad y desarrollo político de la sociedad pueden influir de forma decisiva en la generación de redes de participación y confianza ciudadana.

- Los valores. Detrás del problema de la felicidad se encuentra también un cierto problema de cultura vital o de primacía de un determinado tipo de valores.

- La renta y su distribución. El nivel de renta está asociado positivamente con el grado de felicidad, en tanto que la desigualdad económica lo está negativamente.

Un primer análisis de las correlaciones de Spearman sobre los resultados de la Encuesta Mundial de Valores realizada para Galicia (Tabla 10.1) nos permite establecer unas relaciones básicas que serán de gran utilidad para nuestro análisis posterior. Al mismo tiempo, estas correlaciones nos anticipan las interrelaciones existentes entre los diversos determinantes. 


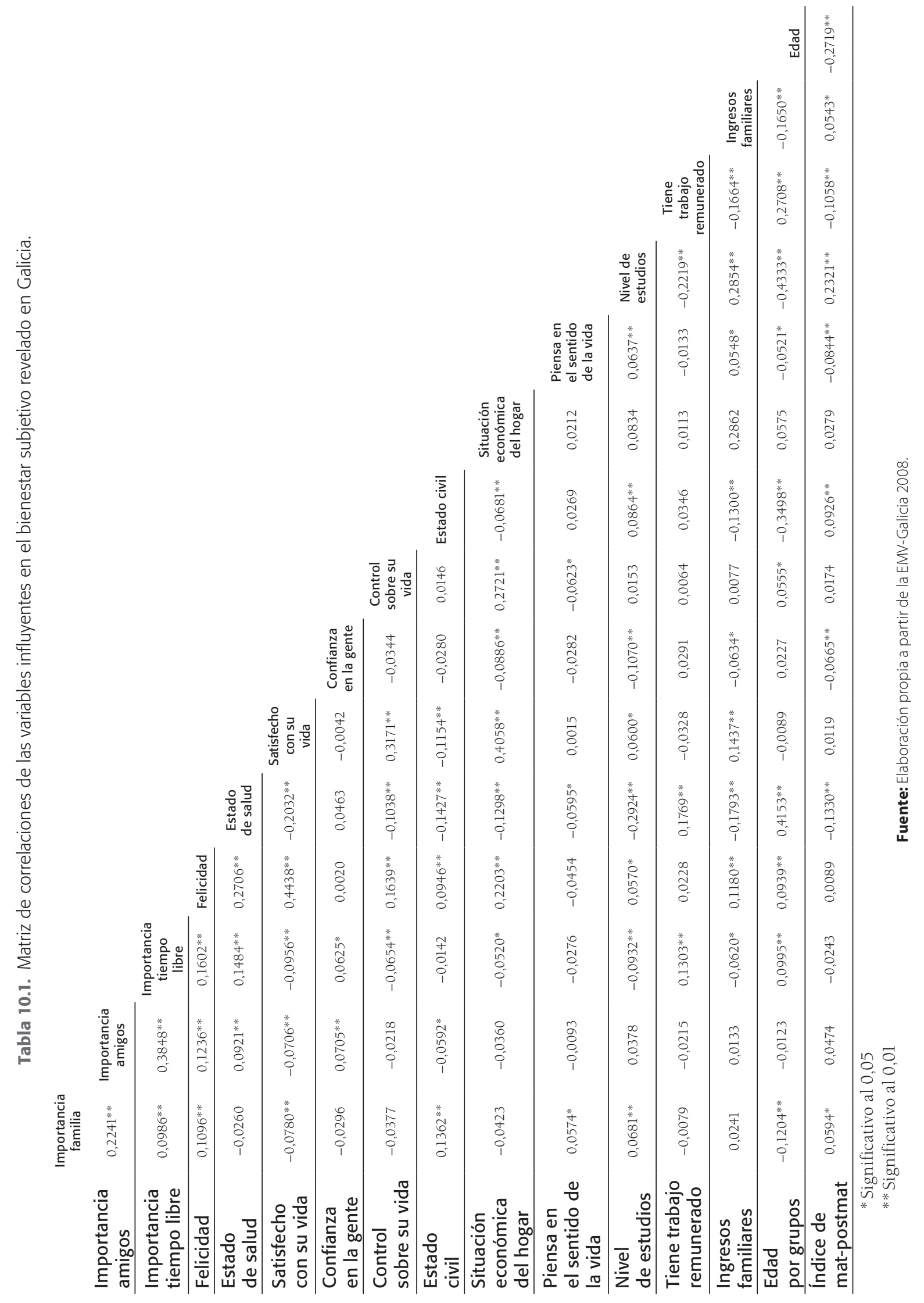


Una primera asociación evidente que se desprende de la tabla de correlaciones es el vínculo existente entre la felicidad y la salud individual. A su vez, también se observa una relación fuertemente significativa entre felicidad y la dotación de una red de relaciones sociales, esto es, el capital social. Ahora bien, es preciso realizar una importante puntualización. Los lazos sociales relevantes parecen ser solo los que podríamos denominar de bonding y bridging, es decir, los lazos familiares y la red de amistad o reciprocidad, no la sociabilidad general. Así, la relación entre felicidad y confianza generalizada es prácticamente irrelevante o no significativa.

Por otra parte, merece ser destacada la robustez de la influencia de la variable "estado civil". En particular, aquellos individuos que presentan una mayor estabilidad en sus vínculos (casados o en pareja) tienden a mostrarse notablemente más felices que los restantes.

Como es lógico, los ingresos familiares y la situación económica del hogar guardan relación directa con los niveles de felicidad expresados. Sin embargo, conviene anticipar que esta relación debe ser analizada pormenorizadamente.

En lo que respecta a la incorporación o no al mercado de trabajo, aunque a primera vista parece no tener una importancia decisiva, dada la variedad de posibles situaciones (inactivos, activos, ocupados, en formación...), el análisis que realizaremos posteriormente revela la existencia de importante vínculo entre la felicidad y esta variable.

Los perfiles valorativos (sistema de valores) de los individuos son otro de los factores que condicionan significativamente su bienestar subjetivo. En particular, el reconocimiento de la importancia de la familia y los amigos, así como del tiempo libre, parece incuestionable. No obstante, contrariamente a lo planteado por Inglehart (1996), la presencia de rasgos posmaterialistas resulta claramente no significativa.

Finalmente, la edad aparece inversamente relacionada con la felicidad, si bien es cierto que este vínculo está condicionado por la evidencia de que la evolución de la salud y los ingresos están estrechamente asociadas a esta variable.

En otro orden de cosas, puede observarse una práctica identidad entre los conceptos "felicidad" "satisfacción vital" y "libertad y control sobre su vida". En tanto que resulta obvia la relación entre las dos primeras, la identidad con la tercera ya había sido resaltada por el enfoque humanista. La felicidad puede ser entendida como un progreso en el proceso de humanización y se traduce por una mayor libertad y realización personal percibida por parte de los individuos.

Llegados a este punto del análisis, y a efectos de la construcción de una función de felicidad de los gallegos, se procede a la estimación econométrica de la siguiente función:

Felicidad $=\alpha+\beta_{1}$ satisfacción económica $+\beta_{2}$ situación familiar $+\beta_{3}$ salud $+\beta_{4}$ valoración de redes personales $+\beta_{5}$ valoración tiempo libre 
La estimación realizada mediante un análisis de regresión Logit nos permitirá determinar cuales son las variables explicativas a la hora de que los individuos se manifiesten como felices. En un primer modelo (Tabla 10.2) optamos por considerar exclusivamente las variables significativas relativas al grupo de aquellos que se autodefinen como muy felices frente a los restantes grupos (en el caso gallego en torno al 28\% de los entrevistados). Los resultados tienen una más que aceptable capacidad explicativa $\left(0,4\right.$ pseudoR ${ }^{2}$ de Nagelkerke) y los coeficientes estimados son altamente significativos. Concretamente, los resultados de la estimación sugieren claramente que existen tres bloques de factores que están influyendo de forma decisiva: salud, entramado social de referencia y percepción de su situación económica.

En lo que se refiere a la valoración del propio estado de salud, aunque es evidente que existe una influencia bidireccional entre ambas variables, aquellos individuos que tienen una valoración positiva sobre su estado de salud tienden a manifestarse como más felices. En segundo lugar, nos encontramos con un conjunto de tres variables claramente axiológicas o valorativas y vinculadas con la red de relaciones sociales de la que disponen los individuos. Aquellos sujetos que le conceden una mayor importancia a la familia y a la red social de pertenencia y que consideran esencial la disposición de un tiempo libre para su desarrollo personal se manifiestan considerablemente más felices. En este mismo sentido la estabilidad de la situación familiar (casados y parejas estables) ejerce una influencia significativa. Finalmente, el nivel de ingresos, tal y como hemos señalado, guarda una relación directa, ahora bien, la variable más explicativa en esta dimensión no es el ingreso en cuanto tal, sino la valoración subjetiva del nivel de renta. Esta variable guarda una relación con el nivel de ingresos, pero toma en consideración también las aspiraciones y acomodación a los mismos.

Tabla 10.2. Determinantes de los que se declaran muy felices en Galicia.

\begin{tabular}{ccc} 
Variables en la ecuación & Coef. & Sig. \\
Estado de salud & 1,158 & 0,000 \\
\hline Importancia de la familia & 0,885 & 0,034 \\
\hline Importancia de las redes de amigos & 0,489 & 0,050 \\
\hline Importancia del tiempo libre & 0,882 & 0,000 \\
\hline $\begin{array}{c}\text { Satisfacción con la situación económica } \\
\text { del hogar }\end{array}$ & 0,418 & 0,000 \\
\hline Situación familiar & 1,055 & 0,004 \\
\hline Constante & 1,922 & 0,077 \\
\hline
\end{tabular}

Fuente: Elaboración propia a partir de la EMV 2008. 
En el segundo modelo desarrollado (Tabla 10.3), el análisis de regresión se realiza sobre los factores que influyen en que los individuos se sitúen en el grupo de los que se afirman como muy felices, así como bastante felices. En este caso, se trata de un grupo más amplio que el que nos sirvió de referencia para la estimación del primer modelo. Por exclusión, en este modelo estamos analizando igualmente las variables más influyentes en aquellos que se autodefinen como no felices o poco felices.

Nuevamente, resultan decisivas las variables axiológicas entre las que destacan el reconocimiento de la importancia de la familia, las redes relacionales y el tiempo libre. Paralelamente, la salud sigue siendo una variable con una elevada capacidad discriminante, sin embargo, la renta y situación familiar pasan a un segundo plano. En este caso presentan un mayor poder explicativo el nivel de estudios y el tamaño del municipio de residencia. En lo que respecta al primero, éste guarda una elevada relación con el nivel de ingresos pero al mismo tiempo está más ligado al nivel de desarrollo humano general. Finalmente, el tamaño del municipio está directamente vinculado a la centralidad municipal y al acceso a los bienes y servicios urbanos (educación, salud...).

Si realizamos una lectura a la inversa, aquellos que se manifiestan como menos felices en Galicia son aquellos con entornos familiares menos estables, peores condiciones de salud, bajos niveles educativos y residentes en municipios de escasa dimensión.

Tabla 10.3. Determinantes de los que se declaran felices en Galicia.

\begin{tabular}{ccc} 
Variables en la ecuación & Coef. & Sig. \\
Importancia de la familia & 0,861 & 0,001 \\
\hline Importancia de las redes de amigos & 0,536 & 0,024 \\
\hline Importancia del tiempo libre & 0,531 & 0,006 \\
\hline Estado de Salud & 1,109 & 0,000 \\
\hline $\begin{array}{c}\text { Tamaño del municipio } \\
\text { de pertenencia }\end{array}$ & 0,336 & 0,013 \\
\hline Nivel de estudios & 0,347 & 0,003 \\
\hline Constante & 3,406 & 0,000 \\
\hline
\end{tabular}

Fuente: Elaboración propia a partir de la EMV-Galicia 2008.

Los resultados de las estimaciones econométricas también son interpretables en términos de dominios de vida. La satisfacción vital depende de la satisfacción en ámbitos concretos de la propia vida: dominio laboral, dominio económico, 
dominio familiar, dominio de tiempo libre. Algunos estudios previos (Rojas, 2007) han puesto de manifiesto que el dominio con mayor peso en la satisfacción vital es el de la familia, y le siguen en importancia el de la salud y el tiempo libre. De menor importancia, aunque estadísticamente significativos, son el dominio laboral y económico. Este último dominio muestra una clara relación con la satisfacción económica, pero menos influencia con la satisfacción vital. Los dos primeros, en cambio, están vinculados con los bienes relacionales, esto es, aquellas acciones desinteresadas de las relaciones humanas y guiadas por motivaciones intrínsecas que producen bienestar al generar experiencias afectivas positivas. Estos bienes tienen la particularidad de no guardar relación con el ingreso y ser tiempo-intensivos, con lo cual contribuyen a explicar que la relación entre ingresos y felicidad no sea tan directa.

En definitiva, la evidencia obtenida para el ámbito gallego viene a corroborar la obtenida en otros estudios realizados a nivel general (Layard, 2005), los factores determinantes de la felicidad más destacables son: la situación financiera y trabajo, las relaciones sociales con nuestra comunidad de referencia, nuestra salud y libertad personal y nuestros valores personales (Figura 10.1). De este modo, la "función de felicidad" derivada de los resultados de la muestra se aproxima a tendencias observadas en otras sociedades desarrolladas, pero refleja también particularidades del entorno gallego. Concretamente, la presencia de variables como el tamaño municipal trasluce las desigualdades de desarrollo socioeconómico y las singularidades de la demografía, es decir, la diversidad de entornos que caracterizan la sociedad gallega.

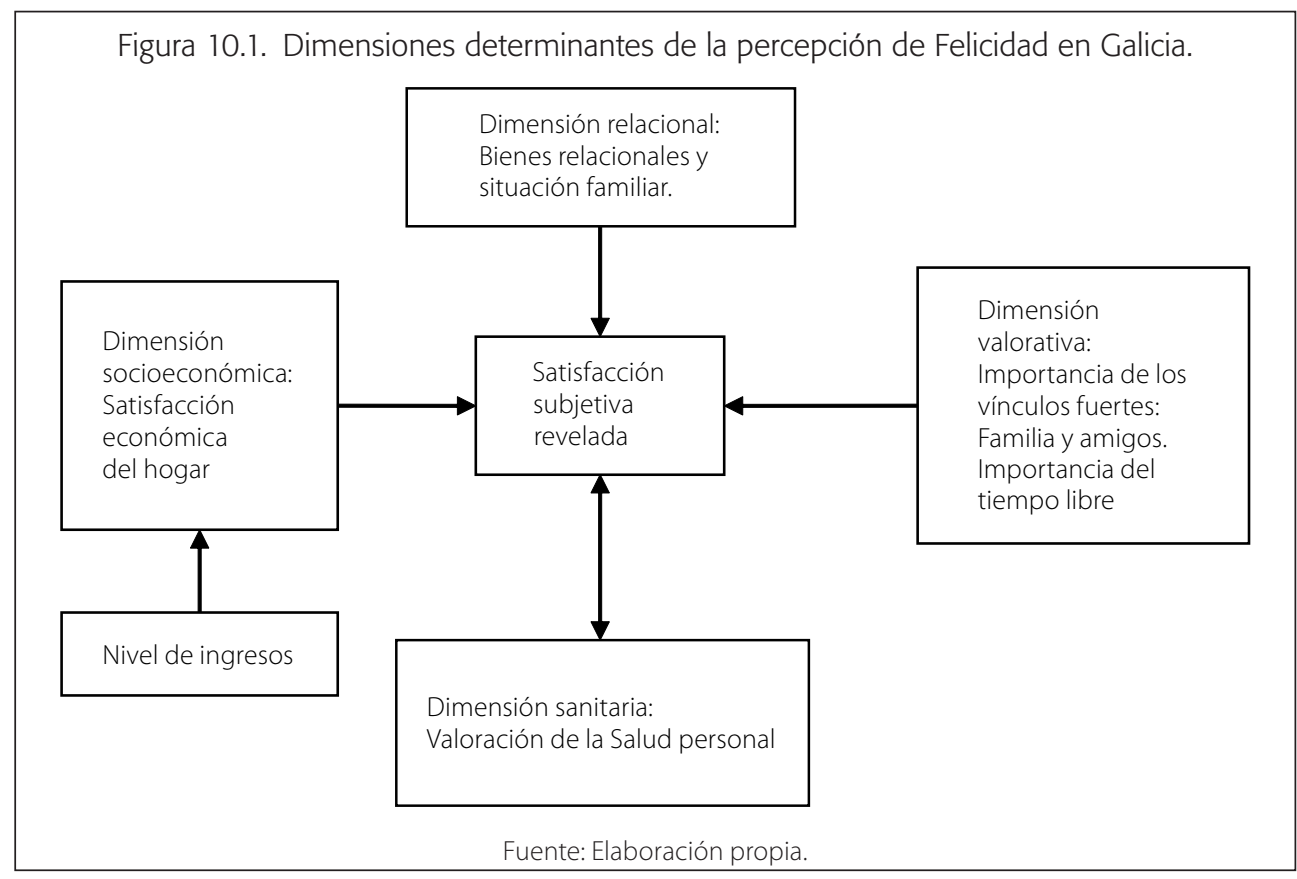




\subsection{TRAYECTORIA DE LA FELICIDAD Y SUS DETERMINANTES EN GALICIA}

La discusión de los resultados que se desprenden del anterior estudio econométrico puede completarse con el análisis descriptivo de la evolución, tanto de la variable dependiente en la ecuación de felicidad como de las variables explicativas de la misma.

\subsubsection{Percepción de la felicidad}

A primera vista, un simple seguimiento de la evolución de la percepción de la felicidad en Galicia (Gráfico 10.1) nos permite constatar dos hechos, por un lado, un muy elevado porcentaje de los gallegos se declara bastante o muy feliz (un porcentaje próximo al 90\%) y, por otro, la mejora experimentada en el período objeto de estudio (1995-2008). Dicha mejora se refleja tanto en la reducción del porcentaje de los que se declaran poco o nada felices (que pasan de cifras cercanas al 14\% a algo inferiores a un 10\%), como en el significativo incremento de aquellos que se declaran muy felices (pasan de un 16,4\% en el año 1995 a un 28,11\% en el 2008).

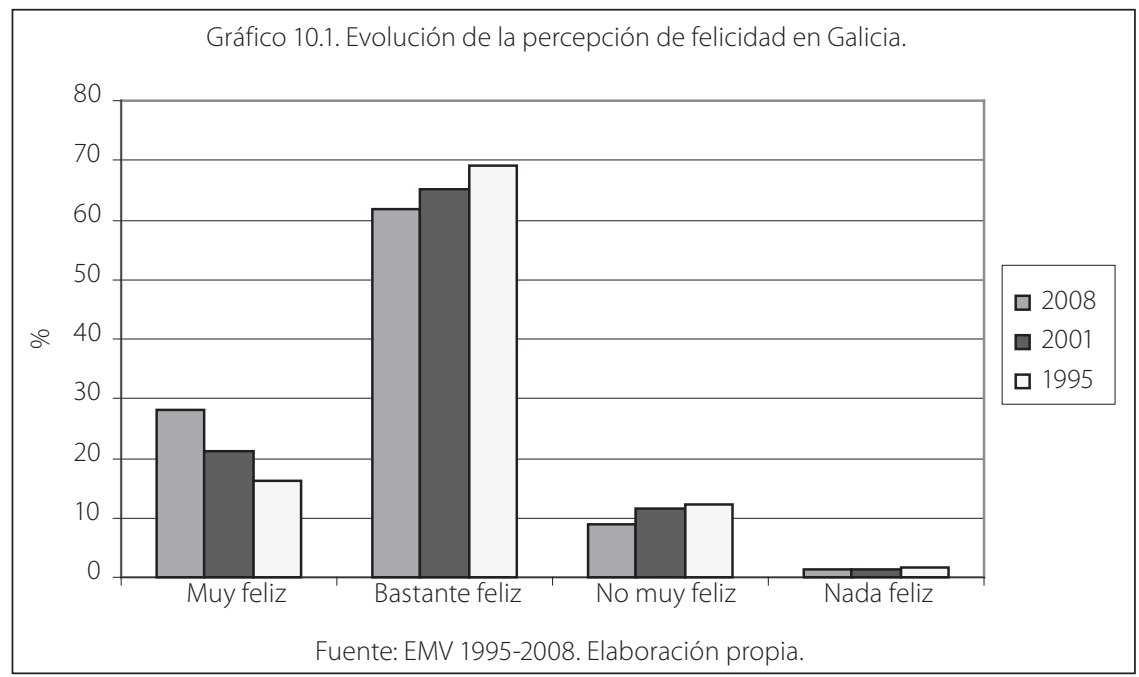

Esta evolución adquiere especial significación en la medida en que supone un notable distanciamiento del contexto general de la sociedad española (Gráfico 10.2). En efecto, para el conjunto de España se verifica una reducción del porcentaje de la población que manifiesta decididamente una elevada satisfacción subjetiva hasta situarse en el 13,6\% (frente al 28\% de los gallegos).

En términos generales se podría hablar de la aparición de una clase de satisfechos en la sociedad gallega que se aproxima a un tercio de la población. Junto a esto, es 
reseñable la ruptura de una tendencia conjunta que caracterizaba a las realidades gallega y española en la evolución de esta variable en el período que va desde el 2000 al 2008. Las causas son notablemente difíciles de determinar y podrían ser tanto de naturaleza económica (evolución de la renta, evolución de las coberturas sociales...) como sociales (particularidades de la sociedad gallega frente a la española...) y políticas. Estos factores no son escindibles los unos de los otros, de forma que habría que considerar el desarrollo socioeconómico en general.

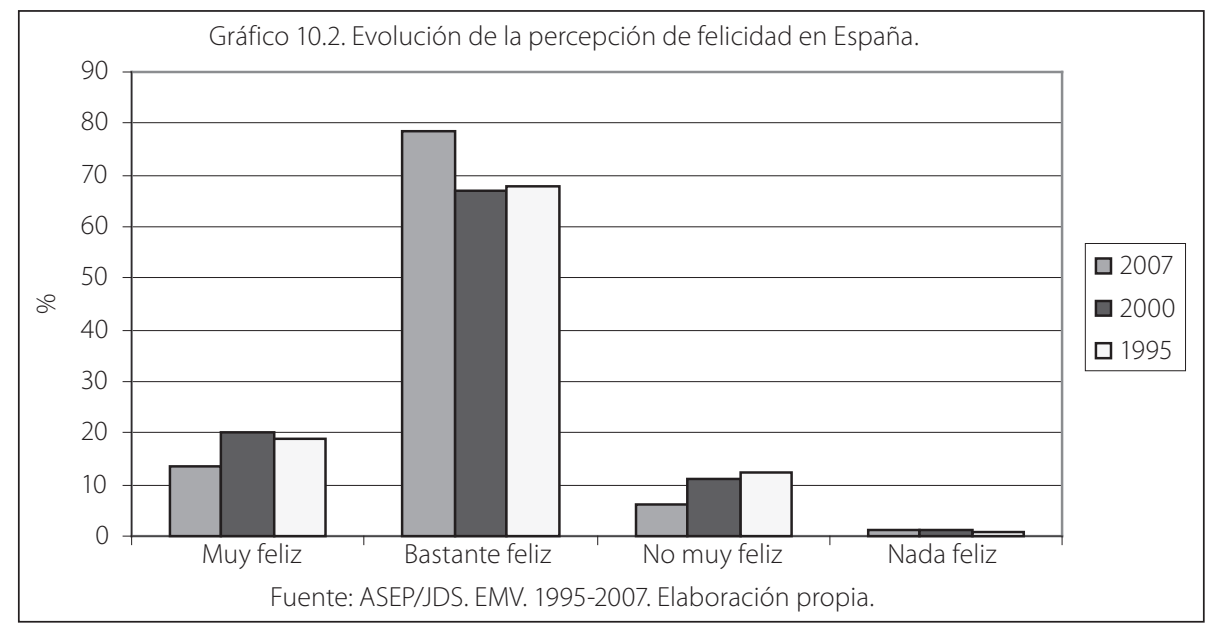

En el contexto de los países europeos para los que existen datos de la EMV, Galicia se sitúa claramente dentro de la tendencia general. Sobre el Gráfico 10.3 puede observarse la relación directa existente entre nivel de PIB, considerado en términos de paridad de poder adquisitivo, y el agregado de aquellos que se consideran muy o bastante felices. Pese a que se trata de un conjunto reducido de datos, concretamente diecinueve, podrían proponerse ya algunas lecturas ligadas a la hipótesis de Easterlin sobre la trayectoria conjunta de ambas variables. En principio una interpretación apresurada apreciaría una relación lineal, no obstante el mejor ajuste de ambas variables es una curvilínea logarítmica e incluso una función cuadrática ( $\mathrm{R}^{2}$ de 0,56 y 0,58 respectivamente). Ambas aproximaciones sugieren tanto la existencia de rendimientos decrecientes en la renta en su capacidad de "generación de felicidad" como, en el segundo de los casos, la posibilidad de incrementos sucesivos en el nivel de renta no den siempre lugar a mejoras en los niveles de satisfacción subjetiva revelada.

Nuestra aproximación a la evolución de la percepción de la felicidad puede complementarse con las respuestas de los gallegos a la pregunta sobre la satisfacción respecto a la propia vida (Gráfico 10.4). En consonancia con lo señalado anteriormente, los resultados ponen de manifiesto el crecimiento del grupo de los que pueden ser calificados como satisfechos. Pese a que en este estudio estamos considerando ambos conceptos como asimilables, conviene aclarar que algunos 
autores, generalmente provenientes del campo de la psicología, distinguen entre felicidad y satisfacción. Esta última supone un proceso cognitivo que involucra las aspiraciones del individuo, en tanto que la felicidad supone un estado afectivoemocional. Ahora bien, muchos factores asociados a la satisfacción vital son, en gran medida, semejantes a los que determinan la felicidad de forma que las trayectorias de ambas están directamente asociadas.

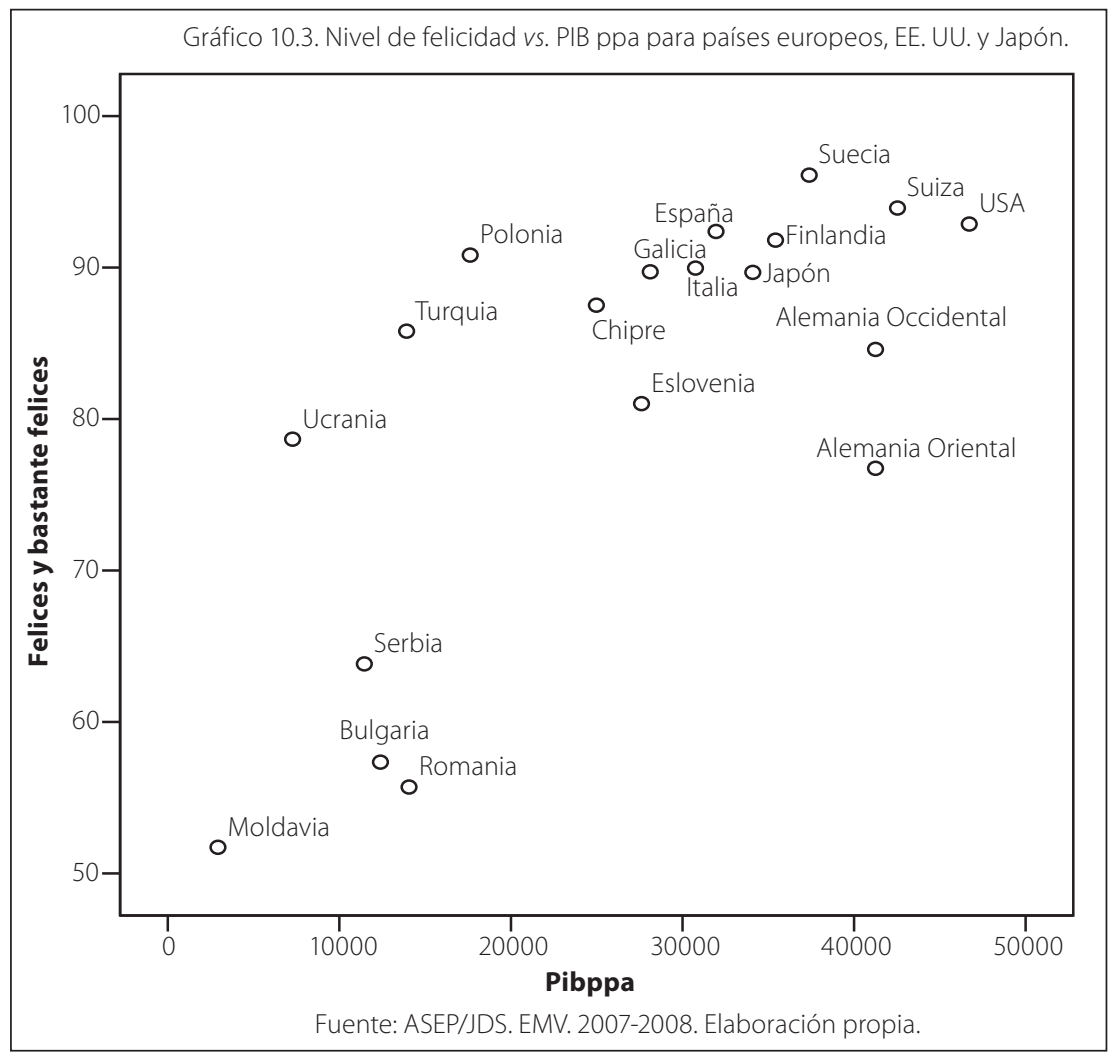




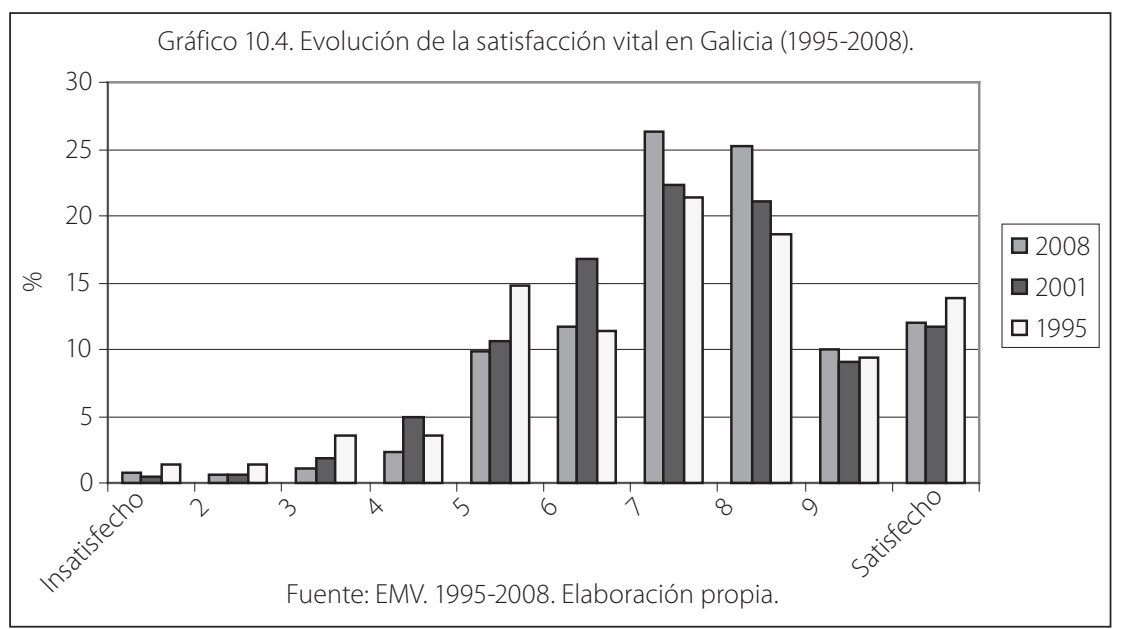

Para el conjunto de la población gallega se observa un considerable incremento de aquellos que se declaran satisfechos con su propia vida a lo largo del período. Por una parte, se reducen progresivamente los que se manifiestan como insatisfechos hasta representar un porcentaje en torno al 5\% en tramos inferiores al 5 en una escala de 10 posiciones. Por otra parte, más de un 70\% de los encuestados se sitúa en posiciones claramente identificables con una notable satisfacción vital (superiores o iguales a 7). Lo que es más, la media, mediana y moda de la muestra se sitúa entre las posiciones 7 y 8 .

En esta variable las diferencias respecto al conjunto de España (Gráfico 10.5), al igual que ocurría en el grupo de los muy felices, vuelven a evidenciar divergencias en el porcentaje de población que se integra entre los muy satisfechos. En Galicia su volumen es más del doble que el español. Concretamente, más de un $12 \%$ de la población se emplaza en el máximo nivel frente a un escaso $6 \%$ en la encuesta realizada sobre la población española. 


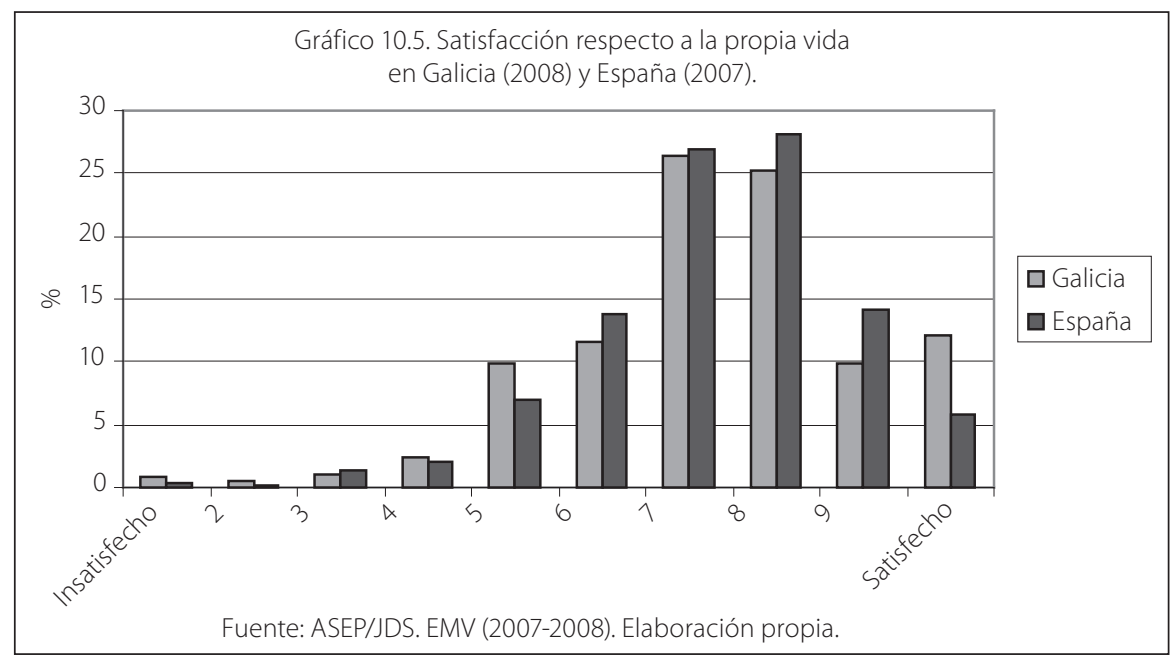

\subsubsection{Renta, desarrollo y felicidad}

Tal y como se ha mencionado anteriormente, de los datos manejados para el caso gallego en materia de percepción de la felicidad parece desprenderse un movimiento hacia una sociedad "satisfecha" en el período que va desde la primera oleada (1995) hasta la última realizada (2008) ${ }^{9}$. Esta constatación, en cierto modo, vendría a contradecir lo planteado por la paradoja de Easterlin, ya que el incremento de la renta y la mejora general de las condiciones de vida en Galicia parecen haber sido más decisivas de lo que predice la teoría.

En particular y en lo que respecta a la evolución de la renta como factor determinante de la felicidad de los gallegos, conviene tener presente que a lo largo del período analizado se ha producido una sensible convergencia que puede contribuir a explicar la relevancia de esta variable ${ }^{10}$. Galicia partía de una posición de retraso relativo en términos de renta per cápita tanto frente a la media española como a la de la Unión Europea (Gráfico 10.6). La recuperación de $10 \%$ de las diferencias desde 1995 (Galicia pasa de disponer un 82\% de la renta media a prácticamente un $88 \%$ y de un $68 \%$ a un $80 \%$, respecto al resto de la Unión Europea) puede explicar una parte de la influencia de la misma sobre la felicidad. Esta influencia sería si cabe más significativa si tenemos en cuenta, tal y como ha sido analizado con anterioridad en este trabajo, que el efecto de una

9 Es evidente que la crisis económica experimentada posteriormente a la encuesta puede suponer un replanteamiento de alguna de las afirmaciones. No obstante, este trabajo analiza la tendencia de largo plazo observada en el período 1995-2008 que tiene componentes estructurales y coyunturales que pueden confundirse en una etapa de crecimiento cuasicontinuado. Las próximas oleadas de la encuesta nos permitirán discernir que parte de este movimiento ha sido coyuntural y los efectos que la crisis ha generado sobre los niveles de satisfacción.

10 No obstante, conviene aclarar que esta convergencia ha sido de carácter pasivo, esto es, por reducción del peso demográfico relativo al mismo tiempo que se experimentaban tasas de crecimiento semejantes a las del conjunto nacional (convergencia activa) (Prada y Lago, 2009). 
mejora en los niveles de renta es particularmente evidente en el momento inicial previo al proceso de acomodación a la nueva situación.

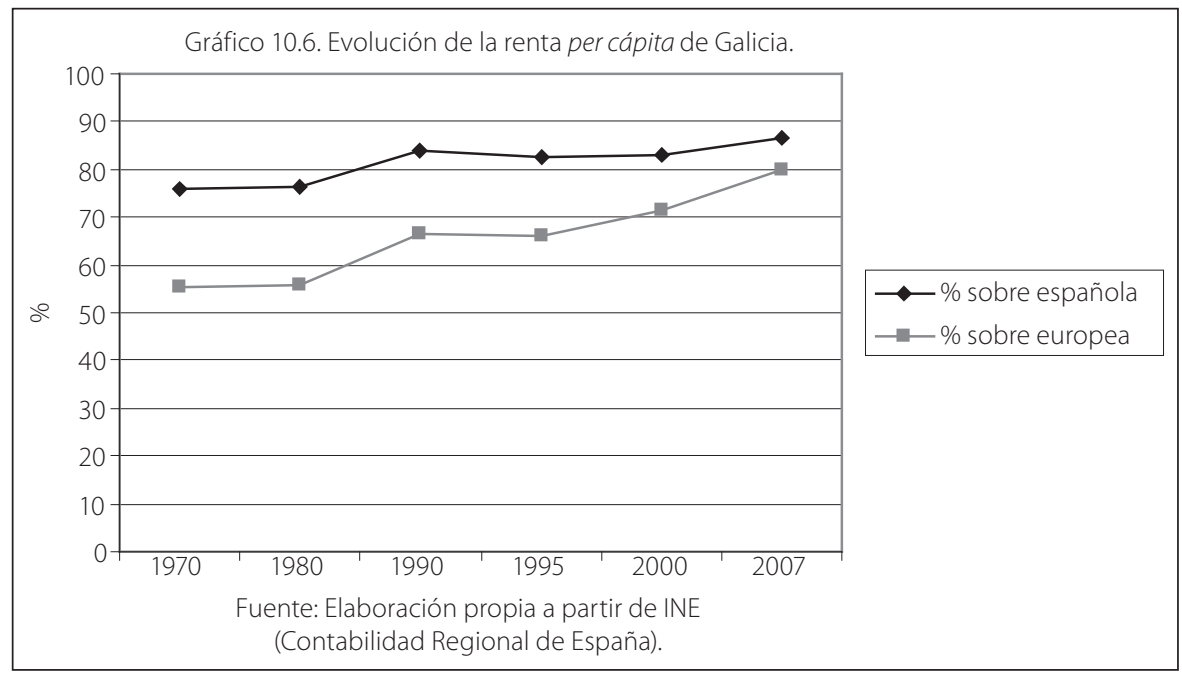

Con el objeto de evitar las visiones simplistas focalizadas en el concepto de renta monetaria, es preciso considerar el más amplio de "capacidades" o "desarrollo humano". En efecto, el incremento de la renta ha ido asociado a la mejora en las prestaciones sanitarias, las coberturas sociales, la educación, etc. que permiten generar la visión de una sociedad satisfecha. En este sentido, el Indice de Desarrollo Humano (IDH) combina de forma normalizada (valores entre 0 y 1) tres indicadores parciales: la esperanza de vida, la educación y la renta per cápita. Lógicamente, un mayor valor del índice está reflejando un mayor nivel de desarrollo de las "capabilities" o un mayor nivel de posibilidades de desarrollo personal o humanización. Junto a este indicador, también cabe considerar el Índice de Desarrollo Humano relativo al Género (IDG) que recalcula el IDH penalizando las diferencias de género y el Índice de Pobreza Humana (IPH) que refleja la probabilidad de que un individuo no supere una esperanza de vida de 60 años, el porcentaje de analfabetos funcionales y el porcentaje de individuos con ingresos por debajo de la media, así como la tasa de paro de larga duración (véase Prada y Lago, 2009).

Los datos para Galicia respecto a estos índices evidencian una importante mejora relativa en los últimos 25 años, más significativa que la convergencia en renta. Aunque Galicia figura ligeramente por debajo de la media española, se sitúa por encima de comunidades con PIB ligeramente superior (Gráfico 10.7). 


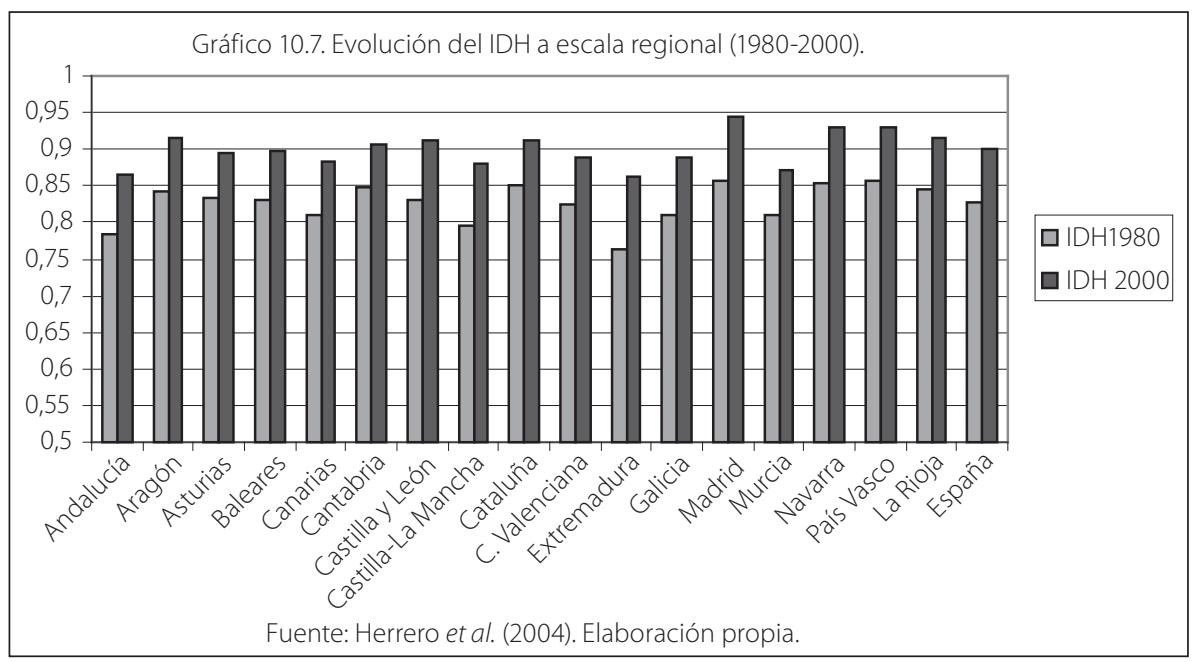

En términos de género, el IDG manifiesta una tendencia muy semejante al IDH, con lo que podría afirmarse que Galicia no es una comunidad donde la discriminación por sexos sea especialmente marcada. Finalmente, en términos de IPH Galicia se posiciona de forma similar aunque ligeramente inferior, lo cual puede verse causado por la persistencia de un pequeño porcentaje de analfabetismo.

A modo de síntesis y atendiendo la evolución de los anteriores indicadores, cabe destacar que, desde una perspectiva dinámica, Galicia ha mejorado sensiblemente su posición relativa en el concierto autonómico. Esta mejora es más ostensible si consideramos indicadores de desarrollo general y no solo de crecimiento de renta. Este período de expansión prolongada asociada a importantes transformaciones sociales y de mejora en las dotaciones de capital humano y prestaciones sanitarias, puede dar razón de estos cambios en la satisfacción subjetiva revelada. Tras esta convergencia más acusada que la derivada del crecimiento en renta relativa se encuentra la extensión del Estado de Bienestar. Así, el mayor peso de este proceso de convergencia ha recaído en el ámbito educativo. La generalización de la educación, la eliminación del analfabetismo y los avances en la educación superior han dado lugar a una importante disminución de las desigualdades en términos de capacidades. Simultáneamente, las mejoras en el sistema sanitario han generado un sensible incremento en la esperanza de vida (Gráfico 10.8). Ahora bien, es importante contextualizar estos resultados en el momento en que se realiza la encuesta, esto es, 2008 y el comienzo de una crisis económica que se agudiza en los años posteriores. Esta nueva coyuntura puede suponer importantes alteraciones tanto en la percepción de los niveles de felicidad como en sus determinantes. 


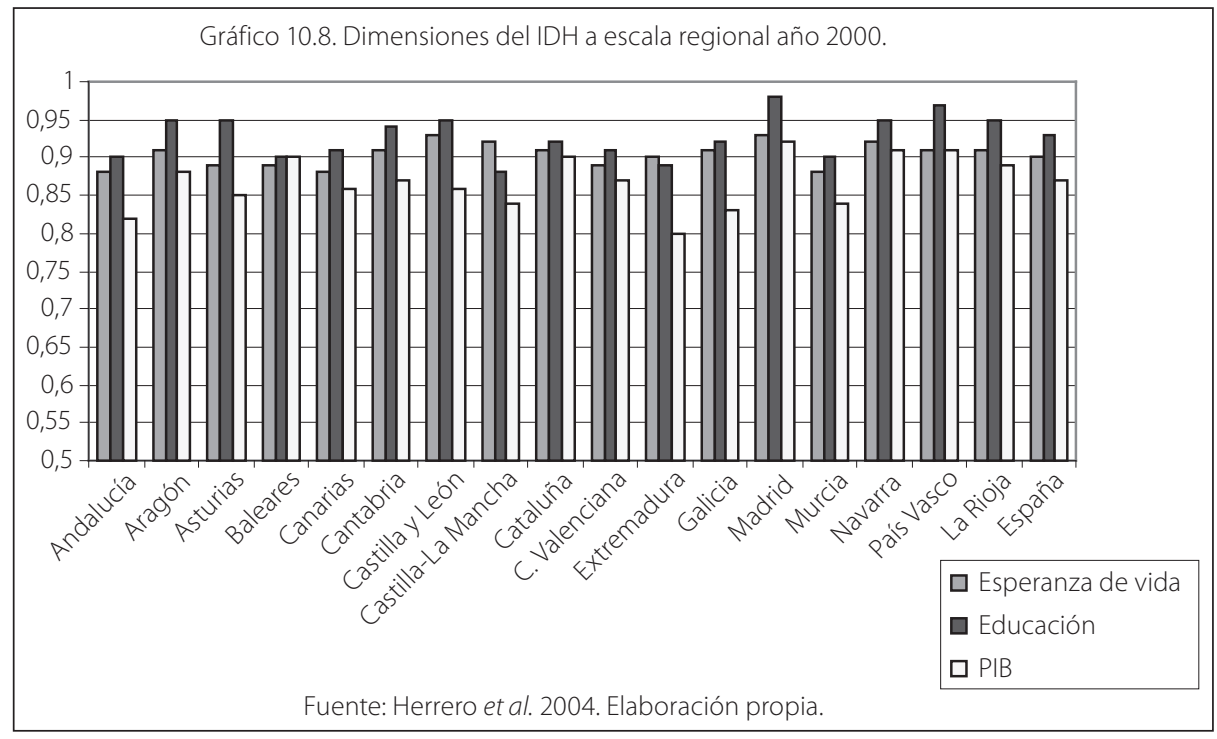

A partir de lo señalado podría hablarse de una cierta convergencia $\beta$. Aquellas regiones que partían de posiciones más retrasadas en términos de desarrollo humano han experimentado un crecimiento más rápido que las más desarrolladas, no solo por un relativamente mayor crecimiento de la renta, sino especialmente por la igualación en prestaciones sociales y en inversión en capital humano (Gráfico 10.9). Todo ello puede derivar en la mejoría de los niveles de satisfacción subjetiva revelada (felicidad), en particular cuando es producto de una etapa reciente para la que todavía no se ha generado un proceso de acomodación.

La valoración que estamos realizando considera las tendencias medias regionales pero oculta notables divergencias a escala microgeográfica. Tal y como se señalará en el capítulo relativo a Valores Económicos, existen al menos dos claras tendencias respecto al desarrollo socioeconómico en el conjunto gallego. De un lado, un área relativamente dinámica que agrupa a los municipios de mayor dimensión y al denominado eje urbano secundario, es decir, municipios de tamaño medio enlazados a los principales ejes de desarrollo. Del otro, nos encontramos con un amplio conjunto de municipios que se encuentran en un claro proceso de vaciamiento o envejecimiento poblacional, eminentemente rurales y agrarios y con un menor nivel de renta. Las consecuencias de esta doble dinámica del desarrollo socioeconómico tienen una clara traducción en la satisfacción subjetiva revelada (Pena y Sánchez, 2007). 

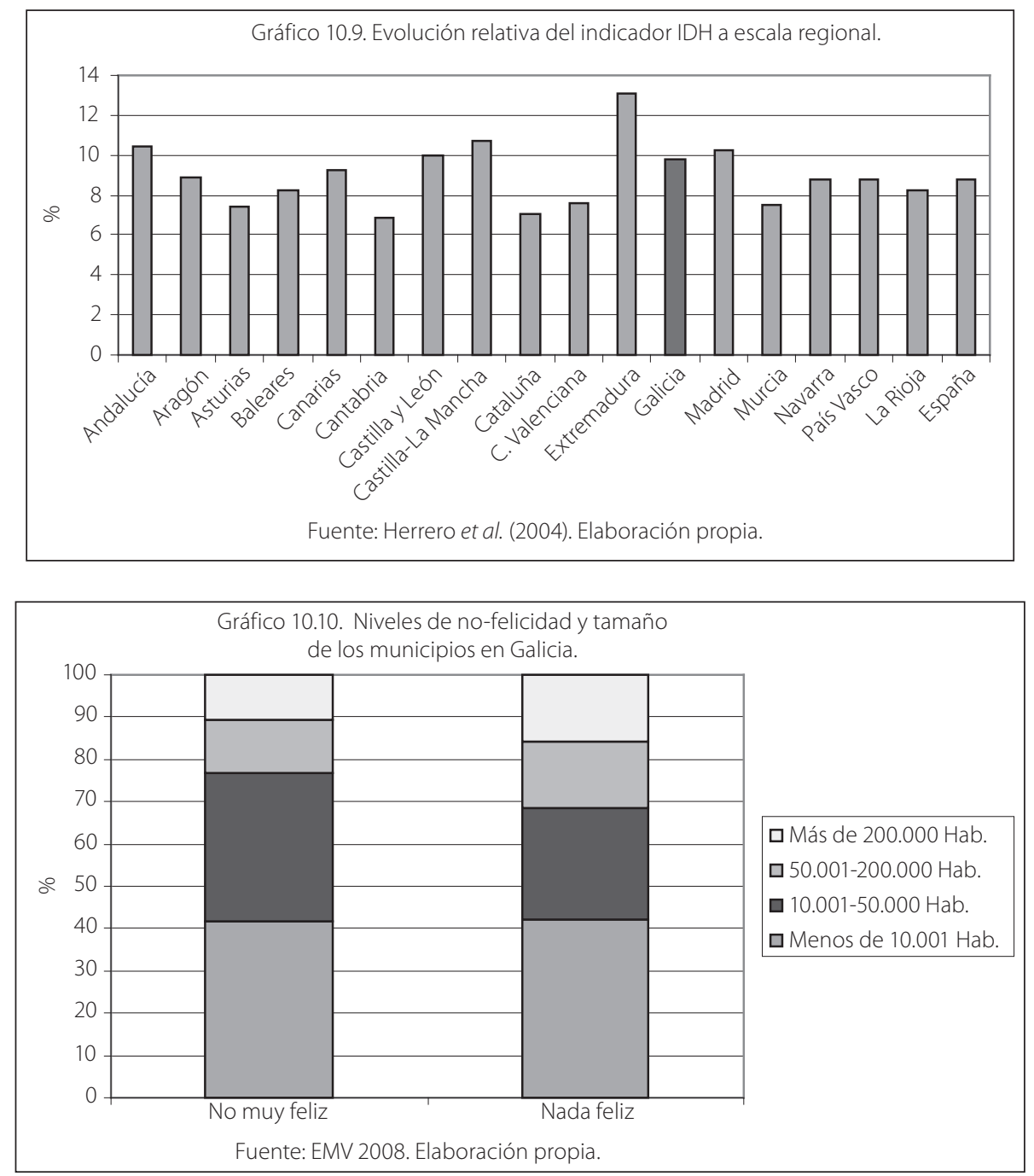

A modo de proxy, si analizamos la localización geográfica de aquellos que se manifiestan como poco o nada felices se observa que mayoritariamente se encuentran en municipios de menos de 50.000 y más de un 40\% en los de menos de 10.000 (Gráfico 10.10). Aunque se trata de un dato que presenta múltiples problemas en su interpretación, en especial si tenemos en cuenta las particularidades de la geografía y demografía gallegas, los municipios de menor dimensión poblacional son aquellos que carecen de condiciones de centralidad en términos christalerianos y coinciden con los menos desarrollados socioeconómicamente, envejecidos y con menor dotación de servicios sociales clave en el desarrollo humano (educación, sanidad...). 
Si trasladamos el análisis a escala individual, en línea con los resultados arrojados por la estimación de la función microeconométrica de la felicidad, existe una clara relación entre los niveles de felicidad de los individuos y su nivel de renta (Gráfico 10.11). Ahora bien, parece evidenciarse también una relación no lineal que estaría traduciendo los lógicos rendimientos marginales decrecientes de la renta. Es decir, incrementos en la renta suponen incrementos progresivamente menos que proporcionales en los niveles de felicidad. Las quintiles de mayor renta se manifiestan como más felices pero, al igual que en cualquier economía desarrollada, cuando el incremento general de la renta permite superar un determinado umbral de seguridad en los ingresos, sucesivas mejoras no tienen su traducción en elevaciones en los niveles de bienestar subjetivo y pueden llegar a ser irrelevantes. No obstante, conviene tener presente, tal y como han puesto de manifiesto los trabajos de Veenhoeven (2000), que las diferencias observadas en el ingreso se deben parcialmente al hecho de la relación positiva existente entre ingreso, salud y socialidad en las sociedades abiertas.

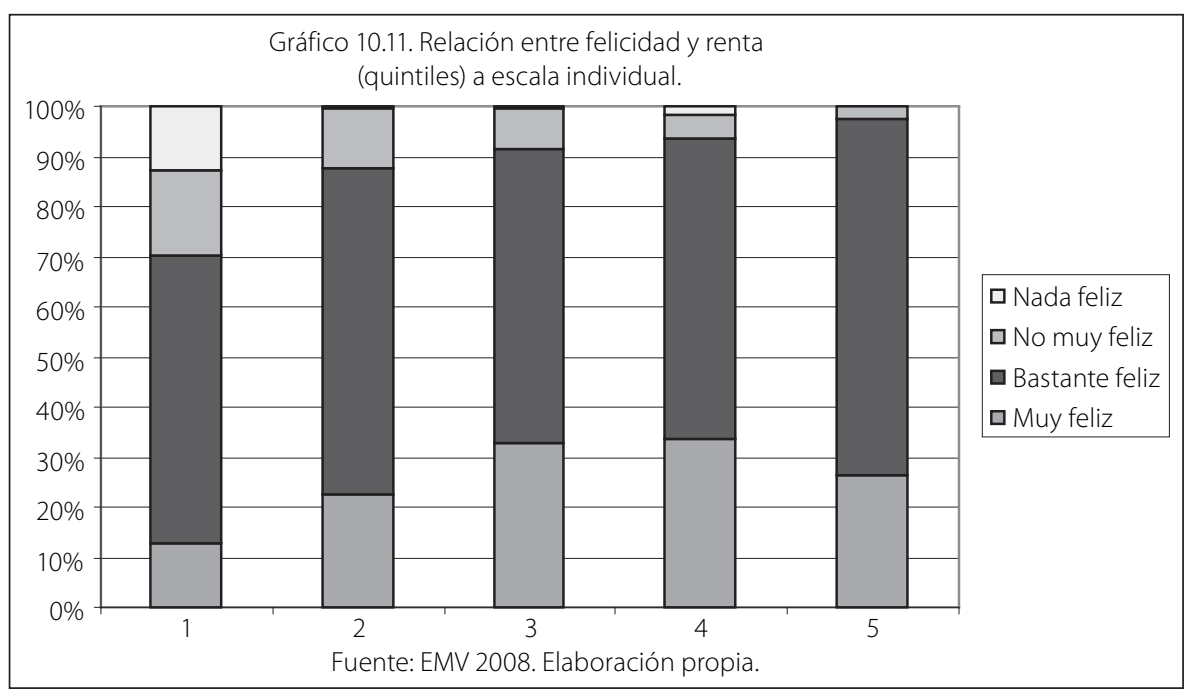

Centrándonos en la satisfacción económica de los gallegos (Gráfico 10.12), nos encontramos con algunas evidencias. En primer lugar, la población gallega ha experimentado en todo este largo período pequeñas variaciones, con lo que la aportación de esta variable a la evolución de la felicidad puede considerarse más limitada de lo que pudiese parecer en primera instancia. Se incrementa el posicionamiento en los puntos centrales de la distribución al mismo tiempo que se reduce el de aquellos que se muestran muy insatisfechos con la situación financiera del hogar. En segundo lugar, una vez más, una lectura agregada de los datos nos permitiría afirmar que la sociedad gallega se encuentra dentro de lo que podríamos denominar "sociedades satisfechas" ya que un 70\% de los encues- 
tados se posiciona en niveles superiores al 5, no obstante, si contrastamos los resultados con los de la satisfacción vital se observa claramente que esta última refleja resultados superiores. Esto es, tal y como se desprendía de la estimación de la función de felicidad y del análisis de la evolución de los niveles de renta e IDH, los determinantes de la felicidad, aunque influidos por el ingreso, parecen ir asociados a mejoras en otras dimensiones.

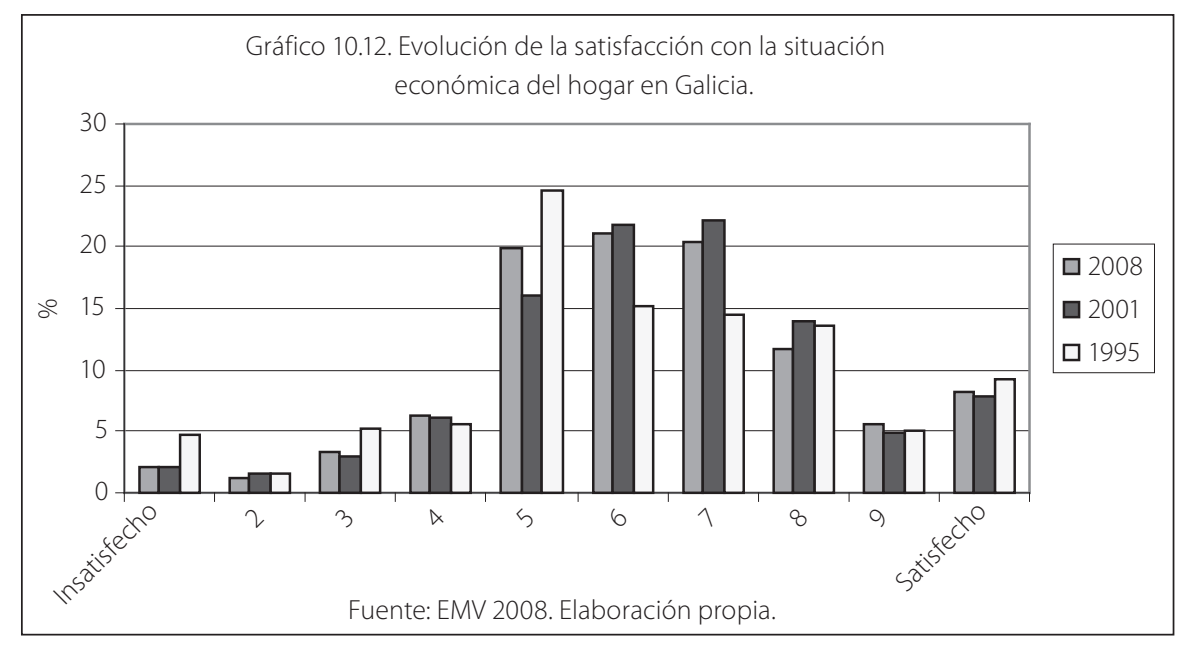

Finalmente, tal y como señalamos al referirnos a la paradoja de Easterlin, la interpretación de estas relaciones es extremadamente compleja. Nos encontramos con distintas tendencias dependiendo de culturas y países. Además, no pueden asociarse solo al ingreso sino que es preciso considerar el problema de la renta relativa, la desigualdad y particularmente el problema de la seguridad en esos ingresos (lo que sería traducible por el problema de la renta permanente). Junto a ello, es preciso considerar los procesos de acomodación a los períodos de crecimiento. Así, la valoración de un proceso de mejora del entorno socioeconómico puede ser especialmente sensible durante el mismo, para verse posteriormente minorada en la medida en que la población se acomoda a los nuevos estándares.

No obstante, no se puede perder de vista que la última oleada de la encuesta que sirve de base para este estudio ha sido realizada en la antesala de una crisis con importantes repercusiones socioeconómicas y, en el futuro, será esencial analizar el componente coyuntural y estructural de estas valoraciones. No en vano, la recesión que se evidenció especialmente tras la última elaboración de esta encuesta puede tener una fuerte repercusión en las valoraciones subjetivas por sus efectos sobre ingresos y empleo y seguridad en ambos. De hecho, puede hablarse de una cierta asimetría o de "efecto trinquete" en el sentido de que los individuos se adaptan a las nuevas situaciones rápidamente y las pérdidas en las mismas se ven reflejadas más fuertemente (Duesenberry, 1949). 


\subsubsection{Los "otros" determinantes de la felicidad}

Una vez discutido el papel de la renta como factor determinante de la felicidad, cabe completar el análisis ahondando en el estudio de los demás factores que, en mayor o menor medida, también se han revelado significativos: la salud, el entramado de relaciones sociales, la situación laboral, el nivel de estudios y el entorno político.

\section{La salud}

Tal y como observamos en la construcción de la función micro de la felicidad, la autovaloración del nivel de salud muestra una significativa correlación positiva y se integra en dicha función. En la valoración del bienestar subjetivo individual los gallegos otorgan un elevado peso a la percepción sobre su nivel de salud, de la misma manera que la propia valoración de la felicidad tiene un efecto sobre la percepción de ésta. Estamos, por tanto, ante una clara relación bidireccional.

Para el conjunto de la población encuestada en Galicia se aprecia un sensible proceso de mejora (Gráfico 10.13). Pese al envejecimiento poblacional que caracteriza la sociedad gallega, en torno a un 7\% de la población encuestada abandona las posiciones de regular o mala para incorporarse a las de buena o muy buena.

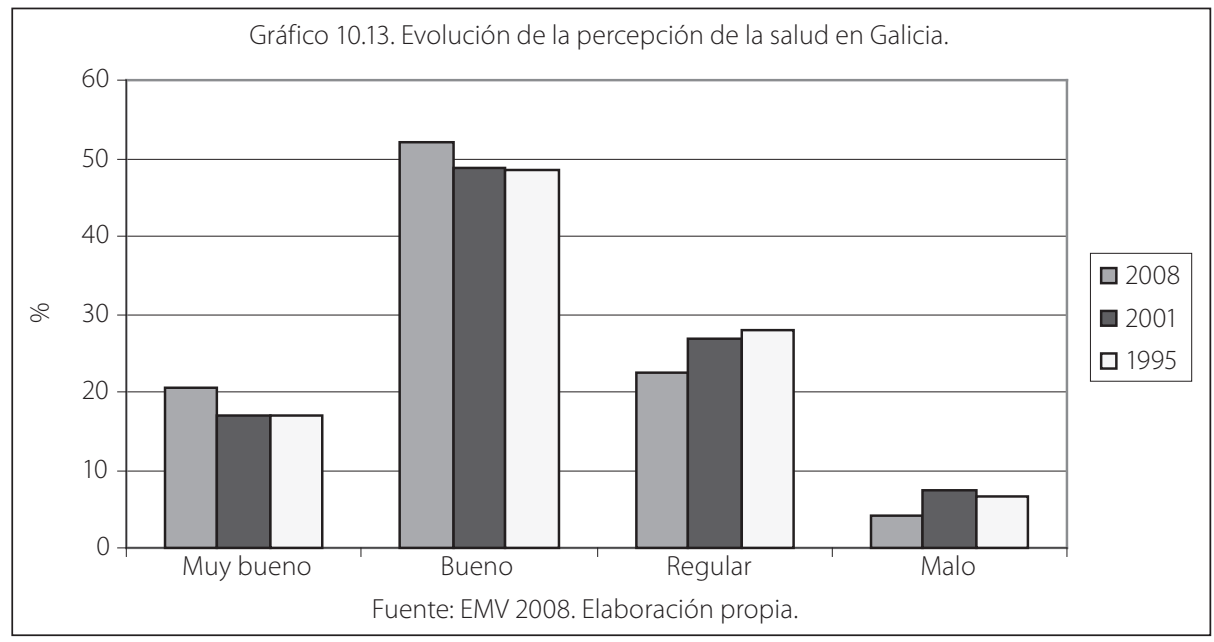

Si bien, en general, esta trayectoria es asimilable al conjunto español, los niveles de salud reflejados por los gallegos son ligeramente inferiores. Los factores que pueden estar detrás de esta leve diferencia pueden ser de muy diverso tipo, desde el mencionado envejecimiento poblacional, hasta las particularidades climáticas o incluso la mayor dificultad para la prestación de servicios sanitarios derivada de la dispersión demográfica. 
Ligada a la variable salud podemos analizar el papel de la variable edad como determinante de la felicidad (Gráfico 10.14). Si nos centramos en el grupo que se declara no feliz (no muy feliz y nada feliz) ${ }^{11}$ éste se incrementa de forma continua a medida que se aumenta la edad, hasta situarse próximo a un 15\% en el tramo superior de edad.

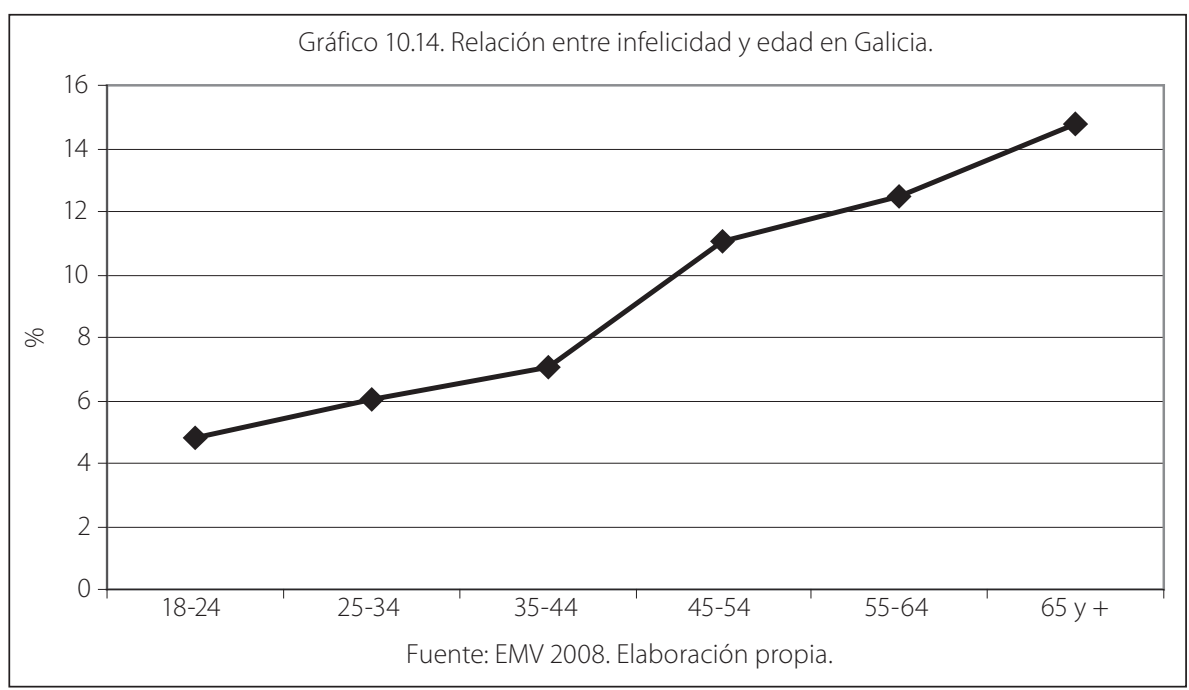

La tendencia general es suponer que los grupos de mayor edad son menos felices, en gran medida por la extensión de cierto culto a la juventud en las sociedades occidentales y, en parte, es así. No obstante, en la explicación no se puede ignorar un conjunto de circunstancias que, más allá de problemas de salud, van desde la reducción de ingresos a la reducción de la red personal de relaciones.

Las relaciones sociales

Al igual que la salud, el entramado de relaciones sociales tiene un efecto directo sobre el nivel de bienestar revelado. El mayor porcentaje de individuos que se manifiestan como nada felices o no muy felices se encuentra en aquellos grupos que carecen de un marco familiar, bien por viudedad, bien por ruptura de la relación previa. En los grupos de divorciados, separados y viudos se incrementa el porcentaje de nada felices o no muy felices (respectivamente $30,6,22,8$ y $24,8 \%$ ) frente a los porcentajes más reducidos que se encuentran en aquellos que disponen de pareja estable, esto es, casados y con pareja $(6,1$ y $6,3 \%$ respectivamente). Por tanto, este efecto está especialmente ligado a la pérdida de una red familiar más que a la no disposición de la misma. Esto es, los solteros, aunque se muestran algo más insatisfechos que aquellos que disponen

11 Calificamos como grupo de no felices al agregado de aquellos que se definen como poco o nada felices. 
de pareja estable, se encuentran considerablemente por encima de aquellos que han perdido esa red de relaciones ${ }^{12}$.

Como se observa en el Gráfico 10.15, las diferencias en la situación familiar pueden ocasionar una enorme variación en la felicidad, por encima de cambios en el nivel de ingresos. Estos efectos son especialmente significativos en el caso de divorcios o viudedad por lo que supone de reconfiguración de la estructura de relaciones personales. En este sentido, lo aparentemente relevante es la calidad y estabilidad de las relaciones y no su forma, dado que no existe diferencia entre matrimonio y parejas de hecho.

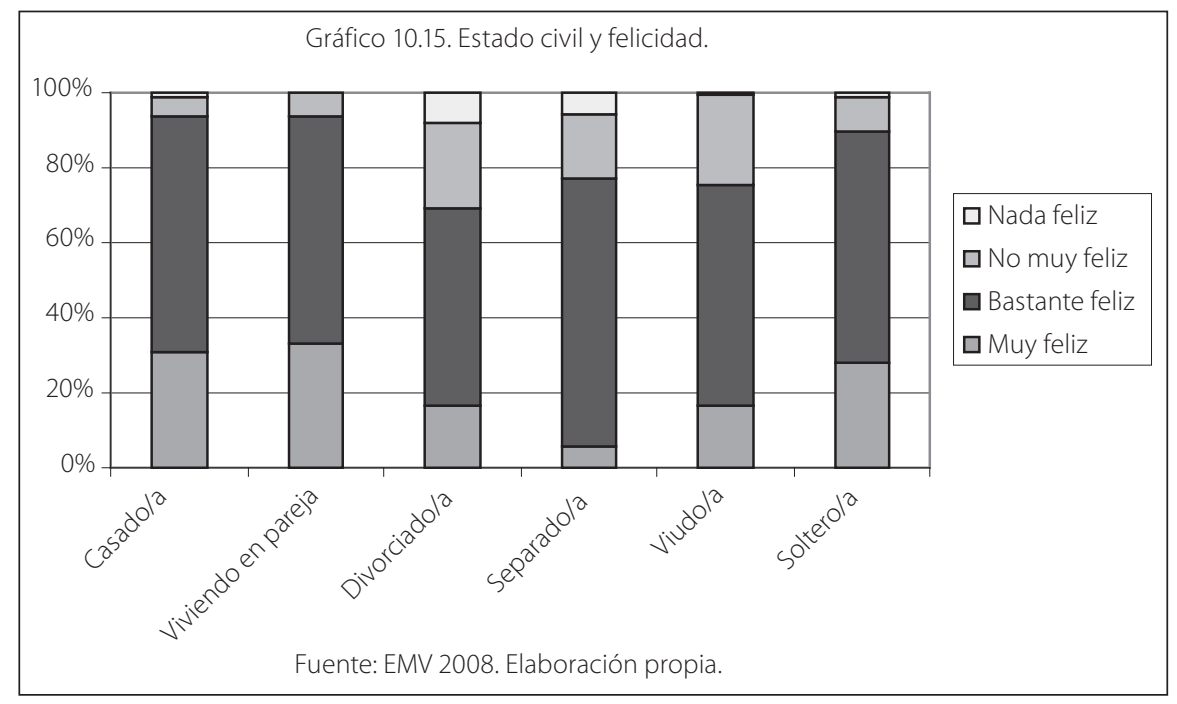

Indudablemente, el hombre es un ser social. Formar parte de una familia, un grupo o un colectivo contribuye de forma decisiva a la felicidad, aportándole una identidad personal. Para el caso gallego, la relación interpersonal que se revela más importante es el matrimonio y la familia. Este hecho es compatible con la hipótesis según la cual el matrimonio aporta desde ventajas de mercado, hasta efectos benéficos en términos de morbidad, salud mental, etc., y, muy especialmente, en términos de felicidad o satisfacción subjetiva revelada, relación que persiste incluso si se controlan variables como la edad, los ingresos o la educación.

La calidad de nuestro entorno social más amplio o capital social se manifiesta como crucial para crear un marco de seguridad y bienestar personal. Pese a que este es un aspecto difícilmente evaluable, podemos encontrar un cierto vínculo con las respuestas relativas a la confianza social generalizada, cuyos niveles presentan correlaciones positivas con la satisfacción subjetiva revelada.

12 El caso de los solteros reviste otras características, dado que se asocian mayoritariamente con población juvenil. 
Si recurrimos a indicadores indirectos sobre la incidencia de las dotaciones individuales de capital social en el nivel de satisfacción subjetiva, otro de los aspectos que se desprenden de los datos manejados, es el elevado consenso sobre el modelo de vida en la sociedad gallega. La práctica totalidad de los entrevistados sitúa los valores ligados a los lazos familiares y de amistad muy por encima de cualquier otro. Además, los individuos que dan una mayor importancia a su red de lazos más directos — bonding social capital_ (familia y amigos) (gráficos 10.16 y 10.17) se manifiestan considerablemente más felices. Esto último, ya se desprendía del análisis de regresión, que identificaba estas variables como altamente significativas. Además, a lo anterior hay que añadir que el peso que se le otorga al disfrute del tiempo libre o su valoración como objetivo vital resultaba crucial. Este rasgo es un claro indicador del establecimiento de una sociedad del ocio.

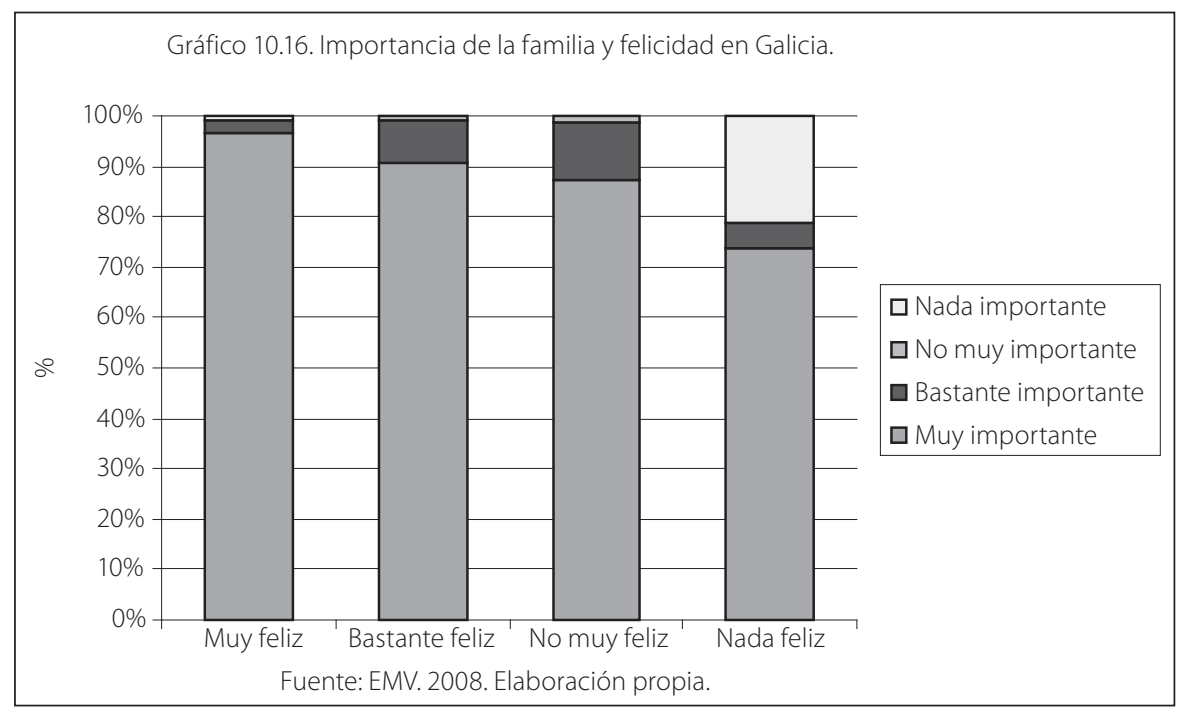

En sentido inverso, los datos disponibles muestran que la práctica totalidad de aquellos que se declaran como no felices se sitúan entre los que consideran poco o nada importante la familia. Del mismo modo, la amistad y el tiempo libre (Gráfico 10.18) aparece como un valor menos relevante para aquellos que se declaran poco felices.

En consonancia con lo apuntado en la introducción al problema de la felicidad, de las anteriores consideraciones se infiere que ésta se encuentra ligada al problema de la sociabilidad del ser humano, es decir, lejos de depender exclusivamente de bienes materiales se asocia igualmente a los denominados bienes relacionales. Ahora bien, como rasgo distintivo de la sociedad gallega, al igual que las sociedades del sur de Europa de tradición católica, cabe señalar que concede una gran relevancia a la familia como base del comportamiento y felicidad individual, hasta el punto 
de que podríamos afirmar que la felicidad o satisfacción se ajusta en terminología beckeriana a una función de producción colectiva.
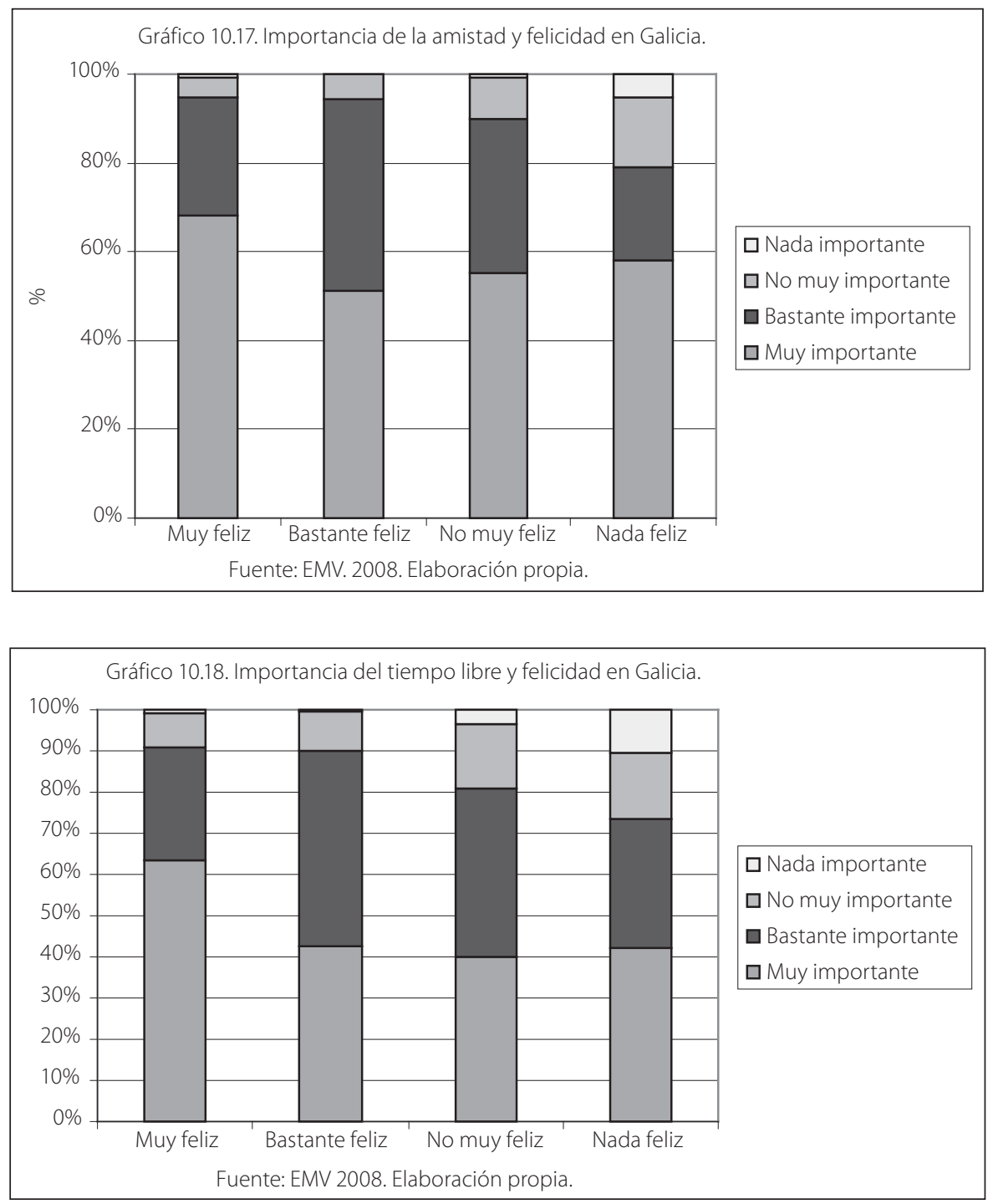

Además de las anteriores variables, la felicidad también depende de nuestro ser interior y de nuestra filosofía de vida, es decir, los valores de los individuos influyen fuertemente en los niveles de satisfacción vital. En esta línea, Rojas (2007) argumenta que la relación ingreso felicidad es contingente de los valores que asuman las personas. Desde su perspectiva, el ingreso es relevante para la felicidad en aquellas personas en las que predominan los valores orientados "hacia fuera", mientras que su relevancia es casi nula en aquellos con valores "hacia adentro". Estos últimos basan su felicidad en factores distintos a la adquisición 
de bienes y servicios. De esta manera, buena parte de los factores explicativos del bienestar dependen de los valores de cada sujeto. En este sentido, en el caso de los gallegos, la familia y la red de amistad, así como el cultivo de un tiempo para el disfrute personal resultan, como ya hemos señalado, determinantes.

\section{Situación laboral}

Existe un claro vínculo entre el nivel de bienestar y la situación laboral que puede presentarse por diversas vías. En primer lugar, está el efecto de la incorporación al mercado de trabajo, esto es, la actividad o inactividad del entrevistado. En segundo lugar, la disposición o no de empleo y, finalmente, el nivel de satisfacción generada por el propio trabajo (Gráfico 10.19).

De acuerdo con los datos, en el colectivo que comprende los que se declaran menos felices tienen un elevado peso los individuos que se sitúan al margen del mercado de trabajo (amas de casa y pensionistas) y los que se encuentran en situación de búsqueda de empleo. La razón reside en que la incorporación al mercado de trabajo supone no solo una mayor independencia económica, sino un cauce de realización personal y la adquisición de una importante red de capital social (bridging). Además, los ocupados perciben que están contribuyendo a la sociedad en un sentido amplio, de esta manera el trabajo no solo proporciona ingresos sino un sentido a la propia vida. El desempleo junto a una pérdida de ingresos, supone también un deterioro de la red de relaciones personales y de significado de la propia existencia. Por consiguiente, se corrobora claramente que los costes de la no incorporación al mercado de trabajo, no son exclusivamente económicos, sino también psíquicos y sociales.

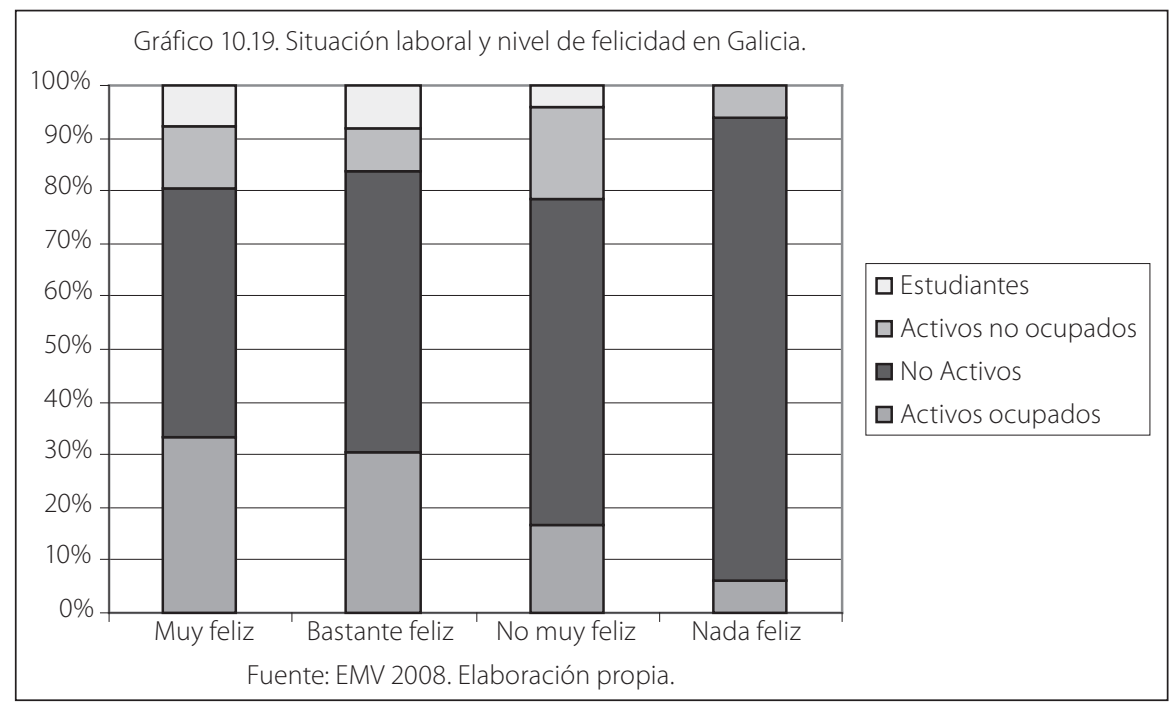

En el caso de los que tienen trabajo, el temor a la pérdida del mismo puede suponer una reducción significativa de la felicidad. Así, en situaciones de rece- 
sión en las que se produce una elevación de los niveles de desempleo, lo lógico es que disminuyan los niveles de satisfacción subjetiva revelada.

En consonancia con lo ya señalado, los no activos son el grupo menos feliz, seguidos del grupo de activos no ocupados y los ocupados. El subgrupo de los estudiantes debe ser tratado aparte, dado que es todavía ajeno al mercado y se encuentra en una fase vital diversa (población juvenil dependiente).

Aunque algunos estudios previos (Frey y Stutzer, 2000) no detectaron una influencia significativa del tipo de empleo sobre los niveles de satisfacción, en nuestro caso, sin embargo, recurriendo a la estratificación presentada por Piore (1971), se obtiene alguna evidencia en sentido contrario. El grupo primario, que incluye a aquellos individuos de elevada cualificación, conductas directivas y muy alta estabilidad laboral e ingresos, presenta un mayor nivel de satisfacción subjetiva. El primario inferior engloba a aquellos individuos que aun contando con elevada cualificación realizan tareas intermedias de conducta consuetudinaria con menor nivel de ingresos, pero igualmente con notable estabilidad laboral, muestra una leve menor satisfacción. Finalmente, el secundario que representa el estrato de trabajadores de baja cualificación, bajas remuneraciones y poca estabilidad, con conductas altamente dependientes, es el grupo que se manifiesta menos feliz (Gráfico 10.20).

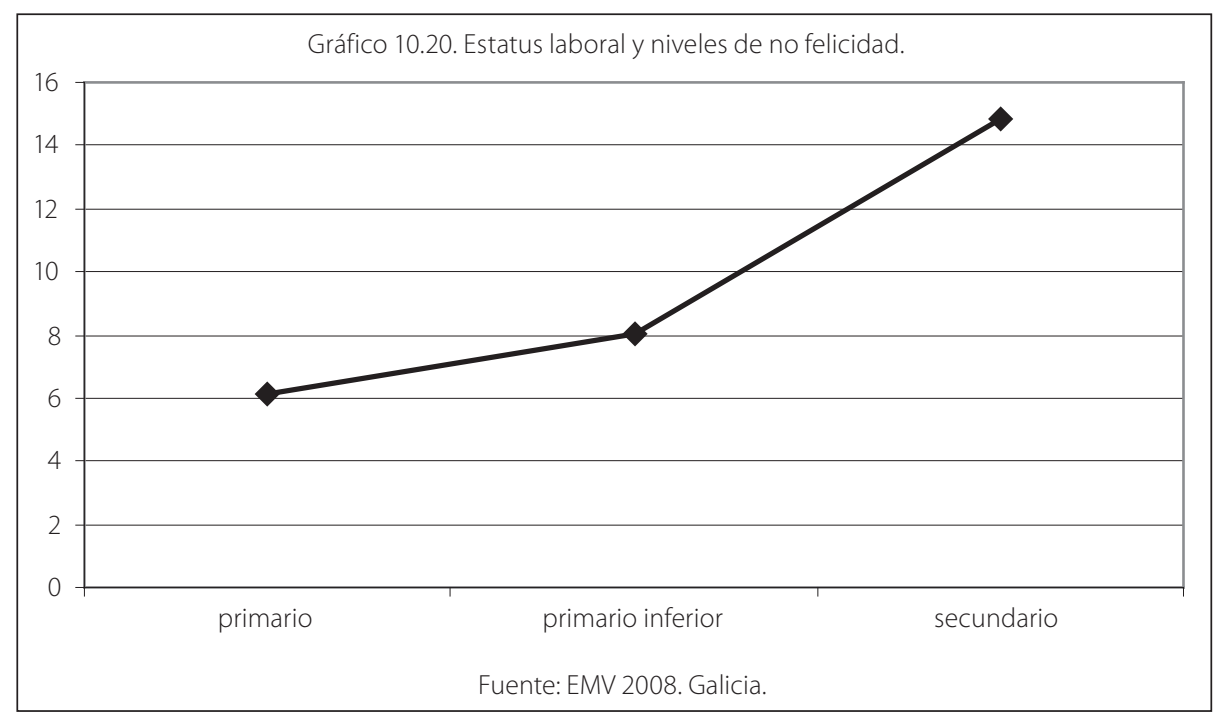

Nivel de estudios

Otra de las variables cuya influencia cabe analizar es la formación. La dotación de capital humano, por diversas vías (ingreso, situación laboral, capital social...) guarda una clara relación directa con la satisfacción subjetiva revelada. Si se observa la composición del colectivo de no felices (no felices y no muy felices) atendiendo al nivel de estudios (Gráfico 10.21), se aprecia una tendencia descen- 
dente a medida que aumenta el nivel de formación, siendo únicamente un 5\% de este colectivo, individuos con estudios universitarios.

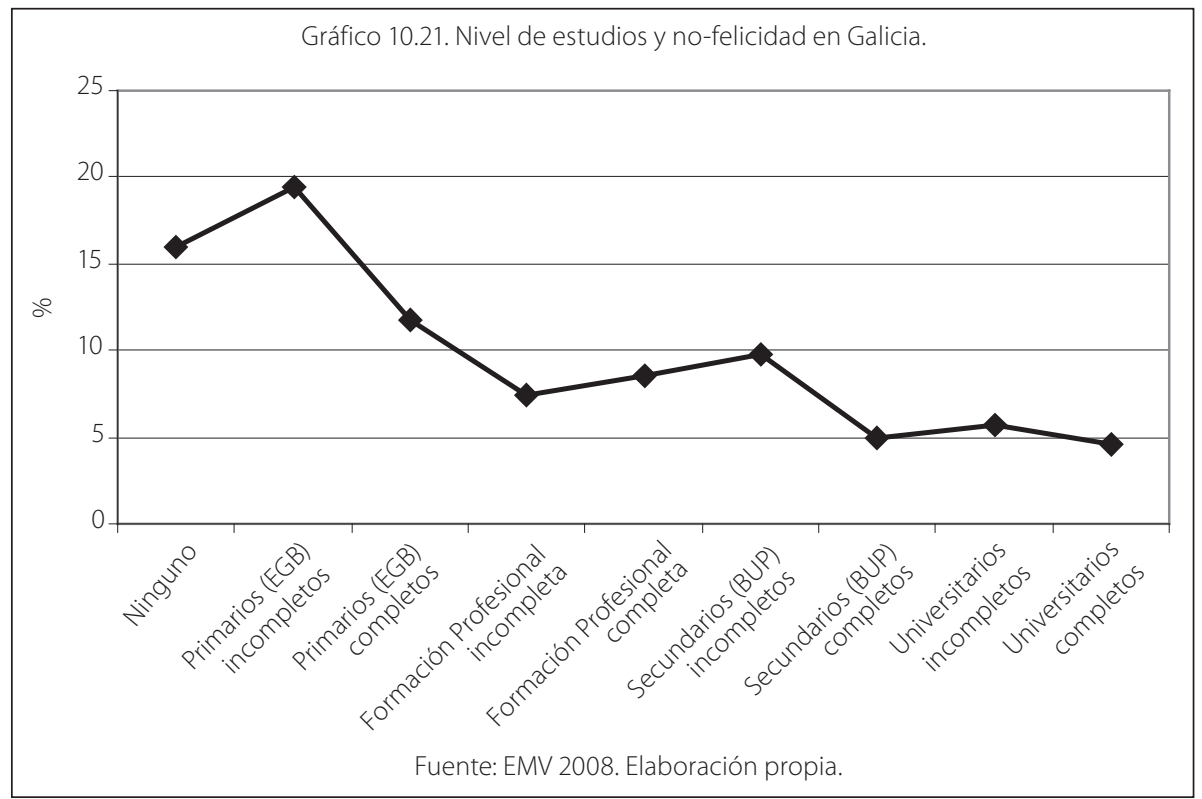

\section{Entorno político}

La felicidad también depende de la calidad de gobierno y el entorno del ejercicio de la actividad política. Bajo el concepto de entorno político se encuentra un complejo entramado de relaciones: la fortaleza del estado de derecho, la estabilidad y ausencia de violencia, la representatividad y estabilidad política, la ausencia de corrupción y la eficacia del sistema legislativo.

Hirschman (1989) ya planteaba la hipótesis de que tener opiniones o, mejor dicho, llegar a tenerlas y expresarlas mediante un proceso de información, deliberación y discusión, es uno de los factores determinantes de la felicidad personal. Por su parte, Frey y Stutzer (2000) han comprobado la validez de esta tesis para el caso suizo, dada su característica democracia directa.

En lo que hace referencia a la libertad política, cuanto menos coercitivo sea un sistema político y mayores sean las libertades individuales y políticas mayor es el nivel de felicidad. De hecho, en algunos casos las correlaciones han revelado niveles de significatividad próximos a los de la prosperidad económica. Un sistema político democrático en el que se garantizan los derechos fundamentales favorece tanto la extensión de los sentimientos de respeto personal y, a largo plazo, la noción de dominio o control sobre su propia vida, que resulta determinante sobre el nivel de felicidad.

En el mismo sentido, el concepto de capacidades al que ya se aludió anteriormente puede ser también traducido en términos de libertad. Concretamente, Sen 
(1999) considera que el desarrollo humano puede ser expresado como una forma de libertad positiva, esto es, capacidad para la humanización o crecimiento en libertad individual. Tal y como se visualiza en el Gráfico 10.22, en el caso gallego observamos un crecimiento del número de personas que tienen sensación de una mayor libertad y control sobre su propia vida.

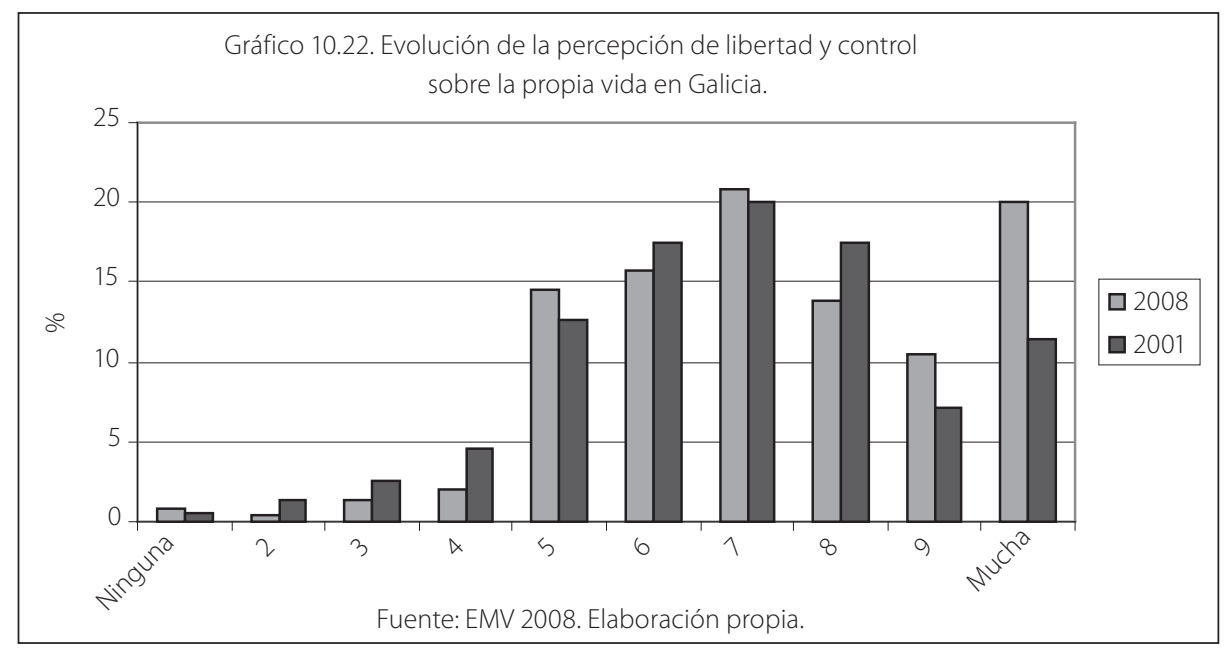

Junto a esto, cabe destacar que no existen grandes diferencias entre los que revelan percibir escasa libertad, tan solo leves reducciones, aunque relevantes si tenemos en cuenta el período al que se refiere el gráfico (2001-2008). De todos modos lo más llamativo es el elevado porcentaje de la población (prácticamente un $45 \%$ ) que se sitúa decididamente entre aquellos que perciben una elevada libertad y control sobre su vida (por encima del nivel de 7). Además, si se comparan estos datos con el conjunto de España, se verifica que la población gallega parece sentir un mayor control sobre su propia vida que la media española.

\subsection{CONCLUSIONES}

En el presente trabajo se replantea el problema de la felicidad en el ámbito de la Socioeconomía y se revisan las principales aportaciones de la denominada Happiness Economics con el objeto de contrastarlas con los resultados de la Encuesta Mundial de Valores en Galicia. En concreto, la investigación llevada a cabo viene a confírmar algunos de los presupuestos básicos del dicho paradigma.

Por una parte, el concepto de felicidad, entendido como la satisfacción subjetiva revelada por los propios individuos, es una aproximación válida para la valoración de la evolución de un ámbito socioeconómico concreto.

Por otro lado, la felicidad responde a cambios más complejos que los originados por la simple elevación de los niveles de renta. Esta constatación, entre otras cosas, cuestiona las perspectivas centradas en el binomio ingreso-bienestar que 
caracterizan buena parte de las propuestas de la política económica que sitúan al crecimiento económico como prioridad absoluta.

En este sentido, la paradoja de Easterlin (la ausencia de un vínculo entre incremento de la renta per cápita y evolución de la satisfacción subjetiva global), pone de manifiesto el carácter complejo de los determinantes de esta variable, en la que los bienes relacionales (redes de relaciones sociales), las dimensiones valorativas o axiológicas (valores personales) y el desarrollo humano en general parecen ser más determinantes que el mismo ingreso.

El estudio descriptivo de los datos de la EMV en Galicia refleja un notable incremento de los niveles de satisfacción subjetiva en la sociedad gallega en los últimos veinte años. Aunque a primera vista estos avances pueden asociarse a la elevación del nivel de renta, el análisis empírico desarrollado y plasmado en la estimación de una función de los determinantes de la felicidad permite verificar que la evolución del bienestar subjetivo revelado por la sociedad gallega presenta una causalidad más amplia.

En términos generales, se puede afirmar que la sociedad gallega solo se acomoda parcialmente a la paradoja de Easterlin. Ahora bien, en línea con las conclusiones de Easterlin, el ingreso en la función de felicidad de los gallegos desempeña un papel secundario y subjetivo, al tiempo que se revelan como muy importantes las variables asociadas a los bienes relacionales. De hecho, las mejoras observadas en Galicia en los indicadores de desarrollo humano (salud, educación e ingreso), es decir, las capacidades (o capabilities en la terminología de Sen), resultan tener más poder explicativo que los aumentos de la renta, tal y como postula la Economía Humanista.

Los resultados del presente trabajo también permiten hablar de cierta convergencia, ya que Galicia, partiendo de posiciones más retrasadas en términos de desarrollo humano, experimentó un crecimiento más rápido que otras regiones más desarrolladas, no solo por un relativamente mayor crecimiento de la renta, sino especialmente por la igualación en prestaciones sociales y en inversión en capital humano. Este hecho contribuiría a explicar la mejoría de los niveles de satisfacción subjetiva revelada (felicidad) de los gallegos, en particular, teniendo en cuenta que es producto de una etapa reciente para la que aún no se generó un proceso de acomodación.

Globalmente y optando por una vía negativa, los factores que parecen determinantes de una situación personal de menor satisfacción revelada (poco o nada felices) son fundamentalmente los bajos ingresos, la carencia de un marco relacional tanto familiar como social, el binomio salud-edad y la precariedad laboral (trabajos de nivel secundario). Además, para el conjunto de Galicia estos trazos se concentran en las zonas menos desarrolladas de forma que, también aquí (al igual que se identifica una doble dinámica del desarrollo socioeconómico a escala 
municipal), puede hablarse de una doble dinámica en la satisfacción subjetiva de los gallegos.

En definitiva, los resultados de la presente investigación permiten afirmar que, en consonancia con el señalado por Ryan y Deci (2001), evitar la pobreza, vivir en un país desarrollado y tener objetivos vitales no directamente relacionados con logros materiales, está asociado a mayores niveles de felicidad y que, a partir de cierto umbral, los incrementos de renta tienen escasa traducción en los niveles de bienestar subjetivo revelado.

\subsection{REFERENCIAS BIBLIOGRÁFICAS}

Ahuvia, A. y Friedman, D. A. (1998): "Income, consumption, and subjective well-being", Journal of Macromarketing 18 2: 153-168.

Argyle, M. (2002): The psychology of happiness. Londres, Routledge.

Bruni, L. (2004): History of Happiness in Economics. Londres, Routledge.

Bruni, L. y Porta, P. (2005): Economics and happiness. Framing the analysis. Oxford, Oxford University Press.

Di Tella, R., Macculloch, R. y Oswald, A. (1999): The macroeconomics of happiness, Working paper, Center for European Integration Studies. University of Warwick.

Duesenberry, J. S. (1949): Income, Saving and the Theory of Consumer Behavior. Cambridge, MA, Harvard University Press.

Easterlin, R. A. (1974): "Does Economic Growth Improve the Human Lot?" en Paul A. David y Melvin W. Reder (Eds.), Nations and Households in-Economic Growth: Essay in Honor of Moses Abramovitz. Nueva York: Academic Press.

Easterlin, R. A. (1995): "Will raising the incomes of all increase the happiness of all?", Journal of Economic Behavior and Organization 27 (1995): 35-47.

Easterlin, R. A. (2001): "Income and happiness: towards a unified theory", Economic Journal 111: 465-484.

Easterlin, R. A. (2002): Introduction to Happiness in Economics. Cheltenham, Edward Elgar.

Esteve Mora, F. (2000): Bienestar y crisis del Estado del Bienestar. Elementos para una economía de la felicidad en R. Muñoz de Bustillo (Ed.), El Estado de Bienestar en el cambio de siglo. Madrid, Alianza.

Frey, B. y Stutzer, A. (2000): "Happiness, economy and institutions", Economic Journal 110: 918-938.

Frey, B. y Stutzer, A. (2001): Happiness and Economics. Princeton, Princeton University Press.

Frey, B. y Stutzer, A. (2002): "What can economists learn from happiness research?", Journal of Economic Literature XL: 402-435.

Gradin, C., Del Rio, C. y Cantó, O. (2006): La distribución de la renta en Galicia. A Coruña, CIEF-Fundación Caixa Galicia. 
Herrero, C., Soler, A. y Villar, A. (2004): Capital humano y desarrollo humano en España, sus comunidades autónomas y provincias Valencia, Bancaja.

Hirschman, A. O. (1982): Shifting involvements, Private interest and Public Action. Princeton, Princeton University Press.

Hirschman, A. O. (1989): "Having opinions-one of the elements of wellbeing", American Economic Review. Papers and proceedings, 79, 2: 75-79.

Inglehart, R. (1996): "The diminishing utility of economic growth", Critical review, 10, 4: 509-531.

Inglehart, R. (2004): Subjective Well-Being Rankings of 82 Societies. www.worldvaluessurvey.org.

Kahneman, D. (1999): Objective happiness, en Kahneman, D., Diener, E., y Schwarz, N. (Eds.), Well-Being: The Foundations of Hedonic Psychology. Nueva York: Russell Sage Foundation.

Kahneman, D., Diener, E., y Schwarz, N. (Eds.) (1999): Well-being: The foundations of hedonic psychology. Nueva York: Russell Sage Foundation.

Layard, R. (2003): Happiness: Has social science a clue? Three Lectures. First lecture: What is Happiness?; second lecture: Income and Happiness: Rethinking Economic Policy; third lecture: What Would Make a Happier Society. Lionel Robbins Memorial Lectures.

Layard, R. (2005): Happiness. Lessons from a New Science. Londres, Penguin Books.

MacIntyre, A. (2001): Tras la virtud, Barcelona, Crítica.

Mill, J. S. (1859) [1991]: On Liberty, J. Gray y G. W. Smith (Eds.). Londres: Routledge. Nussbaum, M. C. y Sen, A. K. (1993): The Quality of Life. Oxford, Clarendon Press.

Putnam, R. D. (2000): Bowling alone: The collapse and revival of American community. Nueva York, Simon \& Schuster.

Oswald, A. J. (1997): "Happiness and Economic Performance", Economic Journal, Royal Economic Society, 107(445): 1815-31.

Peiró Jiménez, A. (2004): "Condiciones socioeconómicas y felicidad de los españoles", ICE, 816: 179-194.

Pena López, J. A. y Sánchez Santos, J. M. (2007): “Organización espacial de la actividad económica y desarrollo local: evidencia para el caso gallego", Revista Galega de Economía, 16 (2).

Piore M. J. (1971): "The dual labor market: theory and implications" en Gordon, D. M. (Ed.), Problems in Political Economy: An Urban Prospective. Lexington. Mass., D. C. Heath.

Prada Blanco, A. y Lago Peñas, S. (2009): Galicia, unha economía europea. Vigo, Galaxia.

Rawls, J. (1971): A Theory of Justice. Cambridge, MA, Harvard U.P. 
Ryan, R. y Deci, E. (2001): "On happiness and human potentials: A review of research on hedonic and eudaimonic wellbeing", Annual Review of Psychology, 52: 141-166.

Rojas, M. (2007): "The complexity of well-being: A life satisfaction conception and a domains-of-life approach" en I. Gough y A. MacGregor (Comps.) Researching wellbeing in developing countries. Cambridge University Press.

Rojas, M. (2009): "Economía de la felicidad. Hallazgos relevantes respecto al ingreso y bienestar", El Trimestre Económico, 303: 537-573.

Sánchez, P., Vaamonde, A. y García, X (2007): A pobreza en Galicia. Santiago de Compostela, Sotelo Blanco.

Sen, A. K. (1999): Development as freedom. Nueva York, A. Knopf, Inc./Random House Inc. (edición en castellano: Desarrollo y Libertad, Ed. Planeta, Barcelona, 2000).

Stutzer, A. (2004): "The role of income aspirations in individual happiness", Journal of Economic Behavior and Organization, 54 (1): 89-109.

Veenhoven, R. (1984): Conditions of happiness. Dordrecht, Kluwer, University.

Veenhoven, R. (1993): Happiness in nations: Appreciation of life in 56 nations. Rotterdam: Erasmus.

Veenhoven, R. (2000): "The Four Qualities of Life. Ordering Concepts and Measures of the Good Life", Journal of Happiness Studies 1: 1-39.

Veenhoven, R. (2001): What We Know about Happiness?, Erasmus University Rotterdam, working paper.

WHOQOL Group (1993) "Study protocol for the World Health Organization project to develop a quality of life assessment instrument" (WHOQOL), Quality of Life Research, 22: 153-159. 


\section{VALORES, ACTITUDES SOCIALES, SISTEMA ECONÓMICO Y PAPEL DEL ESTADO EN LA ECONOMÍA}

José Manuel Sánchez Santos

Pablo Castellanos García

\subsection{INTRODUCCIÓN}

En el ámbito interdisciplinar de la Sociología y la Economía, una de las áreas de investigación que ha ido adquiriendo una creciente relevancia es la que se centra en el estudio de la relación bidireccional entre la cultura y la economía. En este sentido, a la hora de abordar este tipo de cuestiones, la perspectiva propia de la Socioeconomía, entendida ésta como paradigma económico y social alternativo a la economía neoclásica, constituye un complemento analítico de gran interés y capacidad explicativa. De hecho, uno de los principales rasgos que definen este paradigma es el papel fundamental que le atribuye al entorno cultural, conformado por unos valores y sistemas de creencias que, se supone, modelan estilos de vida y priman determinadas demandas y aspiraciones sociales ${ }^{1}$. En particular, si asumimos que los valores y las normas de conducta que se derivan de los mismos son elementos constitutivos de la cultura, reviste un especial interés el análisis de la importancia de este tipo de factores como determinante de las preferencias y decisiones de los individuos en su doble condición de ciudadanos y de agentes económicos.

La falta de unanimidad en el ámbito científico acerca de los orígenes y naturaleza de los valores no impide que exista un amplio consenso en cuanto a considerarlos como algo intrínsecamente vinculado a las preferencias de los sujetos, tanto individuales como colectivos. Aunque valores, normas, convicciones y creencias son características propias de los individuos, cuando son compartidas por la mayoría de los miembros de una sociedad, se puede hablar de valores y/o normas sociales. Estos valores compartidos por las personas que forman parte de un grupo y que tienden a persistir a lo largo del tiempo responden a creencias difundidas en una población dada que son susceptibles de ser ordenadas en escalas de aprobación-desaprobación, es decir, los valores tienen propiedades

Este paradigma se puede decir que ha sido propuesto de forma programática por Etzioni (1988). 
restrictivas sobre la conducta tanto individual como social y a menudo señalan los límites de la acción, determinando lo que es bueno y malo, apropiado e inapropiado (Rokeach, 1973).

En esta línea, una de las posibles acepciones del término cultura económica nos remite a la combinación de valores que guían el comportamiento económico de los individuos. Consecuentemente, desde la óptica del análisis económico, los valores son importantes en tanto que orientan la acción (es decir, condicionan la conducta) tanto individual como colectiva. De hecho, algunos de los síntomas de la cultura económica de una determinada sociedad se pueden expresar a través de elementos tales como: la aceptación del sistema democrático y su influencia sobre la economía de mercado, el papel de la competencia, la iniciativa privada, la responsabilidad individual, las funciones del Estado en la economía, etc.

Visto así, los valores sociales, junto con las leyes formales que rigen y limitan el comportamiento tanto de las instituciones públicas como del sector privado, serían una parte constitutiva del marco institucional y/o del sistema económico. Dentro de este marco, los individuos, en tanto que agentes económicos, toman sus decisiones sobre trabajo, inversión, ahorro y consumo, mientras que, a su vez, el gobierno decide sobre cuándo y cómo intervenir en la economía. En este contexto, los debates sobre la legitimidad de los resultados del mercado como mecanismo de asignación de recursos o sobre el grado en el que las políticas gubernamentales deberían corregir esos resultados, redistribuyendo riqueza de los más favorecidos a los más pobres, suelen ser especialmente controvertidos.

En la explicación de las actitudes sociales hacia estos temas, parte de la evidencia que se ha obtenido en diversos países se ajusta al razonamiento económico estándar basado en el interés individual ${ }^{2}$. De acuerdo con esta argumentación, las personas más ricas, que tienen menos que ganar con la redistribución, deberían mostrarse más partidarias del mercado y menos favorables a dicha redistribución que sus compatriotas más pobres. Esta postura la podrían adoptar asimismo aquellos sujetos que, partiendo de una situación relativamente desfavorable, esperan mejorarla en el futuro con la consiguiente escalada de posiciones en la pirámide social. No obstante, también se ha verificado que la actitud hacia el sistema de economía de mercado y las opiniones sobre la redistribución, varían de un país a otro. Esta constatación es, precisamente, lo que ha llevado a los economistas a preguntarse en qué medida la cultura o los valores influyen en la configuración de las mencionadas opiniones o preferencias de los individuos respecto al mercado y al papel del gobierno en la economía.

En línea con este tipo de planteamientos, en el presente capítulo centramos nuestra atención en el análisis de las actitudes de los gallegos hacia el sistema de economía de mercado, así como de sus preferencias en materia de medidas

Entre los trabajos más destacables que abordan este tipo de cuestiones se encuentran Benabou y Ok (2001), Alesina y Angeletos (2005), Alesina y La Ferrara (2005) y Landier et al. (2008).

344 LA EVOLUCIÓN DE LOS VALORES SOCIALES EN GALICIA 
redistributivas y de prioridades de política económica. El principal objetivo es obtener evidencia que permita identificar algunas peculiaridades de los posicionamientos de la sociedad gallega en los mencionados ámbitos, profundizando en el estudio de sus percepciones sobre la justicia de la competencia social y sobre los determinantes de la desigualdad en la distribución de la renta. Merece la pena tratar de avanzar en el conocimiento de las creencias, valores y motivaciones de los individuos, entre otras razones porque se trata de variables que pueden tener implicaciones en ámbitos tan importantes como la configuración de las instituciones económicas de un país, la marcha de su economía, la elección de gobierno, el tipo de políticas que éste elija o, incluso, el éxito de las mismas.

\subsection{LA ECONOMÍA DE LIBRE MERCADO EN GALICIA: ANÁLISIS DE PREFERENCIAS}

\subsubsection{Los pilares básicos de la economía de mercado: propiedad privada y competencia}

En términos generales, la idea de economía capitalista alude a un sistema de producción con cierto grado de libre mercado y de actividad empresarial privada. A su vez, el sistema económico de libre mercado exige, por definición, la competencia entre los individuos tanto en la esfera de la producción y oferta de bienes y servicios (incluido el trabajo), como en el de la demanda o consumo de los mismos. Dicho principio de la libre competencia opera bajo el supuesto de que la búsqueda del máximo beneficio individual se traduce en una mayor eficiencia económica, aunque ello tenga como contrapartida la generación de desigualdad en diversos ámbitos.

Nuestra primera aproximación al posicionamiento de la sociedad gallega sobre el sistema económico capitalista se basa en la identificación de sus preferencias hacia el mercado y en el análisis de los factores que condicionan las mismas.

Las actitudes y/o preferencias de los ciudadanos por el sistema capitalista se pueden derivar de las opiniones que a éstos les merecen la competencia y propiedad privada, dos de los principios básicos sobre los que se sustenta el modelo de economía de mercado. Concretamente, en el marco de la Encuesta Mundial de Valores $^{3}$ (en adelante EMV), como ejemplo de actitudes favorables hacia el mercado, puede considerarse la creencia de que debería incrementarse la propiedad privada de las empresas y de que la competencia es buena porque estimula a la gente a esforzarse en el trabajo y a desarrollar nuevas ideas. En el otro extremo se situarían las percepciones contrarias al mercado (capitalismo), que se reflejarían en el convencimiento de que debería incrementarse la propiedad estatal de las empresas y de que la competencia es perjudicial, entre otras razones porque saca a flote lo peor de las personas.

Esta es la fuente de datos de referencia para el análisis cuantitativo desarrollado a lo largo de este capítulo. 
Un primer aspecto destacable, tal y como se desprende de los datos de la Tabla 11.1, es la existencia de una asociación muy significativa entre las opiniones que reflejan actitudes ante los principios básicos del capitalismo — propiedad privada y competencia - así como entre las relativas al papel del esfuerzo en el trabajo y la creación de riqueza.

Tabla 11.1. Actitudes de los gallegos hacia los principios básicos de la economía de mercado (coeficientes de correlación de Spearman). Galicia 2008.

\begin{tabular}{|c|c|c|c|c|}
\hline & $\begin{array}{c}\text { Opinión sobre } \\
\text { la propiedad } \\
\text { privada }\end{array}$ & $\begin{array}{c}\text { Opinión } \\
\text { sobre la } \\
\text { competencia }\end{array}$ & $\begin{array}{c}\text { Opinión } \\
\text { sobre el } \\
\text { esfuerzo en } \\
\text { el trabajo }\end{array}$ & $\begin{array}{c}\text { Opinión } \\
\text { sobre la } \\
\text { riqueza }\end{array}$ \\
\hline $\begin{array}{l}\text { Opinión sobre } \\
\text { la propiedad privada }\end{array}$ & 1,000 & & & \\
\hline $\begin{array}{l}\text { Opinión sobre } \\
\text { la competencia }\end{array}$ & $0,120^{*}$ & 1,000 & & \\
\hline $\begin{array}{l}\text { Opinión sobre } \\
\text { el esfuerzo en el trabajo }\end{array}$ & $-0,043$ & $0,187^{*}$ & 1,000 & \\
\hline $\begin{array}{l}\text { Opinión sobre } \\
\text { la riqueza }\end{array}$ & $0,187^{*}$ & $-0,009$ & $-0,225^{*}$ & 1,000 \\
\hline
\end{tabular}

* La correlación es significativa al nivel 0,01 (bilateral).

Fuente: EMV-Galicia 2008. Elaboración propia.

En concreto, aquellos que creen que la riqueza puede crecer de manera que haya bastante para todos son los que se muestran más favorables a la propiedad privada y a la necesidad de mayores incentivos para el esfuerzo individual. Por su parte, también es digno de mención que las personas que participan del convencimiento de que el esforzarse en el trabajo puede servir de base para mejorar, son las que más creen, por un lado, en la bondad de la competencia y, por otro, en que cada uno debería asumir individualmente más responsabilidad para lograr su propio medio de vida ${ }^{4}$.

En lo que respecta a los posibles determinantes de la formación de opiniones sobre la competencia, la propiedad privada y el mercado, suelen plantearse dos tipos de hipótesis (Landier et al., 2008): la hipótesis del "interés particular" (self interest), de acuerdo con la cual los agentes expresan actitudes que representan sus propios intereses individuales, y la hipótesis del "aprendizaje lento" (slow learning), según la cual las opiniones reflejan convicciones honestas sobre el desempeño relativo de los sistemas económicos, cuestión sobre la que es difícil

Este tipo de constataciones puede contemplarse como un reflejo de la consistencia en las preferencias reveladas por los entrevistados.

346 LA EVOLUCIÓN DE LOS VALORES SOCIALES EN GALICIA 
aprender y, por tanto, en las opiniones al respecto los a priori resultan altamente condicionantes.

La primera de las hipótesis sostiene que cada individuo apoya el sistema que maximiza su utilidad, dadas sus dotaciones iniciales de capital físico y humano. En este caso, las actitudes de los ciudadanos no reflejan sus convicciones sobre la eficiencia global del sistema, sino cómo se redistribuye el excedente global que genera el mismo. De hecho, este supuesto está en la raíz de la mayoría de los modelos de economía política, que asumen que los ciudadanos votan en línea con sus intereses individuales.

La segunda de las hipótesis plantea que los agentes forman sus creencias de manera desinteresada, pensando en lo que es óptimo para la sociedad en su conjunto. En estas circunstancias, las actitudes no reflejarían las preocupaciones de los individuos sobre cómo les afectan personalmente los procesos redistributivos, sino más bien diferencias en las opiniones sobre los resultados de los distintos sistemas económicos, medidos éstos fundamentalmente en términos de eficiencia y equidad. Si tales creencias tuviesen una base racional, serían las mismas en todas partes (todos los países). El hecho de que en la práctica esto no sea así, indicaría que en el proceso de formación de aquéllas pondera en exceso la experiencia y la historia locales, con lo cual la evolución de las creencias tendría un fuerte componente inercial.

La distinción entre estas dos perspectivas puede resultar crucial para la optimización de los paquetes de reforma económica: si una reforma pro-mercado se enfrenta a hostilidad por la primera de las razones, el reformador debería asegurarse una base de ciudadanos suficientemente amplia que se beneficie de la misma. Sin embargo, si el rechazo social es consecuencia del segundo tipo de motivación, la tarea crucial del reformador sería usar la pedagogía y garantizar que existiese información accesible y creíble sobre el efecto positivo de reformas similares que hayan sido implementadas en otros países.

Opinión sobre la competencia: hacia un escepticismo creciente

En cuanto a las actitudes sociales hacia la competencia, la información relevante nos la ofrece la opinión que los ciudadanos emiten al posicionarse en un escala de 1 a 10, en la que cuanto más próximo sea el valor a 1 más favorable es la opinión sobre la competencia, mientras que, en el otro extremo, un valor de 10 reflejaría la creencia de que la competencia es perjudicial y que hace aflorar lo peor de las personas.

Teniendo en cuenta estas consideraciones, en el Gráfico 11.1 comparamos la evolución temporal de la media gallega y española. A primera vista, los datos sugieren la posibilidad de que Galicia presente ciertas singularidades con respecto al conjunto de España. Tal y como se visualiza en el mencionado gráfico, la percepción que los individuos tienen de la competencia es relativamente 
favorable. No obstante, las tendencias observadas no son, ni mucho menos, convergentes. En el inicio del período analizado los gallegos manifiestan, por término medio, una visión más positiva de la competencia que los españoles; sin embargo, con el paso de los años la situación se ha ido modificando y parecen apuntarse unas tendencias contrapuestas, en el sentido de que los españoles cada vez se muestran más partidarios de la necesidad de aumentar la competencia, mientras que con los gallegos sucede lo contrario.

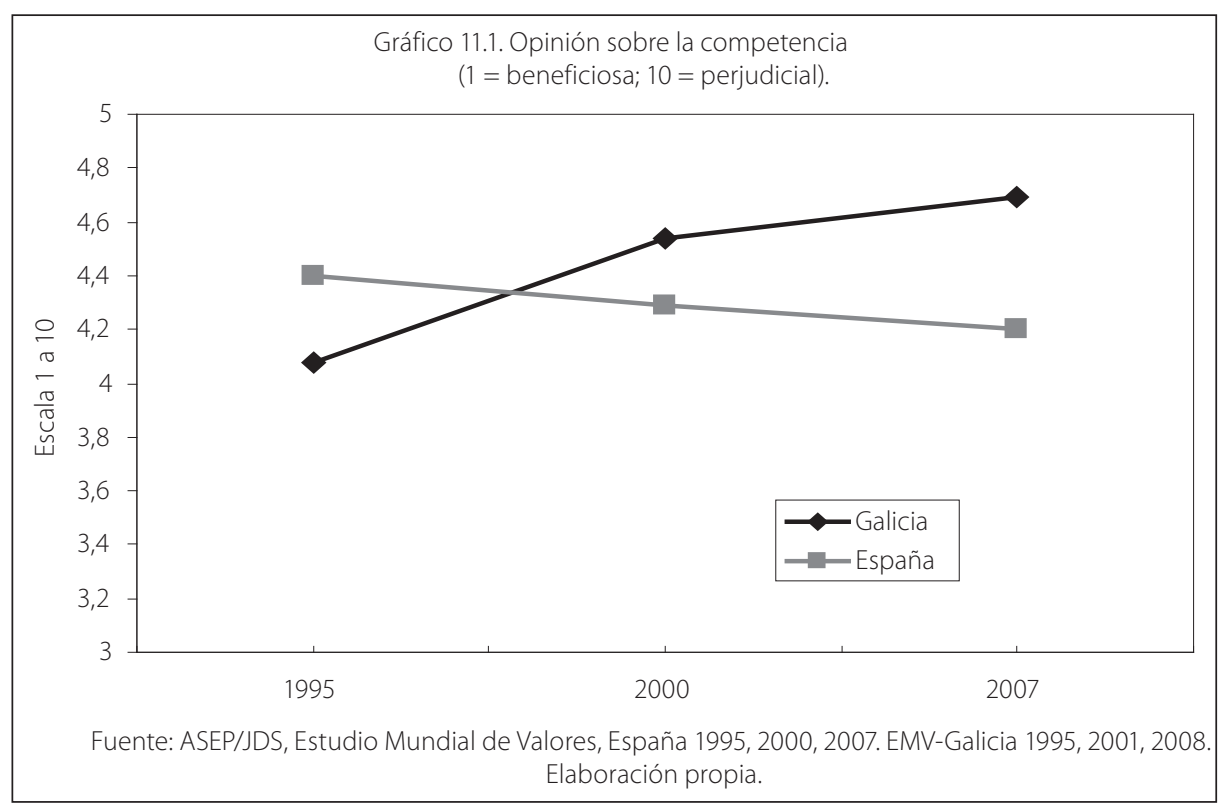

Si descendemos un poco más al detalle de la realidad gallega, pueden realizarse algunas matizaciones de interés (Gráfico 11.2). La proporción de gallegos que considera la competencia como algo claramente beneficioso se ha ido reduciendo ininterrumpida y significativamente a lo largo del tiempo, mientras que el porcentaje de la población que ve la competencia como algo perjudicial ha aumentado. Estos resultados podrían entenderse como síntoma de un incipiente escepticismo de la sociedad gallega sobre las bondades de la competencia, como uno de los principios básicos en el que se sustenta el sistema económico de mercado.

Más allá de esta pauta de carácter general, un examen más pormenorizado de la distribución social de las opiniones sobre la competencia en Galicia permite obtener algún indicio del papel que desempeñan variables tales como condiciones económicas, nivel de estudios, situación laboral, posicionamiento ideológico, etc. como determinantes de la percepción social sobre las ventajas e inconvenientes de dicho sistema económico. 


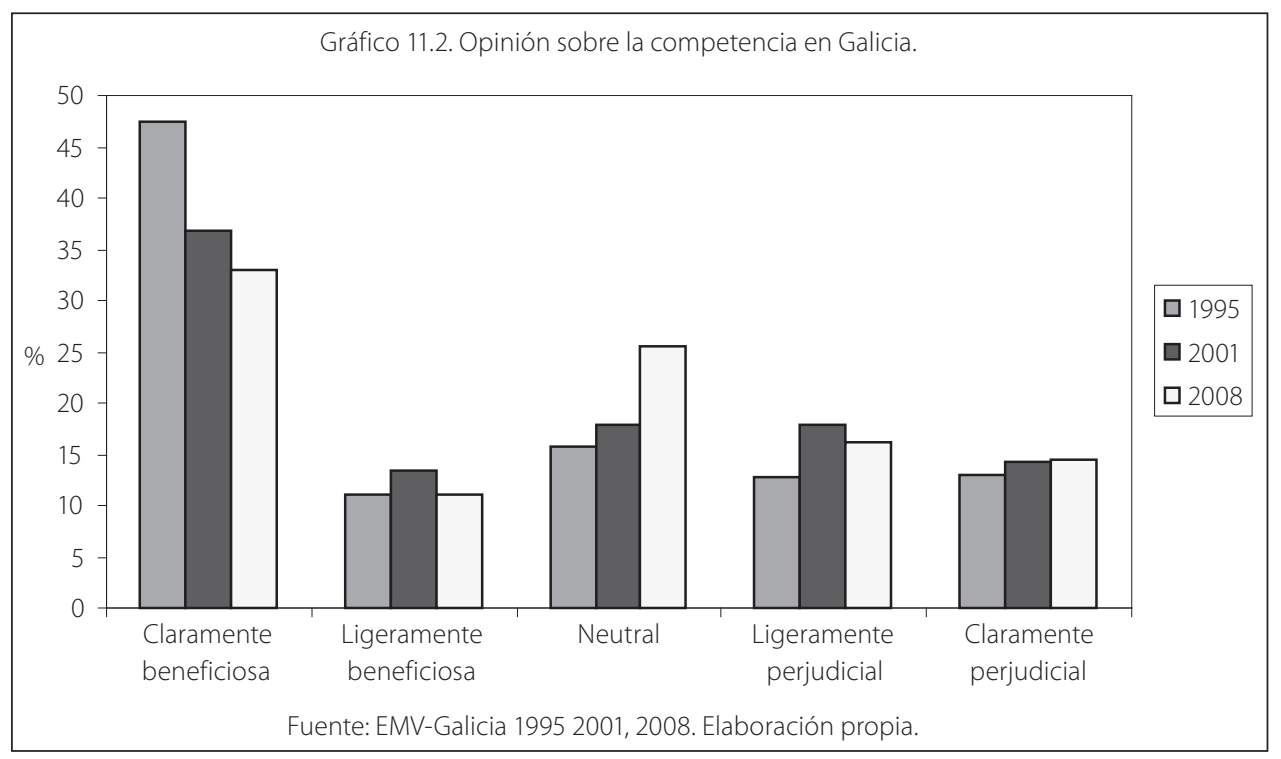

En primer lugar, y en lo que se refiere a la relación entre las condiciones económicas particulares de cada sujeto y su visión de la competencia, las hipótesis más extendidas postulan que los niveles de renta podrían influir significativamente sobre las opiniones de los individuos acerca de los principios en los que se fundamenta el libre mercado ${ }^{5}$. Así, por ejemplo, cabría esperar que aquellos que se ven relativamente beneficiados por un sistema económico basado en la competencia es más probable que consideren a ésta como algo claramente beneficioso. Desde este punto de vista, lo lógico sería que los individuos con mayores niveles de renta se mostrasen más favorables hacia la competencia.

En primera instancia, los resultados que se desprenden de un análisis de correlaciones no parecen confirmar inequívocamente esta hipótesis de que las condiciones económicas son la base fundamental que configura las actitudes hacia la competencia. No obstante, si ahondamos en esta cuestión, encontramos algún soporte para la hipótesis de que el estatus socioeconómico está vinculado a la valoración que los ciudadanos hacen de la competencia. En el Gráfico 11.3 se observa cómo los segmentos de la población con mayores niveles de renta son más partidarios de la competencia, lo que sería compatible con la idea de que la gente con más medios tiende a justificar su posición en la estructura social capitalista interiorizando los valores que son consustanciales a este sistema económico.

En la práctica, a los individuos no les importa tanto el nivel de renta como la satisfacción con la situación económica del hogar. Por lo tanto, parece lógico pensar que si dichos niveles satisfacen sus aspiraciones personales de bienestar es

\footnotetext{
Este tipo de planteamientos también sería compatible, en cierto modo, con la visión marxista tradicional de la estructura económica, según la cual los valores y creencias están determinadas por las condiciones materiales de la clase social a la que pertenece el individuo.
} 
probable que se manifiesten más favorables a la competencia. En este sentido, el Gráfico 11.4 resulta ilustrativo y pone claramente de manifiesto que el colectivo que se muestra más satisfecho con su situación económica es el que parece tener más claras las presuntas bondades de la competencia.
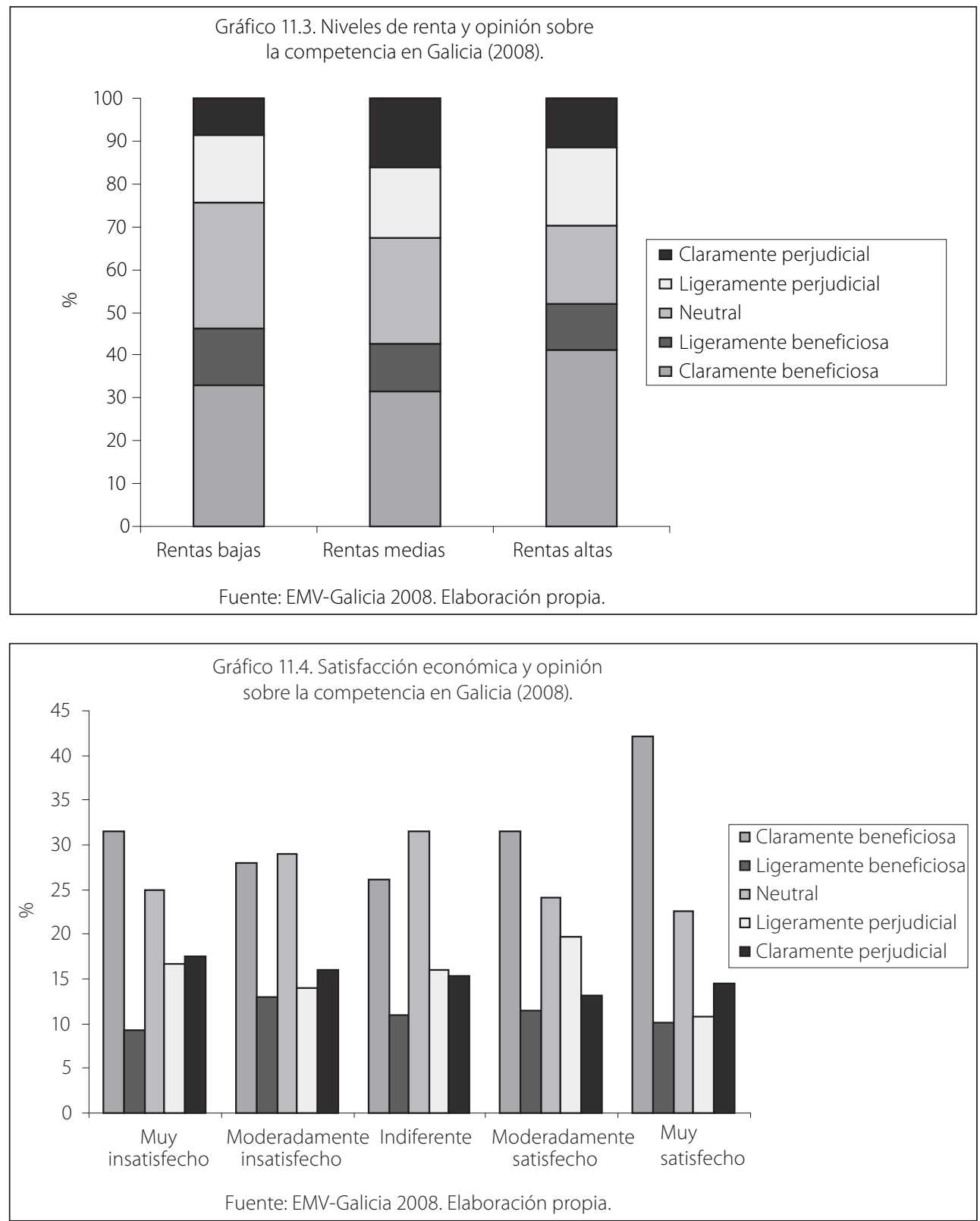

La interpretación de este tipo de relaciones — que, por otra parte, es bastante tenue- estaría sujeta, en todo caso, a ciertas cautelas, porque este análisis de 
carácter descriptivo no permite descartar la posibilidad de que la dirección de la causalidad vaya en sentido contrario, es decir, que la gente que más cree en las bondades de la competencia sea la que alcanza mayores niveles de éxito económico.

En esta misma línea, cabe señalar el escaso efecto de varios factores sociodemográficos que, en principio, deberían ejercer un peso más o menos considerable en la percepción que los individuos tienen del papel de la competencia. Nuevamente, el análisis de correlaciones revela que factores tales como la edad, el nivel de estudios e incluso la orientación ideológica no muestran relaciones significativas con las opiniones sobre la competencia.

A modo de ejemplo, en lo que se refiere a la potencial influencia del nivel de estudios, no faltan argumentos que teóricamente justificarían una actitud más favorable hacia la competencia de los individuos con mayores niveles educativos. Dicha actitud podría estar reflejando que el encuestado ve mayores oportunidades económicas asociadas a la competencia cuando su nivel educativo mejora, o también podría responder al hecho de que la educación hace que el ciudadano sea más consciente de los presuntos beneficios de la competencia. Además, si los individuos más formados tienen una menor aversión al riesgo, lo lógico es que su visión de la competencia sea más favorable. En cualquier caso, lo razonable es que en un entorno donde los más formados disfruten de un abanico más amplio de oportunidades, las diferencias en actitudes hacia la competencia entre individuos con diferentes niveles de estudios deberían ser más amplias. Sin embargo, en el caso gallego, los datos disponibles no corroboran este tipo de hipótesis.

Al margen de las mencionadas variables sociodemográficas que no parecen condicionar significativamente las opiniones de los gallegos sobre la competencia, sí se pueden identificar otros factores que exhiben una correlación significativa. Nos referimos a elementos como la profesión del entrevistado, la localización geográfica (tamaño y perfil socioeconómico del municipio de residencia) e incluso el sexo.

En lo relativo al vínculo de la opinión sobre la competencia con el tipo de puesto de trabajo que ocupa la persona, hemos creído conveniente tomar como referencia la categorización de Piore (1971) y la hipótesis de la dualidad, que divide el mercado de trabajo en dos submercados: el primario y el secundario. El primario se caracteriza por la existencia de altas y crecientes retribuciones salariales, buenas condiciones de trabajo, empleo estable y seguro, y posibilidades de mejora ocupacional. Por el contrario, en el mercado secundario predominan los salarios bajos, las malas condiciones de trabajo, la fuerte variabilidad y la falta de estabilidad en el empleo, así como la inexistencia de posibilidades de promoción. Piore considera el mercado primario dividido, a su vez, en dos segmentos: superior e inferior, según la autonomía en las relaciones de empleo, que es casi total en la parte superior y muy limitada en la inferior. 
En el Gráfico 11.5 aparecen reflejadas las diferentes actitudes hacia la competencia de los trabajadores encuadrados en cada uno de los segmentos previamente delimitados, considerando por separado al grupo de los agricultores, dada la relevancia que la actividad que desarrollan ha tenido tradicionalmente en el caso gallego. En principio, estos resultados no son ni mucho menos sorprendentes, sino que, por el contrario, se podrían calificar como previsibles. Por un lado, los trabajadores que ocupan puestos con mayor cualificación y de mayor estabilidad son los que sistemáticamente muestran una opinión más favorable hacia la competencia, mientras que en el extremo opuesto se sitúan aquellos con empleos menos cualificados y menos estables, que ven la misma con más recelo. El caso de los agricultores llama especialmente la atención por ser el colectivo que, en términos relativos, considera la competencia como más perjudicial.

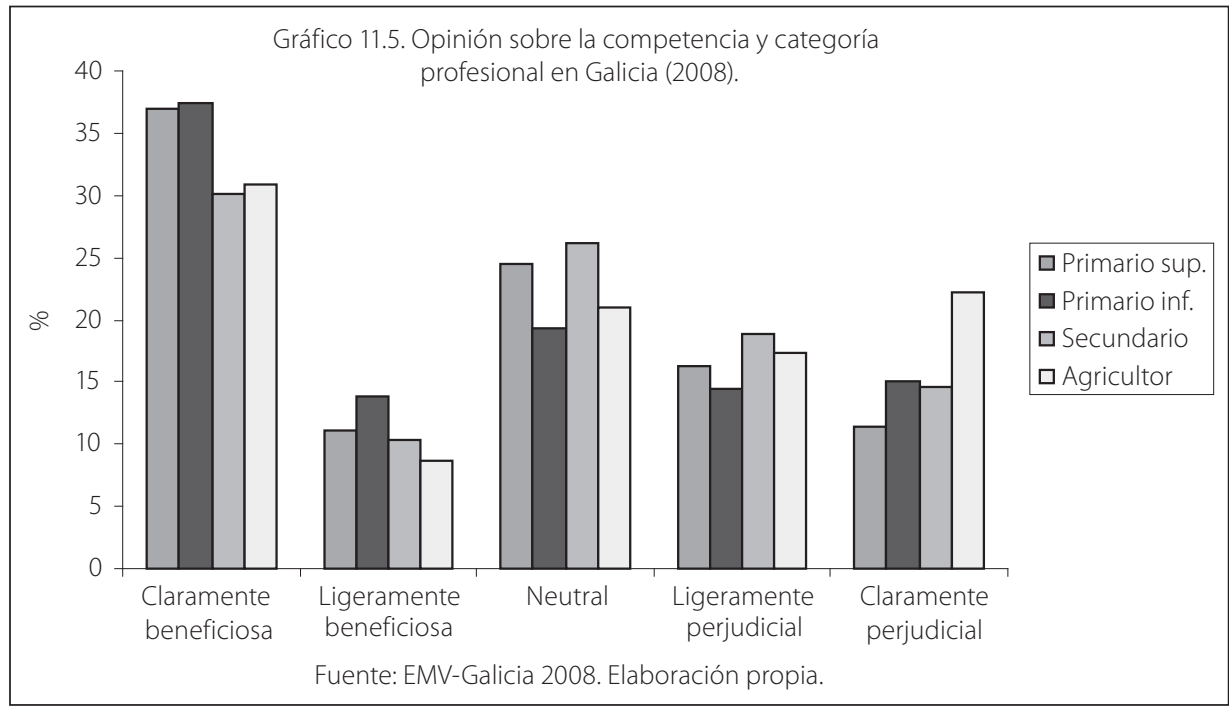

Otro de los colectivos cuyo posicionamiento hacia la competencia merece la pena abordar es el de los empresarios. Si diferenciamos el tamaño de las empresas atendiendo al número de empleados, en Galicia existe un claro predominio de las empresas de menos de diez trabajadores. En términos generales, tal y como se refleja en el Gráfico 11.6, las opiniones de los empresarios son más favorables a la competencia que para la media de la población, algo, por otra parte, lógico, si tenemos en cuenta que competencia e iniciativa privada son dos bases de la economía de mercado en el marco de la cual desarrollan su actividad las empresas.

De los datos disponibles, no se derivan resultados concluyentes sobre la existencia de diferencias significativas entre los posicionamientos de los propietarios y gestores de ambos tipos de empresas. La explicación puede residir en el hecho 
de que elementos de diversa índole condicionan las percepciones del empresariado a este respecto.

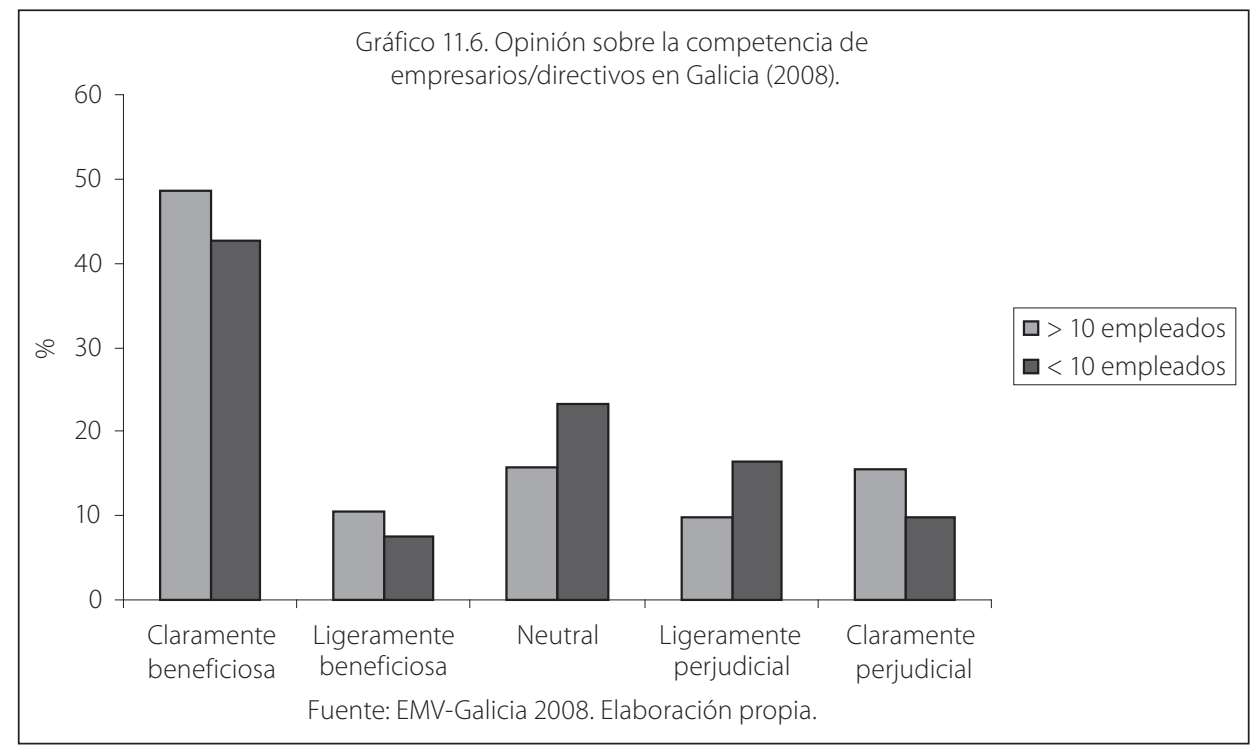

Por ejemplo, autores como Azmat et al. (2007) encuentran evidencia de que la parte del output que se apropian los capitalistas (dueños del capital) tiende a reducirse cuando la competencia aumenta, lo cual es perfectamente compatible con la intuición estándar del análisis económico de que un aumento de la competencia tiende a estrechar los márgenes de beneficio empresarial. Visto así, sería comprensible que el apoyo a la competencia fuese menor en el caso de los agentes económicos más pudientes. Por otra parte, las fuerzas de la competencia también amplifican el nivel de incertidumbre al que están expuestas las empresas. Si bien no es necesariamente perjudicial para los accionistas, en la medida en que tienen la opción de paliar las posibles consecuencias negativas a través de estrategias de diversificación, sí puede resultar más dañino para los trabajadores que ocupan un único puesto de trabajo en cada momento. Por lo tanto, a menos que este segundo tipo de efectos domine el primero, lo lógico sería esperar que el apoyo a la competencia fuese una función decreciente de la ratio capital financiero/capital humano que posee un individuo.

Más arriba apuntábamos la localización geográfica, es decir, el perfil socioeconómico del municipio de residencia, como uno de los factores que potencialmente pueden contribuir a explicar el posicionamiento de los individuos con respecto a la competencia. El hecho de que contempláramos de antemano la influencia de este elemento responde a una peculiaridad propia de la realidad gallega en lo que a la distribución espacial de la actividad económica se refiere: el proceso de crecimiento y de desarrollo económico de las últimas décadas, acentuó la 
concentración de la población y la actividad económica en el litoral de Galicia, ensanchándose la brecha entre las provincias occidentales (costeras) y las orientales (interiores) ${ }^{6}$.

El Gráfico 11.7 ofrece alguna información interesante a este respecto. Apenas se detectan diferencias entre los tres tipos de municipios delimitados: urbanos, rururbanos ${ }^{7}$ y rurales. Únicamente sobresale el porcentaje de personas residentes en municipios rurales que perciben la competencia como algo claramente perjudicial. Estos ayuntamientos carecen de dinamismo económico, se encuentran sometidos a procesos de vacío demográfico y envejecimiento y están especializados únicamente en actividades del sector primario. La constatación de que los habitantes de este tipo de municipios consideran la competencia como algo perjudicial estaría en línea con lo observado al realizar el análisis por categoría profesional, donde poníamos de manifiesto las reservas de los agricultores sobre este particular. En suma, la evidencia disponible sugiere que, en general, los residentes en entornos rurales no confían en la competencia. Para ahondar en las explicaciones habría que indagar en qué medida este tipo de personas se ha visto injustamente tratado por el sistema (evolución de la población empleada en la agricultura, renta, funcionamiento del mercado agropecuario, etc.).

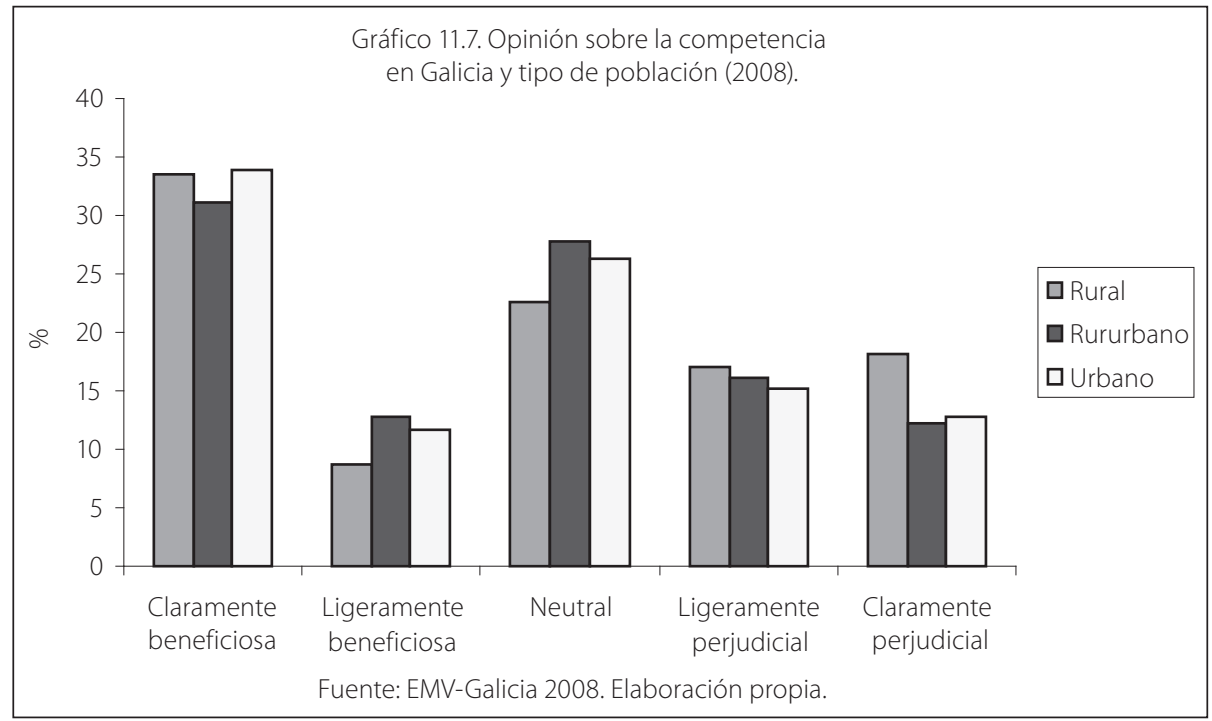

De entre los factores de carácter sociodemográfico que muestran un impacto más significativo sobre las actitudes hacia la competencia, destaca el sexo. Tal y como se observa en el Gráfico 11.8, en Galicia las mujeres dudan más que los hombres de las presuntas virtudes de la competencia.

En Pena y Sánchez (2008) y Prada y Lago (2009) se da cuenta detallada de la naturaleza de este proceso. Término recientemente acuñado en el campo de la geografía económica para referirse a un espacio que sin dejar de estar implantado en el medio rural tiene un cierto carácter urbano-industrial. 


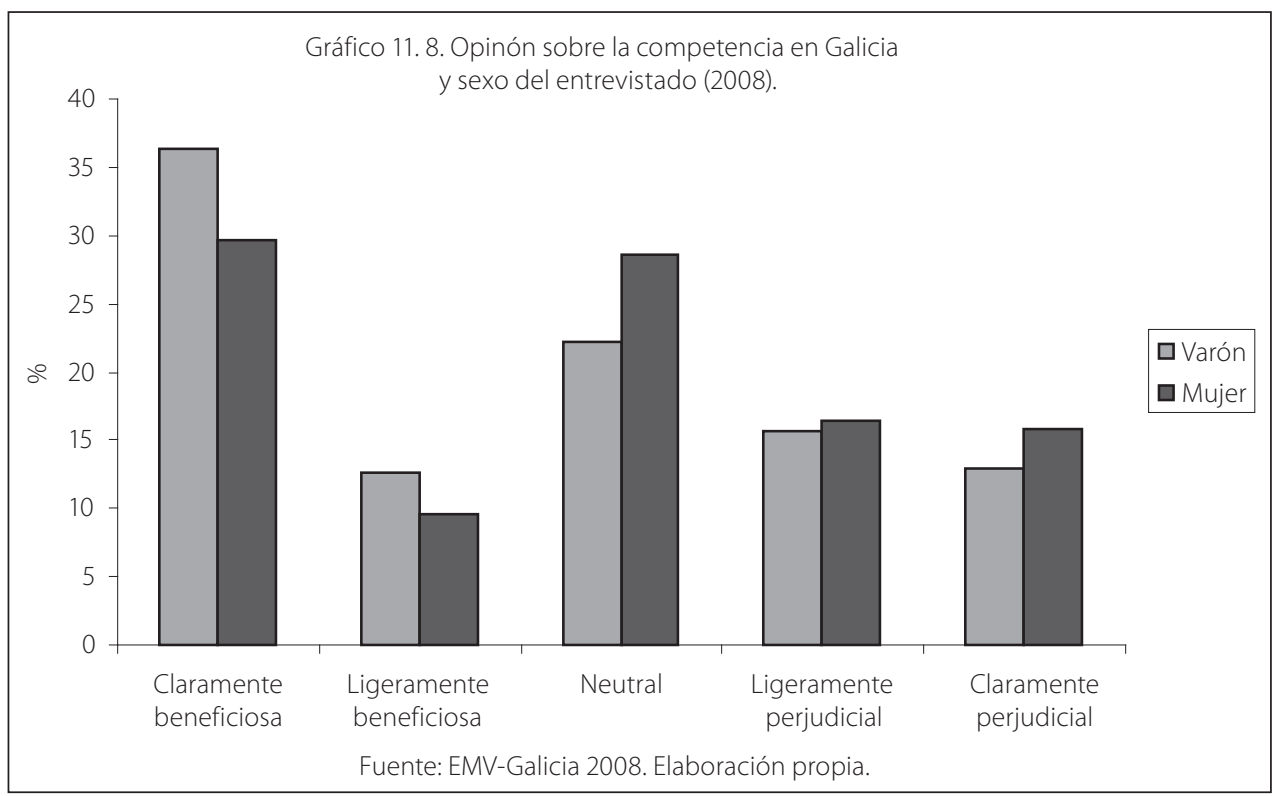

Las razones que están detrás de las diferencias de género en lo que a opiniones sobre la competencia se refiere son de diversa índole. Sociólogos y psicólogos sostienen que el comportamiento abiertamente competitivo de las mujeres suele ser sancionado socialmente, mientras que, por el contrario, en el caso de los hombres es recompensado (Valian, 1999). Los economistas, por su parte, se enfrentan al desafío de encontrar una explicación compatible con la elección racional que permita dar cuenta de las mencionadas diferencias.

La hipótesis de que las actitudes hacia la competencia no están determinadas por diferencias de género congénitas, sino que son resultado, al menos en parte, de comportamientos aprendidos es defendida por Gneezy et al. (2003). De hecho, estos autores obtienen evidencia experimental de que en una sociedad matriarcal es más probable que las mujeres sean seleccionadas en un entorno competitivo que los hombres, mientras que en una sociedad patriarcal sucede justo lo contrario. En esos mismos contextos experimentales, las mujeres se han mostrado menos competitivas que los hombres y su desempeño también ha sido relativamente peor en entornos competitivos, lo que, a su vez, podría llevar asociadas menores remuneraciones. En suma, la existencia de diferencias de género en materia de convicciones personales sobre la competencia no es una cuestión baladí, entre otras razones, porque dichas diferencias pueden ejercer una influencia significativa en la elección ocupacional y, a la postre, en la segregación que se observa en el mercado de trabajo.

La cuestión de si las diferencias de género en dicho mercado son consecuencia de la discriminación contra las mujeres o parcialmente reflejan sus actitudes y preferencias es de gran importancia para la formulación de las políticas de igualdad 
de género. Según Fortin (2005), actitudes favorables hacia la competencia ${ }^{8}$, especialmente las referidas a los hombres, aparecen positivamente asociadas con las tasas de empleo femenino. Así pues, las políticas que impulsen un entorno más competitivo (sin discriminación por razón de sexo) pueden, en última instancia, facilitar la incorporación de la mujer al mercado laboral.

Las consideraciones anteriores deberían ser tenidas en cuenta a la hora de explicar el considerable diferencial que existe entre la realidad gallega y la española en su conjunto y de ofrecer una respuesta a la pregunta de por qué las mujeres gallegas en general se muestran menos partidarias de la competencia que las españolas (Gráfico 11.9). Obviamente, la búsqueda de dicha explicación excede el objeto de un estudio de estas características.

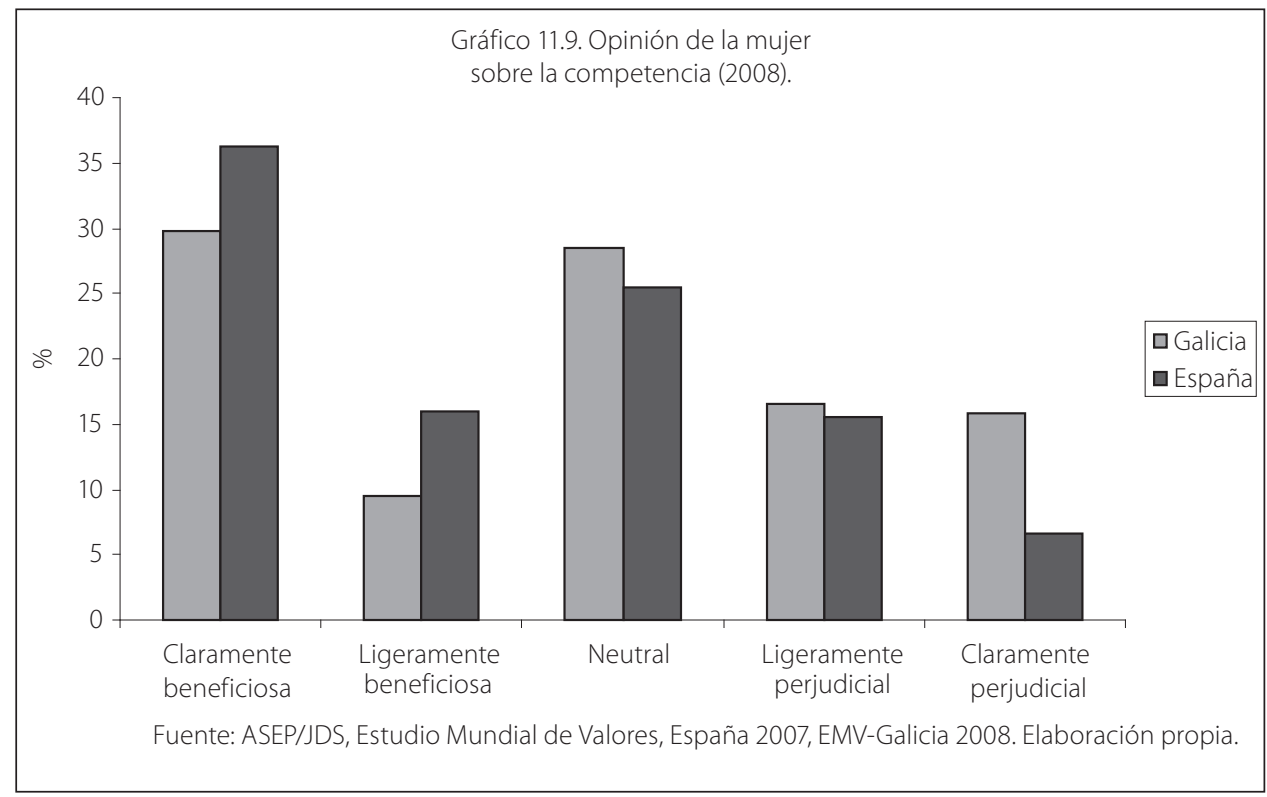

Actitudes sociales hacia la propiedad privada

Con el fin de disponer de más información sobre las actitudes sociales hacia el sistema de economía de mercado, el análisis de la competencia se puede completar con el análisis de la opinión sobre la propiedad privada. En efecto, en el marco del estudio de dichas actitudes, adquiere especial importancia la visión de los ciudadanos sobre los derechos de propiedad y los límites a la capacidad del gobierno para restringir esos derechos. Aunque el apego a la propiedad forma parte del ser humano, sería interesante determinar si existen diferencias al respecto que puedan ser atribuibles a factores histórico-culturales o incluso vinculados a los

8 Por actitudes más favorables hacia la competencia, se entiende, en este contexto, la creencia de que si los puestos de trabajos son escasos, los hombres no deberían tener más derecho que las mujeres a ocuparlos. 
valores. Este tipo de consideraciones son relevantes, por ejemplo, a la hora de entender el apoyo social a la titularidad pública de ciertas empresas (procesos de nacionalización) o a los procesos de privatización o semiprivatización que suelen formar parte de los paquetes de reforma estructural implementados por los gobiernos.

En este caso, se toma como indicador de las actitudes sociales hacia la propiedad privada el autoposicionamiento de la población en una escala de 1 (totalmente de acuerdo con que debería incrementarse la propiedad privada de las empresas) a 10 (totalmente de acuerdo con que debería incrementarse la propiedad estatal de las empresas). Aunque propiedad privada y competencia constituyen dos principios básicos en los que se sustenta la economía de mercado, lo cierto es que, a diferencia de lo que sucedía con la opinión sobre la competencia, en lo que respecta a la propiedad privada observamos una evolución claramente convergente a lo largo del tiempo de los casos gallego y español (Gráfico 11.10).

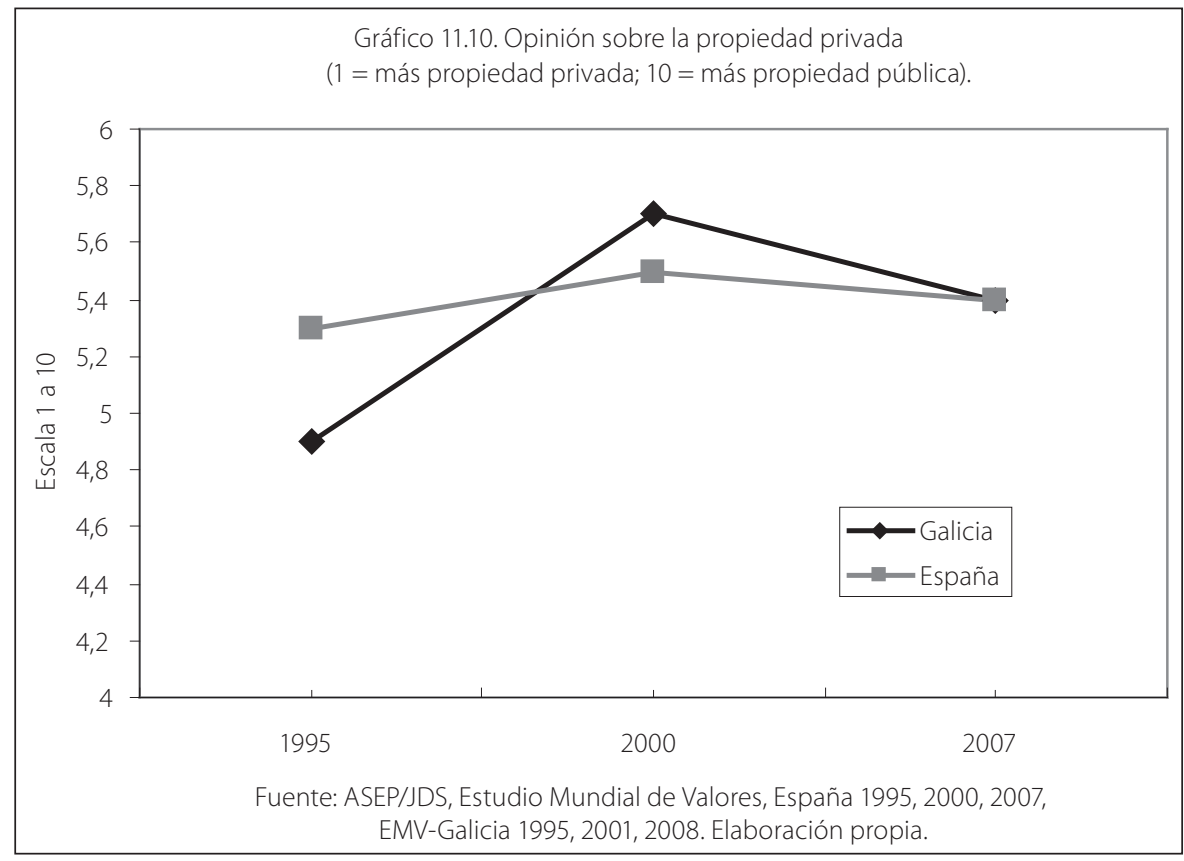

Si nos circunscribimos a la evolución de las percepciones sobre la propiedad privada en Galicia, a la luz de los datos del Gráfico 11.11 en dicha comunidad autónoma se ha reducido considerablemente el apoyo al incremento de la propiedad privada, situándose éste en niveles muy inferiores a los manifestados en la oleada de 1995. Por su parte, la proporción de los que están a favor de aumentar el peso de la propiedad estatal se mantiene prácticamente estable a lo largo del tiempo. Por otro lado, lo que parece consolidarse es una tendencia creciente de la parte de la sociedad que manifiesta posiciones más o menos neutrales. 


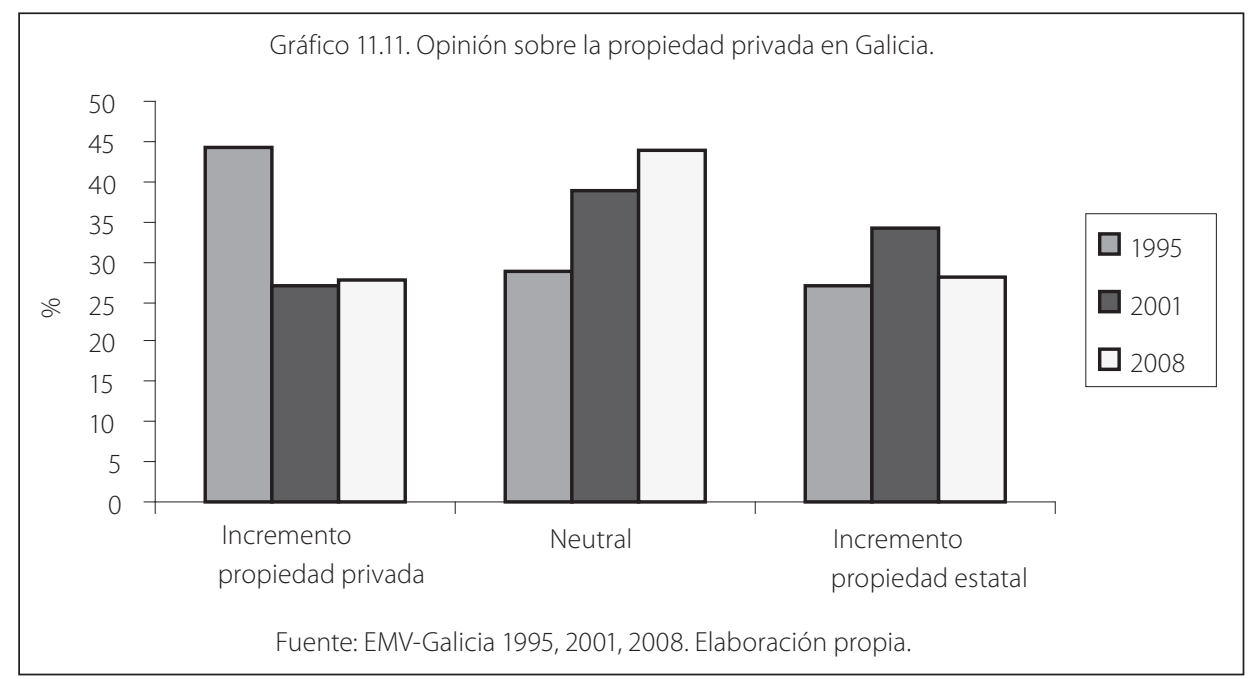

A modo de ilustración del tipo de variables estrechamente vinculadas con las actitudes hacia la propiedad privada, en el Gráfico 11.12 se recoge la relación entre las preferencias ideológicas y la opinión sobre la propiedad privada de los gallegos en el año 2008. En este sentido, todo indica que los votantes de derecha y centroderecha se muestran más partidarios de aumentar el peso de la propiedad privada, mientras que los de izquierda son más partidarios de incrementar la estatal.

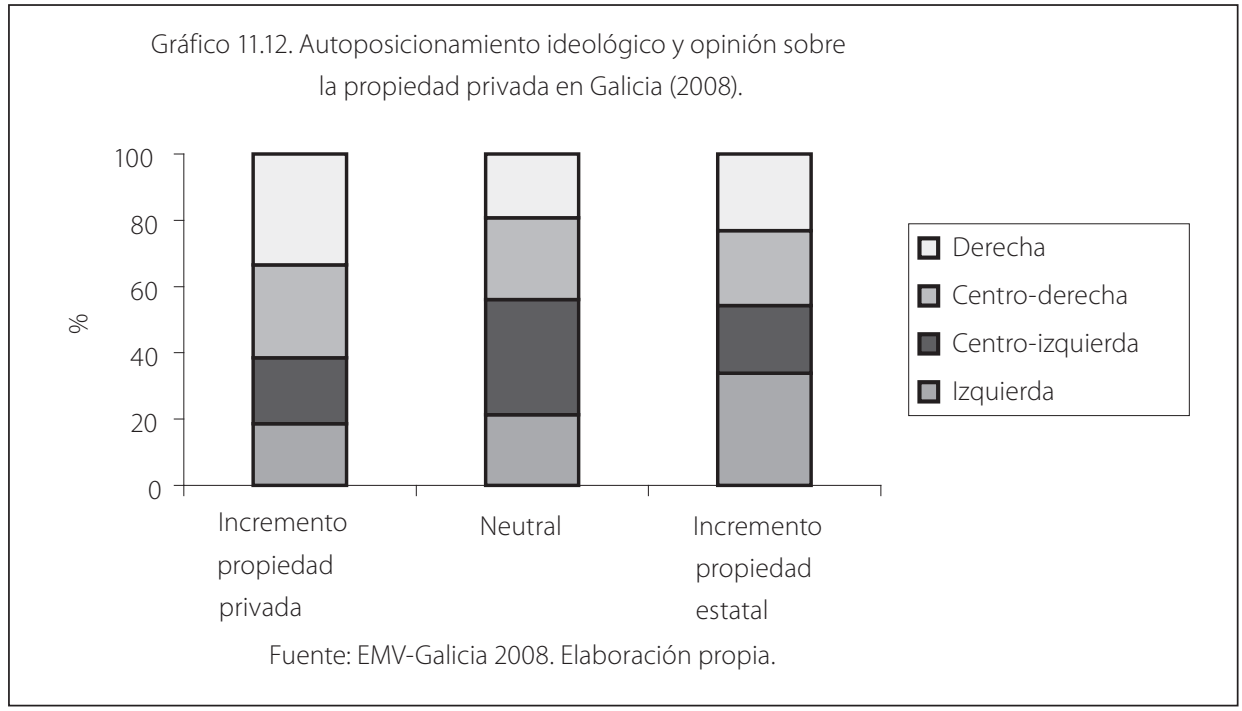

Este tipo de resultados es coherente con lo que cabría esperar de antemano, teniendo en cuenta los consabidos principios ideológicos de ambos extremos del espectro ideológico. Así, por ejemplo, autores como Nozick (1974) defienden que la propiedad privada debe ser protegida frente a cualquier expropiación o limitación 
si tuvo un origen legal (moral), mientras que, por el contrario, la crítica socialista señala que nadie tiene un mayor derecho prima facie que los demás sobre los recursos externos (Walzer, 1983). No obstante, un dato llamativo que no conviene perder de vista es la marcada neutralidad que manifiestan los ciudadanos que se posicionan ideológicamente en el segmento de centroizquierda.

Finalmente, en el Gráfico 11.13 se representa la evolución de indicador sintético de las opiniones sobre el modelo de economía de mercado. Hemos construido este indicador teniendo en cuenta conjuntamente las actitudes hacia la competencia y la propiedad privada que con anterioridad habíamos abordado por separado. El índice está elaborado de tal modo que cuanto menores sean los valores del mismo, mayor es la preferencia por el mercado (competencia más propiedad privada).

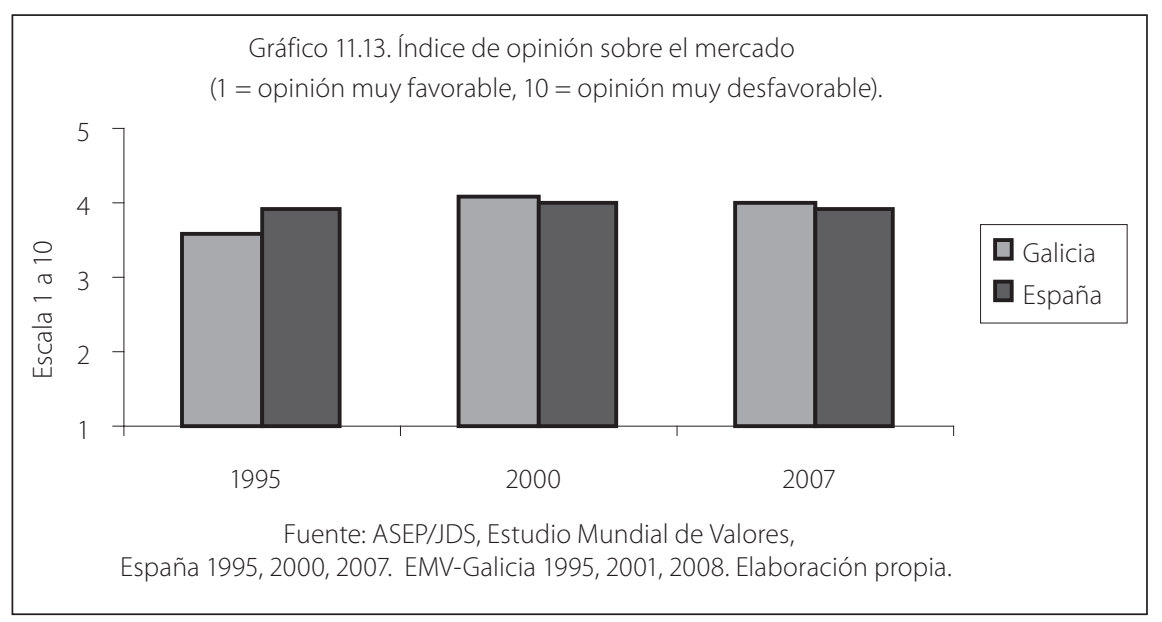

Según los valores del índice sintético, la sociedad gallega no cuestiona el sistema de economía de mercado y apenas muestra diferencias significativas con respecto a España. Sin embargo, la comparación de Galicia con España pone de relieve que en los últimos años el sentimiento hacia el mercado es más favorable en el conjunto de España que en Galicia. Ahora bien, partiendo de que en 1995 la percepción era diametralmente opuesta, no parece que sean factores históricoculturales los que expliquen estas diferencias, sino más bien otros de carácter socioeconómico (convergencia económica regional, distribución de la renta, etc.), algunos de los cuales son de naturaleza coyuntural.

Finalmente y a modo de síntesis, podríamos afirmar que la evidencia que se desprende del análisis conjunto de las actitudes hacia la competencia y la propiedad privada, sugiere que la hipótesis del interés particular está en cierta medida avalada por los datos pero, en cualquier caso, su capacidad explicativa de la visión que la sociedad gallega tiene del modelo de economía de mercado es más bien limitada. 


\subsubsection{Valores morales, creencias y actitudes hacia el mercado}

El estudio de las preferencias sociales por el sistema económico capitalista puede completarse analizando en qué medida las actitudes hacia el mecanismo de mercado están enraizadas en la cultura. De hecho, es lógico que las perspectivas éticas de las personas (absolutismo/relativismo) se reflejen en sus actitudes hacia el mercado en varios dominios: trabajo, responsabilidad del individuo, igualdad de oportunidades, inmigración, desigualdades de renta, etc. ${ }^{9}$. En esta línea, de acuerdo con el planteamiento de Baker y Forbes (2006), a efectos de obtener cierta evidencia sobre la relación entre los valores morales de los gallegos y dichas actitudes, cabe considerar dos dimensiones de la escala valorativa: por un lado, un continuum que va desde los valores tradicionales hasta los racional-seculares y, por otro, el que oscila desde los valores de supervivencia hasta los de autoexpresión.

En concreto, la importancia que Dios, la patria y la familia tienen en la vida de la persona son los elementos constitutivos de la primera dimensión. De este modo, en un extremo se situarían los valores tradicionales, que reflejarían las creencias (posturas) sobre la relevancia de la religión y de Dios en la vida del sujeto, los altos niveles de orgullo nacional y el respeto a la vida (oposición al aborto). En el otro extremo estarían los denominados valores seculares, que enfatizarían las posiciones opuestas. Los datos reflejan que estos valores tradicionales están en cierta medida vinculados a las actitudes sobre el modelo de economía de mercado, aunque en menor grado de lo que cabría esperar (Tabla 11.2). De hecho, los mencionados valores no influyen en la opinión sobre la competencia en ninguno de los casos. Los únicos valores que informan en cierta medida de actitudes favorables al mercado son los relativos al respeto a la vida y a la importancia de Dios en la vida de la persona, que aparecen estrechamente asociados a la postura favorable al incremento de la propiedad privada ${ }^{10}$.

En cuanto a la segunda de las dimensiones valorativas anteriormente mencionada, es preciso señalar que los valores de supervivencia hacen hincapié en la seguridad física, el crecimiento económico y el orden por encima de todo lo demás. Por su parte, los valores autoexpresivos enfatizan aspectos tales como la confianza interpersonal, la tolerancia, la igualdad de género, el bienestar subjetivo, el activismo político, etc.

\footnotetext{
En la medida en que los análisis sobre el trabajo y la inmigración son objeto de estudio en otros capítulos de la presente obra, aquí nos centraremos en los restantes dominios mencionados.

10 Para una interpretación correcta de los datos es preciso tener en cuenta que en la EMV se utilizan escalas que van de 1 (Dios no es nada importante en la vida de la persona/el aborto nunca está justificado/debería incrementarse la propiedad privada/esforzarse conlleva éxito) a 10 (Dios es muy importante/el aborto siempre está justificado/debería incrementarse la propiedad estatal/esforzarse no suele llevar al éxito). Por lo tanto, el signo negativo de los coeficientes de correlación en este contexto refleja que cuanto más importante es Dios en la vida de la persona, más favorable es su opinión sobre la propiedad privada y más participa de la idea de que esforzarse en el trabajo suele llevar a una vida mejor.
} 
Tabla 11.2. Valores tradicionales y actitudes hacia el mercado. Galicia 2008.

(Coeficientes de correlación de Spearman).

\begin{tabular}{|c|c|c|c|}
\hline Valores tradicionales & $\begin{array}{c}\text { Opinión sobre } \\
\text { propiedad } \\
\text { privada }\end{array}$ & $\begin{array}{l}\text { Opinión sobre } \\
\text { esfuerzo en } \\
\text { el trabajo }\end{array}$ & $\begin{array}{l}\text { Opinión sobre } \\
\text { competencia }\end{array}$ \\
\hline Importancia de Dios en su vida & $-0,09 * *$ & $-0,06^{*}$ & 0,02 \\
\hline Importancia del trabajo & $-0,03$ & 0,00 & 0,01 \\
\hline Pertenencia: parte de nación española & 0,01 & 0,04 & $-0,01$ \\
\hline Justificación del aborto & $0,12 * *$ & $0,06^{* *}$ & 0,03 \\
\hline
\end{tabular}

Fuente: EMV-Galicia 2008. Elaboración propia.

Dado que la competencia es un valor que tiende a promover los intereses materiales y va en contra de los objetivos posmaterialistas, lo esperable sería una relación negativa entre la evolución de los valores típicamente posmaterialistas y el apoyo a la competencia. Como es bien sabido, la hipótesis posmaterialista (Inglehart, 1998) predice que cuando las necesidades materiales de las personas están satisfechas, los valores de la población tienden a desplazarse desde aquellos que promueven la supervivencia hacia los que favorecen la autoexpresión. Puesto que la competencia es una estrategia que prima los resultados orientados a la supervivencia individual más que los comportamientos prosociales y de autoexpresión, cabría anticipar que los individuos que otorgan más importancia a los valores posmaterialistas deberían mantener opiniones menos favorables hacia la competencia.

Siguiendo con esta lógica, las mejoras en el desarrollo humano, la emergencia de valores posmaterialistas y un estatus social bajo son factores que teóricamente estarían asociados a la perspectiva de que la competencia no es una fuerza socialmente positiva (Hayward y Kemmelmeier, 2007). No obstante, de los datos más recientes disponibles para Galicia en la oleada de 2008, no se deriva ninguna relación significativa entre los índices de materialismo-posmaterialismo y la opinión sobre la competencia.

En lo que concierne a los valores autoexpresivos, la Tabla 11.3 nos ofrece alguna evidencia que apunta en la dirección de que el compartir este tipo de valores condiciona las actitudes o sentimientos de los individuos hacia el mercado.

En concreto, los valores y el signo de los coeficientes de correlación que resultan ser estadísticamente significativos permiten plantear la hipótesis de que un mayor peso de los valores autoexpresivos está asociado, por un lado, con la creencia de que debería incrementarse la propiedad estatal de las empresas 
(opinión menos favorable a la propiedad privada) y, por otro, con las ideas de que a la larga el esfuerzo en el trabajo suele llevar a una vida mejor y que la riqueza puede crecer de manera que haya bastante para todos.

Tabla 11.3. Valores autoexpresivos y opiniones sobre el mercado. Galicia 2008.

(Coeficientes de correlación de Spearman).

\begin{tabular}{ccccc}
$\begin{array}{c}\text { Valores } \\
\text { autoexpresivos }\end{array}$ & $\begin{array}{c}\text { Opinión sobre } \\
\text { la acumulación } \\
\text { de riqueza }\end{array}$ & $\begin{array}{c}\text { Opinión sobre } \\
\text { el esfuerzo } \\
\text { en el trabajo }\end{array}$ & $\begin{array}{c}\text { Opinión } \\
\text { sobre la } \\
\text { competencia }\end{array}$ & $\begin{array}{c}\text { Opinión sobre } \\
\text { la propiedad } \\
\text { privada }\end{array}$ \\
\hline Imaginación & $-0,002$ & $-0,034$ & 0,005 & $-0,030$ \\
\hline Tolerancia & $-0,096^{* *}$ & $0,128^{* *}$ & 0,002 & $-0,127^{* *}$ \\
\hline Generosidad y altruismo & $-0,188^{* *}$ & $0,097^{* *}$ & $-0,063^{*}$ & $-0,111^{* *}$ \\
\hline
\end{tabular}

* La correlación es significativa al nivel 0,05 (bilateral).

** La correlación es significativa al nivel 0,01 (bilateral).

Fuente: EMV-Galicia 2008. Elaboración propia.

En definitiva, el análisis precedente viene a poner de manifiesto que los individuos que defienden valores más tradicionales (y que a su vez se posicionan más a la derecha en el espectro ideológico) manifiestan una actitud más favorable hacia el mercado, al contrario de lo que sucede con los que participan de valores de carácter más secular. Así pues, de los datos disponibles se desprende que valores e ideología política condicionan el sentimiento de los ciudadanos hacia el mercado.

Además de los valores, entre los factores con una honda raíz cultural que mediatizan las opiniones de la sociedad gallega sobre el mercado, destaca la actitud ante la vida de los individuos. En el Gráfico 11.14 se reflejan las creencias relativas a la influencia del destino en la vida de las personas y a la libertad de elección y grado de control sobre su vida de que gozan las mismas.

Para interpretar este gráfico hay que tener en cuenta que el entrevistado se sitúa en sendas escalas que van de 1 a 10, de tal modo que los valores más próximos a 1 reflejan opiniones de que todo en la vida está determinado por el destino y que el individuo no tiene ninguna libertad de elección, mientras que valores más cercanos a 10 serían indicativos de creencias según las cuales las personas se hacen su propio destino y tienen mucha libertad de elección.

De acuerdo con la información manejada parece constatarse, por un lado, que los españoles en su conjunto tienen una visión menos determinista que los gallegos en lo que a la influencia del destino se refiere. Sin embargo, estos últimos consideran que disfrutan de una mayor libertad de elección y control sobre la manera en que se desarrolla su vida. Una primera interpretación de estos 
resultados puede realizarse a la luz de la conocida distinción entre los conceptos de "libertad negativa" y "libertad positiva" establecida en su día por Berlin (1967). Por un lado, los gallegos creen estar sujetos a menos restricciones externas impuestas por la sociedad que limiten la capacidad de elección del individuo (libertad negativa). Por otro lado, sin embargo, confieren más importancia al destino como factor determinista o, dicho de otro modo, en términos de percepción de niveles de "libertad positiva", son menos optimistas que los españoles, a la hora de valorar las condiciones personales que permiten ejercer la mencionada libertad de elección.

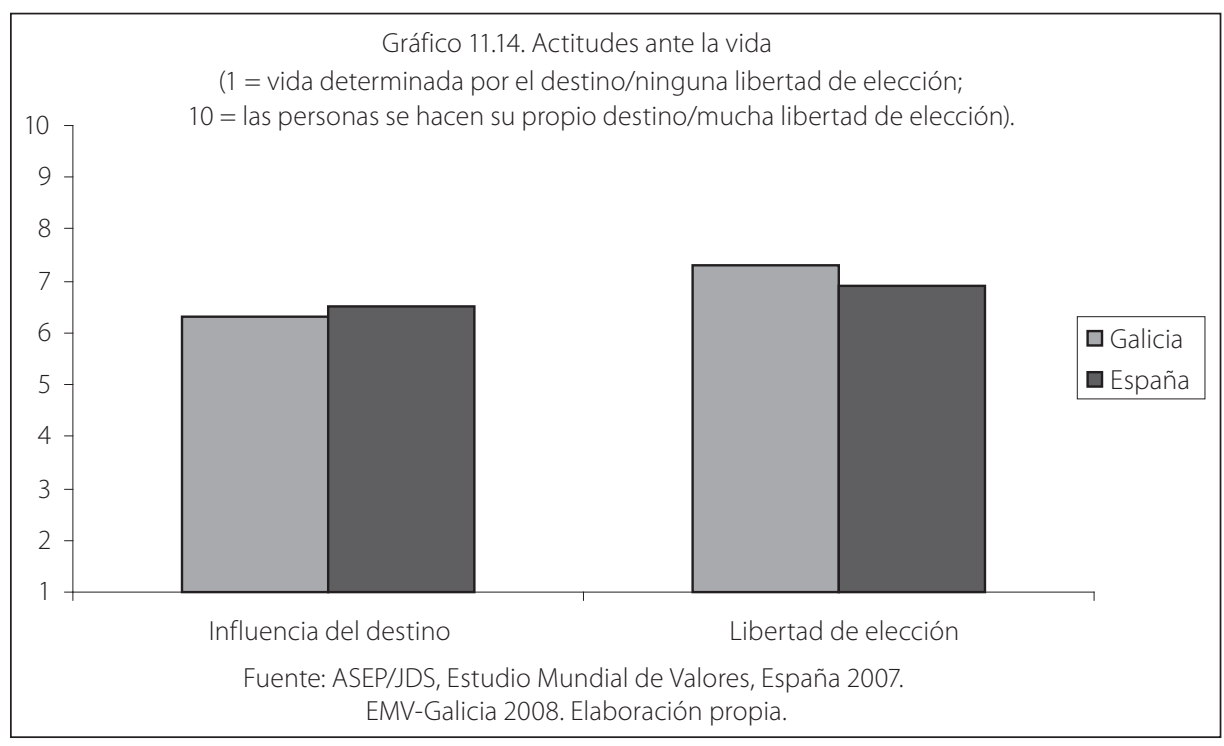

Las posibles explicaciones a estas diferencias detectadas entre España y Galicia son atribuibles a causas de diversa índole. Probablemente respondan en parte tanto a las peculiaridades histórico-culturales como a distintas circunstancias socioeconómicas, pero, una vez más, el entrar en este tipo de consideraciones excede el alcance de este capítulo. No obstante, en este ámbito resulta muy ilustrativa la aportación de Sen (1999) a la teoría económica desarrollando el concepto de capacidad. De hecho, Sen utiliza este concepto para mostrar que un análisis de la igualdad y de la libertad deberá tener en cuenta las distintas capacidades que posee un individuo y que son las que realmente darían una idea de su nivel de riqueza o circunstancia socioeconómica.

Independientemente de las razones que estén detrás de las diferencias de actitudes ante la vida entre gallegos y españoles, lo cierto es que nos encontramos ante elementos con una clara raíz cultural que inciden significativamente en la configuración de las preferencias sociales en materia de sistema económico. A título ilustrativo, las cifras de la Tabla 11.4 revelan una relación hasta cierto punto lógica 
entre las variables que reflejan una actitud ante la vida (influencia del destino y libertad de elección) y las opiniones sobre la competencia. Tal y como puede observarse en dicha tabla, un mayor porcentaje de los encuestados que creen que las personas se forjan su destino y consideran que tienen libertad de control sobre su vida, manifiestan una mayor inclinación hacia la competencia ${ }^{11}$.

Tabla 11.4. Actitudes ante la vida y opinión sobre la competencia. Galicia 2008.

\begin{tabular}{lcc} 
& $\begin{array}{c}\text { La competencia } \\
\text { es buena }\end{array}$ & $\begin{array}{c}\text { La competencia } \\
\text { es perjudicial }\end{array}$ \\
\hline $\begin{array}{l}\text { Vida determinada } \\
\text { por el destino }\end{array}$ & $22,9 \%$ & $11,8 \%$ \\
\hline $\begin{array}{l}\text { Las personas se } \\
\text { hacen su destino }\end{array}$ & $28,3 \%$ & $11,8 \%$ \\
\hline $\begin{array}{l}\text { Mucha libertad de } \\
\text { control sobre su vida }\end{array}$ & $28,4 \%$ & $9,4 \%$ \\
\hline
\end{tabular}

Fuente: EMV-Galicia 2008. Elaboración propia.

En definitiva, el análisis de los factores determinantes de la percepción que tienen los individuos de las fortalezas y debilidades del modelo de economía de mercado nos permite concluir que tanto los valores como los intereses de clase socioeconómicos sustancian las actitudes sociales hacia el mercado. Esto significa, entre otras cosas, que una investigación en profundidad sobre la influencia de los valores en las preferencias sociales requiere tener en cuenta ambos tipos de variables. En otras palabras, la configuración del conjunto de creencias sobre el sistema económico es el producto de un proceso extremadamente complejo, porque dichas creencias y actitudes están fuertemente mediatizadas por una red de elementos interconectados tan diversos como la historia cultural, los valores sociales emergentes, la posición social del individuo, etc.

Por último, a las anteriores consideraciones habría que añadir que los mercados y otras instituciones económicas no se limitan a la asignación de recursos, sino que también ejercen su influencia sobre la evolución de los valores y las preferencias de los individuos (cfr. Bowles, 1998). Es decir, un análisis riguroso de la correspondencia entre valores y actitudes de los individuos hacia el mercado debe contemplar el carácter recíproco de dicha relación ${ }^{12}$. Si asumimos esta premisa, no sería descartable que la última crisis, cuyo inicio suele fijarse a mediados del año 2007, pueda acabar afectando a las creencias u opiniones de los ciudadanos sobre el papel del mercado como mecanismo de asignación de

11 Para la obtención de los porcentajes que figuran en la tabla, en una escala de 1 a 10 se han considerado como opiniones claramente favorables los valores 1 y 2, mientras que como opiniones claramente desfavorables se tomaron los valores 9 y 10.

12 Un ejemplo reciente de enfoque que aborda la influencia recíproca entre valores y economía puede verse en Östling (2009). 
recursos, alterando el balance que éstos realizan de las bondades y distorsiones del mismo. Esto es algo que no debería sorprendernos, en la medida en que la gravísima recesión que padecen la mayoría de las economías occidentales se perciba por parte de la sociedad, por un lado, como un elemento revelador de los excesos del libre mercado y, por otro, como prueba de la necesidad de redefinir las competencias estatales en materia de regulación y supervisión del funcionamiento de dicha institución ${ }^{13}$.

\subsection{LEGITIMIDAD DEL MERCADO Y PAPEL DEL GOBIERNO EN LA ECONOMÍA}

Una idea que goza de amplio grado de aceptación en el mundo académico es que el libre mercado conduce a la eficiencia económica pero, al mismo tiempo, la lógica inherente a su funcionamiento genera desigualdad y, en los casos más extremos, da lugar a situaciones de exclusión social, que pueden acabar convirtiéndose en un fenómeno de carácter estructural. Esta constatación justificaría la creencia de que un sistema democrático liberal bien establecido e integrado no puede existir solamente bajo el modelo de individualismo competitivo. Efectivamente, este sistema exige cierto grado de corrección o atenuación del conflicto a través de la implementación de formas de cooperación y de solidaridad social que garanticen, al menos, el mínimo de justicia necesario para mantener la cohesión social. Tanto es así, que en la mayoría de las economías de mercado, de los tres papeles tradicionales que se le asignan a un gobierno, a saber, provisión de bienes públicos, estabilización macroeconómica y redistribución de la renta, este último ha ido adquiriendo una importancia creciente. De hecho, cualquier explicación del papel de los gobiernos en las economías de las democracias industriales, exige conocer las actitudes sociales hacia la desigualdad, la necesidad de redistribución y la delimitación de los ámbitos de responsabilidad del individuo y del sector público.

\subsubsection{Demanda de redistribución:} factores económicos y conductuales

Con la finalidad de efectuar una primera aproximación, por un lado, a las actitudes de la sociedad gallega hacia la desigualdad de ingresos y el beneficio privado y, por otro, a los factores determinantes de la demanda social de políticas redistributivas, tomamos como referencia las respuestas a la pregunta de la EMV que se formula en términos del grado de acuerdo con las siguientes afirmaciones: "los ingresos deberían ser más iguales" (1) y "debe haber mayores incentivos para el esfuerzo individual" (10). Los valores medios en esa escala de 1 a 10 y la evolución temporal de los mismos en España y en Galicia se representan en el Gráfico 11.15.

13 Es precisamente en el contexto de las respuestas a la crisis económico-financiera en el que surgen declaraciones como la del presidente de Francia, Nicolás Sarkozy, sobre la necesidad de refundar el capitalismo. 


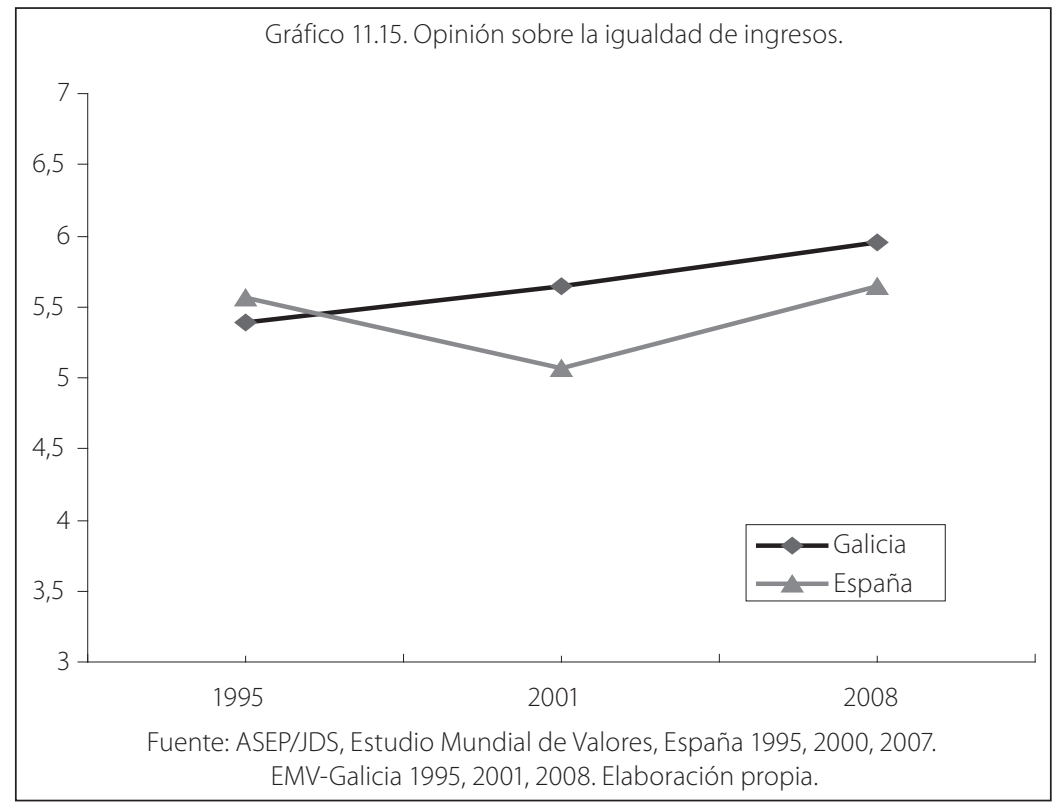

A primera vista, los gallegos se muestran más preocupados por la mejora de los incentivos al esfuerzo individual que en el conjunto de España. No obstante, tal y como señalan Kenworthy y McCall (2008), a la hora de interpretar los resultados a la pregunta de si los ingresos deberían ser más iguales se requiere hacer la siguiente matización. Las respuestas de los encuestados no reflejan única y directamente su consciencia del nivel de desigualdad existente, sino que también revelan sus actitudes hacia la mayor o menor justicia de ese nivel de desigualdad percibido. Por lo tanto, la cuestión de si "los ingresos deberían ser más iguales" combina una evaluación positiva del grado de desigualdad con una opinión (normativa) sobre qué nivel de desigualdad sería justo. Además, las visiones normativas a este respecto pueden diferir considerablemente entre países e incluso entre regiones de un mismo país. Consecuentemente, las diferencias en las respuestas a esta pregunta entre Galicia y España deben ser valoradas con cautela, en la medida en que pueden estar reflejando percepciones distintas de los entrevistados.

En el Gráfico 11.16 se visualiza claramente cómo ha ido variando la opinión de los gallegos sobre la necesidad de promover los incentivos al esfuerzo individual. Este cambio resulta especialmente llamativo si se compara con la opinión del conjunto español. Concretamente, las barras del gráfico representan la diferencia que existe entre el porcentaje de gallegos y españoles con una preferencia clara e inequívoca por incrementar los incentivos al esfuerzo individual. Una de las posibles implicaciones de estos resultados es que viene a poner de manifiesto, entre otras cosas, que para conseguir avances en la implantación de una cultura

366 LA EVOLUCIÓN DE LOS VALORES SOCIALES EN GALICIA 
del esfuerzo, se requiere un replanteamiento del esquema de incentivos que, en última instancia, determina la conducta económica de los individuos.

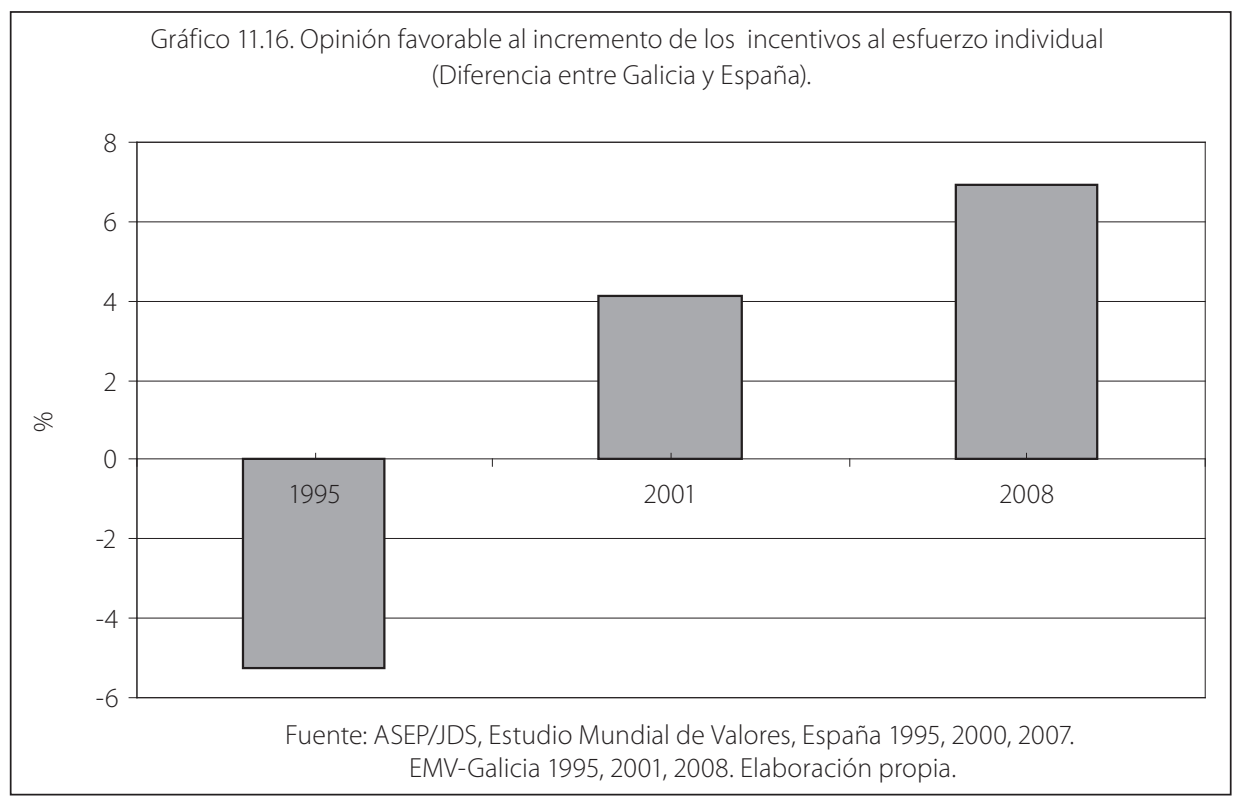

En términos generales, el marco analítico que ofrece una explicación razonable al posicionamiento de la sociedad gallega sobre la justicia de los resultados del mercado y el papel del gobierno en la economía, nos lo proporciona una novedosa y rápidamente creciente literatura que ha abordado los factores determinantes de la demanda de redistribución ${ }^{14}$. Dichos factores suelen agruparse en tres grandes categorías: económicos, políticos y conductuales. En nuestro caso, teniendo en cuenta el objeto de estudio del presente capítulo, en lo que resta de apartado nos centraremos básicamente en los factores económicos y conductuales.

\section{Condicionantes económicos y preferencias redistributivas}

A priori, entre los factores de índole económica, los niveles de renta corriente y su distribución interpersonal podrían ser buenos predictores de las actitudes individuales hacia la redistribución. En principio, tal y como señalan Romer (1975) y Meltzer y Richard (1981), lo lógico sería que los individuos menos favorecidos económicamente (los más pobres) fueran los principales partidarios de las políticas redistributivas. En particular, Meltzer y Richard basan su razonamiento en el teorema del votante mediano. Técnicamente, un mayor nivel de desigualdad generada por el mercado implica una mayor distancia entre la renta media y la mediana (antes de impuestos y transferencias), situándose esta última considerablemente por debajo de la primera. Cuanto menor

14 Cfr. Benabou y Ok (2001), Alesina y Angeletos (2005) y Alesina y La Ferrara (2005). 
sea la renta mediana en relación con la media, más se beneficiará la persona o familia situada en la mediana de las políticas redistributivas que implemente el gobierno, en el sentido de que las transferencias que reciba superarán su contribución vía carga tributaria.

En consecuencia, una desigualdad generada por el mercado conduce a una demanda de políticas redistributivas más generosas. A su vez, en el contexto de un sistema democrático en el que las medidas adoptadas por los gobiernos responden razonablemente a las preferencias de los electores, las mencionadas demandas sociales probablemente se traducirán en la implementación de políticas redistributivas más pródigas por parte de los ejecutivos. Además, de acuerdo con Alesina y La Ferrara (2005), puesto que la redistribución se produce de los más ricos a los más pobres, lo lógico sería esperar que estos últimos se mostraran más favorables y los primeros planteasen una mayor oposición. Este argumento entronca con un enfoque que goza de amplia aceptación y que enfatiza la influencia de las características individuales (circunstancias personales) sobre las actitudes hacia las políticas redistributivas. Se trata de una versión de lo que se ha dado en llamar la "hipótesis del interés particular", que, tal y como se ha señalado en apartados anteriores, asume que aquellos que son o potencialmente pueden ser beneficiarios de los programas del Estado del Bienestar es más probable que manifiesten opiniones más favorables a este tipo de políticas.

No obstante, en el caso gallego, el análisis de los datos disponibles no permite constatar que exista una correlación entre los niveles de ingresos de las familias y la demanda de redistribución. Por otra parte, tampoco detectamos un vínculo significativo entre la satisfacción con la situación económica del hogar y las actitudes de los individuos hacia la desigualdad ni con sus preferencias por la redistribución. Este tipo de evidencia revela que el efecto de la renta sobre las preferencias en materia de redistribución es más complejo de lo que a priori pudiera parecer.

En la medida en que los que actualmente son más pobres puedan mejorar su situación económica en el futuro y viceversa, las expectativas sobre los niveles relativos de renta afectarían a las preferencias presentes por políticas redistributivas. Cabe pensar que éste es un aspecto que los individuos tendrán en cuenta a la hora de evaluar los pros y los contras de la redistribución. En esta línea, Benabou y Ok (2001) centraron su atención en el papel de la movilidad social. De acuerdo con su modelo, como las políticas redistributivas no cambian muy frecuentemente, puede haber un rango de individuos con rentas por debajo de la media que se oponen a tales políticas porque racionalmente esperan situarse por encima de la media en el futuro, de tal modo que el colectivo que no se muestra a favor de la redistribución puede ser mayoritario en el conjunto de la ciudadanía. 
En otras palabras, la perspectiva de movilidad al alza influye en las preferencias del mencionado colectivo por unas políticas redistributivas que, aunque ventajosas en el presente, si se mantienen en el tiempo, pueden convertirlo en perdedor neto en el futuro. Por lo tanto, en un contexto de estas características, además de la renta corriente, la renta futura esperada debería influir en las preferencias de los individuos por el nivel de redistribución.

Adicionalmente, también merece la pena señalar que los niveles educativos no ejercen una influencia clara en las actitudes de la gente hacia la desigualdad. Teóricamente, en la medida en que los individuos con mayores niveles formativos se hayan beneficiado más del crecimiento económico y de la distribución desigual de la renta, deberían ser más comprensivos con el significado e implicaciones de un sistema de economía de mercado que genera desigualdades en dicha distribución. No obstante, la evidencia empírica obtenida en primera instancia para el caso gallego no ratifica esta hipótesis.

\section{Valores sociales y justicia redistributiva}

Además de por las circunstancias socioeconómicas individuales, las preferencias por la redistribución de una determinada sociedad también pueden estar influidas por los valores y creencias sobre la justicia distributiva de los sujetos que la conforman (Fong, 2000). Por ejemplo, la gente puede mostrar una actitud más positiva hacia la redistribución a favor de los pobres porque tiene el convencimiento de que la pobreza es causada por circunstancias que no están bajo el control de los individuos. Por lo tanto, es lógico que la percepción social sobre los factores determinantes de los niveles de renta afecte a la demanda de redistribución.

En la actualidad, se dispone de bastante evidencia experimental que sugiere que las personas tienen un anhelo innato por la equidad y una predisposición a castigar conductas injustas. No en vano, economistas, psicólogos, sociólogos y politólogos han destacado la importancia de un sentido de justicia en la vida privada, social y política de las personas. La gente disfruta de mayor satisfacción cuando sabe (o cree) que vive en una sociedad equitativa, en la que el trabajo duro y la buena conducta tienen su recompensa. De hecho, el deseo de un mundo justo puede ser tan fuerte que llegue a distorsionar la percepción de la realidad por los individuos. En resumen, no hay que descartar la posibilidad de que una convicción fundamental de la sociedad sea que las personas deberían conseguir lo que merecen y merecer lo que consiguen.

En esta línea, Alesina y La Ferrara (2005) estudian cómo, ante un determinado grado de movilidad social, la creencia acerca de si el proceso de movilidad es justo o si la sociedad ofrece igualdad de oportunidades a sus miembros puede incidir en la demanda de redistribución. Es de esperar que aquellas personas que consideran que existe igualdad de oportunidades, de tal modo que el esfuerzo y 
la capacidad determinan el éxito socioeconómico, no sean muy partidarias de las políticas redistributivas. Por otro lado, los que piensan que la competencia entre los individuos por el éxito social no es un juego justo — porque, por ejemplo, es importante conocer a ciertas personas o porque no todos tienen la oportunidad de conseguir una formación adecuada - son más proclives a la intervención gubernamental en materias redistributivas. El problema es que la sociedad no puede identificar el componente de la renta de un individuo que es fruto de la suerte o de actividades improductivas (el "ruido" en la distribución de la renta) o el componente vinculado al talento y al esfuerzo (la "señal"). No obstante, en teoría, el nivel de redistribución socialmente óptimo está inversamente relacionado con el valor de la ratio "señal/ruido" en la distribución de la renta (es decir, la ratio de desigualdad justificable/injustificable).

Este tipo de hipótesis está en línea con la de Piketty (1995), quien propone un modelo en el cual existe un vínculo entre la movilidad social, las convicciones sobre si el esfuerzo y la suerte determinan los ingresos, y las preferencias por la redistribución. En particular, este autor sostiene que es posible encontrarse con diferentes creencias en la medida en que los individuos formen las mismas solo sobre la base de su experiencia personal, sin acabar de asimilar plenamente los verdaderos costes y beneficios de la redistribución.

La idea de "justicia social" es un elemento clave en este tipo de análisis y este término aparece estrechamente asociado a una preferencia social, por un lado, por la reducción en el grado de desigualdad inducido por la suerte y por actividades sin valor, y, por otro, por la recompensa al talento y al esfuerzo individual. Si partimos de esta premisa, conviene prestar atención a las percepciones de la población sobre si, a la larga, esforzarse en el trabajo suele llevar a una vida mejor o, por el contrario, no suele conducir al éxito porque éste depende más de la suerte y los enchufes.

En la Tabla 11.5 se recoge información sobre los porcentajes de la población que revelan una opinión inequívoca en uno u otro sentido ${ }^{15}$. Los datos ponen de relieve que los gallegos mayoritariamente creen que el esforzarse en el trabajo tiene su recompensa y, aunque las situaciones de partida en Galicia y en España mostraban valores diferentes (48,8\%-44,7\%) en 1995, en la última oleada parecen haberse equiparado (41,1\%-41,5\%). Asimismo, los puntos de partida son muy similares en Galicia y España en cuanto al porcentaje de entrevistados que no creen que el esfuerzo en el trabajo suela llevar al éxito (18,9\%-19,3\%). Sin embargo, la situación parece haber cambiado sustancialmente en el caso español $(7,3 \%)$, mientras que en el gallego se mantiene más o menos estable (18,7\%).

15 El resto de los entrevistados manifiestan posturas intermedias de las que no se puede desprender una opinión clara sobre este particular. 
Tabla 11.5. Esfuerzo en el trabajo y éxito en la vida.

\begin{tabular}{lcccc} 
& \multicolumn{2}{c}{ Esfuerzo conlleva éxito } & \multicolumn{2}{c}{ Esfuerzo no conlleva éxito } \\
\cline { 2 - 5 } & $\mathbf{1 9 9 5}$ & $\mathbf{2 0 0 7 / 2 0 0 8}$ & $\mathbf{1 9 9 5}$ & $\mathbf{2 0 0 7 / 2 0 0 8}$ \\
\hline Galicia & $48,8 \%$ & $41,1 \%$ & $18,9 \%$ & $18,7 \%$ \\
\hline España & $44,7 \%$ & $41,5 \%$ & $19,3 \%$ & $7,3 \%$ \\
\hline
\end{tabular}

Nota: La encuesta en España se realizó en 2007 y en Galicia en 2008.

Fuente: ASEP/JDS, Estudio Mundial de Valores, España 1995, 2007. EMV-Galicia 1995, 2008. Elaboración propia.

Al hilo de las anteriores cifras, podríamos realizar una lectura más categórica de los datos, en el sentido de que un porcentaje similar de españoles y gallegos cree que los individuos con niveles de vida bajos podrían mejorar significativamente si se lo propusieran con la suficiente determinación, mientras que, sin embargo, una mayor proporción de gallegos se muestran plenamente convencidos de que la suerte y los contactos, más que el trabajo duro, determina la prosperidad económica ${ }^{16}$.

Los planteamientos teóricos desarrollados por Alesina y Angeletos (2005) permiten ahondar en las posibles consecuencias de este tipo de constataciones. Estos autores demuestran que la interacción entre el nivel de redistribución y la importancia relativa de las fuentes de desigualdad puede conducir a la economía a situaciones de equilibrio que reflejarían situaciones muy diversas. En uno de los equilibrios, nos encontraríamos con que una alta proporción del total de ingresos se debe a la suerte, lo que a su vez hace que un alto grado de redistribución sea socialmente deseable; los impuestos serán relativamente elevados, los individuos invierten y trabajan menos, y la desigualdad es menor. En el otro posible equilibrio, los impuestos son más bajos, los individuos invierten y trabajan más, y la desigualdad se amplía, pero una mayor proporción de la renta se debe al esfuerzo más que al azar.

En otras palabras, si una sociedad interioriza que la renta es fundamentalmente resultado del esfuerzo individual y que todos tienen derecho a disfrutar de los frutos de su talento y empeño, optará por impuestos reducidos y poca redistribución. En este caso, el esfuerzo será alto y el papel del azar limitado, de modo que los resultados del mercado serán relativamente justos y las creencias sociales existentes de antemano se verán confirmadas. Si, por el contrario, una sociedad percibe que la suerte, la cuna, los contactos y la corrupción determinan la riqueza, se decantará por impuestos elevados, dando lugar a una distorsión en la asignación

16 En este sentido, el obtener una conclusión más inequívoca exigiría contrastar que los individuos que piensan que la renta es determinada por la suerte, los contactos y la historia familiar, más que el esfuerzo, la educación y la capacidad individuales, son mucho más favorables a la redistribución, incluso después de controlar un exhaustivo conjunto de otras características personales. 
de recursos que probablemente se traducirá en menores niveles de inversión y de esfuerzo. De nuevo estaríamos ante un caso en el que las creencias previas hacen que la realidad se acabe ajustando a las mismas (ejemplo de fenómeno conocido con el nombre de "profecías o expectativas autocumplidas").

Esta posibilidad teórica de múltiples equilibrios permite entender la existencia de amplias y persistentes diferencias entre economías. Concretamente, en nuestro caso, este enfoque aporta un marco analítico que contribuye, por un lado, a justificar las actitudes y creencias manifestadas por los gallegos hacia el papel de los gobiernos en la implementación de políticas redistributivas que corrijan los resultados del mercado y, por otro, a explicar las diferencias observadas en este terreno entre Galicia y España. En particular, de acuerdo con este planteamiento, las divergencias en las percepciones, actitudes y políticas hacia la desigualdad (o más generalmente, hacia el mecanismo de mercado) entre los dos espacios (España, Galicia) podrían ser consecuencia en parte de distintas condiciones iniciales y/o de shocks que afectan de forma asimétrica a ambas economías.

El análisis de las percepciones de los gallegos sobre la legitimidad de los resultados generados por la economía de mercado puede complementarse con las opiniones de los ciudadanos sobre la naturaleza del proceso de acumulación de riqueza. En lo que se refiere a este aspecto, en el Gráfico 11.17 se constatan ciertas diferencias entre Galicia y España en su conjunto, diferencias que, por otra parte, parece que se amplían con el transcurso del tiempo. En una escala de 1 a 10 , en un extremo (1) se sitúan los que creen que la gente solo puede enriquecerse a costa de los demás y en el otro (10), los que piensan que la riqueza puede crecer de manera que haya bastante para todos. Teniendo en cuenta este tipo de precisiones, la información que se desprende del gráfico sugiere que los gallegos participan en mayor medida que los españoles de la concepción del mercado más como un juego de suma-positiva que uno de suma-cero, en el cual, inexcusablemente, lo que unos ganan se compensa con lo que otros pierden.

En suma, una explicación rigurosa y convincente de las diferencias en el apoyo a las políticas redistributivas entre Galicia y España, requiere un análisis en profundidad de las percepciones sociales relativas a la justicia de los resultados del mercado y las fuentes subyacentes de desigualdad en las rentas.

Las opiniones de la sociedad gallega sobre el papel del Estado en la economía y la justicia redistributiva también dependen en cierta medida de los valores que comparten los ciudadanos. Partiendo de la dicotomía que se puede establecer entre valores tradicionales y autoexpresivos, apreciamos vínculos entre estas dos categorías y la opinión de los individuos sobre el ámbito de responsabilidad del Estado y la desigualdad (Tabla 11.6). Los valores tradicionales están asociados a una opinión menos favorable a la redistribución de ingresos, mientras que en el caso de los autoexpresivos, aflora una correlación entre dichos valores y 
actitudes favorables hacia la redistribución y hacia una ampliación del ámbito de responsabilidad del gobierno.

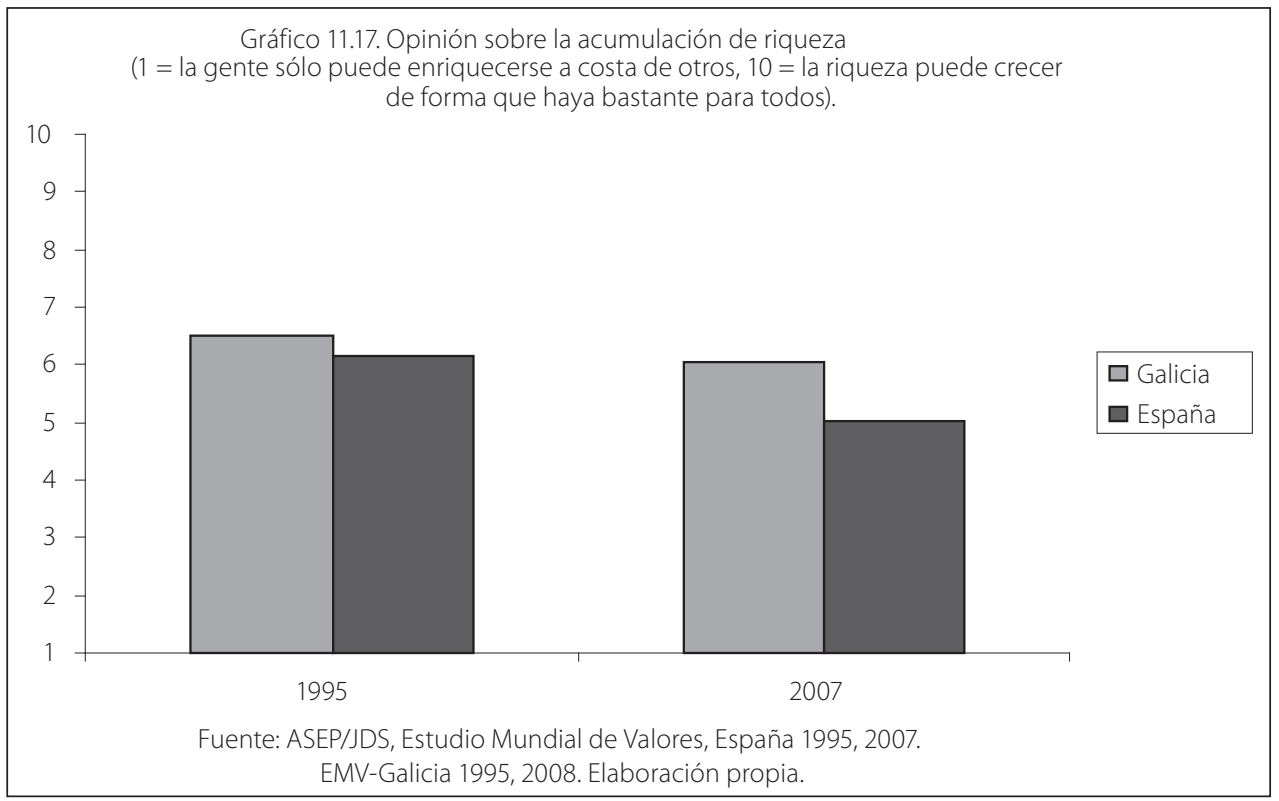

Tabla 11.6. Valores y justicia redistributiva. Galicia 2008.

(Coeficientes de correlación de Spearman).

\begin{tabular}{lcc}
\multicolumn{1}{c}{ Valores tradicionales } & $\begin{array}{c}\text { Opinión sobre la } \\
\text { igualdad de ingresos sobre la }\end{array}$ & $\begin{array}{c}\text { Opinios } \\
\text { responsabilidad del } \\
\text { Estado frente al individuo }\end{array}$ \\
$\begin{array}{l}\text { Importancia de Dios } \\
\text { en su vida }\end{array}$ & $0,09^{* *}$ & $0,07^{* *}$ \\
\hline Importancia del trabajo & $-0,09^{* *}$ & $-0,02$ \\
\hline $\begin{array}{l}\text { Pertenencia: parte de } \\
\text { nación española }\end{array}$ & $-0,12^{* *}$ & $-0,05$ \\
\hline $\begin{array}{l}\text { Justificación } \\
\text { del aborto }\end{array}$ & $-0,13^{* *}$ & $-0,09^{* *}$ \\
\hline Valores autoexpresivos & $0,108^{* *}$ & $0,076^{* *}$ \\
\hline Imaginación & 0,027 & $0,121^{* *}$ \\
\hline Tolerancia & $-0,047$ & $0,072^{* *}$ \\
\hline Generosidad y altruismo & &
\end{tabular}

** La correlación es significativa al nivel 0,01 (bilateral).

Fuente: EMV-Galicia 2008. Elaboración propia. 
Por otra parte, de modo similar a lo detectado cuando analizábamos la relación entre elementos de clara raíz cultural y las actitudes hacia el mercado, comprobamos cómo este tipo de factores incide en la demanda social de redistribución. En la Tabla 11.7 se pone de relieve, por ejemplo, que un mayor porcentaje de quienes tienen el convencimiento de que la vida está determinada por el destino considera que los ingresos deberían ser más iguales. Por el contrario, la creencia de que las personas se labran su propio destino aparece más asociada a la opinión de que debería haber mayores incentivos para el esfuerzo individual ${ }^{17}$.

Tabla 11.7. Actitudes ante la vida y demanda de redistribución.

Galicia 2008.

\begin{tabular}{lcc} 
& $\begin{array}{c}\text { Preferencia por } \\
\text { mayor igualdad } \\
\text { de ingresos }\end{array}$ & $\begin{array}{c}\text { Preferencia por mayores } \\
\text { incentivos al } \\
\text { esfuerzo individual }\end{array}$ \\
\hline $\begin{array}{l}\text { Vida determinada } \\
\text { por el destino }\end{array}$ & $19,6 \%$ & $25,9 \%$ \\
\hline $\begin{array}{l}\text { Las personas } \\
\text { se hacen su destino }\end{array}$ & $13,4 \%$ & $32,1 \%$ \\
\hline $\begin{array}{l}\text { Mucha libertad } \\
\text { de control sobre su vida }\end{array}$ & $17,8 \%$ & $23,1 \%$ \\
\hline
\end{tabular}

Fuente: EMV-Galicia 2008. Elaboración propia.

Sin salirnos del marco del análisis de las percepciones sociales de la justicia distributiva, una vertiente digna de ser señalada es la relación entre ideología y preferencias por la redistribución. En este sentido, el argumento ideológico presume que las actitudes hacia las políticas propias del Estado del Bienestar están enraizadas en el sistema de valores y se eligen las políticas más adecuadas en función de lo que creen que debería ser la correcta relación entre el individuo y el Estado. Así, las políticas redistributivas estarían apoyadas por las creencias que los ciudadanos tienen sobre algunos derechos básicos, incluyendo el de vivir de acuerdo con los estándares sociales prevalecientes. No obstante, esta convicción entra en conflicto con otra también popular según la cual las personas deberían hacer todo lo que esté en sus manos para ser económicamente autosuficientes. En cierta medida, el Estado del Bienestar socavaría este principio, excusando a algunos de sus responsabilidades económicas y estimulando comportamientos inadecuados entre los perceptores de beneficios sociales.

Estos valores y creencias contradictorios proporcionan justificación ideológica tanto para apoyar como para oponerse a los beneficios del Estado del Bienestar y a

17 Para la obtención de los porcentajes que figuran en la tabla, en una escala de 1 a 10 consideramos como opiniones claramente favorables a una mayor igualdad de ingresos los valores 1 y 2 , mientras que como opiniones con una nítida predilección por mayores incentivos para el esfuerzo individual tomamos los valores 9 y 10. 
la redistribución económica. En nuestro caso, utilizando la información relativa al autoposicionamiento ideológico de los individuos, obtenemos algunos datos interesantes sobre el vínculo que se establece entre ideología y demanda de redistribución. En el Gráfico 11.18 observamos una clara correspondencia entre una ideología de izquierdas y mayores preferencias por la igualdad en el reparto de la renta y, consiguientemente, por la implementación de políticas de carácter redistributivo.
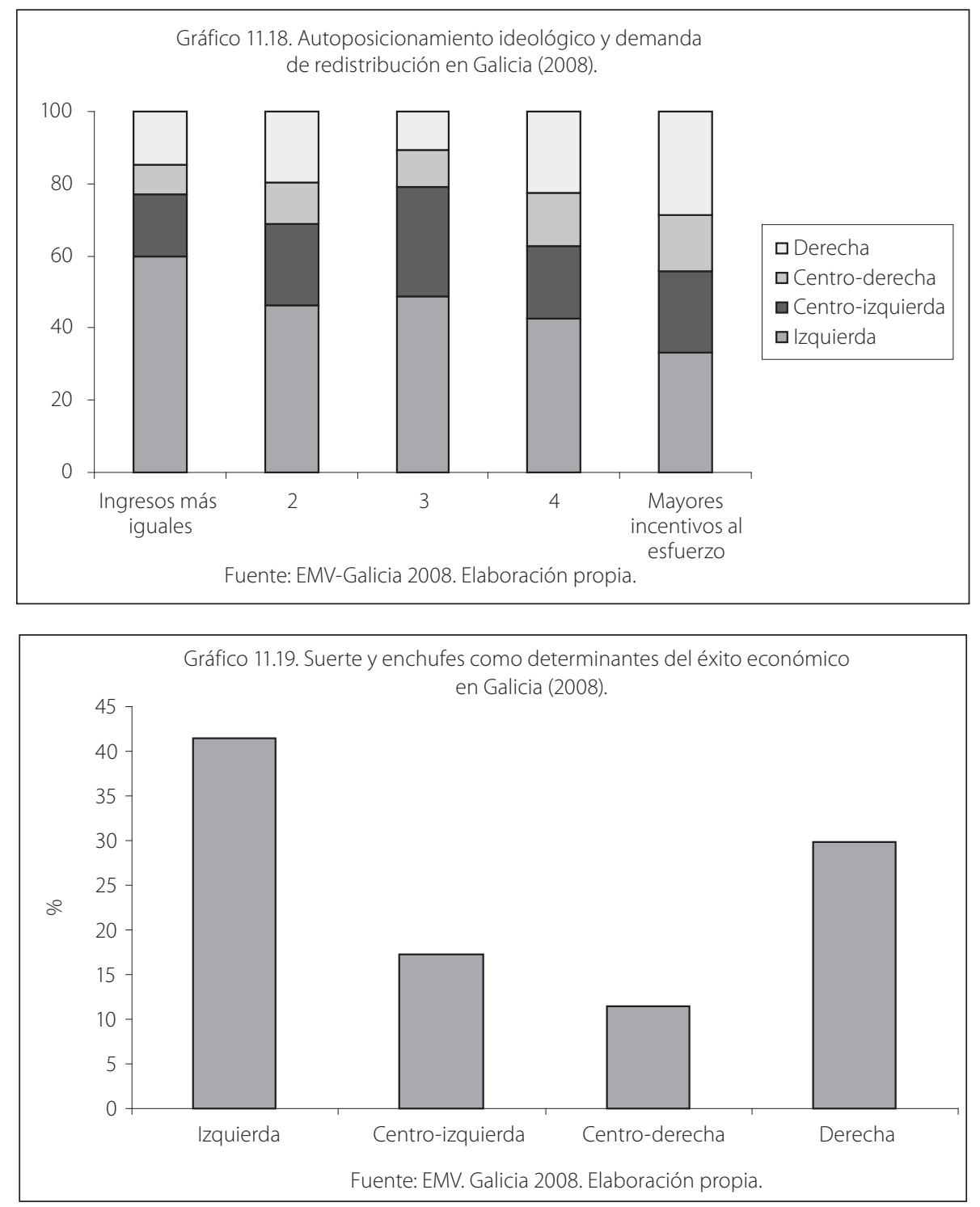

El hecho de que una orientación ideológica de izquierdas aparezca asociada a una actitud más favorable hacia la redistribución y hacia la intervención del gobierno en la economía es coherente con la percepción de los individuos sobre 
las fuentes que determinan la renta. Prueba de ello es la información del Gráfico 11.19, en el que se representan los porcentajes de personas con distintas ideologías que consideran incuestionable que la suerte determina el éxito económico. Tal y como puede apreciarse, esta convicción está fuertemente ligada a un ideario de izquierdas, con lo cual se vislumbra claramente el vínculo entre la orientación ideológica de las personas, las creencias sobre los determinantes del éxito económico y su opinión sobre el papel del gobierno en la economía.

\subsubsection{Responsabilidad individual versus responsabilidad del gobierno: ¿un problema de confianza?}

El análisis de las opiniones de los ciudadanos sobre la delimitación de las esferas de responsabilidad de los individuos y de los gobiernos constituye una vía adicional para completar nuestra aproximación a las actitudes de la sociedad gallega hacia políticas propias del Estado del Bienestar. En este sentido, uno de los aspectos a evaluar son las preferencias de los gallegos por una Sociedad de Bienestar con beneficios sociales extensivos a amplias capas de la población e impuestos altos o por un escenario en el que los impuestos son bajos y los individuos asumen mayores cuotas de responsabilidad.

En esta línea, la opinión sobre el nivel de compromiso que debería asumir el gobierno, así como su evolución temporal se refleja en el Gráfico 11.20. A la hora de interpretar la información que proporciona dicho gráfico hay que tener en cuenta que la escala de respuesta de los individuos va de 1 (el gobierno debería asumir más responsabilidad en proporcionar un medio de vida a todo el mundo) a 10 (cada uno debería asumir individualmente más responsabilidad para lograr su propio medio de vida).

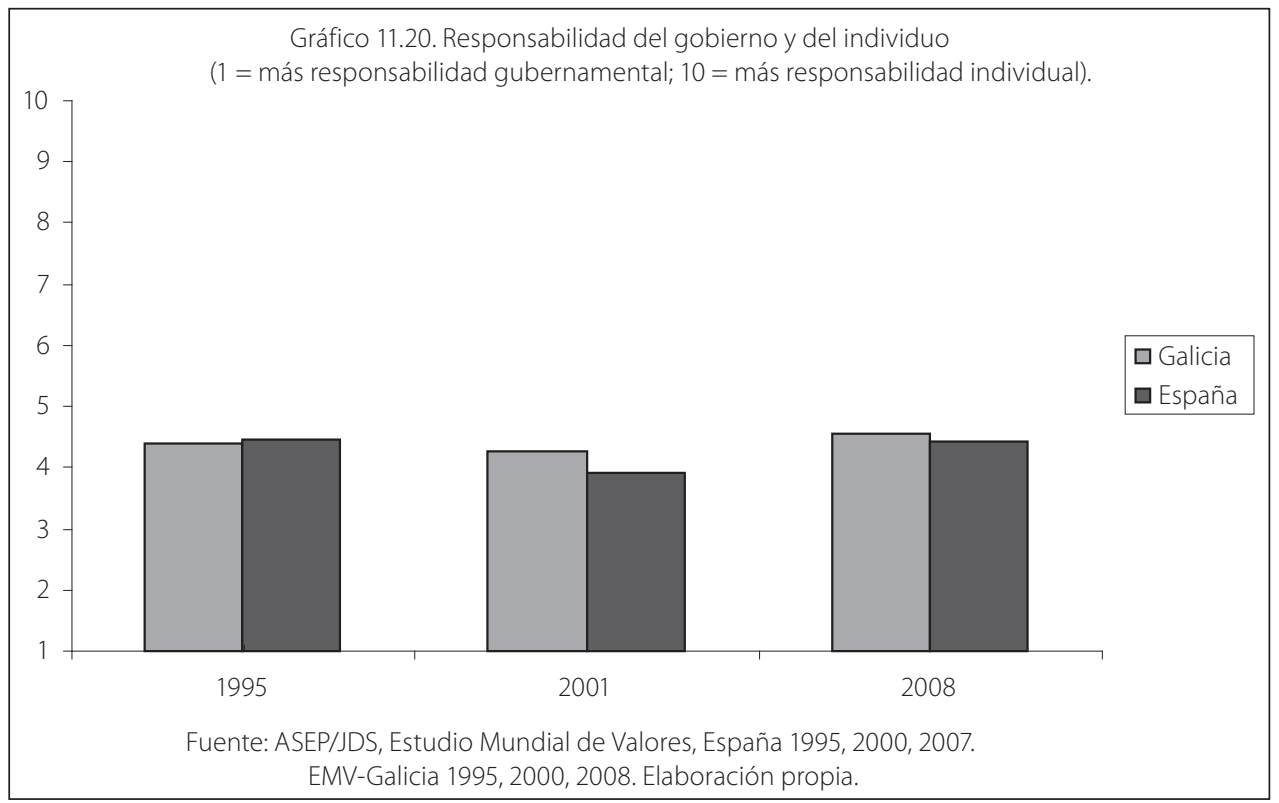


A la luz de los datos del Gráfico 11.20, tanto españoles como gallegos se decantan por la necesidad de una ampliación del ámbito de responsabilidad gubernamental. Además, en la última década, los españoles en su conjunto se muestran ligeramente más partidarios que los gallegos de una mayor implicación del gobierno. Blekesaune (2007) plantea una hipótesis que, teóricamente, podría contribuir a clarificar este tipo de resultados: en una economía en expansión, cuando las tasas de desempleo son reducidas y las familias no sufren aprietos económicos, la gente tiende a confiar más en la responsabilidad individual y a creer que los gobiernos deben desempeñar un papel limitado en la provisión de sustento a determinados segmentos de la población y en la reducción de las desigualdades de renta. Por el contrario, cuando las economías se contraen y más personas se encuentran en una situación peor que la esperada, los ciudadanos tienden a pensar que los gobiernos deberían comprometerse más en proporcionar medios de vida y en reducir las mencionadas desigualdades.

No obstante, en la medida en que la evolución cíclica de las economías gallega y española está bastante sincronizada, esta hipótesis no permitiría explicar las diferencias apreciables en este terreno. Aunque un análisis a nivel de individuos indica qué características personales están asociadas con las preferencias por políticas propias del Estado del Bienestar (subsidios de desempleo, pensiones de jubilación, prestaciones por incapacidad, etc.), la valoración a nivel agregado de la opinión de los gallegos tanto sobre la responsabilidad del gobierno como sobre la igualdad de ingresos hay que contextualizarla teniendo en cuenta el papel desempeñado por el sector público en Galicia y la evolución de la distribución personal de la renta en esta Comunidad.

A este respecto, cabe destacar que aunque el crecimiento económico que ha registrado la economía gallega en el conjunto del período que abarca el presente estudio (1995-2008), evidentemente, se ha traducido en una mejora del bienestar en términos absolutos, dicha mejora se ha visto intensificada por los efectos de las políticas propias del Estado del Bienestar español, tal y como ponen de manifiesto Prada y Lago (2009). Prueba de ello es que a lo largo de toda esta etapa, las familias gallegas han sido beneficiarias de la redistribución interterritorial implícita en los diferentes programas de gastos e ingresos públicos que se encuentran centralizados. De hecho, estos autores concluyen que esta redistribución interterritorial de la renta que realiza el sector público español explica el incremento de la renta de las familias gallegas por encima de lo que le correspondería por su nivel productivo.

Los estudios disponibles sobre el conjunto de comunidades autónomas españolas permiten constatar, por un lado, que en Galicia la distribución interpersonal de la renta ha sido progresivamente más igualitaria y, por otro, que la desigualdad en dicha distribución es inferior a la media española [cfr. Ayala et al. (2005) y Grandín et al. (2006)]. Uno de los factores que ha podido incidir en 
esta evolución ha sido la mejora de las prestaciones sociales, particularmente las pensiones de jubilación e invalidez. En este sentido, Prada y Lago (2009) destacan que los servicios de la Seguridad Social constituyen un elemento fundamental del Estado del Bienestar y han contribuido significativamente a mejorar la distribución interpersonal de la renta.

Si bien parece indudable que el crecimiento económico, los niveles de renta y la distribución de la misma son factores que condicionan las preferencias de los individuos por el papel del Estado en la economía, a éstos habría que añadir un elemento adicional que también puede ayudar a entender la demanda de políticas redistributivas por parte de la población: la confianza que a la sociedad gallega le merece el gobierno responsable de la implementación de dichas políticas. Lógicamente, cabe esperar que los niveles de confianza en el ejecutivo condicionen las actitudes sociales hacia éste como agente corrector de los resultados derivados del funcionamiento del libre mercado.

En la Tabla 11.8 se ofrecen datos sobre los niveles y la evolución de la confianza en el gobierno comparando Galicia con España.

Tabla 11.8. Confianza en el gobierno español.

\begin{tabular}{lcccccc} 
& \multicolumn{3}{c}{ Galicia } & \multicolumn{3}{c}{ España } \\
\cline { 2 - 7 } & 1995 & 2001 & 2008 & 1995 & 2001 & 2007 \\
\hline Mucha & $8,9 \%$ & $8,5 \%$ & $4,8 \%$ & $3,9 \%$ & $7,9 \%$ & $5,5 \%$ \\
\hline Bastante & $22,1 \%$ & $36,6 \%$ & $37,3 \%$ & $27,1 \%$ & $36,3 \%$ & $39,6 \%$ \\
\hline No mucha & $34,6 \%$ & $39,3 \%$ & $48,8 \%$ & $45,6 \%$ & $41,6 \%$ & $41,6 \%$ \\
\hline $\begin{array}{l}\text { Ninguna } \\
\text { en absoluto }\end{array}$ & $34,5 \%$ & $11,7 \%$ & $9,1 \%$ & $23,4 \%$ & $14,2 \%$ & $13,3 \%$ \\
\hline
\end{tabular}

Fuente: ASEP/JDS, Estudio Mundial de Valores, España 1995, 2000, 2007.

EMV-Galicia 1995, 2001, 2008. Elaboración propia.

En general, el patrón en Galicia y en España presenta bastantes similitudes. Si sumamos los porcentajes de entrevistados que declaran tener bastante o mucha confianza en el gobierno, se constata que los niveles de la misma han aumentado de forma considerable a lo largo del período de estudio. Por otra parte, si agrupamos a los que declaran tener no mucha o ninguna confianza en el año 2008, Galicia se sitúa ligeramente por encima de la media española (57,9\% frente a $54,9 \%$ ). En cualquier caso, estos valores son ostensiblemente menores que los registrados en 1995, con lo cual, a la luz de las cifras de la tabla, podríamos afirmar que los niveles de confianza son manifiestamente mejorables, si bien la evolución de la confianza en el gobierno es más bien positiva y va pareja en Galicia y en 
España. Desde esta perspectiva, por un lado estaríamos ante un elemento que contribuiría a explicar el mantenimiento de una visión relativamente favorable a la ampliación de los ámbitos de responsabilidad del gobierno y, por otro, dada la similar evolución en Galicia y en España, la confianza en el ejecutivo no es un factor al que se le puedan atribuir diferencias apreciables en materia de creencias sobre el papel que debería asumir el gobierno en una economía de mercado.

Por último, señalar que la confianza en el gobierno es una cuestión que adquiere mayor relevancia en las fases de crisis económica. Esto es así, entre otras razones, porque las posibles reformas del Estado del Bienestar y del sistema de regulación deben ser amplias y permanentes en el tiempo. En consecuencia, para que resulten políticamente sostenibles, los policy-makers necesitan persuadir a sus electorados de que, si bien tales reformas pueden generar situaciones más injustas en el corto plazo, en última instancia garantizarán resultados más eficientes y más equitativos para las generaciones futuras. Obviamente, para tener éxito en esta tarea es imprescindible que los gobiernos gocen de la confianza social.

\subsection{PRIORIDADES DE POLÍTICA ECONÓMICA EN LA SOCIEDAD GALLEGA}

La prioridad que los ciudadanos creen que deberían tener los asuntos de carácter económico en la agenda de las políticas gubernamentales es otra de las vertientes de las preferencias sociales cuyo análisis reviste un indudable interés. En este ámbito, una cuestión que se ha situado en el centro de la controversia es si los gobiernos le están otorgando una excesiva preponderancia al crecimiento económico como objetivo de sus políticas frente a metas de otra índole.

\subsubsection{Del aumento de la producción a la mejora del bienestar}

En la mayoría de los países industrializados ha ido ganando adeptos la opinión de que se le presta demasiada atención al crecimiento económico, medido éste a través de la evolución del PIB. Dicha percepción suele fundamentarse en la creencia de que, por un lado, el aumento de la producción es un indicador muy imperfecto del bienestar y, por otro, dicho crecimiento puede revelarse como insostenible en el largo plazo. Por este tipo de razones, emerge como una cuestión clave la conveniencia de desplazar el énfasis del crecimiento de la producción a la evolución del bienestar o de la calidad de vida de los ciudadanos.

Apostar por el bienestar subjetivo de los individuos no significa ignorar la importancia del crecimiento económico, pero sí es inexcusable, en la medida en que parece ampliarse la brecha entre la información contenida en los datos agregados sobre el crecimiento del PIB (resultados del mercado) y lo que verdaderamente importa para la calidad de vida o el bienestar de los ciudadanos. La delimitación del concepto de bienestar requiere el uso de una definición 
multidimensional, en la que se suelen incluir, como aspectos claves, los niveles de vida materiales (renta, consumo y riqueza); la salud; la educación; el trabajo y el ocio; la participación política y la gobernanza; las relaciones sociales; el medio ambiente; la seguridad económica y física, etc. Todas estas dimensiones configuran el bienestar subjetivo del individuo y su calidad de vida, y muchas de ellas no están contempladas en las medidas convencionales de crecimiento económico y/o estabilidad económica ${ }^{18}$.

En el caso gallego, la evidencia disponible sugiere que, a pesar de esta diversidad de dimensiones del bienestar, sigue desempeñando un papel decisivo la evolución del componente material. En el Gráfico 11.21 podemos apreciar cómo el porcentaje de gallegos que consideran prioritario el objetivo de mantener un alto nivel de crecimiento económico es sistemáticamente superior a la media española. Quizás esto tenga que ver con que, si bien se han producido avances en cuanto a convergencia interregional de rentas, apenas se ha alcanzado la media nacional.

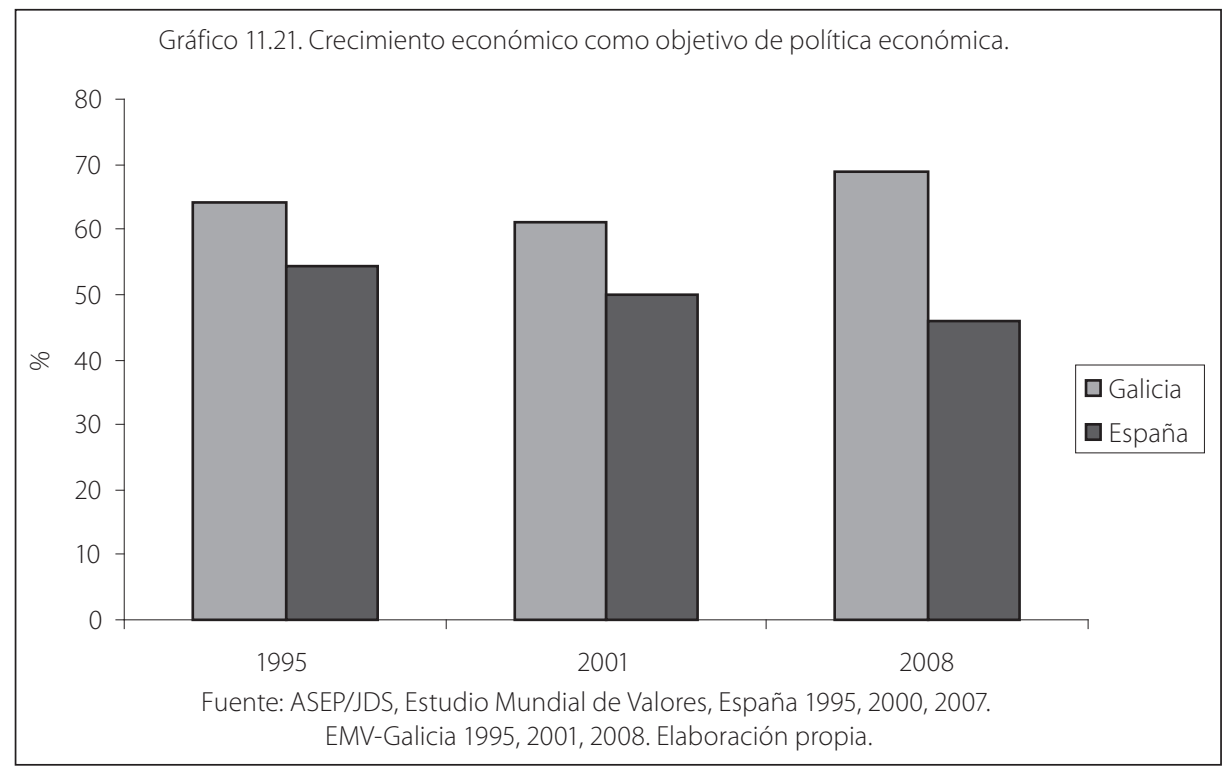

Curiosamente, en lo relativo a la prioridad que se le confiere a la estabilidad de precios, la cual es otro de los objetivos que tradicionalmente ocupa un lugar preponderante en las agendas macroeconómicas de los gobiernos, también se observan notables divergencias entre Galicia y España (Gráfico 11.22). Si bien se vislumbra una tendencia clara en ambos casos en lo que a preocupación por la inflación se refiere, dicha preocupación parece mayor en el caso español, aunque recientemente las distancias parecen estrecharse.

18 Cfr. Stiglitz et al. (2009). Para el caso gallego, véase el contenido del Capítulo 10 incluido en este mismo volumen. 


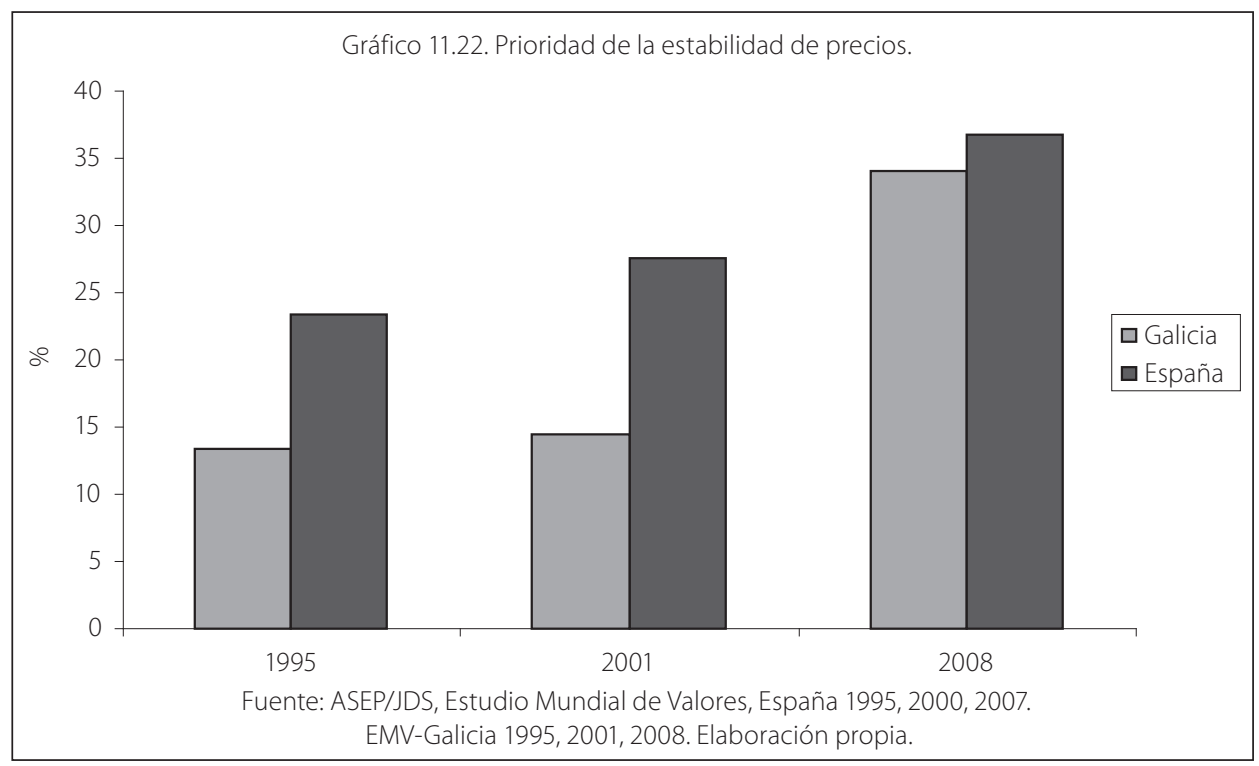

A modo de síntesis, lo que puede resultar revelador de la existencia de cierta heterogeneidad en cuanto a preferencias de políticas públicas, son los patrones contrapuestos de los puntos de vista sobre la importancia que se le confiere a la estabilidad económica como objetivo para los próximos años (Gráfico 11.23).

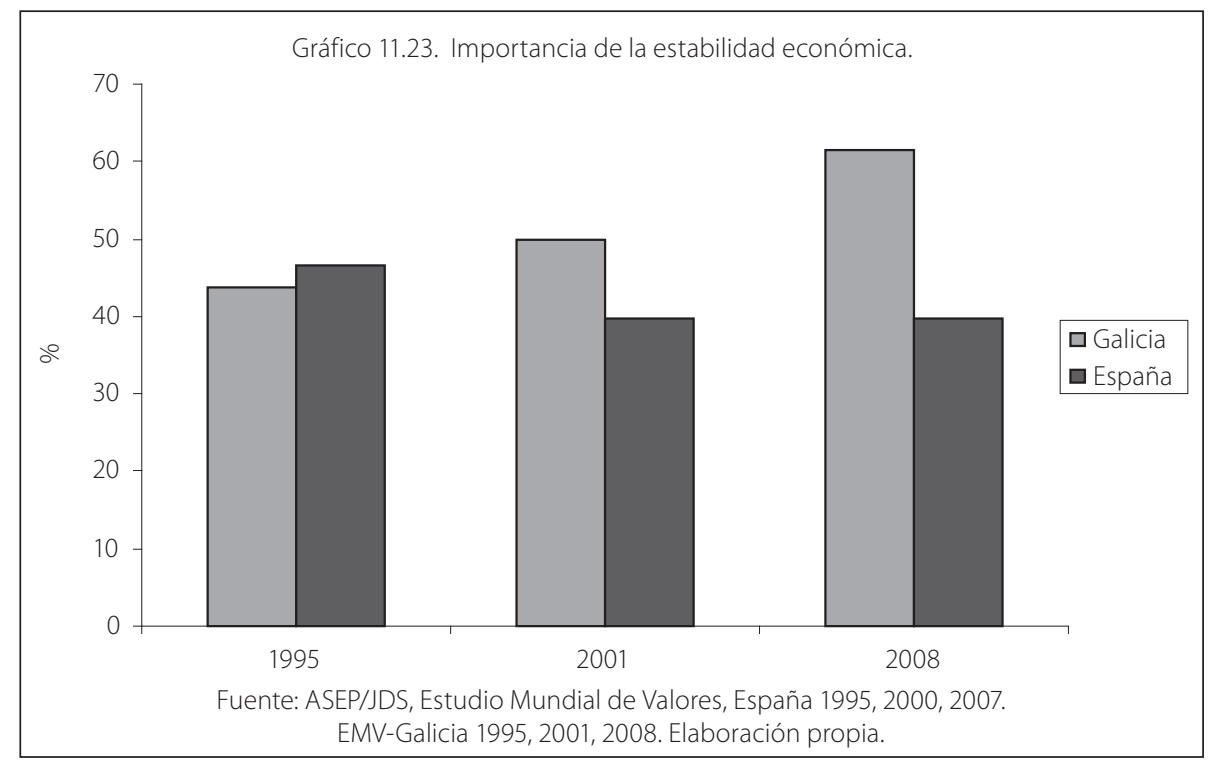




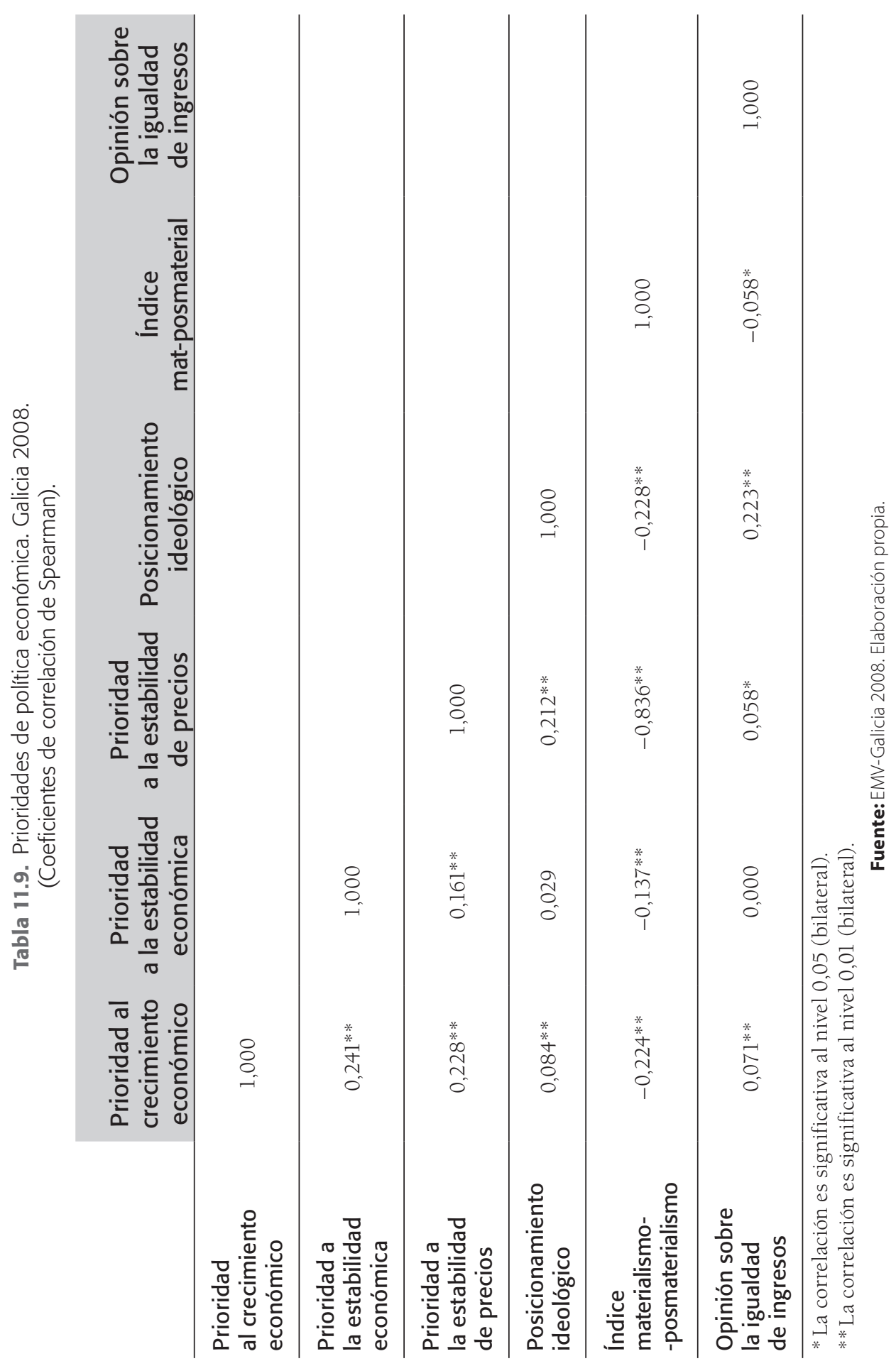


Aunque, en principio, lo lógico es pensar que este tipo de opiniones (las reflejadas en los gráficos 11.21, 11.22 y 11.23) puede estar condicionado en gran medida por factores coyunturales, como por ejemplo la fase del ciclo por la que atraviesa la economía, en nuestro caso, el elemento más significativo son las asimetrías detectadas entre Galicia y España, porque, en términos generales, se puede asumir que para el período analizado la evolución cíclica de ambas economías está bastante sincronizada.

De cara a complementar la explicación de las anteriores constataciones, resulta de interés la evidencia que se desprende de la Tabla 11.9. De los datos que figuran en esta tabla se deduce la existencia de una correlación entre los individuos que fijan como prioridades en sus preferencias económicas el crecimiento económico, la lucha contra la subida de precios y la estabilidad económica, lo cual revela cierta consistencia en las preferencias de los entrevistados.

Por otra parte, las variables que aparecen relacionadas con la preeminencia otorgada a los objetivos de política económica son el índice de materialismoposmaterialismo y el posicionamiento ideológico. Tal y como cabría esperar, los individuos que se sitúan a la izquierda en el espectro ideológico, así como los más posmaterialistas, son quienes se pronuncian más claramente sobre la deseabilidad de una distribución más igualitaria de los ingresos, y quienes relegan a un segundo plano las metas de índole estrictamente económica.

\subsubsection{Crecimiento económico versus medio ambiente}

A pesar de las consideraciones anteriores sobre la prioridad de la que gozan los aspectos vinculados a la estabilidad macroeconómica como objetivos a largo plazo en relación con otras cuestiones (la seguridad nacional, la participación ciudadana, la libertad de expresión, etc.), cuando comparamos el crecimiento económico con la preocupación por el medio ambiente, constatamos que la mayoría de la población le confiere prioridad a la protección de éste (Gráfico 11.24).

No obstante, estos resultados se pueden matizar teniendo en cuenta la disposición a asumir los costes asociados a la sostenibilidad medioambiental en Galicia y en España. Entre los aspectos más sobresalientes que se derivan de la información que contiene la Tabla 11.10 se encuentra la considerable reducción de la disposición a aceptar incrementos impositivos para prevenir la contaminación, algo que contrasta con el aumento de los porcentajes (ya de por si bastante altos) de población que cree que el gobierno debería reducir la contaminación del medio ambiente, pero sin que ello supusiese coste alguno en términos monetarios para el individuo.

En suma, al plantearse este tipo de escenarios surge el dilema moral de quiénes tienen el deber de preservar y hasta dónde llega el mismo. Las sociedades discrepan respecto a la cuestión de hasta qué punto deben sacrificarse las generaciones presentes por las futuras. Los datos que figuran en la tabla anterior invitan a una 
reflexión acerca de cuál es el nivel de consciencia de los deberes de la generación presente y hasta dónde alcanza la voluntad de cambio.

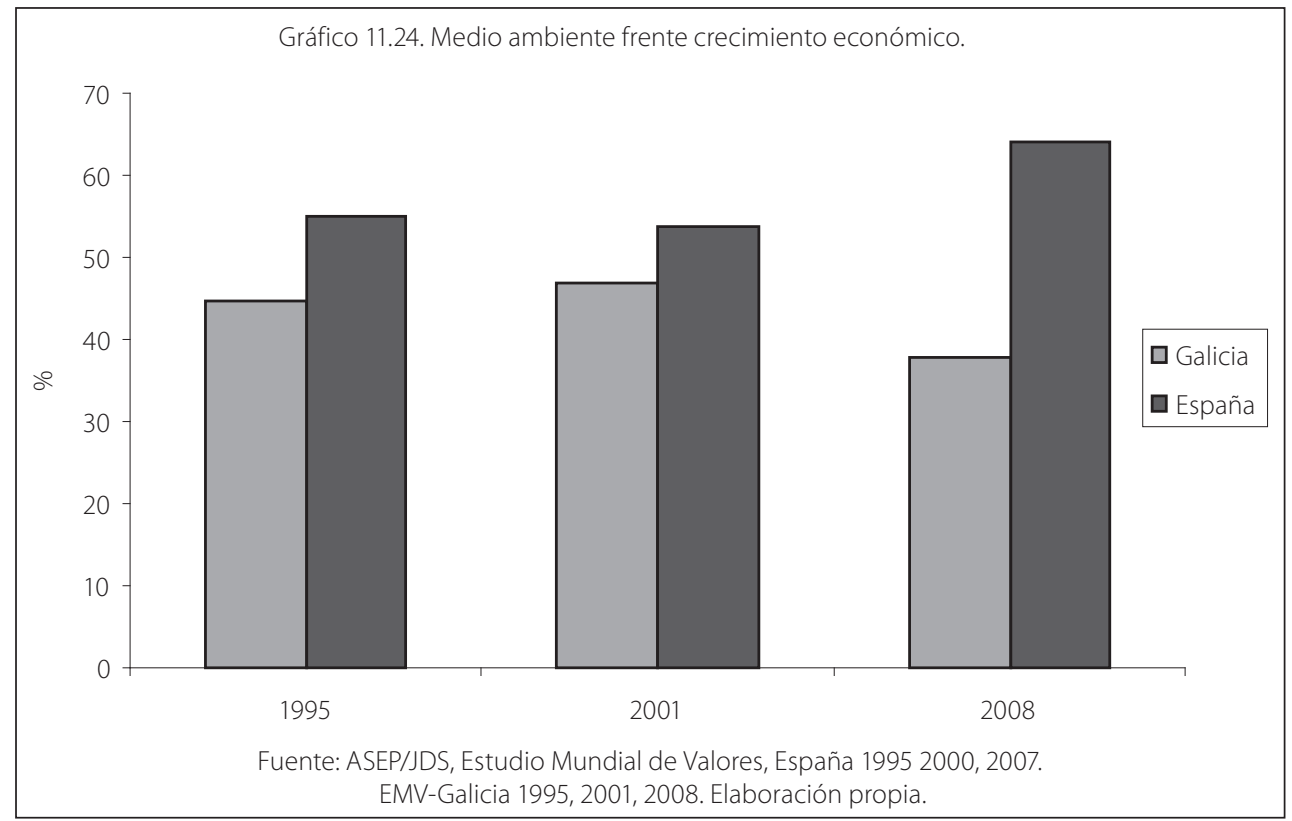

Tabla 11.10. Disposición a aceptar costes de preservación del medio ambiente.

\begin{tabular}{lcccc} 
& \multicolumn{2}{c}{$\begin{array}{c}\text { Aceptación de un } \\
\text { incremento impositivo }\end{array}$} & \multicolumn{2}{c}{$\begin{array}{c}\text { Reducción de la } \\
\text { polución sin coste }\end{array}$} \\
& $\mathbf{2 0 0 7 / 2 0 0 8}$ & $\mathbf{2 0 0 0 / 2 0 0 1}$ & $\mathbf{2 0 0 7 / 2 0 0 8}$ \\
\hline Galicia & $59,0 \%$ & $49,5 \%$ & $81,5 \%$ & $86,7 \%$ \\
\hline España & $61,6 \%$ & $47,3 \%$ & $90,4 \%$ & $91,1 \%$ \\
\hline
\end{tabular}

Nota: La encuesta en España se realizó en 2000 y 2007 y en Galicia en 2001 y 2008.

Fuente: ASEP/JDS, Estudio Mundial de Valores, España 2000, 2007. EMV-Galicia 1995, 2001, 2008. Elaboración propia.

\subsection{CONCLUSIONES}

El análisis desarrollado a lo largo de este capítulo permite efectuar una primera aproximación a las actitudes sociales de los gallegos hacia el sistema de economía de mercado y al papel del Estado en la economía. A modo de síntesis, los resultados más destacables que se desprenden de este estudio se resumen a continuación. 
La evidencia obtenida sugiere que el interés particular derivado de consideraciones de índole económica no siempre es el principal, ni mucho menos el único, factor que determina el sentimiento de los ciudadanos hacia el mercado ni su apoyo a las políticas redistributivas de los gobiernos. En realidad, elementos con una honda raíz cultural, tales como los valores, también condicionan notablemente las preferencias sociales en los ámbitos mencionados.

En particular, en lo que atañe a la competencia como uno de los pilares fundamentales sobre los que se sustenta la economía de mercado, la expresión que mejor define la actitud de la sociedad gallega es la de su creciente escepticismo sobre las presuntas virtudes de dicho principio ordenador de la vida económica y social. De hecho, la opinión de los gallegos es menos favorable que la del conjunto de los españoles.

Más concretamente, en Galicia entre los colectivos que consideran la competencia como algo claramente perjudicial se encuentran las mujeres, las personas que ocupan los puestos de trabajo menos cualificados, los agricultores y los residentes en municipios rurales. En este sentido, resultan especialmente llamativas las diferencias de género: las mujeres se muestran menos partidarias de la competencia y, además, la opinión de las gallegas es claramente más desfavorable que la del conjunto de las españolas. Por el contrario, variables como la renta o los niveles educativos, que a priori podrían influir en las preferencias de los individuos, parecen tener un impacto limitado en las actitudes tanto hacia la competencia como hacia la propiedad privada.

Entre los factores con una clara raíz cultural que resultan más determinantes en la configuración de las preferencias sociales relativas al modelo de economía de mercado y al papel del Estado en la economía, destacan las actitudes ante la vida de los individuos y, más específicamente, la importancia que estos le asignan al destino y las creencias relativas al grado de libertad de elección del que gozan. A este respecto, la evidencia disponible sugiere que los gallegos confieren más relevancia al destino como un factor determinista en sus vidas y son menos optimistas que los españoles a la hora de valorar las condiciones personales que permiten ejercer la mencionada libertad de elección. El predominio de estas actitudes sería uno de los elementos que contribuiría a explicar que el sentimiento hacia el mercado sea menos favorable en Galicia.

Por otra parte, el análisis conjunto de las actitudes sociales de los gallegos hacia el sistema de economía capitalista y hacia el Estado como institución responsable de corregir los fallos de mercado revela algo, a primera vista, paradójico. Por un lado, en términos comparativos, los gallegos muestran un poco más de recelo que los españoles hacia el engranaje que mueve el modelo de economía de mercado, pero, por otro, participan ampliamente de la idea de que el esfuerzo en el trabajo tiene su recompensa en forma de éxito en la vida. Así, se inclinan más que el conjunto de los españoles por promover los incentivos al esfuerzo individual y son menos partidarios de una mayor igualdad de ingresos y de que 
el gobierno asuma más responsabilidad en proporcionar un medio de vida a toda la población.

En lo que se refiere a la prioridad que la sociedad otorga a los asuntos económicos en las agendas de los gobiernos, uno de los aspectos más destacables en el caso gallego, especialmente si se compara con el conjunto español, es que, a pesar de la indudable diversidad de dimensiones de la calidad de vida, la estabilidad económica y el bienestar material siguen ocupando una posición preeminente. Por otro lado, aunque formalmente la preservación del medio ambiente ha ido escalando posiciones en el ranking de objetivos que deberían fijar las políticas públicas, hasta desplazar del primer plano al crecimiento económico, lo cierto es que los datos suscitan dudas razonables sobre cuál es el verdadero nivel de concienciación de la generación presente sobre la gravedad de los problemas medioambientales y hasta qué punto estaría aquélla dispuesta a asumir los costes que conlleva la reducción de la contaminación.

Finalmente, cabe señalar que, en términos generales, las actitudes y los posicionamientos de la sociedad gallega sobre el sistema de mercado y el papel del Estado en la economía no han registrado variaciones ostensibles, lo cual es lógico en la medida en que en el período analizado no han tenido lugar alteraciones estructurales que afecten al sistema político (democracia consolidada), al mercado como sistema de asignación de recursos o al rol del gobierno como agente estabilizador y redistribuidor.

En cualquier caso, en las consideraciones relativas a la influencia recíproca que se da entre la evolución de la economía y los valores sociales conviene tener presente que la bonanza económica registrada en el conjunto del período objeto de estudio (1995-2008) ${ }^{19}$ puede haber incidido en el apoyo y aceptación de los principios básicos que sustentan el sistema de economía de mercado. Por el contrario, la crisis desencadenada a mediados de 2007 y la recesión en la que ha desembocado pueden acabar erosionando dicho apoyo. En este sentido, serán claves para completar este tipo de análisis los resultados que arroje la siguiente oleada de la EMV, que presumiblemente reflejarán las consecuencias que, sobre las opiniones y creencias de los ciudadanos, se desprenderán del contexto de profunda inestabilidad económico-financiera que sufren la mayor parte de las economías desarrolladas y cuyos efectos se han intensificado con posterioridad a la fecha de realización de la última encuesta.

19 Bien es cierto que en este punto convendría aclarar que la última encuesta se realizó en el año 2007 en España y en el 2008 en Galicia, con lo cual la comparativa de los resultados correspondientes a la última oleada debe realizarse con muchas cautelas en tanto en cuanto la percepción de la naturaleza y gravedad de la crisis por parte de gallegos y españoles puede ser distinta. 


\subsection{REFERENCIAS BIBLIOGRÁFICAS}

Alesina, A. y G. M. Angeletos (2005): Fairness and redistribution. American Economic Review, 95 (4): 960-980.

Alesina, A. y E. La Ferrara (2005): Preferences for redistribution in the land of opportunities. Journal of Public Economics, 89 (5-6): 897-931.

Ayala, L., Jurado, A. y F. Pedraja (2005): Desigualdad y bienestar en la distribución interterritorial de la renta, 1973-2000. IEF Working Papers, no 6/05. Madrid: Instituto de Estudios Fiscales.

Azmat, G., Manning, A. y J. Van Reenen (2007): Privatization, entry regulation and the decline of labour's share of GDP: a cross-country analysis of the network industries. CEPR Discussion Papers, $n^{\circ}$ 6348. Londres: CEPR.

Baker, W. y M. Forbes (2006): Moral values and market attitudes. Society, 43 (2): 23-26.

Benabou, R. y E. A. Ok (2001): Social mobility and the demand for redistribution: the POUM hypothesis. Quarterly Journal of Economics, 116 (2): 447-487.

Berlin, I. (1967): "Dos conceptos de la libertad". En A. Quinton, Filosofía Política. México: FCE.

Blekesaune, M. (2007): "Economic conditions and public attitudes to welfare policies". European Sociological Review, 23 (3): 393-403.

Bowles, S. (1998): "Endogenous preferences: the cultural consequences of markets and other economic institutions". Journal of Economic Literature, XXXVI (1): 75-111.

Etzioni, A. (1988): The moral dimension: toward a new economics. Nueva York: Free Press.

Fong, C. (2000): "Social preferences, self-interest, and the demand for redistribution". Journal of Public Economics, 82 (2): 225-246.

Fortin, N. M. (2005): "Gender role attitudes and the labour market outcomes of women across OECD countries". Oxford Review of Economic Policy, 21 (3): 416-438.

Gneezy, U., Niederle, M. y A. Rustichini (2003): "Performance in competitive environments: gender differences". Quarterly Journal of Economics, 118 (3): 1049-1074.

Grandín, C., Del Río, C. y O. Cantó (2006): La distribución de la renta en Galicia. A Coruña: CIEF-Fundación Caixa Galicia.

Hayward, R. D. y M. Kemmelmeier (2007): "How competition is viewed across cultures. A test of four theories". Cross-Cutural Research, 42 (4): 364-395.

Inglehart, R. (1998): Modernización y postmodernización: el cambio cultural, económico y politico en 43 sociedades avanzadas. Madrid: CIS.

Kenworthy, L. y L. McCall (2008): "Inequality, public opinion and redistribution". Socio-Economic Review, 6 (1): 35-68. 
Landier, A., Thesmar, D. y M. Thoenig (2008): "Investigating capitalism-aversion". Economic Policy, July (55): 465-490 y 495-497.

Meltzer, A. y S. F. Richard (1981): "A rational theory of the size of government". Journal of Political Economy, 89 (5): 914-927.

Nozick, R. (1974): Anarchy, State and utopia. Nueva York: Basic Books.

Östling, R. (2009): "Economic influences on moral values". The B.E. Journal of Economic Analysis \& Policy, 9, 1, article 2.

Pena, A. y Sánchez, J. M. (2008): "Disparidades econonómicas intrarregionales a escala municipal: evidencia empírica para el caso gallego". Revista de Estudios Regionales, 81: 15-44.

Piketty, T. (1995): "Social mobility and redistributive politics". Quarterly Journal of Economics, 110 (3): 551-84.

Piore, M. J. (1971): "The dual labor market: theory and implications", en D. M. Gordon (Ed.), Problems in Political Economy: an urban prospective: 90-94. Lexington: D. C. Heath.

Prada, A. y S. Lago (2009): Galicia, unha economía europea. Vigo: Galaxia.

Rokeach, M. (1973): The nature of human values. Nueva York: Free Press.

Romer, T. (1975): "Individual welfare, majority voting and the properties of a linear income tax". Journal of Public Economics, 4 (2): 163-185.

Sen, A. K. (1999): Development as freedom. Nueva York: A. Knopf, Inc./Random House Inc. (edición en castellano: Desarrollo y Libertad, Ed. Planeta, Barcelona, 2000).

Stiglitz, J. E., Sen, A. I. y J. P. Fitoussi (2009): Report by the Commission on the Measurement of Economic Performance and Social Progress, www.stiglitz-senfitoussi.fr/en/index.htm.

Valian, V. (1999): Why so slow? The advancement of women. Cambridge: MIT Press.

Walzer, M. (1983): Spheres of justice. A defence of pluralism and equality. Oxford: Basil Blackwell. 


\section{FICHAS TÉCNICAS}

\section{FICHA TÉCNICA DE LA ENCUESTA MUNDIAL DE VALORES EN GALICIA 1995}

- Universo: Residentes en Galicia, mayores de 18 años.

- Tamaño de la muestra: 1.200 entrevistas personales.

- Error muestral: $\pm 2,89 \%$ para datos globales, para un nivel de confianza del 95,5\% ( $z=2)$ y suponiendo $p=q=0,5$.

- Trabajo de campo: Realizado en noviembre de 1995.

- Tipo de entrevista: A domicilio.

- Selección de los hogares: Por rutas aleatorias.

- Selección de los entrevistados: Por tablas aleatorias entre los miembros de cada hogar.

- Diseño muestral: Muestreo estratificado con afijación proporcional por provincia y estrato de los municipios. Los municipios se dividieron en tres estratos —urbano, semiurbano y rural- atendiendo a criterios como el tamaño de población y la existencia de una serie de servicios -oficina de correos, banco, etc.- - Se realizaron entrevistas en todos los municipios del estrato urbano (A Coruña, Ferrol, Santiago, Lugo, Ourense, Pontevedra y Vigo), en los otros dos estratos se llevó a cabo una selección aleatoria de municipios.

- Ponderación de los cuestionarios: Por sexo, edad y nivel de estudios. 


\section{FICHA TÉCNICA DE LA ENCUESTA MUNDIAL DE VALORES EN GALICIA 2001}

- Universo: Residentes en Galicia, mayores de 18 años.

- Tamaño de la muestra: 1.192 entrevistas personales.

- Error muestral: $\pm 2,9 \%$ para datos globales, para un nivel de confianza del 95,5\% $(z=2)$ y suponiendo $p=q=0,5$.

- Trabajo de campo: Realizado entre diciembre de 2000 y enero de 2001

- Tipo de entrevista: A domicilio.

- Selección de los hogares: Por rutas aleatorias.

- Selección de los entrevistados: Por tablas aleatorias entre los miembros de cada hogar.

- Diseño muestral: Muestreo estratificado con afijación proporcional por estrato de los municipios. Los municipios se dividieron en cuatro estratos atendiendo al tamaño de población. Se realizaron entrevistas en todos los municipios de los dos estratos de mayor tamaño (A Coruña, Ferrol, Santiago, Lugo, Ourense, Pontevedra y Vigo), en los otros dos estratos se llevó a cabo una selección aleatoria de municipios.

- Ponderación de los cuestionarios: Por sexo, edad y nivel de estudios. 


\section{FICHA TÉCNICA DE LA ENCUESTA MUNDIAL DE VALORES EN GALICIA 2008}

- Universo: Residentes en Galicia, mayores de 18 años.

- Tamaño de la muestra: 1.600 entrevistas personales.

- Error muestral: $\pm 2,5 \%$ para datos globales, para un nivel de confianza del 95,5\% $(z=2)$ y suponiendo $p=q=0,5$.

- Trabajo de campo: Realizado en diciembre de 2008.

- Tipo de entrevista: A domicilio.

- Selección de los hogares: Por rutas aleatorias.

- Selección de los entrevistados: Por tablas aleatorias entre los miembros de cada hogar.

- Diseño muestral: Muestreo estratificado con afijación proporcional por provincia y estrato de los municipios. Los municipios se dividieron en cinco estratos atendiendo al tamaño de población. Se realizaron entrevistas en todos los municipios de los dos estratos de mayor tamaño (A Coruña, Ferrol, Santiago, Lugo, Ourense, Pontevedra y Vigo), en los otros tres estratos se llevó a cabo una selección aleatoria de municipios.

- Ponderación de los cuestionarios: Por sexo y edad. 
ANEXOS 
(ENTREVISTADOR: MOSTRAR TARJETA G)

** P.15.- En la siguiente lista hay varios grupos de gente. ¿Podría $\mathrm{Vd}$. indicarme los que no le gustaría tener por vecinos?

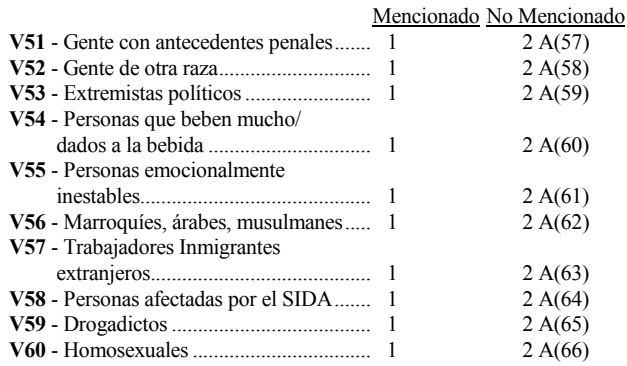

** P.16.- ¿Está Vd. de acuerdo o en desacuerdo con las siguientes afirmaciones?

$\begin{array}{cccc}\text { De } & \text { Ni lo uno } & \text { En } & \text { No } \\ \text { acuerdo } & \underline{\text { ni lo otro }} & \underline{\text { desac. }} & \underline{\text { sabe }}\end{array}$

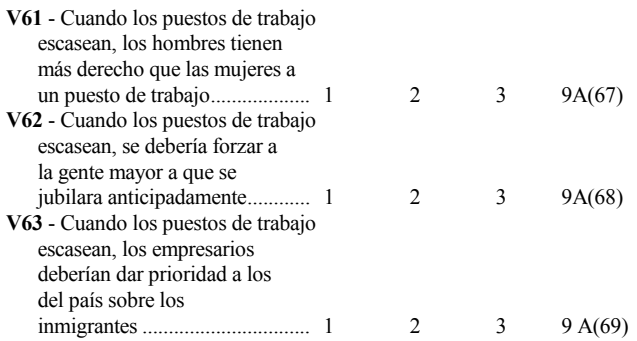

\section{(ENTREVISTADOR: MOSTRAR TARJETA H)}

V64. ** P.17.- ¿En qué medida está Vd. satisfecho o insatisfecho con la situación económica de su hogar? $\mathrm{Si}$ "1" significa que $\mathrm{Vd}$. está completamente insatisfecho y "10" significa que Vd. está completamente satisfecho ¿dónde situaría Vd. en esta escala su nivel de satisfacción con la situación financiera de su hogar?

$$
\begin{array}{cccccccccccc}
1 & 2 & 3 & 4 & 5 & 6 & 7 & 8 & 9 & 10 & 99 & \mathrm{~A}(70-71) \\
\text { Insatisfecho } & & & & & & \text { Satisfecho No sabe }
\end{array}
$$

(ENTREVISTADOR: MOSTRAR TARJETA H OTRA VEZ)

V65. ** P.18.- En general, ¿hasta qué punto está Vd. satisfecho o insatisfecho con su vida actualmente?. Utilice, por favor, esta tarjeta para contestar.

$$
\begin{array}{cccccccccccc}
1 & 2 & 3 & 4 & 5 & 6 & 7 & 8 & 9 & 10 & 99 & \mathrm{~A}(72-73) \\
\text { Insatisfecho } & & & & & & \text { Satisfecho No sabe }
\end{array}
$$

V66. ** P.19.- Algunas persona piensan que tienen complet libertad de elección y control sobre la manera en que se desarrolla su vida, mientras que otras piensan que lo que hacen no produce ningún efecto real sobre lo que les sucede. Utilice, por favor, esta escala, en la que el "1" significa "ninguna en absoluto" y "10" significa "mucha", para indicar cuánta libertad de elección y control piensa Vd. que tiene sobre la manera en que se desarrolla su vida.

$$
\begin{array}{llllllllllll}
1 & 2 & 3 & 4 & 5 & 6 & 7 & 8 & 9 & 10 & 99 & \mathrm{~A}(74-75)
\end{array}
$$$$
\text { Ninguna Mucha No sabe }
$$

\section{ENTREVISTADOR: MOSTRAR TARJETA F)}

P.20.- Ahora me gustaría hacerle algunas preguntas sobre cómo se siente Vd. en su trabajo, tanto si es el trabajo doméstico como el trabajo realizado fuera del hogar.

¿Podría Vd. decirme en qué medida está Vd. de acuerdo o en desacuerdo con cada una de las siguientes afirmaciones? ¿Está Vd. muy de acuerdo, de acuerdo, en desacuerdo o muy en desacuerdo con:

Muy de De En Muy en No acuerdo acuerdo desacu. desacu. Sabe

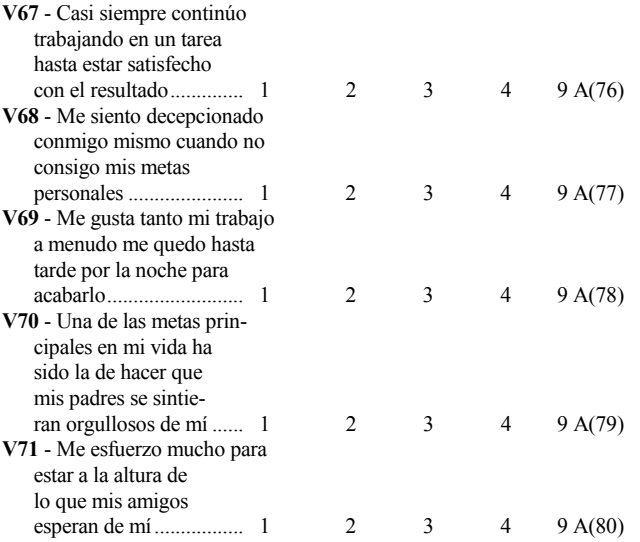

FICHA B

\section{(ENTREVISTADOR: MOSTRAR TARJETA I)}

V72. P.21.- ¿Qué punto en esta escala describe más claramente el valor que concede Vd. al trabajo (incluido el trabajo doméstico y el escolar) por comparación con el tiempo libre o el ocio?

- Es el tiempo libre, y no el trabajo, lo que hace

que merezca la pena vivir ............................................. 1

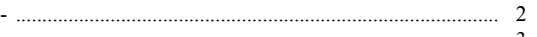

-..................................... 4

- Es el trabajo, y no el tiempo libre, lo que hace

que merezca la pena vivir ................................................ 5

- No sabe ...........................................

(ENTREVISTADOR: MOSTRAR TARJETA J)

V73. P.22.- Ahora me gustaría preguntarle acerca de aquellas cosas que a Vd. le parezcan más importantes personalmente en el caso de que estuviera buscando trabajo. He aquí algunas de las cosas que la gente normalmente tienen en cuenta en relación con su trabajo. Independientemente de si está $\mathrm{Vd}$. de hecho buscando trabajo ahora, ¿cuál de ellas pondría Vd. personalmente en primer lugar si estuviera buscando trabajo?

V74. P.22a.- ¿Y cuál sería su segunda preferencia?

$$
\frac{1^{\circ} \text { Lugar }}{\mathrm{B}(2)} \frac{2^{\circ} \text { Lugar }}{\mathrm{B}(3)}
$$

- Un buen sueldo, de manera que no tuviese

preocupaciones respecto al dinero........................ 1

- Un trabajo seguro que no comporte riesgos

de cierre 0 de desempleo...................................... 2

- Trabajar con gente que sea de su gusto................. 3

- Hacer un trabajo importante que le haga

sentirse realizado

- No sabe 
(ENTREVISTADOR: MOSTRAR TARJETA J2)

* P.23.- Quisiera mostrarle esta lista con algunos otros aspectos relativos al trabajo que la gente dice que son importantes. Por favor, mírelos y dígame cuales de ellos cree Vd., personalmente, que son importantes en un trabajo. (CODIFICAR TODOS LOS ASPECTOS MENCIONADOS)

No

Mencionado Mencionado

V75 - Un buen sueldo/salario

V76 - No demasiado agobiante ............................. 1 2 B(5)

V77 - Alta seguridad en el empleo ...................... 1 2 B

V78 - Un trabajo respetable.............................. 1 2 B(7)

V79 - Buen horario ............................................ 1 2 B(8)

V80 - Que ofrezca oportunidad de utilizar la

iniciativa ................................................. 1 2 1 (9)

V81 - Vacaciones y días festivos

abundantes...

$2 \mathrm{~B}(10)$

$\mathbf{8 2}$ - Un trabajo en el que crea que pueda

llegar a hacer algo ......................................... 1 2 $\mathrm{B}(11)$

V83 - Un trabajo de responsabilidad...................... 1

V84 - Un trabajo que sea interesante ................. 1 2 B(13)

V85 - Un trabajo adaptado a mis

conocimientos y a mi capacidad..................... 1

V86. * P.24.- Imagine dos secretarias de la misma edad y haciendo prácticamente el mismo trabajo. Una de ellas descubre que la otra gana bastante más que ella. Sin embargo, la secretaria mejor pagada es más rápida, más eficiente y se puede confiar más en su trabajo. En su opinión, ¿es justo o no es justo que a una secretaria se le pague mejor que a la otra?

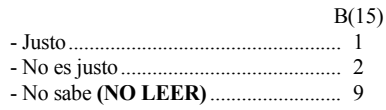

(ENTREVISTADOR: MOSTRAR TARJETA K)

V87. ** P.25.- Hay mucha discusión sobre la manera de dirigir las empresas. ¿Cuál de estas cuatro opiniones está más cerca de la suya? (CODIFICAR SOLO UNA)

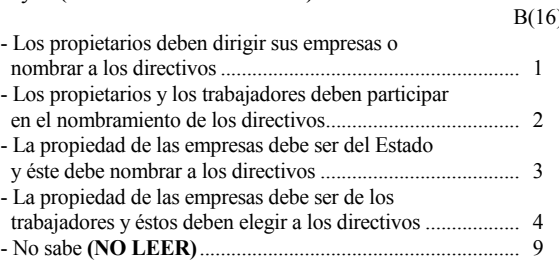

V88. ** P.26.- ¿La gente tiene ideas diferentes a la hora de seguir las instrucciones que se dan en el trabajo. Unos dicen que se deben seguir las instrucciones de los superiores, incluso aún cuando no se esté totalmente de acuerdo con ellas. Otros dicen que se deben seguir las instrucciones del superior únicamente cuando uno se ha convencido de que son las adecuadas. ¿Con cuál de estas dos opiniones está Vd. de acuerdo?

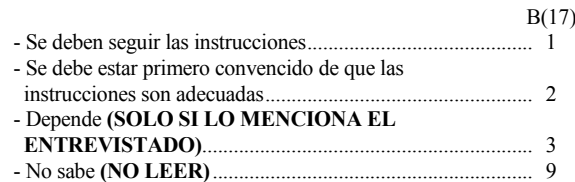

V89. ** P.27.- En la actualidad, está Vd.

(LEA EN VOZ ALTA Y CODIFIQUE UNA SOLA)

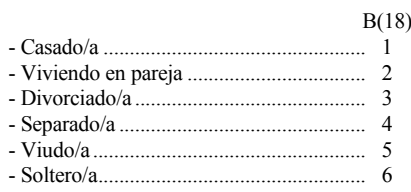

V90. ** P.28.- ¿Ha tenido Vd. algún hijo/a? SI LA RESPUESTA ES SI, ¿Cuántos?

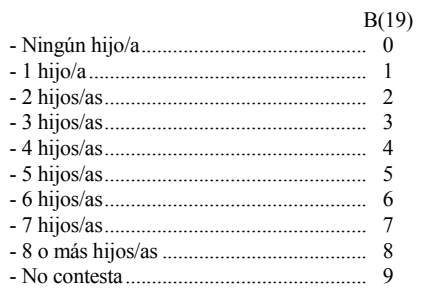

V91. ** P.29.- ¿Cuál cree Vd. que es el tamaño ideal de la familia, es decir, el número ideal de hijos, si es que alguno?

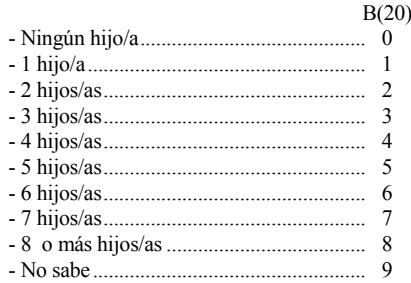

V92. ** P.30.- Si alguien dijera que un niño necesita un hogar donde haya un padre y una madre para poder crecer feliz, ¿tendería Vd. a estar de acuerdo o en desacuerdo?

$\begin{array}{ll} & \mathrm{B}(21) \\ \text { - Tendería a estar de acuerdo ......................... } & 1 \\ \text { - Tendería a estar en desacuerdo................. } & 2 \\ \text { - No sabe (NO LEER) ……....................... } & 9\end{array}$

V93. ** P.31.- ¿Cree Vd. que una mujer necesita tener hijos para realizarse o, por el contrario, cree que ello no es necesario?

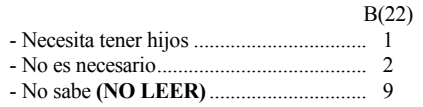

V94. ** P.32.- ¿Está Vd. de acuerdo o en desacuerdo con la siguiente frase? (LEA EN VOZ ALTA): "El matrimonio es una institución pasada de moda"

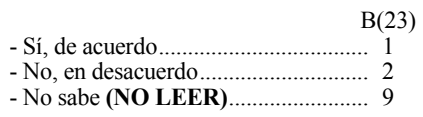


V95. * P.33.- Si alguien dijera que cada individuo debe tener la oportunidad de disfrutar de una completa libertad sexual sin limitaciones, ¿tendería Vd. a estar de acuerdo o en desacuerdo?

$\mathrm{B}(24)$

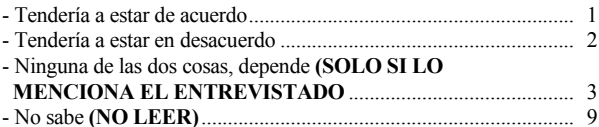

V96. ** P.34.- Si una mujer quisiera tener un hijo como madre soltera, sin querer al mismo tiempo mantener una relación estable con un hombre, lo aprobaría o lo desaprobaría?

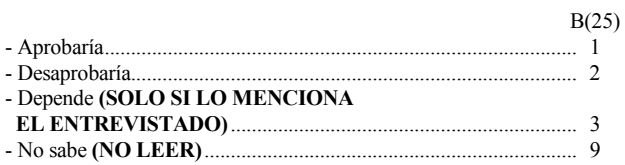

V97. ** P.35.- Si solo pudiera Vd. tener un hijo, preferiría Vd. que fuese niño o niña?

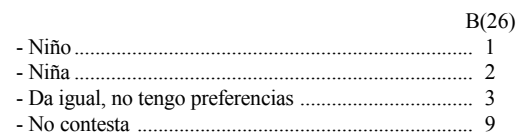

(ENTREVISTADOR: MOSTRAR TARJETA F)

* P.36.- La gente habla de los papeles cambiantes de los hombres y mujeres de hoy. ¿Podría decirme, para cada una de las afirmaciones que le vaya leyendo, en qué medida está $\mathrm{Vd}$. de acuerdo con cada una de ellas? ¿Está Vd. muy de acuerdo, de acuerdo, en desacuerdo o muy en desacuerdo?

$$
\begin{aligned}
& \text { Muy de De En desa- Muy en No } \\
& \text { acuerdo Acuerdo cuerdo Desacue. Sab }
\end{aligned}
$$

V98 - Una madre que

trabaja puede

tener una relación

tan cálida y segura

con sus hijos

como una que no

trabaja .....................

V99 - Ser ama de casa es

tan satisfactorio

como trabajar por

un sueldo/salario....

V100 - Tanto el hombre

como la mujer

deberían contri-

buir a los ingre-

sos del hogar.........

V101 - En general, los

hombres son mejores

líderes políticos

que las mujeres ........

V102 - Si una mujer gana

más que su marido,

es casi seguro

que ello cause

$\begin{array}{llllll}\text { problemas................ } 1 & 2 & 3 & 4 & 9 \mathrm{~B}(31)\end{array}$

V103 - Obtener una educa-

ción universitaria

es más importante

para un hombre que

para una mujer .........
(ENTREVISTADOR: MOSTRAR TARJETA L)

V104. * P.37.- Se habla mucho hoy en día sobre cuáles deberían ser los objetivos de este país para los proximos diez años. En esta tarjeta hay varios objetivos a los que diversas personas darían prioridad. ¿Podría decirme cuál, de entre éstos, considera Vd. el más importante? CODIFIQUE UNA RESPUESTA SOLAMENTE BAJO "Primer objetivo elegido".

V105. P.37a.- ¿Y cuál sería para Vd. el segundo objetivo más importante? CODIFIQUE UNA RESPUESTA SOLAMENTE

\begin{tabular}{|c|c|c|}
\hline & $\begin{array}{c}\begin{array}{c}\text { Primer } \\
\text { Objetivo Elegido }\end{array} \\
\mathrm{B}(33)\end{array}$ & $\begin{array}{c}\begin{array}{c}\text { Segundo } \\
\text { Objetivo Elegido }\end{array} \\
\mathrm{B}(34)\end{array}$ \\
\hline $\begin{array}{l}\text { - Mantener un alto nivel de } \\
\text { crecimiento económico....................... }\end{array}$ & .... 1 & 1 \\
\hline - Asegurar que este país tenga unas & & \\
\hline $\begin{array}{l}\text { Fuerzas Armadas importantes ............. } \\
\text { - Lograr que la gente pueda participar } \\
\text { más en cómo se hacen las cosas en su }\end{array}$ & 2 & 2 \\
\hline $\begin{array}{l}\text { lugar de trabajo y en su comunidad.... } \\
\text { - Intentar que nuestras ciudades y }\end{array}$ & …....... 3 & 3 \\
\hline nuestro campo sean más bonitos ......... & ............. 4 & 4 \\
\hline - No sabe (NO LEER) & ........... 9 & 9 \\
\hline
\end{tabular}
BAJO "Segundo objetivo elegido".

(ENTREVISTADOR: MOSTRAR TARJETA M)

V106. ** P.38.- Si tuviera que escoger, ¿cuál es, de las cosas que aparecen en esta lista, la más importante según Vd.?

V107. ** P.38a.- ¿Y cuál sería la segunda más importantes? CODIFIQUE UNA RESPUESTA SOLAMENTE.

$$
\frac{1^{\mathrm{a} O p c i o ́ n}}{\mathrm{~B}(35)} \quad \frac{2^{\mathrm{a}} \text { Opción }}{\mathrm{B}(36)}
$$

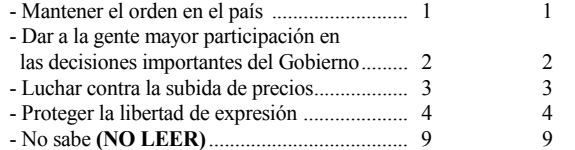

No sabe (NO LEER)

(ENTREVISTADOR: MOSTRAR TARJETA N)

V108. * P.39.- He aquí otra lista. En su opinión, ¿qué es, de lo que aparece en ella, lo más importante según Vd.? CODIFIQUE SOLAMENTE UNA RESPUESTA.

\begin{tabular}{|c|c|c|}
\hline & $\frac{1^{\text {a } \text { Opción }}}{\mathrm{B}(37)}$ & $\frac{2^{\mathrm{a}} \text { Opción }}{\mathrm{B}(38)}$ \\
\hline 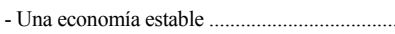 & ..... 1 & 1 \\
\hline $\begin{array}{l}\text { - Avanzar hacia una sociedad menos } \\
\text { impersonal y más humana .................................. }\end{array}$ & .... 2 & 2 \\
\hline $\begin{array}{l}\text { - Avanzar hacia una sociedad en donde las } \\
\text { ideas sean más importantes que el dinero ....... }\end{array}$ & .... 3 & 3 \\
\hline - La lucha contra la delincuencia........................... & .... 4 & 4 \\
\hline 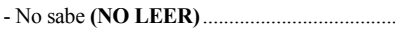 & $\ldots .9$ & 9 \\
\hline
\end{tabular}

V109. * P.39a.- ¿Y qué sería lo segundo más importante? CODIFIQUE UNA RESPUESTA SOLAMENTE.

V110. ** P.40.- Ni qué decir tiene que todos esperamos que no haya otra guerra, pero si la hubiera, ¿estaría Vd. dispuesto a luchar por su país?

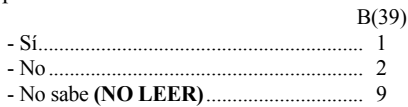




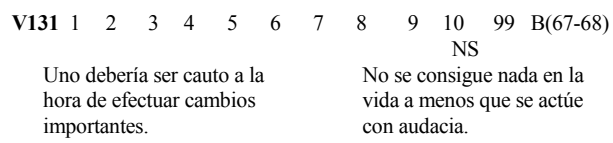

Uno debería ser cauto a la hora de efectuar cambios importantes.

No se consigue nada en la vida a menos que se actúe con audacia.

\section{(ENTREVISTADOR: MOSTRAR TARJETA S)}

P.51.- La gente tiene diferentes opiniones sobre el sistema para gobernar este país. Aquí tiene una escala para valorar lo bien que van las cosas: 1 significa que las cosas van muy mal, y 10 que las cosas van muy bien.

$\begin{array}{lllllllllll}1 & 2 & 3 & 4 & 5 & 6 & 7 & 8 & 9 & 10 & 99 \\ \text { Muy } & & & & & & & & & \begin{array}{l}\text { Muy } \\ \text { Bien }\end{array} \\ \text { Mal } & & & & & & & & & \\ \text { Sabe }\end{array}$

V151. - ¿En qué punto de esta escala situaría Vd. el sistema político en tiempos de Franco?

$$
\overline{\text { (Escribir la puntuación de } 1 \text { a 10) }}
$$

V152. - ¿En qué punto de esta escala situaría Vd. el sistema político actual?

$$
\overline{\text { (Escribir la puntuación de } 1 \text { a 10) }}
$$

V153. - ¿En qué punto de esta escala situaría Vd. el sistema político tal y como $\mathrm{Vd}$. espera que sea dentro de 10 años?

V134. P.49.- Respecto a la gente que viene de otros países a trabajar aquí, ¿qué es, de lo que le menciono a continuación, lo que debería hacer el Gobierno? (SOLO UNA RESPUESTA)

- Permitir que venga quien quiera

$\mathrm{B}(72)$

- Permitir que venga quien quiera …............................................ 1

- Establecer límites estrictos en el número de extranjeros que

puedan venir........

- Prohibir que vengan personas de otros países. ……..........................

FICHA C

** P.50.- Voy a enumerar una serie de instituciones y organizaciones. Para cada una de ellas, ¿podría decirme cuánta confianza tiene en ella: mucha confianza, bastante confianza, no mucha confianza o ninguna confianza en absoluto?

\section{No Ninguna en}

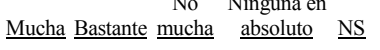

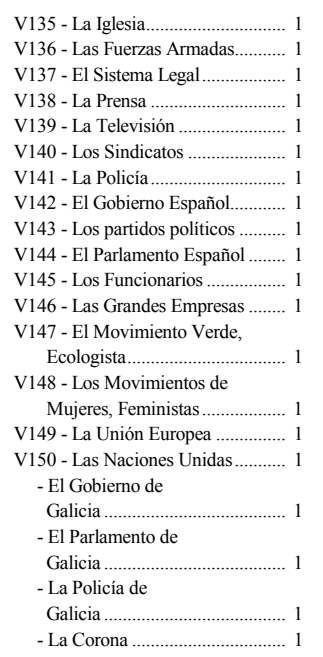

2
2
2
2
2
2
2
2
2
2
2
2
2
2
2
2
2
2
2
2

$9 \mathrm{C}(1)$

$9 \mathrm{C}(2)$

$9 \mathrm{C}(3)$

$9 \mathrm{C}(4)$

$9 \mathrm{C}(5)$

$9 \mathrm{C}(6)$

$9 \mathrm{C}(7)$

$9 \mathrm{C}(8)$

$9 \mathrm{C}(9)$

$9 \mathrm{C}(10)$

$9 \mathrm{C}(11)$

$9 \mathrm{C}(12)$

$9 \mathrm{C}(13)$

$9 \mathrm{C}(14)$

$9 \mathrm{C}(15)$

$9 \mathrm{C}(16)$

$9 \mathrm{C}(17)$

$9 \mathrm{C}(18)$

$9 \mathrm{C}(19)$

$9 \mathrm{C}(20)$

$$
\text { C (25-26) }
$$

$\overline{\text { (Escribir la puntuación de } 1 \text { a 10) }}$

P.52.- Ahora voy a describirle diversos tipos de sistemas políticos y a preguntarle qué piensa Vd. de cada uno de ellos como forma de gobernar este país. Para cada uno de ellos ¿diría Vd. que es un modo muy bueno, bastante bueno, bastante malo o muy malo de gobernar este país?

$$
\begin{array}{cccc}
\text { Muy } & \text { Bast. Bast. } & \text { No } \\
\underline{\text { Bueno }} & \underline{\text { Bueno }} & \underline{\text { Malo }} & \underline{\text { Malo }} \underline{\underline{\text { Sabe }}}
\end{array}
$$

V154 - Tener un líder fuerte que no tuviera que preocuparse por el parlamento ni por

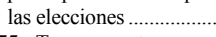

V155 - Tener expertos, no un Gobierno, que tome las decisiones de acuerdo con lo que ellos piensen que es lo mejor para V156 - Tener un gobierno militar ....... $1142 \quad 3 \quad 4 \quad 9$ C(29) V157 - Tener un sistema político democrático............ $\begin{array}{llll}2 & 3 & 4 & 9 \mathrm{C}(30)\end{array}$

V158. P.53.- En política, los distintos partidos tienen frecuentemente puntos de vista diferentes. ¿Qué cree Vd. que es mejor?

- El/la líder de un partido debe mantenerse firme en lo que

él o ella cree, incluso si los demás no están de acuerdo..

- El líder de un partido debe estar dispuesto a colaborar

con otros grupos, incluso si ello significa llegar a

compromisos en algunos principios importantes ............................ 2

V159. P.54.- Si tuviera que elegir, ¿cuál diría Vd. que es la responsabilidad más importante de un gobierno?

$\mathrm{C}(32)$

- Respetar la libertad de los individuos .....................................

- NSAC $\begin{array}{lllllll}\text { este país............................................ } 1 & 2 & 3 & 4 & 9 \mathrm{C}(28)\end{array}$

- Mantener el orden en la sociedad... 
V177. ** P.67.- ¿Con qué frecuencia piensa Vd. sobre el significado y el objeto de la vida, si es que piensa alguna vez en ello? (LEASE INVIRTIENDO EL ORDEN EN CADA ENTREVISTA)

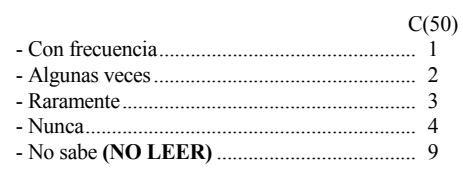

\section{(ENTREVISTADOR: MOSTRAR TARJETA T)}

V178. ** P.68.- Aquí tiene Vd. dos opiniones que la gente manifiesta cuando discute sobre el bien y el mal. ¿Cuál es la que mejor responde a su propio punto de vista?

A) Existen líneas directrices absolutamente claras sobre lo que es el bien y el mal. Y se aplican siempre a todas las personas, cualesquiera que sean las circunstancias.

B) No puede haber nunca líneas directrices absolutamente clara sobre lo que es el bien y el mal. Lo que es bueno y malo depende completamente de las circunstancias del momento.

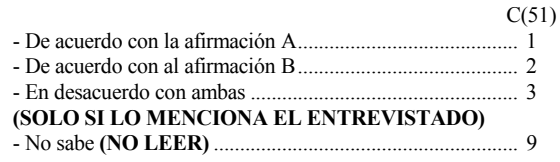

V179. ** P.69.- ¿Pertenece Vd. a alguna religión? SI LA RESPUESTA ES SI: ¿A CUAL?

SI LA RESPUESTA ES NO: CODIFIQUE 0

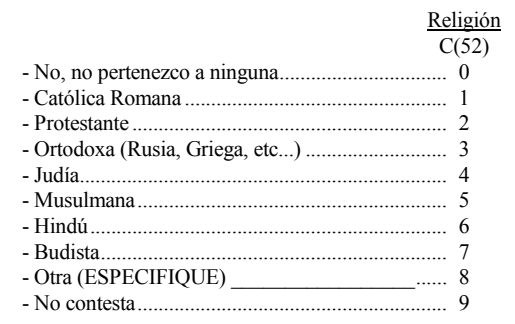

(A TODOS)

V180. * P.70.- ¿Fue Vd. educado religiosamente en su casa?

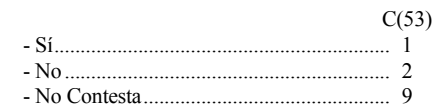

(ENTREVISTADOR: MOSTRAR TARJETA U)

V181. ** P.71.- Aparte de bodas, funerales y bautizos, ¿con qué frecuencia va $\mathrm{Vd}$. a la iglesia últimamente?

\begin{tabular}{|c|c|}
\hline \multirow{2}{*}{ - Más de una vez a la semana } & $C(54)$ \\
\hline & \\
\hline 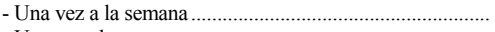 & .. 2 \\
\hline - Una vez al mes ................................................. & 3 \\
\hline - Sólo en festividades religiosas concretas....... & 4 \\
\hline 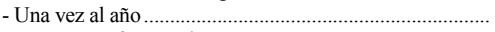 & 5 \\
\hline - Con menos frecuencia ...................... & 6 \\
\hline 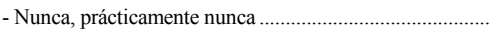 & 7 \\
\hline 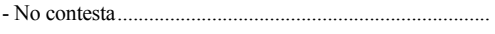 & .. 9 \\
\hline
\end{tabular}

V182. * P.72.- Tanto si va Vd. a la Iglesia como si no, ¿diría Vd. que es... (LEA EN VOZ ALTA)

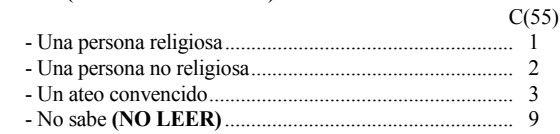

** P.73.- ¿En cuáles de las siguientes cosas cree Vd., si es que cree en alguna? (LEA EN VOZ ALTA Y CODIFIQUE UNA RESPUESTA PARA CADA UNA)

\begin{tabular}{|c|c|c|c|}
\hline & $\underline{\text { Sí }}$ & $\underline{\text { No }}$ & $\begin{array}{l}\text { No } \\
\text { sabe }\end{array}$ \\
\hline V183 - ¿Cree Vd. en Dios? & $\overline{1}$ & $\overline{2}$ & $9 \mathrm{C}(56)$ \\
\hline $\begin{array}{l}\text { V184 - ¿Cree Vd. en la vida después } \\
\text { de la muerte? }\end{array}$ & 1 & 2 & $9 \mathrm{C}(57)$ \\
\hline V185 - ¿Cree Vd. que las personas & & & \\
\hline tienen alma? ............ & 1 & 2 & $9 \mathrm{C}(58)$ \\
\hline V186 - ¿Cree Vd. que el demonio existe? ....... & 1 & 2 & $9 \mathrm{C}(59)$ \\
\hline 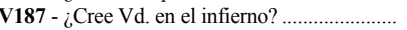 & 1 & 2 & $9 \mathrm{C}(60)$ \\
\hline 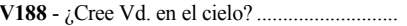 & 1 & 2 & $9 \mathrm{C}(61)$ \\
\hline 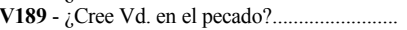 & 1 & 2 & $9 \mathrm{C}(62)$ \\
\hline
\end{tabular}

\section{(ENTREVISTADOR: MOSTRAR TARJETA V)}

V190. ** P.74.- ¿Y en qué medida es importante Dios en su vida? Utilice esta tarjeta, por favor, para indicarlo: 10 significa muy importante, y 1 nada importante.

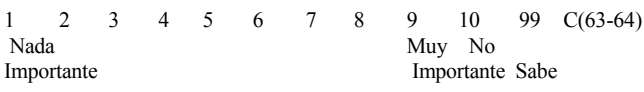

V191. ** P.75.- ¿Encuentra Vd. consuelo y fortaleza en la religión?

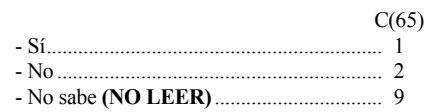

(ENTREVISTADOR: MOSTRAR TARJETA W)

FICHA D

** P.76.- Para cada una de las siguientes afirmaciones, dígame, por favor, si piensa Vd. que siempre puede estar justificado, si nunca puede estar justificado, o si cree que su grado de justificación se encuentra en algún otro punto intermedio de la escala que aquí le presento. LEA EN VOZ ALTA LAS AFIRMACIONES. CODIFIQUE UNA RESPUESTA PARA CADA AFIRMACION.

$\begin{array}{ll}\text { Nunca } & \text { Siempre No } \\ \text { Justific. } & \underline{\text { Justific. }} \underline{\text { Sabe }}\end{array}$

\begin{tabular}{|c|c|c|c|c|}
\hline $\begin{array}{l}\text { V192 - Reclamar beneficios } \\
\text { del Estado a los que }\end{array}$ & & & & \\
\hline no se tiene derecho ..................... 1 & 234 & 56789 & 10 & $99 \mathrm{D}(1-2)$ \\
\hline \multicolumn{5}{|l|}{$\begin{array}{l}\text { V193 - Evitar pagar el billete } \\
\text { en algún transporte }\end{array}$} \\
\hline público.................................... 1 & 234 & 56789 & 10 & 99D(3-4) \\
\hline \multicolumn{5}{|l|}{ V194 - Engañar en el pago de } \\
\hline impuestos, si se puede $. . . \ldots \ldots \ldots \ldots \ldots . . . . .1$ & 234 & 56789 & 10 & $99 \mathrm{D}(5-6)$ \\
\hline \multicolumn{5}{|l|}{ V195 - Comprar algo sabiendo } \\
\hline que ha sido robado ....................... 1 & 234 & 56789 & 10 & $99 \mathrm{D}(7-8)$ \\
\hline \multicolumn{4}{|l|}{ V196 - Que alguien acepte un } & \\
\hline de sus funciones ......................... 1 & 234 & 56789 & 10 & $99 \mathrm{D}(9-10)$ \\
\hline V197 - La homosexualidad ............. 1 & 234 & 56789 & 10 & 99D(11-12) \\
\hline V198 - La prostitución .......................... 1 & 234 & 56789 & 10 & $99 \mathrm{D}(13-14)$ \\
\hline V199 - El aborto $\ldots \ldots \ldots \ldots \ldots \ldots \ldots \ldots . . . .1$ & 234 & 56789 & 10 & $99 \mathrm{D}(15-16)$ \\
\hline V200 - El divorcio ……………….... 1 & 234 & 56789 & 10 & 99D(17-18) \\
\hline \multicolumn{5}{|l|}{ V201 - La eutanasia (poner fin a } \\
\hline incurable). & & & 10 & 99D(19-20) \\
\hline V202 - El suicidio & 234 & 56789 & 10 & $99 \mathrm{D}(21-22)$ \\
\hline
\end{tabular}




\section{DATOS SOCIODEMOGRAFICOS BLOQUE G}

BLOQUE G

V214. ** D.1. Sexo del encuestado/a

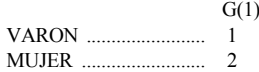

V215. ** D.2. ¿Puede decirme su fecha de nacimiento, por favor? 1.9 $\mathrm{G}(2-3)$

V216. ** D.2a. En otras palabras, tiene Vd. ....... años.

V217. D.3. ¿Cuál es el nivel de estudios más alto que ha alcanzado Vd.? (SI ES UN/A ESTUDIANTE, CODIFICAR EL NIVEL DE ESTUDIOS MAS ALTO QUE ESPERE COMPLETAR)

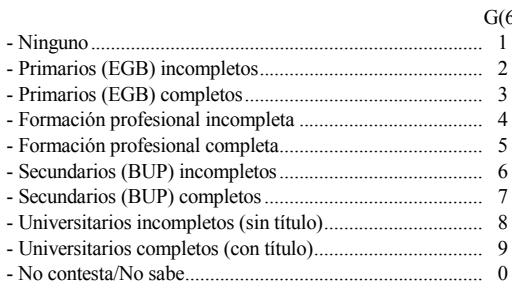

V218. ** D.4. ¿A qué edad completó o completará Vd. sus estudios, bien sea en el colegio (escuela), en el instituto o en la Universidad? Por favor, excluya aprendizajes en puestos de trabajo: (SI ES UN/A ESTUDIANTE, CODIFICAR LA EDAD A LA QUE ESPERA FINALIZAR SUS ESTUDIOS)

AÑOS G(7-8)

V219. ** D.5.- ¿Vive Vd. con sus padres?

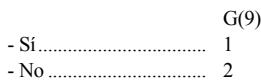

V220. ** D.6. ¿Tiene Vd. ahora trabajo o no?

$-\quad-$ SI

- ¿Cuántas horas trabaja Vd.? Si tiene Vd. más de un trabajo, refiérase sólo al trabajo principal

Tiene un trabajo remunerado

- A tiempo completo ( 30 horas semanales o más)

- A tiempo parcial (menos de 30 horas semanales)

Autónomo

$\underline{\text { Si no tiene trabajo remunerado }}$

- Jubilado (a)/pensionista

- Ama de casa sin otro trabajo

- Estudiante

- Parado/a.

- Otro: POR FAVOR, ESPECIFIQUE:
V221. ** D.7. En qué profesión/actividad económica o industria trabaja o trabajó Vd.? Si tiene o tuvo más de un trabajo, refiérase sólo al principal. ENTREVISTADO ESCRIBA PROFESION

¿Cuál es/era su trabajo ahí? ESCRIBA Y CODIFIQUE EN G (11-12) ABAJO

Empresario/directivo de establecimiento con 10 ó

más empleados (incluidas empresas agrícolas)

Empresario (a)/directivo(a) de establecimiento con meno

de 10 empleados (incluidas empresas agrícolas)..

- Profesional: abogado, contable, profesor, etc

-Empleado no-manual que supervisa a otros (incluir

mandos intermedios)

- Empleado no manual que no supervisa a otros ..............................................

- Capataz (trabajador manual)

- Trabajador manual especializado .................................................................

- Trabajador manual semi-especializado .......................................................... 8

- Trabajador manual sin especificar (o peón) ..............................................

- Agricultor por cuenta propia (incluyendo arrendatarios

- Trabajador agrícola (o jornalero)............................................................. 1

- Miembro de las Fuerzas Armadas, personal de seguridad .......................... 12

- Nunca ha tenido un trabajo

V222. ** D.8. ¿Es Vd. la persona con mayores ingresos en su hogar?

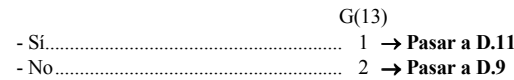

V223. ** D.9. ¿Tiene ahora trabajo la persona con mayores ingresos en su hogar?

$$
\begin{aligned}
& \text { - Sín............................................... } 1 \\
& \text { - No ………………………………..... } 2
\end{aligned}
$$

V224. ** D.10. En qué profesión/ocupación trabaja/trabajaba la persona con mayores ingresos en su hogar?. Si tiene más de un trabajo, refiérase al trabajo principal. ¿Cuál es/era su trabajo? ESCRIBA Y CODIFIQUE G(15-16) ABAJO

Empresario/directivo de establecimiento con 10

más empleados (incluidas empresas agrícolas)

- Empresario (a)/directivo(a) de establecimiento con menos

de 10 empleados (incluidas empresas agrícolas)...

Empleado no-manual que supervisa a otros (incluir

mandos intermedios)

eado no manual que no supervisa a otros........

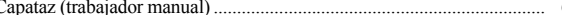

- Trabajador manual especializado ................................................................ 7

- Trabajador manual semi-especializado .................................................... 8

- Trabajador manual sin especificar (o peón) ...................................

Agricultor por cuenta propia (incluyendo arrendatarios

y aparceros) .................................................................................. 1

- Trabajador agrícola (o jornalero) ............................................................... 1

- Miembro de las Fuerzas Armadas, personal de seguridad ........................ 12

Nunca ha tenido un trabajo

(A TODOS)

V225. D.11. A lo largo del año pasado, su familia:

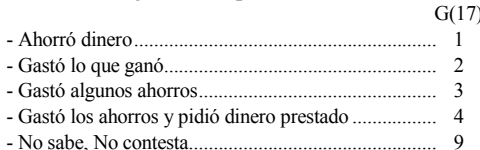


P.14b. B) ¿Y para cual, si procede, está Vd. realizando actualmente trabajo voluntario, sin remunerar? (CODIFICAR TODAS LAS RESPUESTAS AFIRMATIVAS CON UN 1; SI NO SE MENCIONA CODIFICAR CON UN 2).

$$
\begin{gathered}
\begin{array}{c}
\text { Hace trabajo } \\
\text { voluntario }
\end{array} \\
\text { menciona } \\
\hline
\end{gathered}
$$

V54 - Servicios sociales para ancianos discapacitados o gente desfavorecida

V55 - Iglesia u organizacione religiosas

$\begin{array}{ll}1 & 2 \\ 1 & 2 \\ & \\ 1 & 2 \\ 1 & 2 \\ 1 & 2 \\ & \\ 1 & 2 \\ & \\ 1 & 2 \\ & \\ 1 & 2 \\ 1 & 2 \\ 1 & 2 \\ 1 & 2 \\ 1 & 2 \\ 1 & \\ 1 & 2 \\ 1 & \end{array}$

(ENTREVISTADOR: MOSTRAR TARJETA G)

** P.15.- En la siguiente lista hay varios grupos de gente. ¿Podría $\mathrm{Vd}$. indicarme los que no le gustaría tener por vecinos?(CODIFICAR UNA RESPUESTA PARA CADA GRUPO).

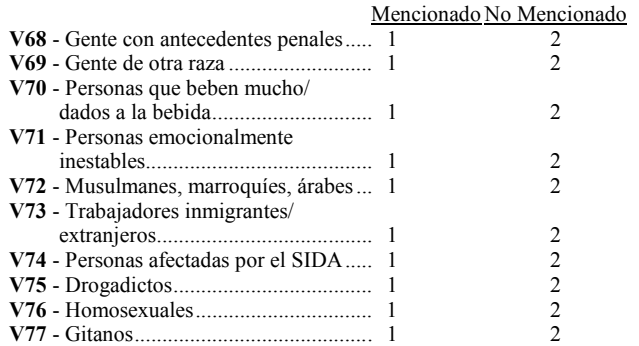

** P.16.- ¿Está Vd. de acuerdo o en desacuerdo con las siguientes afirmaciones?

$$
\begin{array}{cccc}
\begin{array}{c}
\text { De Ni lo uno } \\
\text { acuerdo }
\end{array} \underline{\underline{\text { ni lo otro }}} & \underline{\text { desac. }} & \begin{array}{c}
\text { No } \\
\text { sabe }
\end{array}
\end{array}
$$

V78 - Cuando los puestos de trabajo

escasean, los hombres tienen

más derecho que las mujeres a

un puesto de trabajo ................ 1
V79 - Cuando los puestos de trabajo

escasean, los empresarios

deberían dar prioridad a los

del país sobre los

inmigrantes.
(ENTREVISTADOR: MOSTRAR TARJETA H)

V80. ** P.17.- ¿En qué medida está Vd. satisfecho o insatisfecho

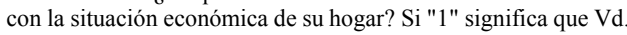
está completamente insatisfecho y "10" significa que Vd. está completamente satisfecho ¿dónde situaría Vd. en esta escala su nivel de satisfacción con la situación financiera de su hogar?

$$
\begin{array}{ccccccccccc}
1 & 2 & 3 & 4 & 5 & 6 & 7 & 8 & 9 & 10 & 99 \\
\text { Insatisfecho } & & & & & & \text { Satisfecho } & \text { No sabe }
\end{array}
$$

\section{(ENTREVISTADOR: MOSTRAR TARJETA H OTRA VEZ)}

V81. ** P.18.- En general, ¿hasta qué punto está Vd. satisfecho o insatisfecho con su vida actualmente?. Utilice, por favor, esta tarjeta para contestar.

$$
\begin{array}{ccccccccccc}
1 & 2 & 3 & 4 & 5 & 6 & 7 & 8 & 9 & 10 & 99 \\
\text { Insatisfecho } & & & & & & \text { Satisfecho } & \text { No sabe }
\end{array}
$$

\section{(ENTREVISTADOR: MOSTRAR TARJETA I)}

V82. ** P.19.- Algunas personas piensan que tienen completa libertad de elección y control sobre la manera en que se desarrolla su vida, mientras que otras piensan que lo que hacen no produce ningún efecto real sobre lo que les sucede. Utilice, por favor, esta escala, en la que el "1" significa "ninguna en absoluto" y "10" significa "mucha", para indicar cuánta libertad de elección y control piensa Vd. que tiene sobre la manera en que se desarrolla su vida.

$$
\begin{array}{ccccccccccc}
1 & 2 & 3 & 4 & 5 & 6 & 7 & 8 & 9 & 10 & 99 \\
\text { Ninguna } & & & & & & & \text { Mucha } & \text { No sabe }
\end{array}
$$

\section{(ENTREVISTADOR: MOSTRAR TARJETA J)}

V83. P.20.- ¿Qué punto en esta escala describe más claramente el valor que concede Vd. al trabajo (incluido el trabajo doméstico y el escolar) por comparación con el tiempo libre o el ocio?

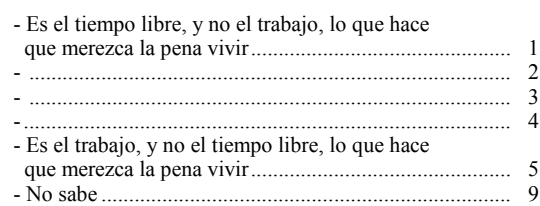

(ENTREVISTADOR: MOSTRAR TARJETA J2)

V83a. P.20a.-Aquí hay algunas frases relativas a los motivos por los que trabaja la gente. Independientemente de que tenga $\mathrm{Vd}$. trabajo o no, ¿cuál de ellas se acerca más a lo que piensa?

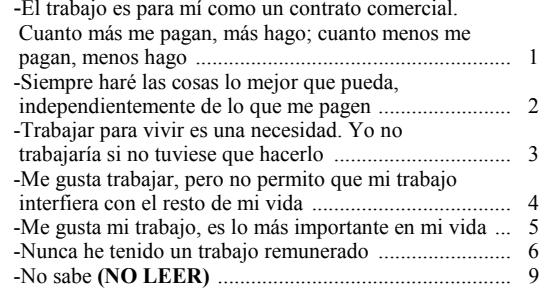


(ENTREVISTADOR: MOSTRAR TARJETA K)

V84. P.21.- Ahora me gustaría preguntarle acerca de aquellas cosas que a Vd. le parezcan más importantes personalmente en el caso de que estuviera buscando trabajo. He aquí algunas de las cosas que la gente tiene normalmente en cuenta en relación con su trabajo. Independientemente de si está Vd. de hecho buscando trabajo ahora, ¿cuál de ellas pondría Vd. personalmente en primer lugar si estuviera buscando trabajo?

V85. P.21a.- ¿Y cuál sería su segunda preferencia? $\underline{1^{\circ} \text { Lugar }} \underline{2^{\circ} \text { Lugar }}$

- Un buen sueldo, de manera que no tuviese

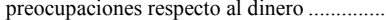

- Un trabajo seguro que no comporte riesgos

de cierre o de dese upleo...

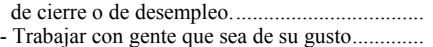

- Hacer un trabajo importante que le haga

sentirse realizado

- No sabe.

1
2
3
4
9

\section{(ENTREVISTADOR: MOSTRAR TARJETA L)}

* P.22.- Quisiera mostrarle esta lista con algunos otros aspectos relativos al trabajo que la gente dice que son importantes. Por favor, mírelos y dígame cuales de ellos cree Vd., personalmente, que son importantes en un trabajo. (CODIFICAR TODOS LOS ASPECTOS MENCIONADOS)

No

$\underline{\text { Mencionado }} \underline{\text { Mencionado }}$

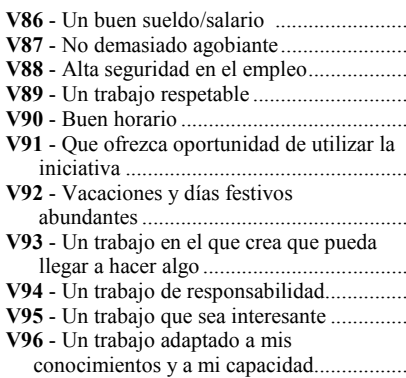

2

2

(ENTREVISTADOR: MOSTRAR TARJETA M)

P.23. - ¿Está Vd. de acuerdo o en desacuerdo con las siguientes afirmaciones?

\section{Muy de De Ni de acuerdo ni En Muy en} acuerdo acuerdo en desacuerdo desacuerdo desacuerdo NS

V97-Para poder

desarrollar el

talento completamente

es necesario tener

$\begin{array}{llllll}\text { un trabajo } & 1 & 2 & 3 & 4 & 5\end{array}$

V98-Es humillante

recibir dinero $\sin$

tener que trabaja

$\begin{array}{lllllll}\text { para conseguirlo } & 1 & 2 & 3 & 4 & 5 & 9\end{array}$

V99-La gente que no

perezosa

V100-El trabajo

es un deber hacia

la sociedad

V101-La gente no

tendría por qué

trabajar sin querer

hacerlo
V102- El trabajo

debería ser siempre

lo primero, incluso

si ello implica

menos tiempo

libre

V103. * P.24.- Imagine dos secretarias de la misma edad y haciendo prácticamente el mismo trabajo. Una de ellas descubre que la otra gana bastante más que ella. Sin embargo, la secretaria mejor pagada es más rápida, más eficiente y se puede confiar más en su trabajo. En su opinión, ¿es justo o no es justo que a una secretaria se le pague mejor que a la otra?

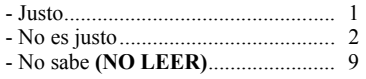

(ENTREVISTADOR: MOSTRAR TARJETA N)

V104. ** P.25.- Hay mucha discusión sobre la manera de dirigir las empresas. ¿Cuál de estas cuatro opiniones está más cerca de la suya? (CODIFICAR SOLO UNA)

- Los propietarios deben dirigir sus empresas o

nombrar a los directivos

- Los propietarios y los trabajadores deben participar

en el nombramiento de los directivos

- La propiedad de las empresas debe ser del Estado

y éste debe nombrar a los directivos...

- La propiedad de las empresas debe ser de los

trabajadores y éstos deben elegir a los directivos .......... 4

- No sabe (NO LEER)

V105. ** P.26.- La gente tiene ideas diferentes a la hora de seguir las instrucciones que se dan en el trabajo. Unos dicen que se deben seguir las instrucciones de los superiores, incluso aún cuando no se esté totalmente de acuerdo con ellas. Otros dicen que se deben seguir las instrucciones del superior únicamente cuando uno se ha convencido de que son las adecuadas. ¿Con cuál de estas dos opiniones está Vd. de acuerdo?

- Se deben seguir las instrucciones

- Se debe estar primero convencido de que las

instrucciones son las adecuadas

- Depende (SOLO SI LO MENCIONA EL

ENTREVISTADO).

- No sabe (NO LEER)

V106. ** P.27.- En la actualidad, está Vd...

(LEA EN VOZ ALTA Y CODIFIQUE UNA SOLA)

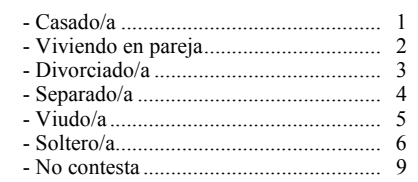


V107. ** P.28.- ¿Ha tenido Vd. algún hijo/a? SI LA RESPUESTA ES SI, ¿Cuántos?

\begin{tabular}{|c|}
\hline - Ningún hijo/aa 1 hijo/a.tas... \\
\hline
\end{tabular}

V108. ** P.29.- ¿Cuál cree Vd. que es el tamaño ideal de la familia es decir, el número ideal de hijos, si es que alguno?

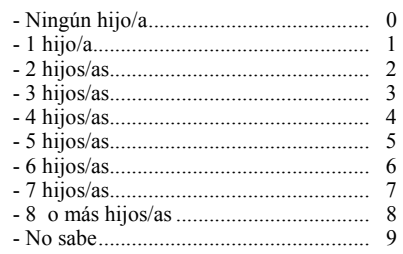

V109. ** P.30.- Si alguien dijera que un niño necesita un hogar donde haya un padre y una madre para poder crecer feliz, itendería Vd. a estar de acuerdo o en desacuerdo?

$\begin{array}{ll}\text { - Tendería a estar de acuerdo .................... } & 1 \\ \text { - Tendería a estar en desacuerdo ............. } & 2 \\ \text { - No sabe (NO LEER) ............................ } & 9\end{array}$

V110. ** P.31.- ¿Cree Vd. que una mujer necesita tener hijos para realizarse o, por el contrario, cree que ello no es necesario?

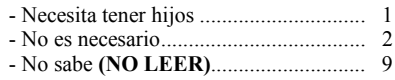

V111. ** P.32.- ¿Está Vd. de acuerdo o en desacuerdo con la siguiente frase? (LEA EN VOZ ALTA): "El matrimonio es una institución pasada de moda"

- Sí, de acuerdo ............................... 1
- No, en desacuerdo....................... 2
- No sabe (NO LEER) .................... 9

V112. ** P.33.- Si una mujer quisiera tener un hijo como madre soltera, sin querer al mismo tiempo mantener una relación estable con un hombre, ¿lo aprobaría o lo desaprobaría?
*P.34. ¿Podría Vd. decirme en qué medida está de acuerdo o en desacuerdo con cada una de las siguientes afirmaciones? ¿Está Vd. muy de acuerdo, de acuerdo, en desacuerdo o muy en desacuerdo con:

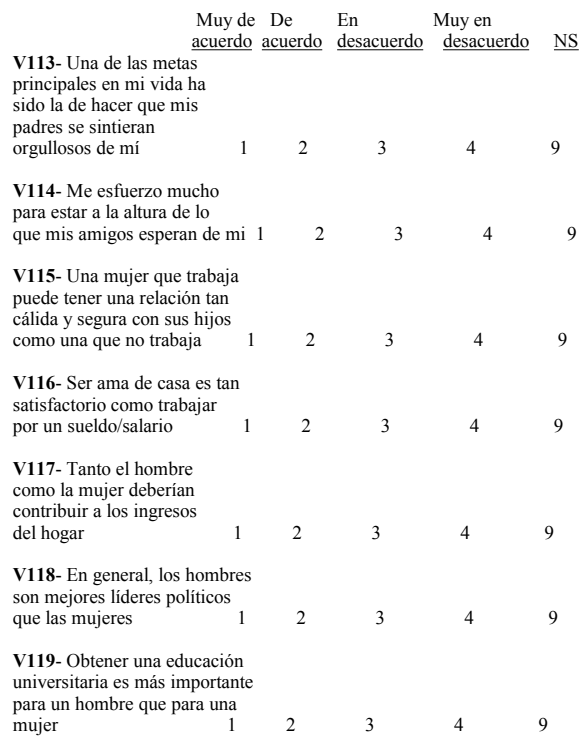

(ENTREVISTADOR: MOSTRAR TARJETA Ñ)

V120. * P.35.- Se habla mucho hoy en día sobre cuáles deberían ser los objetivos de este país para los próximos diez años. En esta tarjeta hay varios objetivos a los que diversas personas darían prioridad. ¿Podría decirme cuál, de entre éstos, considera Vd. el más importante? CODIFIQUE UNA RESPUESTA SOLAMENTE BAJO "Primer objetivo elegido".

V121. P.35a.- ¿Y cuál sería para Vd. el segundo objetivo más importante? CODIFIQUE UNA RESPUESTA SOLAMENTE BAJO "Segundo objetivo elegido".

Primer Segundo objetivo elegido objetivo elegido

\begin{tabular}{|c|c|c|}
\hline $\begin{array}{l}\text { - Mantener un alto nivel de } \\
\text { crecimiento económico }\end{array}$ & 1 & 1 \\
\hline - Asegurar que este país tenga unas & & \\
\hline $\begin{array}{l}\text { Fuerzas Armadas importantes......................... } \\
\text { - Lograr que la gente pueda participar } \\
\text { más en cómo se hacen las cosas en su }\end{array}$ & 2 & 2 \\
\hline lugar de trabajo y en su comunidad........ & 3 & 3 \\
\hline $\begin{array}{l}\text { - Intentar que nuestras ciudades y } \\
\text { nuestro campo sean más bonitos........................ }\end{array}$ & 4 & \\
\hline - No sabe (NO LEER) & 9 & 9 \\
\hline
\end{tabular}

- Aprobaría. Desaprobaría 


\section{(ENTREVISTADOR: MOSTRAR TARJETA T)}

* P.45. - Ahora me gustaría que me dijera Vd. qué opina sobre diversas cuestiones. ¿Dónde colocaría Vd. su opinión en esta escala? 1 significa que $\mathrm{Vd}$. está totalmente de acuerdo con la afirmación que se encuentra a la izquierda, 10 significa que Vd. está totalmente de acuerdo con la afirmación que aparece a la derecha; y si su opinión se encuentra en algún otro lugar intermedio de la escala, puede elegir el número que corresponda.

\begin{tabular}{|c|c|c|}
\hline $\begin{array}{lllll}\text { V141 } & 1 & 2 & 3 & 4\end{array}$ & 6 & $\begin{array}{llll}8 & 9 & 10 & 99\end{array}$ \\
\hline $\begin{array}{l}\text { Los ingresos deberían } \\
\text { ser más iguales. }\end{array}$ & & $\begin{array}{l}\text { Debe haber mayore } \\
\text { incentivos para el } \\
\text { esfuerzo individual }\end{array}$ \\
\hline
\end{tabular}

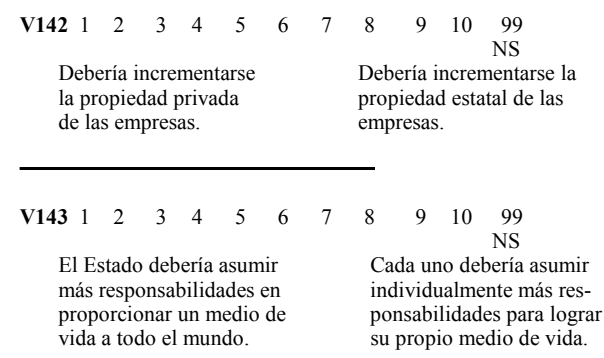

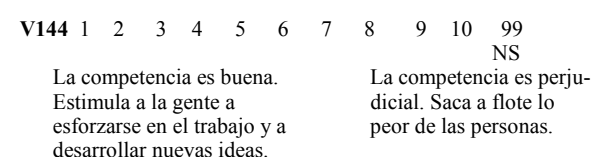

P.45a. A continuación voy a leerle una serie de afirmaciones de dos en dos. Para cada par, elija la afirmación que, en su opinión, describa mejor la situación actual del país (LEER FRASES Y MOSTRAR TARJETA U)

V145a

FRASE 1: Una sociedad igualitaria donde la diferencia entre ricos y pobre es pequeña, sin tener en cuenta los logros conseguidos.

FRASE 2: Una sociedad competitiva donde la riqueza se distribuye según los logros conseguidos por cada uno.

-Más de acuerdo con la primera afirmación... 1

-Algo más de acuerdo con la primera afirmación 2

-No puede decidirse ........................................................... 3

-Algo más de acuerdo con la segunda afirmación ........................ 4

-Más de acuerdo con la segunda información .............................. 5

-No contesta ............................................................. 9

V145b

FRASE 1: Una sociedad con un amplio sistema social de bienestar pero con impuestos elevados.

FRASE 2: Una sociedad con bajos impuestos donde los individuos se responsabilizan de ellos mismos.

-Más de acuerdo con la primera afirmación.

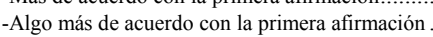

1

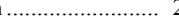

(n).... 3

-Algo más de acuerdo con la segunda afirmación ........................ 4

-Más de acuerdo con la segunda información.............................. 5

-No contesta .......................................................................... 9
V145c

FRASE 1: Una sociedad donde se garantiza la seguridad y la estabilidad mediante una regulación apropiada.

FRASE 2: Una sociedad no regulada donde las personas son responsables de sus propias acciones.

-Más de acuerdo con la primera afirmación.

-Algo más de acuerdo con la primera afirmación ......................... 2

-No puede decidirse ........................................................... 3

-Algo más de acuerdo con la segunda afirmación ........................ 4

-Más de acuerdo con la segunda información ............................ 5

-No contesta ......................................................................... 9

P.45.b Y ahora, ¿podría Vd. decirme a qué tipo de sociedad DEBERÍA aspirar este país en el futuro? Para cada par de afirmaciones, ¿preferiría Vd. estar más cerca de la primera o de la segunda alternativa?

\section{(LEER FRASES Y MOSTRAR TARJETA U)}

\section{V145d}

FRASE 1: Una sociedad igualitaria donde la diferencia entre ricos y pobres es pequeña, sin tener en cuenta los logros conseguidos.

FRASE 2: Una sociedad competitiva donde la riqueza se distribuye según los logros conseguidos por cada uno.

-Más de acuerdo con la primera afirmación.

-Algo más de acuerdo con la primera afirmación .......................... 2

-No puede decidirse ......................................................... 3

-Algo más de acuerdo con la segunda afirmación ........................ 4

-Más de acuerdo con la segunda información .............................. 5

-No contesta ......................................................... 9

V145e

FRASE 1: Una sociedad con un amplio sistema social de bienestar pero con impuestos elevados.

FRASE 2: Una sociedad con bajos impuestos donde los individuos se responsabilizan de ellos mismos.

-Más de acuerdo con la primera afirmación.

-Algo más de acuerdo con la primera afirmación ......................

-No puede decidirse ............................................................ 3

-Algo más de acuerdo con la segunda afirmación ......................... 4

-Más de acuerdo con la segunda información .............................. 5

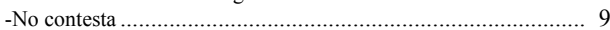

V145f

FRASE 1: Una sociedad donde se garantiza la seguridad y la estabilidad mediante una regulación apropiada.

FRASE 2: Una sociedad no regulada donde las personas son responsables de sus propias acciones.

-Más de acuerdo con la primera afirmación. 1

-Algo más de acuerdo con la primera afirmación .......................... 2

-No puede decidirse ........................................................ 3

-Algo más de acuerdo con la segunda afirmación ........................ 4

-Más de acuerdo con la segunda información ............................... 5

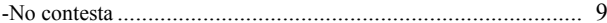

V146. P.46.- Respecto a la gente que viene de otros países a trabajar aquí, ¿qué es, de lo que le menciono a continuación, lo que debería hacer el Gobierno? (SOLO UNA RESPUESTA)

- Permitir que venga quien quiera

- Permitir que venga la gente mientras haya trabajos

disponibles ................................................................... 2

- Establecer límites estrictos en el número de extranjeros

que puedan venir ............................................................ 3

- Prohibir que vengan personas de otros países......................... 4

- No sabe ……........................................................ 9 
V229a.D.6a (SÓLO A LOS QUE TIENEN TRABAJO) ENTREVISTADOR: MOSTRAR TARJETA Z7

En conjunto, ¿hasta qué punto está Vd. satisfecho o insatisfecho del trabajo que tiene?

$\begin{array}{ccccccccccc}1 & 2 & 3 & 4 & 5 & 6 & 7 & 8 & 9 & 10 & 99 \\ \text { Insatisfecho } & & & & & & \text { Satisfecho } & \text { No sabe }\end{array}$

V230. ** D.7. En qué profesión/actividad económica o industria trabaja o trabajó Vd.? Si tiene o tuvo más de un trabajo, refiérase sólo al principal. ENTREVISTADOR ESCRIBA PROFESION

¿Cuál es/era su trabajo ahí? ESCRIBA Y CODIFIQUE EN V230 ABAJO

- Empresario/directivo de establecimiento con $10 \mathrm{o}$ más empleados (incluidas empresas agrícolas)

- Empresario (a)/directivo(a) de establecimiento con menos

de 10 empleados (incluidas empresas agrícolas)

- Empleado no-manual que supervisa a otros (inclui

mandos intermedios)

Empleado no

nual que no supervisa a otros ......................... 5

- Capataz y supervisor.................................................................... 6

- Trabajador manual especializado......

- Trabajador manual semi-especializado.....

- Trabajador manual sin especificar (o peón)

- Agricultor por cuenta propia (incluyendo arrendatarios

y aparceros).

- Miembro de las Fuerzas Armadas, personal de seguridad ..... 12

- Nunca ha tenido un trabajo..................................................... 13

V231. ** D.8. ¿Es Vd. la persona con mayores ingresos en su hogar?

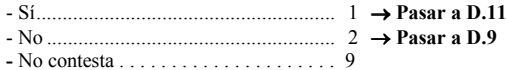

V232. ** D.9. ¿Tiene ahora trabajo la persona con mayores ingresos en su hogar?

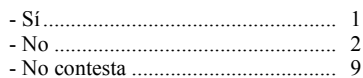

V233. ** D.10. En qué profesión/ocupación trabaja/trabajaba la persona con mayores ingresos en su hogar?. Si tiene más de un trabajo, refiérase al trabajo principal. ¿Cuál es/era su trabajo? ESCRIBA Y CODIFIQUE V233 ABAJO

- Empresario/directivo de establecimiento con 100 más empleados (incluidas empresas agrícolas) .......

- Empresario (a)/directivo(a) de establecimiento con menos

de 10 empleados (incluidas empresas agrícolas)

- Profesional: abogado, contable profesor, etc ....................... 2

- Empleado no-manual que supervisa a otros (incluir

mandos intermedios).

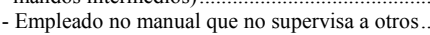

- Capataz (trabajador manual)....

- Trabajador manual especializ

- Trabajador manual semi-especializado ................................................ 8

- Trabajador manual sin especificar (o peón) ..................................... 9

- Agricultor por cuenta propia (incluyendo arrendatarios

y aparceros)

等

- Trabajador agrícola (o jornalero).................................................. 11

- Miembro de las Fuerzas Armadas, personal de seguridad ........... 12

- Nunca ha tenido un trabajo.
(A TODOS)

V234. D.11. A lo largo del año pasado, su familia:

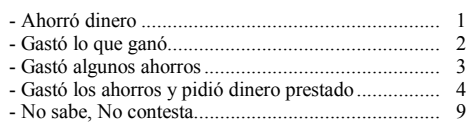

V235. ** D.12. Algunas veces, la gente se describe a sí misma como perteneciente a la clase trabajadora, a la clase media o a la clase alta o baja. Vd. se describiría a sí mismo como perteneciente a la:

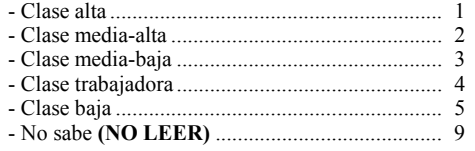

(ENTREVISTADOR: MOSTRAR TARJETA Z8)

V236. ** D.13. He aquí una escala de ingresos; nos gustaría saber en qué grupo se encuentra su hogar, incluyendo todos los sueldos, pagas, pensiones y otros ingresos. Simplemente dígame la letra que corresponda a su familia, antes de sustraer los impuestos y otras deducciones.

$\begin{array}{lllllllllll}1 & 2 & 3 & 4 & 5 & 6 & 7 & 8 & 9 & 10 & 99 \\ \mathrm{C} & \mathrm{D} & \mathrm{E} & \mathrm{F} & \mathrm{G} & \mathrm{H} & \mathrm{I} & \mathrm{J} & \mathrm{K} & \mathrm{L} & \text { No contesta }\end{array}$

V237. D.14. ¿Suele ver Vd. la televisión? Si la ve, ¿cuánto tiempo suele pasar viendo la televisión como promedio en un día de diario? (NO FINES DE SEMANA)?

\footnotetext{
- No veo la TV o no tengo acceso a ella..............................

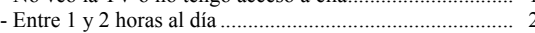

- Entre 2 y 3 horas al día ................................................ 3

- Más de 3 horas al día .................................................. 4

- No sabe ............................................
} 


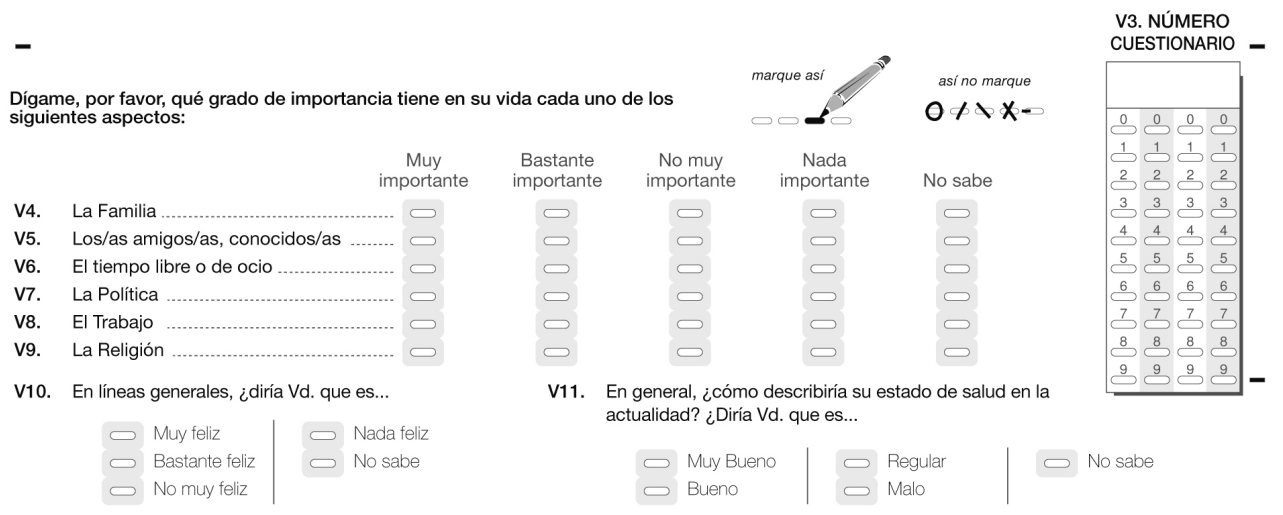

\section{(ENTREVISTADOR: MOSTRAR TARJETA A)}

Aquí tiene una lista de cualidades que se pueden inculcar a los niños en el hogar. ¿Cuál considera Vd. especialmente importante, si es Aqui tiene una lista de cualidades que se pueden inculcar a los niños en el hogar. ¿ ¿ Cuál conside
que considera alguna? ¡Por favor seleccione hasta cinco! (MARCAR CINCO COMO MÁXIMO)

\begin{tabular}{|c|c|c|c|c|c|}
\hline & Menciona & No Menciona & & Menciona & No Menciona \\
\hline V12. & Independencia & $\varnothing$ & V17. & Sobriedad y espíritu de ahorro & $\varnothing$ \\
\hline V13. & Esfuerzo en el trabajo & 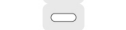 & V18. & Determinación, perseverancia ............... & 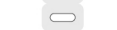 \\
\hline V14. & Sentido de la responsabilidad & $\varnothing$ & V19. & Fe religiosa & 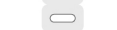 \\
\hline V15. & Imaginación & $\varnothing$ & V20. & Generosidad, altruismo & 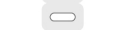 \\
\hline V16. & Tolerancia y respeto hacia los demás ... $\square$ & 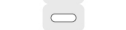 & V21. & Obediencia & $\triangleleft$ \\
\hline
\end{tabular}

V22. En una escala de $\mathbf{1}$ a 10, ¿cómo calificaría Vd. su satisfacción con su vida en general? (El $\mathbf{1}$ significa "completamente insatisfecho" y el 10 significa "completamente satisfecho")

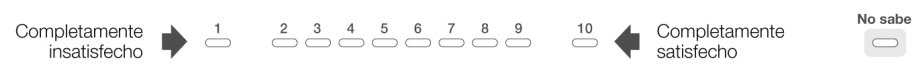

V23. Hablando en términos generales, ¿diría Vd. que se puede confiar en la mayoría de la gente o que hay que ser muy prudente al tratar con los demás?

$$
\square \text { Se puede confiar en la mayoría de la gente } \square \text { Hay que ser muy prudente } \quad \square \text { No sabe (NO LEER) }
$$

Ahora voy a leerle una lista de organizaciones voluntarias. ¿Podría decirme, para cada una de ellas, si es Vd. un miembro activo, un miembro

\begin{tabular}{|c|c|c|c|c|}
\hline & & $\begin{array}{c}\text { Miembro } \\
\text { activo }\end{array}$ & $\begin{array}{l}\text { Miembro } \\
\text { no activo }\end{array}$ & $\begin{array}{c}\text { No } \\
\text { miembro }\end{array}$ \\
\hline V24. & Iglesia u organizaciones religiosas ............................ & $\ldots \varnothing$ & $\square$ & $\varnothing$ \\
\hline V25. & Organizaciones deportivas o de ocio & $\ldots \varnothing$ & $\subset$ & $\varnothing$ \\
\hline V26. & Organizaciones artísticas, musicales o educativas & $\varnothing$ & $\varnothing$ & $\varnothing$ \\
\hline V27. & Sindicatos & $\ldots \varnothing$ & 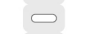 & $\varnothing$ \\
\hline V28. & Partidos políticos & $\varnothing$ & $\varnothing$ & 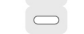 \\
\hline V29. & Organizaciones medio-ambientales & $\ldots \triangleleft$ & $\triangleright$ & $\sqcup$ \\
\hline v30. & Asociaciones profesionales & $\ldots \triangleleft$ & 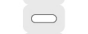 & 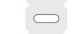 \\
\hline V31. & Organizaciones humanitarias o de caridad & $\ldots \varnothing$ & 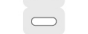 & $\varnothing$ \\
\hline V32. & Organizaciones de consumidores ................. & $\ldots \varnothing$ & 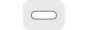 & 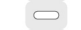 \\
\hline V33. & Otra (escríbala): & $\ldots \varnothing$ & $\varnothing$ & $\varnothing$ \\
\hline
\end{tabular}
inactivo, o no es miembro de ese tipo de organizaciones?

\section{(ENTREVISTADOR: MOSTRAR TARJETA B)}

\begin{tabular}{|c|c|c|c|c|c|}
\hline & Menciona & No Menciona & & Menciona & No Menciona \\
\hline V34. & 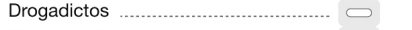 & $\varnothing$ & \multirow[t]{2}{*}{ V40. } & \multirow{2}{*}{$\begin{array}{l}\text { Personas que beben mucho / dados } \\
\text { a la bebida }\end{array}$} & \\
\hline V35. & Gente de otra raza & $\varnothing$ & & & $\square$ \\
\hline V36. & Personas afectadas por el SIDA $\ldots . . . . . . \square$ & $\varnothing$ & V41. & Parejas no casadas que viven juntos $\ldots . \varnothing$ & $\varnothing$ \\
\hline V38. & Homosexuales & $\varnothing$ & & diferente (al suyo) & $\square$ \\
\hline V39. & Personas de otra religión .................... $\square$ & 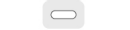 & V43. & Gitanos & $\varnothing$ \\
\hline
\end{tabular}

En la siguiente lista hay varios grupos de gente. ¿Podría Vd. indicarme todos aquellos que no le gustaría tener de vecinos? 
¿Está Vd. de acuerdo, en desacuerdo, o no tiene opinión sobre las siguientes afirmaciones?

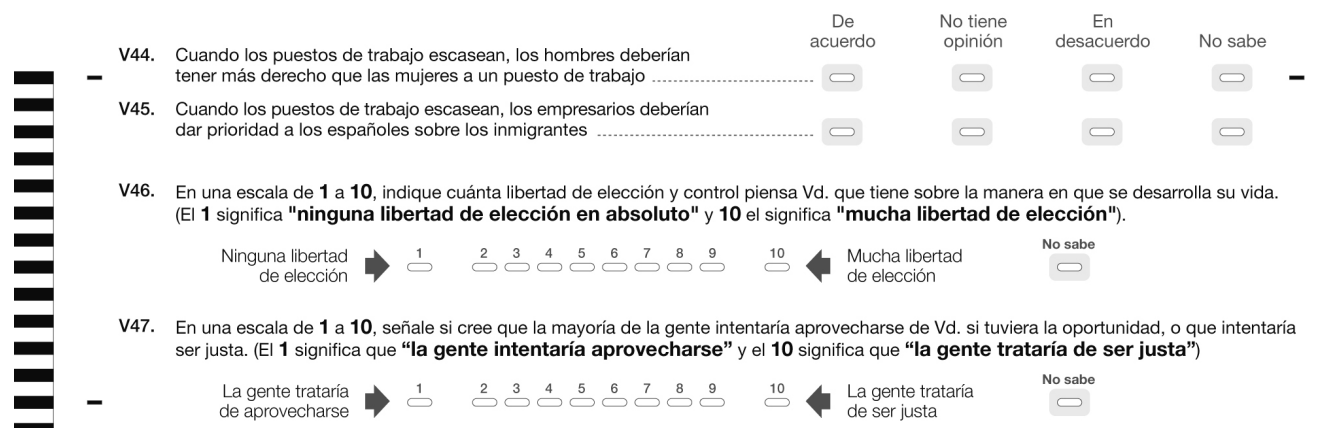

V48. En caso de que Vd. estuviese buscando trabajo ¿Cuál de las siguientes cosas pondría en primer lugar?

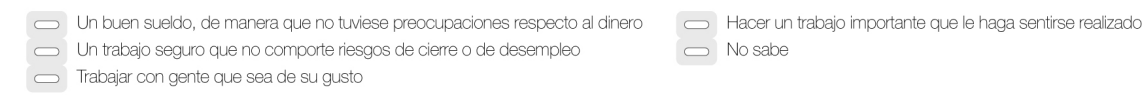

V49. ¿Y cuál sería su segunda preferencia?
$\square$ Un buen sueldo, de manera que no tuviese preocupaciones respecto al dinero $\square$ Hacer un trabajo importante que le haga sentirse realizado Un trabajo seguro que no comporte riesgos de cierre o de desempleo $\square$ No sabe

Trabajar con gente que sea de su gusto

Por favor, especifique para cada una de las afirmaciones siguientes su grado de acuerdo o en desacuerdo. ¿Está Vd. muy de acuerdo, de acuerdo, no tiene opinión, está en desacuerdo o muy en desacuerdo?

V50. Para poder desarrollar completamente el talento, es necesario
tener un trabajo

V55. En la actualidad, está Vd...

\begin{tabular}{|c|c|c|c|c|c|c|}
\hline$\lessdot$ & Casado/a & $\varnothing$ & Divorciado/a & $\varnothing$ & Viudo/a & $\square$ No contesta \\
\hline$\varnothing$ & Viviendo en pareja & $\square$ & Separado/a & $\varnothing$ & Soltero/a & \\
\hline
\end{tabular}

V56. ¿Ha tenido Vd. algún hijo/a?

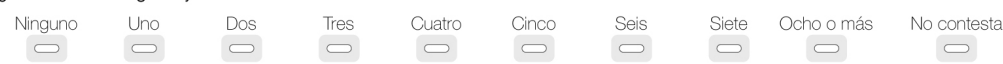

V57. Si alguien dijera que un niño necesita un hogar donde haya un padre y una madre para poder crecer feliz, ¿tendería Vd. a estar de acuerdo o en desacuerdo?

$$
\text { Tendería a estar de acuerdo }
$$

Tendería a estar en desacuerdo

No sabe (NO LEER)

V58. ¿Está Vd. de acuerdo o en desacuerdo con la siguiente frase?: "El matrimonio es una institución pasada de moda"
$\hookrightarrow$ Sí, de acuerdo
No, en desacuerdo
$\square$ No sabe (NO LEER)

V59. Si una mujer quisiera tener un hijo como madre soltera, sin querer al mismo tiempo mantener una relación estable con un hombre, ¿lo aprobaría o lo desaprobaría?
Aprobaría
$\square$ Desaprobaría
Depende (NO LEER)
No sabe (NO LEER)

V68. En una escala de $\mathbf{1}$ a 10, ¿en qué medida está Vd. satisfecho o insatisfecho con la situación económica de su hogar? (El 1 significa "completamente insatisfecho" y el 10 significa "completamente satisfecho").
Completamente
insatifecho

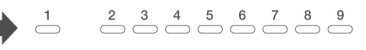
10 Completamente satisfecho

\section{LA EVOLUCIÓN DE LOS VALORES SOCIALES EN GALICIA}


V69. Se habla mucho hoy en día sobre cuáles deberían ser los objetivos de este país para los próximos diez años. En esta tarjeta hay varios objetivos a los que diversas personas darían prioridad. ¿Podría decirme cuál, de entre estos, considera Vd. personalmente el más importante?

V70. ¿Y cuál sería para Vd. el segundo objetivo más importante?

\begin{tabular}{|c|c|c|}
\hline & $\begin{array}{c}\text { V69 } \\
\text { 1er. objetivo }\end{array}$ & $\begin{array}{c}\text { V70 } \\
2^{\circ} \text { objetivo }\end{array}$ \\
\hline Mantener un alto nivel de crecimiento económico & $\ldots . . \varnothing$ & $\varnothing$ \\
\hline 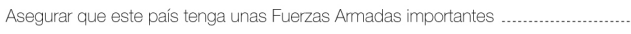 & $\ldots . . \triangleleft$ & $\varnothing$ \\
\hline $\begin{array}{l}\text { Lograr que la gente pueda participar más en cómo se hacen las cosas en su lugar } \\
\text { de trabajo y en su comunidad }\end{array}$ & $\varnothing$ & $\square$ \\
\hline Intentar que nuestras ciudades y nuestro campo sean más bonitos ....................... & $\varnothing$ & 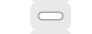 \\
\hline . & .... $\square$ & $\square$ \\
\hline
\end{tabular}

\section{(ENTREVISTADOR: MOSTRAR TARJETA D)}

V71. Si tuviera que escoger, ¿cuál es, de las cosas que aparecen en esta lista, la más importante según Vd.?

V72. ¿Y cuál sería la segunda más importante?

$$
\begin{array}{cc}
\text { V71 } & \text { V72 } \\
\text { 1er. objetivo } & 2^{\circ} \text { objetivo }
\end{array}
$$

Mantener el orden en el país

Dar a la gente mayor participación en las decisiones importantes del Gobierno

Luchar contra la subida de precios

Proteger la libertad de expresión

No sabe (NO LEER)

\section{(ENTREVISTADOR: MOSTRAR TARJETA E)}

V73. He aquí otra lista. En su opinión, ¿qué es, de lo que aparece en ella, lo más importante según Vd.?

\begin{tabular}{|c|c|c|}
\hline & $\begin{array}{c}\text { V73 } \\
\text { 1er. objetivo }\end{array}$ & $\begin{array}{c}\text { V74 } \\
2^{\circ} \text { objetivo }\end{array}$ \\
\hline Una economía estable & ..... $\varnothing$ & $\varnothing$ \\
\hline 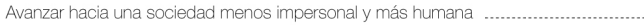 & $\square$ & $\square$ \\
\hline Avanzar hacia una sociedad en donde las ideas sean más importantes que el dinero & $\varnothing$ & $\varnothing$ \\
\hline lucha contra la delincuencia & 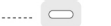 & $\square$ \\
\hline No sabe (NO LEER) & ...... $\square$ & 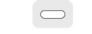 \\
\hline
\end{tabular}

V74. ¿Y qué sería lo segundo más importante?

V75. En caso de que hubiera una guerra, ¿estaría Vd. dispuesto a luchar por su país?
$\bullet$ Sí
$\hookrightarrow$ No
No sabe (NO LEER)

He aquí una lista con algunos cambios referidos a nuestro estilo de vida que podrían tener lugar en un futuro próximo. Por favor, dígame, para cada uno de ellos, y suponiendo que éstos se produjeran, si Vd. piensa que sería algo bueno, algo malo, o le da igual.

V76. Que disminuya la importancia del trabajo en nuestras vidas

v77. Que se dé más importancia al desarrollo de la tecnología

V78. Que haya un mayor respeto a la autoridad

V79. Que se dé más importancia a la vida familiar

v90. A largo plazo, cree Vd. que los avances científicos que se están logrando ayudarán a la humanidad o la perjudicarán?

$$
\text { La ayudarán } \square \text { La perjudicarán } \square \text { Un poco de cada (NO LEER) } \square \text { No sabe (NO LEER) }
$$

Ahora, me gustaría leerle algunas afirmaciones y preguntarle en qué medida está Vd. de acuerdo o en desacuerdo con cada una de ellas. Para cada una de estas frases, el 1 significa que Vd. está "completamente en desacuerdo", y el 10 significa que Vd. está "completamente de acuerdo".

v91. La ciencia y la tecnología hacen que nuestras vidas sean más saludables, fáciles y confortables

$$
\begin{aligned}
& \text { Completamente }
\end{aligned}
$$

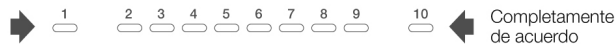

cnología, habrá más oportunidades para las próximas generaciones

v92. Debido a la ciencia y a la tecnologia, habra más oportunidades para las próximas generaciones

$$
\begin{aligned}
& \text { Completamente } \\
& \text { Completamente }
\end{aligned}
$$

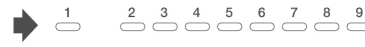

$$
\begin{aligned}
& \text { de acuerdo }
\end{aligned}
$$


V95. ¿En qué medida está $\mathrm{Vd}$. interesado/a en la política?

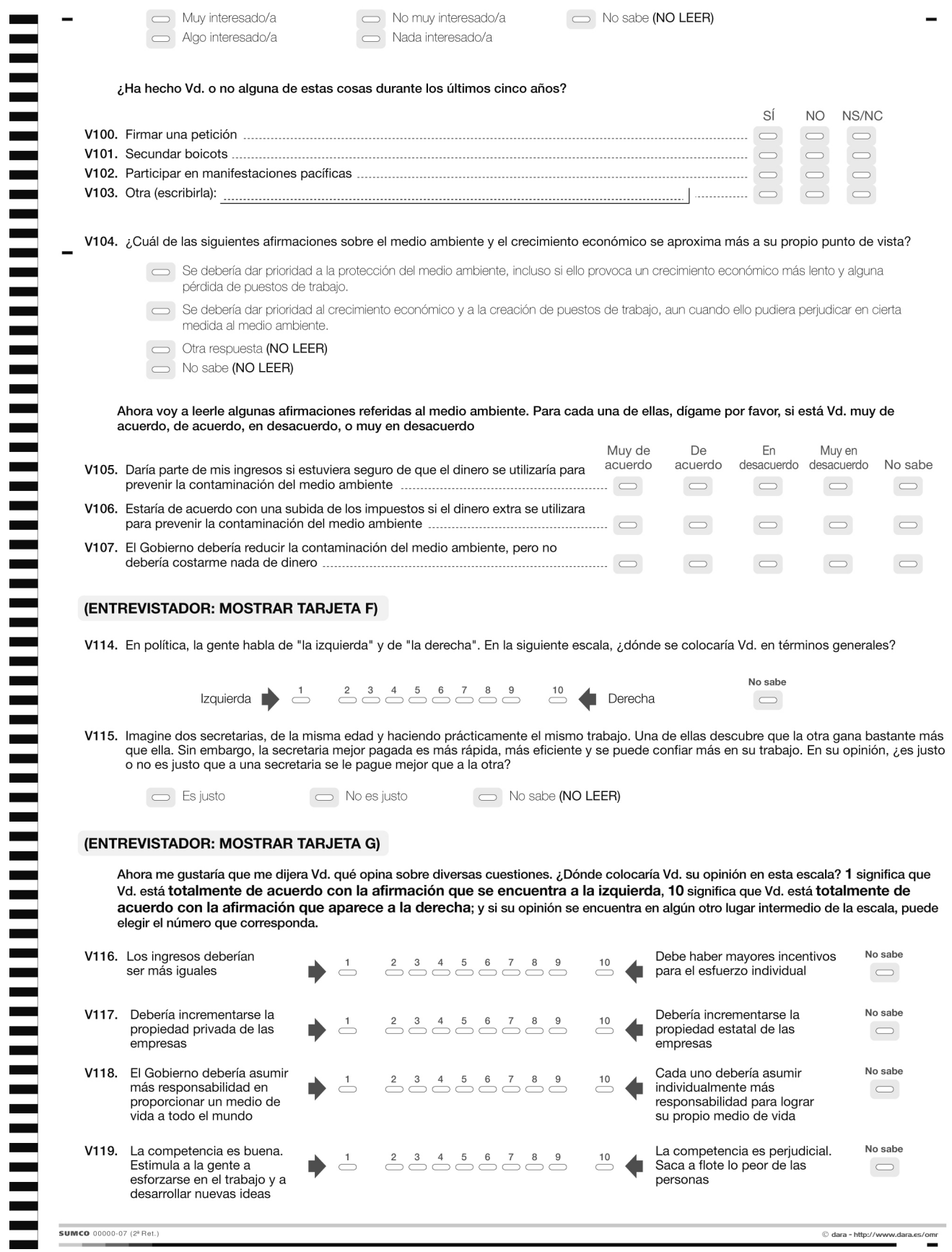


V121. La gente solo puede enriquecerse a costa de otros

La riqueza puede crecer de manera que haya

V124. Respecto a la gente que viene de otros países a trabajar aquí, ¿qué es, de lo que le menciono a continuación, lo que en la vida está predeterminado por el destino", y el 10 significa que "las personas se hacen su propio destino".

\section{debería hacer el Gobierno? \\ Todo en la vida está

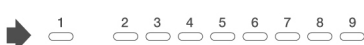 \\ $\bigodot^{10}$}

propio destino

Prohibir que vengan personas de otros países No sabe (NO LEER)

Me gustaría que me dijera cuánto confía en personas de diferentes grupos. ¿Podría decirme para cada grupo si Vd. confía en las personas de este grupo completamente, algo, no mucho o nada en absoluto?

V125. Su familia
V126. Su vecindario

Voy a enumerar una serie de instituciones y organizaciones. Para cada una de ellas, ¿podría decirme cuánta confianza tiene en ella: ¿mucha confianza, bastante confianza, no mucha confianza o ninguna confianza en absoluto?

V131. La Iglesia
V132. Las Fuerzas Armadas
V133. La Prensa
V134. La Televisión
V135. Los Sindicatos
V136. La Policía
V137. Los Tribunales de justicia
V138. El Gobierno Español
V139. Los Partidos Políticos
V140. El Parlamento Español
V141. Los Funcionarios
V142. Las Grandes Empresas .......
V143. Las organizaciones para el medio ambiente
V144. Las organizaciones feministas, para la mujer
V145. Las organizaciones de caridad o humanitarias
V146. La Unión Europea ......
V147. Las Naciones Unidas ......
V147a. La Xunta de Galicia .......
V147b. El Parlamento de Galicia
V147c. El Gobierno Municipal
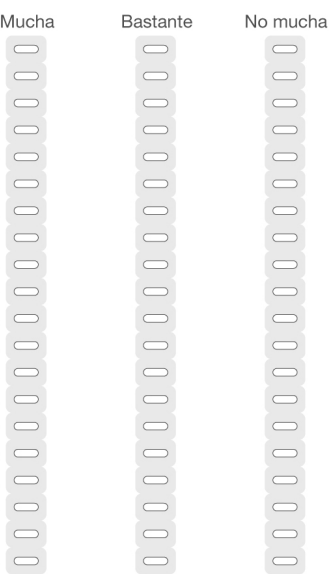

Ninguna en

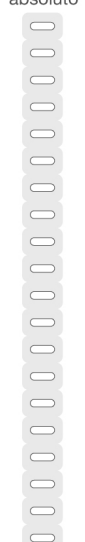

No sabe

Ahora voy a describirle diversos tipos de sistemas políticos y a preguntarle qué piensa Vd. de cada uno de ellos como forma de gobernar este país. Para cada uno de ellos, ¿diría Vd. que es un modo muy bueno, bastante bueno, bastante malo o muy malo de gobernar este país?

\begin{tabular}{|c|c|c|c|c|c|}
\hline V148. & $\begin{array}{l}\text { Tener un líder fuerte que no tuviera que preocuparse por el } \\
\text { parlamento ni por las elecciones }\end{array}$ & $\begin{array}{c}\text { Bastante } \\
\text { bueno } \\
\square\end{array}$ & $\begin{array}{l}\text { Bastante } \\
\text { Malo } \\
\square\end{array}$ & Muy malo & $\begin{array}{c}\text { No sabe } \\
\square\end{array}$ \\
\hline V149. & $\begin{array}{l}\text { Tener expertos, no un Gobierno, que tome las decisiones de } \\
\text { acuerdo con lo que ellos piensan que es lo mejor para este país ... }\end{array}$ & $\varnothing$ & $\square$ & $\varnothing$ & $\varnothing$ \\
\hline V150. & Tener un gobierno militar & $\varnothing$ & $\varnothing$ & $\varnothing$ & 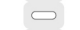 \\
\hline V151. & Tener un sistema político democrático & $\square$ & $\varnothing$ & $\square$ & $\square$ \\
\hline
\end{tabular}


V177. ¿Estaría Vd. dispuesto a pagar más impuestos para aumentar la ayuda exterior de España a los países pobres?

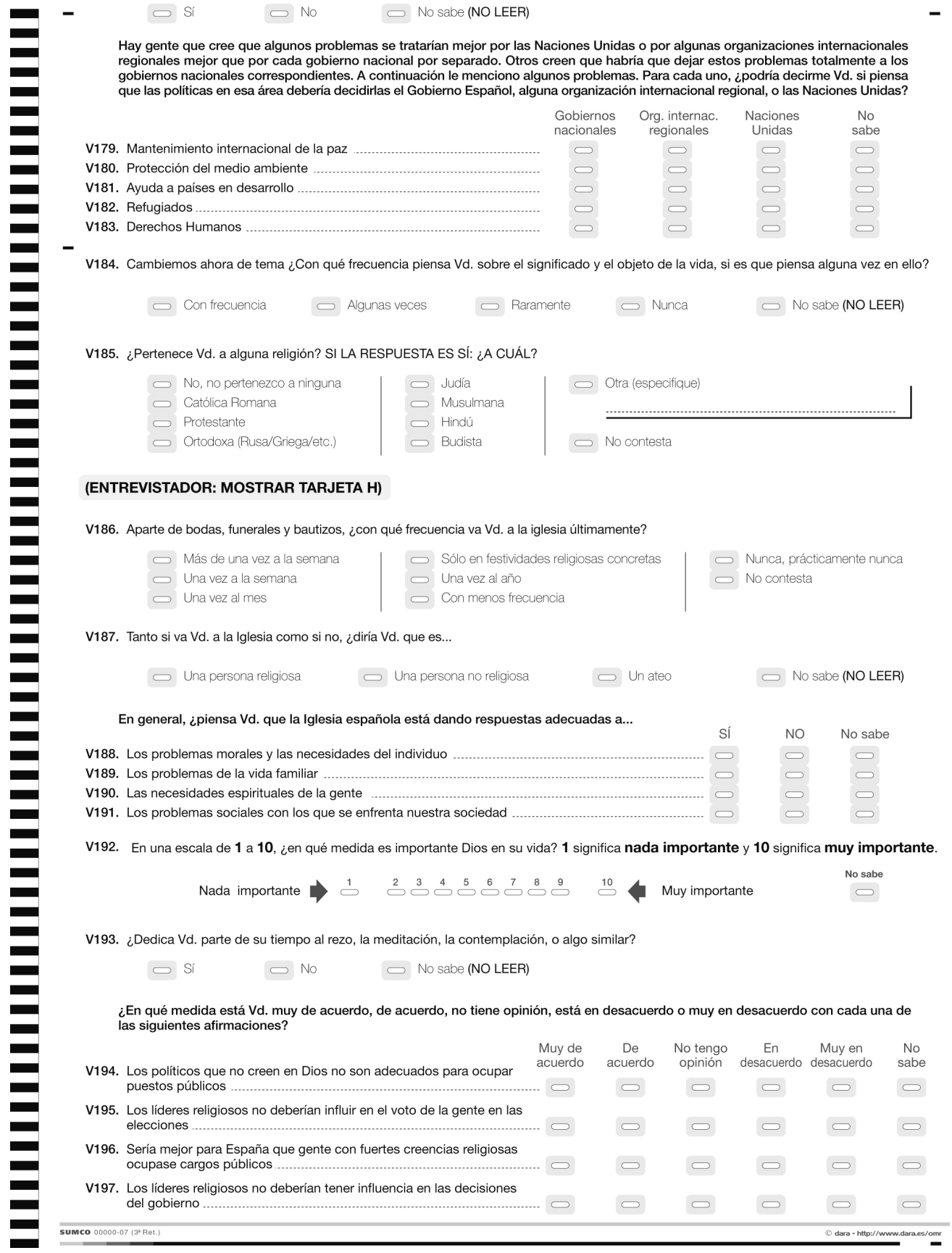


En una escala de 1 a 10, dígame por favor, para cada una de las siguientes afirmaciones, si piensa Vd. que siempre puede estar justificado, que nunca puede estar justificado, o si cree que su grado de justificación se encuentra en algún otro punto intermedio de la escala, 1 significa nunca justificado y 10 siempre justificado

V198. Reclamar beneficios del Estado a los que no se tiene
derecho
V199. Evitar pagar el billete en algún transporte público ....
V200. Engañar en el pago de impuestos, si se puede
V201. Que alguien acepte un soborno en el cumplimiento
de sus funciones
V202. La homosexualidad
V203. La prostitución
V204. El aborto
V205. El divorcio
V206. La eutanasia (poner fin a la vida de un enfermo incurable)
V207. El suicidio
V208. Que un hombre maltrate a su esposa ....................

Nunca Siempre

$1 \quad 23456989$

$\underbrace{2}_{2} \underset{3}{\infty} \underset{4}{\infty} \underset{5}{5} \underset{6}{5} \underset{8}{5} \underset{8}{5}$ justificado $2 3 4 5 \longdiv { 6 } \begin{array} { l } { 6 } \\ { 6 } \end{array}$

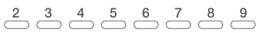

$2 \underbrace{}_{3} \int_{5} \underbrace{}_{7} \underbrace{}_{8}$

$2 \quad 3 \quad 4 \quad 5 \quad 6 \quad 7 \quad 89$

$\underbrace{}_{3} \underbrace{}_{4} \underbrace{}_{6} \underset{8}{9}$

$\begin{array}{llllllll}2 & 3 & 4 & 5 & 6 & 7 & 8 & 9\end{array}$

$\underset{2}{2} \underset{3}{9} \underset{5}{9} \underset{7}{9} \underset{9}{9}$

$\begin{array}{llllllll}2 & 3 & 4 & 5 & 6 & 7 & 8 & 9\end{array}$

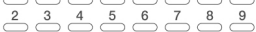

V209. ¿En qué medida está Vd. orgulloso/a de ser gallego/a?
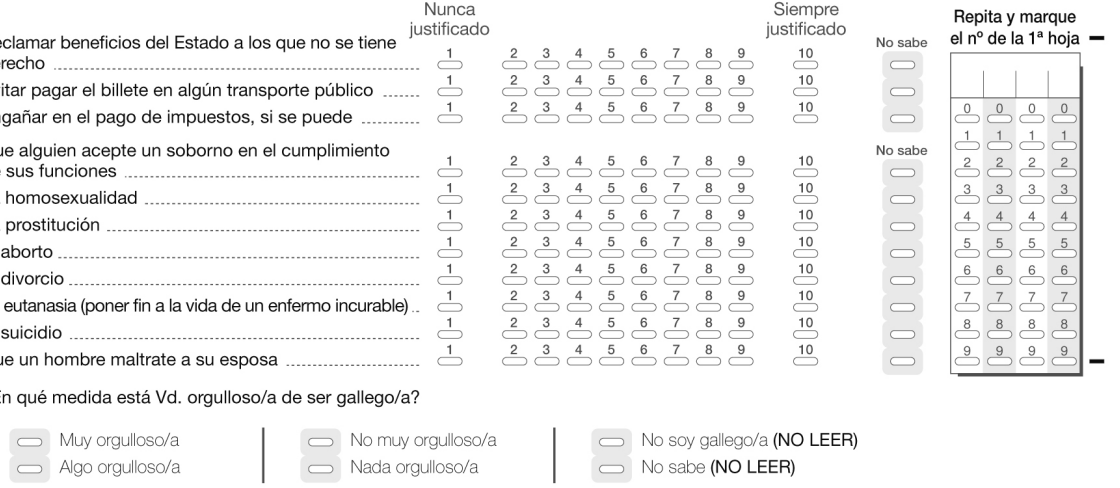

V213. Me veo como parte de la Unión Europea

V214. Me veo como un individuo autónomo

V222. ¿Qué lengua habla Vd. normalmente en casa? (CODIFICAR UNA RESPUESTA)

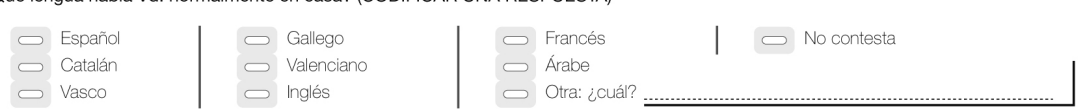

La gente utiliza diferentes medios para saber qué es lo que pasa en su país y en el mundo. Para cada uno de los siguientes medios indique, por favor, si lo utilizó Vd. la semana pasada o no lo utilizó la semana pasada para obtener información.

\begin{tabular}{|c|c|c|c|c|}
\hline & & $\begin{array}{l}\text { Lo utilizó la } \\
\text { semana pasada }\end{array}$ & $\begin{array}{l}\text { No lo utilizó la } \\
\text { semana pasada }\end{array}$ & $\begin{array}{l}\text { No } \\
\text { sabe }\end{array}$ \\
\hline V223. & Periódico & ....... $\varnothing$ & $\bullet$ & $\varnothing$ \\
\hline V224. & Programas informativos de radio o TV.. & ....... $\square$ & $\triangleright$ & $\bullet$ \\
\hline V225. & Revistas & ...... $\bullet$ & 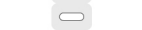 & 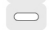 \\
\hline V226. & Informes en profundidad en radio o TV. & $\ldots$ & 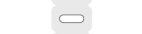 & 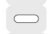 \\
\hline V227. & Libros & $\ldots \ldots \varnothing$ & $\bullet$ & $\bullet$ \\
\hline V228. & Internet, e-mail & .... $\square$ & 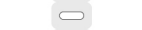 & $\triangleright$ \\
\hline V229. & Conversaciones con amigos o colegas & ......... $\varnothing$ & $\varnothing$ & $\varnothing$ \\
\hline
\end{tabular}

V230. ¿Con qué frecuencia utiliza Vd. un ordenador personal, si es que lo utiliza?

\begin{tabular}{l|l}
$\square$ Nunca & $\square$ Frecuentemente \\
$\square$ Ocasionalmente & $\square$ No sé lo que es un ordenador personal (NO LEER)
\end{tabular}

\section{(ENTREVISTADOR: MOSTRAR TARJETA J)}

V231. Si hubiese elecciones generales mañana, A) ¿a qué partido de la lista votaría Vd.? Dígame sólo su número en esta tarjeta. Si NO SABE, ¿cuál es el partido que más le atrae?

V232. B) ¿Qué partido elegiría Vd. en segundo lugar?

V233. C) ¿Hay algún partido en esta lista al que nunca votaría? Código

A B C Código

01 Partido Popular (PP)

02 Partido Socialista Obrero Español (PSOE)

03 Unión Centrista-Centro Democrático y Social (UC-CDS)

04 Izquierda Unida (IU)

05 Ecologistas (Verdes) .

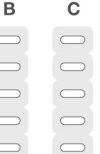

Código

06 Convergencia i Unió (CiU)

07 Esquerra Republicana de Catalunya (ERC)

08 Partido Nacionalista Vasco (PNV/EA.J)

09 Eusko Alkartasuna (EA)

10 Herri Batasuna / Euskal Heritarrok (HB-EH) 
Continuación de la pregunta anterior

Código

\begin{tabular}{|c|c|c|c|c|c|}
\hline \multicolumn{3}{|c|}{ Código } & A & B & C \\
\hline - & 11 & Unidad Alavesa (UA) & 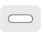 & 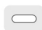 & 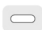 \\
\hline & 12 & Unión del Pueblo Navarro (UPN) .......... & $\square$ & $\varnothing$ & $\varnothing$ \\
\hline & 13 & Bloque Nacionalista Galego (BNG) ...... & $\square$ & $\varnothing$ & 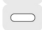 \\
\hline & 14 & Partido Andalucista (PA) & $\square$ & $\varnothing$ & $\varnothing$ \\
\hline & 15 & Coalición Canaria (CC) ......... & 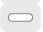 & $\varnothing$ & 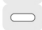 \\
\hline & 16 & Partido Aragonés (PAR) ............................. & $\square$ & $\varnothing$ & $\varnothing$ \\
\hline & 17 & 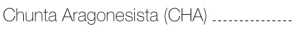 & $\varnothing$ & $\varnothing$ & $\varnothing$ \\
\hline & 18 & 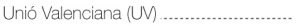 & $\bullet$ & $\bullet$ & $\varnothing$ \\
\hline
\end{tabular}

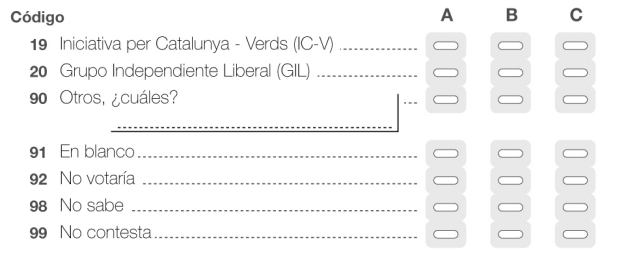

V234. ¿Votó Vd. en las últimas elecciones generales de marzo del 2004?

\section{$\square$ Si $\square$ No $\square$ No contesta (NO LEER) \\ DATOS SOCIODEMOGRÁFICOS}

V235. (Codificar sexo del entrevistado/a por observación):

$$
\square \text { Hombre } \square \text { Mujer }
$$

V236. ¿Puede decirme el año en que nació, por favor?

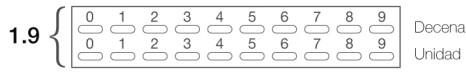

V237. En otras palabras, tiene Vd.

V238. ¿Cuál es el nivel de estudios más alto que ha alcanzado Vd.? (SI EL ENTREVISTADO ES UN/A ESTUDIANTE, CODIFICAR EL NIVEL DE ESTUDIOS MÁS ALTO QUE ESPERE COMPLETAR)
$\hookrightarrow$ Ninguno
Primarios (EGB) incompletos
Primarios (EGB) completos
Formación profesional incompleta
$\square$ Formación profesional completa
Secundarios (BUP) incompletos
Secundarios (BUP) completos
Universitarios incompletos (sin título)

$\square$ Universitarios completos (con título)

No contesta/No sabe

V239. ¿A qué edad completó o completará Vd. sus estudios, bien sea en el colegio (escuela), en el instituto o en la Universidad? Por favor, excluya aprendizajes en puestos de trabajo: (SI ES UN/A ESTUDIANTE, CODIFICAR EDAD A LA QUE ESPERA FINALIZAR SUS ESTUDIOS)

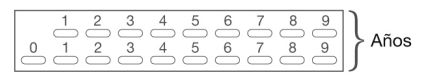

V240. ¿Vive Vd. con sus padres?

$\lessdot$ Sí

$\square$ No

No contesta

V241. ¿Tiene Vd. ahora trabajo o no? En caso afirmativo, ¿cuántas horas trabaja Vd. a la semana? Si tiene Vd. más de un trabajo, refiérase sólo al trabajo principal. (CODIFICAR UNA RESPUESTA)

- Sí, tiene un trabajo remunerado

$$
\text { Por cuenta ajena a tiempo completo ( } 30 \text { horas semanales o más) }
$$

Por cuenta ajena a tiempo parcial (menos de 30 horas semanales)

- No, no tiene trabajo remunerado

$\square$ Jubilado (a) / Pensionista

Ama de casa no empleada

$$
\hookrightarrow \text { Estudiante }
$$
Parado/a

V242. ¿En qué profesión/actividad económica o industria trabaja o trabajó Vd.? Si tiene o tuvo más de un trabajo, refiérase sólo al principal. ¿Cuál es/era su trabajo ahí? ENTREVISTADOR ESCRIBA PROFESIÓN.

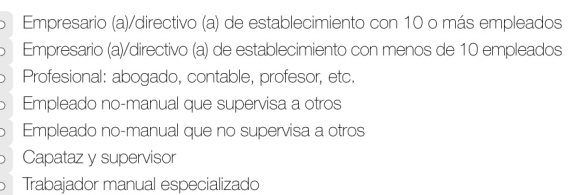

Empresario (a)/directivo (a) de establecimiento con 10 o más empleados Empresario (a)/directivo (a) de establecimiento con menos de 10 empleados

Profesional: abogado, contable, profesor, etc

Empleado no-manual que supervisa a otros

Empleado no-manual que no supervisa a otros

Capataz y supervisor

Trabajador manual especializado

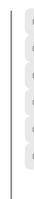

Trabajador manual semi-especializado

Trabajador manual no especializado

Agricultor por cuenta propia

Trabajador agrícola (o iornalero)

Miembro de las Fuerzas Armadas, personal de seguridad

- Nunca ha tenido un trabajo (Si se ha marcado esta opción PASAR A V249)

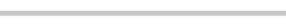

dara - http://wwww.dara.es/omer 
V243. ¿Trabaja Vd. para el Gobierno o para una institución pública, para una empresa privada, o para una organización privada sin fin de lucro? Si no está Vd. trabajando en la actualidad refiérase a su trabajo principal en el pasado.

HOJA 5

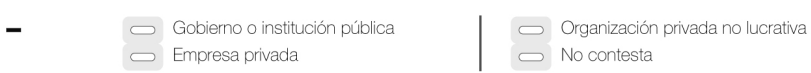

V244. En una escala de 1 a 10, diría que las tareas que Vd. realiza en su trabajo ¿son principalmente manuales o principalmente mentales? Si no está Vd. trabajando en la actualidad refiérase a su trabajo principal en el pasado. El 1 significa que las tareas son "principalmente manuales" y el $\mathbf{1 0}$ significa que las tareas son "principalmente mentales".

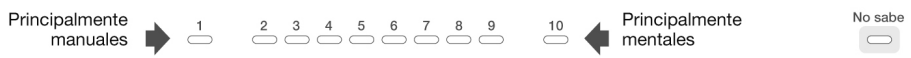

V245. En una escala de 1 a 10, diría que las tareas que Vd. realiza en su trabajo ¿son principalmente rutinarias o principalmente creativas? Si no está Vd. trabajando en la actualidad refiérase a su trabajo principal en el pasado. El 1 significa que las tareas son "principalmente rutinarias" y el $\mathbf{1 0}$ significa que las tareas son "principalmente creativas".

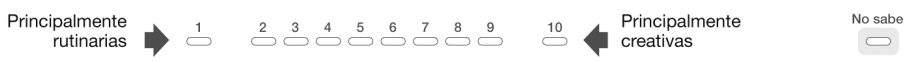

V246. En una escala de 1 a 10, ¿cuánta independencia tiene Vd. para realizar las tareas en su trabajo? Si no está Vd. trabajando en la actualidad refiérase a su trabajo principal en el pasado. El $\mathbf{1}$ significa que no tiene "ninguna independencia" y el $\mathbf{1 0}$ significa que tiene "total independencia".

$$
\begin{array}{r}
\text { Ninguna } \\
\text { independencia }
\end{array}
$$

V247. ¿Supervisa o supervisaba Vd. el trabajo de otras personas?

$$
\square \text { Si } \square \text { No } \square \text { No contesta }
$$

V248. ¿Es Vd. la persona con mayores ingresos en su hogar?

$$
\text { Sí, PASAR A V251 } \square \text { No, PASAR A V249 } \square \text { No contesta }
$$

V249. ¿Tiene ahora trabajo la persona con mayores ingresos en su hogar?

$$
\square \text { Sí } \square \text { No } \square \text { No contesta }
$$

V250. ¿En qué profesión/ocupación trabaja/trabajaba la persona con mayores ingresos en su hogar? Si tiene o tenía más de un trabajo, refiérase al trabajo principal. ¿Cuál es/era su trabajo? ESCRIBA Y CODIFIQUE ABAJO

$\square$ Empresario (a)/directivo (a) de establecimiento con 100
más empleados
$\square \quad$ Empresario (a)/directivo (a) de establecimiento con menos
de 10 empleados
$\square$ Profesional: abogado, contable, profesor, etc.
$\square$ Empleado no-manual que supervisa a otros
$\square$ Empleado no-manual que no supervisa a otros
$\square$ Capataz y supervisor

$$
\begin{array}{|ll}
\square & \text { Trabajador manual especializado } \\
\square & \text { Trabajador manual semi-especializado } \\
\square & \text { Trabajador manual no especializado } \\
\square & \text { Agricultor por cuenta propia } \\
\square & \text { Trabajador agrícola (o jornalero) } \\
\square & \text { Miembro de las Fuerzas Armadas, personal de seguridad } \\
\square & \text { Nunca ha tenido un trabajo }
\end{array}
$$

V251. A lo largo del año pasado, su familia:

$$
\begin{array}{l|l|l}
\square \text { Ahorró dinero } & \square \text { Gastó algunos ahorros } & \varnothing \text { No sabe, no contesta } \\
\square \text { Gastó lo que ganó } & \square \text { Gastó los ahorros y pidió dinero prestado } &
\end{array}
$$

V252. Algunas veces, la gente se describe a sí misma como perteneciente a la clase trabajadora, a la clase media o a la clase alta o baja. Vd. se describiría a sí mismo como perteneciente a la:

$$
\begin{array}{l|l|ll}
\text { Clase alta } & \square \text { Clase media-baja } & \square \text { Clase baja } \\
\text { Clase media-alta } & \square \text { Clase trabajadora } & \square \text { No sabe (NO LEER) }
\end{array}
$$

\section{(ENTREVISTADOR: MOSTRAR TARJETA DE INGRESOS K)}

V253. De acuerdo con esta escala, ¿cuál es el nivel de ingresos de su hogar, incluyendo todos los sueldos, salarios, pensiones, y otros ingresos?

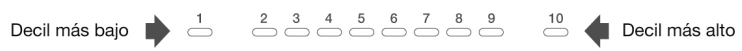




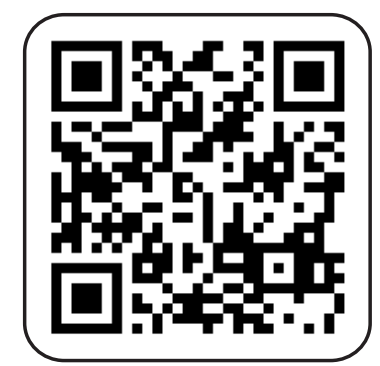

\section{¿Cómo se utiliza?}

Si tu móvil no dispone de lector de códigos, descarga e instala de manera gratuita el más adecuado según tu teléfono.

Estas son algunas recomendaciones:

D Si se trata de un iPhone, I-nigma es una buena opción: www.i-nigma.com/Downloadi-nigmaReader.html

D Para modelos de Blackberry, puedes instalar Beetagg: http://get.beetagg.com

- Si el teléfono es un Nokia o similar prueba, por ejemplo, Kaywa Reader:

http://reader.kaywa.com

Abre la aplicación y enfoca el código QR.

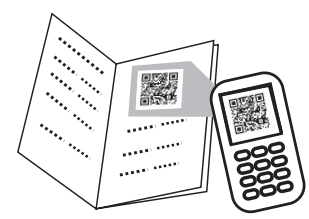

Al aceptar, se abrirá una ventana con el contenido del código. 
